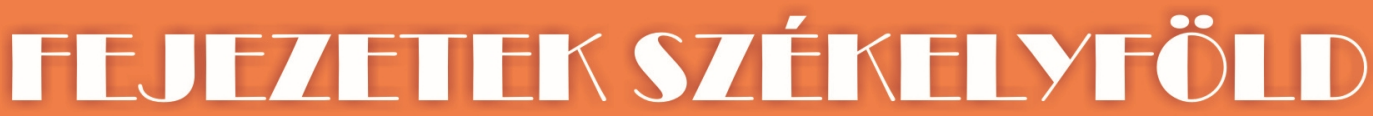 UECHNIKATO̊RUÉNEUÉBÖL
}

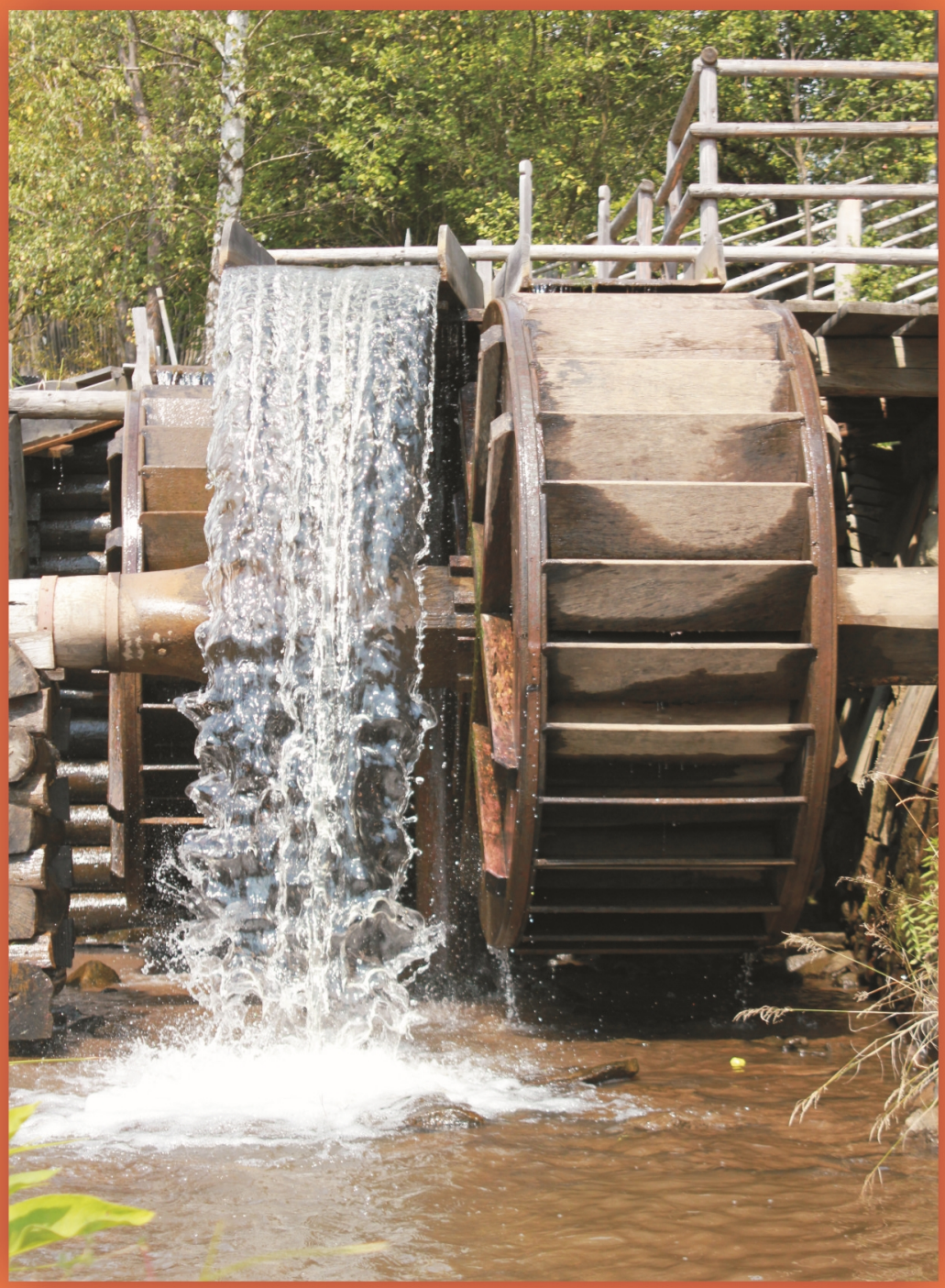

Erdélyi Múzeum-Egyesület 
FEJEZETEK SZÉKELYFÖLD TECHNIKATÖRTÉNETÉBŐL 


\section{A KÖTET SZERZŐI}

(Zárójelben a fejezetek száma)

Bitay Enikő $(3,8,10)$

Botár István (3)

Darvas Lóránt (3)

Daczó Katalin (10)

Farkas Aladár (9)

Szőcsné Gazda Enikő (1)

Hoffmann Edit (3)

Jakab Gyula (2)

Kerekes Ibolya (7)

Kovács Zsombor (3)

Márton László $(3,4,7,8,10)$

Sófalvi András (5)

Szabó Mária $(6,10)$

Sztáncsuj Sándor-József (3)

Talpas János $(3,4,10)$

Veres Péter (12)

Végvári Ferenc (3)

Zepeczáner Jenő (11) 


\title{
FEJEZETEK SZÉKELYFÖLD TECHNIKATÖRTÉNETÉBŐL
}

\author{
Szerkesztette \\ MÁRTON LÁSZLÓ
}

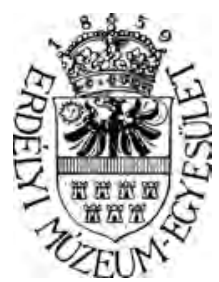

ERDÉLYI MÚZEUM-EGYESÜLET

Kolozsvár

2019 
A kötet megjelenését támogatta a Nemzeti Kulturális Alap, a Communitás Alapítvány, a Bethlen Gábor Alapkezelő Zrt., a Magyar Tudományos Akadémia és az EME Műszaki Tudományok Szakosztálya.
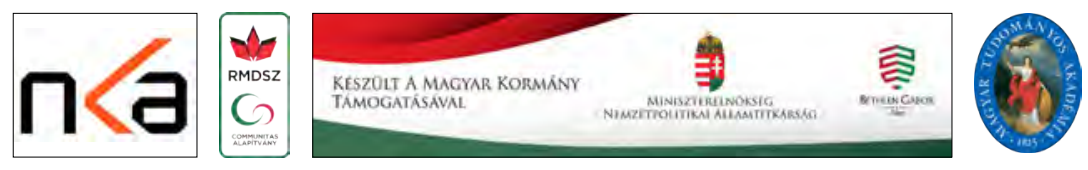

(C) A szerzők, EME 2019

Szaklektor: Gazda István, Perjámosi Sándor, Tóth László

Kiadó: Erdélyi Múzeum-Egyesület

Felelős kiadó: Biró Annamária

Szerkesztő: Márton László

Olvasószerkesztö: Kerekes György

Müszaki szerkesztő: Szilágyi Júlia

Fotó: Borbély Katalin, Jász Anikó, Kémenes Ârpád, ifj. Márton László Ábrák: Laczkó Szabolcs

Borítóterv: Szilágyi Júlia

Borítón: Vízikerék, Gyergyóremete (Eszenyő) felújított vízimalma.

Borbély Katalin felvétele

Nyomdai munkálatok:

F\&F International Kft. Kiadó és Nyomda, Gyergyószentmiklós

Ügyvezető igazgató: Ambrus Enikő

Tel./Fax: +40-266-364171

\section{Descrierea CIP a Bibliotecii Naţionale a României}

Fejezetek Székelyföld technikatörténetéből / szerkesztette: Márton László. - Cluj-Napoca : Erdélyi Múzeum-Egyesület, 2019

Conţine bibliografie

ISBN 978-606-739-138-1

I. Márton, László (ed.)

62 


\section{TARTALOM}

Prológus

1. A kerámiakészítés technikatörténeti vázlata 11

A kerámiaművesség adottságai Székelyföldön. . .11

Agyagok, festékanyagok a mai Székelyföld területén 11

A technikatörténet koronkénti változásai 17

Őskori agyagművesség a mai Székelyföld területén 18

A római kerámia és a népvándorlások korának agyagművessége 20

Az Árpád-kori kerámiaművesség 21

16-17. század - a székelyföldi fazekasság intézményesülése 23

Falusi fazekasság Székelyföldön 26

A székelyföldi közelmúltbeli fazekasság technikai jellemzői. 32

A kályhacsempék készítésének technikája 50

A székelyföldi kőedény- és majolikakészítő műhelyek. 54

2. Székelyföld érctelepei

Vulkáni-üledékes rézércesedések a Békény-patak és a Csanód-patak térségében. 60

A balánbányai rézércesedés 60

Vulkáni-üledékes ólom-, cink- és rézércesedések a Sötétputna völgyében 62

Paltini típusú hidrotermás ércesedések... 62

A Hărlăgia- és a Huruba-patak vidékén kialakult polimetalikus ércesedések 63

A vasérc székelyföldi előfordulása. 63

A csíkmadarasi sziderites vasérc 64

Sziderites vasércesedések Lövéte-Kiruly környékén. 64

Kovászna vasérctelepei. 66 
3. Bányászt és kohászat Székelyföldön ………………………………………....... 69

Az őskori fémművesség emlékei ............................................................................... 69

Vasércbányászat, vaskohászat...................................................................................... 86

A vashámor anyagmaradványainak elemzése ......................................................... 100

Az anyagmaradványok mikroszerkezetének vizsgálata ......................................... 101

A salakmaradvány vizsgálata ............................................................................. 101

A nyersvasmaradvány vizsgálata..................................................................... 102

Az acélmaradvány vizsgálata ........................................................................... 105

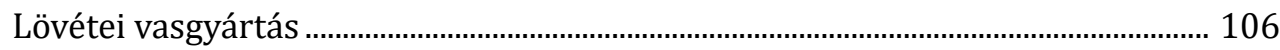

Erdővidék vasgyártása.............................................................................................. 112

Vasgyártás a Kormos völgyében, Erdőfülén ......................................................... 115

Vasgyártási kísérletek...................................................................................... 118

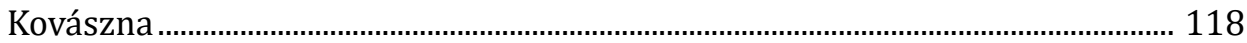

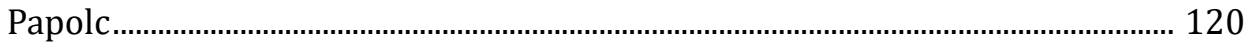

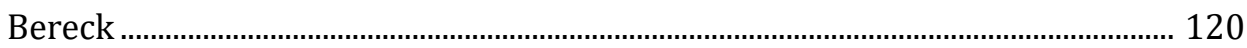

Vasgyártási kísérletek a Gyergyói-medencében …………........................................ 121

Gyergyócsomafalva............................................................................................ 121

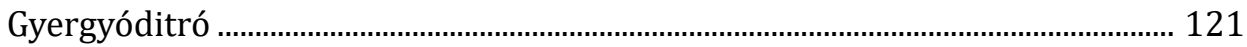

4. Székelyföldi harangöntészet ................................................................................... 127

Készült Székelyudvarhelyen, Lázár Imre öntödéjében ............................................. 132

5. A székelyföldi sóbányászat ………………………………………………………..... 137

Előzmények ………………………….................................................................. 137

Sóbányászat és sókereskedelem a középkorban ....................................................... 138

A székelyföldi sókitermelés az Erdélyi Fejedelemség korszakának kezdetén..... 144

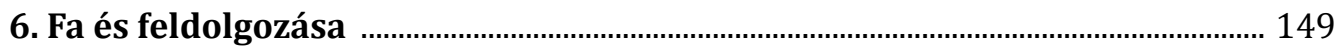

A Kommandó-Kovászna siklópálya ....................................................................... 149

A siklópálya szerkezete, működése ........................................................................ 149

A siklópálya üzemeltetése és karbantartása ........................................................ 156

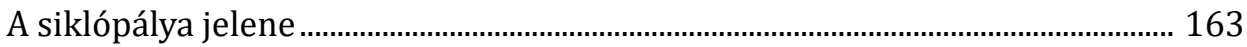

7. Textil- és bőripar Székelyföldön ………………………………………………..... 167

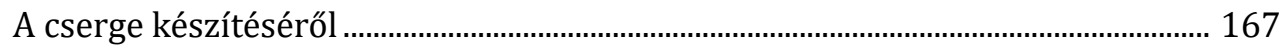

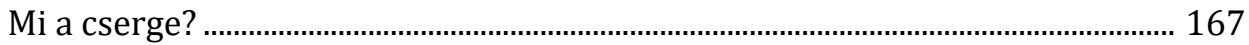

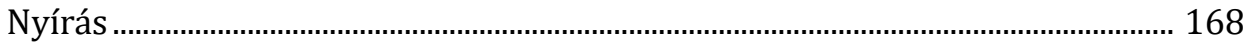

Áztatás, mosás, szárítás............................................................................................ 171 


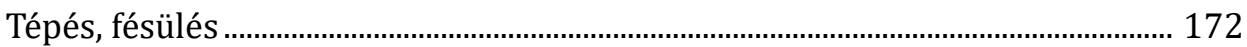

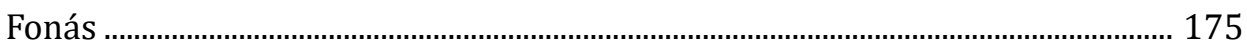

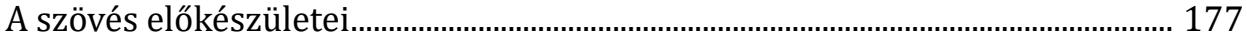

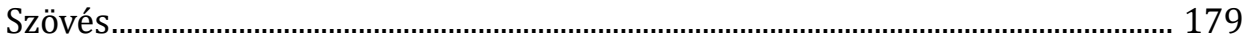

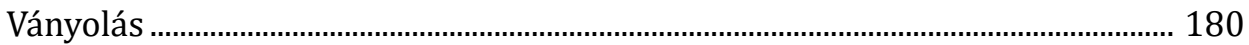

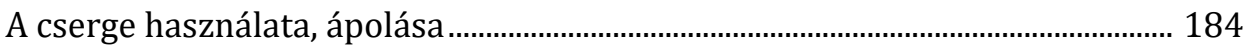

A cserge készítésének átalakulása....................................................................... 185

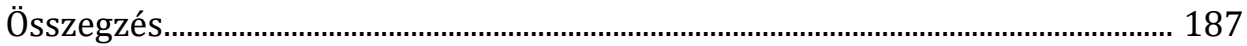

Gyergyószentmiklósi örmény tímárok hírneves terméke: a kordován................... 192

A kovásznai posztógyár ................................................................................................. 195

8. Székelyföldi vízimalmok térben és időben ........................................................... 199

A vízenergia jelentősége a bányászatban, kohászatban, fémfeldolgozásban....... 221

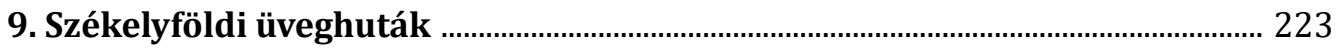

Kárpát-medencei üveghuták..................................................................................... 223

Székelyföldi üvegcsűrök.............................................................................................. 224

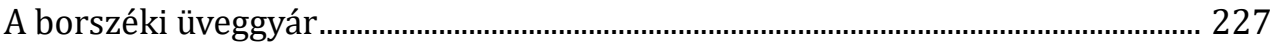

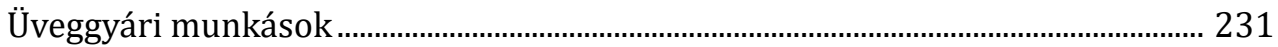

A borszéki üvegek utóélete ............................................................................................ 232

Az üveggyártás technikája........................................................................................ 233

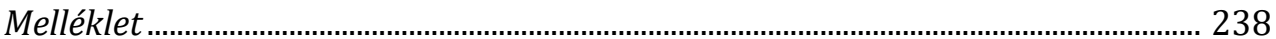

10. A villamos energia hasznosításának kezdetei .................................................... 239

Fejezetek Csíkszereda villamosításának történetéből .............................................. 239

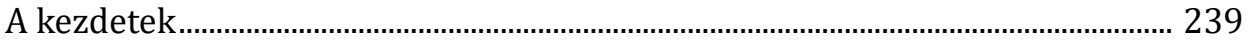

A megvalósítás......................................................................................................... 242

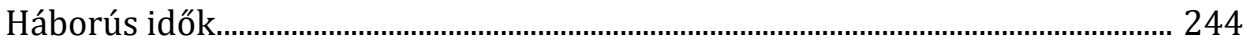

A villanytelep és a város...................................................................................... 246

Kinek kellett a fény? ...................................................................................................... 246

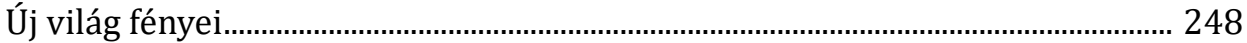

A villamosítás első évtizedei Székelyudvarhelyen................................................... 251

A villamos energia használatának kezdetei Gyergyószentmiklóson és a

Gyergyói-medence településein....................................................................... 255

Gyilkos-tó, Békás-szoros hidroelektromos erőmű építésének tervei

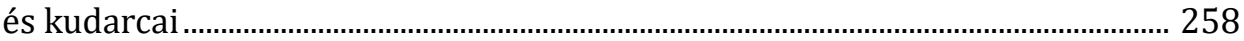

Kommandó villamosításának története................................................................ 265

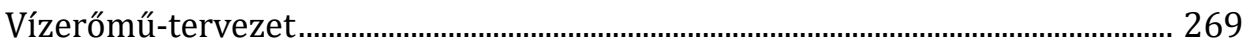




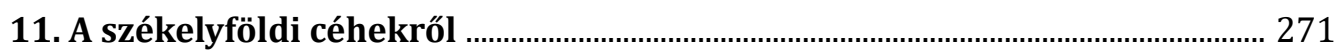

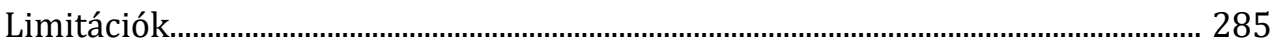

A limitációk a céhek életében .................................................................................... 285

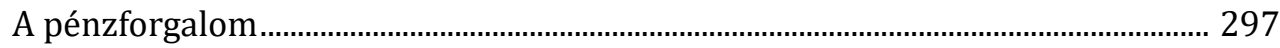

Pénzrendszer a birodalomban .......................................................................... 299

A mértékekről.............................................................................................................. 300

A céhen kívül dolgozó iparosok, a kontárok............................................................. 303

Melléklet ........................................................................................................................ 315

12. Öröknaptár az oklándi unitárius templom mennyezeti kazettáinak

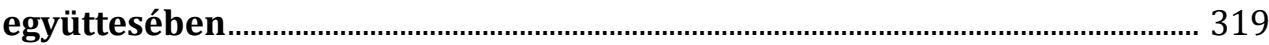

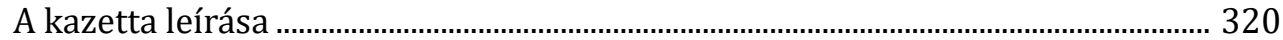

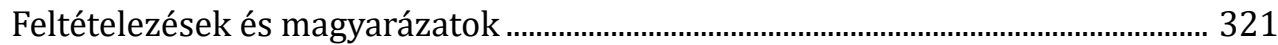

A húsvétkazetta használata ..................................................................................... 323

A Julianus-naptár szerinti húsvétszámítás …………………………....................... 324

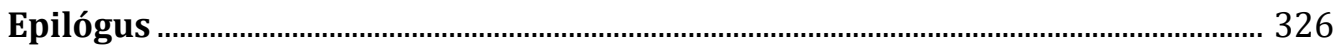

Capitole ale istoriei tehnicii în Ținutul Secuiesc (rezumat) ……………………………... 328

Chapters of Tehnical History in the Székely Land (abstract) ......................................... 333 


\section{Prológus}

Napjainkban az emberiséget soha nem tapasztalt kihívások sokasága sürgeti halaszthatatlan feladatainak megoldására, mint például a globális felmelegedés, a mérhetetlen környezetszennyezés, víz- és élelemhiány stb. Ennek ellenére alkotó energiájának jelentős hányadát továbbra is a fejlesztésekre összpontosítja, mondván: a műszaki fejlődés az általános társadalmi előrehaladás velejárója, tehát elkerülhetetlen. A műszaki fejlődés a társadalom motorja.

Megszoktuk a modern közlekedési eszközöket, ezek ma már életünk részévé váltak. Várjuk az egyre nagyobb teljesítményű hírközlési eszközök megjelenését, a gépesítés térhódítását az élet minden területén, de alig foglalkoztatja a fogyasztói társadalom emberét, minket például, a fogyatkozó energiaforrások helyzete, a nagymértékủ pazarlások, különösen, ami a vizet és az élelmiszereket illeti. Ilyen körülmények között aligha gondolunk általános műveltségünk fejlesztésére, történelmi múltunk megismerésére, ennek velejárójaként a műszaki fejlődés több évezredes múltra visszatekintő fejlődésének megismerésére. Pedig tudjuk, hogy a fejlődés alapfeltétele a művelt ember, aki mindent figyelembe véve életfogytiglan tanul, képezi magát, ragaszkodik hagyományaihoz, és tudása javát fordítja egy élhetőbb társadalom javára, mert ezek önbecsülésének alapjai. Jártasak vagyunk abban a műszaki környezetben, amelyben dolgozunk, de alig tudunk valamit a műszaki fejlődés korszakairól, a kezdetekről, mindarról, ami általános műveltségünkhöz is hozzátartozik. Természetes, hogy naponta kenyeret vásárolunk, de nem gondolunk arra, hogyan értük el azt, hogy nagy teljesítményủ malmaink őrlik a gabonát, hogy gépek végzik azt a nehéz fizikai munkát, amit egykor kizárólag emberi erővel végeztek. Szinte semmit sem tudunk például az egykori molnárról, aki több szakmát művelt, hogy ezermesterként építse malmát, annak minden elemét, hogy fogaskerék-áttételt, vízikereket készített iskolázottság nélkül, mi több, nem hallott a $\pi$ számról, aminek alkalmazása nélkül ma ilyen jellegű feladat megoldása elképzelhetetlen.

Fémekből készült tárgyak végtelen sokaságát használjuk, de nem gondolunk arra, hogy a fémgyártásnak, az emberiség egyik legnagyobb vívmányának több évezredes múltra visszatekintő története van. 
Mit tudunk, hogyan készült ruházata, lábbelije régmúlt századok székelyföldi emberének? Mikor és kik alkották meg Székelyföld első, igazi ipari létesítményeit, milyen eszközöket használtak a fakitermelésben, szállításban? Lám, a kérdések sorakozhatnak a végtelenig, és sajnos alig van kérdéskör, amiben nem volnának nyitva maradt kérdések.

Ma természetes, hogy egy kapcsoló elfordításával világossá válik az éjszaka, gépek, gépsorok lépnek múködésbe, hogy életünk minden perce az elektromos energia használatától függ. Hogyan honosodott meg Székelyföldön az elektromos energiatermelés, kik voltak úttörői annak a jövőbe mutató, forradalmi kezdeményezésnek, amely az általános villamosításhoz, mai függőségünkhöz vezetett? Megannyi kérdés, amire kimerítő választ csak hosszas tanulmányok eredményeként kaphatunk. Mindez, amire választ keresünk csepp abból a tengernyi kérdésből, ami válaszra vár. A választ pedig a technikatörténet tudományától, ennek kutatóitól várhatjuk csupán. Ilyen és hasonló gondolatokat foglal magába jelen kötetünk, amely igazi csapatmunka eredménye.

Néhány gondolattal próbáltuk érzékeltetni könyvünk tematikájának fontosságát, aktualitását.

Nem tévedünk, ha azt állítjuk, hogy könyvünk hiánypótló kiadvány, annak ellenére, hogy az utóbbi tíz-tizenöt esztendőben az Erdélyi Múzeum-Egyesület égisze alatt évente szerveződtek technikatörténeti kutatások, amelyek eredményei a Tudomány és Technikatörténeti Füzetek című sorozatban váltak sokak számára kedvelt olvasmányokká. Hasonló kezdeményezést jegyezhetünk a csíkszeredai Pallas-Akadémia Könyvkiadó technikatörténeti kiadványaival kapcsolatosan is. Mára mind könyvritkaságok, újrakiadásuk is indokolttá vált.

Jelen tanulmánygyűjtemény az Erdélyi Múzeum-Egyesület kiadói tevékenységének újabb terméke. Szerzői ismert szakírók, kutatásaik eredményeiről a könyv fejezetei tesznek tanúbizonyságot.

A szerzők és a kiadó, de a kiadás költségeit fedező intézmények is bíznak abban, hogy jelen tanulmánykötet egyrészt gazdagítja művelődéstörténeti jellegű irodalmunkat, és betölti hiánypótló indíttatását, másrészt pedig érdekes olvasmányává válik mindazoknak, akik gyarapítani, kiegészíteni szeretnék általános múveltségüket a Székelyföld technikatörténetéről szóló témakörrel. Meggyőződésünk, hogy az érdeklődő olvasó talál magának új és érdekes gondolatokat a technikatörténet kérdésköréből, amelyek megerősítik kötődését szűkebb pátriánkhoz, szülőföldünkhöz, a Székelyföldhöz.

A szerzők 


\section{A KERÁMIAKÉSZÍTÉS TECHNIKATÖRTÉNETI VÁZLATA*}

\section{A KERÁMIAMÜVESSÉG ADOTTSÁGAI SZÉKELYFÖLDÖN}

\section{Agyagok, festékanyagok a mai Székelyföld területén}

A kerámiaművesség alapanyaga, az agyag a földpátokat tartalmazó kőzetek málási terméke, amely szilikátokat és a legtöbb esetben kvarcot, földpátot, agyagásványokat, csillámokat, valamint különböző szennyeződéseket tartalmazhat (Csupor István - Csuporné Angyal Zsuzsa 1998. 17.). Székelyföld területe nagyon gazdag agyaglelőhelyekben, ezért már a korai századokban adottak voltak a feltételek az agyagművesség különböző válfajainak kialakulásához. A legfontosabb agyaglelőhelyekről csupán a 19. század végéről és a 20. század elejéről vannak felméréseink, ezekből látható, hogy e területen sok, eltérő minőségű agyag található, ezeknek kerámiaművességbeli felhasználhatósága nagyban függött az agyag összetételétől, tűzállósági fokától.

A csaknem ötvenfajta agyagásvány közül a kaolin és az illit egyaránt fehér színúek. A kaolin vagy más néven porcelánföld magas tűzállósági fokú, sovány. A tűzállósági fok elsősorban az alumínium-oxid és a szilícium-dioxid arányától függ, mennél tǔzállóbb az agyag, annál több alumínium-oxidot tartalmaz (Csupor István - Csuporné Angyal Zsuzsa 1998. 17-19.). Az agyagot képlékenysége szerint zsíros (kövér) vagy sovány típusokra szokás osztani. A sovány és kövér agyag az átlagos szemcseméretben tér el egymástól. A túl zsíros agyagot homokkal szokták soványítani, ezzel csökkentik a képlékenységet, ami a megmunkálás szempontjából előnytelen, viszont javul a száríthatósága, égetés során kevesebb selejt keletkezik (Szakmány György 2008. 51).

Kalecsinszky Sándor 20. század eleji német nyelvű agyagipari felméréséből jól látható, hogy Székelyföld területén a legtűzállóbb agyagok Gyergyóújfalu és Székelyudvarhely határában voltak, de magas lángállósági fokú, nagyon jó minőségű agyagot találtak Csíkvárdotfalván, Gyergyószárhegyen, Csíkszentsimonban, Csíkszentmihályon is. Ezek az agyagok maximálisan alkalmasak voltak sütő- és főzőedények készítésére. Ezek mellett több település határában találtak edényvagy téglagyártásban alkalmazható agyagot: Agyagfalván, Ákosfalván, Baróton, Bereckben, Bibarcfalván, Csíkdánfalván, Csíkmadarason, Gyergyóditrón, Gyergyószentmiklóson, Gyergyótölgyesen, Kászonimpéren, Korondon, Kőrispatakon, Magyarhermányban, Makfalván, Marosvásárhelyen, Nagybaconban, Sepsiszentgyörgyön, Székelykeresztúron, Szinden, Tordán (Kalecsinszky, Alexander von 1906).

A Petrik- és a Kalecsinszky-féle agyagipari felmérések nem tekintették át Székelyföld összes agyaglelőhelyét, eléggé esetleges volt 
ezeknek a feltérképezése. Így például kimaradt a felmérésből a kézdivásárhelyi fazekasok híres lelőhelye Csernáton határában, de Kálnok, Páva, Atyha, Backamadaras, Küsmöd, Szolokma, Etéd, Várfalva, Homoródalmás fazekastelepülések agyaglelőhelyeit sem azonosították be. Más településekről viszont több agyagmintát is összegyüjtöttek, ezzel is jelezve, hogy egy helységen belül is változott az agyag minősége. A 20. század eleji felmérések hiányait azóta is csak kismértékben pótolták környékünk geológusai. Bár Székelyföldet kereskedelmi útvonalak szelték át, és ennek köszönhetően jelentős kerámiaimport is kialakult, mégis az e vidékről előkerülő kerámiák 90\%-a a környéken készült, a székelyföldi agyaglelőhelyek nyersanyagait dolgozta fel. Természetes tény, hogy kerámiakészítés ott alakulhatott ki, ahol a jó minőségű nyersanyag a közelben fellelhető volt. Még a nyugat-európai fazekasközpontok 19. századi kutatásai során is kiemelték, miszerint az agyaglelőhelyek legtöbbjének 15 km² es távolságában jöttek létre a legfontosabb feldolgozási gócpontjai, ez az észrevétel a fejletlenebb közlekedési viszonyokkal rendelkező Székelyföld esetében még inkább helytálló.

Több forrás áttekintése nyomán és szóbeli visszaemlékezésekből, gyűjtésekből ismertek a székelyföldi agyagműves helységek legfontosabb agyagbányái, az ezekből bányászható agyagok pedig meghatározták, hogy milyen edényeket lehetett belőlük készíteni.

Az 1. táblázat csupán az ismertebb agyagfeldolgozó helységek bányáit tekintette át, ezek mellett még számos olyan település van, ahol a rövidebb ideig működő téglagyárak bizonyították a környék agyagjának feldolgozásában rejlő lehetőségeket. A 20. század elején a kovásznai Cserépgyár dűlőben, Sepsiszentgyörgyön az Eprestető környékén és az Őrkő határában, Csíkszépvízen, Tap- locán, Gyergyószárhegyen, a század végén Torján, napjainkban Kászonaltíz és Újfalu között működtek és működnek téglagyárak és cserépcsűrök, amelyek a környék agyagját dolgozták fel. Ezek az adatok jelzik, hogy Székelyföld nagyon gazdag agyaglelőhelyekben, így a kerámiakészítés feltételei megvoltak.

Az agyag nem mindig volt optimális minőségű, évszázados technikai megfigyelések alapján alakultak ki a vegyítésnek a szabályszerűségei. A zsíros agyagot soványítással tették formálhatóbbá, a soványítás koronként más-más adalékanyagok hozzáadásával történt. Az őskori agyagművesség egyes korszakaiban növényi soványítóanyagokat, tört kerámiát, apró kavicsot kevertek az agyaghoz. Leghosszabb ideig - egészen napjainkig - a homokkal való soványítás maradt a legelterjedtebb eljárás, ezt a patakok partjáról gyűjtötték össze, és többszöri átmosás után tették az agyagba.

$\mathrm{Az}$ is ismert eljárás volt, hogy a kövér és a sovány agyag összevegyítésével próbálták elérni az optimális összetételt. Erre elsősorban azokban a helységekben került sor, ahol mindkét fajta agyag előfordult. Makfalván például a főzőedényekhez két rész sovány és egy rész kövér agyagot kevertek össze a fazekasok (Suba László 1996. 2.).

Korsók, magas falú edények készítését elsősorban azokban a helységekben lehetett megvalósítani, ahol az agyag magasabb vasoxid tartalommal rendelkezett. Nem véletlen tehát, hogy Székelyföld területén a legfontosabb korsós központoknak Magyarhermány vagy Csíkmadaras számított, ezeknek a helységeknek a határában vasérctelepek is voltak.

A mésszel szennyezett agyagot nem alkalmazták tűzálló edények készítésére, mert nagy a hőtágulása, és a hőtágulási különbségek miatt az edény elrepedhet. 
1. táblázat. Székelyföldi agyagmüves helységek legfontosabb agyagbányái és agyaguk minősége

\begin{tabular}{|c|c|c|}
\hline Helységnév & $\begin{array}{l}\text { Agyagbánya pontos } \\
\text { helye }\end{array}$ & A fellelhető agyag minősége \\
\hline Agyagfalva & Szénégetőpatak & Főzőedények készítésére alkalmas \\
\hline Ákosfalva & & Pipakészítésre használt agyag \\
\hline Barót & $\begin{array}{l}\text { Bibarcfalvi } \\
\text { Farkabükk }\end{array}$ & Főzőedények, bokályok készítésére alkalmas agyag \\
\hline Bereck & $\begin{array}{l}\text { Magyaroshegyalja } \\
\text { Dorogi dúlő }\end{array}$ & Főzőedények készítésére alkalmas \\
\hline Bibarcfalva & Farkabükk & Főzőedények készítésére alkalmas \\
\hline Bodok & & $\begin{array}{l}\text { Mázas főzőedények, háztetődíszek, kályhacsempék ké- } \\
\text { szültek az itteni agyagból }\end{array}$ \\
\hline Csíkdánfalva & $\begin{array}{l}\text { Alsó- és Felső-Olthegyi } \\
\text { dúlő }\end{array}$ & Főzőedények készítésére alkalmas \\
\hline Csíkmadaras & Agyaghegy & $\begin{array}{l}\text { Jó minőségú túzálló fehéragyagot bányásztak itt, mely } \\
\text { túzálló edények és korsók elóállítására alkalmas }\end{array}$ \\
\hline Csíkszentsimon & Aladárhegy & $\begin{array}{l}\text { Nagyon jó minőségú kaolinos agyag, majolikagyártásra } \\
\text { is bevált, a marosvásárhelyi kályhagyár, a görgényi kőe- } \\
\text { dénygyár is használta }\end{array}$ \\
\hline Gyergyóditró & Lövöldöző & \\
\hline Gyergyószárhegy & $\begin{array}{l}\text { Szármány Güdüzpataká- } \\
\text { ra hajló északi oldala }\end{array}$ & $\begin{array}{l}\text { Fehér poros agyag, a görgényi keménycserép gyártásá- } \\
\text { hoz nagy mennyiségben szállították }\end{array}$ \\
\hline Kálnok & Sáros gödör & $\begin{array}{l}\text { Mázas fózőedények, kályhacsempék készültek az itteni } \\
\text { agyagból }\end{array}$ \\
\hline Keresztényfalva & Segen-Gottes-Stelle & $\begin{array}{l}\text { A Brassó közelében lévő kitúnő tűzálló agyagot kőe- } \\
\text { dénygyártásra, vízvezetékcsövekre, kályhacsempére } \\
\text { használták, több székelyföldi fazekashelység szállított } \\
\text { innen agyagot tűzálló edények és kályhacsempék ké- } \\
\text { szítésére, amelyet a környéken bányászható agyagokkal } \\
\text { vegyítve hasznosítottak }\end{array}$ \\
\hline Kézdivásárhely & Csernáton határában & $\begin{array}{l}\text { Elsősorban bokályok és kályhacsempék készítésére al- } \\
\text { kalmas }\end{array}$ \\
\hline Korond & $\begin{array}{l}\text { Lapágy, Firtos alatti } \\
\text { Szakadát }\end{array}$ & $\begin{array}{l}\text { Jó agyag, a régibb korokban durva homokkal vegyítve } \\
\text { mázatlan főzőedényeket készítettek belőle, később má- } \\
\text { zas díszedények készítésénél is alkalmazták }\end{array}$ \\
\hline
\end{tabular}


1. táblázat. Székelyföldi agyagmüves helységek legfontosabb agyagbányái és agyaguk minösége (folytatás)

\begin{tabular}{|c|c|c|}
\hline Helységnév & $\begin{array}{l}\text { Agyagbánya pontos } \\
\text { helye }\end{array}$ & A fellelhető agyag minősége \\
\hline Kőrispatak & Falu északi határa, Libuc & Főzőedények gyártására alkalmas \\
\hline Küsmöd & $\begin{array}{l}\text { Ligand, Kövesárok, } \\
\text { Somköze }\end{array}$ & $\begin{array}{l}\text { Kályhacsempék, bokályok, háztetődíszek, főzőedények } \\
\text { gyártására alkalmas }\end{array}$ \\
\hline Magyarhermány & $\begin{array}{l}\text { Bükkösfej, } \\
\text { Barnahágó, } \\
\text { Mélypatak }\end{array}$ & $\begin{array}{l}\text { Vörösagyag, korsók, főzőedények, kályhacsempék gyár- } \\
\text { tására egyaránt alkalmas. Barnahágónál a mázhoz való } \\
\text { anyagot is termeltek }\end{array}$ \\
\hline Makfalva & Nagyhegy, Agyagas & $\begin{array}{l}\text { Főzőedények, kályhacsempék készítésére egyaránt al- } \\
\text { kalmas }\end{array}$ \\
\hline Marosvásárhely & $\begin{array}{l}\text { Nagyhegyszőlő felé veze- } \\
\text { tő út mellett }\end{array}$ & Konyhai edények, kályhacsempék készítésére alkalmas \\
\hline Nagybacon & Csinódhegy & Elsősorban tetőcserép, de bokályok is készültek belőle \\
\hline Páva & $\begin{array}{l}\text { Kovászna felőli országút } \\
\text { mellett, Epreskert }\end{array}$ & $\begin{array}{l}\text { Mázas fazekakat, bokályokat, kályhacsempéket készí- } \\
\text { tettek belőle }\end{array}$ \\
\hline Siménfalva & $\begin{array}{l}\text { Álba-patak, } \\
\text { ma Fehér-Nyikó partja }\end{array}$ & Fehéragyag \\
\hline Székelyudvarhely & Szarkakő lába & $\begin{array}{l}\text { Egyik agyag finom mészanyagot tartalmaz, ezért inkább } \\
\text { tányérok, tálak, bokályok, mázas szilkék, tárolófazekak } \\
\text { készítésére alkalmas. Másik agyag finom fehéragyag, } \\
\text { magas hőállósági foka miatt kályhacsempék készítésére } \\
\text { is alkalmas }\end{array}$ \\
\hline Székelykeresztúr & $\begin{array}{l}\text { Csekefalva felé vezető út } \\
\text { mellett, a Cserépcsűr, } \\
\text { valamint az Ughy-féle } \\
\text { téglagyár }\end{array}$ & $\begin{array}{l}\text { Edények, kályhacsempék, téglák készítésére egyaránt } \\
\text { alkalmazták }\end{array}$ \\
\hline Szind & Kukulye, Sándor hegye & $\begin{array}{l}\text { Fehéragyag, több fazekasközpont engób készítésére } \\
\text { használta az agyagját. Bár a falu nem tartozott a törté- } \\
\text { nelmi Székelyföldhöz, Parajdon és Görgényben a kőe- } \\
\text { dény gyártásában is alkalmazták az itt fellelhető agyagot }\end{array}$ \\
\hline Szolokma & $\begin{array}{l}\text { Szálapos, küsmödi } \\
\text { Somköze }\end{array}$ & $\begin{array}{l}\text { Pala, főzőedénynek nem volt jó, tányérok és tálak ké- } \\
\text { szültek belőle. Tudomásunk van róla, hogy kályhacsem- } \\
\text { pék is készültek itt, ehhez valószínűleg - akárcsak az itt } \\
\text { készült bokályokhoz is - Korond környékéről szállítot- } \\
\text { ták az agyagot }\end{array}$ \\
\hline Torda & $\begin{array}{l}\text { Labirintus-dűlő } \\
\text { Malomoldali dűlő }\end{array}$ & $\begin{array}{l}\text { Az előbbit elsősorban kályhacsempék és téglák, az utób- } \\
\text { bit edények készítésére alkalmazzák, ez utóbbi nem tűz- } \\
\text { álló, így inkább tányérok, bokályok készültek belőle }\end{array}$ \\
\hline
\end{tabular}


Ugyanakkor a mész a levegő nedvességtartalmának hatására kipattanhatott az edényből. Mészszemcséket tartalmazott például a székelyudvarhelyi egyik agyag, éppen ezért alakult ki itten inkább tál- és tányérkészítés. A fazekasok vigyáztak arra, nehogy gipsszel szennyeződjön az agyag, mivel a gipsz az agyag egységes színén belül fehér foltokat eredményezett. A nyers agyag és a soványítóanyagok mellett a fazekasok a magasabb esztétikai igény kielégítése céljából színes agyagokat (engóbokat), festékföldeket is bányásztak. Székelyföld területéről e színezőanyagokat is be lehetett szerezni. Néhány fazekastelepülésről ismert, hogy milyen színezőanyagokat használtak, és ezeket honnan szerezték be.

„A legkorábbi szándékosan kiégetéssel, agyagból készült műtárgy a Dolní Véstonice néven ismert mintegy $10 \mathrm{~cm}$ magas Vénuszszobor, amely mintegy 30 ezer évvel ezelőtt készült, vagyis felső paleolit korú, és Brno mellett (Morvaország, DK-Csehország), a névadó település közelében bukkantak rá a régészek több kisebb égetett agyag szobrocska társaságában. Ez tekinthető jelenleg a kerámiakészítés kezdetének. Az eddigi kutatások alapján a legkorábbi ismert hétköznapi használatra készült edények Krisztus előtt mintegy 10000 körül készültek, tehát hozzávetőleg 12 ezer évesek, és Japánból, valamint Kelet-Ázsiából, a Jomon (dzsómon) kultúrából kerültek elő. Európába, és így a Kárpát-medencébe a kerámia és ezzel együtt a fazekasság ismerete nagy valószínűséggel délkeletről, a Balkán félsziget felől érkezett a kora neolitikum során. Magyarország legkorábbi kerámialeletei a Körös-, valamint a Starčevo-kultúrákból származnak, és mintegy 8000 évesek." (Szakmány György 2008. 50.).
A kerámiakészítésben leginkább a fehérföldet (fehér engóbot) alkalmazták, ezt az edény fehér alapozásához vagy díszítő csíkok festéséhez használták. Orbán Balázs szerint a siménfalvi Álba-patak (mai Fehér-Nyikó) martján lévő fehérföldet már a rómaiak is alkalmazták edényeik díszítésére (Orbán Balázs 1868. I. 117.). A makfalvi fazekasok az edényeikhez használt fehérföldet Tordáról hozták, ahol mind a román, mind pedig a magyar egyház rendelkezett fehérföldbányákkal (Suba László 1996. 6.). Fehéragyag-lelőhely volt Csíkcsicsóban is (Haáz Ferenc 1940. 184-185.). A Székelyudvarhely határában lévő Szarkakő lábánál Kalecsinszky Sándor geológus és kutatótársai szintén fehérföldlelőhelyeket azonosítottak. Széles fazekasréteg (Magyarhermány, Görgényszentimre, Marosvásárhely, Székelyudvarhely, Korond fazekasai) hordta a fehérföldezéshez és a porcelánkészítéshez az agyagot a Csíkszentsimon határában lévő Aladár nevű helyről, itt a kémiai elemzések szerint kaolin volt, akárcsak a Hargita-hegységben. A mai Hargitafürdő közelében a fehérföld előfordulása olyan jelentős mennyiségű volt, hogy a 20. században bányát is működtettek ennek kitermelése és hasznosítása céljából. Kaolinbányászatra Székelyszáldobos határában is tettek kísérleteket az első világháborút megelőző években, ám ott a magas szennyezettségi fok miatt felhagyták a bányát.

A barna szín előállításához a „barnakô" vagy "feketekô" bányászása nyújtott segítséget. Ez a mangántartalmú agyag nagyobb mennyiségben a nagybányai bányavidéken fordul elő, a céhek elsősorban innen szerezték be közösen, ám kisebb, a helyi fazekasokat ellátó mennyiségben több helység határán is előfordult. A makfalvi fazekasok a helyi ún. cséjei határból (Suba László 1996. 6.), a háromszéki Páva fazekasai úgyszintén a helyi 
határból szerezték be ezt. Magyarhermány fazekasai a feketeföldet a helyi Keselyőpatakról szállították (Seres András 1974. 361.). A korondi fazekasok a „burusnyánfekete” föl$\operatorname{det}^{1}$ a kőrispataki hegyről bányászták (Incze Lajos 1939. 124.). A „barnakő” feltérképezése és kitermelése a 19. század közepéig még teljesen magánúton történt: bár a korabeli mineralógusok ismerték azt, hogy „Erdélyben barnakő, arszenik, piskolt, grafit, kén s egyéb fémek és hasznos ásványok is vannak", ezeknek bányászati úton való szélesebb értékesítésére nem történt konkrét lépés (Hunfalvy János 1862. 183.).

Szívesen alkalmazott dekorációs nyersanyagnak számított a vörös színű agyag is, amelyet helyenként festőföldként alkalmaztak az edények színezésére. Magyarhermányban a vörösföld a Mélypatakban fordult elő, agyagbányászás közben kisebb menynyiségben ezt is kitermelték, külön tárolták, és csak díszítésekhez alkalmazták (Seres András 1974. 361.). A korondi fazekasoknak is megvolt a saját vörösagyag-lelőhelyük, a farkaslaki határ Demeslaki hídnak nevezett dủlőjében (Incze Lajos 1939. 124.).

E fehér és színes engóbok mellett a fazekasoknaka mázakelőállításához szükséges anyagok lelőhelyeiről is pontos ismereteik voltak. A mázazáshoz alkalmazott ólomgelétet nagyobb mennyiségben az óradnai kohóktól, valamint Nagybánya környékéről szállították, ám kisebb mennyiségben Tölgyes felső végénél is bányászták. A leggyakrabban alkalmazott zöld színű mázat részben házilag keverték, mégpedig úgy, hogy a réz-oxidot az ólommázhoz őrölték. A rezet por alakban is árusították a nagyobb hozamú lelőhelyek környékén. Az etédi, ún. Tömlöc árkából az eső által lemosott rézport vékáslag értékesítették a helybeliek, de a Csernáton melletti Bartafalvi határon is rézpalát állítottak elő.
„Az ólomgelét az ezüsttartalmú rézérczek ólmozása $\mathrm{s}$ az ezüst elválasztása alkalmával nyeretik s a cserépedények zománczozására használtatik." (Hunfalvy János 1862. 182.).

A Tölgyes felső végénél lévő rézbányák művelését 1848-ban hagyták fel (Orbán Balázs 1868. I. 185, 1869. III. 100, valamint 1869. II. 132.). Nagyobb rézmennyiség alkalmazására a 18. század végétől, a balánbányai rézlelőhelyek felfedezésétől, majd ezek 1803-mal kezdődő nagymérvű kitermelésével adódott meg a lehetőség.

A kék máz előállítására alkalmazott kobalt-oxid ritkán fordult elő, így a Székelyföldön ritkán is alkalmazták. A kobalttartalmú mázakat Erdélyben elsőként az alvinci habán telep fazekasai alkalmazták, valószínűleg morvaországi kapcsolataik révén, majd szászországi importként a szász fazekasok is használták, ők terjesztették pénz ellenében a székelyföldi céhes fazekasoknak is. Az oravicai kobaltbányák megnyitására csupán a 19. században került sor, így a kék mázalapanyag nagybani használatára csak ezt követően lehetett számítani.

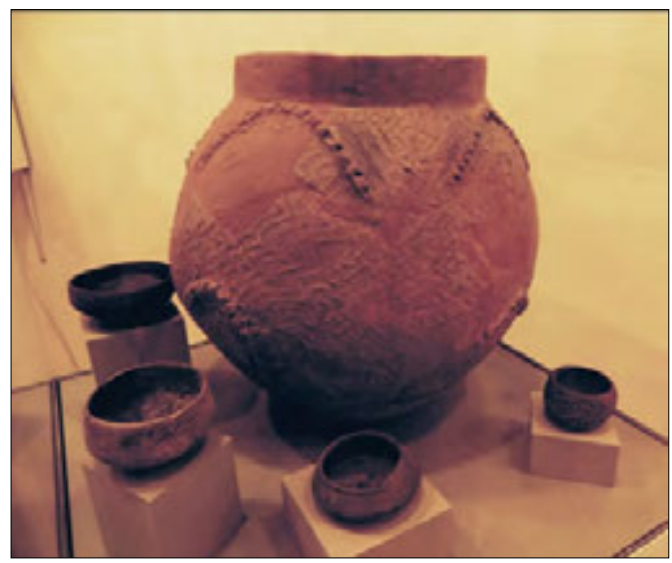

1. kép. Újkőkori agyagedények, Körös-kultúra. Székely Nemzeti Múzeum (SzNM) 


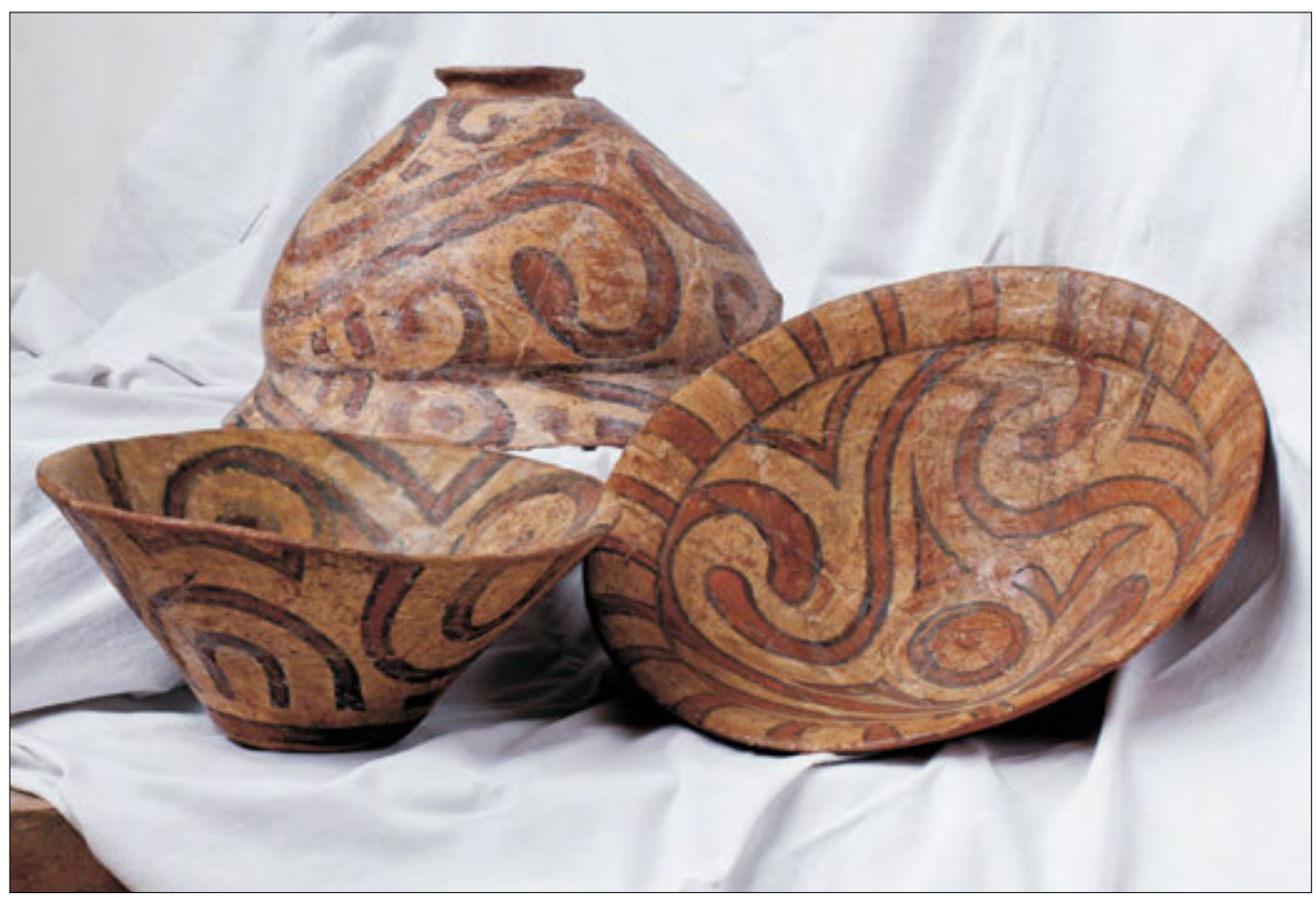

2. kép. Rézkori agyagedények, Erôsdi kultúra. SzNM

A sárga színú máznak legrégibb formái talán ólmosabb kerámiamázból készültek, a 19. századtól viszont már az antimonos alapú mázak használata is ismert volt.

E bányák, agyaglelőhelyek azonosítása és használata nem újkeletű, és a fazekasság technológiáját is már ősidők óta alkalmazta a Székelyföld mai területén élt népek sokasága.

\section{A technikatörténet koronkénti változásai}

Az agyag megmunkálásának története nem állandó folyamat, koronként és népenként valamennyire variálódott. A kerámiáról szóló legtöbb tanulmány a változásokat elsősorban a használt ornamentika alapján elemezte, holott a kerámiakutatók tudják, hogy a motívumelemzés a legkevésbé biztos támpont egy-egy edény származási helyének vagy éppen keletkezési korának meghatározásánál. A gyorsan változó díszítményekkel szemben a kerámia időt állóbb elemei közé tartozik számos technikai elem: az alkalmazott formavilág, a korongozási technikák, a fül illesztésének módjai, a mázösszetétel vagy egy-egy sajátosabb égetési technika. Bár a legtöbb technikai megoldás általánosan elterjedt, és szélesebb övezetekben ismert, a földrajzi környezet és a fellelhető nyersanyagok, egy-egy vidék zártsága vagy nyitottsága, az adott térben megjelenő népcsoportok vándorlása és kapcsolathálója mindenképpen hatással volt arra, hogy egyes technikai jellemzők mikor és hogyan jelentek meg, mennyire váltak elterjedtekké.

E sorok írója nem régész, így a régészeti kerámia technikatörténeti áttekintésére csak dióhéjban tér ki, a variálódás értelmezése céljából. 


\section{Őskori agyagmúvesség a mai Székelyföld területén}

A Székelyföld területén végzett régészeti ásatások egyik leggyakoribb lelettípusa a kerámiaedény, amely sírleletként vagy a valamikori lakóhelyek területén kerül felszínre. Ezek a leletek még egyáltalán nem kötődnek a székelységhez, csak e földrajzilag körülhatárolható területről kerülnek elő, a leggyakoribb esetekben valamely konkrét népcsoporthoz vagy etnikumhoz való kötésük is problémás. Az őskori kerámiakészítők szinte kizárólag használati edényeket készítettek, amelyhez a környékbeli agyaglelőhelyek nyersanyagát dolgozták fel. Archeometriai kutatások jelzik, hogy az őskor embere többnyire 7 km-t meg nem haladó távolságból szállította az edényeihez szükséges agyagot, a távoli importáruk szállítása nagyon ritka jelenségnek számított.

A neolitikumban a kerámia agyagját többnyire pelyvával soványították (Szakmány György 2008. 54.). E kerámiák jellemzője az ún. „szendvics-szerkezet”: belül sötétebb, a kéregben világosabb színű az agyag. Ezek égetési hőmérséklete a mai égetési hőfokoknál jóval alacsonyabb volt (Szakmány György - Gherdán K. - Starnini E. 2004. 30.). A korong ismeretlensége miatt az edényeket kézzel formálták. Előfordult, hogy az elkészített kerámiát - a porózusság megszüntetése miatt - agyagbevonattal (slip) látták el. Ez a módszer eltért a későbbi engóbos bevonástól, ugyanis a folyékony agyagpép ugyanolyan színű volt, mint maga az edény. A rézkor kerámiakultúrája gyönyörű emlékeket őrzött meg Székelyföldön. A kőkor-rézkor átmeneti periódusában, „a tiszai kultúrával egyidőben Háromszéken kifejlődik a bekeretezett díszítésü festett kerámia, az un erôsdi kultúra" (Székely Zoltán 1948. 14.). Erősd
Sepsiszentgyörgy közelében fekszik, a csodálatos kerámialeletek a Tyiszk hegyen kerültek elő. Az 1907-től kezdődő szisztematikus ásatásokból rengeteg edénytöredék került Sepsiszentgyörgyre (Székely Nemzeti Múzeum), Kolozsvárra (Erdélyi Múzeum) és Budapestre (Nemzeti Múzeum), többségük háromszínű festéssel (vörös, fehér, sötétbarna). Az öblös fazekak, talpas tálak meglepően változatos formavilága nem pusztán a Székelyföld területén bukkant fel: a Kárpátokon túl, a cucuteni-i kultúra leletállománya is hasonló edénytípusokat termelt ki. Az erősdi típusú kerámialeletek agyagját homokkal soványították. Gyakoriak voltak a kihajló peremű fazekak, amelyeket gyakran függőlegesen átlyukasztott bütyökfüllel láttak el, vagy a fület helyettesítő funkcionális dudorokkal dekoráltak. Az erősdi kultúra gyakori leletei a tálak is, ezek formailag igen változatosak voltak, de a telep formailag gazdag kerámialeletei között csőtalpat, agyagkanalakat és -idolokat, kisebb edényeket is találunk. A finomabb kerámiák felületét égetés előtt festették és fényesítették (Sztáncsuj Sándor József 2003. 6-7.). Az erősdi telephely későbbi, 1960-70-es évekbeli ásatásaiból nyolc darab, valószínűleg kerámiaégető-kemence került elő. Ezeknek egy része 80-100 cm átmérőjű, kör alaprajzú volt. Az ásatás egy kemencekomlexumot is a felszínre hozott, amely egy központi, $110 \mathrm{~cm}$ átmérőjű és boltozott tetejű kemencéből és ehhez kelet és nyugat irányból csatlakozó egy-egy oldalkemencéből állott. A központi kemencének agyagkéménye volt (Székely Zoltán - Bartók Botond 1979. 55-58.). Székely Zoltán arról valószínűsítette, hogy kerámiaégető-kemencék voltak ezek, hogy a kemence ásatási területén kerámiadarabokat is talált. A későbbi szakirodalom a kerámia jelenlétét óvatosabban magyarázza, ugyanis a sütőkemencék 
szájához is helyeztek edényeket ételmelegítés céljából. Ennek ellenére az erősdi kemencékről feltételezik, hogy tényleg kerámiák égetésére szolgálhattak, mivel a telephely szélén némileg elkülönültek a lakásoktól, és egymás mellett több kemence volt (Horváth Tünde 2010. 54.).

A Székelyföldön feltárt, másfajta kerámiát tartalmazó rézkori telepek egy részén (pl. Gémvára, Őrkő) jó iszapolású agyagból készült a kerámia, amelyet körömbenyomásos díszítéssel, a vastagabb falú edények esetében ujjbenyomásos bordadísszel dekoráltak. A perem alatti ujjbenyomásos bordadísz a Brassó melletti Schneckenberg-kultúra edényeivel mutat rokonságot, de ritka elemként Háromszéken is feltűnik a zsinegdíszes kerámia. Jellegzetes elem a vízszintesen átfúrt bütyökfül vagy szalagfül (Székely Zoltán

\section{(Az agyag soványítása)}

„A korábbi tapasztalataim szerint a hétköznapi sóderben sok mész van, ezért ha ezt közvetlenül használjuk, akkor az égetés után néhány nappal mészkukacos lesz a bográcsunk. Ezt elkerülendő felhasználás előtt a meszet el kell távolítanunk a kavicsokból. Ezt kétféle módon tehetjük meg. A korhűbb megoldás, hogy a szitált (1-3 mm-es) apró kavicsokat parázsban vagy más módon lassan felhevítjük, majd hűlni hagyjuk, és ezután rövid időn belül vízbe szórjuk. A vizet lecseréljük, átöblítjük a kavicsokat és így már felhasználható. Ebben az esetben a kavicsok között levő, vagy rájuk tapadó mész a tűzben égetett mésszé alakul, majd a vízben oltott mész lesz, amit öblítéssel eltávolítunk a kavicsok közül. Bár nincs adatunk rá, lehetséges, hogy használtak régen ilyen eljárást. A kevésbé korhű megoldás, ha valamilyen savval (például háztartási sósavval) oldjuk ki a meszet." (Véninger Péter 2010. 388.).
1948. 15-18.). A rézkor folyamán az agyag soványítására elsősorban kerámiazúzalékot használtak.

A bronzkorban sem használtak még korongot, hanem agyagszalagokból építették fel edényeiket, olyanképpen, hogy a kivágott szalagokat spirál alakban egymásra rakták, majd kézzel kívül-belül elsimították a szalagokat.

Az agyaghurkás edényépítés technológiáját magyarországi leletek alapján Gucsi László értelmezte: „a kör keresztmetszetű agyaghurkákat az egymásra helyezés pillanatában a hüvelykujj, a mutatóujj és a középső ujj összeszorítő mozdulatával lapították kissé oválisra." Az agyaghurkás technika mellett a fülek felhelyezésének speciális módjai is megfigyelhetők voltak. „Mindegyik esetben az elkészült edény oldalába a fül támaszkodási pontjainak helyére kisebb félgömb alakú mélyedést készített az egykori fazekas, majd ebbe a mélyedésbe dolgozta bele a frissen formázott fület. Egy esetben ugyanezt a módszert alkalmazták egy bütyök felhelyezésénél is. Ez a megoldás a későbbi fülcsapolás előzményének tekinthetô. A különbség csupán annyi, hogy nem lyukasztották át teljesen az edény falát." (Gucsi László 2006. 9.)

Ezt követte a díszítés és a kiégetés. Mivel bronzkori égetőkemencék nem kerültek elő, így nincs pontos elképzelés arra vonatkozóan, hogyan is égethették ki az edényeket. $\mathrm{Az}$ edényfelületeken felbukkanó foltok arra utalnak, hogy az égetési eljárások még nem voltak eléggé fejlettek, feltételezhető, hogy gödrökben vagy boglyákban égettek, 650-850 fokos hőmérsékleten.

A vaskor óriási technikatörténeti fejlődést hozott a mai Székelyföld területén is. A betelepedő szkíták révén a Kárpát-medence megismerkedett a fazekaskoronggal, de ennek általánosabb használatát a kelták terjesztették 
el. A Székelyföld területén is sok lelőhellyel jelen lévő kelta típusú (La-Tène) fazekasság már használja a korongot. Ugyancsak ezekhez a népekhez kötik a kétosztatú, rostélyos égetőkemencék elterjesztését is (Szabó Miklós 1971 adatait közli Csupor István - Csuporné Angyal Zsuzsa 1998. 118.). A vaskor úgynevezett hallstatti kultúrájában gyakran alkalmazták az ún. redukciós égetést is, ami abból állott, hogy az égetés utolsó fázisában elfojtották a tüzet, és a benn rekedt füst sötétté tette vagy bekormozta az edényt. Székelyföld mai területén jó pár jelentős kelta jellegű kerámialelet került elő. Legnagyobb hírnévre talán a Maroskeresztúron lelt nagy mennyiségű kerámiaedény tett szert, az itt feltárt edények közt kiemelt szerepűek a gömbölyödő hasú tálak, amelyeknek növényi motívumait árkokkal választották el egymástól. A keltákhoz köti a szakirodalom az ún grafitos kerámia előállítását is. Mivel a grafit

..említést kell még tennem egy keramikai termékről, mely a rómaiaknál jelképes és vallásos jelentőségű volt, de a mellett a közönséges életben is pótolhatatlan szerepet játszott. Ez volt a lámpa vagy tulajdonképpen mécses (lucerna, görögül: lychnos). Mellőzve a gyantával telített s gyékényből sodrott, ritkán használt gyertyafélét, a római rendesen csak olajmécsessel világította mind a kunyhót, mind a caesar palotáját. Olajat égettek mind a két hely lámpájában, legföljebb hogy megszagosították az előkelő házában. Az eszköz azonban, még ha aranyból készült is, bizony csak közönséges mécses volt és az egyiptomiaktól származott át a rómaiakra. (...) Ezrével találtak bronz és agyaglámpákat a római sírokban. E tárgyak ugyanis alkalmi ajándékul szolgáltak és a halottnak emlékül adták a sírba." (Wartha Vincze 1892.60-61.) növelte a kerámiák hőállóságát, ezért ezen tulajdonságai miatt alkalmazták a főzőedények, öntőtégelyek készítésében (Havancsák Izabella et al. 2009). A magyarországi dunaszentgyörgyi lelőhely kapcsán az archeometriai felmérések bebizonyították, hogy az ott fellelhető grafitos edények jelentős része helybeli agyagból készült, így csupán a grafitot szállították távolabbról - tehát minden grafitos edényben nem szükségszerű import terméket látni. Székelyföldön Gyergyószentmiklós és Gyergyótekerőpatak határában (Koch Antal 1885. 215.), valamint Vargyas, Felső- és Alsórákos környékén kisebb grafitlelőhelyek is voltak, ${ }^{2}$ ám ezeknek régi használatáról nincsenek információink.

\section{A római kerámia és a népvándor- lások korának agyagmúvessége}

Az agyagművesség történetében különlegesen fontos szerep jutott a római kor kerámiájának. A római kerámia nem pusztán a gazdag formavilágával, de technikai igényességével is elkápráztatja a mai szemlélőt. A korszakban több kerámiatípus élt párhuzamosan egymás mellett: a korongolt finomkerámia mellett mindvégig jelen volt egy kézzel formált, rusztikusabb edénytípus is, amelynek durva agyagja, kezdetlegesen formált vastag edényfala merőben más kultúrkörre utal. Ezek mellett import áruként megjelent a terra sigillata, a rómaiak híres terméke, amelyet az ókor porcelánja névvel is szoktak jelölni (Wartha Vincze 1892. 55.). A terra sigillaták többnyire asztali készlethez tartozó, finoman megmunkált edények voltak, finom csillogó felülettel, igényesen pecsételt mintavilággal. Ezeknek a kivitelezéséhez a fazekasok formatálakat, agyagsimítókat használtak. A sigillaták máig is egyedülálló, vöröses felületét egy agyagoldatban való fürdetés adta, voltaképpen ezt is slipnek nevezzük, a 
korábban említettek szerint: „Ezt az agyaglét külön kellett elkészíteni. Hamuval keverték, majd sók hozzáadásával érték el, hogy a nyúlós agyag és kaolin a vízzel folyékony agyagiszappá váljon, amelyben a nehéz részecskék leülepedtek. A felszínen maradó, csak nagyon kisméretű részecskéket tartalmazó oldatból lett a terra sigillata bevonata. Minôsége az oldatban lévő illit nevü, vastartalmú ásvány magasabb vagy alacsonyabb százalékarányától függött." (Gabler Dénes 2006. 25.)

2012-ben Mikháza és Deményháza közt tártak fel egy római kori civil települést, amely a mikházi castrumot szolgálta. Az ásatások során több kézművesműhely került felszínre, az itt talált olajmécses- és présformák arra utalnak, hogy biztosan e telephelyen készítették ezeket (Vajda György 2012). A rómaiak már használták kerámiáikon a zöldes vagy sárgás színű, jelentős ólomtartalmú mázakat.

A Székelyföld területén nemcsak a mikházi lelőhelyen, de több helyszínen is ráakadtak a mécsesek présformáira, ez a tény egyértelműen jelzi, hogy a római kori fazekasságban az elsődleges használati tárgyak helyben készültek.

A római kerámiában nagy hírnévre szert tett terra sigillaták ezzel szemben import termékek voltak, ezeket a mai Székelyföld területén nem készítették. A nagyobb erdélyi római telepeken feltárt sigillaták azonosítása bebizonyította, hogy elsősorban Gallia, Moesia és Pannonia területéről, valamint itáliai manufaktúrákból importálták ezeket. A mai Erdély területén Apulum (ma Gyulafehérvár), Porolissum (Szilágy megye), Potaissa (ma Torda), valamint Napoca (ma Kolozsvár) római telepein készült lokális gyártású, kevésbé igényes kivitelezésű terra sigillata (Rusu-Bolindeț Viorica 2007. 138-172.).

Csupán néhány szóval említjük meg, hogy a közelmúltban Székelyföld területén néhány vizigót telepet tártak fel, amelyek fontos információkkal járultak hozzá a környék kerámiatörténetének ismeretéhez. Telekfalván, Kadicsfalván világosszürke, szürke, részben finoman iszapolt, részben apró kaviccsal soványított tálak, fazekak, kónikus edények kerültek elő (Nyárádi Zsolt - Sófalvi András 2010-2011). Székelyudvarhely határában egy vízigót telepen két edényégető-kemence is előkerült, és több hatalmas, kb. 50 literes edény töredékeit sikerült felszínre hozniuk a feltáró régészeknek. ${ }^{3}$

\section{Az Árpád-kori kerámiamüvesség}

Bár az Árpád-korban Székelyföld területén eléggé sürű településhálózat alakult ki, a korabeli lakóházak feltárására csak szórványosan került sor. Székely Zoltán Zabolán és Székelypetőfalván Árpád-kori temetőket tárt fel. A magyar temetőkben viszont ritkán található kerámia sírlelet, ezért a régészek hosszú ideig nem figyeltek eléggé a magyarok kerámiaművészetére (lásd Fehér Katalin 2009. 29.). A Székelyföld területén végzett várásatásokból ugyan formailag és díszítmény szerint 12. századi jellegú kerámialeletek is kerültek elő, a régészek óvatosságra intenek ezek esetében: „Miután Székelyföld

„Az agyagművesség Európában csak az iparművészet elvilágiasodásával, a gótika kései szakaszában jut keleti hatásra nagyobb művészi jelentőséghez. Ennek oka az, hogy a cserépedényeknek az egyház nem vehette hasznát, $s$ a középkor végéig minden művészi tevékenység főrugója Isten dicsősége s templomaink minél pompásabb felszerelése volt." (Divald Kornél A magyar iparmúvészet története. Szent István Társulat, Budapest, 1929. 148.). 
Árpád-korából nincsen egyetlen biztos, pénzzel keltezett kerámialeletünk sem, a datálással nem árt óvatosan bánni. Szem elôtt kell tartani azt is, hogy a székely történelem sok vonatkozásban egy megkésett magyar történelem, és nagyon sok benne az archaizmus." (Sófalvi András 2005. 37.)

A kengyelekkel, zablákkal együtt előkerülő Árpád-kori leletek közül a csíkzsögödi 10. századiról tudott, hogy tartalmazott kerámiát is. Benkő Elek Keresztúrszék területén 8-12 lelőhelyről gyűjtött össze „kevés és jellegtelen" cseréptöredéket, ám nagyobb leletegyüttest csak pár helyről jelzett: Székelykeresztúr belterületén a 11. századra keltezhető edényeket tárt fel, ezeknek jellemzői közt a szögletes edényperemet, a hullámos vonalkötegeket, a fésűszerű eszközzel ferdén benyomkodott mintát emelte ki. Szentábrahámról hasonló kerámiát, Küsmödről hengertagos idomtéglát jelzett, ám mindezen leletekhez hozzáfúzte, hogy problémás lenne ezeket egyértelműen székelyekhez kötni. A Székelykeresztúron feltárt kerámia egy részéről kiemelte, hogy a „napjainkig alig kutatott - korabeli szász kerámia felé utal" (Benkő Elek 1992. 26-28.). Sófalvi András Felsősófalva, Sóvárad és Korond területén jelzett "formailag és díszítése alapján a XII. századra tehetó" kerámiát, ezeknek egy részén bekarcolt hullám- és csigavonalat, egyszerü peremeket figyelt meg (Sófalvi András 2005. 51-52.).

A technikatörténeti szakirodalom magyar jellegzetességként tárgyalja a jellegzetes bordás nyakú edényeket, a peremen belül elhelyezett fülű cserépüstöket (bográcsokat). Ezek egy része bolgár-török formavilágra, illetve sztyeppei bőredényekre vezethető vissza. Ezeken kívül különböző tálakat, fazekakat, bögréket, palackokat, játékokat (sípok, csörgők, kerámiagyöngyök, golyók) is készítettek a magyar fazekasok (Fehér Katalin 2009. 29-31.). A Székelyföldön Gyergyószárhegy területérôl jelezték korai cserépbogrács(ok) előkerülését, ám ezek valódi meglétét kérdésesnek könyvelik el korunk régészei (Sófalvi András 2005. 149.).

Holl Imre a budai ásatásokból előkerült 13. századi kerámiát megvizsgálva megállapította, hogy az Árpád-kori magyar kerámia még kézi korongon készült, hurkatechnikával. Ezt elsősorban az edények fenekének és oldalának illesztésénél figyelte meg: a fenékrész oldalát jobban oda kellett nyomni a koronghoz, mint a közepét, mivel ezt a részt fel kellett kissé húzni a hurkák odaillesztése céljából. Az edényfenék közepe így kissé fennebb került volna, ha nem homokozzák meg kellőképpen. Következtetéseit elsősorban a leírásokból még ismert kelet-európai, 19-20. század eleji, hurkatechnikával dolgozó népi fazekasság párhuzamaiból sikerült levonnia (Holl Imre 1956, 178-184.).

„Kaolin bányáink közül a csíkszentsimonit tartották üzemben, ha ugyan üzemnek nevezhető a tudás és rendszer nélküli kezelés, mit ezen fölötte értékes anyag kibányászásánál elkövetnek. Egyszerű falusi napszámosok ásnak itt, ásnak amott, anélkül, hogy bár a felső földréteget eltakarítanák. A föld beomlik és elpiszkolja, máshol meg eltemeti a fehér kaolint. [...] Kaolin van még a Hargita fürdő telepén és Csicsó község határában. Ezekről tudunk. Azonban a Hargita-hegylánc egész vonalán, így például Csíkszereda város határában is található helyenként nagyobb területen ez az anyag." (A Marosvásárhelyi Kereskedelmi- és Iparkamara jelentése Marostorda, Csík, Háromszék, Udvarhely vármegye és Marosvásárhely szab. Kir. Város közgazdasági állapotáról az 1912. évben, Marosvásárhely, 1913. 100-101.). 


\section{6-17. század - a székelyföldi fazekasság intézményesülése}

A 16-17. századtól a székelyföldi kerámiakultúra nagy átalakuláson ment át. Míg korábban a leggyakoribb a vörös, érdes felületű edény volt, és ritka luxuscikknek számított a mázas kerámia, addig a 16-17. század fordulójára Székelyföldön is megsokasodott a finomabb agyagból készült mázas kerámiaedény. Az edénytípusokban is óriási fejlődés ment végbe, nem pusztán formailag, de méreteiben is egyre szélesebbé vált a fazekasok termékskálája (Szőcs Péter Levente 2004). A fejlődés nem pusztán a mesterek számának megnövekedésén mérhető, hanem az intézményesülési igény megjelenése is ennek a jele.

A céhrendszer egyrészt a mesterek reprezentációs igényeit és a közös érdek képviseletét teremtette meg, másrészt a fazekasok termékeinek vitathatatlan minőségi javulásához is hozzájárult: a céh keretein belül külön látómester működött, aki a piacozások és vásározások előtt ellenőrizte a termékek minőségét, a selejtes edényeket elkobozta, ezáltal is ügyelve arra, hogy rossz minőségű termékekkel ne csorbíthassák a mesterek a céh jó hírnevét. Ugyanakkor a közös nyersanyagbeszerzés megkönnyítette a mázhoz, engóbhoz való hozzájutás feltételeit. Ez egyben azt is jelentette, hogy a céhes fazekasság élesen elkülönült a parasztfazekasságtól. Míg valamennyi céh keretében finomabb megmunkálású díszkerámia is készült, amelyet a céh a helység határain kívül is értékesített, a falusi központokban az érdekképviselet hiánya a régies formákhoz való szorosabb kötődést és a máz mérsékeltebb használatát eredményezte.

1573-ban Udvarhelyen megalakult az első székelyföldi fazekascéh, amely a szász céh- szabályzatok múködési elvei alapján szerveződött. A céh 1745-ös, máig fennmaradt magyar nyelvű szabályzata a kályhák és kályhacsempék készítését említi, és a további 18. század közepi rendelkezések a fazekak, csuprok, mély tálak, tányérok, háromlábú lábasok, korsók, fedők készítésére térnek ki. Ezek az adatok azt jelzik, hogy a termékskála egyre szélesebbé vált, így a 18. századra már csaknem valamennyi edényforma elkészítéséhez adott volt a kompetencia a céh keretein belül. Ugyanakkor a fehérfölddel való díszítésre, a zöld és a sárga máz használatára, illetve tiltására vonatkozó megjegyzések egyértelművé teszik, hogy az udvarhelyi céhes igényszint már túljutott a mázatlan egyszerű főzőedények készítésén. A 19. századtól az udvarhelyiek híres termékévé vált a bokály, ez a karcsú, magas díszedényforma, amely Székelyföld díszítőművészetében jelentős karriert futott be (Szőcsné Gazda Enikő 2008. 500.). Udvarhely Székelyföld tálas központjának számít, mivel a mészszemcséket is tartalmazó agyag nem volt jó a főzőedények készítésére. Az udvarhelyi mesterek a 19-20. század fordulóján a közelben fellelhető ragyogó fehérfölddel teljesen befödték az edényeiket (a fazekak alját is), és írókás kék mázdíszítményekkel írták tele a jórészt díszedénynek gyártott egyfülü fazekakat, tálakat, csuprokat (3. és 4. kép).

1612-ben Marosvásárhelyen is megalakul Székelyföld második fazekascéhe, amely a szabályzatát az udvarhelyi mesterektől vette át (Balogh Ödön 1972. 314.). A vásárhelyi ásatásokból előkerült nívós 17. századi kályhacsempék egyértelműen jelzik, hogy az intézményesülés időszakára már itt is fejlett technikai tudással rendelkező agyagmúvesek éltek (Zrínyi Andrei 1975), akik a 18. századtól úgyszintén változatos edényállományt készítettek. A céh termékei között bizonyára 
fontos szerepet játszhattak a bokályok, ám ezek megbízható azonosítását még nem végezte el a szakkutatás. A marosvásárhelyi történelmi múzeumban őrzött ragyogó zöld mázú, nagyméretű rátétdíszes edények bizonyára a helyi céh termékei lehetnek. A 20. század elején a céh 25-30000 használati edényt állított elő évente (Kalecsinszky, Alexander von 1906. 131.), és ekkor egy nagyobb kályhagyár is múködött itt.

Kézdivásárhely fazekasainak céhalapítását egy 19. századi céhkorsón szereplő dátum szerint 1649-re tesszük. Az itteni mesterek a fehérföldezésen, mázazáson, festésen kívül egy ritkább fazekastechnikát is meghonosítottak Székelyföldön. A sgrafitto vagy alákarcolásos technika lényege, hogy a fehérfölddel (engóbbal) leöntött, félig megszárított edénybe hegyes eszközzel belekarcolták a mintát. Az engób átkarcolásával előtűnt a minták körvonalainál az agyag természetes

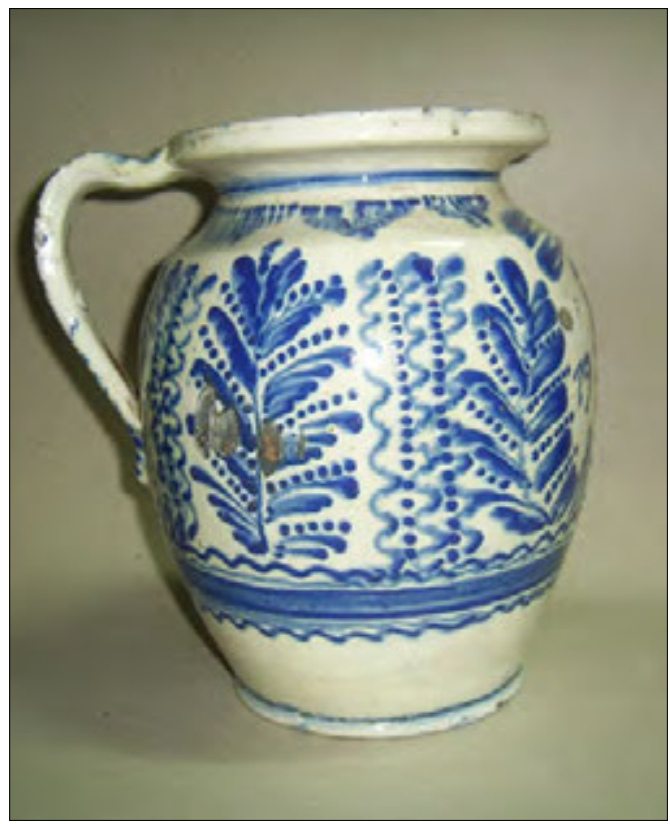

3. kép. Székelyudvarhelyi fazekasműhelyben készült írókás díszítésü fazék. 19. sz. SzNM színe, emellett pedig a bemélyített felület plaszticitást is adott a mintáknak. A karcolt vonal a színes engóbbal ecsettel kifestett mintákat keretezte tehát, utólag pedig az edényt színtelen mázzal födték be. Mivel a technika viszonylag korán kikopott a használatból, így nem tudjuk eldönteni, hogy milyen eszközt használtak a karcolásra (Szőcsné Gazda Enikő 2010a). Kézdivásárhely fazekasainak híres terméke volt a bokály, amelyről a 19. század közepétől eltûnt a karcolás, ekkortól az írókás díszítés került túlsúlyba. A nagyobb céhedényeken feltűnik a plasztikus pecsétdísz. A céhes fazekasok vizeskorsókat, csészéket is készítettek, és híres termékük volt a nagyméretű, zöld mázas vagy mázatlan csillámos kályhacsempe is (5. kép).

Céhszerű fazekastömörülések még több helységben múködtek. Így például a berecki fazekastársulat 1838-ban alakult (Gazda Enikő 1997-98. 65.), céhesedése előtt az

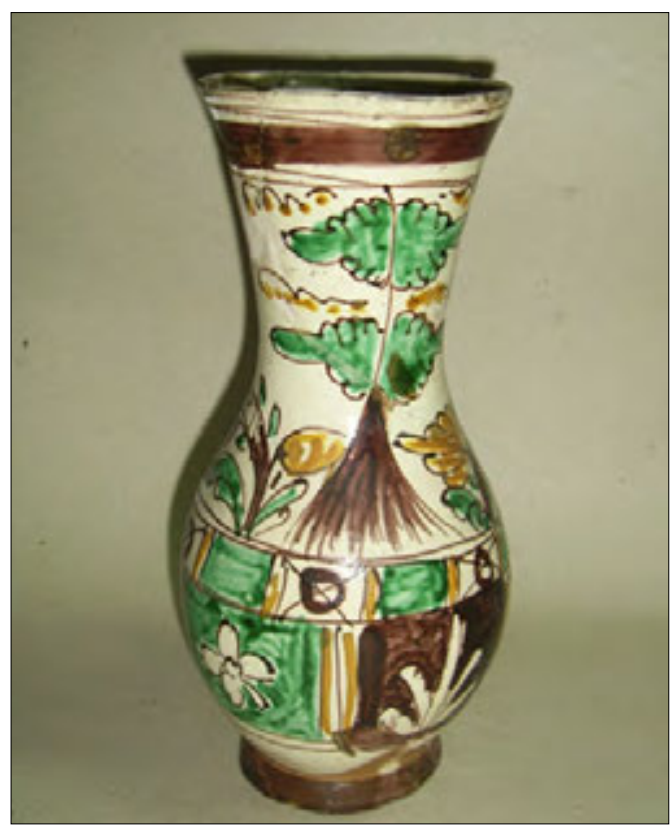

4. kép. Székelyudvarhelyi céhes múhelyben készült bokály. 19. sz. SzNM 
ojtozi vámszolgálat számára szolgáltatott be edényeket, később pedig a környékbeli megrendeléseknek tett eleget használati edények készítése révén. A Székely Nemzeti Múzeum számára 1883-ban megvásárolt berecki edényeknek elsősorban finom formai elemei lepnek meg. A kiöntőcsőrös kanna, levesestál, fazék kifinomult formavilágához képest visszalépést jelentenek a 20. század húszas-harmincas éveiben keletkezett vastag falú, zöld alapon barnával csíkozott korsók, fazekak, gyertyatartók. 1906-ban a berecki fazekasok már csak évi 3-4000 edényt készítettek, ami a más nagyobb fazekastömörülések éves hozamához képest hanyatló mesterségre vall (Kalecsinszky, Alexander von 1906. 48.). A fazekalás végleges megszűnése itt is az hatvanas években történt meg (6. kép).

Az erdővidéki Baróton 1827-es szabadalommal úgyszintén múködött egy fazekas-

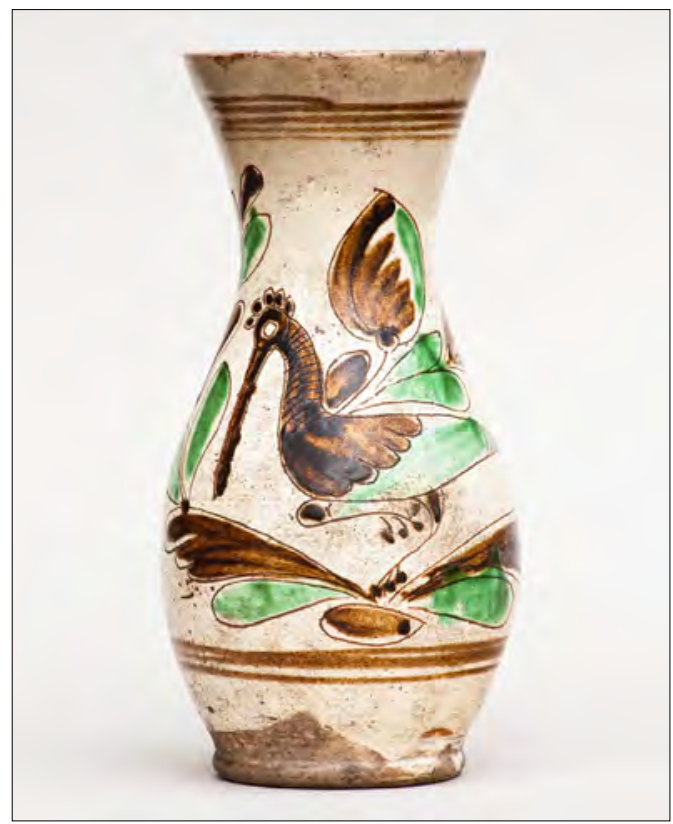

5. kép. Sgraffito technikával készült bokály, Kézdivásárhely, 18-19. század fordulója céh, amelynek tagjai között köpeci mesterek is dolgoztak. Bár a céh termékeiről nincs átfogó képünk, annak jelentős termelésére világít rá a Kalecsinszky-féle felmérés, amely szerint 1906-ban évi 46800 edény készült itt (Kalecsinszky, Alexander von 1906. 43.). A céh presztízsedényeiként számontartott céhkancsókról maradt fenn csupán néhány rossz minőségű fotó. Az Erdővidékről előkerült jó mázú sötétbarna edények és a hasas bokályformák is talán e központ termékei lehetnek.

A fazekastömörülések közül még fontos szerepe volt Székelykeresztúrnak, ahol az ásatásokból előkerült nagyszámú, helyben készült 16-17. századi csempe- és edénytöredék egyértelműen jelzi a mesterség régi gyökerét (Benkő Elek - Ughy István 1984). A keresztúri fazekasok csempéi és mázas edényei roppant fejlett agyagiparról tanúskodnak. Az 1860-ban alakult székelykeresztúri

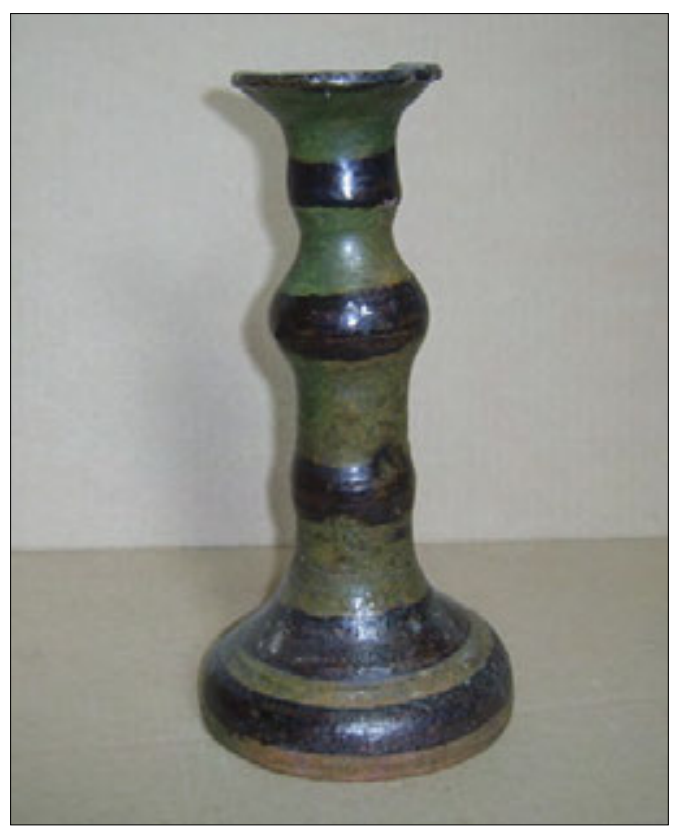

6. kép. Berecki gyertyatartó, 20. sz. eleje. SzNM 
ipartársulatban is több fazekas dolgozott, az utolsó mester az 1930-as években hagyta abba a mesterséget (Sándor-Zsigmond Ibolya 2005. 28-29.). A kézdivásárhelyi céh termékeivel rokonítható karcolt bokályok, tányérok, kulacsok is készültek itt, de elterjedt volt az engóbozott felületen írókával díszített korsó, tál, tányér, fazék is. Az eddigi feltárások azt sejtetik, hogy Székelykeresztúrt a jelentős központok között kell számontartanunk (Csupor István 2008. 24.).

\section{Falusi fazekasság Székelyföldön}

A fontosabb céhes központokon kívül számos olyan kisebb helység található Székelyföldön, amely a határában lévő jó minőségú agyagot kihasználva edény-, kályhacsempevagy pipakészítéssel foglalkozott.

1902: „Udvarhelymegyében Korond népének jelentékeny része, állítólag mintegy 600 egyén foglalkozik fazekas háziiparral és készíti az átlagosan ösmert mázolatlan, jó korondi főzőedényt. Jelentőségénél fogva már több ízben tétettek kísérletek a korondi edényipar föllendítésére. Így mintegy nyolcz évvel ezelőtt hosszabb ideig tartó tanfolyam rendeztetett az oda kiküldött vándortanító által, néhány évvel ezelött pedig három fazekas államköltségen a székelyudvarhelyi szakiskolán rendezett tanfolyamon vett részt. Sajnos, a tanfolyamnak érdemleges eredménye nem volt. A korondi főzőedénynek használata erősen apadóban van, mert mázolatlan lévén, nehezen vagy éppen nem tisztitható és igy a kissé kényesebb igényeket már nem elégiti ki. Tetszetősebb és mázas edényt a korondiak ösmereteik korlátoltságánál fogva késziteni nem tudnak." (Örley János 1902. 183).
A legtöbb fazekasfalu talán Udvarhelyszék területén volt. Közülük napjainkig a legismertebb a sóvidéki Korond, ahol már 1616-ban feljegyezték a mesterség művelését (Balassa Iván 1989. 152.). A korondi fazekasság történetének több, markánsan elkülönülő korszakát különböztethetjük meg. Igazán híresekké a főzőfazekaik, vízeskorsóik váltak, amelyeknek elkészítéséhez homokkal erősen soványított agyagot használtak. A korondi mesterek technikai tudását jelzi az a tény, hogy még kétvékás (csaknem 50 literes) fazekat is készítettek, melynek korongozásához nem kis erőfeszítés és gyakorlat kellett (Kresz Mária 1991. 77.). A régi korondi fazék teljesen mázatlan, ún. parasztedény volt, amelynek puritán díszei között csak a fehérfölddel vagy vörösfölddel való csíkozás, hullámvonalas dekoráció, illetve az agyag peremezése figyelhető meg. Egyszerüsége és tartóssága miatt a korondi edényeket már a 17-18. században is messze földre szállították. A korondiak a mázazás technikáját a 19 . század végétől kezdték elsajátítani. 1892-ben a község területén közel félesztendős háziipari tanfolyamot létesítettek, ezen már próbálták finomabb munkákra nevelni a fazekasokat (Székely Nemzet 1892. július 2. X. évf. 98. szám). 1893-ban a székelyudvarhelyi kő- és agyagipari szakiskola megalakulásával újabb lendületet vett a mázazás oktatása, mivel az iskolában néhány korondi diák is tanult, így a technika hazakerült a településre, ám ennek széles körű alkalmazása csupán az 1930-40es években valósult meg (7. kép).

Az udvarhelyszéki települések közül Etéden is több fazekas múködött, akik kályhacsempéket és különböző cserépedényeket készítettek. A székelykeresztúri Molnár István Múzeumban lévő Jacobus Dosa de Etéd feliratos kályhacsempe egyértelműen jelzi, 
hogy Etéden a 18. században már kiforrott technikai tudással rendelkező fazekasok éltek. A 19. században - akárcsak a közeli Küsmödön - itt is nívós mázas kályhacsempék, szép formájú háztetődíszek, edények készültek.

Küsmöd fazekasai különleges hírnevüket úgyszintén a színpompás kályhacsempéiknek köszönhetik. A 19. század közepétől itt élt és alkotott Székelyföld egyik leghíresebb kályhásmestere, Bereczki Zsigmond. Bereczki hírnevét elsősorban kísérletező hajlamának köszönheti. Csempéin, edényein a különlegesen szép színű, ragyogó felületű mázak a figyelemre méltók. Bereczki mázainak szépségére már a 20. század legelején felfigyeltek a kutatók, úgy vélték, hogy megreformálta a mázkészítést. Valószínű, hogy ő már értett ahhoz, hogyan ellenőrizze, hogy meszes-e az agyag vagy sem, és kikísérletezhette azt is, hogy hogyan viszonyulnak egymáshoz az engóbok és a mázak. Edényein, csempéin ugyanis nagyon jól tapadnak a mázak, pattogzó mázat még másfélszáz évvel a keletkezésük után sem látunk rajtuk. Míg kora faluhelyeinek csempéin általában csak a népi faragás ornamentikáját láthatjuk (mivel falusi asztalosmesterek készítették a csempedúcokat is), addig Bereczki már újszerű díszítményeket is készített. Dúcainak nagy része még fából készült, de már ívelő felületeket, rátétdíszeket is alkalmazott a kályháin. Ugyanakkor a szokványos füstelvezetési módszereken is változtatott: kályhacsempéinek nagy része már nem a klasszikus székelyföldi nyílt tűzhelyes cserepesekhez készültek, hanem a polgárházakban is használható oszlopkályhák felé is nyitott. Csempéin a viasszal való batikolás technikáját is felismerhetjük, tehát próbált túllépni a korára jellemző egyszerú fazekasmódszereken (Szőcsné Gazda Enikő 2010b. 50-51.). Bereczki Zsigmond utód-

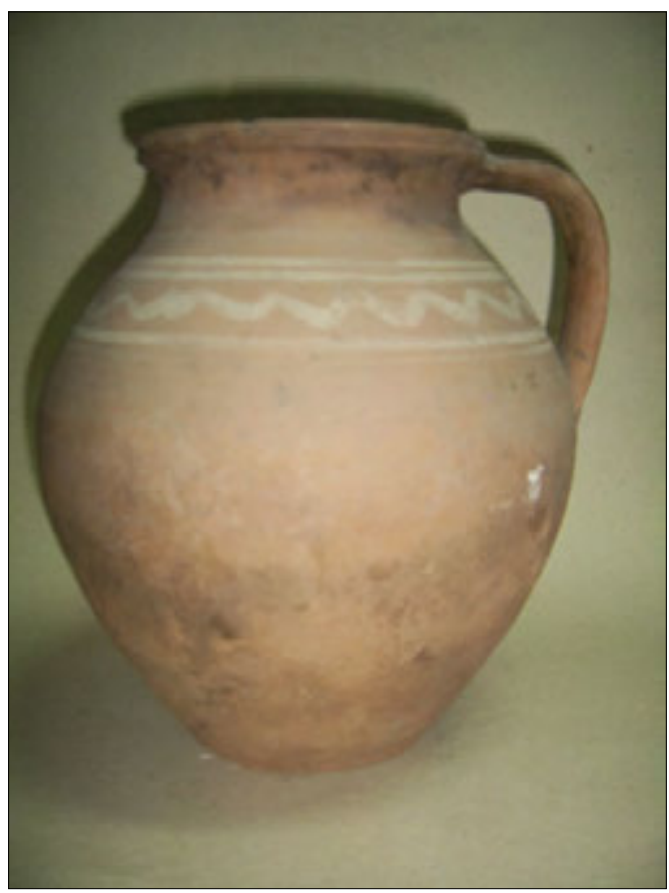

7. kép. Korondi mázatlan fazék, 19. sZ. SzNM

ja, Imre formai bravúrokkal próbálta elődje technikai zsenialitását túlszárnyalni, termékei közt harangokat, furcsa alakú kis edényeket, de olyan érdekességeket is látunk, mint például a sárga mázazású, cserépből készült vadászkürtök (8. kép).

A Rika-hegység lábainál elhelyezkedő települések közül Homoródalmás és Magyarhermány fazekasai is ismertekké váltak jó termékeikről. Magyarhermányon már egy 1750-es összeírás is megemlíti a fazekasokat, és Fényes Elek statisztikája szerint 1840-ben évi 20-25 000 edényt készítettek. A hermányi fazekasok által készített edényformákra viszonylag jó rálátásunk van, mivel Csog Ferenc helyi mester múhelye és terméktípusai az 1940-es években a Székely Nemzeti Múzeumba kerültek. A jó minőségű, vörös színű, vastartalmú agyagnak köszönhetően Magyarhermányban nagyméretû lakodalmi káposztásfazekaktól kisebb fazekakig, kan- 


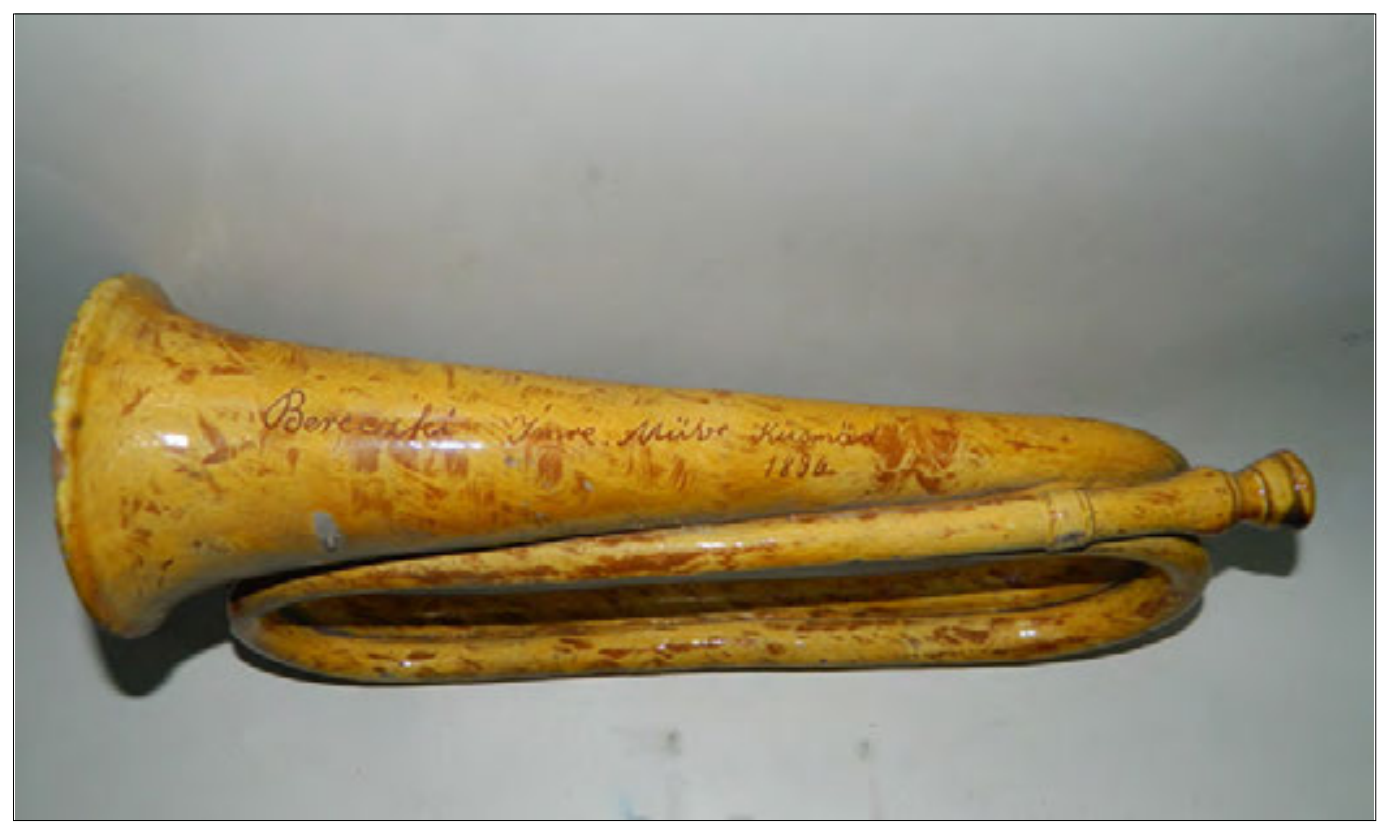

8. kép. Küsmödi agyagkürt, 19. sz. SzNM

tákig, levesestálakig, korsókig, cserép kürtöskalácssütőtől tölcsérig és padlólocsolóig, dohánytartó medvétől tálakig, tányérokig, kályhacsempékig, pálinkamelegítő edényekig csaknem minden edényforma készítéséhez értettek (Seres András 1974). A mélyzöld, barna és sárga mázak mellett a hermányi mesterek több készítéstechnikai érdekességgel tették szebbé edényeiket. A nagy, kétfülü fazekak kedvenc dísze volt az abroncsozás, a plasztikus agyaghurkákból félhold alakban kicsíptek vagy kivágtak, így tették még dekoratívabbá azokat. A dohánytartó medvék szőrének imitálását az agyag krumplitörőn való átnyomásával, ennek az edényfelületre való felragasztásával érték el. Kedvelt eljárás volt a máz vagy fehérföld kanállal való öntése, az így keletkezett félköríves foltok körvonalait ecsettel megpöttyözték. A nagyobb edényeken a mázatlan felületre engóbbal csíkokat húztak, és a még nyers engobót bevagdosott bőr- vagy gumidarabbal meghullámozták, így keletkezett a fésűs minta. A fehérfölddel díszített edényt zöld mázba mártották, így az engóbos felület világosabb zöld, az edény vöröses falára tapadó máz pedig sötétebb zöld lett. Az edény felületére néha szamártövissel fröcskölték fel a többszínű mázat, de szívesen használták a szaruból készült írókát, sőt az ecsetet is. Az utolsó hermányi fazekas az 1970-es évek végéig készítette az edényeket (9. és 10. kép).

A csíki fazekasfalvak közül a legnagyobb hírnévre a csíkmadarasi fazekasság tett szert, itt a 19. század közepén csaknem az egész falu edénykészítéssel foglalkozott. A vasas agyag nagyon kedvezett az állóedények készítésének, és híresen jó főző- és vizesedények sora készült a helységben. A csíkmadarasi fazekasság ma elsősorban a puritán díszítésű fekete edényeiről ismert, ezeket a füst visszafojtásával, úgynevezett redukciós égetéssel állították elő. A fekete edény készítéséhez más típusú égetőkatlan kellett, mint 


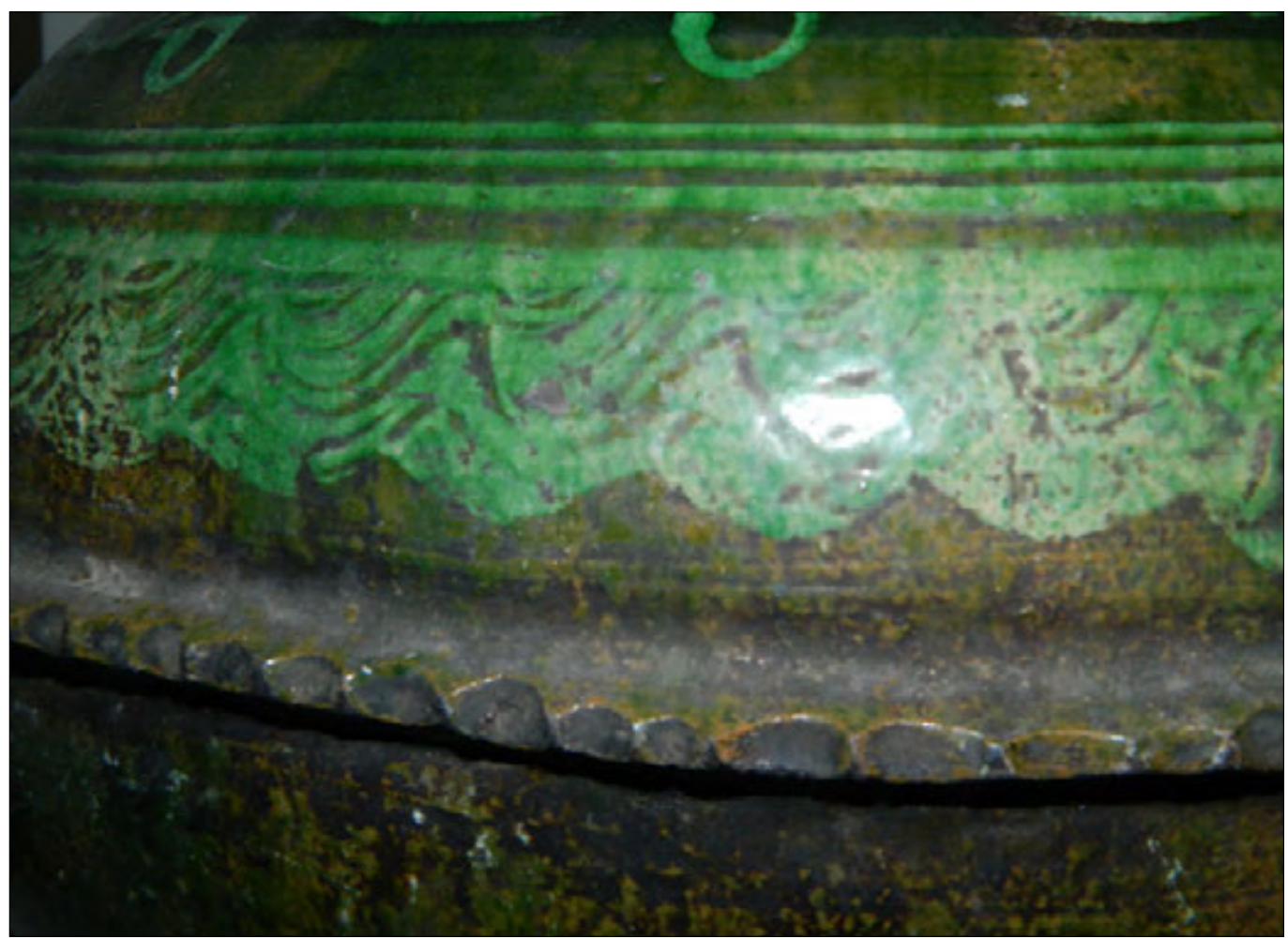

9. kép. Magyarhermányi edény fésűs és rátétmintája, 19. sz. SzNM

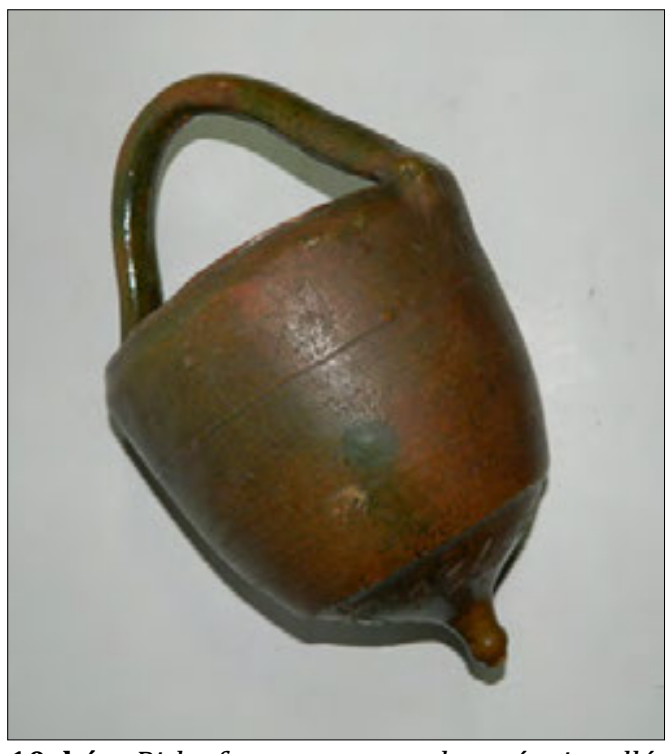

10. kép. Ritka forma a magyarhermányi padlólocsoló, 19. sz. SzNM amelyet a mázas edényekhez használtak. A csíkmadarasi edények díszítési technikái közt az egyszerű karcolóeszközök, cserép pecsételők használata mellett feltűnik a fogaskerékkel való díszítés: a nyers agyagedényen végiggörgetett fogaskerék apró pontsort eredményezett az edényeken. Csíkmadarason készült zöld és sárga mázas kerámia is, amelyek közül kiemelkedik két ritka forma. Itt készítették a csíkszenttamási templom 17. századi korongolt, impozáns méretű toronygombját (Farkas Irén 1997-98. 104.). A szakirodalom egy jellegzetesen székelyföldi edényfajtát, a pálinkamelegítőt elsősorban Csíkban elterjedtnek tekinti, és fő készítési helyszíneként Csíkmadarast említi (Rangyák József, V. 1998) (11. és 12. kép). 
A kályhacsempe készítésének szintén jelentős hagyománya alakult ki a településen: már a 18. század eleji vashámor összeírásakor felsorolták a hámor melletti házak parasztkályháit, de a településről előkerült nagyszámú, mázatlan és zöldmázas csempe és az ezek elkészítésére használt, fából készült nyomódúcok a kályhásmesterség elterjedtségét jelzik.

A Madaras tôszomszédságában található Csíkdánfalva szintén korai központ. A helység fazekasai szintén vasas agyagot használtak, ám az ebből készült fazekakat, vizeskorsókat, csészéket, tálakat és tányérokat, lábasokat, kürtöskalácssütőket mázazták, ezzel próbálták a madarasi edény konkurenciáját megteremteni. A Csíkdánfalván készült edények közt van egy jellegzetes, ritka forma, amelyet csak az 1940-es években készítettek: a kereskedelemben tapasztalható üveghiány

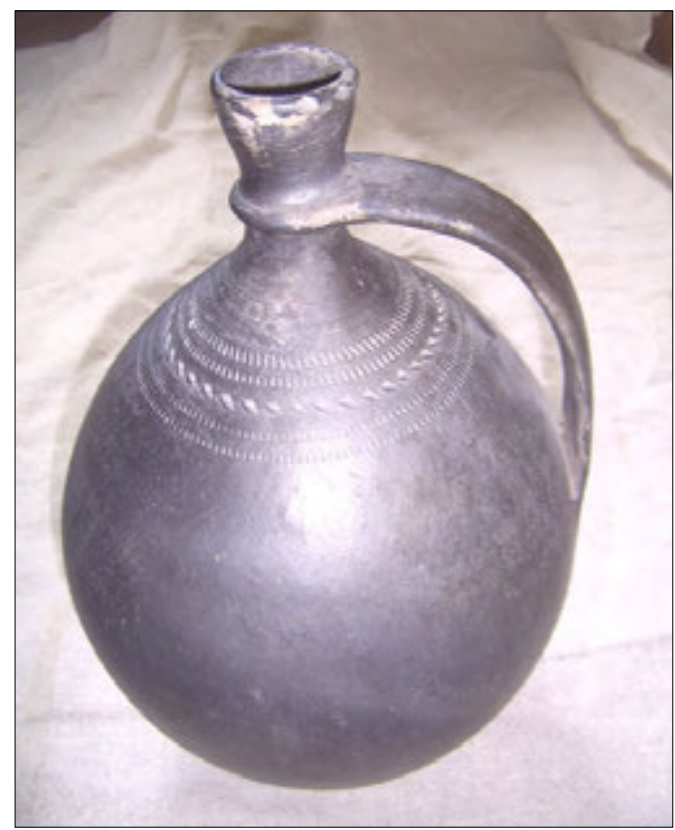

11. kép. Redukciós égetésű fekete korsó, Csíkmadaras, 19. sz. SzNM

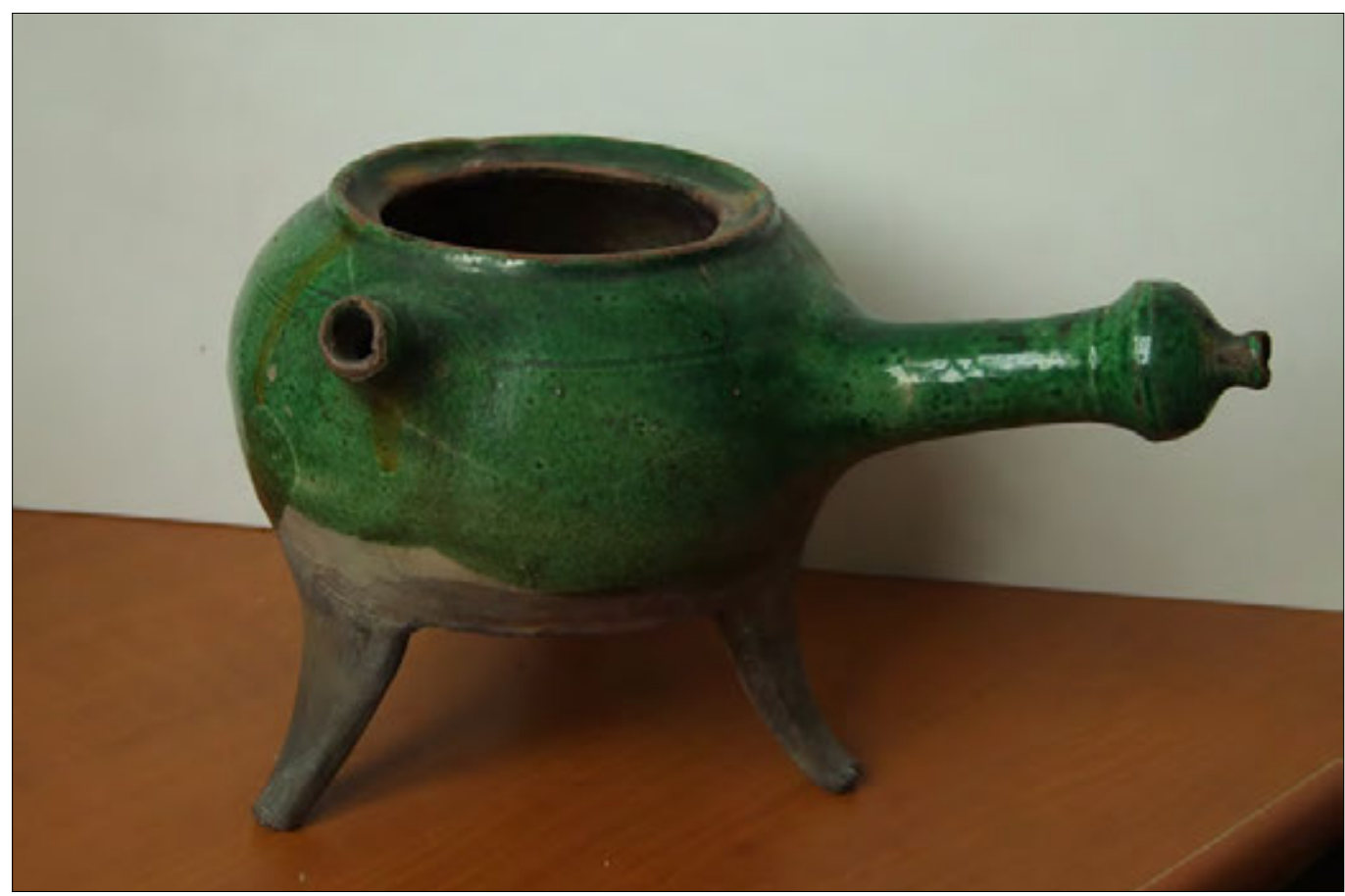

12. kép. Pálinkamelegítő, Csíkmadaras, 19. sz. SzNM 
hatására széles szájú uborkásedényeket készítettek, amelyeknek formája a 3 és 5 literes edényekre vezethető vissza. A csíkdánfalvi fazekasság számára technikatörténetileg újabb fejezetet nyitott az 1940-es években az ún. Kerámiaműhely megnyitása. A kisebb méretű gyárként jellemezhető műhelyben a fekete díszkerámiát benzinben vagy fáradt olajban feloldott szurokkal vízhatlanították, majd ennek száradása nyomán az edény felületét kővel, vászonnal csiszolták és simították. A díszítés nem pusztán az impregnálási, vízhatlanítási módszerekben volt különleges, de a fafaragáshoz szokott munkások az edények felületét is kifaragták. A kerámiamúhely a helyi hagyományoktól elrugaszkodó kerámiaformákat honosított meg: a görögös szűk nyakú, széles szájú edényeken kívül a nyolcvanas években kedvenc termékük volt a hatalmas méretű padlóváza.

Háromszéken olyan méretű fazekasgócok, mint Korond vagy Csíkdánfalva, nem léteztek, ám a falvak határában lévő jó minőségű agyag több helyen is arra késztette az embereket, hogy az ingyen nyersanyagot kipróbálják. A sepsiszéki Bodokon 18. századi adataink vannak fazekasok működésére. 1883-ban Bodokról került a Székely Nemzeti Múzeumba pár nagyméretű fazék, tál, korsó, de cserép háztetődíszeket is készítettek itt. A 19. századtól a kályhacsempék készítését is megpróbálták az Olt menti településen, és a betelepedő baconi cserépvetők a tégla- és cserépkészítést is meghonosították. A bodoki edények zöld, barna vagy áttetsző mázúak, díszítményük széles ecsetvonásokkal, fehérfölddel készült. A közelben lévő Kálnok fazekasságának az első jele egy 1776-os, mesterneves kályhacsempe (Szőcsné Gazda Enikő 2010b. 55.). 1883-ban a Székely Nemzeti Múzeum számára vásároltak pár edényt innen, ezek és a későbbi gyűjtések szerint barna, illetve sárga mázas, fröcskölt tányérok, levesestálak, korsók készültek itten. A kálnokiak leggyakrabban a mintát mázzal festették fel az edényekre, az engóbokat nem - vagy csak visszafogott mennyiségben - használták.

Az orbaiszéki Páva és Zabola fazekassága a 19. században bontakozott ki. Páván több, Zabolán kevesebb fazekas élt, és a két település egymáshoz közeli fekvése miatt nehéz elkülöníteni, hogy hol mi készült. A pávai mesterek naiv virágmintával, ecsetfestéssel ellátott bokályokat is készítettek, de különféle használati edényeket is csináltak. Páván zöld mázas kályhacsempék is készültek, tulipánbimbós és madaras díszítéssel. A pávai csempék sekély plaszticitása azt jelzi, hogy a dúcokat faragáskor nem mélyítették nagyon be.

Erdővidéken Barót és Magyarhermány mellett a legjelentősebb központ Nagyajta volt. E település a 19. században járási székhely is volt, jelentős iparossággal. Jó ideig Nagyajtához kötötte a szakirodalom a karcolt körvonalú sgrafitto díszkerámiát (amelyet Kézdivásárhelynél mutattunk be). Valószínűbb, hogy Nagyajtán elsősorban főzőfazekak és különféle használati edények készültek, a település elsősorban a 19. század második felétől vált fontosabb központtá. A jó minőségű agyagnak köszönhetően Ajtán nagyon nagy méretű edényeket (fazekakat, korsókat) is készítettek, amelyeknek díszítésére a fehér engóbot sárgás árnyalatú ólommázzal födték le, így edényeik a világosbarna és sárga árnyalataiba játszanak. A faluban végzett padláskutatások és a múzeumba bekerült darabok azt jelzik, hogy a korsókon és különböző méretű fazekakon kívül lapos fenekű tejfőző edényeket (ún. kászrókat), szilvatörő edényeket, különböző méretű tálakat, tányérokat, némákat (perselyeket) készítettek (saját gyüjtés, 2014). 
Marosszék központjai közül méreteiben kiemelkedik a 18. század elejétől Makfalva, ahol jelentős csempés és használati edényeket készítő centrum működött. A makfalviak nagyméretű korsói, főzőfazekai nagyon szép formájúak és nagyon szép mázazásúak. Edénykészletük változott attól függően, hogy éppen melyik időszakban és milyen piacokra mentek. Tavasszal inkább egyliteres korsót, nyáron 2-3 literes korsót, ősszel a borszüret idején a zöldmázas, 5-10 literes nagykorsót igényelték. Gyakran készítettek kisebb gyermekjátékokat is: kis tányért és korsót, perselyt, sípot. A mezei munkások ellátására csatlóst, csészéket, fennfüles edényeket is készítettek. Makfalván rengeteg, hatalmas méretű, zöld mázazású kályhacsempe készült, félkész darabokból jól látható, hogy ezeket a máz alatt fehérfölddel födték le, ennek köszönhette a zöld ragyogó világos színét. Ritka kerámiatípusa a központnak a mázas kürtőcső, ennek szép darabjai láthatók a falu helyi múzeumában. A zöld és sötétbarna mázzal is változatos színárnyalatokat értek el az itteni fazekasok, általában azzal a módszerrel, hogy a fehér engóbot csak az edény egy részére öntötték rá, így a zöld máz hol erre a fehér felületre, hol az edény vöröses agyagjára került, eszerint különböző színhatásokat nyújtott. Szélesebb tejfőző edényeik, lábosaik között gyakori a belül mázazás, függőlegesen csíkozott mázfelülettel. Az edények felületébe gyakran fakéssel csíkot mélyítettek, de az igen kedvelt háztetődíszekre agyaghurkákat, kisebb rátétdíszeket is formáltak (Suba László 1996. 3-4.).

Marosszék másik jelentős központja Szolokma, itt a tálak és tányérok készítése vált elterjedtté, mivel magas edények készítésének nem kedvezett az agyag (Tófalvi Zoltán 1996. 94.).

A történelmi Aranyosszék települései köréből a várfalvi fazekasság kapott jelentősebb szerepet, ebben a helységben változatos használati edényeket készítettek.

\section{A székelyföldi közelmúltbeli fazekasság technikai jellemzői}

Székelyföld újabb kori kerámiaművességét már könnyebb technikai szempontból is elemezni, mivel számos tanulmány tér ki az edények készítéstechikájára, és egyes hagyományos központok esetében (Korond, Dánfalva) közvetlen megfigyeléseket is végezhetünk. Napjainkban kevés kivétellel korongozással készülnek a fazekastermékek (néhány préselt tányértól, formába öntött edénytől eltekintve), kályhacsempék esetében pedig a gipsz vagy fa nyomódúcok alkalmazása figyelhetö meg.

Az agyag bányászását nagyobb időközönként és nagyobb mennyiségben végezték el, mivel a kibányászott agyagnak jót tett az állás. A csíkdánfalvi fazekasok például késő ősszel, a vetemények kikerülése után fejtették ki a humuszréteg alól az agyagot, és ha sikerült, ekkor hozták be az egész esztendőre valót, mivel jót tett amúgy is az agyagnak a fagy, porhanyóbbá tette azt (saját gyűjtés 1998). A magyarhermányi fazekasok is őszszel 8-10 szekérnyi agyagot hordtak be, hogy a fagy szétporlaszthassa (Seres András 1974. 359.).

A kibányászott agyag finomításának több módszere volt. Bodoki fazekasleszármazottak emlékei szerint a nagyobb kockákra leszelt agyagot botokkal potyolták, majd egy speciális szelőkéssel vékony szeleteket vágtak belőle, ennek célja az volt, hogy a kavicsokat, gyökereket ezáltal megtalálják és eltávolítsák, mivel ezek mind a korongozáskor, mind az égetéskor problémát okozhattak.

Az agyagszelő késnek több formája volt. Magyarhermányban a helyi kovácsok a hasz- 
nált kaszákat alakították át görbe agyagszelő késekké (13. kép).

Amennyiben egy fazekas nem rendelkezett szelőkéssel, a szeletelésre alkalmas volt a rézdrót is, ennek a vékony drótnak a végére vásznat kötöztek, hogy a nedves kézből nehezebben csússzon ki. A szeletelést többször is elvégezték, mert nagyon fontos volt az agyag kellő megtisztítása.

A rögölés előtt fontos volt annak az ellenőrzése, hogy tartalmaz-e az agyag meszet. Nem tudjuk, hogy a régebbi korokban hogyan ellenőrizték ezt, valószínúleg a használat során tapasztalták meg, hogy érdemes-e egy bizonyos lelőhely agyagját főzőedények készítésére használni. A hetvenes években a korondi fazekasok úgy ellenőrizték a mésztartalmat, hogy kevés sósavat cseppentettek a palára, és amennyiben az pezsgett, akkor ez a mész jelenlétét jelezte (István Lajos 1973. 4.). Időnként az agyag jó minőségén a homokkal való soványítás nem javított, hanem rontott: a homok ugyanis mészszemcséket is tartalmazhatott. A mész égetéskor vagy a nedves levegő hatására kipattant az edényből.

Kézdivásárhelyen napjaink csempekészítő mestere, László Károly a Kászonújfaluból

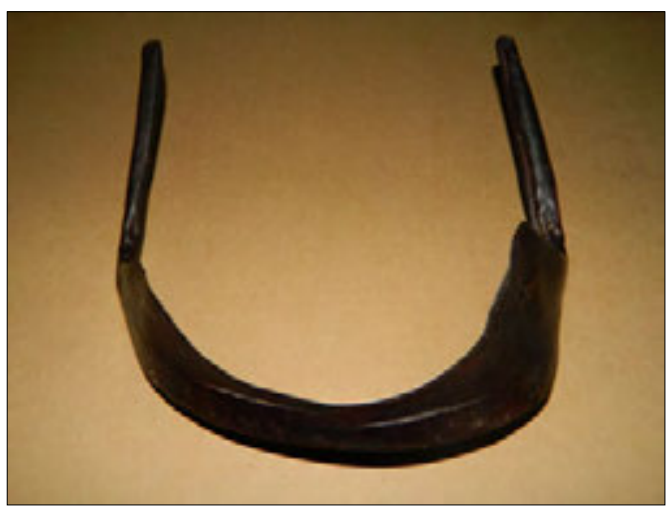

13. kép. Agyagszelő kés, Magyarhermány, 20. sz. eleje. SzNM beszerzett agyag soványítására a kereskedelemből vásárolt aluminium-oxidot $\left(\mathrm{Al}_{2} \mathrm{O}_{3}\right)$ alkalmaz, mivel csak így tud biztos lenni abban, hogy a soványítóanyag nem tartalmaz meszet, és nem rontja meg a csempe minőségét.

A kevés mésztartalmú agyagot Marosvásárhelyen a mázatlan vizeskorsók készítésére használták, mivel ezt még megbírta az edény (Balogh Ödön 1972. 319.).

A többszörösen felvagdalt agyagot Korondon taposással tették képlékenyebbé, ezt mezítláb végezték, hogy a kisebb kavicsokat a lábbal is érzékelhessék (14. kép).

Modernebb eljárás az őrlés. A különböző agyagőrlők egy részét a fazekasok maguk készítették el. Legegyszerűbb típusuk a két hengerből kialakított őrlőeszköz, amely a szúk résen átpréseli az agyagot, ezáltal a csomók vagy kövek szétzúzódnak vagy az őrlőben maradnak. Modernebb típusú a nagyobb kapacitású dobmalom, amelyet a kereskedelemből szereztek be.

Az agyag milyensége megszabta azt, hogy milyen edénytípusra alkalmazták. A híres korondi 18-19. századi főzőfazekak felületének érdessége mutatja, hogy az itteni jó tűzálló agyagot sok kvarchomokkal soványították. Az így előállított érdes felület mázazása nem érvényesült volna, így a korondi edények 19. század végétől kezdődő mázazása az agyagelőkészítés megváltoztatásával kezdődött. Egy-egy új edénytípus bevezetése gyakran a felhasznált agyag megváltoztatásával járt együtt. Korondon például a takaréktűzhely lapjához alkalmazkodó széles fenekü vagy seggen ülő fazék készítéséhez nem volt elég jó a helyi agyag, ezért a Bihar megyei Körösrévről hozattak ehhez szükséges, jó lángálló agyagot (Kresz Mária 1960. 311.).

Korondon, Magyarhermányban, Dánfalván, Csíkmadarason egyaránt a szürkéskék agya- 


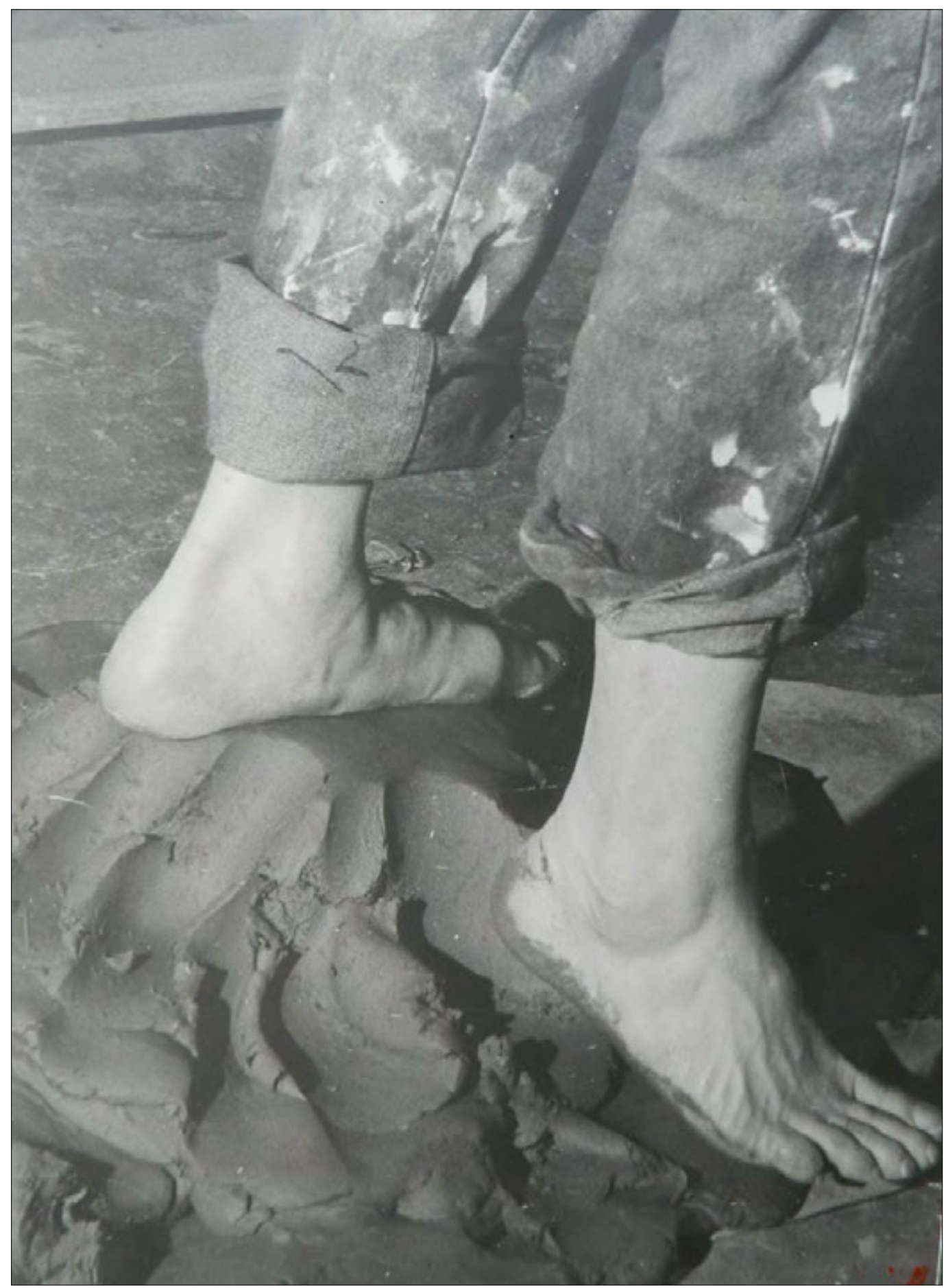

14. kép. Agyagfinomítás taposással. Korond, 20. sz. Haáz Rezső Múzeum Székelyudvarhely 
got palának nevezték, nevében is elkülönítve a gyengébb minőségűnek tartott, más típusú agyagoktól. Bár a szürkés agyag szennyezettsége miatt vált ilyen színűvé, jó képlékenysége miatt Magyarhermányban csupán a finomabb edények készítésére használták (Seres András 1974. 359.).

Erdély fazekasságában különleges szerepe alakult ki az ún. hólyagos edényeknek, amelyeknek nagy hírét elsősorban jó szigetelő hatásuk biztosította. A hólyagos edényeknek több központja is működött: leghíresebb a járai hólyagos csupor volt, de Kolozsváron, Désen, Lónán, Csíkdánfalván és a távoli Nagybányán is készítettek ilyen edényt (Balassa Iván 1989. 85.). Alsójárán egy 1768 -as levél szerint etédi vagy korondi fazekasok honosították meg e ritka edénytípus készítését (Tófalvi Zoltán 1972. 170.). A sepsiszentgyörgyi Székely Nemzeti Múzeum őriz egy Kovásznáról bekerült, törött hólyagos edényt, amelynek

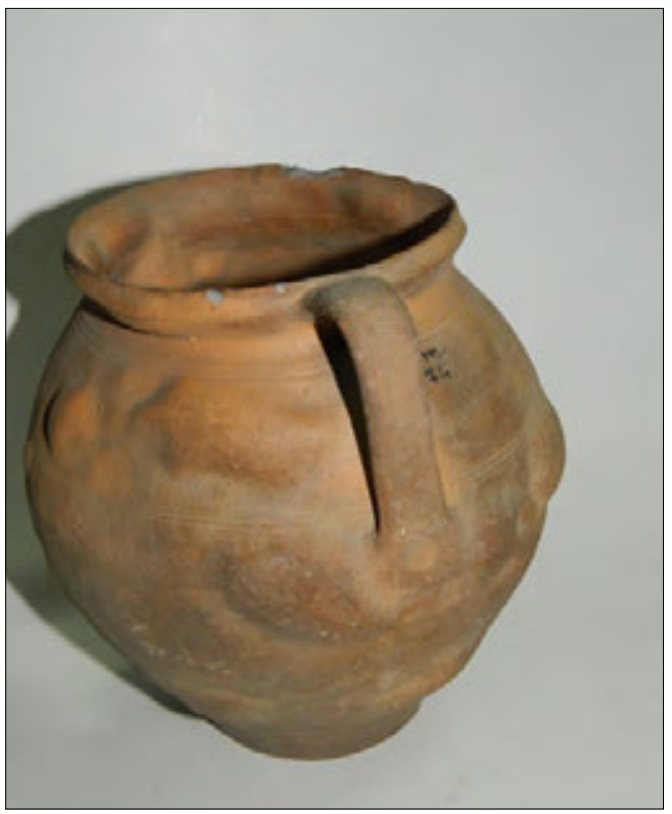

15. kép. Hólyagos csupor, 18. sz. SzNM törésvonala egyértelműen mutatja, hogy a hólyag nem valamilyen mesterségesen előállított dudor volt, hanem a felhasznált agyag valamely égetési körülmény hatására magától hólyagosodott fel. Kőváry László szerint a hólyagosodást az agyag „enyvessége” okozta (Kőváry László 1847. 69.) (15. ábra).

Kresz Mária csákvári példákból kiindulva megállapította, hogy „a szó szoros értelmében fazekasnak csak azt nevezték, aki tüzálló földből, ún fazékföldből [...] dolgozott és föző-sütő edényeket készített, fazekat, ezenkívül lábost, sütôt, tűzálló vájlingot. Ezzel szemben a tálasok, a tál, tányér, köcsög, bögre, kancsó mesterei más anyagból dolgoztak, ún. tálföldből, sárga földből, amely nem volt tűzálló és nem is abból az agyagbányából eredt, mint a fazékföld." (Kresz Mária 1960. 298.).

Ez a leírás is jelzi, hogy egyes kövér agyagokat nem lehetett jól felhúzni, álló edények készítésére nem lehetett használni, így a

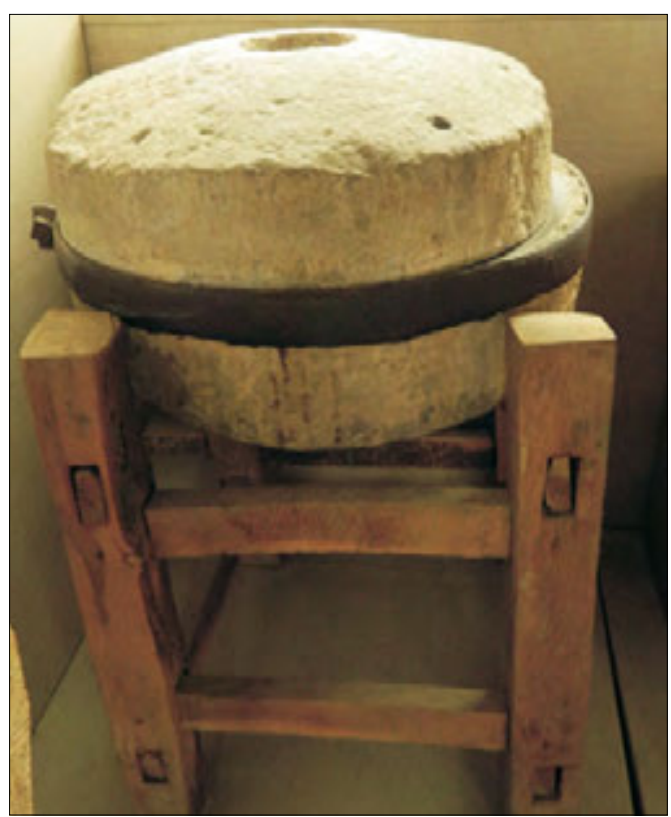

16. kép. Mázőrlő kő Magyarhermányról, 19. Sz. SzNM 
környékbeli agyag minősége nagyon meghatározta, hogy milyen edények készítésére tudják alkalmazni.

A rögölés tehát már eleve az alkalmazni kívánt agyag minőségének az ismeretében történt: a nagyobb agyagkockából kisebb kerek gömböket készítettek, kisebb-nagyobb méretekben, attól függően, hogy mekkora és milyen típusú edényt szándékoztak belőle készíteni. A korondi fazekasok "gyakorlati szempontok miatt” "elöször a nagy edényt rögölik fel, mint tál, korsó, kancsó, fazék, tányér $s t b "$ (Incze Lajos 1939. 123.). A rögöket a korongozóasztal mellé készítették, hogy legyen a fazekasnak a keze alatt. A rögölt agyagot nedves ronggyal borítják be, hogy ne száradjon ki, és a gömb felülete ne repedezzen meg, így egy hétig is korongozható állapotban marad (17. kép).

A rögölést követő lépés a korongolás.

A Székelyföld peremvidékétől nem meszsze elhelyezkedő Déda településen egészen az 1950-es évekig fennmaradt a helyi román fazekasok közt a kézikorong, amelyet az archaikus agyaghurkás technológiával készített edények véglegesítéséhez használtak. A szászrégeni múzeumhoz begyüjtött dédai fazekas eszközkészletből ismerjük, hogy milyen volt az ottani kézikorong (Diaconescu, Aurelia 2011. 21.). Mivel Székelyföldről nem maradt fenn kézikorong, így csak valószínűsíteni tudjuk, hogy a közeli dédai koronghoz hasonló eszközöket használhattak vidékünkön is (1., 2. ábra és 18. kép).

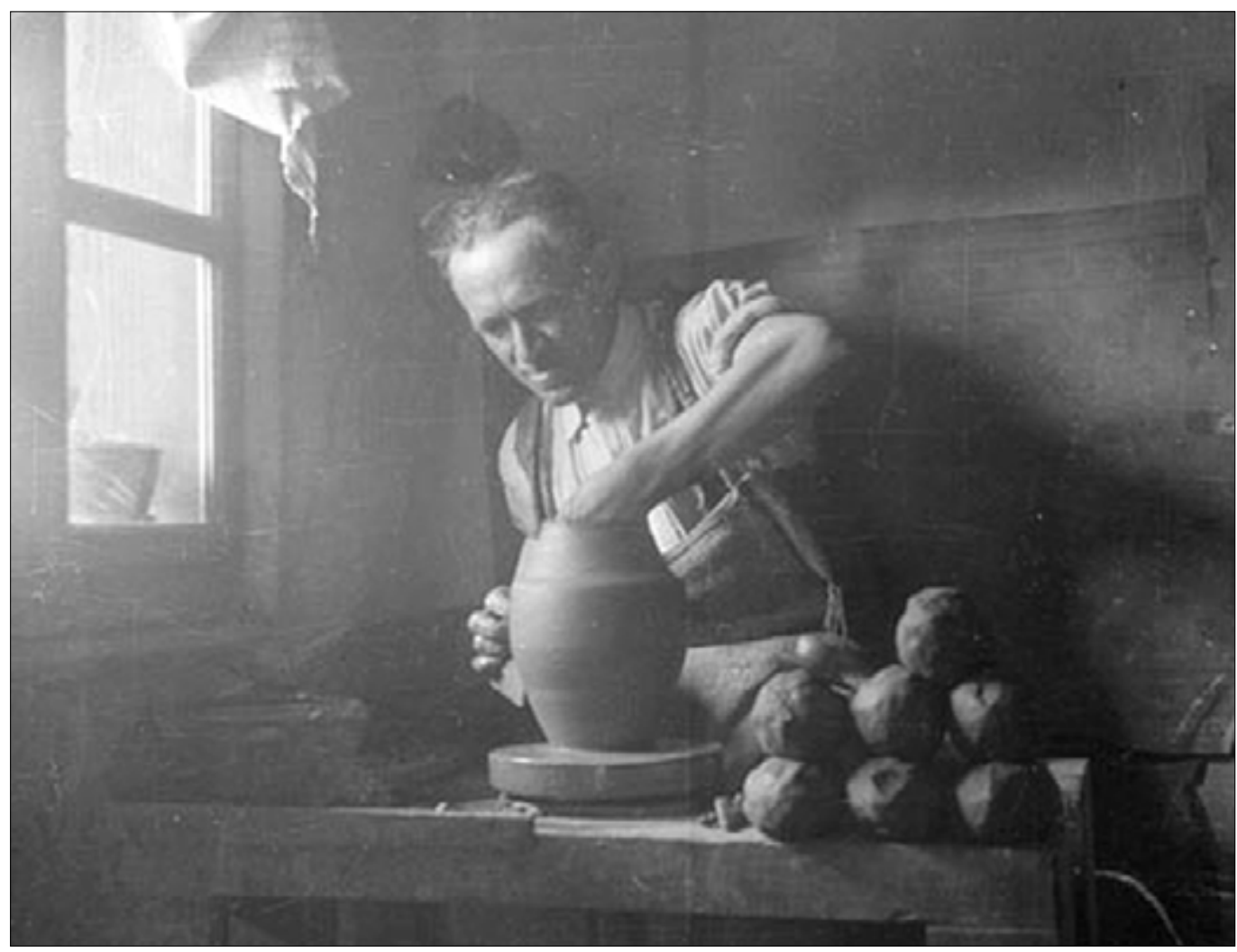

17. kép. Rögölés, Csíkmadaras, 20. sz. dr. Kós Károly fotója, Kriza János Néprajzi Társaság fotótékája, Kolozsvár 
A lassú korongon formált edényt nem kellett erősen feltapasztani a korong felületére, mivel nem volt annyira gyors annak a pörgése, hogy veszélyeztette volna az edény leröpülését. Ennek köszönhetően sokszor homokosabb az edény alja, mint a gyors- korongon készülteknek, és egyáltalán nem vagy pedig csak a külső fenékrészen látszanak rajta a korongról való leválasztás nyomai.

Napjainkban Székelyföld területén már egyáltalán nem készül kézikorongos kerámia, már régen átvette ennek a helyét a gyorskorong használata. A gyorskorong régészeti kifejezés, napjaink fazekasai nem nevezik így ezt az eszközt (19., 20. és 21. kép).

A gyorskorongok nagyjából egységes képet mutatnak Székelyföld területén: két kör alakú falapból és egy ezeket összekötő tengelyből állnak, az alsó falap nagyobb, mint az edény formálására használt felső lap. A gyorskorongot a 20. század közepéig lábbal hajtották. Csíkmadarason fényképről, Csíkdánfalván még 20. század végi megfigyelésekből is látható volt, hogy a fazekasok többnyire mezítláb korongoztak, mivel így tudta a leginkább szabályozni a korong forgásának gyorsaságát, de így tudta lassítani is a túl felgyorsult kereket a mester.

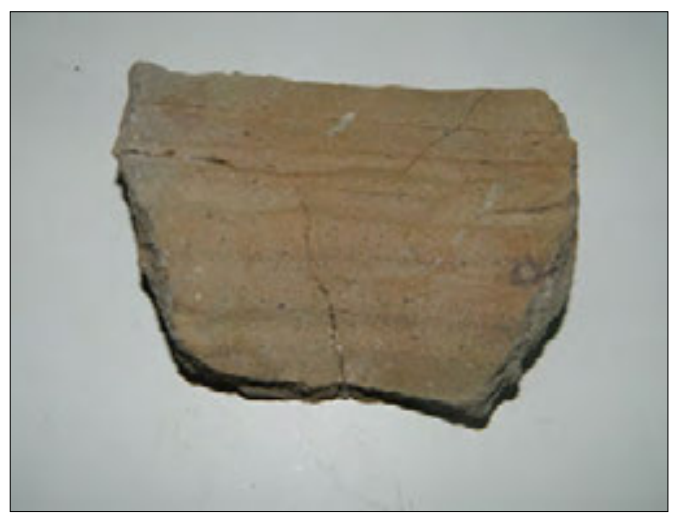

18. kép. Kézikorongon készített agyaghurkás technika nyomai egy 17. sz.-i edénytöredéken

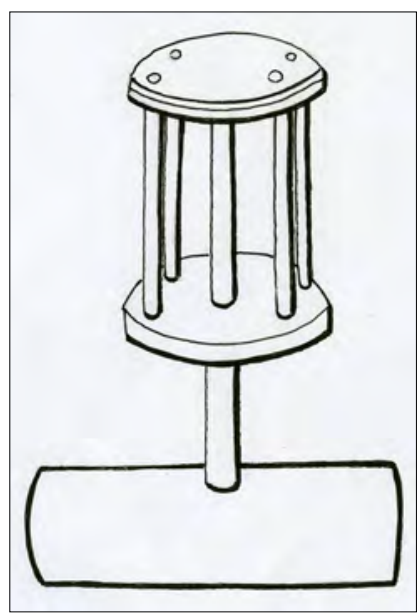

1. ábra. Kézikorong, Déda, 20. sz.

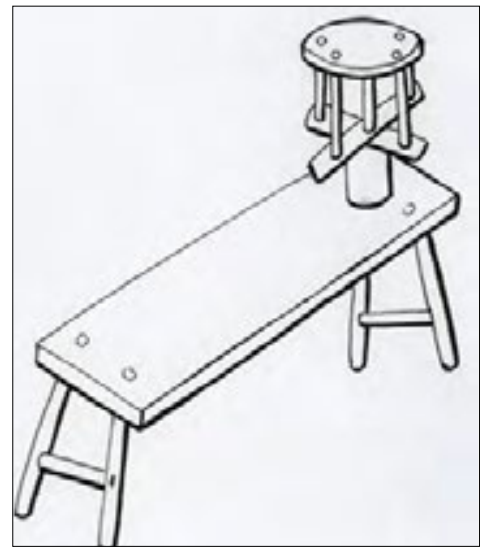

2. ábra. Kézikorong, 19. sz.

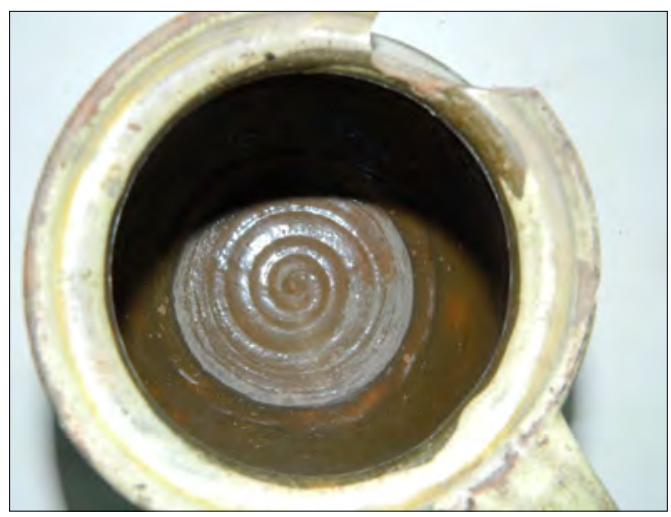

19. kép. Korongozási nyomok egy edény belsejében, SzNM 


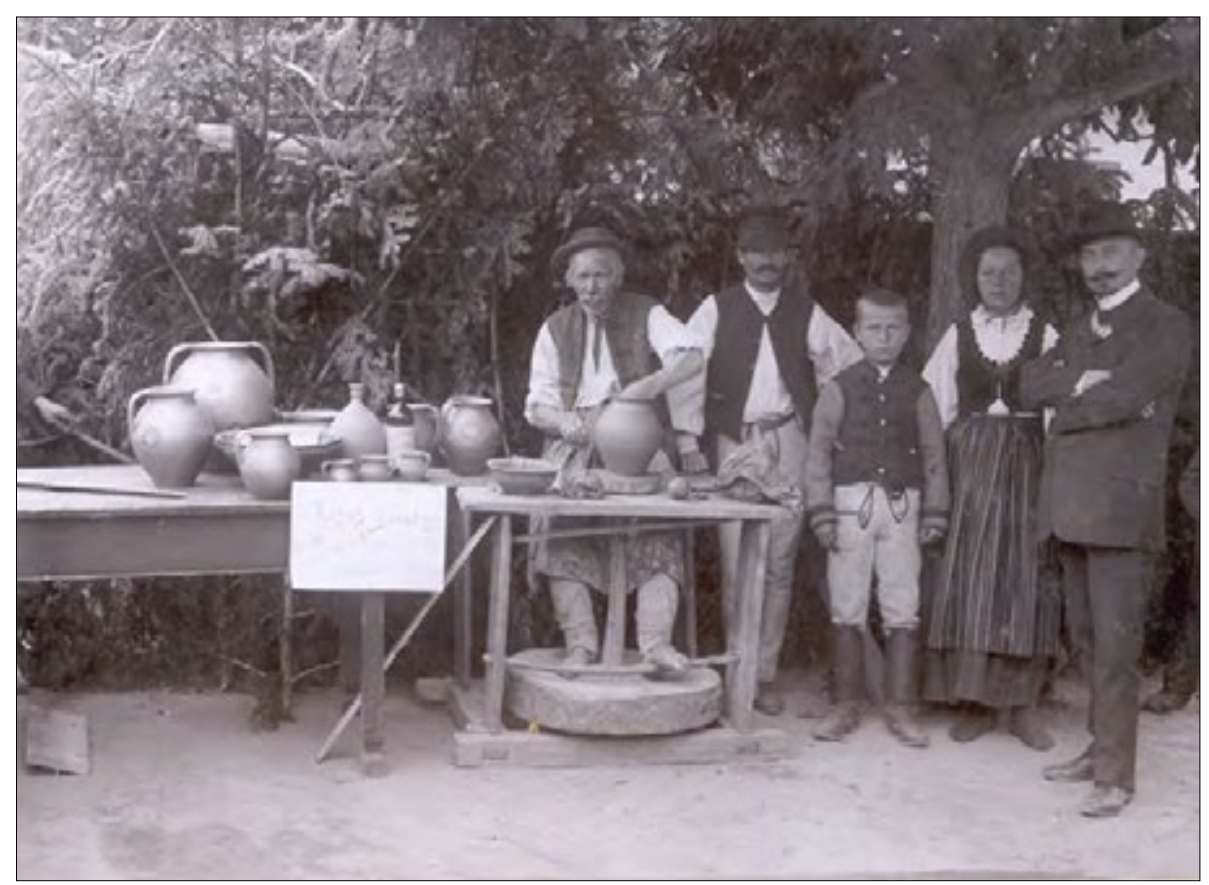

20. kép. Korongozás, Csíkmadaras, 20. sz. eleje, SzNM

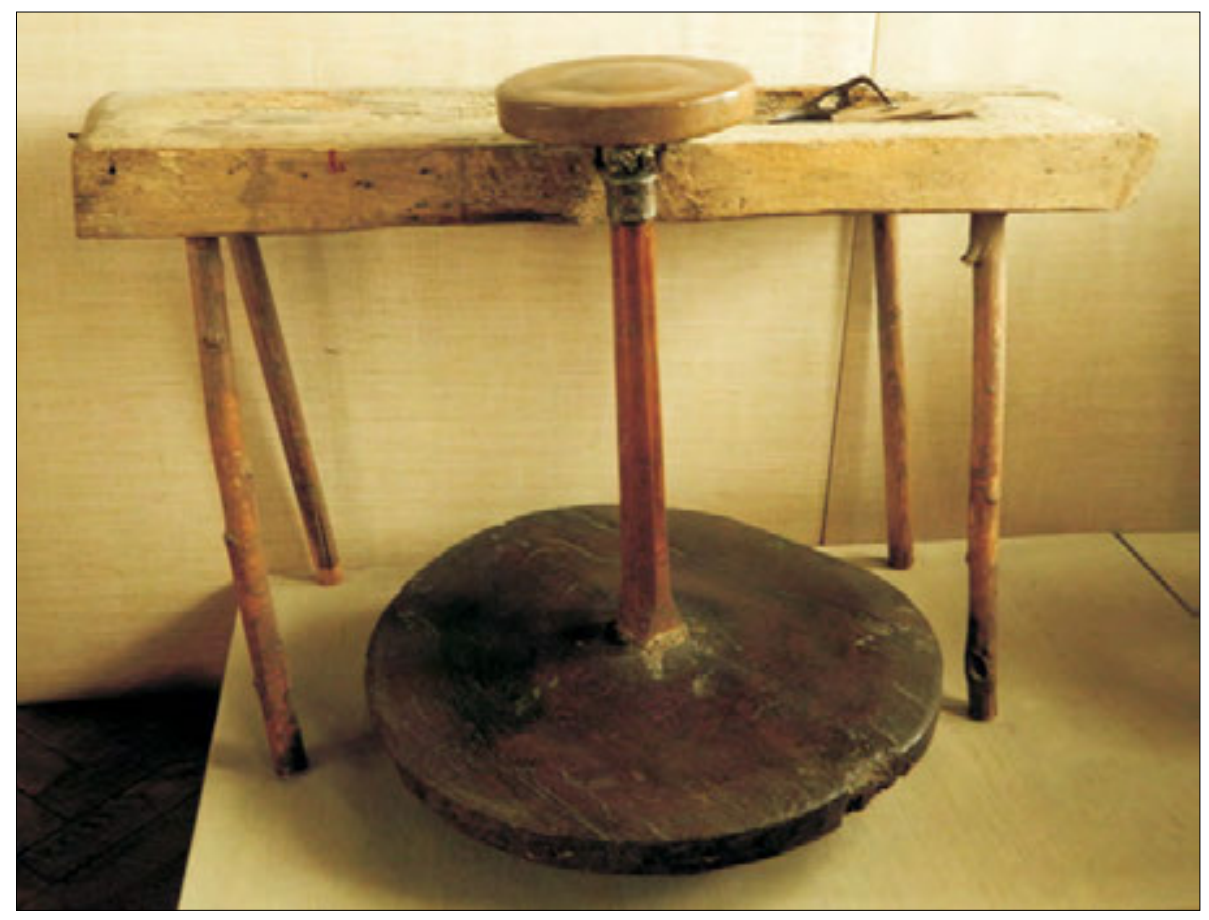

21. kép. Gyorskorong Magyarhermányról, 20. sz. eleje. SzNM 
A korongolás férfimunka volt, a díszítést inkább asszonyfeladatnak tekintették (22. és 23. kép).

A fazekasok egybehangzóan azt mondják, hogy legnehezebb a nagyobb méretű edények készítése volt, ezt csak gyakorlott mester tudta elkészíteni, aki érezte, meddig húzható fel az edény, meddig vékonyítható az agyag anélkül, hogy az edény teste összeroskadjon. Úgyszintén nagyobb gyakorlati tudást igényel a korsók, palackok, perselyek elkészítése is. A kisebb korsókat egyben korongozták úgy, hogy előbb hengert formáltak, és belül kialakították a kívánt felületet, majd a szájrészt összeszűkítették. Nagyobb korsók esetében a szájrész összeszúkítését úgy

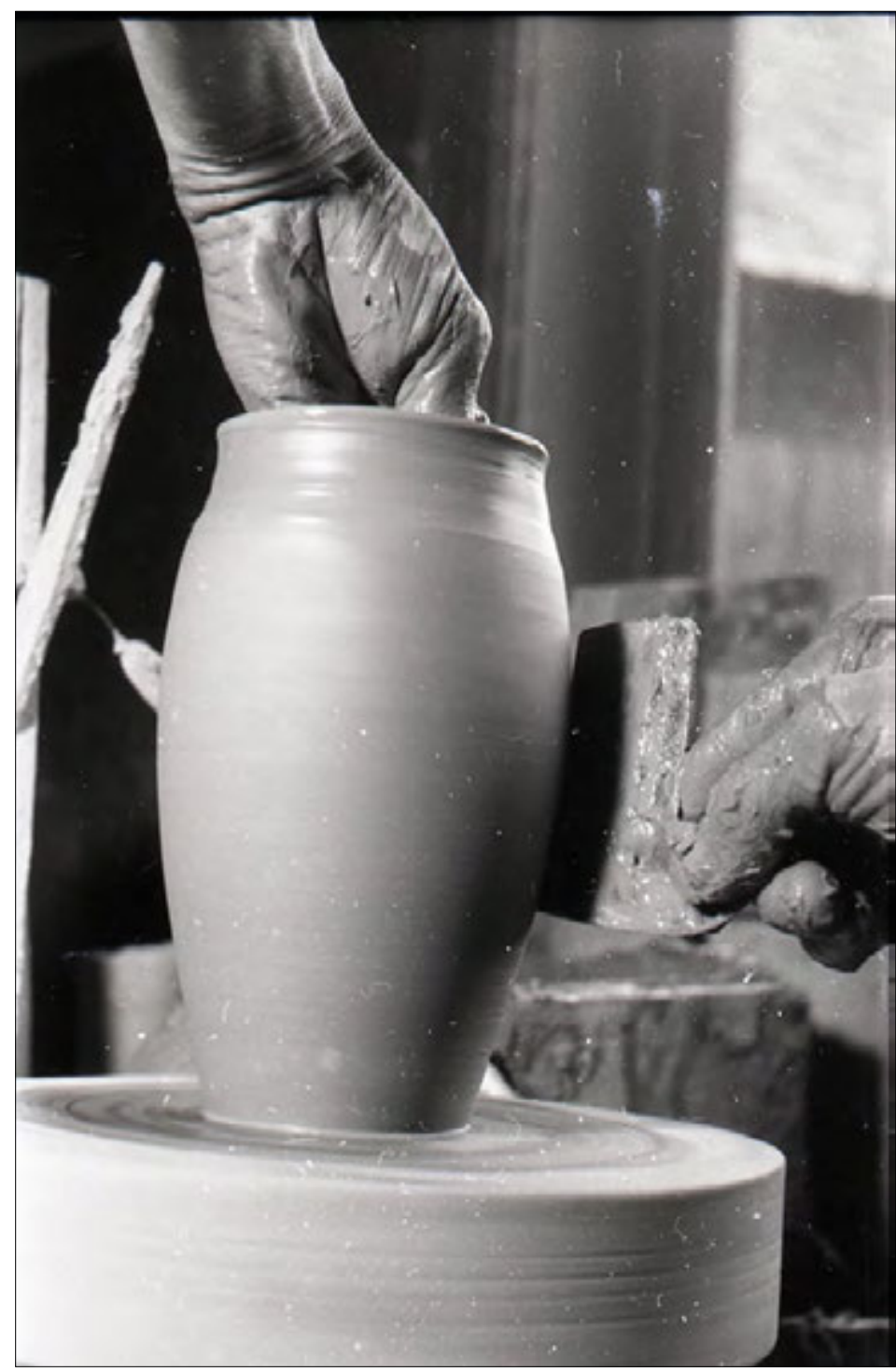

22. kép. Korongozás fakéssel, Korond, 20. sz. Fóris Pál felvétele, SzNM 


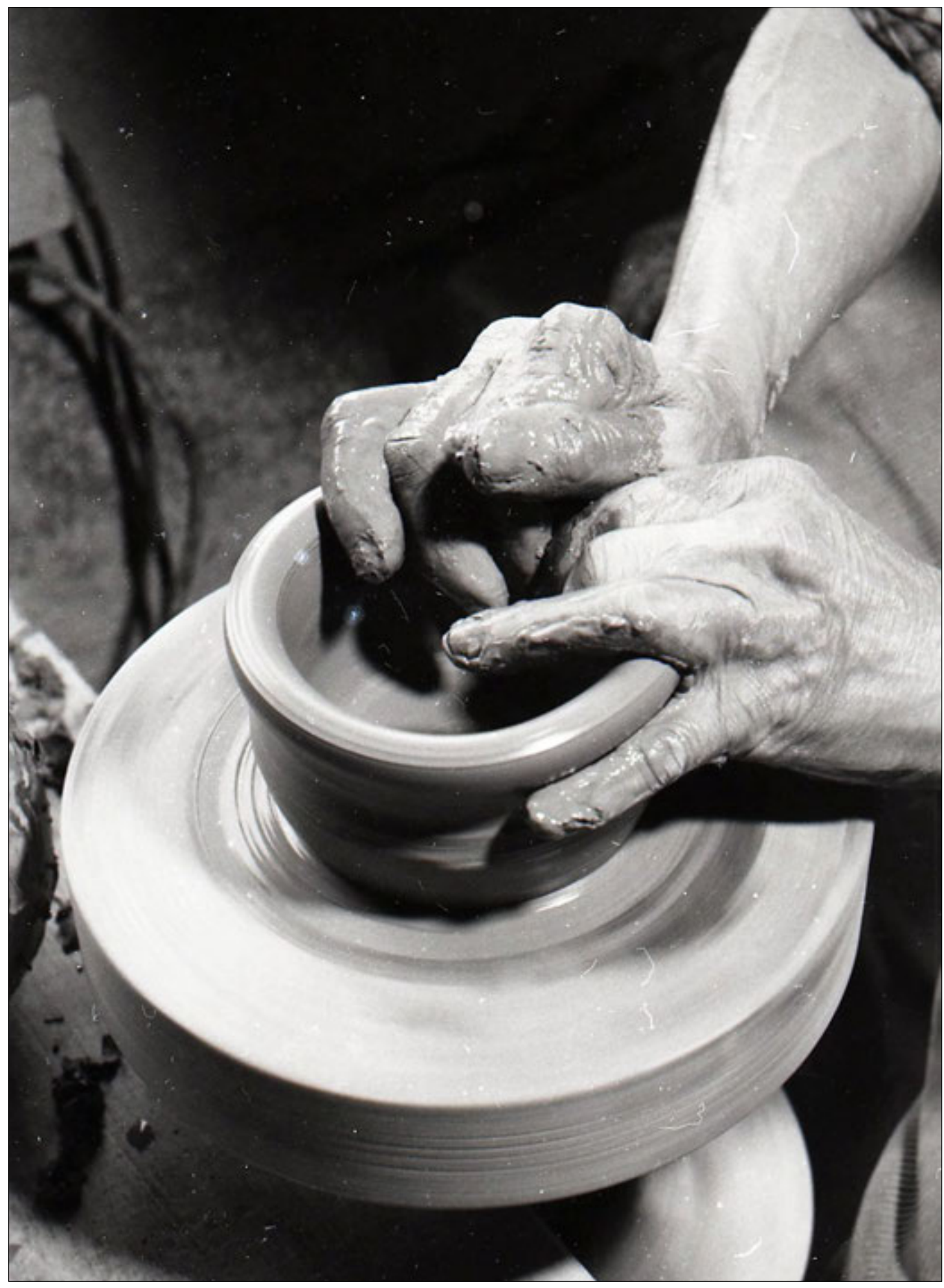

23. kép. Az edény felhúzása, Korond, 20. sz. Fóris Pál felvétele, SzNM 
oldották meg, hogy külön korongozták azt, majd összeillesztették a két részből készült edényt. A papírvékony falu magas edény a mesterségbeli tudás magas szintjét jelzi, a mai fazekasok csodálattal beszélnek azokról a régi mesterekről, akik nagyon vékony falú korsót készítettek. A korongozás során néhány olyan elemi munkaeszközt használtak, amely valamennyi fazekasközpontban egységes volt: a fa- és vaskések egész Székelyföld területén nagyjából egységes alakúak voltak, a középen elhelyezett lyuk a könnyebb fogást segítette. E kis falap a korongolt, felhúzott felület simításában játszott fontos szerepet, és segített kialakítani az edény hajlatait. A fazekaskések közül csupán a fenékszögvágó nevü eszköznek, valamint a tálkésnek van kissé más alakja (24., 25., 26. és 27. kép).

A korongozásnál fontos volt a víz jelenléte: a mester a kezét és a fakését többször mártja a focsos tálba vagy fazékba, egyrészt hogy a rárakódott agyagdarabokat lemossa,

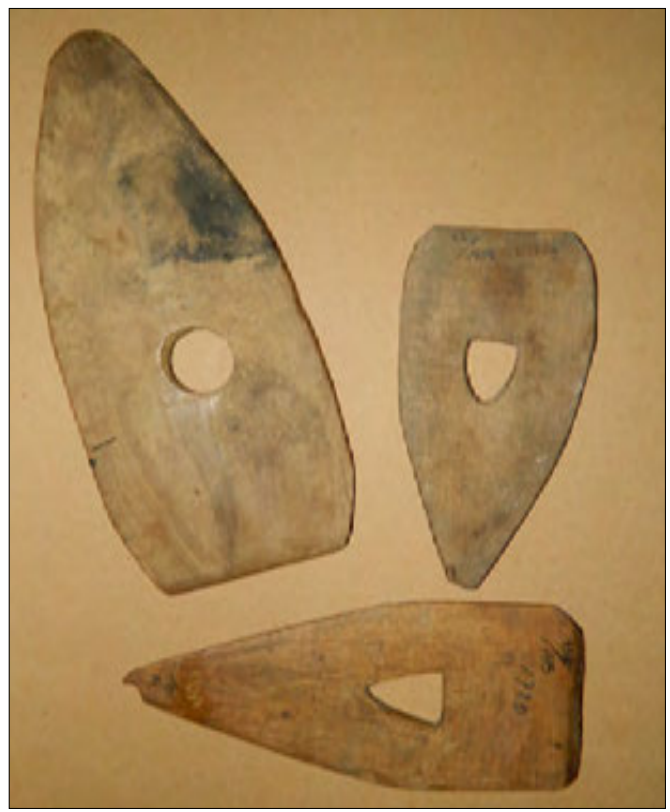

24. kép. Kések korongozáshoz, Magyarhermány, 20. sz. eleje, SzNM másrészt hogy folyamatosan tudja biztosítani a kéz és az eszköz könnyű csúszását az egyenletesebb felület elérése érdekében. A fazekasasztalon jelen lévő szivacs elsősorban az edény belsejében fennmaradó víz kiszívatására, kitörlésére használt.

Az edények hasonló méretének ellenőrzése céljából a fazekasok mértékeket is használtak, ezek rovásokkal ellátott fadarabok voltak.

A korongozás záró fázisában alkalmazták a csípőbőrt, ez egy kis bőrdarab volt, amellyel az edény száját simították el. A rézdrót vagy rézcérna szintén fontos eszköze volt a gyorskorongos fazekalásnak: a korongra tapadt edényt ezzel metszették le a korongról.

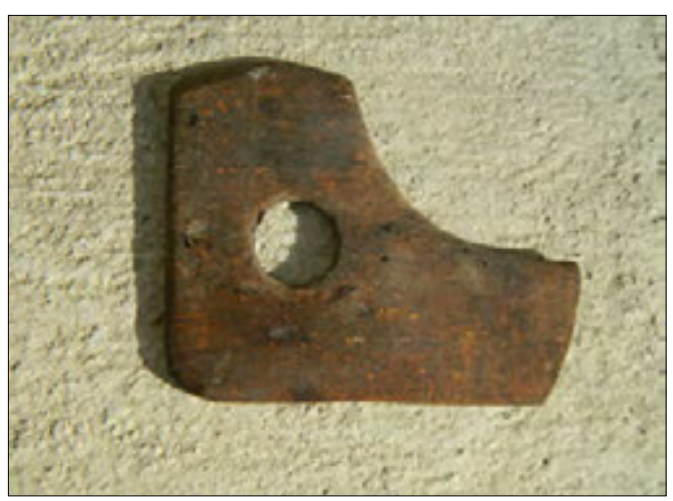

25. kép. Fakés a korongozáshoz, Korond, 20. sz., Haáz Rezső Múzeum Székelyudvarhely

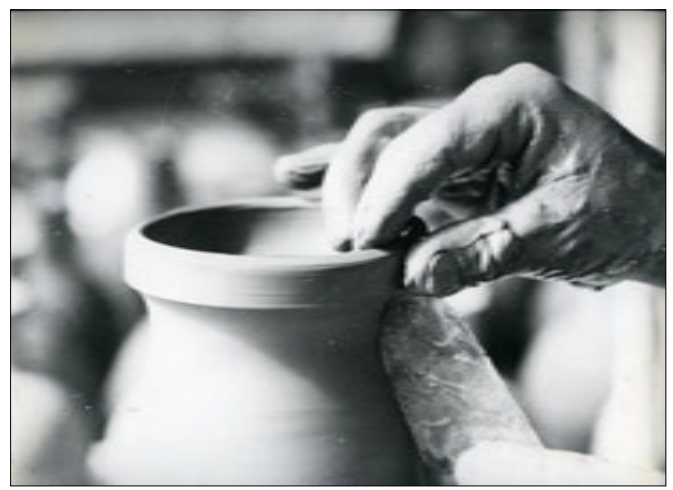

26. kép. A száj kialakítása fakéssel, Korond, 20. sz. Fóris Pál felvétele, SzNM 


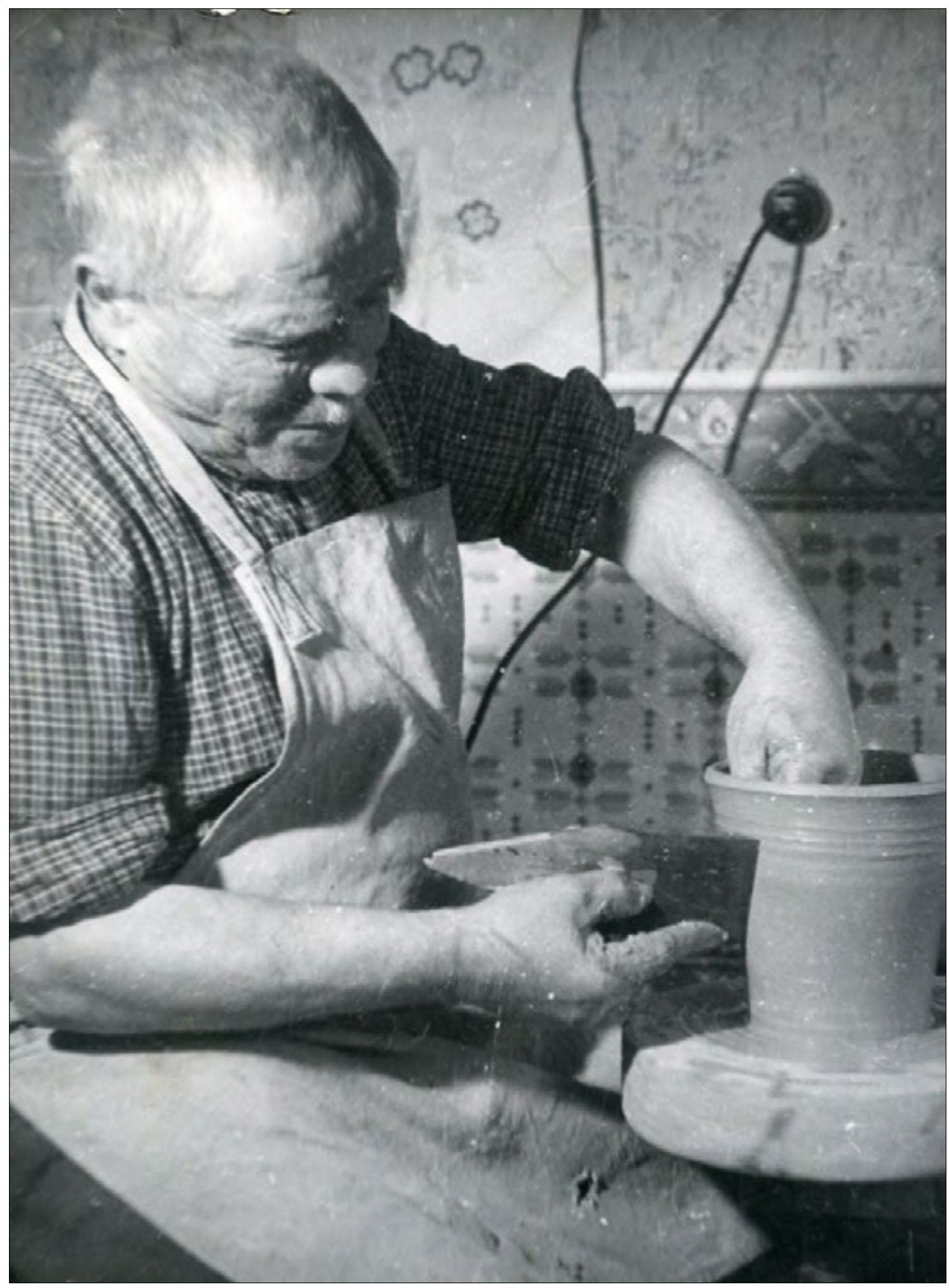

27. kép. Simítás fakéssel, Korond, 20. sz. Haáz Rezső Múzeum, Székelyudvarhely 
Csíkdánfalván az iparművészeti ihletettségű fazekasmúhelyben az agyagedények felületét az 1960-as évektől faragták, ehhez különböző fa vésőket is használtak.

A fazekas az elkészített edényt a múhelyben lévő szárítópolcokra helyezte el. A szikkadás nem lehetett túl gyors, mivel az edény könnyen elhasadt.

Az edénynek kis száradás kellett ahhoz, hogy a fület felilleszthessék rá. A fül alakja és illesztési módja fontos ismérve a fazekasközpontoknak vagy az egyes mestereknek. A régi fazekasok a fület kihúzták: az agyagrögből egyenletes vastagságban fejtették le a fület.

Csíkmadarason a csuprok, fazekak fülét felül a száj karimájával, lenn az edény falával összedolgozták, itt a fazekasok legtöbbször egy újnyomattal dekorálták. A korondi fazekasok a kantáik nyakrészét levágták, és a

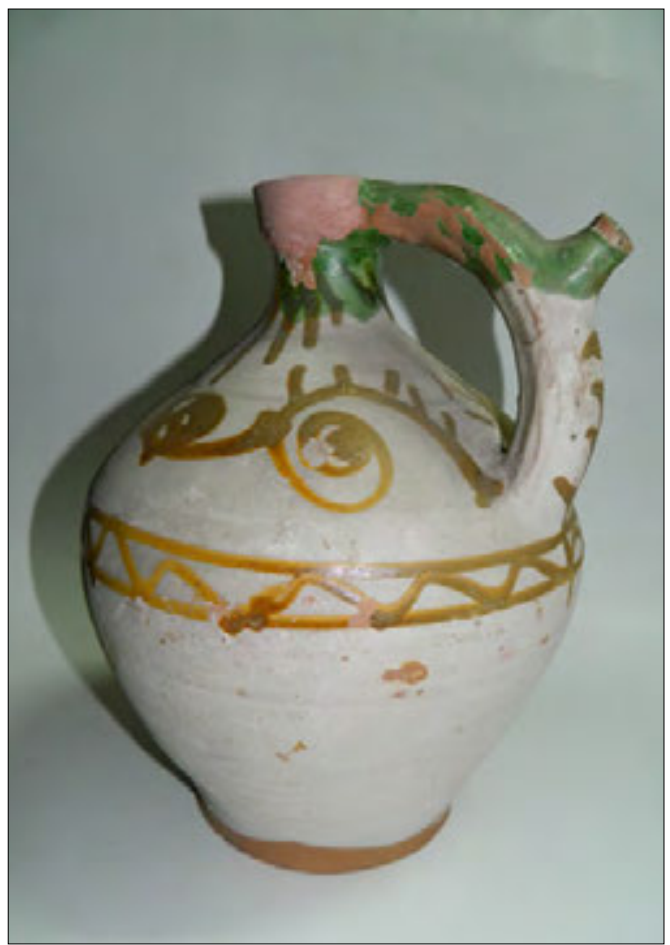

28. kép. Korongolt fül, Kálnok, 19. sz. SzNM fület e vágásvonalba illesztették, majd erre illesztették ismét rá a levágott darabot, enyhe rámával dolgozták össze. ők a fül alsó rögzítésénél úgyszintén szerették az 1, 2 vagy 3 újnyomatos dekoratív rögzítést. A 19. század végétől és a 20. század elejétől a fazekasok körében divattá vált a fülnyomó prés készítése: ezt helybeli kovácsokkal vagy bádogosokkal készíttették. A székelyudvarhelyi fazekasok már a 19. század végén is jobbára préselt fülű edényeket készítettek, a fül alsó felét a dekorativitás kedvéért csúcsosra formálták, és nem simították be az edény felületébe, hanem hagyták, hogy kiemelkedjen kissé az edény síkjából. Napjaink csíkdánfalvi fazekasa, Vízi Jenő olyan fülnyomó prést készített magának, amely kettősre tagolja a fül felületét, középen rovátkolva azt (28., 29. és 30. kép).

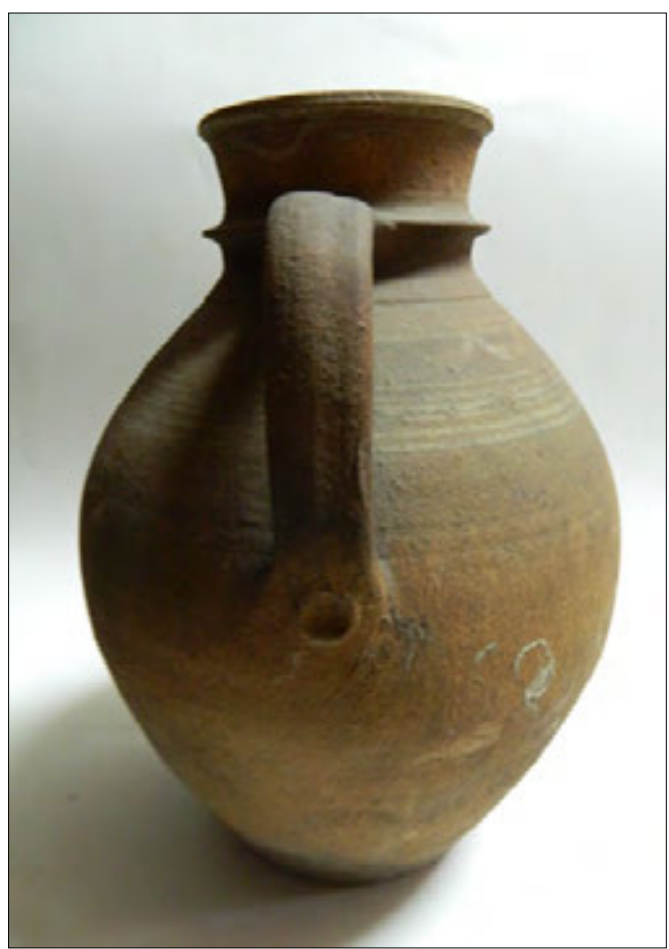

29. kép. Korondi kanta fülrögzítési módja, 19. sz. SzNM 


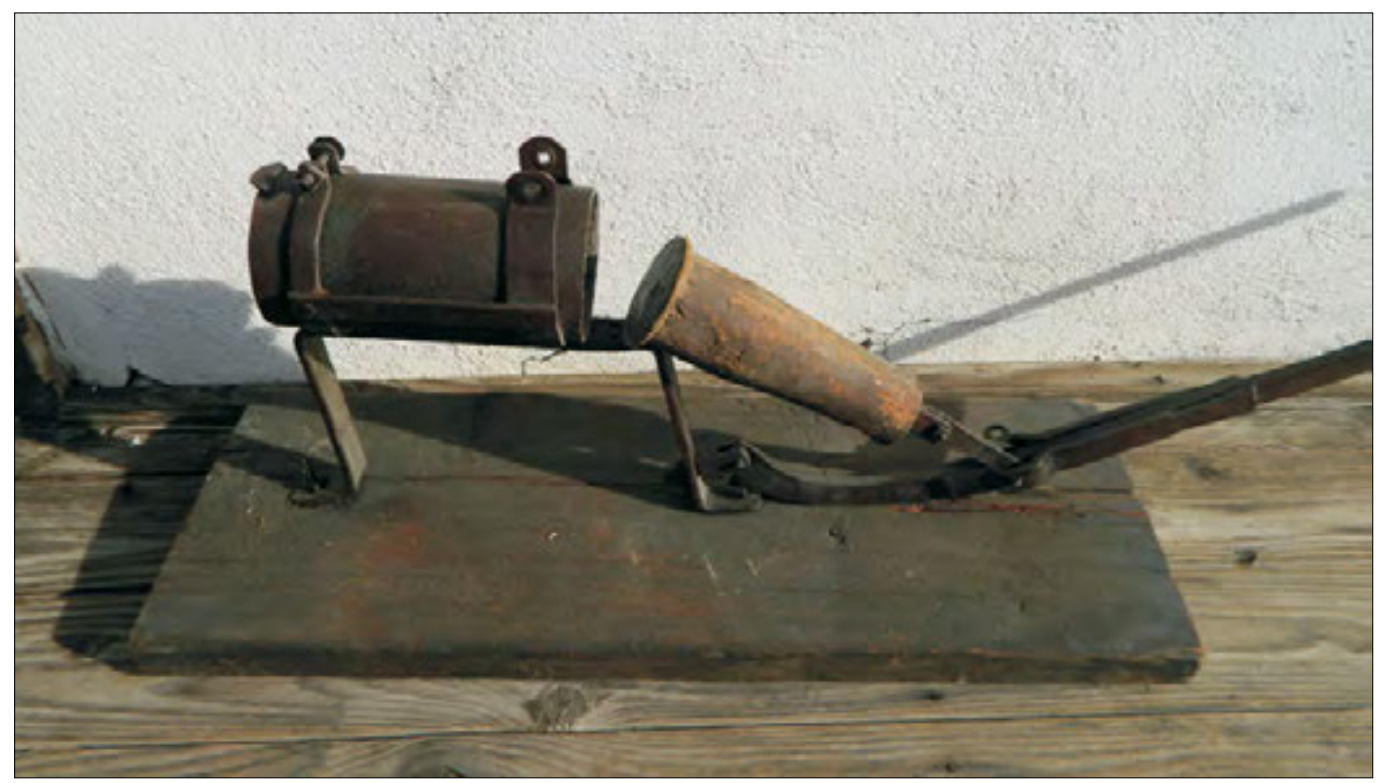

30. kép. Fülnyomó prés, Székelyudvarhely, 19. sz., Haáz Rezső Múzeum Székelyudvarhely

Külön technikával készült a csalikorsó vagy a csicses korsó füle: korongozott fület készítettek, és úgy illesztették fel azt a korsóra, hogy a folyadéktartalom a fülbe is behatolhasson. A fülön kiképezett lyukon keresztül a korsóból úgy lehetett inni, hogy ne vizezze össze magát az ember. A nagyobb edények fülét Magyarhermányban újbenyomásokkal, rátétdíszekkel tették dekoratívabbakká.

A száradást követik a díszítési eljárások. Technikatörténetileg minket nem az edényekre felfestett díszítőmotívumok érdekelnek, hanem elsősorban a festékföldek előkészítése, illetve a díszítés technikai kivitelezése.

Korondon a harmincas években a csíkszentsimoni fehérföldet vízzel hígítva kétszer őrölték át a házi készítésű őrlőn. A boltból vásárolt drága fekete festéket a határból kitermelhető, önmagában szürkés színű borostyánfeketével vegyítették, majd a kellő színhatás elérése érdekében még másfél súlyrész vörösfölddel szaporították. A zöld- höz 12, a kékhez 24 súlyrésznyi fehérföldet kevertek, így nem pusztán világosabb árnyalatokat nyertek, de szaporábbá vált a festékföld is (Incze Lajos 1939. 124.).

A díszítésnek több érdekes módszerét jegyezték le vagy mesélték el a különböző központokban. Legegyszerübb eljárás az öntés vagy a fröcskölés volt. Az öntést Magyarhermányban nagy fakanalakkal végezték (31. kép), a fröcskölés eszköze a szamártövis volt: a festékföldbe mártott tövis viszonylag egyenletes pöttyöket fröcskölt az edény felületére. Szolokmán kukoricacsuszát, cipőkenő kefét használtak a spriccolásra (Tófalvi Zoltán 1996. 91).

Korondon a harmincas években divatossá vált a rázott edény készítése: ennek eredetileg az volt a készítési módja, hogy különböző színű foltokat tettek egymás mellé, majd addig rázták az edényt, míg a színek összefolytak, és szivárványos felületet biztosítottak. A harmincas évektől ehhez az eljáráshoz külön kis munkaeszköz készült: „Udvarhelyi 
bádogosoktól ötös rekeszű pléh festéköntőt vásárolnak, megtöltik az öt különböző színnel és hullámvonalban csorgatják az egyenesen forgatott edényre, fóleg kancsókra és virágvázákra." (Incze Lajos 1939. 125.)

A kerámia díszítésének egyik régi, jellegzetes eszköze az íróka vagy írószaru. E kis eszköz végeredményben egy csőrszerűen elkeskenyedő kis tartály, amelybe a festékföldet betöltötték. Az írószaru készülhetett marhaszarvból, kerámiából vagy bádogból, az elkeskenyedő csőrbe többnyire lúdtoll alsó szárából kivágott kis csövecskét illesztettek, ami egyenletes vastagságban engedte a festékanyagot az edényre. Egyedi esetekben más eszközt is befoghattak az íróka helyettesítésére. Szolokmán például fülmosó pumpát használtak erre (Tófalvi Zoltán 1996. 91.).

Kézdivásárhelyen az írókás kontúrozás a 19. század második felében szorította ki a korábban általános sgrafitto technikát, vagyis a motívumok fehérföldön keresztüli bekarcolását. Balassa Iván e helységbeli, 1942es fényképéről jól látható, hogy az íróka használata nem volt könnyű. A lúdtoll időnként eldugult, ilyenkor a fazekas belefújt, így próbálta kidugaszolni. Korondon a hetvenes

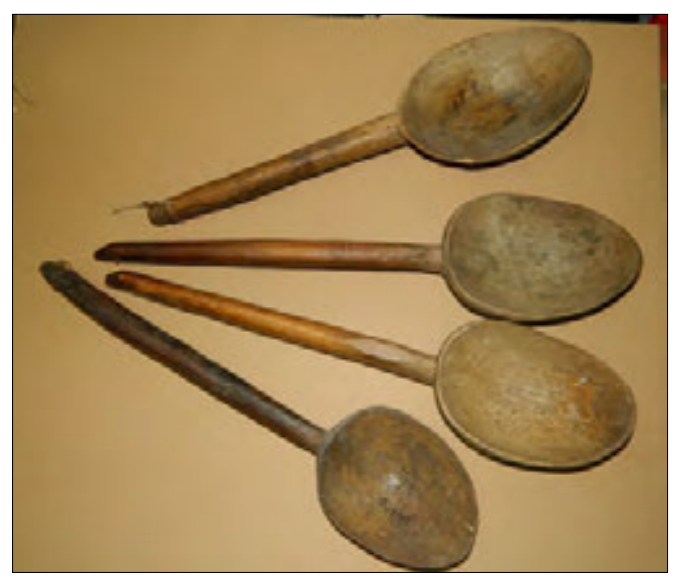

31. kép. Mázöntő kanalak, Magyarhermány, 19. sz., SzNM években az írókát már csupán a minták kontúrozásához használták, a színeket ecsettel töltötték ki (3. ábra, 32., 33., 34. és 35. kép).

$\mathrm{Az}$ írókázás székelyföldi visszaszorításában a 19. század végi és 20 . század eleji fazekastanfolyamokat okolhatjuk, amelyek a gyorsabb és könnyebben elsajátítható ecsetes festést tanították az erdélyi fazekasok körében (Györffy István 1939. 105.). Míg a 19. század első felének díszkerámiáján még vékony, finom ecsetdíszt használtak, a 19. század végén és a 20 . században a nagyobb folthatásokat biztosító, szélesebb ecsetek váltak elterjedtekké. Egyes fazekasközpontok az ecset használatát archaikusabb technikai megoldásokkal ötvözték. Csíkmadarason és Csíkdánfalván például az ecsettel húzott csíkot ujjal meghullámozták, ez a technika Csíkdánfalván napjainkig él (36. kép).

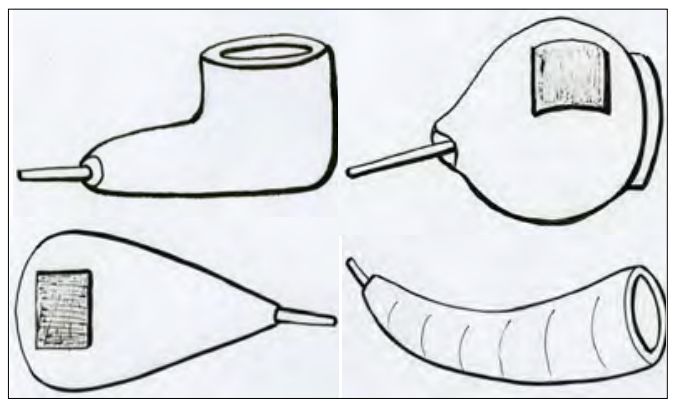

3. ábra. Székelyföldi írókaformák, 20. sz.

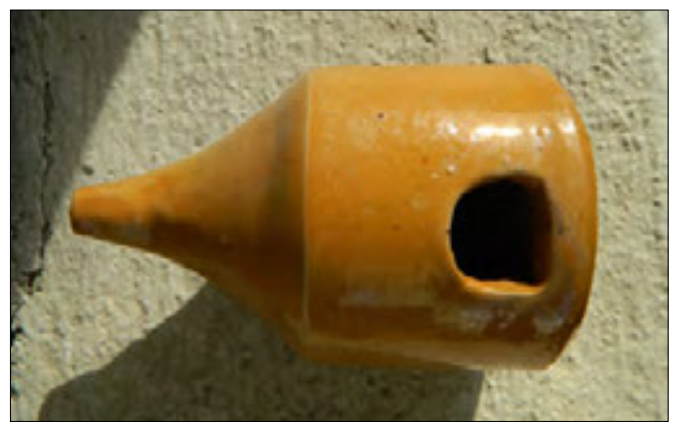

32. kép. Korondi íróka, 20. sz., Haáz Rezső Múzeum Székelyudvarhely 


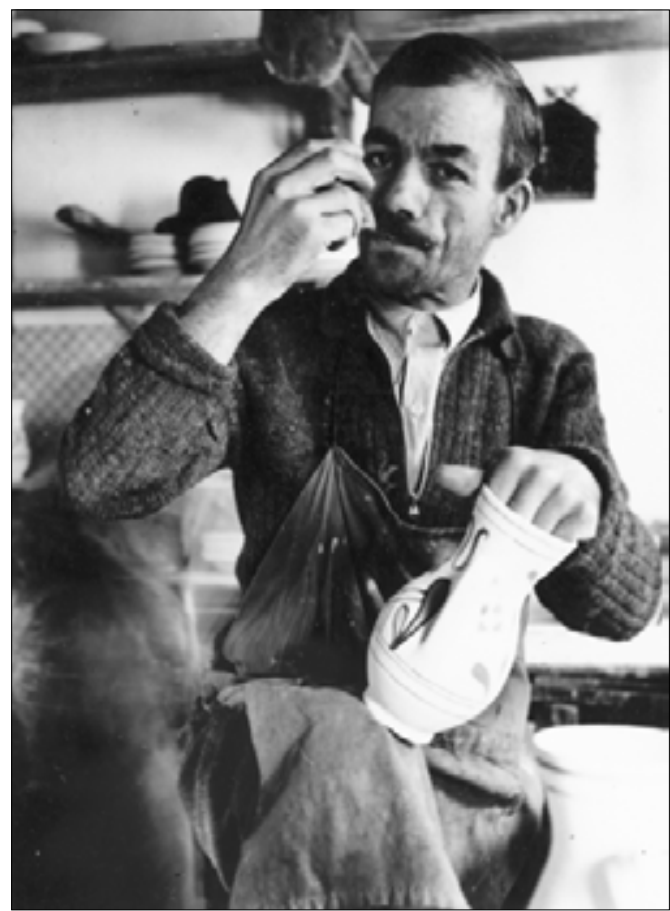

33. kép. Az íróka megfújása, Kézdivásárhely. Balassa Iván felvétele, 1942. SzNM fotótékája

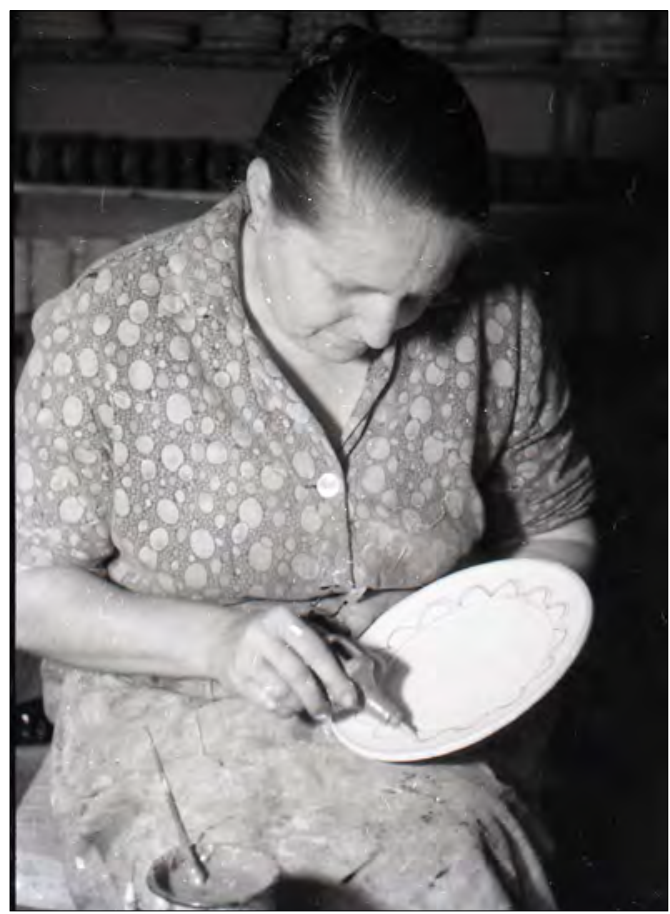

34. kép. Az íróka használata, Korond. Fóris Pál felvétele, 1970-es évek. SzNM fototékája

35. ábra. Írókázás szaruval, Csíkdánfalva, 20. sz., dr. Kós Károly felvétele, Kriza János Néprajzi Társaság fotótékája, Kolozsvár

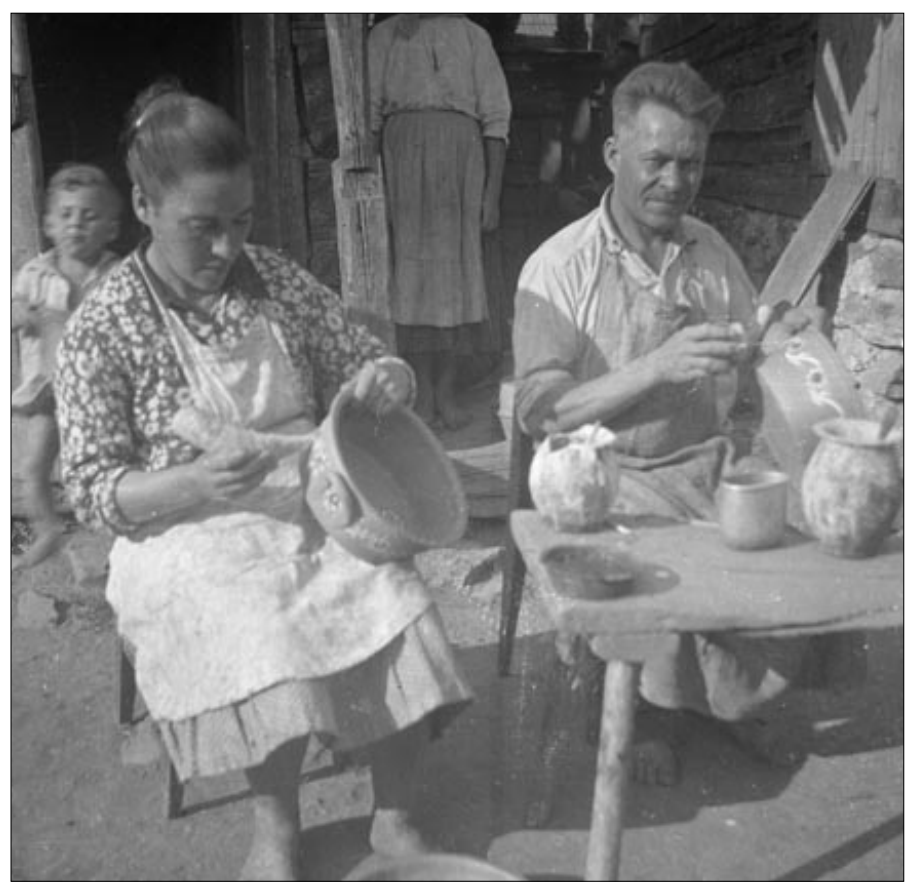




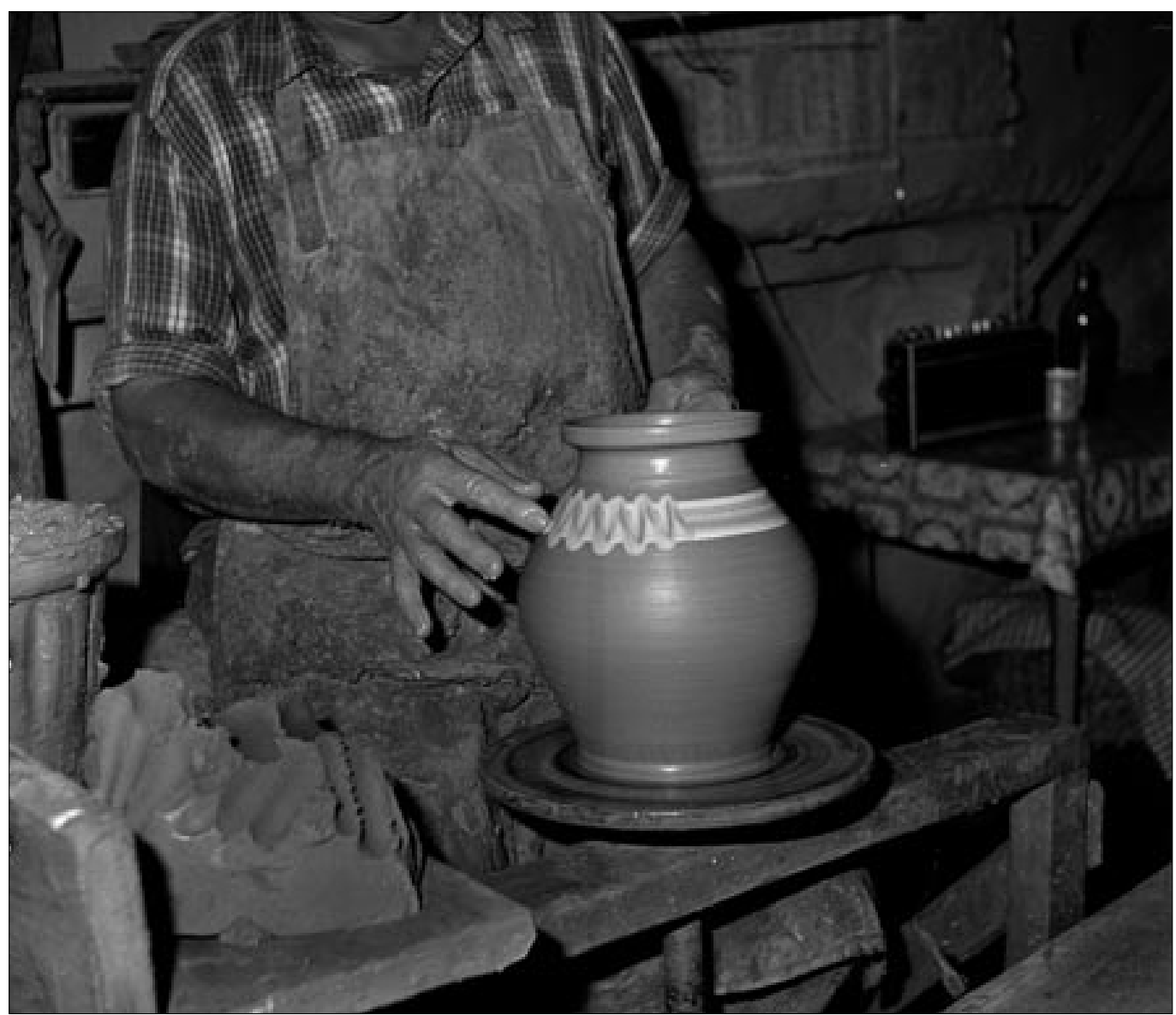

36. kép. Hullámozás ujjal, 20. sz., dr. Kós Károly felvétele, KJNT fotótékája, Kolozsvár

Igen archaikus technika a fazekasságban a fésűs minta készítése. Ennek az a lényege, hogy egy bőrdarab szélét fésűszerűen bevagdossák, majd ezt mártják a festékföldbe, és az edény felületén e kezdetleges eszközzel hullámvonalas díszt húznak. Az azonos technikai eljárás több eszközzel készülhetett, a fazekas felszereltségétől függően. Bereckben és Kálnokon - ha hihetünk az 1990-es évekbeli visszaemlékezéseknek - állítólag szamártövissel is készítették ezt a hullámozást. Magyarhermányban seprüből kiszedett ciroknyalábbal készült a fésűs minta. Csíkdánfalván az újabb fazekasságban már új anyag- ból - bicikligumiból - készítették a fésűt.

Az agyagpecsételőkkel nyomott minták szintén kedvelt díszítőeljárások voltak. A csíki fazekasságban ennek több használt eszköze volt. A csíkmadarasi fekete kerámiában például nagyon kedvelt eszköz volt az órakerék, a derelyevágó-szerű mintás görgő, amely apró, dekoratív pontsorokat nyomott az agyagfelületbe. Csíkdánfalván a kerámiamühelyben somfából vagy a kecskerágó bokrának ágaiból kis pecsétnyomókat készítettek, amelyekbe apró díszeket faragtak, ezekkel csíkokban díszítették a különböző edényeket (37. kép és 4. ábra). 


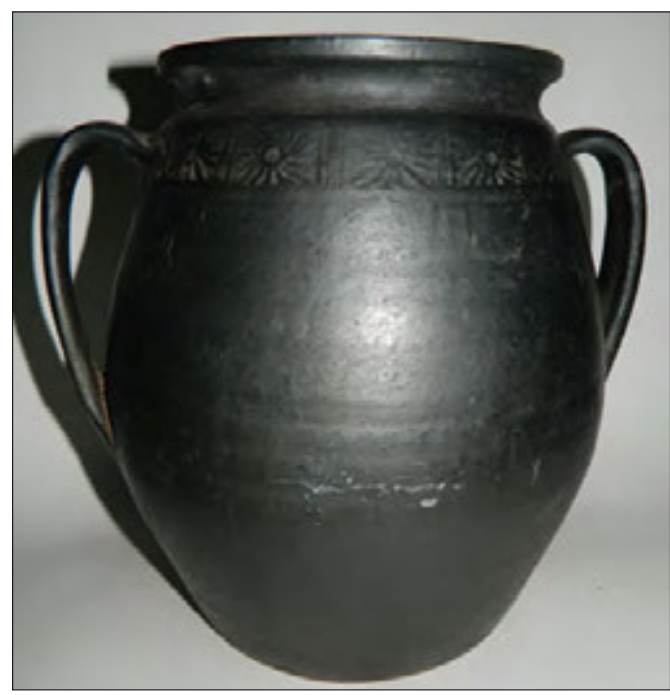

37. kép. Pecsételt minta csíkmadarasi fazékon, 19. $s z ., S z N M$

A kerámia díszítési eljárásai közül a legsajátosabb eljárás a mázazás volt.

A mázat a 19. században a legtöbb fazekasfalu Radnáról szerezte be. A marosvásárhelyi fazekascéh levéltárából ismert, hogy az 1870-es években több máztípust forgalmaztak: a lágy ólom mellett „veres zúzott mázag”-ot, „zöld zúzott mázag”-ot és „zöld darabos mázag"-ot árusítottak, ezek métermázsájának ára alig különbözött. Ha valami okból kifolyólag Radnán kifogyott a máz, akkor az abrudbányai, nagybányai és zalatnai lelőhelyeket keresték fel (Balogh Ödön 1972. 317.).

A székelyföldi fazekasságban elsősorban az ólommázakat alkalmazták, mivel ezeknek olvadási hőmérséklete alacsonyabb volt, így könnyebben lehetett velük a közönséges falusi kemencékben is sikeres mázazást elérni, mint az alkáli mázakkal.

A mázat mázőrlő kővel megőrölték, vagy mozsárban megtörték, majd vízzel vegyítették. A mázak vegyítési arányairól kevés feljegyzés van, mivel ezeket szakmai titokként féltékenyen őrizték. Korondon a harmincas

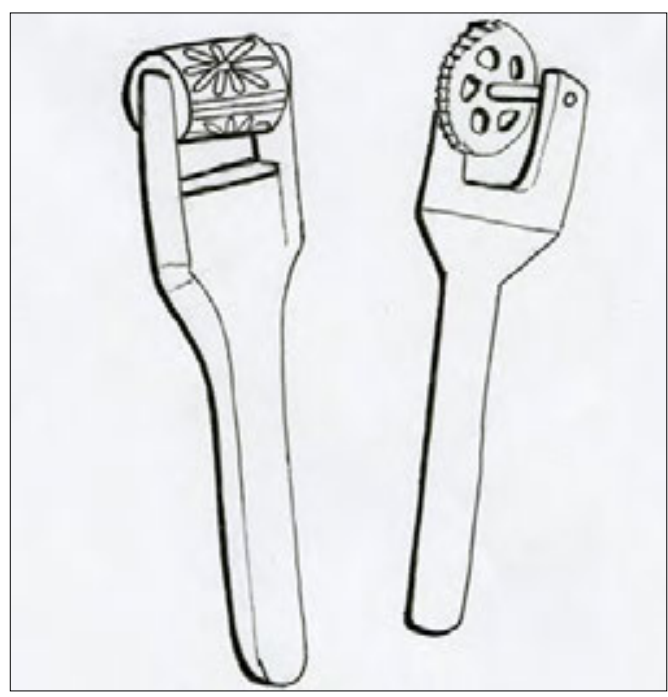

4. ábra. Pecsételőkorongok, Csíkmadaras, 19. sz., dr. Kós Károly nyomán

években 20 kiló, kereskedelemben beszerzett fénymázhoz 8 kiló békasót (kvarc vagy kova) adtak, amelyet mozsárban jól megtörtek (Incze Lajos 1939. 124-125.) (38. kép).

A 2000-es években a székelyföldi fazekasok a mázakat elsősorban a Cerasil nagyváradi, majd fogarasi lerakataiból, illetve az Interkeram segesvári telephelyéről szerzik be, a legtöbben innen hozzák az engóbokat is. A saját vegyítéstől, színezéstől, réz- vagy vasoxid hozzáadásától idegenkednek.

Az egyszínű mázazáshoz a porlasztópisztolyok, kerámiapisztolyok használatára is találunk adatokat, például László Károly kézdivásárhelyi csempekészítő esetében.

A 20. század közepén a népművészeti boltokban feltűnő tiroli tarka edények és szobrocskák hatására a korondi fazekasok a kerámiáik díszítéséhez az ún. dukkófestékeket is felhasználták. Ez az erőteljes piros színű autófesték semmiképpen sem volt olyan időtálló, mint a hagyományos kerámiamáz, így csupán rövid ideig - az 1960-80-as években - alkalmazták (39. kép). 


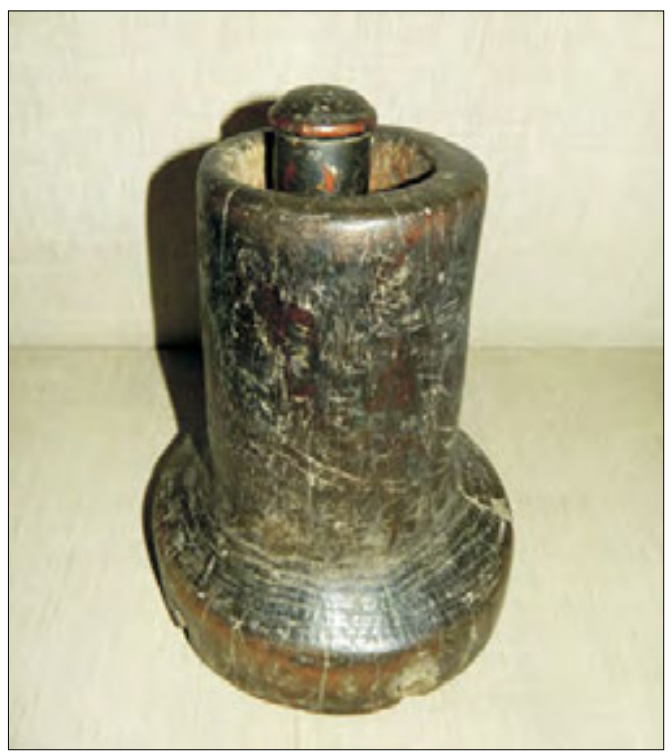

38. kép. Máztörő mozsár Magyarhermányról, 20. század eleje. SzNM

Ugyancsak ebben a periódusban a makfalvi és szolokmai állat- és ember alakú szobrocskákat gyártó fazekasok is új anyagokhoz nyúltak: a kereskedelemből beszerezhető bronzfestékkel födték be kis tárgyaikat (Bandi Dezső 1958). E periódus az új színezési eljárások felé mozdította el a csíkdánfalvi ún. kerámiaműhely alkalmazottait is. Hogy a mázatlan fekete edényt tartósabbá tegyék, szurkot oldottak fel benzinben vagy gázolajban, ezzel kenték be a díszedények felületét. A csillogó hatás elérése kedvéért a gázolajat étolajjal vegyítették, ezzel bekenték az edény felületét, majd csiszolóvászonnal simították és fával fényezték a felületet. Az áhított vörös szín előállítására itt lakkot, étert használtak (Gazda Klára 1982). Ezen anyagok (benzin, gázolaj, éter) beépülése a színező- és tömítőanyagok közé nemcsak egészségügyi szempontból, de kellemetlen szaga miatt a kilencvenes évekre csaknem teljesen kiszorította a piacról a csíkdánfalvi kerámiaműhely termékeit. Ugyancsak új felületkezelő anya-

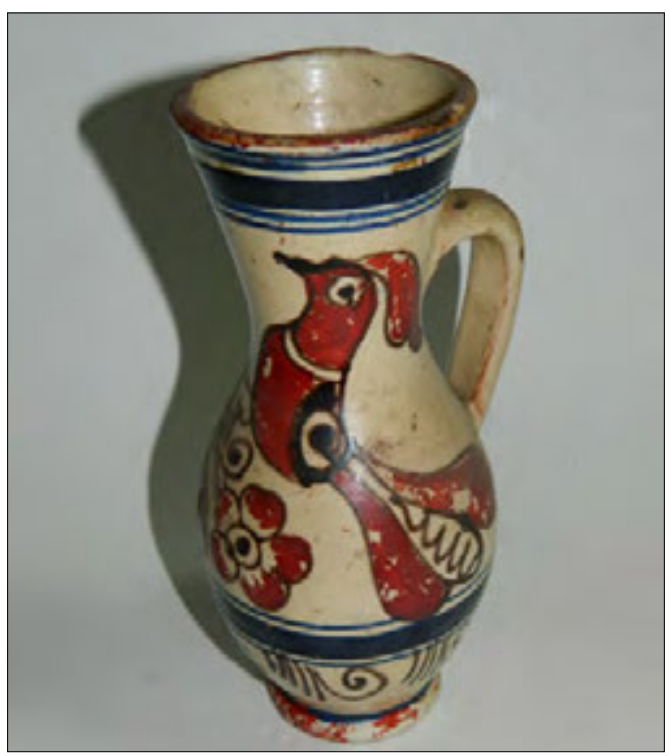

39. kép. Autófestékes „dukkós” kerámia, Korond, 1980-as évek, SzNM

got kísérletezett ki a kézdivásárhelyi László Károly is a 21. században az általa készített kályhacsempék befödésére. A csempemásolatokat, régies csempéket készítő mester nagyobb megrendeléseket kapott a máz nélküli csempékre, ám azok felületét valamivel mégis le kellett födnie, hogy az esetleges füstölés nyomait el lehessen tüntetni. Az antikolást a mester saját találmányának nevezi: a csempelapokra vas-oxidos-vizes oldatot visz rá, majd a fölösleget letörli. Ezt falfixáló típusú vizes oldattal rögzíti, amely jól bírja a hőt, és többéves használat után újrafesthető. Az antikolás tehát egy matt barnás réteg, amely elfödi a mázatlan csempe pórusait.

A fazekasok edényeiket napjainkban is kétszer égetik: az első égetést zsengélésnek, a másodikat pedig rendes vagy mázas égetésnek nevezik. A régi katlanok sajnos majdnem teljesen eltűntek a vidékünkről, így csupán a publikációkból lehet megismerni, milyenek is voltak ezek. Míg Magyarország fazekaskatlanjairól nagyon hasznos német nyelvű 
publikáció látott napvilágot, amelyből megismerhetők az ottan használt típusok variációi (Duma György 1982b), addig sajnos Székelyföldről csak néhány rajz és pár nyitott tetejü, alultüzelős, rostélyos fazekaskemence képe maradt fenn. Csíkdánfalván a 20. század közepén külön kemencetípus készült a fekete

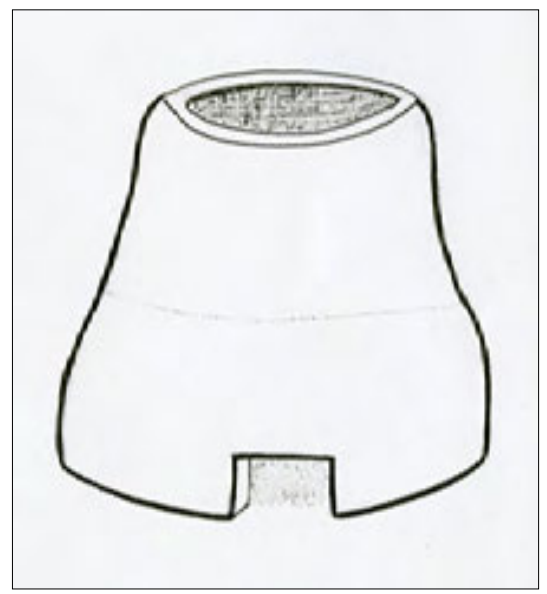

5. ábra. Edényégető kemence, Magyarhermány, 20. sz. edények égetésére (saját gyüjtés, 2014) (5., 6. ábra és 40. kép).

Az égetés nagyon kényes feladat volt, többnyire vékony, száraz fát kellett rá használni, mert a hirtelen beáramló forró levegő elhasíthatta az edényt. A piros edényeket egymásba rakva is tudták égetni, ám a fekete

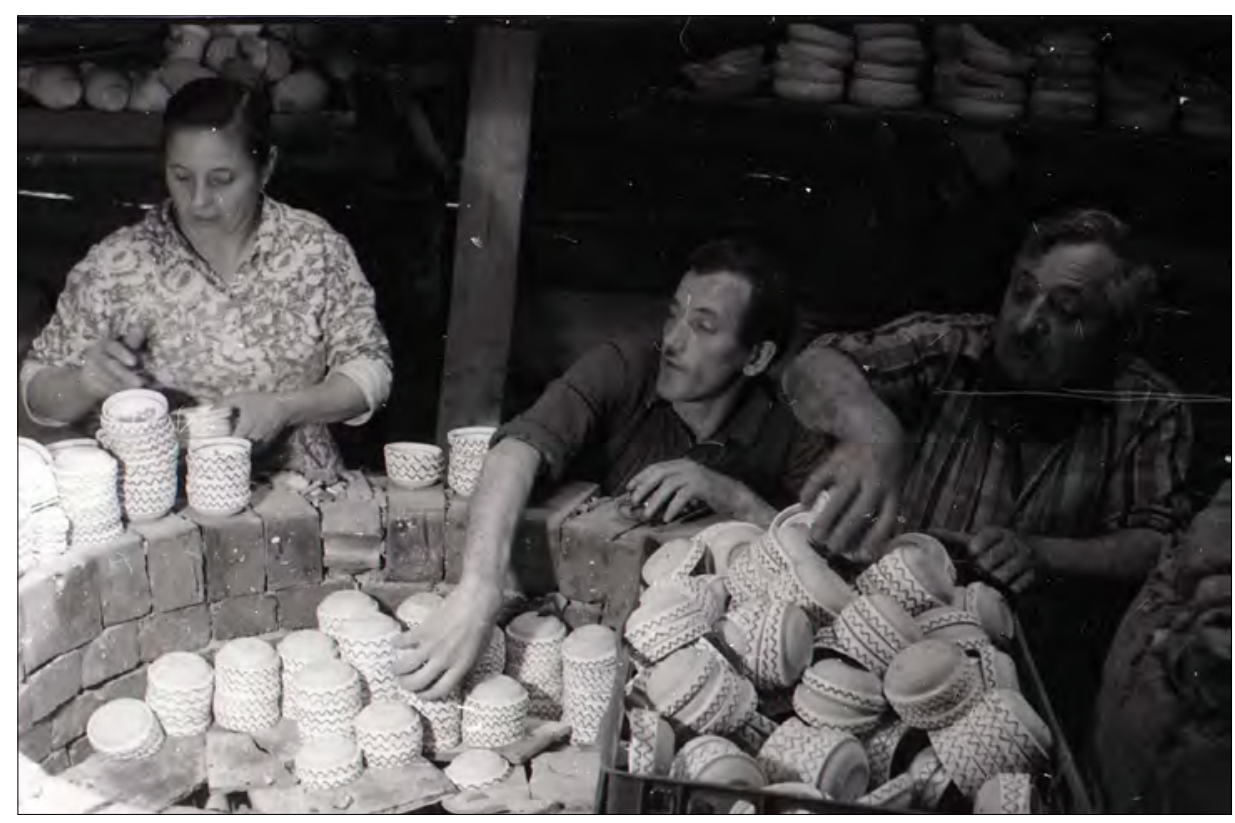

40. kép. Edényégetés, Korond, 20. sz., Fóris Pál felvétele, SzNM 
edények, ha egymásba tették, foltossá váltak az érintkezési pontoknál. A kerámiaégetés hosszú ideig tartott, és akkor lett kész, mikor fehéres színűnek látszottak az edények. A fekete edény égetéséhez az égetés utolsó fázisában jól füstölő anyagot adtak, majd régebben száraz marhatrágyával, újabban a kemence agyagos letapasztásával érték el azt, hogy a füst ne tudjon eltávozni (Kós Károly, dr. 1976. 253-259.).

\section{A kályhacsempék készítésének technikája}

Akárcsak a fazekas és a tálas, a régibb korokban a csempekészítés is többnyire külön mesterség volt. Történeti forrásaink tanúsága szerint egy-egy céhes központban időnként egy-egy mester csak csempekészítéssel foglalkozott, és úgy tűnik, a céhek is szemet hunytak afölött, hogy pl. valaki kizárólag csak csempe remeket mutasson be a céh elöljárói előtt (Szőcsné Gazda Enikő 2010b. 48.).

A kályhacsempék készítésének nagyon fontos eleme volt a dúc elkészítése, amelyet a középkorban még agyagból, a későbbiek folyamán fából, újabban gipszből készítenek. A csempekészítők gyakran egy-egy ügyesebb kezű asztalost vagy faragómestert kértek meg a dúc elkészítésére, aki többnyire körtevagy égerfából készítette ezt el, a szálasabb, puhább fenyő nem felelt meg erre a célra. Külön dúc kellett a lapcsempéknek, a sarokcsempéknek (ebből jobbost és balost egyaránt készítettek), de a kályha befejezésénél használt párkányok, csipkék számára is kellett a negatív, amivel elkészíthették ezt (41., 42., 43. és 44. kép).

A csempe számára tűzállóbb, homokosabb agyagot készítettek elő, és mivel a cél a csempelaptól való könnyebb elválasztás volt, így az agyag túlzott vizezése sem volt ajánlott. $\mathrm{Az}$ előkészített agyagot régebb többnyire

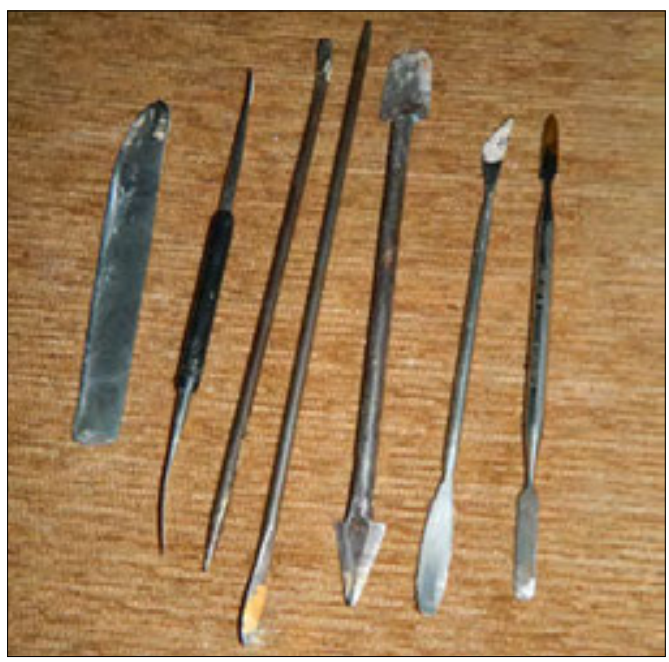

41 kép. Csempedúc készítésére használt szerszámok, 21. sz., Kézdivásárhely

vászonnal nyomták be a negatív formába, ez annyira beleragadt az agyagba, hogy könynyebbé tette a kiemelést. A csempék összerakásához, egymáshoz illesztéséhez kellett egy kis keret a díszítetlen belső laprészre, ezt a könnyebb kiemelés kedvéért nem a dúccal készítették, hanem egy keskeny agyagcsíkot újjnyomásokkal odadolgoztak a csempelaphoz. Ezt a keretet néha vagdosással kissé megcsíkozták, hogy a kályha felrakásakor a felhasznált focsos agyag jobban tapadjon bele. Szokás volt a keret átlyukasztása is, ami a csempék drótos egymáshoz illesztését szolgálta. A könnyebb kiemelés kedvéért és azért, hogy az égetéskor ne roskadjon be a csempelap belseje, a csempe hátoldalára kis agyagcsapokat is tettek, amelyeket az égetést követően letörtek (45. kép).

A régibb mázatlan csempéknél divatos volt a dúc csillámmal való beszórása, ebbe nyomták bele az agyagot, a kvarctartalmú homok égetés után csillogó felületű szemcsékkel telítette a sápadt agyagfelületet (Szőcsné Gazda Enikő 2010b. 33-38.). 


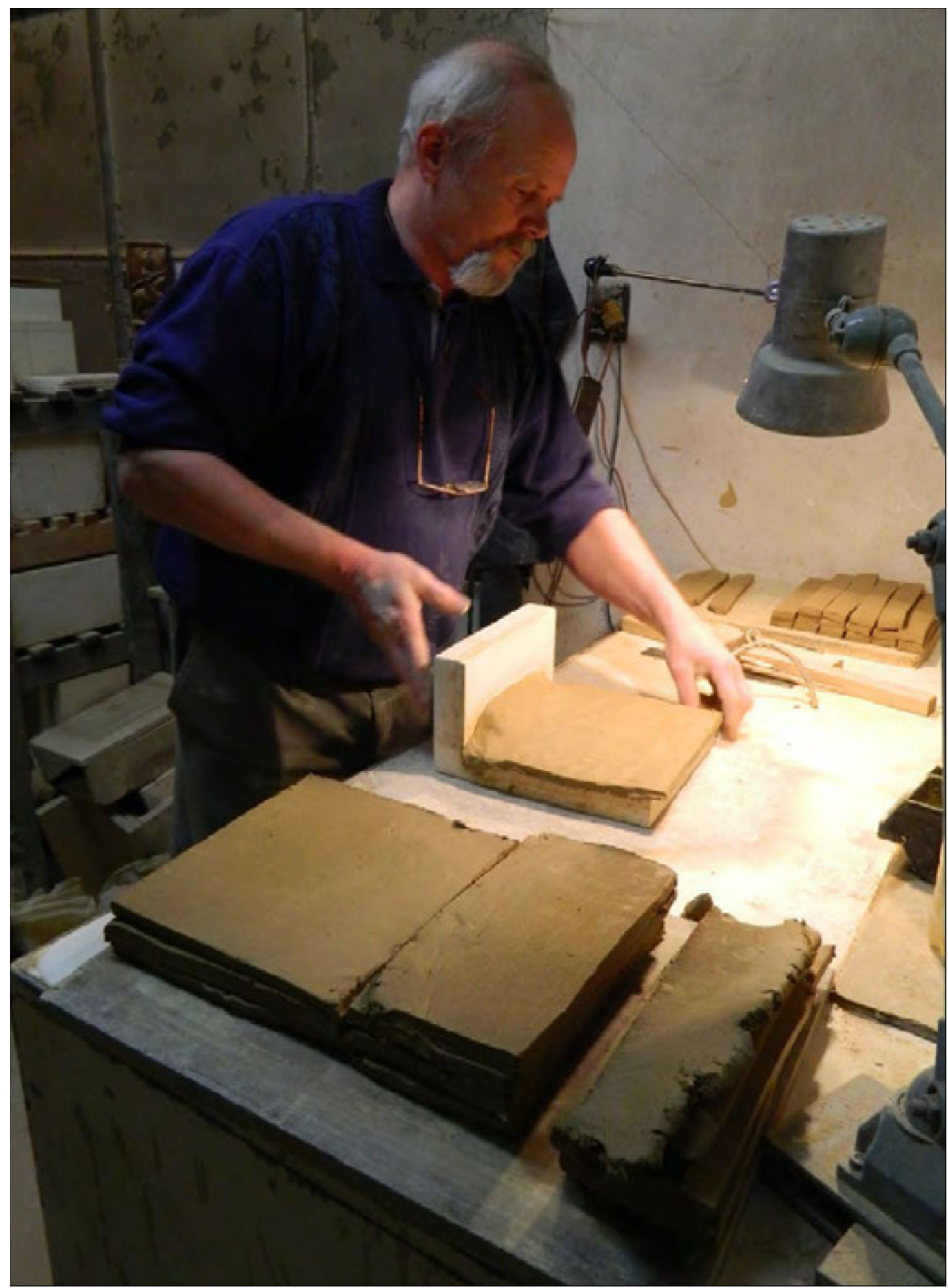

42. kép. Csempekészítés, 21. sz., Kézdivásárhely 


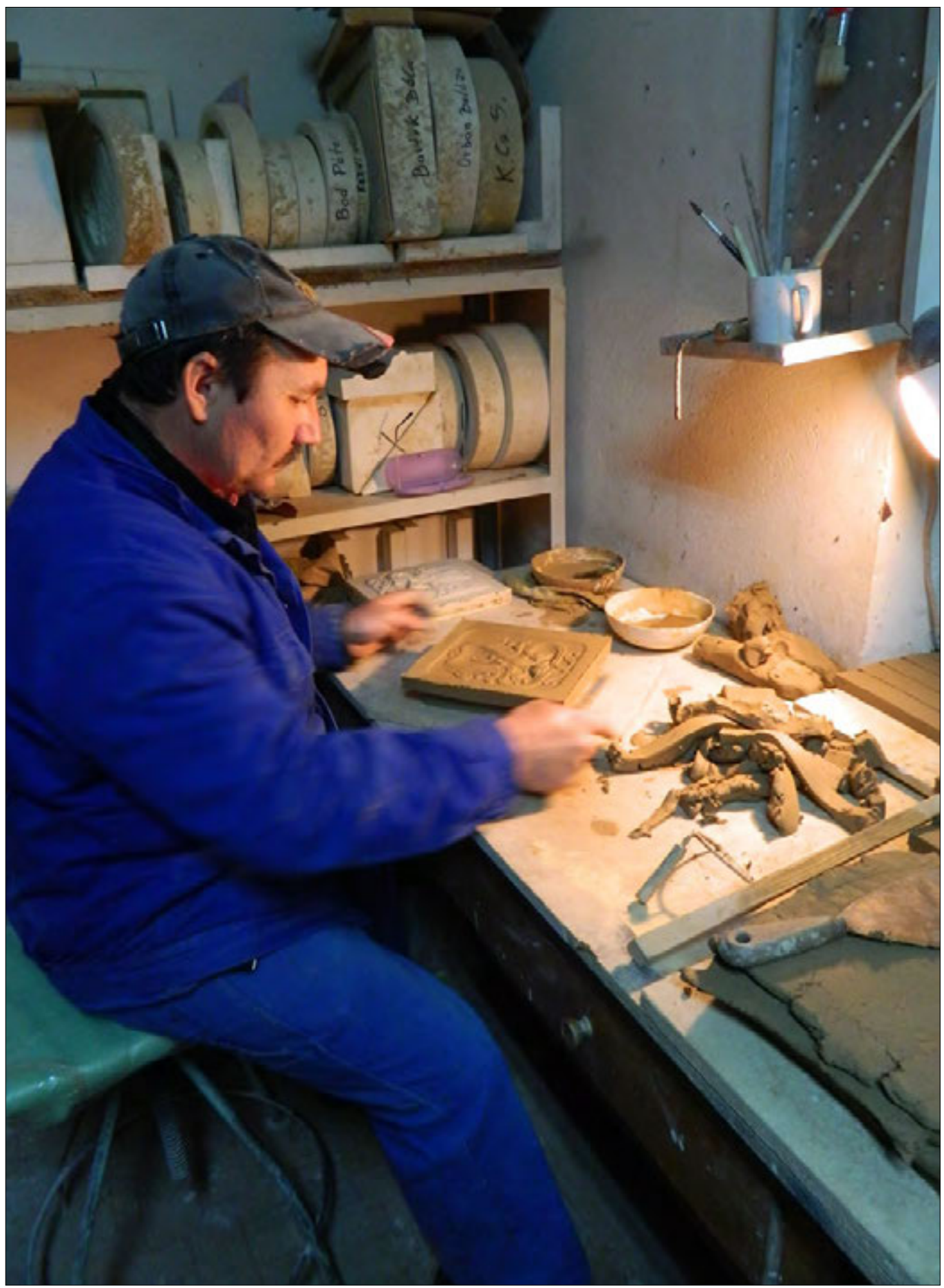

43. kép. Csempekészítés, 21. sz., Kézdivásárhely 


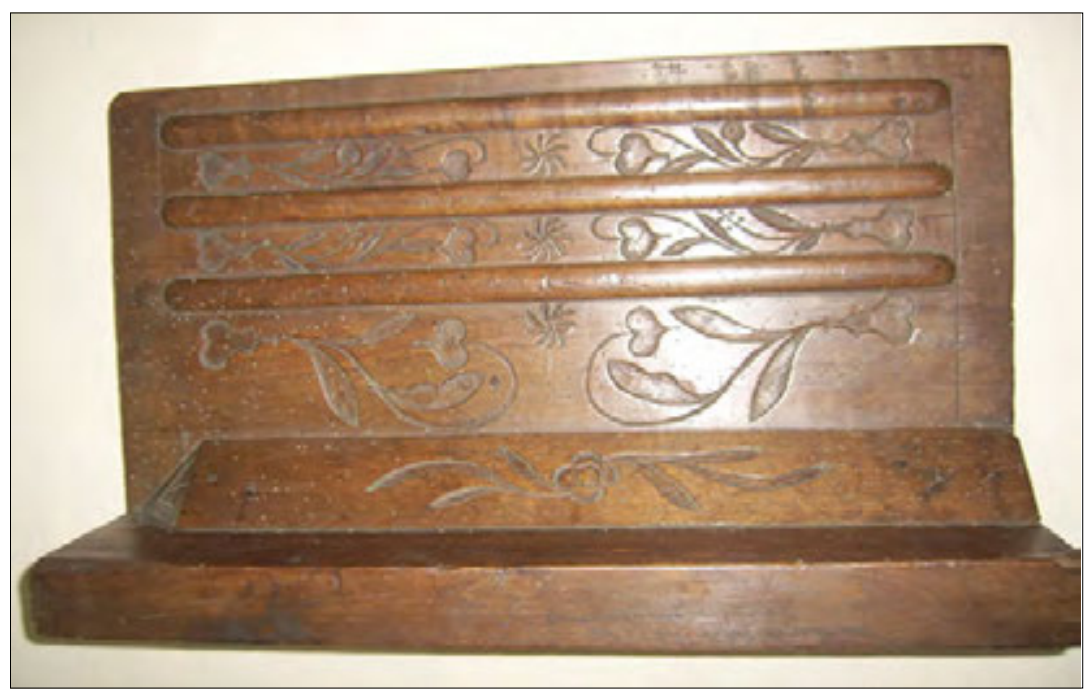

44. kép. Kályhacsempedúc, Magyarhermány, 19. Sz., SzNM

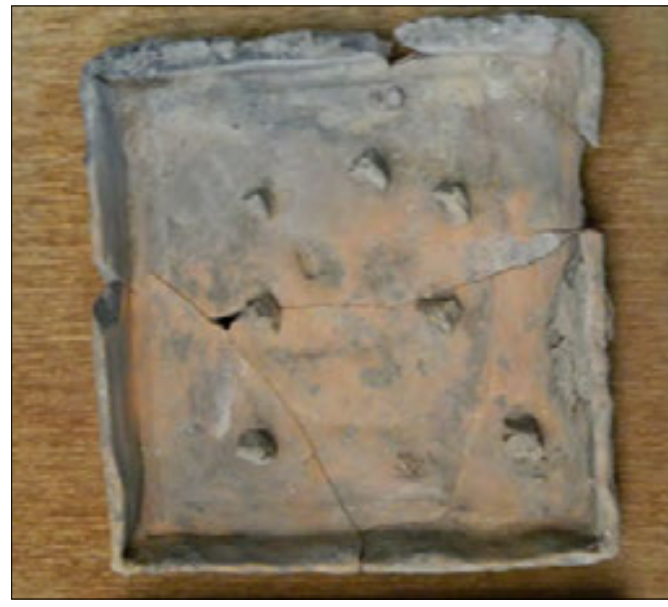

45. kép. Agyagcsapos készítési technika nyomai egy kályhacsempe hátoldalán, SzNM

\section{A székelyföldi kőedény- és majolikakészítő mühelyek}

Székelyföld iparosodásában különleges szerepet töltenek be a kisebb méretű, de magasabb technikai színvonalat követelő kőedény- és majolikagyártó műhelyek. Ezeknek termelése, árukészlete a környék terméktípusaihoz képest más alternatívát kínáltak, így egyszersmind más réteget is szólítottak meg, mint a falusi fazekasok által készített termékek.

A kőedény alapanyaga a kaolin, amelyhez finomra őrölt kvarcot vegyítenek, ezzel növelve az agyag képlékenységét. Előállítása nem pusztán azért volt drágább és nehezebb, mert jóval ritkább és nehezebben beszerezhető volt a kaolin, hanem azért is, mivel a kőedény kiégetéséhez a katlanban sokkal magasabb hőfokot kellett biztosítani. Míg a klasszikus mázatlan vagy szimpla ólommázas kerámiát alacsony hőfokon már elő tudták állítani, a kőedény- és majolikagyártás feltétele volt az 1100-1300 fokos hőmérséklet elérése.

Székelyföld szűkebb területén több kőedény- és majolikaműhely működéséről tudunk, ezeknek termelése viszont nem volt annyira nagy, mint a magyarországi manufaktúráké vagy éppen Brassó, Szeben vagy Kolozsvár műhelyeinek.

Székelyföld legjelentősebb kőedénykészítő műhelye Görgényszentimrén működött. Alapítását 1820-ra tehetjük, és a 20. század 
legelejéig működött. Termékeit mind Erdély, mind Moldva és Törökország felé terjesztette. Egy 1883-as beszámoló szerint a gyár a kincstár tulajdonát képezte, 12 korongon és 2 égetőkemencében készítették az edényeket. A görgényi kőedénygyár a szindi és a szárhegyi agyagot a helyi mészpáttal és a Csehországból hozott kvarchomokkal vegyítette. A gyár egyes leírások szerint különleges, egyedi technikát dolgozott ki: az egyszer kiégetett ún. bisquites edényt konyhasóoldatba mártották, majd újból kiégették. Ennek hatására az edényben lévő vas-oxid vas-kloriddá változott és elillant, az edény pedig egyedi fehér színű, máz fölött égetett kőedénnyé alakult. Ez az eljárás egyedivé, viszont drágává tette a műhely termékeit (Katona Imre 1978. 124-125.). Technikatörténészek megkérdőjelezik, hogy valóban a só hatására lett-e fehér az edény, vagy pedig mázazás történt. Székelyföld másik kőedénygyára, amely néhány évtizednyi ideig fenn tudott maradni, és így tárgyi bizonyítékok maradtak utána, Nagykászonban működött. A gyár egyes feltételezések szerint 1840 körül, más adatok szerint 1868-ban alakult, és az 1890-es évekig működött (Katona Imre

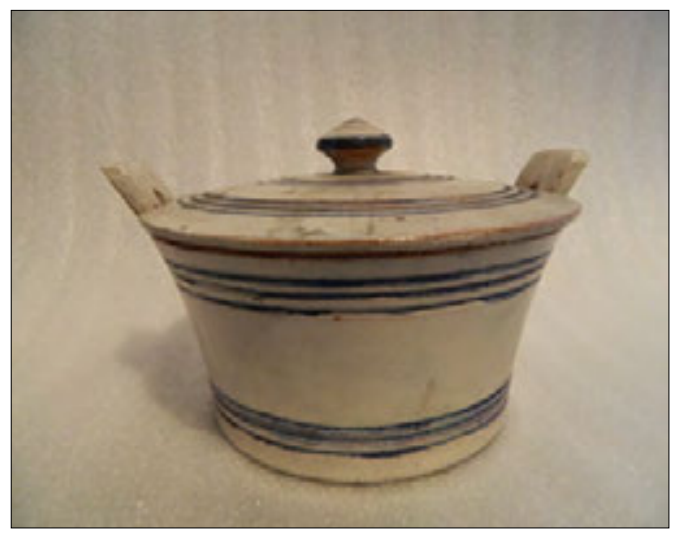

46. kép. Majolika a sepsiszentgyörgyi majolikagyártó műhelyből, 19. század vége. SzNM
1978. 135-136.). Edényeihez az agyagot vásárolták, és a feldolgozásra szánt kis kulacsokat, változatos tányérformákat Ojtoz környékéről hozott gipszformákba öntötték (Gyárfás Győző 1892). A kászoni keménycserép vörösesbarna színű, és fehérföldes vagy zöld színű ecsetes, írókás díszítménnyel dekorálták.

A húszadik században rövid ideig keménycserép-készítés folyt a marosszéki Szolokmán is. A sárga, érdes alapanyagú kis egyenes falú fazekak, pálinkamelegítő edények a gyár rövid idejű működése miatt szűk számban maradtak ránk. Rövid ideig majolikagyártó műhelyek működtek Sepsiszentgyörgyön és Csatószegen is. Sepsiszentgyörgyön 1882-ben indult el egy cserépedénygyár, amely a város területén fellelhető, a barnaszén fedőrétegeként előforduló ún. pontusi szürke tályogot használta fel, de kísérletet tett a csíki kaolin felhasználására is (Nemere, 1882. március 5. XII. évf. 19. szám). A Székely Nemzeti Múzeum tulajdonában fennmaradt edényállomány szerint a fehérfölddel bevont edényeken a sgrafitto technikát alkalmazták: a félszáraz festékföldet visszakarcolták, így előtűnt az agyag színe (46. és 47. kép).

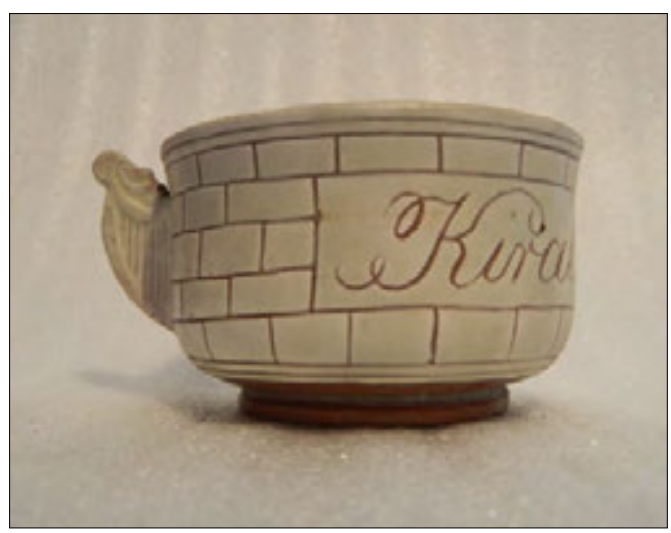

47. kép. Majolika a sepsiszentgyörgyi majolikagyártó múhelyből, 19. század vége. SzNM 
Elsősorban kisebb csészéket, kannákat, tojástartókat, gyertyatartókat készítettek itt. Csatószegen a helyben lévő híres fehérföld felhasználására tett kísérletet egy fazekasmester. A sötétbarna mázú tálak, tányérok mellett magasabb, oszlop alakú edényeket, kuglófsütő edényeket készítettek a kis csíki településen (Farkas Irén 2004. 498.).

\section{Jegyzetek}

* A tanulmány szövege 2014. decemberében zárult, így nem használja az azután megjelent szakirodalmat.

1. A fazekasok körében használt borostyán megnevezésnek semmi köze nem volt a voltaképpeni borostyánhoz, a német Brauensteinból származó szó népetimológiaként burusnyán formában élt több fazekashelységben

2. Köszönöm Domokos Levente festékanyagokkal foglalkozó restaurátornak, hogy a grafit előfordulási helyeinek kiderítésében segítségemre volt.

3. Sófalvi András és Nyárádi Zsolt ásatásaik eredményeit nemrég vándorkiállításon ismertették.

\section{Felhasznált irodalom}

Balassa Iván: A határainkon kívüli magyarok néprajza. Gondolat Kiadó, Budapest, 1989.

Balogh Ödön: A marosvásárhelyi fazekasmesterség. (Története, munkamenete, szókészlete) Ethnographia, LXXXIII. évf. 2-3. szám, 1972. 313-329.

Bandi Dezső: A Magyar Autonóm Tartomány népi kerámia művészetének felvirágzásáért. Vörös Zászló, 1958. augusztus 31.

Benkő Elek: A középkori Keresztúr-szék régészeti topográfiája. Varia Archeologica V, Budapest, 1992.

Benkő Elek - Ughy István: Székelykeresztúri kályhacsempék. Kriterion Könyvkiadó, Bukarest, 1984.
Csupor István: Erdély népi kerámiamüvészete. Novella Kiadó, Budapest, 2008.

Csupor István - Csuporné Angyal Zsuzsa: Fazekaskönyv. Planétás Kiadó, Budapest, 1998.

Diaconescu, Aurelia: Ceramica în suluri de lut din colectiile etnografice mureșene. Muzeul Județean Mureș, Târgu Mureș, 2011.

Divald Kornél: A magyar iparművészet története. Szent István Társulat, Budapest, 1929.

Duma György: Mázas cserépedények a római korból. Építőanyag 34. 1982. 138-144. www.mutargymasolatok.hu/dgy/romaimaz.htm

Duma György: Holzgefeuerte Ofentypen der Hafnerin Ungarn. Keramik13.1982.53-79. http://mutargymasolatok.hu/dgy/Holzgefeuerte_Ofentypen.pdf

Farkas Irén: A csíki fazekasság történeti áttekintése. In: Bárth Dániel - Laczkó János (szerk.): Halmok és havasok. Tanulmányok a hatvanesztendős Bárth János tiszteletére. Bács-Kiskun Megyei Önkormányzat Múzeumi Szervezete, Kecskemét, 2004. 489-504.

Fehér Katalin (szerk.): Pannon enciklopédia. Magyar ipar- és technikatörténet. II. kiadás. Urbis Könyvkiadó, Budapest, 2009.

Gabler Dénes: A terra sigillata gyártása és mühelyeinek struktúrája. In: Holló Szilvia Andrea - Szulovszky János (szerk.): $A z$ agyagművesség évezredei a Kárpát-medencében. Az MTA VEAB Kézművesipar-történeti Munkabizottsága és az Archeometriai és Iparrégészeti Munkabizottsága közös kiadványa, Budapest-Veszprém, 2006. 23-32. Gazda Enikő: Centre de olari din Trei Scaune. Háromszéki fazekas központok. In: Cserei Zoltán et al.: Centre de olari din Sud-estul Transilvaniei - Fazekas központok Délkelet-Erdélyben. Sf. Gheorghe - Sepsiszentgyörgy, 1997-98. 47-82.

Gazda Klára: Feljegyzések a dánfalvi kerámia szövetkezetről. Székely Nemzeti Múzeum néprajzi dokumentumtára, Sepsiszentgyörgy, D. 293-as leltárszám, 1982. 
Gucsi László: Rézkori és kora bronzkori kerámiákon végzett technikai megfigyelések. In: Holló Szilvia Andrea - Szulovszky János (szerk.): Az agyagmüvesség évezredei a Kárpát-medencében. Az MTA VEAB Kézművesipar-történeti Munkabizottsága és az Archeometriai és Iparrégészeti Munkabizottsága kiadása, Budapest-Veszprém, 2006. 7-18.

Gyárfás Győző: Az Ojtozi szoros. Erdély, 1892. 5. szám. In: www.erdelyigyopar.ro/ 1892-5/2987-az-ojtozi-szoros.html

Györffy István, Dr:: Az új magyar művelődés alapjai. Hitel, 1939. 2. szám. 97-121.

Haáz Ferenc Rezső: Adatok a korondi fazekas mesterséghez. Néprajzi Értesítő XXXII, 1940. 184-186.

Havancsák Izabella - Bajnóczi Bernadett - Tóth Mária - Kreiter Attila - Szöllősi Szilvia: Kelta grafitos kerámia: elmélet és gyakorlat dunaszentgyörgyi kerámiák ásványtani, petrográfiai és geokémiai vizsgálatának tükrében. Archeometriai Műhely, 2009/1. www.ace.hu/am/2009_1/AM09-01-HI.PDF

Holl Imre: Adatok a középkori magyar fazekasság munkamódszereihez. Budapest Régiségei, 17. évf. 1956. 177-193.

Horváth Tünde: Megfigyelések a középső és késő rézkori kultúrák fazekasáruin Balatonőszöd temetôi dűlő lelőhelyen. Archeometriai Műhely, 2010/1. 51-81.

Hunfalvy János: A magyar korona területének bányászata. In: Statistikai közlemények: a hazai állapotok ismeretének előmozdítására. 3. kötet, I. füzet. Pest, 1862. 161-230.

Incze Lajos: A korondi fazék. Hitel, 1939/2.

István Lajos: Korondi kerámia. Népi Alkotások és Műkedvelő Tömegmozgalom Megyei Irányító Központja, Csíkszereda, 1973.

Kalecsinszky, Alexander von: Die untersuchten Tone der Länder der Ungarischen Krone. Franklin, Budapest, 1906.
Katona Imre: A magyar kerámia és porcelán. Képzőművészeti Alap Kiadóvállalata, Budapest, 1978.

Koch Antal: Erdély ásványainak kritikai átnézete, 5. Közlemény. Orvos-természettudományi Értesítő, VII. kötet III. füzet. 1885. 185-216.

Kós Károly, Dr.: Csíki fazekasfalvak és fazekasságuk. In: Uő: Tájak, falvak, hagyományok. Kriterion Könyvkiadó, Bukarest, 1976. 218-276.

Kőváry László: Erdélyország statistikája. Első kötet. Tilsch János, Kolozsvár, 1847.

Kresz Mária: Fazekas, korsós, tálas. (Néhány szempont fazekas-központjaink kutatásához és összehasonlításához). Ethnographia 71. 1960. 297-379.

Kresz Mária: Magyar fazekas mûvészet. Corvina-Forum, Novi-Sad, 1991.

Nyárádi Zsolt - Sófalvi András: Vizigót településrészlet Telekfalván. In: Körösfői Zsolt - Sándor-Zsigmond Ibolya (szerk.): Erdély és kapcsolatai a kora népvándorlás korában. Molnár István Múzeum - Hargita Megye Tanácsának Műemlékvédelmi Közszolgálata, Székelykeresztúr, 2010-2011. 177-190.

Orbán Balázs: A Székelyföld leírása történelmi, régészeti, természetrajzi $s$ népismei szempontból. I. Pest, 1868.

Örley János: Agyagipar. In: Buday Barna (szerk.): Székely kongresszus. Pátria Nyomda, Budapest, 1902.

Rangyák József, V.: Egy jellegzetes székelyföldi edénytípus: a pálinkamelegítő. Ethnographia, 109. évf. 1998. 169-174.

Rusu-Bolindeț, Viorica: Ceramica romană de la Napoca. Contribuții la studiul ceramicii din Dacia Romană. Editura Mega, Cluj-Napoca, 2007.

Sándor-Zsigmond Ibolya: „Mesében éltem”. A székelykeresztúri iparosság története. Ajka Város Önkormányzata - Székelykeresztúri Magánvállalkozók Szövetsége, Ajka-Székelykeresztúr, 2005. 
Seres András: Hermányi fazekasság. In: Almanahul Muzeului din Cristuru Secuiesc A Székelykeresztúri Múzeum emlékkönyve. Studii și comunicări - Tanulmányok, közlemények. Comitetul de Cultură și Educație Socialistă al judetului Harghita, Miercurea Ciuc - Csíkszereda, 1974. 359-368.

Seres András: Kovászna megye régi fazekas központjai. Aluta, Sepsiszentgyörgy, 1974-75.

Sófalvi András: Sóvidék a középkorban. Fejezetek a székelység korai történelméböl. Haáz Rezső Múzeum, Székelyudvarhely, 2005.

Suba László: Paraszt fazekasok. Néprajzi Múzeum Etnológiai Adattára, EA 27180-as jelzet, 1996.

Szabó Miklós: A kelták nyomában Magyarországon. Hereditas. Corvina Kiadó, Budapest, 1971.

Szakmány György: Kerámia nyersanyagok, kerámiák a mai Magyarország területén a neolitikumtól a XVIII. század végéig. In: A Miskolci Egyetem Közleménye, A sorozat, Bányászat, 74. kötet, 2008. 49-90.

Szakmány Gy. - Gherdán K. - Starnini E.: Kora neolitikus kerámia készítés Magyarországon: a Körös és a Starcevo kultúra kerámiáinak összehasonlító archeometriai vizsgálata. Archeometriai Műhely, 2004/1. 28-31.

Székely Zoltán: Sepsiszentgyörgy története a középkor végéig. Jókai Nyomda Rt., Sepsiszentgyörgy, 1948.

Székely Zoltán - Bartók Botond: Cuptoare de ars oale din așezarea neolitică de la Ariușd. In: Materiale și cercetări arheologice. A XIII-a sesiune anuală de rapoarte. Muzeul Țării Crișurilor, Oradea, 1979. 55-58.

Szőcsné Gazda Enikő: A székelyudvarhelyi fazekasság a céh-és ipartársulati jegyzőkönyvek tükrében. Acta Siculica 2008. Székely Nemzeti Múzeum, Sepsiszentgyörgy, 2008. 497-508.
Szőcsné Gazda Enikő: A kézdivásárhelyi fazekasság végnapjai - Balassa Iván 1942-es kézdivásárhelyi felmérésének margójára. Acta Siculica 2009. Székely Nemzeti Múzeum, Sepsiszentgyörgy, 595-604.

Szőcsné Gazda Enikő: A székelyföldi sgrafitto kerámia. Székely Nemzeti Múzeum, Sepsiszentgyörgy, 2010.

Szőcsné Gazda Enikő: Erdélyi kályhák és kályhacsempék. Terc Kiadó, Budapest, 2010.

Szőcs Péter Levente: Kerámiaedények a régészet és az írott források tükrében. http:// www.korunk.org/?q=node/8\&ev=2004\&honap=7\&cikk=7578

Sztáncsuj Sándor József: Erôsdi leletek a Magyar Nemzeti Múzeumban. Erdélyi Múzeum 65. évf. 3-4. szám, 2003. 1-14.

Tófalvi Zoltán: A korondi fazekasság. Korunk, 1972/11. 1699-1713.

Tófalvi Zoltán: A sóvidéki népi fazekasság. Mentor, Marosvásárhely, 1996.

Vajda György: Régészeti ásatások Mikházán. Felszínen az ókori római település maradványai.

www.e-nepujsag.ro/op/article/régészetiásatások-mikházán

Véninger Péter: Soványító anyagok erôsségének mérése. Az agyag képlékenysége és a formázási eljárások közötti összefüggések vizsgálata. In: Petkes Zs. (szerk.): Hadak útján XX. Népvándorláskor Fiatal Kutatóinak XX. összejövetelének konferenciakötete. Budapest-Szigethalom, 2010. 375-391.

Wartha Vincze: Az agyagipar technológiája. K. M. Természettudományi Társulat, Budapest, 1892.

Zrínyi Andrei: Olarii din Târgu Mureș și produsele lor în lumina cercetării materialului rezultat din săpături. Marisia V. 1975. 93-112. 


\section{SZÉKELYFÖLD ÉRCTELEPEI}

A fellelhető szakirodalom és a 20. század közepén kezdődő feltárások eredményei átfogó képet nyújtanak Székelyföld ásványkincseiről, érctelepeiről.

Székelyföldre igen változatos földtani képződmények jellemzők, az ércesedések, ásványtömörülések is sokfélék. Ennek köszönhető például, hogy „a rézmúvesség már több évszázaddal azelött virágzott a Balkánon, neveze- tesen a mai Bulgáriában, Romániában, és DélJugoszláviában, mielött az Égeikumban a fejlődés hasonló szintjét elérte volna" (Colin Renfrew 1995, 177.). Abban a civilizációs korban, amikor Európában kialakult a rézművesség, már ismertek voltak a Kárpátok rézérclelőhelyei. A Keleti-Kárpátok karélya mentén elhelyezkedő Székelyföld területén előkerült rézből készült régészeti leletek is ezt bizonyítják.

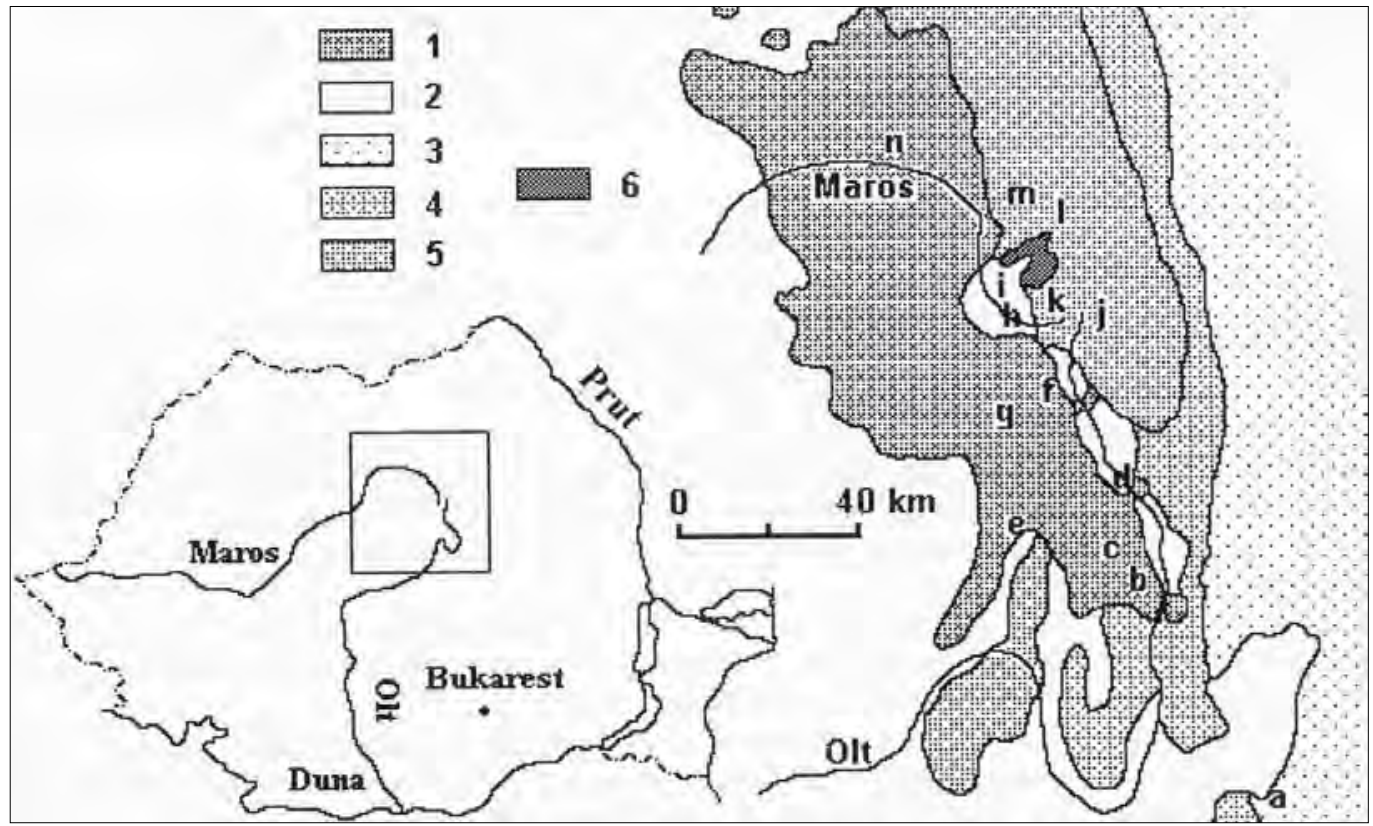

1. ábra. A székelyföldi érctelepek helyszínrajza (Kräutner \& Bindea 1995 nyomán). 1. neogén-kvarter vulkanizmus - Kelemen-havasok-Görgényi-havasok-Hargita hegyvonulat; 2. poszttektonikus fedörétegek; 3. Moldavidák (flisövezet); 4. Civcin-Severin rift- és az ehhez társuló flisegységek - Külső-Dacidák; 5. Geta-Bukovinai egység - Középső-Dacidák; 6. Ditrói alkáli masszívum. a. Kovászna; b. Kakukk-hegy; c. Csíkszentimre-Büdösfürdő; d. Csíkszereda; e. Lövéte-Szentegyháza-Kiruly; f. Csíkmadaras; g. IvóKokojzás-kráter; h. Gyergyószentmiklós; i. Ditró; j. Balánbánya; k. Békény-patak; l. Gyergyóholló-Tölgyes; m. Hărlăgia-Huruba; $n$. Gödemesterháza 
Székelyföld területén végzett legújabb, a rézércek előfordulásával kapcsolatos kutatások eredményei arra utalnak, hogy ezek a kristályos-mezozoos övhöz kötődő ércesedések, és néhány, jól meghatározható lelőhelyhez kapcsolhatók (1. ábra).

Ezek a következők:

\section{Vulkáni-üledékes rézércesedések a Békény-patak és a Csanód-patak térségében}

A Keleti-Kárpátok tölgyesi sorozatának epimetamorf kristályos képződményeiben egész sor réz- vagy réz-ólom-cink-ércesedés ismert. Ilyen terület a Békény- és Csanód-patak által közrezárt terület is. Ez a terület a Gyergyói-medencétől keletre fekszik, a Gyergyói-havasok (Munții Giurgeului) keleti peremén. A terület a baláni érctelep északi folytatásának tűnik. Az ércesedés főleg réztartalmú, a tölgyesi sorozat kristályos képződményeihez tartozó kloritos palákban helyezkedik el. A paragenézis egyszerű kalkopirit, pirit és klorit. Az ércesedés a Csanód-pataknak a bal oldali lejtőjén, a Békény mellékpatakjaiban, a Nyerges- és Nagygyőr-patakban a felszínre is bukkan. Az ércesedés réztartalma helyenként aléri az 1-1,2\%-ot (Csanód-patak) és a 0,4-0,5\%-ot (Nyerges-patak). Ezek csapásirányát, illetve mélységi kifejlődését az elvégzett kutatásokkal nem sikerült meghatározni, viszont igen nagy valószínűséggel fennáll annak lehetősége, hogy ezeket az ércesedéseket a térség bonyolult tektónikája rejti el. Nem zárható ki annak lehetősége, hogy csapásirányban, illetve mélységben az ércesedés kiterjedése nagyobb. Erre példa a csíkszentdomokosi Várbükk teleprész. Az ércesedés eredete vulkáni-üledékes, keletkezése egyidejű a kristályos palákéval.

\section{A balánbányai rézércesedés}

A balánbányai érctelep a Keleti-Kárpátok epimetamorf paláiban, a tölgyesi sorozatban található (Krautner, H. G. et al. 1988).

Kitermelésre érdemes érctelep az Olt folyó és a Szabó-patak összefolyása, valamint az ezektől északra lévő Sipos-patak által közrezárt területen található (2. ábra).

„A természetben a kőzetekben a vas két vegyértékű változata létezik, a két vegyértékű $\left(\mathrm{Fe}_{2}\right)$ és a három vegyértékű $\left(\mathrm{Fe}_{3}\right)$ vas-oxidjai, hidroxidjai, karbonátjai, szulfitjai. Ezek ipari felhasználásra, vasgyártásra alkalmas vasércek.

A két vegyértékű vas, a $\mathrm{Fe}_{2}$ könnyen oldódik szén-dioxidot tartalmazó ásványvizekben. Az így keletkezett kémiai vegyület a vas-bikarbonát, a $\mathrm{Fe}\left(\mathrm{HCO}_{2}\right)_{2}$. Ha a széndioxid $\left(\mathrm{CO}_{2}\right)$ valamilyen külső hatás következtében kilép a vas-bikarbonát-oldatból, létrejön egy új vegyület, a vas-karbonát $\left(\mathrm{FeCO}_{3}\right)$, ami már alapanyaga lehet a vasgyártásnak.

Egy másik folyamat, ami szintén vastartalmú vegyületet hozhat létre, a kén jelenlétéhez kapcsolódik. A kéntartalmú ásványok oxidációjának eredményeként, ahol a vas is jelen van, ásványvízzel érintkezve vas-szulfát és kénsav keletkezik a következő vegyi reakció szerint:

$2 \mathrm{FeSO}_{2}+2 \mathrm{H}_{2} \mathrm{O}+7 \mathrm{O}_{2}=2 \mathrm{FeSO}_{4}+2 \mathrm{H}_{2} \mathrm{SO}_{4}$

A két vegyértékű vas szulfátja a $\mathrm{Fe}_{2} \mathrm{SO}_{4}$, ami vízben disszociálva vas-hidroxidra és kénsavra bomlik. A vas-hidroxid vízben vasionokat szabadít fel, és colloid állapotúvá válik A kolloidoldat lassan kiszárad, és rétegekben leüllepedik. A folyamat főleg mocsaras vagy a múltban mocsaras területeken megy végbe, és a felszínhez közeli rétegekben képez változó vastagságú vasérctelepeket." (Guran, Mircea 1978. 23.) 


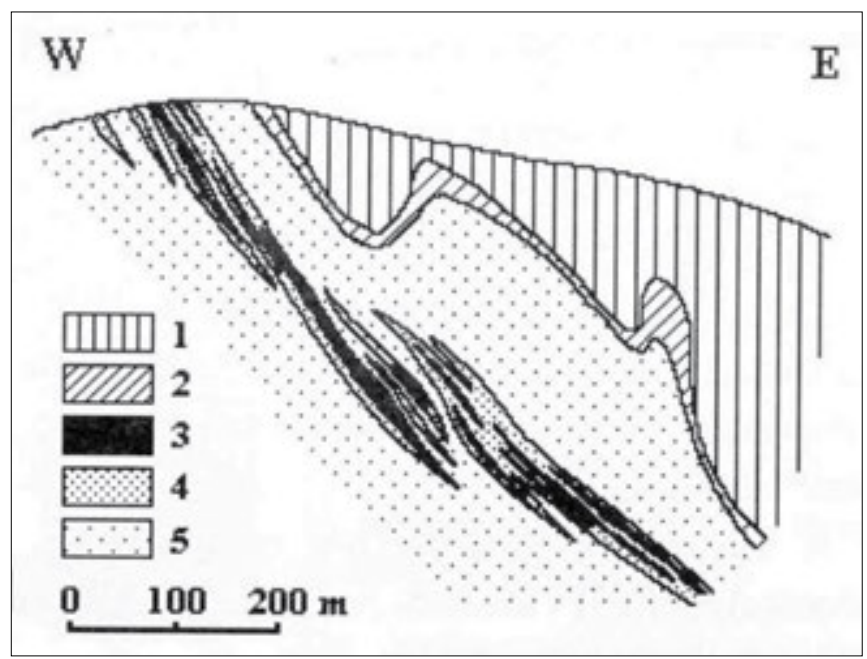

2. ábra. Földtani szelvény a balánbányai rézérc első felében. 1. szericites-kloritos palák (Valea Băii); 2. baláni metariolitok; 3. hintett rézércesedés; 4. kloritos kvarcitok és kloritos palák \pm pirit, helyenként magnetittel és/vagy vaskarbonátokkal; 5. szericites-kloritos fillitek, helyenként grafitos fillit beékelödésekkel

Ettől a területtől északra és délre helyenként még találni néhány kisebb érctestet, de ezek csekély kiterjedésűek. Az érc hordozókőzetei kisfokú metamorfózist mutató kloritos és szericites-kloritos palák (Krautner, H.G. 1965). $\mathrm{Az}$ érctestek ÉÉNy-DDK irányúak, 50-60 fokos keleti csapással. Az ércesedett zóna kb. $8 \mathrm{~km}$ hosszúságban, mélységben pedig több száz méteren követhető. Az érc hintett jellegű, túlnyomó részben piritből és kalkopiritből áll. Ezen ásványok mellett még előfordul a szfalerit, galenit, tetraedrit, bournonit, galenobizmutin, jamesonit, teallit, kubanit, termésbizmut, arany, ezüst, magnetit, hematit, ilmenit, kasziterit, rutil, kvarc, klorit, szericit, sziderit, ankerit, apatit, barit és turmalin (Krautner, H.G. 1965. 10/1. 195-227.).

Helyenként a hasznosítható ásványok kis telérek, lencsék és erecskék formájában is megjelennek. Ezek vastagsága a centiméteres nagyságrendet nem haladja meg.

$\mathrm{Az}$ érctelep eredete sokáig vitatott volt. Voltak, akik vulkáni-üledékesnek, mások pedig egykori savanyú magmatizmus hidrotermás fázisának tartották (Krautner, H.G. 1965. 10/1. 195-227.). Az ércesedés egy konvektív hidrotermás rendszerhez kötődik, amely kevés tengervizet is tartalmaz, és amely a fémes elemeket az érintett vulkanikus és nem vulkanikus kőzetekből oldotta ki. Ezt bizonyítják az izotóp elemzések.

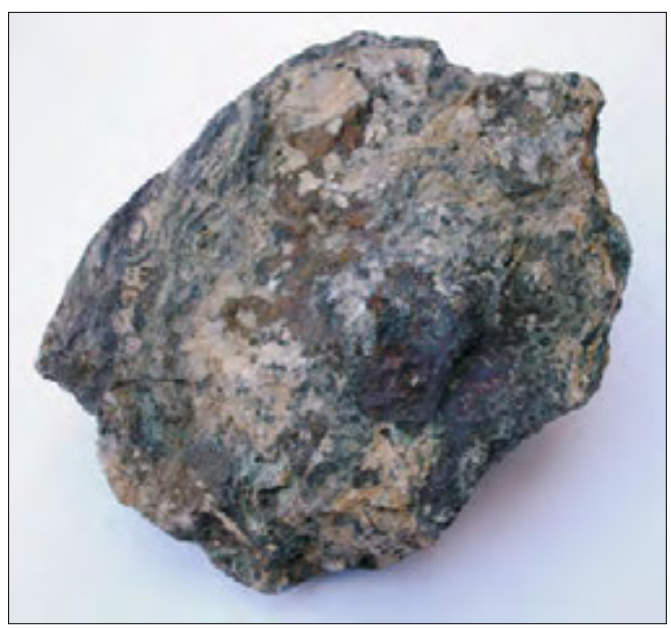

1. kép. Kalkopirit - Balánbánya 
A balánbányai rézércesedés kitermelése az 1790-es évektől kezdődően folyamatosan ment végbe a 20. század kilencvenes éveiig, amikor gazdaságosságának alacsony szintjére hivatkozva (a réztartalom átlagértéke a feltárt területeken $0,8 \%$ ) a kitermelés megszűnt.

\section{Vulkáni-üledékes ólom-, cink-, rézércesedések a Sötétputna völ- gyében}

Ezen ércesedések is a Gyergyói-havasokban találhatók, a Sötétputna völgye mentén, Tölgyestől (Tulgheș) nyugatra. Az ércesedés kloritos és szericites-kloritos, kvarcos palákban található. Ez a formáció a Balán-Békény érchordozó komplexum észak irányú folytatását képezheti. Az ércesedés eredete szintén vulkáni-üledékes, kora paleozoikumi korú. Keletkezése egyidejű a hordozó palákéval. A paragenézis egyszerű, elsősorban piritből, szfaleritből, galenitből, kalkopiritből és kloritból áll.

A felszíni feltárásokban csak egyes, elkülönült pontokban figyelhető meg, jelenlétére gyenge limonitosodás vagy kissé megemelkedett ólom-, cink- vagy réztartalom utal. Az ólom- és réztartalmú ércesedést fúrások-

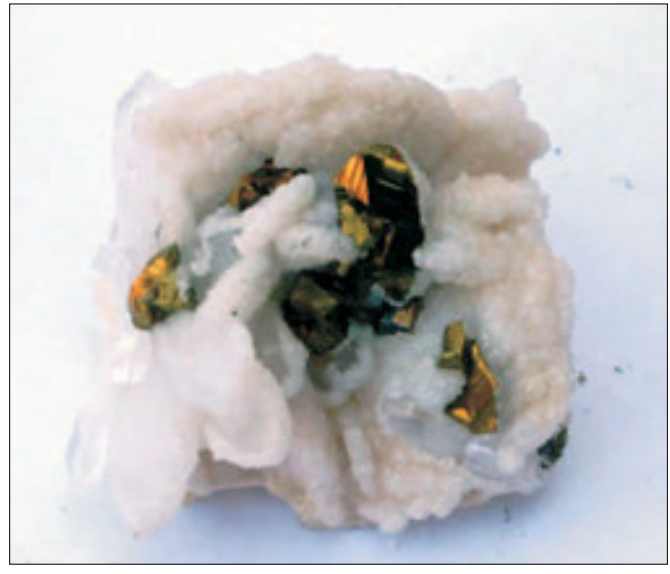

2. kép. Kalkopirit - Tölgyes, Holló kal 70-200 méteres mélységben azonosították, elsősorban a Balázs-, a Baratu Mare és a Somlyó-pataknál egy régebbi bányamunkálat is elért egy réztartalmú ércesedést. Az 1. táblázat a rézércek vegyi összetételét és réztartalmát mutatja (Dănilă P.-Dănilă M. 1982).

1. táblázat. Rézércek vegyi összetétele és réztartalma

\begin{tabular}{|l|l|c|}
\hline Megnevezés & \multicolumn{1}{|c|}{ Vegyi képlet } & $\begin{array}{c}\text { Réztartalom } \\
{[\%]}\end{array}$ \\
\hline Termésréz & $\mathrm{Cu}$ & 99,9 \\
\hline Kalkopirit & $\mathrm{CuFeS}_{2}$ & 34,6 \\
\hline Kavelin & $\mathrm{CuS}$ & 66,5 \\
\hline Kalkozin & $\mathrm{Cu}_{2} \mathrm{~S}$ & 79,8 \\
\hline Borait & $\mathrm{Cu}_{5} \mathrm{FeS}_{4}$ & 63,3 \\
\hline Enargit & $\mathrm{Cu}_{3} \mathrm{AsS}_{4}$ & 48,3 \\
\hline Tetraedrit & $\left(\mathrm{As}_{3} \mathrm{Sb}_{4} \mathrm{~S}_{13} \mathrm{Cu}\right.$ & 12 \\
\hline \multicolumn{3}{|c|}{ Oxidált rézércek } \\
\hline Kuprit & $\mathrm{CuO}_{2}$ & 46,7 \\
\hline Tenorit & $\mathrm{CuO}$ \\
\hline Malachit & $\mathrm{CuCO}_{3} \cdot \mathrm{Cu}(\mathrm{OH})_{2}$ & 88,8 \\
\hline Azurit & $2 \mathrm{CuCO}_{3} \cdot \mathrm{Cu}(\mathrm{OH})_{2}$ & 55,3 \\
\hline Kalkantit & $\mathrm{CuSO}_{4} \cdot 5 \mathrm{H} \mathrm{H}_{2} \mathrm{O}$ & 25,5 \\
\hline Brochantit & $\mathrm{CuSO}_{4} \cdot 3 \mathrm{Cu}(\mathrm{OH})_{2}$ & 56,2 \\
\hline
\end{tabular}

\section{Paltini típusú hidrotermás ércesedések}

Ez az ércesedéstípus Gyergyóholló (Corbu) és Gyergyótölgyes (Tulgheș) helységek térségében több ponton is a felszínre kerül. Általában a tölgyesi sorozat kristályos képződményeinek porfiroblasztos kőzeteiben található.

Legjelentősebb kibukkanásai a Paltin-patak völgyében és az Aszó-patak völgyének területén a Ciungilor-patak, Véres-, Tölgyes-, Aszód-, Fügés-, Barasău-, és Argintaria-patak térségében vannak. 
„Csodálatosképpen a bronzkortól kezdve a rézbányászatra vonatkozó adataink kimaradtak, s csak nagy későn, az 1700as évek elejére vonatkozólag kapunk elfogadható újabb adatokat.

Egykorú leírások szerint Opra János tomafalvi (ma Székelykeresztúrba beolvadt falu) származású kecskepásztornak tűntek fel a Balán havasán, az elérhetetlennek látszó sziklákon csillogó, aranyszínű érckibújások. Nagy nehezen sikerült belőlük egy mintadarabot letörni, s ezt bemutatta a hatóságoknak, mert nagy jutalomra számított. A kincstár művelés alá is vette a területet és Oprának jutalmul évi 80 pengő forint járadékot adott." (Endes Miklós 1937. 25-26.).

Az érc legnagyobb részét galenit, szfalerit, pirit, arzenopirit, kalkopirit stb. alkotja. Az ércesedések hidrotermás eredetűek.

A fó hasznos elemek az ólom és a cink, amelyekhez egész sor elem társul. Így például a galenit magas ezüsttartalma meghaladja az 1500-2000 g/t mennyiséget. Az ezüst mellett magas a galenit-, sztibium- és bizmuttartalma is. A szfarelit gazdag kadmiumban (3000-5000 g/t). A piritben gyakran igen magas az arzéntartalom.

\section{A Hărlăgia- és a Huruba-patak vidékén kialakult polimetalikus ércesedések}

A Kis-Beszterce folyó felső medencéjében a Huruba- és Hărlăgia-patak vidékén előforduló polimetallikus szulfidércesedések lencse formájúak, erősen töredezettek. Folytonosságuk nehezen követhető az erősen tektonizált kőzetekben. Az itt található ércesedés hasznosítható ásványai a kalkopirit, pirit, galenit, valamint a szfalerit. Arany-ezüst és komplex hidrotermás ércesedés található Gödemesterházán, a Kelemen-havasok déli részén. Ezek neogén érces telérek (Peltz $\mathrm{S}$. 1969. 1/4. 1-206.).

Eredetük hidrotermás, hasonló a Kelemenhavasok északi térségében, valamint a Nagybányán található ércesedésekhez. A telérek a következőket tartalmazzák: pirit, arzenopirit, szfalerit, galenit, antimonit.

\section{A vasérc székelyföldi előfordulása}

A vasérctartalmú kőzetek előfordulása a Kárpátokban már az ókorban is ismert volt. Erről tanúskodnak az egykori vasgyártás jelei, a bucakemence-maradványok és salaklerakatok.

Egyik legjelentősebb kora vaskori régészeti lelet a székelyföldi Csernátonban, az itt feltárt ókori erődített település helyéről került elő (Székely Zsolt 2007. 18.). A Csernátonban feltárt vastárgyak a korra jellemző, fejlett vasgyártásról és feldolgozásról tanúskodik.

A késő vaskorban is folytatódik a vasgyártás a Keleti-Kárpátokban, a későbbi Székelyföldön. A kora vaskori szkitákat a dák kultúra, a rómaiak, majd a kárpok, gótok, szlávok évszázadai követik. Mindenikük hagyott létét bizonyító, a vasművességgel kapcsolatos régészeti leletet, hírmondóit korukról.

A vasérclelőhelyek rendszeres felkutatása, ipari méretű felhasználás céljából a 16. század közepére tehető. Ennek a tevékenységnek jelei a Székelyföldön főleg Csíkmadarasról, Csíkdánfalváról, Csíkszentdomokosról, Madéfalváról, Csíkszeredáról, Csíkszentkirályról, valamint a Kis-Homoród mentéről, illetve Kirulyból kerültek elő. A kovásznai, erdőfülei, Magyarhermány határában található Bodvaj vasérceinek ipari méretű hasznosítása későbbi keletű, és a 18-19. századhoz kapcsolódik. 


\section{A csíkmadarasi sziderites vasérc}

Csíkmadaras vasérclelőhelyei az Erdélyi Fejedelemség korában váltak jelentőssé, iparosíthatóvá, és a csíkmadarasi vashámor és vasgyár működésével hozhatók összefüggésbe. A csíkmadarasi vasérctelep földtani metszete a 3. ábrán látható.

A vasérctartalmú medence aljzata átlagosan 400-450 m mélységben található, és kristályos kőzetekből épül fel, rájuk néhány $10 \mathrm{~m}$ vastagságban oligocén/alsó miocén üledékek rakódtak le, melyekben később a vastartalmú karbonátos meteorikus vizek hatására metaszomatózis során kialakult a sziderit típusú vasérc. Az egészet egy 300-450 m vastag vulkáni törmelékes összlet borítja be (vulkanoklasztok), amely kitölti az egész medencét.
A szferosziderites vasérc a paleorelief és a vulkanoklasztok alsó határán néhány métertől néhány tíz méteres vastagságig terjedő lencséket képez 15-46\% közötti vastartalommal (Tănăsescu I. 1967. 7. 189-206.).

\section{Sziderites vasércesedések Lövéte-Kiruly környékén}

A Lövéte-Szentegyháza-Kiruly környékén található vasérc ipari méretű kitermelése a 18. század elejétól (1720) a közelmúltig tartott.

A környék földtani képződményeit a közeli Vargyas-kaldera kitörési termékei (lávafolyások, piroklasztitok, sárfolyások, törmelékes lavinák), és az Erdélyi-medence üledékei (konglomerátum, homokkő, márga, agyagmárga, homok) alkotják (4. ábra) (Bányai 1927. 10. 94-106.).

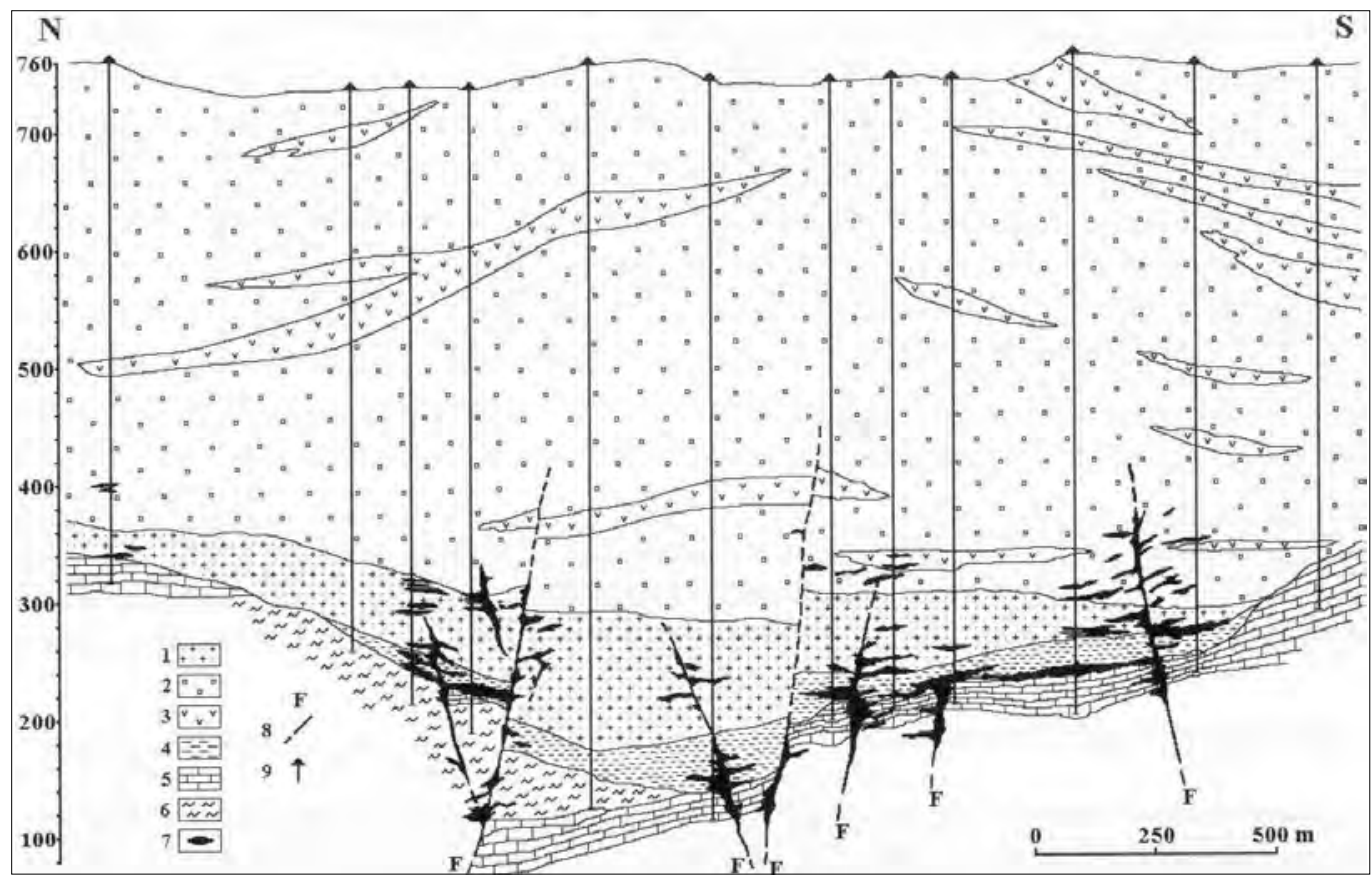

3. ábra. A csíkmadarasi vasérctelep földtani metszete (Tãnãsescu 1967). 1. andezittufák; 2. vulkanoklasztok; 3. andezitlávák; 4. üledékes kõzetek; 5. mészkõ és dolomit; 6. kristályos palák; 7. vasérc (sziderit); 8. vetõ; 9. fúrás 


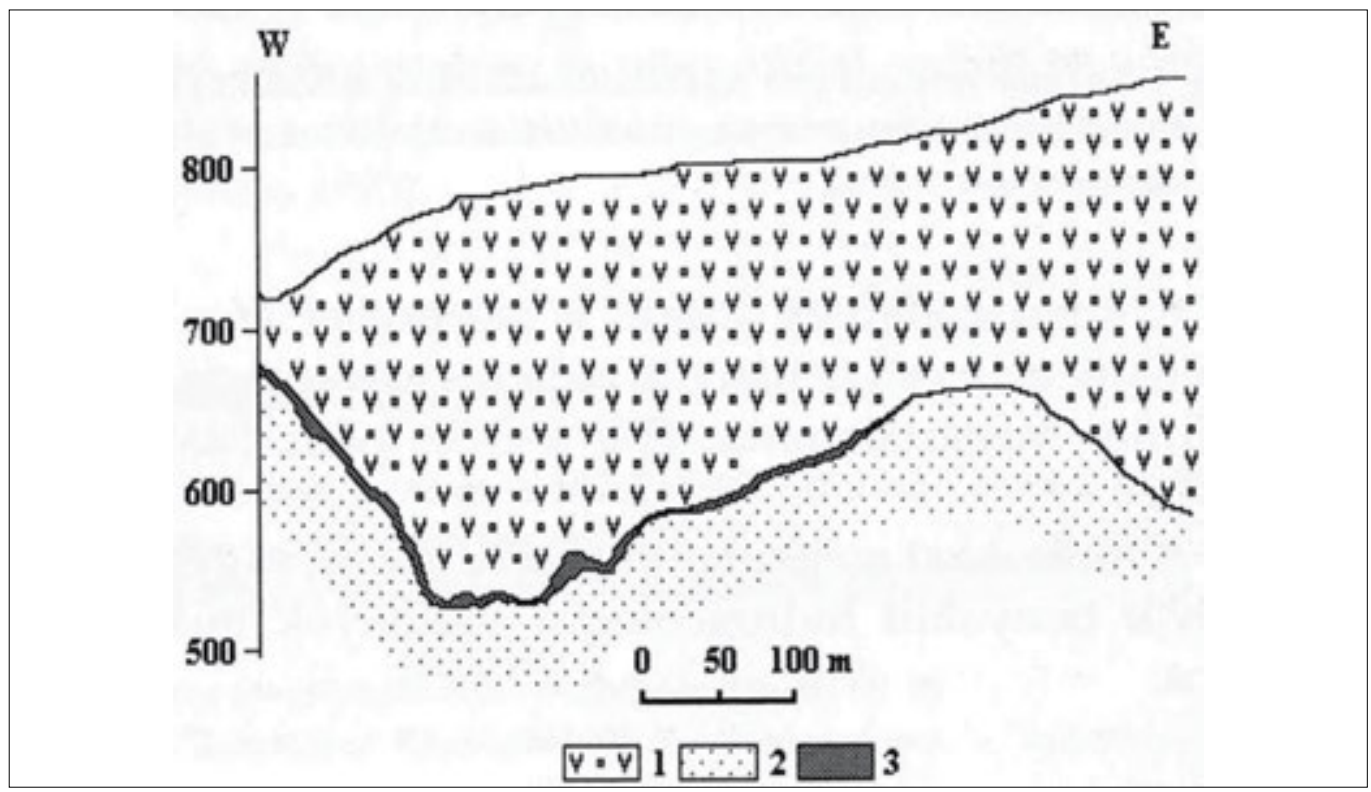

4. ábra. Földtani szelvény a Lövéte-Szentegyháza-Kiruly vidékén található vasércesedés területén (Peltz et al. 1981). 1. vulkanoklasztok; 2. miocén kori üledékek; 3. vasérc (sziderit, limonit).

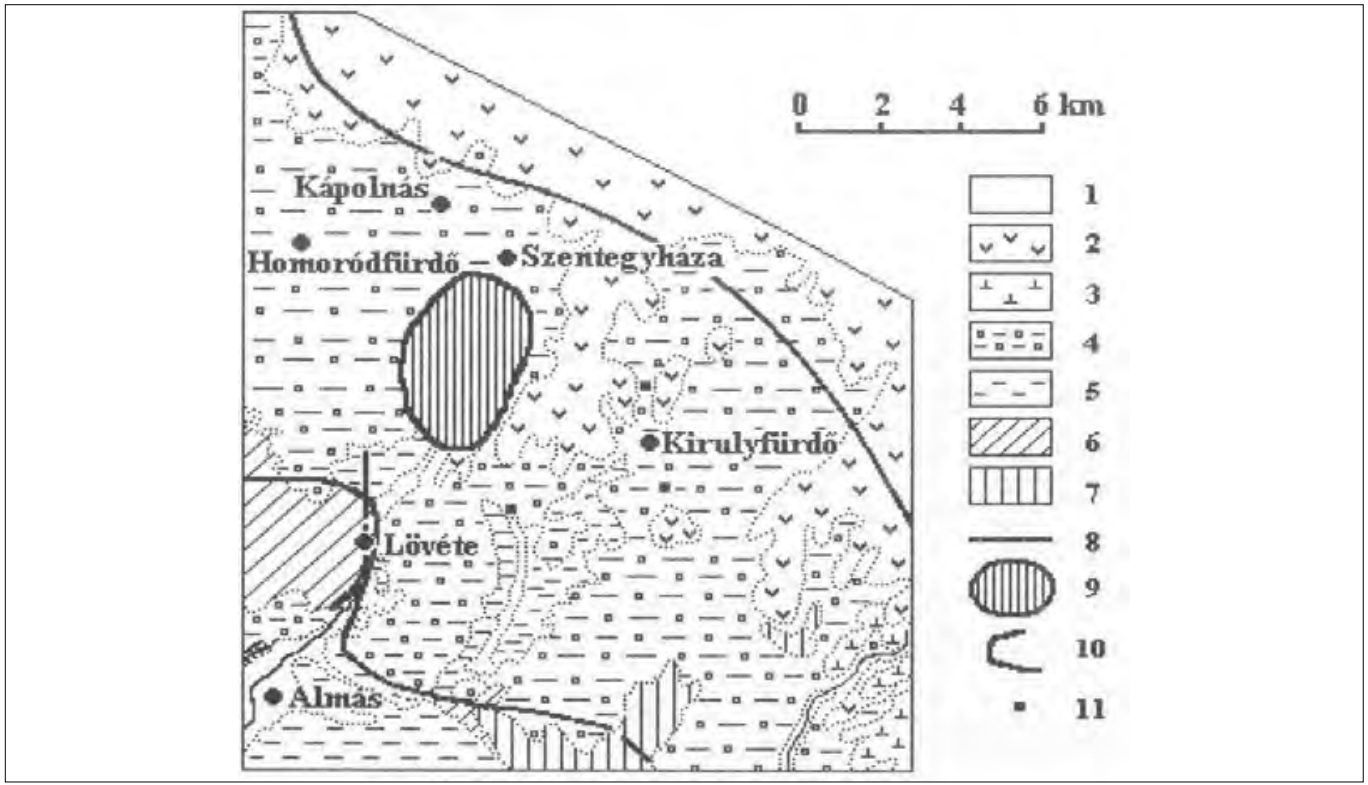

5. ábra. Földtani térkép Lövéte-Szentegyháza-Kiruly környékérõl (Peltz et al. 1981). 1. negyedidõszaki üledékek; 2. piroxénandezit; 3. hornblende-piroxénandezit; 4. vulkanoklasztok; 5. felsõ miocén (konglomerátum, homokkõ, márga); 6. késõ badeni (konglomerátum, homok); 7. kréta üledékek és magmatitok; 8. vetõ; 9. metallogéniai mezõ; 10. metallogenetikai határ; 11. vasércesedésre utaló ásványosodási pontok 
A vasércesedés szideritesedett kőzetek formájában van jelen. Az ércesedés ásványai a sziderit és a limonit (Szakács At. 1992. 75/1. 44.) (3. és 4. kép). Lövétén ezen ásványok mellett jelentős opállerakódás található. A vasérc három különböző rétegben található: az üledékes összletek felső részében, az ősfelszín és a vulkanoklasztok határán, illetve ezek belsejében. $\mathrm{Az}$ ércesedés átlagosan 0,5 m vastagságú lencsék és konkréciók formájában, a felszínközeltől 300 m mélységig található (5. ábra). $\mathrm{Az}$ átlagos vastartalom 10-25\% (Peltz S. 1981. 64/2. 81-116.).

A Lövéte-Szentegyháza-Kiruly területen található vasérc a beszivárgó meteorikus vizek hatására metaszomatózis útján alakult ki (Szakács At. - Gaftoi E. 1992.75. 39-43.).

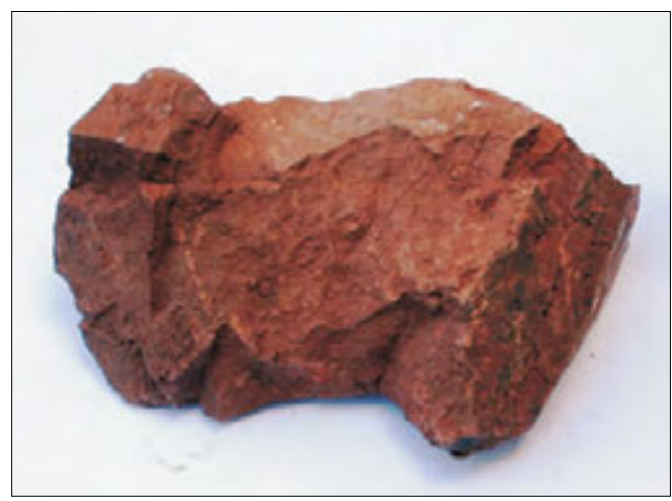

3. kép. Limonit, Csíkmadaras

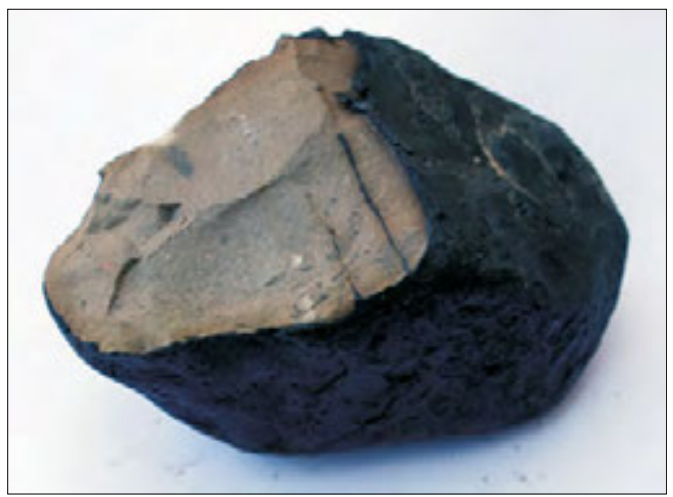

4. kép. Sziderit vasérc
„A tiszta Réz, nyulandó, veres, rugalmas, kemény, hangzó, savakban széksóban, olajokban, kék, vagy zöld színnel, kénkővel is könnyen öszve olvadó, tüzön pedig nehezen, és akkor vízbe öntetvén, nagy tsattanást okoz; savadgya az üveget zöld színüvé teszi. Tulajdon neheze 8876:1000." (Gergelyfi András: Technologia, vagyis a mesterségek és némely alkotmányok rövid leírása. Pozsony, 1809. 105.).

\section{Kovászna vasérctelepei}

„Az Erdélynek Moldva felé való határhegységét képező kiterjedt kárpáti homokkőterület nyugati szélén Kovászna, Körös, Papolc és Zágon községeknél palaanyag, bitumenes pala (Braunschafa), homokkö és kovapalák rétegei számtalan sok vasérc-betelepüléssel több ezer lépés szélességben lépnek napvilágra. Ezeket a Kovászna-patak bal partján átellenben a régi vashámorral láttam legjobban feltárva" - írta B. Cotta német ércgeológus 1861-ben, aki kora legnagyobb szaktekintélye volt ebben a témakörben. Feljegyzéseiben Kovászna település környékén a vasércnek négyféle előfordulását jelezte:

- szideritréteg néhány cm vastagságtól méteres vastagságokig;

- szferoszideritrétegek vékony palák formájában;

- szferosziderit egy méter vastagságú rétegekben;

- gyenge minőségű, vastartalmú agyagpala rétegekben.

A szferosziderit frissen törött felületének barna színe a levegő oxigénjével érintkezve rozsdavörössé változik. Vastartalma 25\% körüli, míg a vastartalmú agyagpala csupán 20\% koncentrációjú. 
2. táblázat. A vasércek vegyi összetétele és vastartalma

\begin{tabular}{|l|c|c|c|}
\hline \multirow{2}{*}{\multicolumn{1}{c|}{ Megnevezés }} & \multirow{2}{*}{ Vegyi képlet } & \multicolumn{2}{c|}{ Vastartalom [\%] } \\
\cline { 2 - 4 } & & Pörkölés elõtt & Pörkölés után \\
\hline Magnetit & $\mathrm{Fe}_{3} \mathrm{O}_{4}$ & 72,4 & 72,4 \\
\hline Hematit & $\mathrm{Fe}_{2} \mathrm{O}_{3}$ & 70,0 & 70,0 \\
\hline Limonit & $2 \mathrm{Fe}_{2} \mathrm{O}_{3}, \mathrm{H}_{2} \mathrm{O}$ & 60,0 & 70,0 \\
\hline Sziderit & $\mathrm{FeCo}_{3}$ & 48,3 & 70,0 \\
\hline Pirit & $\mathrm{FeSO}_{2}$ & $10-35$ & $10-40$ \\
\hline Ilmenit & $\mathrm{FeTiO}_{3}$ & 36,8 & 70,0 \\
\hline
\end{tabular}

A Hargitáról dél-délnyugat irányba folyó patakok völgyeiben a patakok medrében $30 \%$ körüli vastartalmú kőzetek is előbújnak, de a 38-43\% vastartalmú gyepvasércek is gyakran alkotnak képződményeket. Vargyas, Száldobos, Erdőfüle, Magyarhermány települések határában folytak eredményes vasérctelep-kutatások. Említésre méltó a Száldobos közelében található gyepvasérc, $50 \%$ vastartalommal.

A Székelyföldön jó néhány kisebb vasérctelep is ismeretes. Balánbánya, Ditró, Csomafalva, Gelence, Zabola határában található piritlencsék kapcsán indultak helyi vasgyártási próbálkozások. Ezek egész sorát tárták fel régészeti kutatások. A 2. táblázat a vasércek vegyi összetételét és vastartalmát foglalja össze (Guran M. 1978. 23-26.).

Összegezve: Székelyföld vasérctelepeinek vastartalma 20-40\%, igen szegényes, zömében szferosziderit és piritércek előfordulásához kapcsolódik.

„Napjainkban (1791 körül) legnevezetesebb a dévai és a csíkszentdomokosi rézbányászat s ezek között is fóleg az utolsó, melyet a kincstár 1816-ban 2000 pengő frton adott volt el a Zakariás testvéreknek."(Kővári László 1847. 78-94.).

\section{Felhasznált irodalom}

Bányai János: Studiu geologic asupra flancului de vest mijlociu al muntelui Harghita. D.S.I.G.R. București.

Dănilă Petre - Dănilă Maria: Cuprul. Editura tehnică, București, 1982.

Endes Miklós: Csík, Gyergyó, Kászon-Székek (Csíkmegye) földjének és népének története 1918-ig. A szerző kiadása. Budapest, 1937.

Guran, Mircea: Fierul. Editura Tehnică, București, 1978.

Kővári László: Erdélyország statistikája. I. Kolozsvár, 1847. 78-94.

Krautner, H. G.: Considerații genetice asupra zăcămintelor de sulfuri complexe din cristalinul Carpaților Orientali. St. Cerc. Geof. Geogr. Seria Geol. 1965.

Krautner, H. G. ș.a.: Studiul de sinteză asupra formațiunilor purtătoare de minereuri singenetice ale grupului Tulgheș pe tronsonul dintre Leul Ursului și Bălan. A SC. Geolex SA. Arhívuma, Csíkszereda.

Peltz, S.: Studiul petrografic al părții de sudest a Munților Călimani. Institutul Geol. St. Tehn. Econ., 1969.

Renfrew, Colin: A civilizáció előtt. Osiris Kiadó, Budapest, 1995.

Szakács, Attila: The siderite of the neogene volcanism-relatea iron ores int the East Carpathians (Romania). Mineralogical and chemical features. Roumanian Journal of Mineralogy 75/1. (1992). 
Szakács, A. - Gaftoi E.: Isotopik composition of oxygen, carbon and sulphur in siderite ore deposits associated to neogene volcanism in the East Carpathians - preliminari data. Roumanian Journal of mineral deposits, 75 (1992).

Székely Zsolt: Csernáton község régészeti monográfiája. Státus Kiadó, Csíkszereda, 2007.

Tănăsescu, I.: Date noi asupra formațiunilor geologice de adâncime din bazinul Mădăraș și asupra mineralizației de siderită. St. Geol. Ec. 1967. 


\section{BÁNYÁSZAT ÉS KOHÁSZAT SZÉKELYFÖLDÖN}

\section{Az őskori fémmüvesség emlékei}

A történelmi Székelyföldként ismert terület a Maros és az Olt felső folyásának, a Küküllők, illetve a Feketeűgy és mindezek mellékvizeinek medencéit foglalta magába, de hozzá tartozott az V. István által kézdi székelyek ide telepítésével a szorosan vett Erdélyi-medence nyugati oldalán enkláveként létrehozott Aranyosszék is, amely a rajta átfolyó Aranyosról kapta nevét. Ezek a területek természetesen a székelyek 13. századi betelepítése előtt sem voltak lakatlanok, s így a Székelyföldhöz füződő fémművesség kezdetei is évezredekkel korábbra nyúlnak vissza. ${ }^{1}$

Az ivóvíz, a lakható és védhető teraszok, szerszámok, háztartási eszközök, fegyverek készítéséhez alkalmas nyersanyagok lelőhelyei a legrégibb időktől fogva meghatározó tényezői voltak a kis települések kialakulásának a Kárpát-medencének ezen a részén. $A z$ itt végzett régészeti ásatások eredményei bizonyítják az őskőkortól a középső kőkoron át az új kőkorszakig és tovább is az őskor emberének jelenlétét. Az újabb kőkor idején e terület már viszonylag sűrűn lakott (Roska Márton 1929. 263.). Jelen munkának nem célja e terület kőkorszakának ismertetése. Csupán azt jegyezzük meg, hogy a fémhasználatra utaló első régészeti leletek az újabb kőkorszakra jellemző festett kerámiával együtt kerültek elő Erdély-szerte (Roska Márton 1929. 268, 274.). Ebből a korból Erősdön (Kovászna megye) kerültek elő réz- tárgyak maradványai, pl. rézár, kis rézlemezecske és egy rézpenge. ${ }^{1}$

$\mathrm{Az}$ újkőkor végén, az i. e. negyedik évezredének utolsó századaiban új kultúra kezdetéről is beszél a régészet tudománya, amit átmeneti korként határoz meg, és ami a bronzkorig vezet. Ennek az átmeneti időszaknak a második fele a rézkor. Erről, az e korból származó jó néhány rézből készült lelet is tanúskodik. I. e. 3000-2500-ban lehettek azok a népek, amelyek megjelenéséhez a rézkor kezdetét társítja a régészet.

Szlávok, germánok, görögök, latinok, kelták, de irániak, indiaiak, albánok is őseiknek mondhatják azokat a népeket, amelyeket gyűjtőnév alatt indoeurópai népeknek neveznek, és akiknek a későbbi Székelyföldön 2-3 ezer évvel korábbi létezésük számos jelét tárták fel régészek (Székely Zsolt 2007. 13.).

A rézművesség kezdetei rezet tartalmazó ércek természetes lelőhelyeinek közelségéhez kapcsolhatók. Jó néhány elmélet érvvel a mellett, hogy a rézművesség (rézöntés) kifejlődése több helyszínen, egymástól függetlenül is létrejöhetett. „Érckutatók kellett hogy bevezessék az olvasztás és öntés tudnivalóit, de úgy tünik, hogy az erdélyi termékek helyi rézből készültek" (Colin Renfrew 1995. 177.). $\mathrm{Az}$ erdélyi rézkor rézművessége részeként kell értékelnünk a székelyföldi rézművességet.

A székelyföldi rézművesség nyersanyagbázisa nem kellően tisztázott témakör, de nem kizárt, hogy a Csíkszentdomokos-Balánbánya határában található komplex rézérc is 
lehetett. Részletes helyszíni feltárások hiánya mellett a székelyföldi rézkori leletek sem nyújtanak átfogó és reális képet a kor rézmüvességéről, különösképpen arról nem, hogy a leletek valóban a csíkszentdomokosi-balánbányai vonulat rézércéből készültek. Ennek tisztázása természettudományos módszerek segítségével volna lehetséges, spektroszkópos vizsgálatokkal lehetne a problémát meghatározni, pontosítani. A tellúr ${ }^{2}$ vagy más elemek jelenléte, koncentrációja a réztárgy anyagában fontos információ lehetne a rézérc balánbányai, esetleg más erdélyi rézérclelőhelyéről, eredetéről. Ismeretes, hogy bizonyos rézércek, ide tartozik a balánbányai kalkopirit is, meghatározható koncentrációban tartalmaznak tellúrt. A tellúr egyedivé tesz minden olyan rézércet, amely ezt az elemet is tartalmazza.

A tellúr koncentrációjának meghatározásával, valamint a szennyező összetevőként jelen lévő elemek kimutatásával értékelhe- tő pontossággal meghatározható az illető bronztárgy alapanyagának eredete. Ehhez előzetesen ismerni kell a feltételezett eredet rézércének összetételét. Ezt napjaink metallográfiai tudománya rutinelemzésként kezeli. A természettudományos módszerek minél szélesebb körű alkalmazása a régészetben új utakat nyithat letűnt évszázadok fémművességének megismeréséhez.

Az 1. táblázat néhány székelyföldi régészeti ásatás rézből készült leleteit, ezek lelőhelyét foglalja össze a teljesség igénye nélkül. A leletek az i. e. 4. évezred utolsó századaiból származó réztárgyak. Csupán a feltételezés kategóriájába tartozik, hogy: a leletek nyersanyaga a csíkszentdomokosi-balánbányai rézérclelőhelyekhez is kapcsolható, ugyanis az itt végzett régészeti kutatások nem bizonyították a rézérc bányászatának őskori nyomait, netán a rézérc kohósítását. Azt is meg kell jegyeznünk, hogy az említett terület archeológiai feltárása sem teljes. Colin Renfrew

1. táblázat. Rézkori leletek

\begin{tabular}{|c|c|c|}
\hline Helység & Lelet & Megjegyzések \\
\hline \multirow[t]{2}{*}{ Erősd (Kv) } & $\begin{array}{l}\text { Vörösrézhuzal töredékek, kéthe- } \\
\text { gyű vékony rézár, huzalból készült } \\
\text { kis karikák }\end{array}$ & $\begin{array}{l}\text { Több ásatási rétegből származnak } \\
\text { más hasonló leletekkel, kerámiatö- } \\
\text { redékkel együtt }\end{array}$ \\
\hline & Kettős, ellentétes élű rézcsákány & $\begin{array}{l}\text { A kőkorszak és a bronzkorszak kö- } \\
\text { zötti átmeneti időkből }\end{array}$ \\
\hline Gyergyószentmiklós (Hr) & $\begin{array}{l}\text { Egyélü rézcsákány, másik kilenc } \\
\text { darabbal együtt }\end{array}$ & $\begin{array}{l}\text { A Lázár grófok birtokán találták, } \\
\text { pontos helye ismeretlen }\end{array}$ \\
\hline Árkos (Kv) & Két fejszéből álló lelet & \\
\hline Sáromberke (Ms) & Nyéllyuknyúlványos balta & $\begin{array}{l}\text { Hasonló balták kerültek elő Nyárád- } \\
\text { gálfalván, Altorján, Kovásznán, Sep- } \\
\text { sibesenyőn, Székelyzsomboron }\end{array}$ \\
\hline $\begin{array}{l}\text { Várhegy (Hr) } \\
\text { Albis (Kv) } \\
\text { Bodok (Kv) } \\
\text { Csernáton (Kv) } \\
\text { Székelyudvarhely (Hr) }\end{array}$ & Kettős ellentétes élű rézcsákányok & $\begin{array}{l}\text { Ezek már a kezdeti bronzkor idősza- } \\
\text { kából származnak }\end{array}$ \\
\hline Csikbánkfalva(Hr) & Rézcsákány & $\begin{array}{l}\text { Magángyűjteményben, különleges } \\
\text { kiképzésű fokkal }\end{array}$ \\
\hline Sepsibesenyő (Kv) & Rézfokos & $\begin{array}{l}\text { A Székelyföldön előforduló egyetlen } \\
\text { példány }\end{array}$ \\
\hline
\end{tabular}


viszont leszögezi, hogy „[a]felól kétségünk sem lehet, hogy a felhasznált réz helyi eredetú volt" (Colin Renfrew 1995. 177.).

Első réztárgyait a kor embere, termésrézből ${ }^{3}$ készítette. Tetszetős színe értékessé tette az addig csupán kőből, csontból, fából készült, főleg dísztárgyakkal, egyszerű ékszerekkel szemben. A kalapálásos hidegalakítás volt az első technológiai múvelete a termésréz feldolgozásának. Megtanulta az őskor rézművese, hogy a vörös színű fém könnyen alakítható kalapálással, ugyanakkor az ütések hatására keménnyé, rideggé válik, ami megnehezíti a további alakváltoztatást. Azt is kitalálta, hogy felmelegítéssel a rideg, törékeny réztárgy ismét meglágyul, további alakításra is alkalmassá válik. Hosszú századoknak kellett eltelniük, amíg a mesterségbeli tudás gyarapodása meghozta eredményét: a rézércben található fém kinyerését olvasztással. A kezdetekkor csak bizonyos rézércek mutatkoztak alkalmasoknak fémréz előállítására. Ma már világos, hogy a réz-oxidok, réz-karbonátok voltak ezek az ércek, amelyek könnyebben redukálhatók ${ }^{4}$, mint például a szulfid típusú rézércek.

A kuprit $\left(\mathrm{CuO}_{2}\right)$, az azurit $\left(2 \mathrm{CuCO}_{3}\right.$. $\mathrm{Cu}\left(\mathrm{OH}_{2}\right)$ ), a malachit $\mathrm{CuCO}_{3} \cdot \mathrm{Cu}(\mathrm{OH})_{2}$ ) hevítéssel aránylag könnyen redukálódó ércek. A faszén, égése közben, az olvadási hőt is, de a redukáló közeget is kialakította. Ez $700{ }^{\circ} \mathrm{C}$ körüli hőmérsékletet jelent a következő vegyi reakció létrejöttével:

$$
\mathrm{CuO}_{2}+\mathrm{C}=\mathrm{Cu}+\mathrm{CO}_{2} \text {. }
$$

Ez még nem az igazi, vörös színű réz előállításának fázisa, mert a réz olvadási hőmérséklete $1083{ }^{\circ} \mathrm{C}$. A rézmüvesség megjelenésének kezdetén fontos szerepe volt a fazekasságnak. A kerámia gyártásában használatos kemencék hőmérséklete elérte a $600-700{ }^{\circ} \mathrm{C}$ is, ami már a rézércolvasztás előssarnoka is lehetett. A fújtató, a többlet- levegő befújásával létrehozott hőmérséklet-emelő szerepe valóságos ugrást jelentett az ércek feldolgozásában általában, nem csak a rézércek esetében.

A balánbányai rézérc, a kalkopirit $\left(\mathrm{CuFeS}_{2}\right)$ szulfid típusú érc, amelynek pirotechnikai feldolgozása őskori módszerekkel szinte lehetetlen volt. A kalkopirit feldolgozásának alapja szintén redukciós folyamat. A folyamat részeredményeként az égést tápláló oxigén egy részének kénnel való reakciójában a végtermék a kén-dioxid, ami az égési gázok öszszetevőjeként távozik a kemencéből. A megmaradt részből a vasnak szintén az oxigénnel való reakciója következtében vas-oxid keletkezik, ami a salaknak egyik összetevője lesz. De ez a folyamat nem ilyen egyszerü, mert a kvarchomok folyamatos adagolásával a vasszulfiddal vegyi reakcióba lép a következő vegyi reakció szerint:

$$
2 \mathrm{FeS}+3 \mathrm{O}_{2}+\mathrm{SiO}_{2}=2 \mathrm{FeOSiO}_{2}+\mathrm{SO}_{2} \text {. }
$$

Tulajdonképpen ez az első salakképző folyamat. Mivel a salak könnyebb a rézben dúsult olvadéknál, a felszínen összegyúl, amit el lehet távolítani az olvadékról. A megmaradt réz-szulfid (CuS) olvadék a további levegő befújás következtében redukálódik:

$$
\mathrm{CuS}+\mathrm{O}_{2}=\mathrm{SO}_{2}+2 \mathrm{Cu} \text {. }
$$

Még ez a vegyi reakció is kétfokozatú. Először a réz-oxid és a réz-szulfid képez részleges redukciót. A maradék réz-szulfid és a réz-oxid reakciójából keletkezik a fémes réz:

$$
2 \mathrm{Cu}_{2} \mathrm{O}+\mathrm{Cu}_{2} \mathrm{~S}=\mathrm{SO}_{2}+6 \mathrm{Cu} \text {. }
$$

A vas olvadáspontja $\left(1535^{\circ} \mathrm{C}\right)$ jóval magasabb a réz olvadáspontjánál, ezért az érc vastartalma a salak összetevője marad. Ezért tartalmaznak a szulfid típusú rézércek salakjai vas-oxidot.

Hogyan találta ki az őskor embere a réz kinyerését érceiből 2500 évvel Kr. e.? Amint azt az előbbiekben megjegyeztük, a rézmüvesség az újkőkor második felében, a festett kerámiával egy korban keletkezett. A kerá- 
mia gyártásának már évezredes múltja volt akkor. Viszonylag jól kidolgozott technológiája volt az agyag feldolgozásának. Jó néhány típusú égetőkemencét üzemeltettek a kor fazekasműhelyei. A kőből épült, agyaggal kitapasztott égetőkemence lehetett a réz ércéből való kinyerésének kiindulópontja. Feltehetőleg az égetőkemence építésekor falazatába rezet tartalmazó kő is bekerülhetett, olyan rézérc, aminek a réztartalma ismeretlen volt az őskor ember számára. Maga a fém is ismeretlen volt abban a korban.

Az edényégető kemence többszöri használata a falazat többszöri felhevülésével járt, így a réztartalmú kőben végbementek azok a folyamatok, amelyek a későbbiekben az érc pörkölését, olvasztását, a fémréz kinyerésének folyamatát jelentették a rézércek kohósításában. Ezt nevezhetjük a rézművesség igazi kezdetének, amikor a kor emberének meg kellett találnia azt a követ, amelyik rezet tartalmaz, de nem csupán natív rezet. Ezután a kemény sziklából, kőből készített szerszámaival ki kellet fejtenie azt a réteget, amelyik színével, netán természetes natívréz-tartalmával kivált környezetéből. Iszonyú nehéz munka lehetett. Az egész folyamat a bányászástól az olvasztáson át a kinyert réz feldolgozásának elsajátításáig hosszú évszázadokon át tökéletesedett, és lassan terjedt az őskorban. És ha a kor embere már tudatosan kereste a felszínen található termésrezet is tartalmazó követ, tapasztalatot is szerzett azzal kapcsolatosan, hogy a megolvadt fém, az égetőkemence falában található rézérc terméke bele is folyhatott valamelyik edényébe. Ez vezethette arra a felfedezésre, hogy egyes, rezet tartalmazó kövek agyagedényben is megolvaszthatók, és hogy a megdermedt, megszilárdult fém felveszi az edény belső formáját. Ez lehetett az a lépés, amelyik elvezette az embert az öntőforma elkészíté- séhez, a fémöntés igazi kezdetéhez. A Székelyföld területén végzett ásatások alkalmával öntőforma maradványai is előkerültek.

A kétrészes öntőforma használata volt a fémművesség következő állomása, amely már bonyolult alakú végtermékek előállítását is lehetővé tette.

Az igazi, korszakalkotó ugrást a fémmüvességben az ötvözés ${ }^{5}$ gyakorlata jelentette. A rézhez egy másik, alacsonyabb olvadási hőmérsékletű fémet olvasztottak. A két fém keveredéséből i. e. 2500 körül keletkezett az új, korszakalkotó fémötvözet, a bronz. Ennek az új fémnek az emberi civilizációra és kultúrára gyakorolt hatása egy új történelmi kort is kialakított, a bronzkort.

Összegezve az őskor rézművességének történetét, amely i. e. 4000-4500 körül kezdődhetett, megállapítjuk, hogy ebben a korban alakult ki a következő évezredek fémművességének mesterségbeli alaptudása. A fejlődés néhány szakasza véletlenszerű, a folytatás viszont logikus és egyre tudatosabb folyamattá alakult az évezredek folyamán.

„A bronzkor szerves folytatása a már említett aeneolitikus, illetőleg rézkori periódusnak, ennek alapján a fokról-fokra fejlődést, mint általában Erdélyben, a Székelyföldön is nyomon kellene követnünk." (Roska Márton 1929, 278.)

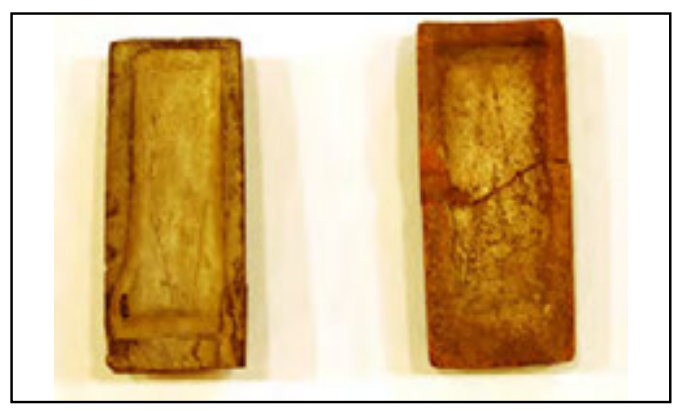

1. kép. Öntőforma Kovászna megye területén végzett régészeti ásatásból. A Székely Nemzeti Múzeum tulajdona, Sepsiszentgyörgy 
Székelyföld területén végzett ásatások alkalmával előkerült nagyszámú bronzleletből néhányat a 2. táblázat foglal magában.

A leletek nagy száma, amelyek néhol egykori nyersanyag- és késztermék-raktárakra utalnak (Székely Zsolt 2007. 70-79.) (Felsőcsernáton, Bánkfalva) öntőkanál-maradványok, öntött tárgyak a bronzművesség magas szintjéről, öntőműhelyek működéséről tanúskodnak. Mindez i. e. 3000-3500-ból a mostani Hargita és Kovászna megye területéről (2. kép).

Mit tudtak, milyen technológiai tapasztalat halmozódhatott fel ahhoz, hogy Erdély és ezen belül a székelyföldi rész híressé váljon bronzművességéről? Az őskor mestere ismerte a használható, rezet tartalmazó ásványi érceket. Tudott olvasztókemencét építe- ni, agyag és porrá tört kerámia keverékéből olvasztótégelyt készíteni. Tudott faszenet égetni és a szenet felhasználni olvasztókemencéjének fütéséhez. Tudott huzatos égőteret létrehozni, amivel növelhette az olvasztási folyamat hőmérsékletét. Ismerte az ón tulajdonságait, szerepét, jelentőségét abban a keverékben, aminek tudatos elóállítási végterméke az új fémötvözet a bronz keletkezett. Megtanulta az ötvözőelem részarányának jelentőségét, és a bronz rendeltetésének függvényében elő tudott állítani különböző tulajdonságú bronzötvözeteket. Ékszerek (fibulák, karkötők), használati tárgyak (balták, kések, sarlók), harcászati eszközök (dárdák, kardok, harci szekercék) jellegzetes összetételű ötvözeteit is előállította (3. és 4. kép).

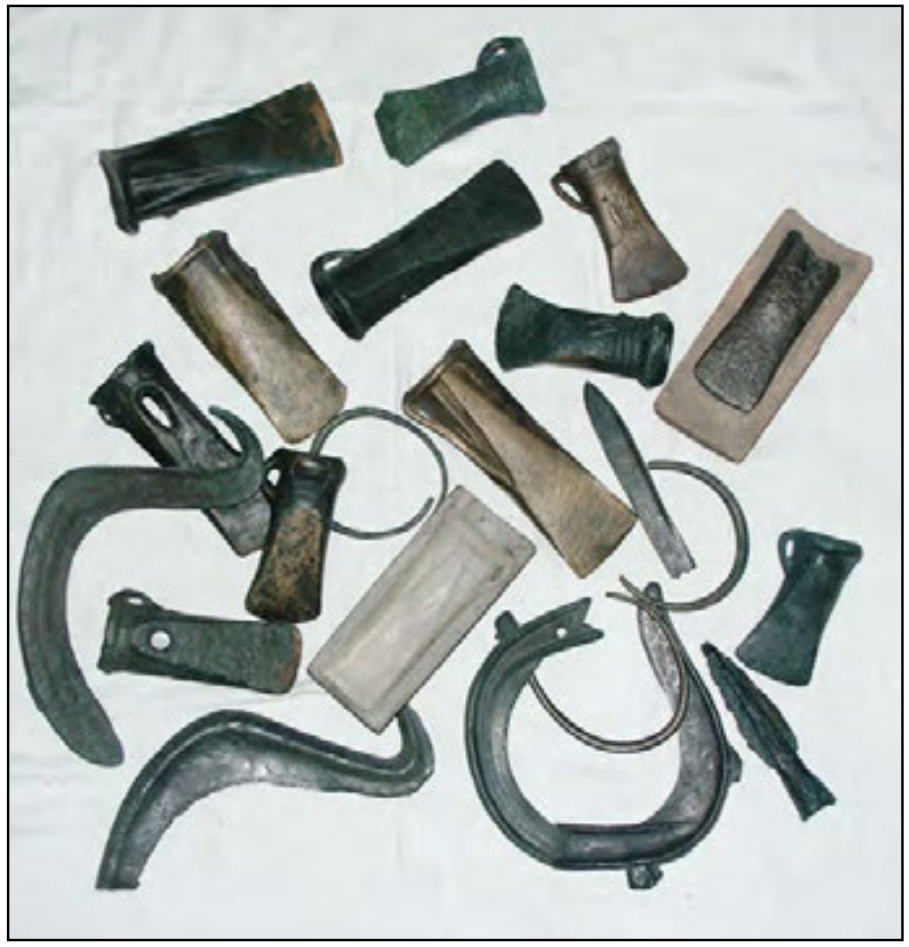

2. kép. Őskori bronztárgyak Kovászna megye területén végzett régészeti ásatásokból. Székely Nemzeti Múzeum tulajdona, Sepsiszentgyörgy 
2. táblázat. Bronzkori leletek

\begin{tabular}{|c|c|c|}
\hline Helység & Lelet & Megjegyzések \\
\hline Sepsiszentgyörgy (Kv) & Talpas bronzfejsze & \\
\hline Bölön (Kv) & Bronz szárnyas fejszék & $\begin{array}{l}\text { Ugyanitt sarló és tokos balta töredékek, } \\
\text { bronzkorong, bronzedény }\end{array}$ \\
\hline Kézdivásárhely (Kv) & Tokos füles balták & $\begin{array}{l}\text { Egy félholdasan bevágott szájút a szak- } \\
\text { irodalom mint magyar típust ír le }\end{array}$ \\
\hline Zágon (Kv) & Tokos kalapács & Ritkaságszámba menő \\
\hline Málnás (Kv) & $\begin{array}{l}\text { Bronzsarló (erdélyi típus), } \\
\text { bronzkés }\end{array}$ & $\begin{array}{l}\text { Hasonló példányok kerültek elő Csík- } \\
\text { bánkfalván (HR) }\end{array}$ \\
\hline Firtosmartonos (Hr) & Bronztőr & $\begin{array}{l}\text { Hasonló lelet Zaboláról (KV) is ismere- } \\
\text { tes. Az erdélyi bronzkor legvégén ké- } \\
\text { szült }\end{array}$ \\
\hline Maroshéviz (Hr) & Tőrpengetöredék, fürész, tőr & \\
\hline Bardóc (Kv) & Bronztőr & $\begin{array}{l}305 \mathrm{~mm} \text { hosszúságú, rövid kardnak is } \\
\text { megfelel }\end{array}$ \\
\hline Magyaros (Ms) & Bronzkard & $\begin{array}{l}920 \text { mm hosszú hasonló lelet Kovász- } \\
\text { nán is előkerült }\end{array}$ \\
\hline $\begin{array}{l}\text { Bardóc (Kv) } \\
\text { Marosfelfalu (Ms) } \\
\text { Altorja (Kv) }\end{array}$ & Bronzkard & $\begin{array}{l}\text { Különböző típusú és formájú fegyverek, } \\
\text { bronzfejsze, } 25 \text { gyưrű nagyságú arany- } \\
\text { lemez, bronzüst, bronzsarló }\end{array}$ \\
\hline Sáromberke (Ms) & Bronzkard & Görbe alakú pengéje lapos \\
\hline Nyárádszentanna (Ms) & Harci csákány & Hasonló lelet Sáromberkén is előfordult \\
\hline $\begin{array}{l}\text { Mezőbánd (Ms) } \\
\text { Kedezér (Ms) } \\
\text { Marosfelfalu (Ms) }\end{array}$ & $\begin{array}{l}\text { Lándzsacsúcs, balták, karpere- } \\
\text { cek, fibulák, övrészletek, kardtö- } \\
\text { redékek }\end{array}$ & $\begin{array}{l}\text { A lándzsahegy gyakori a székelyföldi } \\
\text { kincsleletekben. Például Zágonban ki- } \\
\text { lenc darabot találtak. Hasonló leletek } \\
\text { Bereck és Nagygalambfalva leleteiben } \\
\text { is megtalálhatók }\end{array}$ \\
\hline Réty (Kv) & Bronz karperec & Az anyagot csavarással teszik tetszőbbé \\
\hline Zágon (Kv) & Bronz karperec töredék & $\begin{array}{l}\text { Hasonló lelet Bölönből, Málnásról, Csík- } \\
\text { bánkfalváról is előkerült }\end{array}$ \\
\hline Marosfelfalu (Ms) & $\begin{array}{l}\text { Több példánya a bronz karperec- } \\
\text { nek }\end{array}$ & $\begin{array}{l}\text { Töredékek is találhatók ebben a lelet- } \\
\text { ben }\end{array}$ \\
\hline Bereck (Kv) & Bronzbalta, lándzsacsúcsok & \\
\hline Csikdánfalva (Hr) & $\begin{array}{l}15 \text { tokos, füles balta,5 karperec,1 } \\
\text { sarló,2 lándzsacsúcs }\end{array}$ & $\begin{array}{l}\text { A lelet öntőműhely maradványaival } \\
\text { együtt képezi a bronzkincset. A sarlók } \\
\text { nagy része erdélyi típus }\end{array}$ \\
\hline Bardóc (Kv) & 30 bronzbalta, bronzkard & $\begin{array}{l}\text { A balták a kard körül szabályos körben } \\
\text { voltak elhelyezve }\end{array}$ \\
\hline Erdőszentgyörgy (Ms) & $\begin{array}{l}12 \text { tokos, füles balta, fokos, véső, } \\
\text { füles kiscsésze, bronztányérka, } \\
\text { bogrács, lószerszámdísz }\end{array}$ & $\begin{array}{l}\text { A lelet egyes darabjain vasrozsdafoltok } \\
\text { voltak }\end{array}$ \\
\hline Olasztelek (Kv) & bronzsarló & töredék, karperec, halászhorog \\
\hline Csikszentkirály (Hr) & $\begin{array}{l}\text { Bogrács, csésze, serpenyő, bronz- } \\
\text { karika az i. e. 9. századból valók }\end{array}$ & $\begin{array}{l}\text { Ekkor Székelyföldön is megjelenik a vas } \\
\text { használata. A csíkbánkfalvi leletek és } \\
\text { a marosfelfalusi lelet is rozsdafoltokat } \\
\text { tartalmaznak. }\end{array}$ \\
\hline
\end{tabular}




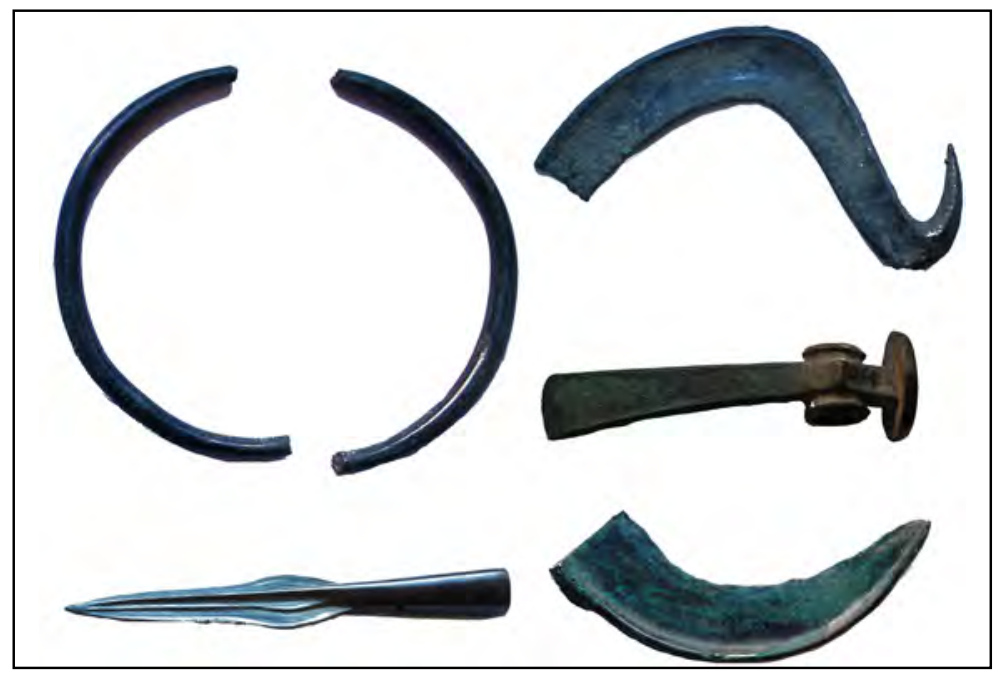

3. kép. Bronzleletek Hargita megye területén végzett ásatásokból. A Csiki Székely Múzeum tulajdona

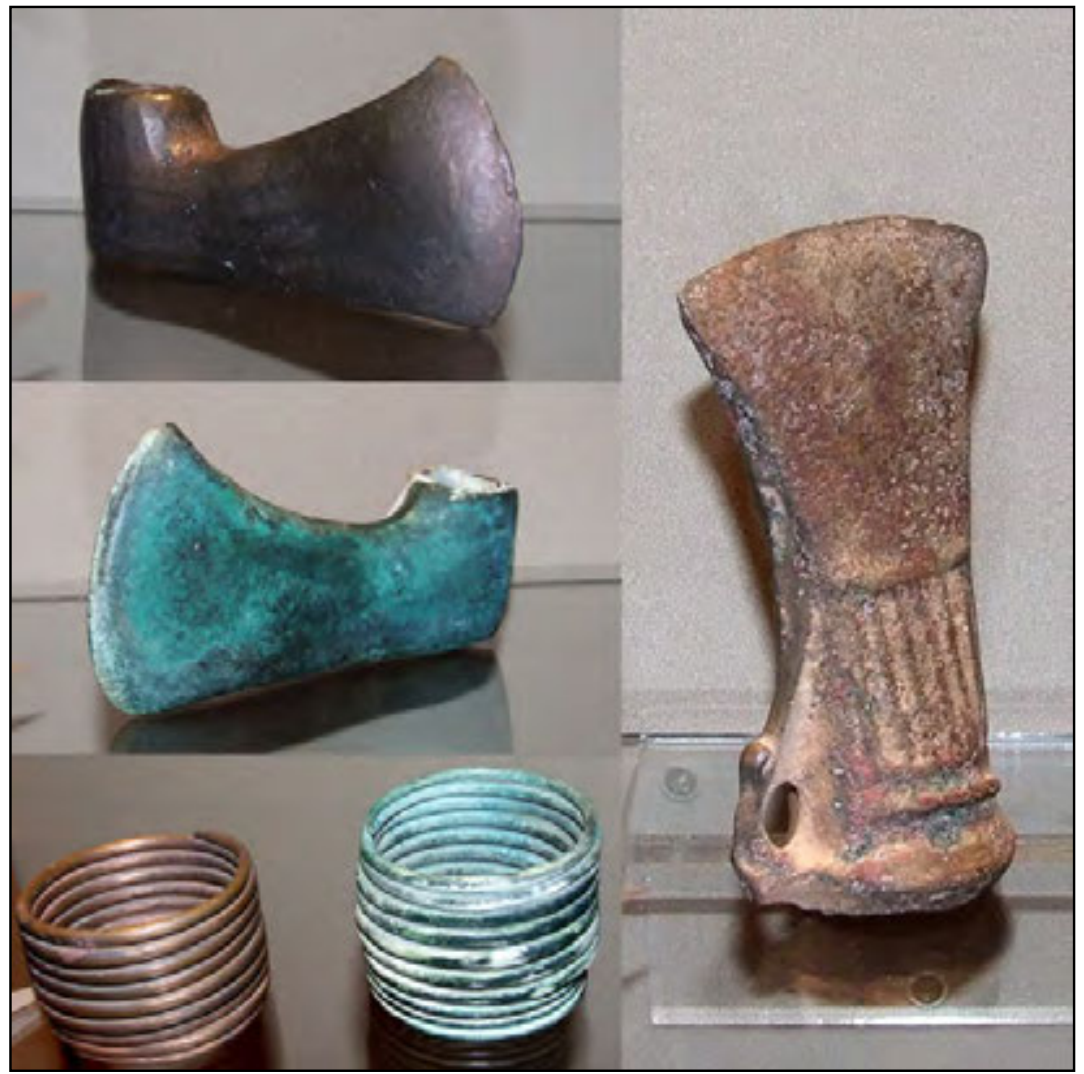

4. kép. Öskori bronztárgyak a baróti Erdôvidék Múzeuma időszakos kiállításában, Barót Dénes István geológus (1954-2005) családjának tulajdona. 
Azt is meg kell említenünk, hogy a feltárt öntőszerszámok, például Felsőcsernátonban agyagból készült öntőkanál-töredéke, öntőforma-töredék, jelentős mennyiségű salakmaradvány a régészek szerint a bronzkort meghatározó összes fejlődési szakasz nyomait magukon viselik, a kezdetektől a kora vaskorba is beleolvadva: „A szerszámtípusok görögországi és általában balkáni kapcsolatokra utalnak." (Székely Zsolt 2007. 79.) A kora vaskor B szakaszában az új fém, a vas együtt jelentkezik bronztárgyakkal. Ez a bronzkor végét és a kora vaskor kezdetét jelenti. A vasrudacskák jelenléte a bronz öntőminták együttesében részint a vasfeldolgozás együtt fejlődését jelenti a bronzöntés technikájával, bár a bronztól a vasművességig egy évezrednek kellett eltelnie. Az említett korszakban a vasötvözetek hőkezelésének technikája ismeretlen volt.

A bronzkori bronzmúvesség csúcstechnológiáját a viaszveszejtéses formázási és öntési eljárás feltalálása és gyakorlata jelentette. Ezzel a formázási, öntési eljárással már bonyolult alakzatú tárgyakat is elő lehetett állítani. Szobrászkodva méhviaszból elkészítették annak a tárgynak a viaszból készült mását, modelljét, amelyet bronzba akartak önteni. A viaszmodellt tehéntrágya és agyag pépes állagú keverékével többször is bekenték, majd szárították. Ezt a múveletet többször megismételték, amíg a felhordott keverékből elég vastag réteg képződött. Az így nyert, bevonattal ellátott viaszmodellt homokágyba illesztették. A megolvadt fémnek beömlőnyílást, a keletkező gázoknak több apró nyílást fúrtak a kéregbevonaton.

A folyékony bronz a méhviaszformát megolvasztotta, ami a fém nyomásának és hőmérsékletének hatására a gázkieresztő nyílásokon kifolyt. A viasz helyén maradt üreget a folyékony halmazállapotú bronz kitöltötte, majd megdermedt. A kihűlés után a formát széttörték, és a bronztárgy, a viaszforma hű mása készen volt.

Ebben az időben nem fúrtak lyukat a bronzöntvényekre, a hegesztést, ragasztást sem ismerték. A fémtárgyak iránt egyre nőtt az igény. Az új helyzet a vas felé fordította a fejlesztés irányát. És annak ellenére, hogy a bronz és a vas gyártása még sok évszázadon át párhuzamosan haladt, az egyre több technológiai ismeret felhalmozódásából adódóan vezető szerepet nyert a vasgyártás.

Az i. e. 12. században Egyiptomból, ahol már fejlett vasgyártás folyik, a görög szigeteken, Görögországon, Szicílián át egyre északabbra terjed a vas bányászatának, kohászatának tudománya. Az új fém utáni civilizációs és kulturális korszakot Hallstatt-kultúraként, első vaskorszakként tartja számon a történelem tudománya.

A kelták magas szinten művelték és terjesztették a vasgyártást, ezért egy új fejlődési szakasz kezdetét, a La Tène-kultúrát, a második vaskort társítják jelenlétükhöz Európában. A kelta kultúra és civilizáció nem fejeződött be egyik napról a másikra. Jelenléte és terjeszkedése folytatódik az i. sz. 3. században is. A germánok egyre erőteljesebb jelenléte Európában a Római Birodalom és a kelta társadalom bukásához vezetett. Kiterjedt kereskedelmi kapcsolataik révén Észak-Olaszországból, Görögországból, valamint keletre tartó kereskedelmi kapcsolataik révén hoznak Erdélybe vasból készült tárgyakat, és hozzák magát a vasgyártás technológiáját is.

A hosszú ókori évszázadok lassú fejlődését követően az első ezredfordulót és az utána következő száz esztendőt a megújulás, a rohamos fejlődés jellemzi. Ekkor már a mívességek technológiájának leírása is megjelenik írott receptek formájában. Az első ilyen receptkönyv, amely a 
misztikus magyarázatok mellőzésével mutatja be az első ezredfordulót követő első évszázadok rézművességét is, a Schedula Diversarum Artium, Theophilus Presbyter bencés apát műve. Leírása olyannyira valósághű, hogy például a réz- és bronzművesség szakmai ismereteit ma is alkalmazható technológiaként tárja olvasója elé.

Az ókor természetes folytatása az őskornak, bár határozott és egyértelmű válaszvonalat kijelölni a két civilizáció között lehetetlen, a több évezred alatt végbement fejlődés jelei nyilvánvalóvá válnak. Megváltozik a hagyomány és az újítások közötti arány, elötérbe kerül a szellemi alkotás, a tudomány, a művészetek, amelyek egyenrangú elismerésben részesülnek a fizikai munkával.

A kelták, a rómaiak tovább fejlesztik a bányászatot, a kohászatot, fémművességet. A harcos birodalmaknak nagy mennyiségű fegyverre, harci eszközre volt szükségük, ezek túlnyomó része még mindig bronzból készült. A népesség számbeli növekedése kényszerként hatott az erdős területek mezőgazdaságra alkalmas, megmunkálható területekké való átalakítására, ami megfelelő eszközök, szerszámok nélkül elképzelhetetlen lett volna. Sarlók, csákányok, fejszék tömeges gyártásának szükségessége menynyiségi és minőségi ösztönzőjévé vált a fémművességnek, ennek fejlesztésének.

Azoknak az ókori népeknek, amelyek a tanulmányozott területen megfordultak, lehetett ugyan a kor színvonalán bronzművességük, de akkor már a vas az uralkodó fém. Nem kétséges, hogy a dákoknak, rómaiaknak fejlett bányászatuk, fémművességük, kohászatuk volt. Erre utal többek között a csíkszentkirályi, 20 darabból álló ezüstkincs ${ }^{6}$ is, amelynek keletkezését az i. e. 1. századra teszi a régészet. Kultúrtörténeti megjegyzés csupán, hogy Homérosz művében, az Iliász- ban sokkal többször említi a vasat (279szer), mint a bronzot (23-szor). (Rakoczy Sámuel 1910. 18.).

$\mathrm{Az}$ is nehezíti az ókor végéhez, a középkor kezdeti évszázadaihoz kapcsolódó fémmüvesség eredményeinek megismerését, hogy a Székelyföld területén végzett régészeti feltárások nem bizonyították e kor kimagasló bányászatát, kohászatát, fémművességét. A római uralom ugyan hagyott néhány castrummaradványt (Mikháza, Sóvárad, Firtos stb.), de ezek teljes feltárása még napjainkban is várat magára.

I. sz. 270 körül a vizigótok, 450 körül a gepidák, 568 után az avarok, majd a bolgárok már a népvándorlás koráról tanúskodnak. Így közeledünk az első ezredfordulóhoz, amikor Nyugat-Európában, amint már említettük, több műszaki jellegű receptes könyv is megjelenik, azt bizonyítva, hogy új lendületet vett a kézművesipar, többek között a fémművesség is. A mai „Székelyföld területén székely csoportok masszív beköltözése aligha előzhette meg a 12. század második felét" (Székelyföld története 2016. I. 150.). Tulajdonképpen ettől az időszaktól beszélhetünk Székelyföldről és fémművességéről.

A betelepedés körülményeinek tisztázása, valamint az itt található népközösségekkel kapcsolatos történések ismertetése nem technikatörténeti kategória. Az azonban bizonyos, hogy mint láttuk, nem teljesen lakatlan területre érkeztek, és a betelepülés sem egyik napról a másikra ment végbe. Az új lakhely új élet kezdetét jelentette a fémművesség szempontjából is. Erre már olvasztókemence-töredékek, salakmaradványok utalnak. Ezek zöme a vasgyártásra utal. Nem ismeretes semmi olyan feljegyzés vagy ásatásokból előkerült lelet, amely a népvándorlás korában vagy a székelyek letelepedésének idején, működő rézércbányászatra, 
kohászatra utalna. Az ebből a korból származtatható néhány öntött bronztárgy (Vargyas, Székelyudvarhely-Budvár) már abba a kategóriába tartozik, amelyekről Benkő Elek 2003-ban közölt tanulmányában így ír: „Székelyföld leleteinek egy része erdélyi szász közösségek jelenlétét vagy - ugyanakkora eséllyel - közelségét jelzi. E közvetlen közelröl érkezô impulzusok a középkori Székelyföldön éppúgy történelmi jelentőségúek, mint azok távolról, de esetleg szintén erdélyi, vélhetōen többek között erdélyi német áttétellel, helyi kereskedők közvetítésével érkező hatások, amelyek a Székelyföld középkori tárgyi világát az eddig sejtettnél gazdagabbá, árnyaltabbá tették." (Benkő Elek 2003. 46-58.)

A rézzel kapcsolatos legkorábbi írásos emlék az Erdélyi Magyar Szótörténeti Tárban a rézedény címszó alatt található, és 1551-ből származik. Székelyföldi említése 1589-ből egy székelyudvarhelyi bíráskodási protokollumban olvasható (Székely Oklevéltár, új sorozat I. 1983, 40.), és rézmozsár háztartási eszközzel kapcsolatos.

A Székelyföld egyetlen rézérclelőhelye, amelyen felszínre kibúvó, natív réz is megjelenik, az Olt folyó forrásvidékén, a NagyHagymás hegyvonulatban található. Itt, az Olt folyó 350-400 m szélességú völgyében alakult ki bányásztelepülés, a későbbi bányaváros Balánbánya. Gazdag rézérclelőhelyéről vált nevezetessé a kis hegyi település, amely a 19-20. században érte el fénykorát, termelésének csúcsát. A Balánbánya helységnév eredete tisztázatlan, bár nem kizárt, hogy a bányatelep eredetét az egykori Tarkő nevű település rejti régmúlt idők homályába.

Tarkő 1333-ban Tarku, majd Tarkov, amely 1334-ben hat banálist fizet a pápai tizedjegyzék szerint, tehát adófizető, ami azt is feltételezi, hogy temploma és papja is volt (Lestyán Ferenc 1996. 215.). Ismeretlen körülmények között, ismeretlen időben tûnt el a település templomával együtt, de nem kizárt, hogy éppen Balánbánya települése a folytatás. Számos spekulatív megközelítés is ismeretes a település születésének időpontjáról, alapítóiról. Biztos forrás csupán az 1790-1791-ből származó említés Balánbányáról, amely az Erdélyi Országgyűlés jegyzőkönyveiben található.

Az iparszerű kitermelés-feldolgozás valamikor az 1785-1790 közötti időszakban indulhatott, a pontos idő meghatározása szinte lehetetlen. Lehet, hogy a rézérc kitermelésére irányuló kezdeményezések évszázadokkal megelőzték az első bányatelep bejegyzését, 1802. október másodikát a székelyudvarhelyi bányakapitányságnál. Ez nem lehetett igazi ipari szintű kitermelés, csupán a népi bányászat kategóriájába lehet besorolni. Ezek a próbálkozások szakmai ismeretek és tőke hiányában kudarcba fulladtak.

A 19. század elején Erdély jelentősebb bányavidékein már bányamérnökök is dolgoztak, és a bányászati tevékenységet is egyre többen elsajátították. A kincstár is jónak látta a csíkszentdomokosi rézérc feltárását, a kitermelés és feldolgozás megkezdését.

Kilenc év múlva 1811-ben már több érctelepet is feltárnak, és elindítják a feldolgozó részleget is. A bányászati szakiskola, amely Nagyágon működött, bányászokat és segédmunkásokat képezett. A bevándorló szakemberek és a szakiskolát végző diákok építették fel az első balánbányai ércfeldolgozót, amelynek termelése 1811-ben 464,63 tonna rézérc feldolgozása volt.

Az első ismert, rézércet feldolgozó üzem felszerelése a következő gépeket foglalta magában: kőzúzda, ércpörkölő, magaskohó, kisolvasztó, tárcsaréz-öntöde. A 19. század bányászati technológiája nem sokban különbözött a középkorban alkalmazott érc- 
bányászat módszerétől. Gépesítésről nem beszélhetünk, a kitermelés kézi szerszámai a csákány, a kalapács, a repesztőék, ásó, kapa, érchordó kosár és teknő, hátra szerelhető szállítóedény, olajmécses.

A kibányászott ércet kosarakba rakták, és a gurítóhoz szállították, ahol a csúszdán az alsó szintre továbbították. A nagyobb menynyiségű ércet fából készült csillével szállították. A csillék fakerekei fasínen haladtak. A csille két hátsó kereke nagyobb volt, ami könnyebbé tette a súlyos jármű irányítását. Ez a csilletípus fakutya megnevezéssel került be a bányászati szakirodalomba.

A tárnák szellőztetése természetes huzattal valósult meg, nem lévén ebben az időben Balánbányán mesterséges légbefújás.

A rézkinyerés hosszas folyamat eredménye volt, amelynek első művelete, a válogatás még a tárnában történt. Csak a dús, szemmel is kivehető réztartalmú darabokat szállították a felszínre, további feldolgozásra. A válogatás müveletében gyermekek is szerepet kaptak, a felszíni második válogatást nők végezték. A feldolgozás előtt ez volt az utolsó válogatás.

A szulfid típusú ércek pirotechnikai feldolgozása hosszas és bonyolult folyamat. A válogatás után az első, hőenergiát igénylő, művelet a pörkölés volt, aminek rendeltetése a kén egy részének az eltávolítása, kiűzése volt a szulfidércből. Fából rakott ágyra rakták a nagyság szerint szétválasztott ércdarabokat, úgy, hogy a nagyobb méretűek alul, a kisebbek a máglya felső részére kerüljenek. Az így kialakított máglyát beföldelték, hogy a keletkező hő a máglya belsejében maradjon. Az égési gázok a máglya közepén kialakított kürtőszerű, huzatkeltő nyíláson át távoztak. A faágyat meggyújtották, a keletkező hőenergia felizzította az ércet, aminek hatására az érc kéntartalmának egy része kipárolgott, a közegnedvesség tartalmával kénessavat ké- pezett. A pörkölés hosszas és faigényes müvelet volt, addig kellett fenntartani, amíg az érc vas-szulfid része, a pirit vas-oxiddá és kén-dioxiddá alakult. A kén-dioxid kénessavként a máglya alatti üregben gyül össze, de egy része kén-dioxidként távozott a máglyából.

$\mathrm{Az}$ átalakult pirit az ércdarabok felületén képezett törékeny réteget, amit töréssel választott le a rézben, réz-oxidban dúsított magról. Ez a pörkölés nem eredményezett tiszta rezet, csupán koncentrátumot. A koncentrátumot tovább finomították, mészkő hozzáadásával olvasztókemencében újra megolvasztották, ami egy második redukciós folyamatot eredményezett. Ezúttal nem fát használtak a kemence felfütésére, hanem faszenet. Az így előállított koncentrátum is csupán $60 \%$ rezet tartalmazott, amit egy újabb, a harmadik finomító pörköléssel dúsítottak. A termék az ún. fekete réz, 90-95\% réztartalommal. A fekete rezet ismét megolvasztották, de már falazott kemencében, faszénnel hevítve, levegőbefújással. Ez egy újabb oxidáló olvasztás volt, és a maradék kéntartalom kiűzésére irányult. A keletkező gázok színéből, az olvadékszikra kibocsájtásából, valamint a vasrudas próba eredményéből lehetett következtetni a réz finomsági fokára. A vasrudas próba abból állt, hogy az olvadékba merítettek egy vasrudat, majd gyorsan kihúzták, és vízben lehűtötték. A rúd felületére rakódott vékony rézréteg színéről a szakember megállapította a redukciós folyamat eredményét, a réz tisztasági fokát, és ha jónak látta, megállította a folyamatot, megszüntette a további hevítést.

Ezután az olvadék felszínéről lehúzták a salakréteget, majd vízzel hűtötték a megolvadt réz felületét, ami egy bizonyos mélységig megszilárdult. Ezt a szilárd rézkorongot kiemelték az olvadékból, és újabb hűtéssel addig ismételték a rézkorongok képzését és 
kiemelését, amíg a kemence megüresedett. A múveletet tárcsaszakításnak nevezték.

Bár nem tartozik Balánbánya technikatörténetéhez, a gyakori tulajdonosváltás és a tulajdonosok törekvése a bányászat és ércfeldolgozás terén meghatározó tényezői voltak a bányatelep technikatörténetének. A kezdeti időszak 464,63 tonna réz termelése harminchét esztendő múlva a kétszeresére emelkedett, a réztermelés csúcséve 1581 mázsával a forradalom és szabadságharc éve, 1848 volt. Ekkor a bánya és feldolgozóüzem a részvényesek tulajdona, fó részvényesek a gyergyószentmiklósi Zakariás testvérek, Antal és István. Ők a rézművet (bányát és feldolgozóüzemet) a Kincstártól 2500 ezüstforint értékben megvásárolták. Kereskedők voltak, ezért alkalmazták Bodor Ferenc bánya- és kohómérnököt, akinek szaktudása és a Zakariás családhoz füződő kapcsolata hozzájárult a vállalat tevékenységének felíveléséhez.

A Zakariás testvéreknek és Bodor Ferencnek a bányatelep szervezése, vezetése mellet jelentôs szerepük volt a forradalom és szabadságharc székelyföldi eseményeiben is, különösen az ágyúcsőöntés nyersanyagának és műszaki kérdéseinek megoldásában. Zakariás Antal jelentős mennyiségű rezet ajánlott fel ágyúcső gyártására, Bodor Ferenc szerepe az öntési technológia kidolgozásában, a puskaporgyártás terén vált ismertté. A forradalom és szabadságharc éveiben a rézfeldolgozó üzem a kor műszaki színvonalát tükrözi, és a következő berendezés üzemelt: két kisolvasztó kemence, egy kohó két csigafúvóval ${ }^{7}$, amelyeket vízikerék hajtott. Az ércet 21 nyíllal zúzóműben aprították. Négy vízikerék hajtotta a hámori részt, a két laposverőt és a két kalapácsot. A bánya és az ércfeldolgozó üzem 1825-től 1849 végéig volt a Zakariás testvérek tulajdonában, ekkor a kincstár visszaveszi a Zakariás testvérektől a balánbányai ipartelepet, de hamarosan rájön, hogy ez nem volt ésszerü lépés. Ezért 1851 júniusában visszaadja az előbbi tulajdonosoknak a rézművet.

A forradalom és szabadságharc leverése után már nem tapasztalható felívelés a balánbányai rézmű́nél, ráadásul az osztrák tőke beavatkozása is hozzájárult ahhoz, hogy Zakariásék 1858-ban eladják a rézmüvet, sajnos éppen a konkurenciának. De nemcsak Balánbánya váltott gazdát ebben az időben. Ugyanaz az osztrák társaság megszerez több erdélyi bányát és kohóművet is.

1860 az új tulajdonosok ambiciózus fejlesztésének éve. Bővítik az olvasztókapacitást az ötödik kohó felépítésével. Ennek megfelelően a zúzómúvet hengerzúzóval korszerüsítik, ennek termelékenysége fölülmúlja a zúzónyilas törő-porító termelékenységét. Ekkor a réztermelés 2861 mázsa. 1869-ben a vízikerekeket gőzgép beszerelésével helyettesítik. A termelt rézmennyiség 3171 mázsa. Mindezek ellenére 1869 után a termelés nem növekedett, mi több, az üzem csődbe is megy. Csak tizenegy év múlva, 1880 körül jelezhetünk újabb fellendülést, amikor ismét egyéni vállalkozók szerzik meg a bányát és a feldolgozóüzemet. 1876-ban a besszemerezést mint finomítási eljárást is bevezetik Balánbányán, a termelés azonban nem éri el a korábbi évek szintjét. 1895-ben a réztermelés szünetelt, a kényszerleállás két évig tartott.

$\mathrm{Az}$ is érdekes, hogy míg a csíki és gyergyói vasbányák és más kitermelések bányáinak leltára a 17. század közepétől ismeretes, balánbányai leltár csak 1869. október 5-én készült. Ettől eltekintve a székelyföldi rézércbányászat, kohászat, még ha megszakításokkal is, Balánbányához kapcsolódik.

1868-ban Orbán Balázs, aki székelyföldi vándorlásai során Balánbányára is eljutott, észre- 
vételeit a következőképen tudatja olvasóival: „...im elóttünk van már Balánbánya füstölgố kohóival, a vidéket visszhangoztató roppant zajával, ott vannak azok a barna olvaszdák óriási fúvóikkal, lassú méltósággal mozgó nagy kerekeikkel, roppant sziklatörö kalapácsaikkal, hol az ember a teremtés müfolyamát utánozza..." (Orbán Balázs I. 1868. 93.)

Harminc év elteltével 1898-ban megjelent kiadvány, amely az akkori Magyarország öszszes színes és nemesfémbányájának termelését bemutatja, Balánbányáról a következőket írja: „A balánbányai rézkohó az elmúlt évtől kezdődőleg fémkohászattal nem foglalkozott." (Szathmáry Béla - Mály Sándor 1896. 126.) Ugyanitt található a balánbányai fémkohászat megszűnésének magyarázata is. „A rézkohósítás terén elért vívmányok ellenére mutatkozó visszaesés csakis annak következménye, hogy a réz árának hanyatlása miatt a rézbányamúvek és ezzel kapcsolato- san a rézkohók nagy része [...], Balánbánya stb.- üzemen kívül helyeztettek. Röviden, a réz túltermelés és az iparnak az olcsóbb vas felhasználása felé fordulása lett jó néhány réz termelő vállalat bezárásának fó oka."

A bányatelepülés életútjának a többszöri leállás és újraindulás volt a meghatározó vonása. Az 1909-es év a nagy fejlesztések időszakaként szerepel, ami a francia érdekeltségű Erdélyi Bányászati Társaság fejlesztési stratégiájának eredménye. A Bányászati és Kohászati Lapok 1909. évi számában található közlemény a balánbányai rézérc feldolgozásának helyzetét mutatja be (Zsigmond Árpád. 1909. 500-504.). A szerző már a bekezdésben leszögezi, hogy „Magyarország réztermelése 40 év óta folyton hanyatlik". 1866-ban az átlagtermelés 1911 tonna. Miután 1904-ben a bánya francia érdekeltségbe került, tulajdonosai az akkori európai színesfémbányászati és -kohászati techno-

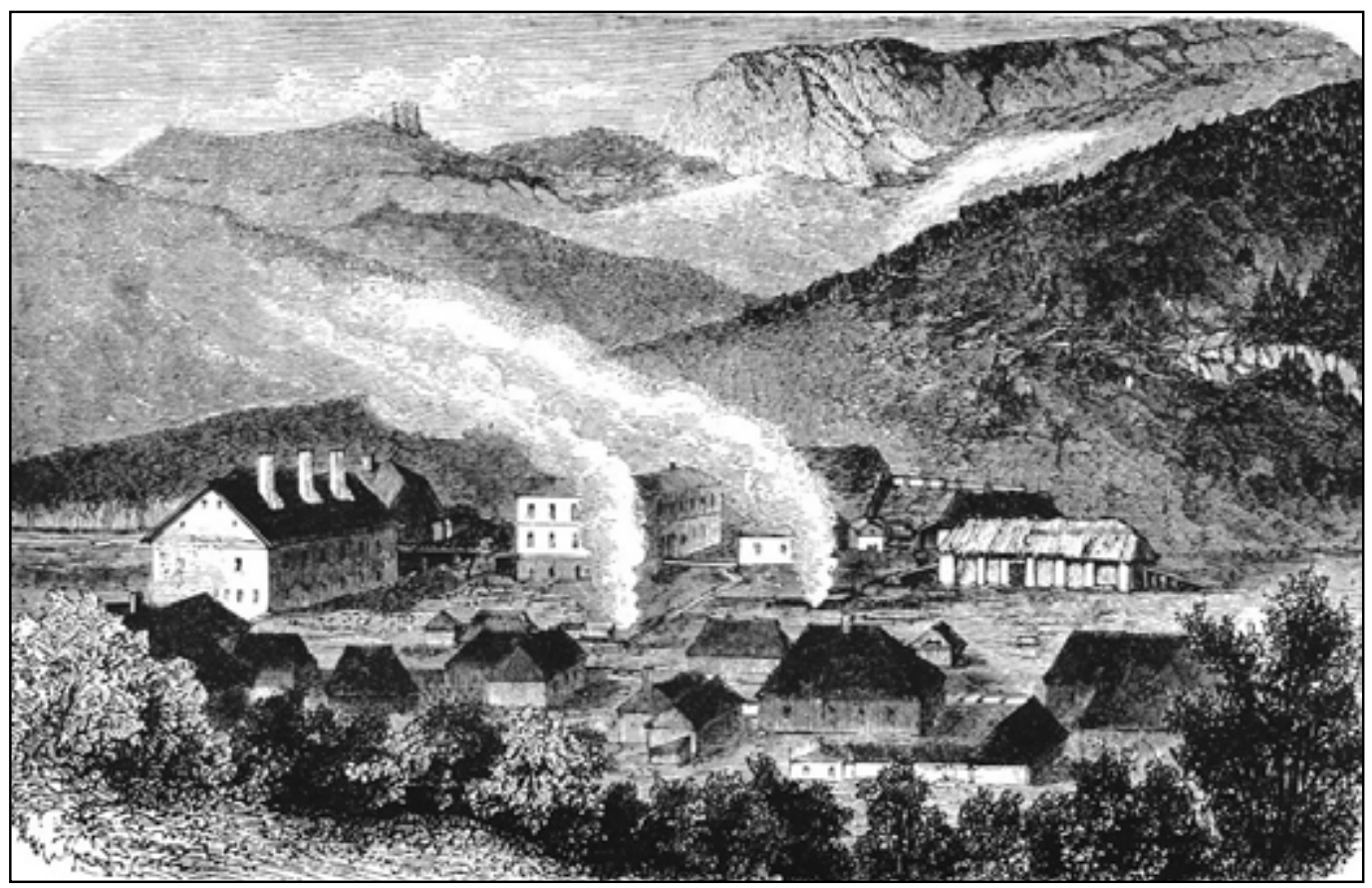

5. kép. Balánbánya füstölgő rézkohóival, ahogy Orbán Balázs látta 
lógiájának színvonalára emelik a rézércfeldolgozást. Ugrásszerűen megnő a termelés. 1907-ben ismét tulajdonosváltás következik be, a bánya és a rézércfeldolgozó üzem a Magyar Rézművek Részvénytársaság tulajdonába megy át. Nem véletlenszerű fejlesztés történik, ugyanis ezekben az években geológiai kutatások 1-4 méter vastagságú telért mutattak ki, amely 10-25 méterenként ismétlődött. Az ércvonulat helyenként a 120 méter magasságot is elérte. Az említett tanulmány szerint a balánbányai rézércet három osztályba sorolták:

1. az I. osztályba az 5 százaléknál nagyobb réztartalmú ércek,

2. a II. osztályba az 1,5-5 százalékig terjedő réztartalmú ércek,

3. a III. osztályba az 1,5 százaléknál alacsonyabb réztartalmú ércek tartoztak.

A továbbiakban a közlemény a feldolgozás technológiáját is ismerteti. Az alkalmazott rézkinyerési eljárás szerint az $5 \%$ rezet tartalmazó ércet aprítása után a rézolvasztóba irányítják. Ez a magasabb réztartalmú érc az összes feldolgozott anyag 30\% körüli részét teszi ki. A II-III. osztályba tartozó rézércet mosása után nedves töményítésnek vetik alá. A fennmaradt mennyiség a hányóra kerül, bár ennek is van réztartalma, igaz, $1 \%$ alatt. Ezt cementálás útján hasznosítják, akárcsak a bányából kifolyó vizet, amelynek réztartalma jelentős. A bányavizet favályúkon át vezetik, amelyekbe vassíneket, rudakat helyeznek. A végbemenő elektrokémiai folyamat hatására a réz-szulfát-oldat, amelyet a bányavíz tartalmaz, leadja rézionjait az elektronegatívabb vasfelületre, a következő vegyi reakció szerint: $\mathrm{CuSO}_{4}+\mathrm{Fe}=\mathrm{FeSO}_{4}+\mathrm{Cu}$.

Az így keletkező 50-60\% réztartalmú lerakódás lefejthető a vasfelületről, a keletkező réz mennyisége évente a több tíz tonnát is elérheti. Akkor, a 19. század végén, már

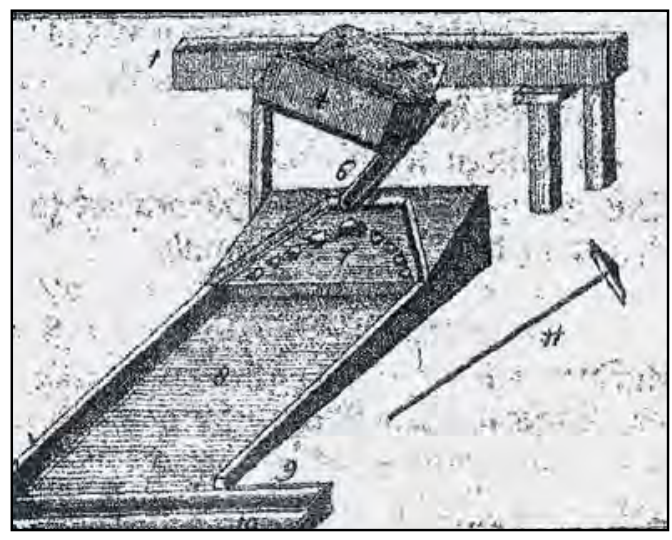

1. ábra. Porrá tört rézérc fajsúly szerinti szétválasztása szérrel.

sűrített levegővel működtetett fúrógépeket használtak a kitermelésben, megkönnyítve ezáltal a bányászok nehéz fizikai munkáját, a kézi fúrást. A kor bányagépesítésének alkalmazása meghozta látványos eredményét, a réztermelés 1908-ban már évi 3000 tonnára emelkedett. Említettük, hogy a II-III. osztályú rézérc további feldolgozás előtt az ércmosóba került. Balánbányán két kőtörőt, négy aprítót, négy rázóasztalt használtak, amelyet válogatószalag, választódobok követtek. $\mathrm{Az}$ itt szétválasztott rézércnek a legkevesebb rezet tartalmazó része további őrlés céljából golyós malomba és osztályozó tölcsérekbe került, majd a termelési kapacitásnak megfelelő felületnagyságú, 12 darabból álló szérre ${ }^{8}$ irányították. A szér fajsúly szerint osztályozza, vízáram segítségével, a porrá zúzott ércet. Az így nyert dúsított ércport oltott mésszel (20-30 százalékban) keverik, majd tojásbriketté préselik. Az így nyert brikettek az olvasztókemencébe kerülnek, ahol a nagyobb koncentrációjú rézérccel együtt olvadnak meg.

Ez volt nagyjából a 19. századi rézércfeldolgozás technológiája.

Theophilus Presbyter $A$ különféle müvességekről című könyvében a rézérc feldolgozá- 
sát a következőképpen mutatja be: „....Ha rezet találnak, nagy fáradsággal, ásással vagy töréssel termelik ki. Zöld színü, nagyon kemény ásvány, természettôl fogva ólommal van keverve. A nagy mennyiségben kiásott kőzetet máglyára teszik, és mész módjára égetik. Közben a színét nem veszti el, de a keménységét igen, és törékennyé válik. Utána apróra törve kemencébe rakják, és fújtatók segítségével, széntüzön éjjel-nappal fújtatják. Ezt gondosan és óvatosan kell csinálni. Előbb szenet kell a kemencébe rakni, majd az apróra tört követ ráönteni, majd újból szenet és újból követ kell rakni, amíg a kemence megtelik. Amikor a kö kezd elolvadni, az ólom bizonyos nyílásokon kifolyik, és bent csak a réz marad vissza. Miután ezt a müveletet hosszú ideig fújtatva elvégezték, hütik és kiszedik, majd további ércet raknak be hasonló módon." (Theophilus Presbyter 1986. 115-116.)

Olvasztókemencéjének leírása is olyanynyira pontos, hogy ma is elkészíthető, alkalmazható rézérc olvasztására: „Négy kő áll keresztbe kereszt alakban, egymástól egy lábnyi távolságra, részben a földbe ásva, egy láb magasságra azonban a földből egyformán kiállnak és a felületük teljesen sík. Ezekre a kövekre négy darab ujjnyi vastagságú, négyszögletes vasat tesznek, amelyek olyan hoszszúak, hogy az egyik kôtôl a másikig érnek. Közéjük középre ugyanolyan méretü vasakat tesznek, egyenlő távolságban, mégpedig egymástól háromujjnyira. Ezekre keresztirányban további - alakra és méretre az alsókhoz hasonló - vasakat helyeznek oly módon, hogy közöttük négyszögletes nyílások képződjenek. Amikor ezt így elrendezték, a vasakra alaposan átgyúrt és lótrágyával kevert agyagot raknak, háromujjnyi vastagon, úgy, hogy az a vashoz és a kövekhez mindenütt jól tapadjon, és olyan alakú legyen, mintha a köveken egy kerek tüzhely állna. Ezután kerek fával a vasak közötti hézagokba nyílásokat csinálnak, akkorákat, amekkorát lehet, és utána alaposan kiszárítják. Ezután a tüzhelytől felfele apró kövekből falat raknak és ugyanabból az agyagból egy köcsögszerü képződményt alakítanak ki, amely a közepétől kezdve szúkül, és magasabb, mint amilyen széles. Még négy vagy öt vaspánttal is körülveszik, kívül-belül ugyanazzal az agyaggal alaposan kikenik. Amikor befejezték, eloltott szénnel kevert égö szenet tesznek bele, rövidesen az alsó nyílásokon beáramló levegőfújtatás nélkül lángra lobbantja, és a rárakott fémet azonnal megolvasztja." (Theophylus Presbyter 1986. 116.) Az olvasztókemence sematikus elvi rajza a 2. ábrán látható.

Tüzálló olvasztótégely készítésének leírása is szerepel a Schedulában, amellyel a rézérc olvasztásából nyert rezet többször is újra lehet olvasztani: „Végy cserepeket olyan régi edényekből, amelyekben korábban vörösvagy sárgarezet olvasztottak, és kövön törd ezeket apróra. Ezután végy földet, amiből a fazekakat készítik, és aminek két válfaja van: egy fehér és egy szürke színü. Ezek közül a fehér az arany színezésére alkalmas, míg a másik a tégelyek készítésére. Amikor már egészen finomra megörölted, keverd ezt a nyers földet meghatározott arányban a már kiégetett és megörölt cseréphez, a következő módon. Végy valamiféle edényt és töltsd meg kétszer nyers, háromszor kiégetett agyaggal., hogy ily módon két rész nyers és három rész kiégetett agyagod legyen. Az egészet rakd be együtt egy nagy edénybe és öntsd fel langyos vízzel, gyúrd át alaposan, kalapácsokkal és kézzel, amíg egészen sûrűn folyóvá válik. Ezután végy egy kerek fát, olyan nagyot, amekkora edényt kívánsz csinálni, illetve a kemence méretének megfelelőt, és formázz rajta tégelyt, a megformázás után kend be száraz hamuval, és tedd kemencébe, amíg megszárad. Ilyen módon formázz annyi edényt, amennyit akarsz. 
Amikoralaposan kiszáradtak, tégy hármat, négyet vagy ötöt a kemencébe, amennyi belefér, és rakd körül szénnel." (Theophilus Presbyter. 1986. 116.)

Összehasonlítva a 19. században használt olvasztókemencét, amelyet Balánbányán is felszereltek, a Theophylus által bemutatott kemencével jól látható a közel másfél évezredes fejlődés, fejlesztés eredménye. Az évszázadok folyamán kialakult, rezet igénylő iparágak fejlettsége az olvasztókemencék komplexitásában, termelékenységében is érzékelhető. A rézércek feldolgozásában a

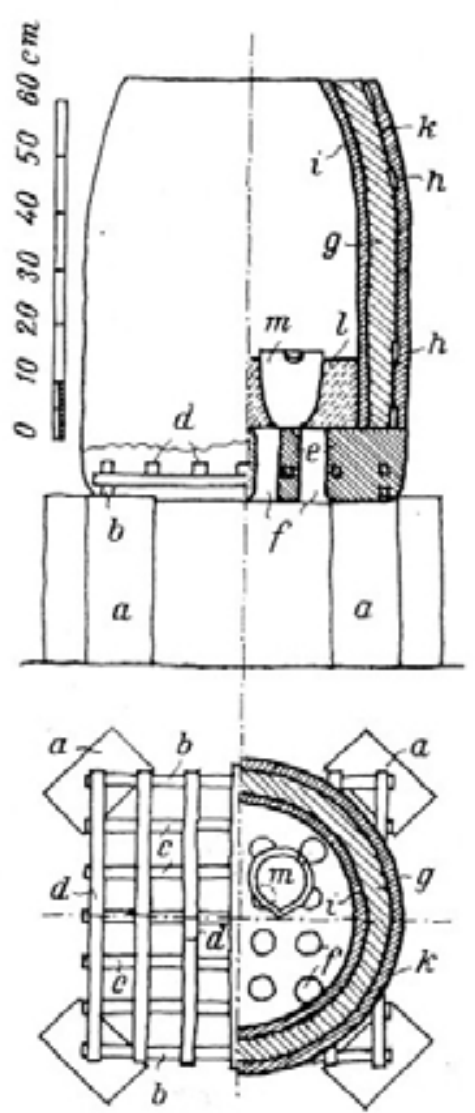

2. ábra. Rézolvasztó kemence Theophylus Presbyter nyomán
19. század igazi ugrásszerű fejlődést jelentett. Balánbányán is üzembe helyeztek új Water Jacket-kemencét, amely vízköpenyes típusként vált ismertté. Termelékenységének köszönhetően a napi 75 tonna rézérc feldolgozásával fölülmúlta minden addig ismert rézércfeldolgozási technológia termelékenységét. Mindezt 13 tonna koksz, 20 tonna salakképző mészkő és 6-7 tonna rézsalak hozzáadásával, amiből 3,5-4 tonna tiszta réz keletkezett. A kemence egyszerüsített rajza a 3. ábrán látható, és a következő fő részekből állt:

1. feltöltőnyílás;

2. levegőbefújó csövezet;

3. égési gázokat kivezető nyílás;

4. olvadékkieresztő vagy csapolónyílás;

5. az olvasztótér vízköpenyes hütése;

A. olvasztókád;

B. olvasztótégely (kreuzet);

A kemencében végbemenő pirotechnológiai folyamat hat szakaszra osztható, és ennek

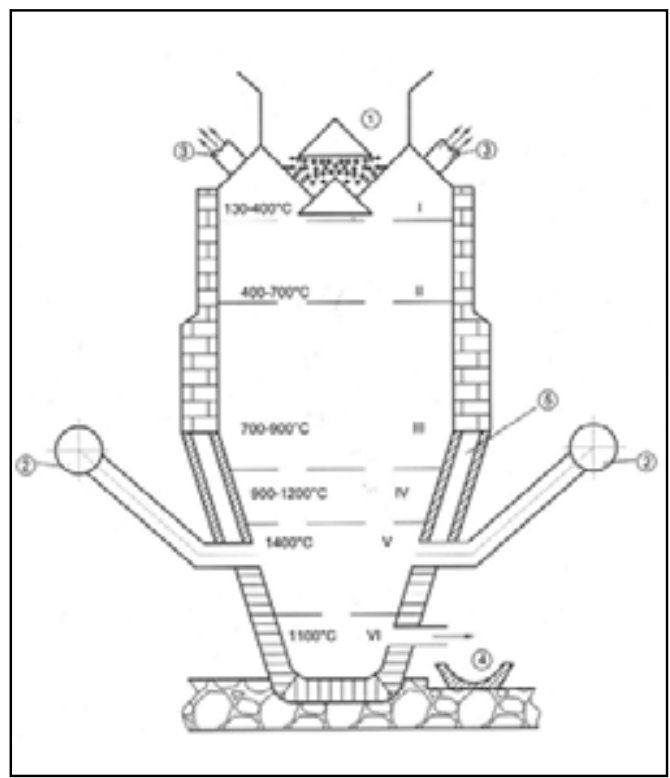

3. ábra. Water Jacket vízköpenyes, rézércolvasztókemence 
megfelelően öt funkcionális része van az olvasztókemencének. Az I., II., III. részben a redukciós folyamatok mennek végbe, a IV. rész az olvasztási zóna, az V. a túlhevített zóna és a VI. a szétválasztó zóna, ahol a kisebb fajsúlyú salak és a megolvadt, magasabb fajsúlyú fém szétválik.

Az olvasztókemencében előállított réz tisztaságának javítására szolgált a következő kétlépcsős hőkezelés. Első lépésben a megolvadt rezet, amely bizonyos mennyiségű salakanyagokat is tartalmazott, Bessemerkonverterben tovább hevítették. A konverter belső fala salakképző anyaggal volt kibélelve, $30 \mathrm{~cm}$ vastagságban. A bélés anyaga kvarchomok és agyag keveréke. Ezt a konverter belső falára tapaszként felvitték, majd lassú melegítéssel, később hevítéssel kiszárították, kerámia minőségre kiégették. Az így kiképzett Bessemer-körtében (így nevezték körte alakjára utalva) maximum 8-9 finomítási eljárást lehetett véghezvinni, ugyanis a konverter bélésének anyaga a magas hőmérséklet hatására vegyi reakcióba lépett a rézércből visszamaradt salakkal, kivonva azt a fémolvadékból. Minden egyes eljárás után a bélés vékonyodott, elhasználódott.

Ahhoz, hogy ez a finomítási eljárás végbemenjen, levegőt fújtattak át az olvadékon, nagy kapacitású légsűrítőt használva erre a célra. A többletlevegő oxigéntartama megnövelte az olvadék hőmérsékletét, a salak kisebb fajsúlya következtében a túlhevített fémolvadék felszínére emelkedett. A konverter tégelyének billentőszerkezete pedig lehetővé tette a salak többszöri leöntését, végül az olvadt fém rudakba öntését.

Balánbányán ebben az időben öt konverter volt használatban, amelyből négy előkészületben (szigetelésük újjátételét jelentette), egy pedig használatban volt. A konverterezés eredménye 99,4-99,7\% tisztaságú réz, amit további finomítás céljából egy újabb olvasztással, lángpest kemencében, 12-16 órás hevítéssel magas hőmérsékleten tartva már 99,97\% tisztaságú rezet nyertek. A magas tisztasági fokú réz volt a balánbányai rézmű hírnevének megalapozója a felhasználói piacon. Nem hagyhatjuk ki a fejlődés-fejlesztés sorából a rézérc dúsításának új technológiáját, a nedves dúsítást. Ez helyettesítette a bemutatott középkori hosszas és költséges pörköléses dúsítást. Az új eljárás a kibányászott rézérc aprításával kezdődött, ahol a nagyobb réztartalmú ércdarabokat külön technológiával, a régi módszerrel dúsították. A rézérc aprítását Balánbányán két kőtörő gép, négy aprító végezte, amelyekhez négy rázóasztalt csatlakoztattak. A rázóasztalról a nagyobb ércdarabokat a válogatószalagra, a kisebb darabokat a választódobokba irányították. A választódobok ismét szétválasztották az apró rézércet fajsúly szerint, ami lehetővé tette a kevés rezet tartalmazó érc további feldolgozását golyós malmokban. A golyós malmokban porrá őrölt érc szérekre került. Itt ismét egy újabb, fajsúly szerinti szétválasztás következett. A szérelésre szánt őrleményt vízzel összekeverték, így keletkezett a zagy, amit a szérelő ferde felületére irányítottak. A zagy folyásának sebességét a szérasztal dőlési szögének változtatásával szabályozták, mert ez meghatározta a zagy áramlási sebességét a szér felületén, a rézrészecskék különválását a meddő kőportól. A szérelést addig ismételték, amíg az őrlemény fajsúly szerint teljes mértékben szétvált, és már nem maradt rézpor a művelet után a szérasztalon. A művelet elég lassú és vízigényes. Minden szérhez egy kiszolgáló személyt alkalmaztak, aki a beáramló víz hozamát szabályozta, és a keletkezett rézport eltávolította a szérasztalról. A keletkezett rézport oltott mésszel keverve briketté 
préselték, így került az olvasztókemencébe. A meddő iszapot vízsugárral a csatornába irányították.

A bemutatott eljárást a 20. század elején, 1908-ban még alkalmazták Balánbányán. Ez a kor leginkább használt technológiája volt az érckohászatnak. A kor bányászati csúcstechnológiáját alkalmazva az éves termelés 3000 tonna volt (Barabási László 1996. 68.).

Az 1890-91 közötti időszakban kísérleteket végeztek egy új rézércdúsító eljárás bevezetésével, ami a szegényebb réztartamú ércek feldolgozására irányult volna. Ennek lényege az őrlemény többszörös lúgzásában állt, de a kísérlet nem végződött a várt eredménnyel. Így a korábban alkalmazott eljárás továbbra is használatban maradt. (Weisz Tádé 1891. 149.).

Az első világháború küszöbén egy újabb csődhelyzet alakul, amit semmi sem bizonyít jobban, mint hogy az egykor 400 személynél is több alkalmazottból csupán három személy maradt a rézműnél, az őrségi feladatok ellátására. 1916-ban a császári és királyi katonai parancsnokság egyszerűen tulajdonába veszi a rézmúvet, egy év múlva pedig 1917-ben eladja a Budapesti Phönix Kénsav és Vegyi termék Gyár RT-nek. Ezáltal létrejött a balánbányai kénsavgyártás, amelynek nyersanyaga az addig felhasználatlan pirit (vas-szulfid) kéntartalma.

Az új tulajdonos ismét jelentős beruházásokkal kezdi működését. 677 kW generátorteljesítményre növeli a erőművet, a fogyasztás 465 kW. A nagy fejlesztések hátterében a hadiipar felvevőpiaca volt. Háborús évek jártak, a réznek hatalmas felhasználója volt a hadiipar.

A háború végével a réz piaci ára is csökkent, ami egy gazdasági válság előjeleként is értelmezhető volt. De nemcsak a réz piaci ára csökkent, a kitermelt rézérc fémtartalma is alacsonyabb volt. Ezért a tulajdonosok a rézsalak újrafeldolgozásával kísérleteztek, az olcsóbb réz reményében.

Az 1929-33 közötti időszakot a nagy gazdasági világválságként jegyzi a történelemtudomány. A válság közvetlenül érinti a balánbányai rézművet, amely 1930. november 15-én ismét bezár. A feldolgozóüzem gépeit a cég leszerelte, és a Nagybánya körzetéhez tartozó vállalataihoz szállították. Ezzel végérvényesen megszűnt a rézkohászat Balánbányán.

A második világháború idején a kitermelt rézércet a további feldolgozás céljából más feldolgozóüzemekbe szállították. 1944. szeptember 8-án Balánbányán is átvonult a front, ennek következtében a kitermelést is megszüntették. A következő időszak Balánbányán 1948 után, az államosítást követően alakult ki, de rézkohászat többé nem létezett Balánbányán. A kitermelés újraindult, de ezt már a népi demokratikus, majd a szocialista tervgazdaság szabályai szerint fejlesztették, irányították

\section{Vasércbányászat, vaskohászat}

A vasat már i. e. 2000 évvel ismerték, igazi elterjedése azonban a kora középkorhoz kapcsolható. Az emberiség legtöbbet használt anyaga „a földkéregben az oxigén, a szilícium és az alumínium után a leggyakoribb elem" (Tichy Géza 2007. 315.). A népesség rohamos növekedése újabb, megmúvelhető és termő mezőgazdasági területek kialakítását tette szükségessé. A föld megművelését aligha lehetett volna fából készült szerszámokkal, eszközökkel hatékonyan végezni. A kezdetekkor ritkább fém, mint a bronz, de az igavonó állatok patkolása, az ekevas alkalmazása, vasból készült szerszámok készítése, majd az építészeti alkalmazások, nem is beszélve a fegyverkészítésről vasat igénylő 
tevékenységek, amelyek meghatározták az új fém egyre szélesebb körű alkalmazását. „Számos nézőpontból a vas sokkal hasznosabb az embernek, mint az arany [...] Vas nélkül a nép nem védekezhetne ellenségeitôl, minden kézművesség a vasat használja" - szögezi le 1260-ban a híres ferences rendi angol tudós, Barthélemy (Jean Gimpel 1983. 37.).

Nyugat-Európa középkori vasiparát az angliai Sussexben, Svédországban, Spanyolországban találjuk, de számos régészeti lelet bizonyítja, hogy a vasgyártás a Kárpát-medencében sem volt ismeretlen. Somogyban, Magyarországon, régészeti ásatások 45 kemencét magában foglaló vasolvasztó műhelyegyüttest tártak fel, amelynek ipartörténeti értéke mellett korai művelődéstörténetünk megismerése szempontjából is nagy jelentősége van. Arra a kerámia fúvókatöredékre utalunk, amelyet itt találtak, és amelyen a 9-10. századi nyelvemlékünk, a székely-magyar rovásírásos bevéset, a FÚNÁK szó betűi találhatóak, ami mai értelmezésben fújtassak. Ezt az első magyarul írt műszaki szavunknak is tekinthetjük.

Erdélyben és Székelyföldön a vas elterjedését, a vasgyártás kezdeteinek nyomait a szkíták nyugatra tartó vándorlásával, foglalásával, az i. e. 1600-1550 körüli, majd Erdély meghódítása után az i. e. 700-400-ig terjedő időszakhoz lehet társítani. A folytatás már a keltáknak tulajdonítható, akik elől a szkíták visszavonulásra kényszerülnek (Roska Márton 1929. 302.).

Bár írott dokumentumok csupán a 17. századtól léteznek, az őskori és ókori vaskőfejtés nyomai, de különösen a vasolvasztó kemencék maradványai, kemencetöredékek, salakmaradványok tanulmányozható tárgyi emlékei letűnt korok vasgyártásának. Csíkdánfalván, Csíkszentdomokoson, Bardócon, Madéfalván Csíkszentkirályon, Csíkszent- simonban, Kirulyban, Székelyszáldoboson, Nagybaconban, Bibarcfalván és még jó néhány település körzetében kerültek elő a kezdetleges vasgyártás ilyen maradványai, eszköztöredékei. A kezdetekkor a felszínre került vasköveket gyűjtötték össze, és ha ez már nem volt eredményes, nyílt gödrökből termelték ki, majd ezután folyamodtak földalatti tárnák kialakításához.

A felhasznált vasércek, vaskövek töbnyire oxid típusúak voltak. A magnetit, a hematit, limonit és sziderit a gyakrabban előforduló vasércek. Egyes régészek a kalkopiritet is a vasat tartalmazó és a kezdeti vasgyártásban feldolgozható ércek közé sorolják. A Hargitahegység vulkanikus és posztvulkáni tevékenységének eredményeként a vastartalmú kőzetek a hegyvonulat teljes hosszában megtalálhatók. A 3. táblázat Székelyföld vasérceinek vegyi összetételét és néhány lelőhelyét tartalmazza. A vaskő vas-oxid tartalma mellett jó néhány más vegyületet is tartalmaz. Ezek főleg szilikátok, aluminátok stb., amelyektől a kohósítás folyamán meg kell szabadulni, ezek alkotják a kohósítás salakját. Az érc olvasztása a keletkező fém és salakanyagok részarányának függvényében változó mennyiségű hőenergiát igényelt. Az olvadáshoz szükséges hőenergiát faszénégetéséből nyerték. A székelyföldi vasgyártás szénigényes művelet volt. Ott, ahol huzamosabb ideig működtettek olvasztókemencéket, valóságos erdőirtás is folyt. Az őskori és ókori vasgyártás termékei erősebben korrodálódtak, mint az ásatag réz- és bronztárgyak, ezért jóval kisebb arányban gyarapítják a régészet által feltárt tárgyak sorát. Számos bronzlelet felületén vas-oxid-szennyezés észlelhető, ami vasból készült, de eltűnt tárgyakkal való érintkezésükre utal. A vas nedvességet és oxigént tartalmazó közegben erőteljesen, a teljes megsemmisülésig korrodálódik. 
3. táblázat. Székelyföld néhány vasérclelőhelye az előforduló vasérc vegyelemzésével (Technika Történeti Konf. Szilágysomlyó 2014. június 27-28.)

\begin{tabular}{|l|c|c|c|c|c|}
\hline \multicolumn{1}{|c|}{ Tartalom: } & \multicolumn{1}{|c|}{ Limonit: } & $\begin{array}{c}\text { Agyagvasérc } \\
\text { (szferosziderit): } \\
\text { Szzáldobos }\end{array}$ & $\begin{array}{c}\text { Mangán- } \\
\text { vasérc: } \\
\text { Gyergyóholló } \\
\text { bánya, Lövéte }\end{array}$ & $\begin{array}{c}\text { Kovasavas } \\
\text { vörös vaskő: } \\
\text { Vargyas, } \\
\text { Füzes oldal }\end{array}$ & $\begin{array}{c}\text { Kovasavas } \\
\text { vörös vaskő: } \\
\text { Alsórákos, } \\
\text { Kárhágó }\end{array}$ \\
\hline Vas-oxid & $65,14 \%$ & $48,02 \%$ & $13,52 \%$ & $12,52 \%$ & $22,46 \%$ \\
\hline Kovavas & $17,82 \%$ & $28,80 \%$ & $56,86 \%$ & $83,58 \%$ & $50,08 \%$ \\
\hline Réz-oxid & $0,01 \%$ & - & - & - & - \\
\hline Alumínium-oxid & $2,53 \%$ & $5,24 \%$ & - & nyom & $11,88 \%$ \\
\hline Mangán-oxid & $2,43 \%$ & $1,93 \%$ & $21,05 \%$ & nyom & - \\
\hline Kén & $0,05 \%$ & - & $0,04 \%$ & - & - \\
\hline Kalcium-oxid & $0,57 \%$ & $1,56 \%$ & $1,88 \%$ & nyom & $2,91 \%$ \\
\hline Magnézium-oxid & $0,47 \%$ & $0,59 \%$ & $0,02 \%$ & nyom & $2,12 \%$ \\
\hline Foszforsav & $0,17 \%$ & - & $0,04 \%$ & - & - \\
\hline Izzítási vesztesség & $12,54 \%$ & $12,73 \%$ & $1,40 \%$ & $2,24 \%$ & $10,26 \%$ \\
\hline
\end{tabular}

Az őskori és ókori vasgyártás helyszíneit salak, valamint olvasztókemence-romok együttese jelzi. A vasolvasztó kemence nem volt egy grandiózus építmény. A henger vagy csonka kúp alakú kemencét a helyszínen található kő és agyag felhasználásával építették, zömében a vastartalmú érc lelőhelyének szomszédságában. A kemence 30-40 cm belső átmérőjű 60-70 cm magas építmény volt, belső falát agyaggal simára tapasztották, majd lassú tűzzel kerámia minőségre kiégették. Zárt térben, léghuzat hiányában csupán lassú égés keletkezhet, aminek hőmérséklete nem éri el a vasérc összetevőinek olvadási hőmérsékletét. A természetes huzat növelése volt a kohósítási folyamat első, tudatos fejlesztése. Ez abbólállt, hogy a kemence falának alsó szakaszán nyílásokat készítettek. A beáramló levegő és a kemence tetején kiáramló égési gázok hőmérséklet-különbségéből adódó nyomáskülönbség keletkezett. Minél nagyobb volt ez a különbség, annál nagyobb lett a kemencén átáramló levegő sebessége. Ennek következtében nagyobb mennyiségű levegő, több oxigén áramlott át a kemence izzórakományán, növelve ennek hőmérsékletét. A rakomány faszenet, vaskövet tartalmazott, olyan elrendezésben, hogy legalul a szén, utána az aprított vaskő váltakozott vékony rétegekben.

A faszén égésének kettős hatása van a kemencében: egyrészt az égés hőhatása, másrészt az égéstermékek, a szén-dioxid és szén-monoxid keletkezése. Akármilyen tökéletes égést is elértek, szén-monoxid is keletkezett. A szén-monoxid redukciós hatására magas hőmérsékleten a vas-oxid oxigénjével szén-dioxidot alkot, a vegyi reakció végtermékei a szén-dioxid és a szivacsos vas. A legegyszerűbb redukciós folyamat a következő:

$\mathrm{FeO}+\mathrm{CO}=\mathrm{Fe}+\mathrm{CO}_{2}$.

A folyamat ennél jóval bonyolultabb. A befújt levegő az izzásban lévő szénnel, a teljes égés eredményeként, szén-dioxidot képez:

$$
\mathrm{C}+\mathrm{O}_{2}=\mathrm{CO}_{2} \text {. }
$$

A keletkezett szén-dioxid mint a füstgázok összetevője a kemence felső nyílása felé ha- 
ladva újabb izzó szénrétegen halad át, ahol a következő vegyi reakció megy végbe:

$$
\mathrm{CO}_{2}+\mathrm{C}=2 \mathrm{CO} \text {. }
$$

A keletkezettszén-monoxid redukálja a vasoxidot:

$$
\mathrm{Fe}_{3} \mathrm{O}_{4}+\mathrm{CO}=\mathrm{Fe}_{2}+3 \mathrm{FeO}+\mathrm{CO}_{2} / \mathrm{CO}
$$$$
\mathrm{FeO}+\mathrm{CO} / \mathrm{C}-\mathrm{Fe}+\mathrm{CO}_{2} / \mathrm{CO} \text {. }
$$

A természetes huzatot tovább kellett növelni, mert a keletkezett hőmérséklet nem volt elegendő a vasérc megolvasztásához. Kémény kialakításával elérték azt, hogy a vasérc salakanyaga, amelynek olvadáspontja jóval alacsonyabb a vas olvadáspontjánál, megolvadt, és egy része kicsorgott, elvált az érctől. A vas, bár még így sem vált folyékonynyá, egy szivacsos állagú lepénnyé állt össze. Ezt a 10-15 kg körüli korongot vaslepénynek, bucavasnak, a kemencét bucakemencének nevezték. A kezdetleges, kémény nélküli őskemence hosszanti metszetét a 4. ábra mutatja, a 5. ábra pedig a fújtatós kemencéjét.

Ezzel az eljárással csupán annyit értek el, hogy a vastól idegen anyagok egy része megolvadt, és kicsorgott a szivacsos bucából. Csak ezután kezdődött az emberi erőbedobás, a buca kiszabadítása. A kemencét szétszedték, majd a megszilárdult salakkal körülvett bucát kiszabadították a kemence

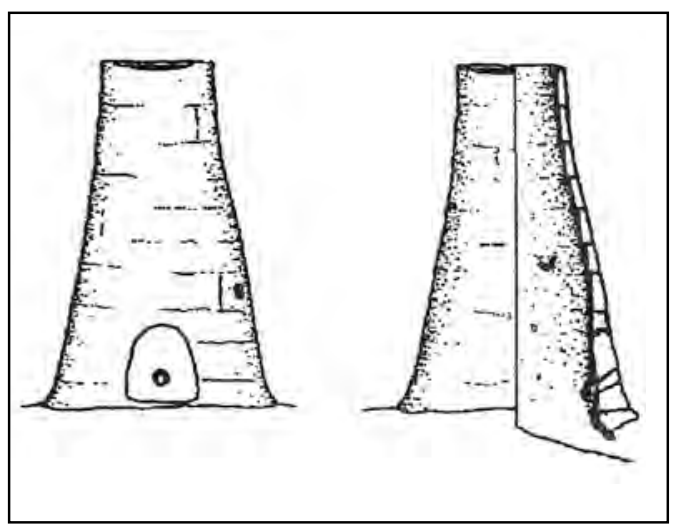

4. ábra. Kémény nélküli bucakemence szorításából, és a vaslepényről kalapálással eltávolították a szilárd salakot. Ezután a bucát újból felizzították, és darabokra vágták. A bucadarabokat ismét izzították és kalapálták. A többtonnás kalapácsütés erőhatásának köszönhetően valósággal kikalapálták a szivacsos szerkezetből a maradék salakot, egyben zömítve is a vaslepényt. Hosszú évszázadokon át alkalmazták a bucaeljárást. Több mint 10-15 kg vasszükségletnél több kemencét is működtettek egy időben. Minden buca után a kemencét újból felépítették, ami meglehetősen időigényes munka volt. A kemencetípus nem csak Erdélyben volt használatban. Szkíták, kelták, a görög-római világban is ismerték és használták. Ezért nem egyértelmű, hogy az erdélyi vasgyártás őskori és ókori szakaszában használt bucakemencét honnan eredeztesse a régészet (Ferenczi István 1999. 122.).

Régészeti ásatások felszínre hoztak olyan olvasztókemence-maradványokat is, amelyeket természetes földlépcsőhöz építettek úgy, hogy a kemence mellvédfala leszerelhető volt. A mellvédfal tartalmazta a levegőző nyílásokat és a fúvócsövet, amit égetett agyagból készítettek. A mellvédfalat többször is felhasználták, természetesen az esetleges meghibásodások kijavítása után. A félko-

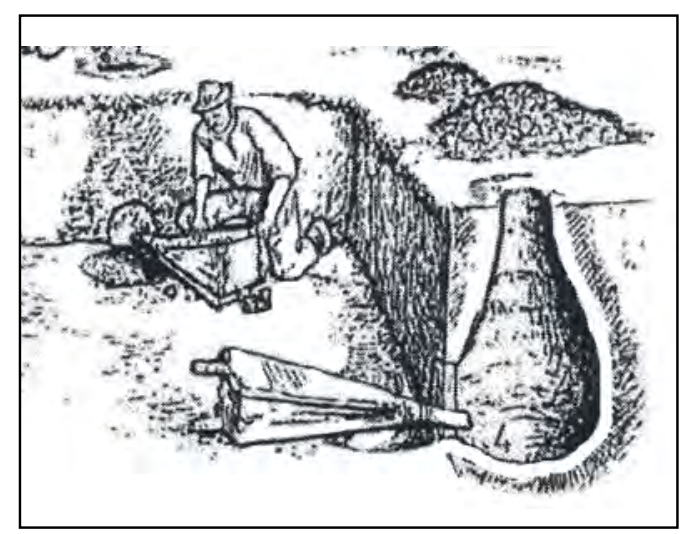

5. ábra. Fújtatós kemence 
rongos, fúvócsöves, égetett agyagból készült mellvédes kemence újításnak számított, egyes feltételezések szerint dák eredetűként is elképzelhető. Ez a kemencetípus csupán Székelyszáldobosról és Sepsibesenyőről ismeretes (Ferenczi István 1999. 122.).

A bucaeljárás tökéletesítését a mesterséges léghuzat, a fújtatás alkalmazása jelentette. Juh- vagy kecskebőrből készítettek fújtatót, amit kézzel, emberi erővel működtettek. A kemence huzatkeltő nyílásához kerámiacsövet illesztettek, agyaggal rögzítették, majd ehhez csatlakoztatták a fújtatót. Olvasztókemence falmaradványai fújtatócsőmaradványokat is tartalmaznak, arra utalva, hogy mesterséges huzattal működő vasércolvasztásról van szó. A megnövekedett huzat hatására nőtt az égést tápláló oxigén menynyisége, a szén égési hőmérséklete, a vasérc is hamarabb megolvadt, a salak is folyékonyabbá vált. A bucakemencék fala építőjük igyekezete ellenére nem volt egyenletes. De nem csak ezért omlottak össze használatuk beszüntetését követően. Az idő, a természeti környezet hatása és maga a fejlődés juttatta oda a bucakemencéket, hogy „máig tudott esetben (egy)sem maradt épen" (Ferenczi István 1999. 123.).

Vegyi, akár spektroszkópos elemzések hiányában nehéz megállapítani, hogy mikor kezdték alkalmazni az őskori vagy ókori vasgyártás kezdetleges technológiájában a salakképző anyagot, a mészkövet, aminek hatására a salakkiválasztás hatékonyabb lesz, mivel a salak folyékonyabbá válik. A salakképző anyag a székelyföldi vasércek környezetében fellelhető, ennek ellenére a kezdetleges vaskohászat maradék nyersanyagai és salakmaradványai között csak nagyon ritkán van jelen a salakképző anyagként használt mészkő. A kemence rakományának minden harmadik rétege salakképző anyag kellett hogy legyen.

A Hargita-hegység vulkanikus és posztvulkáni tevékenységének eredményeként gyakoriak a vaskőképződmények. A felszínre törő limonit vagy hematit jelzései lehetnek egykori vasgyártásnak, kemence és salaktöredékek létezésére is utalhatnak. Így kerültek elő Székelyföld településeinek közelében bucakemencék maradványai. Ezek: Barót, Bibarcfalva, Bözöd, Csíkdelne, Csíkkozmás, Csíkmadaras, Csíkszentkirály, Felsőcsernáton, Csíkszettamás, Magyarhermány, Székelyszáldobos, Torja, Székelypetőfalva, Csíkszentdomokos, Csíkcsicsó, Csíkszentsimon, hogy csak azokat említsük, amelyek szakdolgozatokban is szerepelnek. Néhány kemence környezetében vasból készült tárgyak is előkerültek. Legkorábbi tárgyak, amelyeket az i. e. 12-11. századra datáltak, Felsőcsernátonból és Székelypetőfalváról származnak. A folytonosságra, a 12-13. század vasmüvességére utalnak azok a leletek, amelyeket Csíkcsatószeg, Csíkszentimre, Csíkszentkirály vagy Nagygalambfalva körzetében tártak fel (Ferenczi István 1999. 127-128.).

A következőkben csupán két helység feltárt kincseinek bemutatásával ecseteljük azt az örökséget, amelyet több ezer évvel előttünk élt népek hagytak az utókorra. Kincseknek nevezzük, amikről vitatkozni is lehet. Kincs alatt valami nagyon nagy értékű tárgy jelenik meg képzeletünkben. Meg is mosolyogjuk, ha egy salak és kemencemaradványt a kincsek kategóriájába sorolunk. De gondoljuk csak meg, mennyivel szegényebbek lennénk, ha nem tudnánk ezekről, és nem ismerhetnénk meg az itt élő, békésen alkotó őskori/ókori népek mindennapjaihoz tartozó fémművességet.

Felsőcsernáton Hegyes-tetőn, 1980-ban egy vízmosásban nyéllyukas vasfejszét mosott ki a tavaszi hóolvadás, esőzés, jelezve, hogy a környéken feltárást érdemes végezni. 
A feltárás meg is történt, aminek eredménye: kora vaskori település jellegzetes kerámiatöredékekkel, a vasfeldolgozásra utaló töredékes öntőkanál,- öntőminta- és vassalakmaradványokkal, és ami nagyon fontos, darab vas is gazdagította a leletegyüttest. Spirálkorongos bronzfibula, vaskés, szárnyas vasbalta különböző méretű (14-17 cm) vasrudak, öntőkanáltöredék, amit bronzöntésnél használhattak, a leletegyüttes, amelyben számos más tárgy vagy töredékük, lakóház alapja, tűzhelymaradványok mind azt igazolják, hogy „a feltárt település a kora vaskorba, a Hallstatt B-be sorolható "(Székely Zsolt 2007, 73-79.). A bronz lándzsahegy, a bronzfibulák jelenléte vastárgyak együttesében arra utal, hogy a két fém, a bronz meg a vas még hosszú évszázadokon át együtt volt használatban, és arra is, hogy már a késő bronzkorban vaseszközöket is tudtak készíteni.

Az ókori vasgyártásban felhasznált vaskövek gyakorta felhasznált típusai a Csíki-medencében az ásványvízforrások környezetében, mocsaras rétek és árterületek viszonylag könnyen kitermelhető, felszíni vas-oxid lerakodásaiként keletkeztek, nyersanyagbázisát képezve az új fém előállításának, a vasnak. A könnyen kitermelhető vasérc lehetővé tette a vasgyártást a medence lakóinak, a dákoknak, gótoknak vagy más népvándorlás kori népeknek, akik ezen a területen évszázadokon át éltek, és akik már idetelepülésük előtt is ismerték a vasat, vagy egymás hagyatékát tovább vitték. Nyersanyagbázisként szolgáltak az új fém technológiájának meghonosodásához a felszíni vasércek (limonit, hematit). Kitermelésük és felhasználásuk jelei a Csíki-medence majd minden zugában fellelhetőek. Salaktömbök, a kor vasgyártására jellemző, vas-oxidot redukáló kemencék romjai, maradékok, vasérc és salakképző anyagok maradványai mind arról tanúskodnak, hogy a szóban forgó terület évszázadokon át a vasgyártás központjainak adott otthont. Azt sem kell elhallgatnunk, hogy mindezek ellenére a Csíki-medence nem sorolható a Kárpát-medence legfejlettebb, legnagyobb vasgyártó vidékeihez, bár nem kétséges, a vasgyártást szakosodott-kötelezett népességréteg müvelte itt is (Botár István 2015. 3; Botár István 2001. 165-172.), és főleg helyi igények kielégítésére irányult.

Csíkmindszent határában, Csíksomlyón, Csíkszereda Mikó-várának környezetében nagy kiterjedésű, feltárásra váró területen kerültek elő vasgyártásra utaló töredékek. Csíkszentkirály határában egy vasolvasztó töredékeit hozták napvilágra, ami arra utal, hogy itt rendszeresen folytattak vasércolvasztást (6. és 7. kép).

A csíktaplocai Vasfúvó-domb Csíkszeredától 5 km-re kaszálós-szántós területből emelkedik ki, és amint neve is elárulja, egykor itt vasérckitermelés, vasgyártás folyhatott. Erre utalnak a domb különböző részein máig behatárolható érckitermelés gödrei. A domb gejzírmaradványnak tekinthető, ugyanis az itt gyakori meleg ásványvizű minigejzírek, langyos borvízforrások lefolyó vizéből a limonit kiválik (Vörösváry Béla 2009. 125.). A Vasfúvó-domb limonitjának aránylag gazdag vastartalma van, bizonyos helyeken eléri a 40-41\%-ot. A limonitréteg vastagsága is változó, a legvastagabb lerakodás a 2,5-3 m is eléri. A domb és környéke régészeti szempontból nincs feltárva, csupán a vastag kohósalakréteg árulkodik egykori vasolvasztásról.

A késő vaskor végén (i. e. 500-12) az őskori és ókori vasgyártás ugrásszerű fejlődésen megy át, amihez a kor legfejlettebb fémműveseinek, a szkítáknak, a keltáknak és a dákoknak volt jelentős hozzájárulásuk. E három nép öröksége tovább élt, mi több, tovább is fejlődött a rómaiak közel két év- 


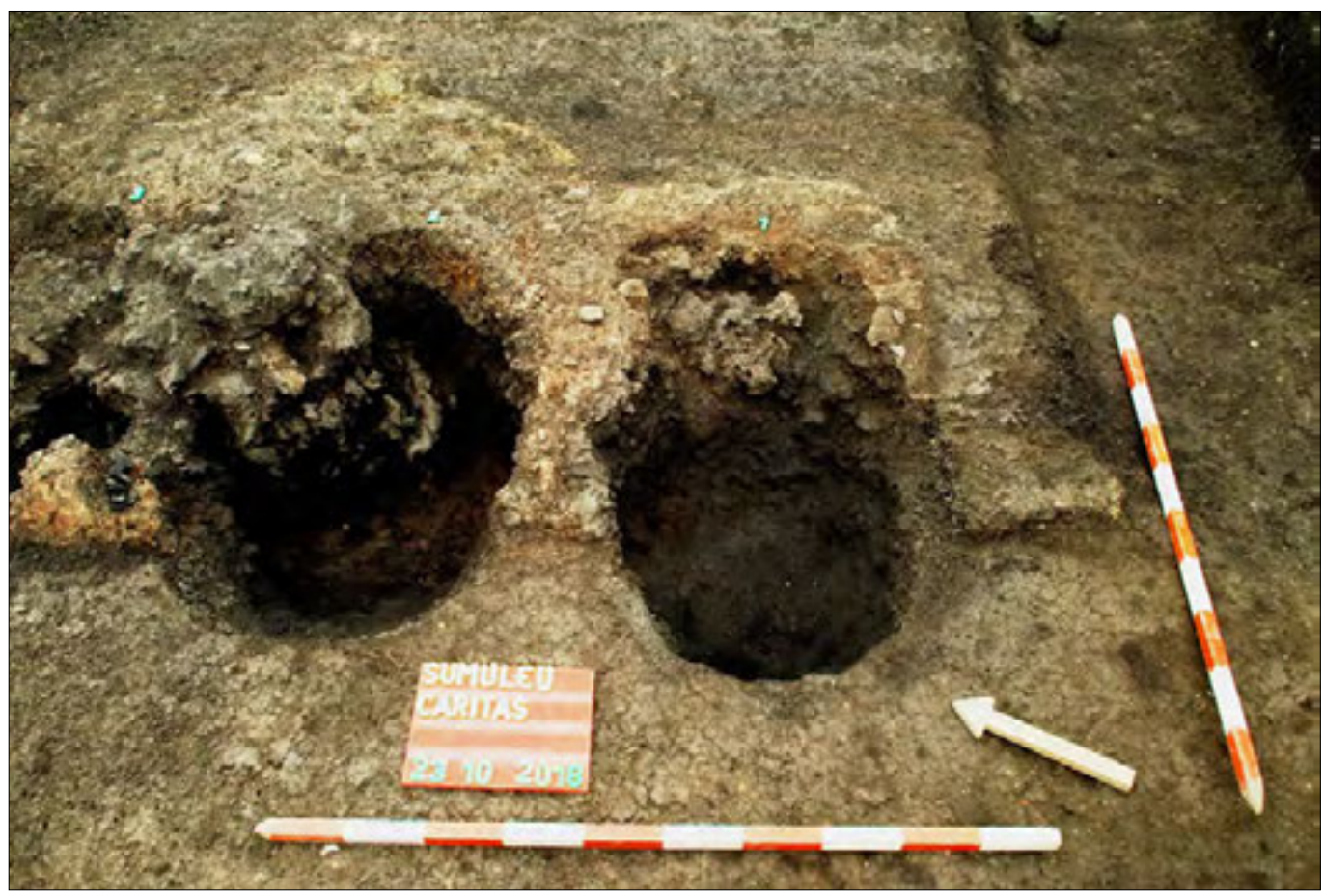

6. kép. Bucakemence salakgödre a csíksomlyói feltárásból (2019)

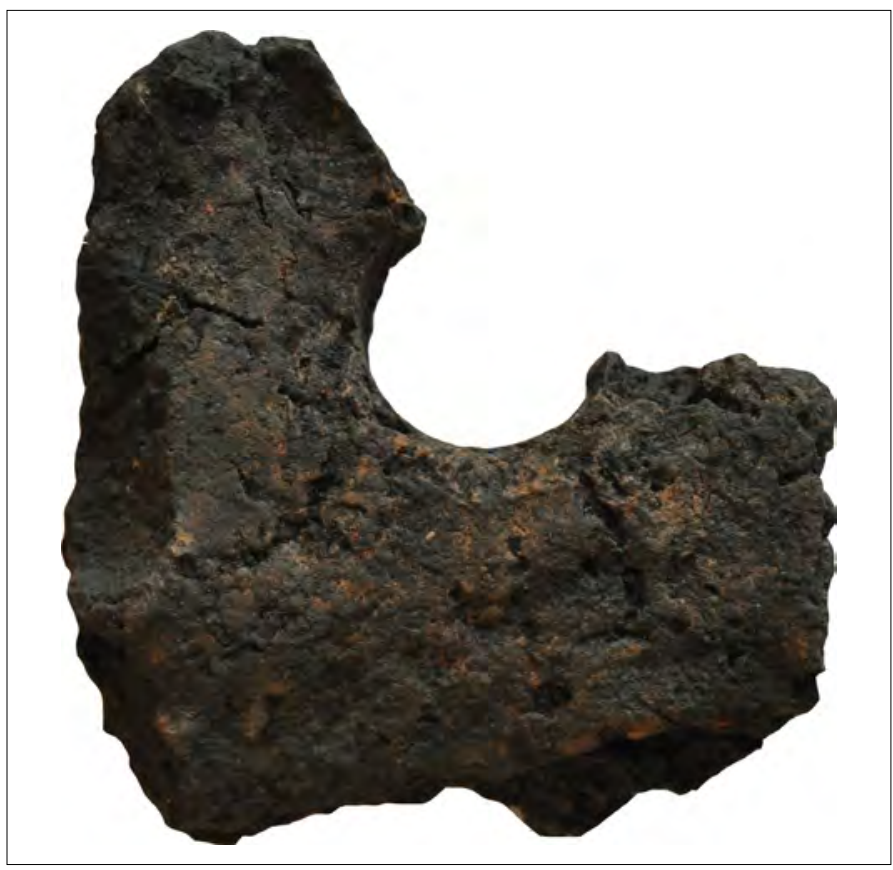

7. kép. A bucakemencetöredék levegőbefújásának nyílása 


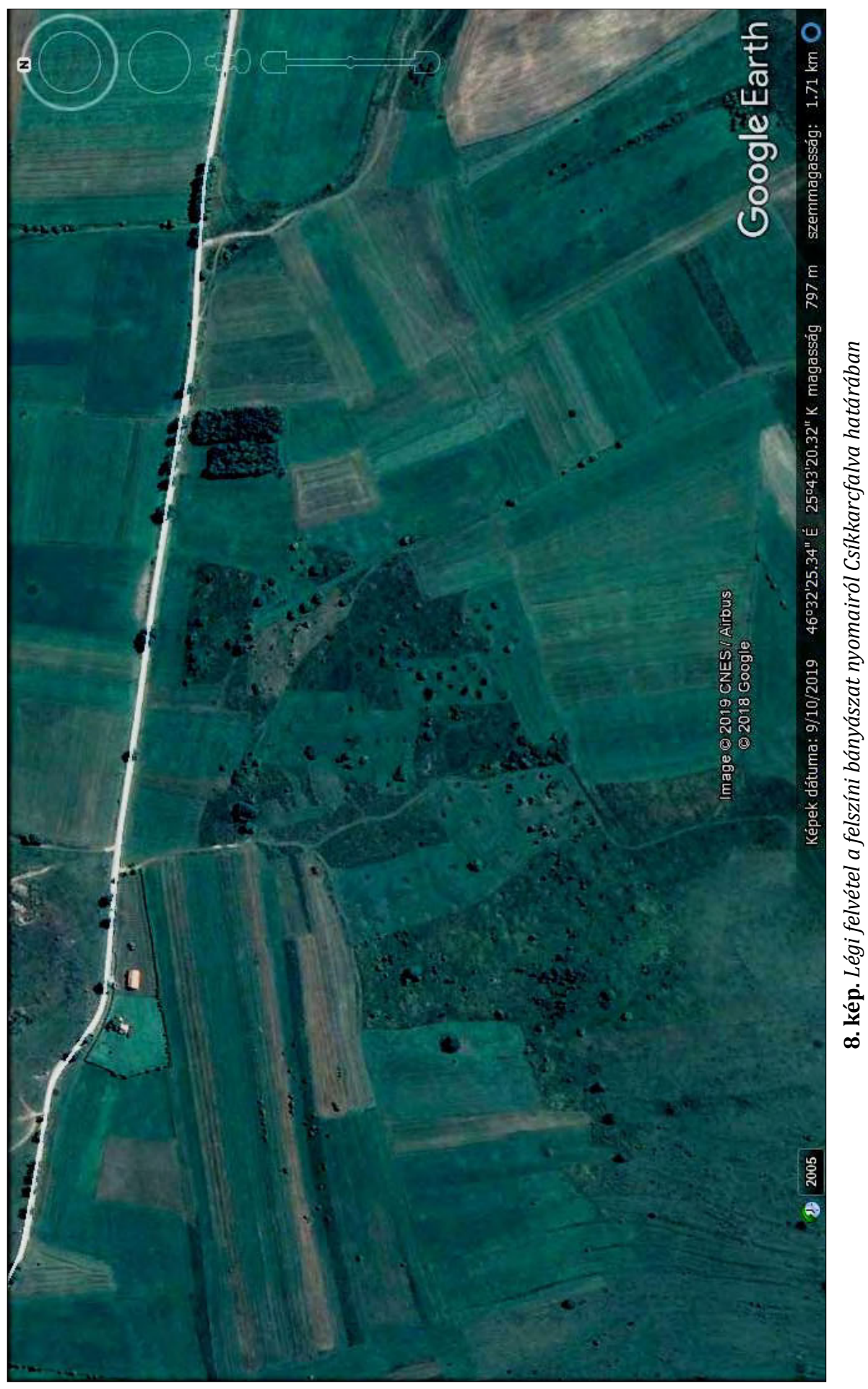


százados dáciai tartózkodása idején. Ekkor Európa legjelentősebb, vasércben gazdag területei római kézben voltak (Gabler Dénes 2009. 43-53.). A rómaiak a vasat széles körben használták. A legnagyobb vasfelhasználó a hadsereg volt, ugyanis: „Egy római legionárius felszereléséhez mintegy $7 \mathrm{~kg}$ vasra volt szükség. Ha arra gondolunk, hogy a császárkorban a 30 légió 180 ezer katonájának, ezenkívül a segédcsapatokban és a flottában szolgálatot teljesítô személyeknek mennyi támadó és védő fegyverre volt szüksége, mennyit használtak fel a hajítógépek, ostromtornyok, hadihajók alkatelemeihez, akkor több ezer tonnára becsülhetjük csupán a hadsereg vas iránti igényét." (Gabler Dénes 2009. 4353.)

A római kor bányászattal és kohászattal kapcsolatos emlékei főleg a határvédelmi vonal, a limes mentén kerültek elő a Székelyföldön. A határvédelmet biztosító katonai táborok, castrumok vonala követi a Keleti-Kárpátok vonulatát, ahol a vasérc bányászatának és kohósításának reális lehetőségét azonosíthatták.

$A$ védelmi vonal mentén, a katonai táborok és castrumok környezetében végzett régészeti ásatások a római kor vasművességének számos tárgyi bizonyítékát, a civil lakosság használati tárgyait, szerszámait, eszközeit tárták fel. A római kor vasgyártásának jelentős központjai Vajdahunyad környékére tehetők, ahol hatalmas vasérclelőhelyek voltak, pl. Gyaláron vagy Alsótelek határában. Az itt előkerült olvasztókemencék kivitelezése, bár azok elvileg megegyeznek a székelyföldi kemencék működési elvével, jelentős fejlődést mutat, és több évszázadon át, a római kort is túlélve, használatban voltak. A 6. ábrán egy természetes huzatú bucakemencének hosszanti metszete és alaprajza látható. A kemence, ha a 9. században működött (Kerpely Antal 1896, 210.), feltételezhetően a római korban is használatos volt.

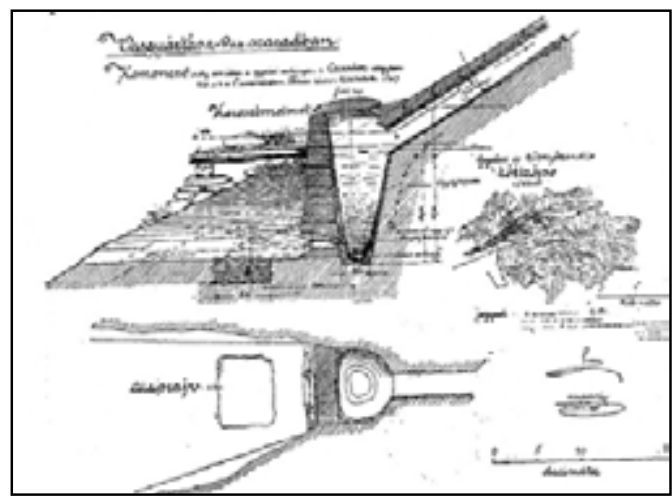

6. ábra. Természetes huzatú bucakemencének hosszanti metszete és alaprajza

A kemencét sziklába vájt hátsó falával, terméskőből épített melső falával, ferde kéményével, 1600 mm magasságával, rakodógaratjának lezárhatóságával, a rakodást elősegítő hídlásával, a későbbi korok (18-19. század) olvasztókemencéinek előfutáraként értékelhetjük. A fenti kemencében egy bucavasat is találtak, ami a kemence feladása után keletkezésének helyén, a kemence aljában maradt. Ebből is következtethető, hogy a római korban sem tudták a vasat folyékony állapotba hozni. „A fújtatók alkalmazása ellenére sem tudták elérni az $1535{ }^{\circ} \mathrm{C}$ hömérsékletet, amelyre a vas teljes kiolvasztásához lett volna szükség. (Általában csak $1300{ }^{\circ} \mathrm{C}$-ig tudták fokozni.) Ezért pl. a nyugat-boszniai bányák mintegy 2 millió tonna salakja még 48\% vasat tartalmaz, amit a rómaiak nem tudtak kiolvasztani." (Gabler Dénes 2009. 45.)

A római kor vasércbányái mind felszíni, mind földalatti tárnák lehettek. A hosszú, folyosószerű, tárnákat faoszlopokkal aládúcolták, így próbálták megelőzni a beomlásokat. A következő történelmi korok bányaművelése ráépült a római bányákra, folytatva azokat az adott kor műszaki fejlettségének megfelelően. De a gyakori beomlások és természeti folyamatok környezetváltoztató hatásának 
eredményeként csak ritkán kerülnek elő eredeti állapotukban római kori vájatok. A Székelyföldön egyáltalán nem. Kútszerű akna típusú érckitermelést mutat be a 9. kép, ami egy ókori fogadalmi tábla illusztrációja.

A bucavasat izzított állapotban feldarabolták, a darabokat tovább kovácsolták. A kovácsolás az olvasztásnál is régebbi művelet, a kezdetekkor, amikor még ismeretlen volt a meleg megmunkálás, hidegen kovácsolva alakították ékszerekké, szerszámokká, fegyverekké a termésaranyat és a rezet. A római kor kovácsoltvas tárgyi emlékei aránylag gyakoriak a castrumok környezetében. Példaként említjük a Székelyudvarhely központjában, építkezési munkálatokhoz kapcsolódó ásatásokkor előkerült római kovácsműhely termékeit szerszám- és eszközkészletét (Radu Zăgreanu - Zsolt Nyárádi 2011. 262-265.). Ezeket láthatjuk 7. ábrán. A székelyudvarhelyi leletegyüttes vaseszközeihez hasonló kovácstermékeket tártak fel a védelmi vonalhoz tartozó másik székelyföldi castrum környezetében, Mikháza mellett, Markodon.

A római hódítással nem vált rómaivá az egész Kárpát-medence lakossága, de együtt azok a népek, amelyek a Birodalom alatt éltek, megteremtették a nagyipari szintű bányászati és kohászati termelést (László Gyula 1974. 127.). „A római közigazgatásnak a katonai alakulatoknak, sôt a népesség döntő többségének a római Dacia tartományból való kivonulása után, a tervinegek (vizigótok), gepidák, avarok, onogur bolgárok, szlávok kisebb-nagyobb közösségekben való betelepedése után szinte minden tekintetben gyökeresen megváltozott a helyzet. E több évszázadra rugó időszakban a római korban megszokott termelési tevékenység és kereskedelem tetemesen megcsappant, eljelentéktelenedett, lelassult." (Ferenczi István 1999. 124.)

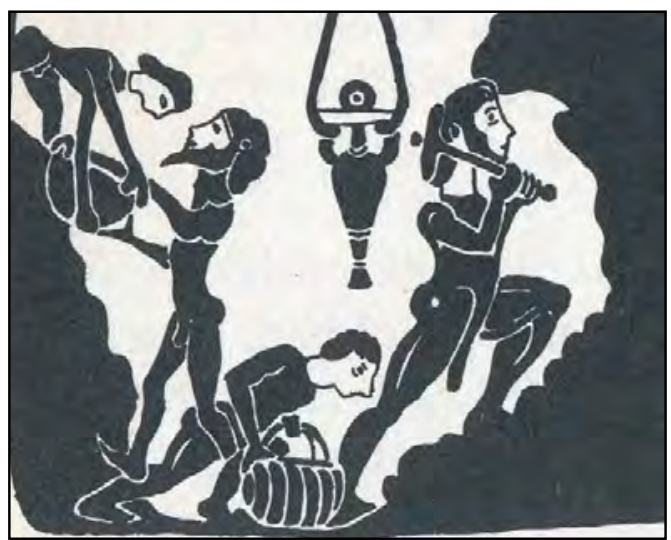

9. kép. Akna típusú érckitermelés egy ókori fogadalmi tábla illusztrációján

Mi történt a kivonulás után azon a területen, amit ma Székelyföldként jegyzünk? Megkezdődött a népvándorlás kora és időszámításunk kora is. De ez már nem technikatörténeti kategória, ugyanis az első ezredfordulóig a fémművesség műszaki szempontból a római kor hagyományait, örökségét vitte tovább. Annyit azonban meg kell említenünk, hogy: „A népvándorláskor történeti előzményeként [...] a meglehetôsen jelentôs dák jelenlét, majd a várakat uraló dák vezetöréteg jelenlétének a római Dacia provincia szomszédban zajló kialakulása vetett véget." (Botár István 2015. 2.) A 3. században a gótok jelentős mennyiségű, vasgyártásra utaló salakot, olvasztókemence-maradványokat hagytak kivonulásuk után, a limonitban gazdag területek szomszédságában. Az ezt követő korban a vasművesség méreteinek jelentős csökkenése következett. Ezt bizonyítják a régészeti ásatások.

A lovak patkolása a 9. századtól kezdődően lendületet adott a vasgyártásnak Európa-szerte.

A vasgyártás további fejlődését az egyre nagyobb mennyiségben igényelt fém tette szükségszerűvé. A harcászatban már amúgy 


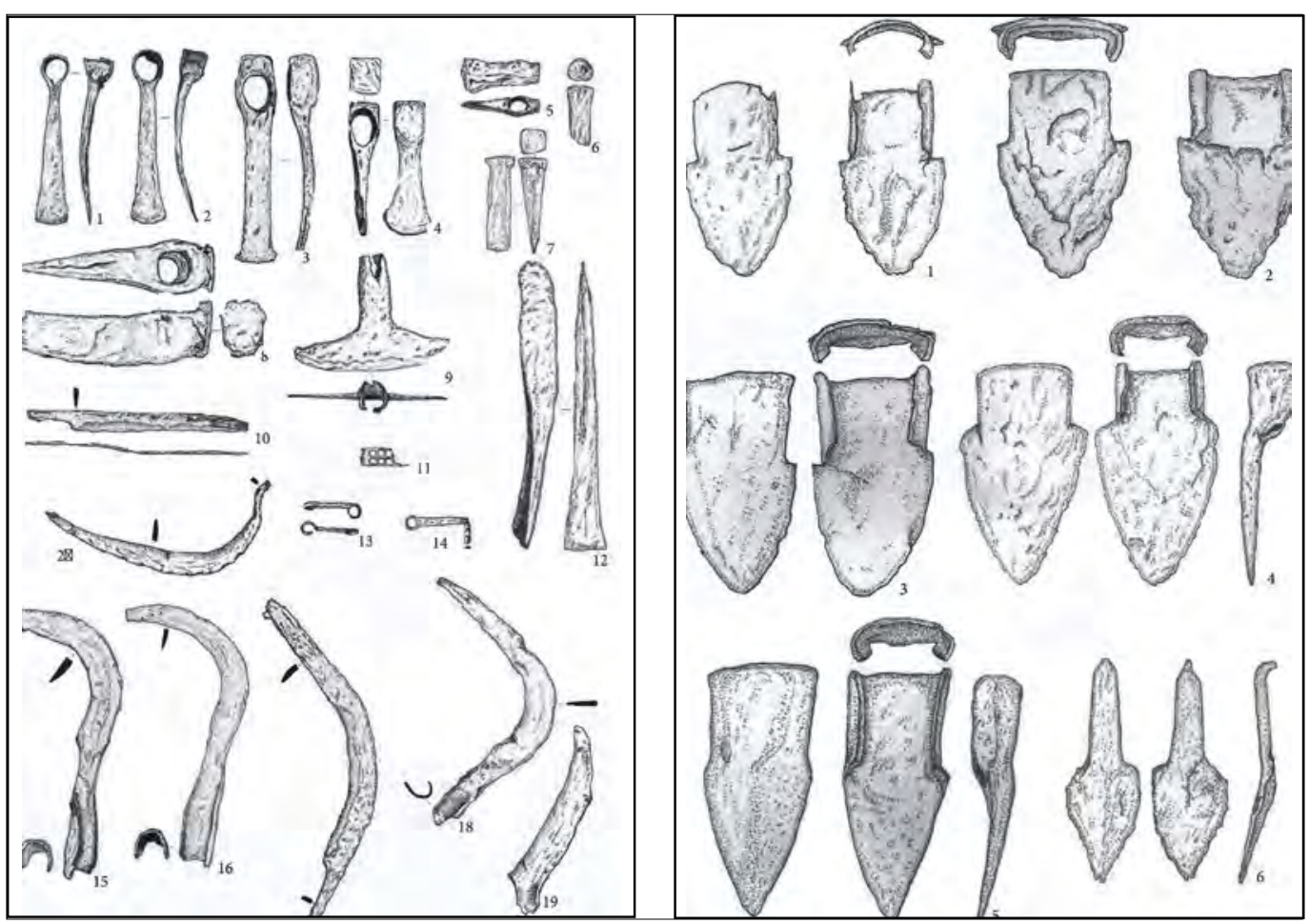

7. ábra. Római kovácsmühely termékei Székelyudvarhely központi részén történt régészeti ásatásból

is jelentős a vasból készült támadó és védekező katonai felszerelés, amihez a mezőgazdasági eszközök, szerszámok vasazása is csatlakozott egyre növekvő igényekkel.

A vasgyártás kezdeteitől a középkor utolsó évszázadaiig a kis térfogatú, kis termelékenységű bucaeljárásos kemencék voltak használatban. A természetes léghuzattal vagy izomerővel működtetett fújtatókkal nem lehetett elérni a vasérc folyási hőmérsékletét a kemencében. Az évszázadokon át használt bucaeljárást a 14. század elején vízi kerékkel hajtott, megnövekedett teljesítményű fújtatók váltották fel, forradalmasítva ezáltal az európai vasgyártást.

Az elérhető magasabb hőmérséklet következtében a vasérc és természetesen a vas is folyékony halmazállapotúvá vált, de nem csak ennyi. A magas hőmérsékleten a füst- gázokban található szén-monoxid széntartalmából és az izzószénből nagy százalékban oldódik a szén a vas kristályszerkezetében. A kohósítás eredményeként 2,06-6,67\% szén tartalom esetén öntöttvas keletkezett, amelynek olvadáspontja jóval alacsonyabb a vas olvadáspontjánál, és amely jóval folyékonyabb. Az öntöttvas jelentette az igazi múszaki forradalmat a vasgyártásban.

Mint előbb említettük, az első ezredforduló környékén már számos mesterségnek müszaki leírása van. Így például a már említett Theophilus Presbyter bencés szerzetes kéziratos múve, a Schedula Diversarum Artium. A könyv ugyan nem tartalmaz a vasgyártással kapcsolatos leírást, de a szeggyártás és huzalkészítést mint a kovácsmesterséghez tartozó műveletet ma is alkalmazható módon ismerteti. 


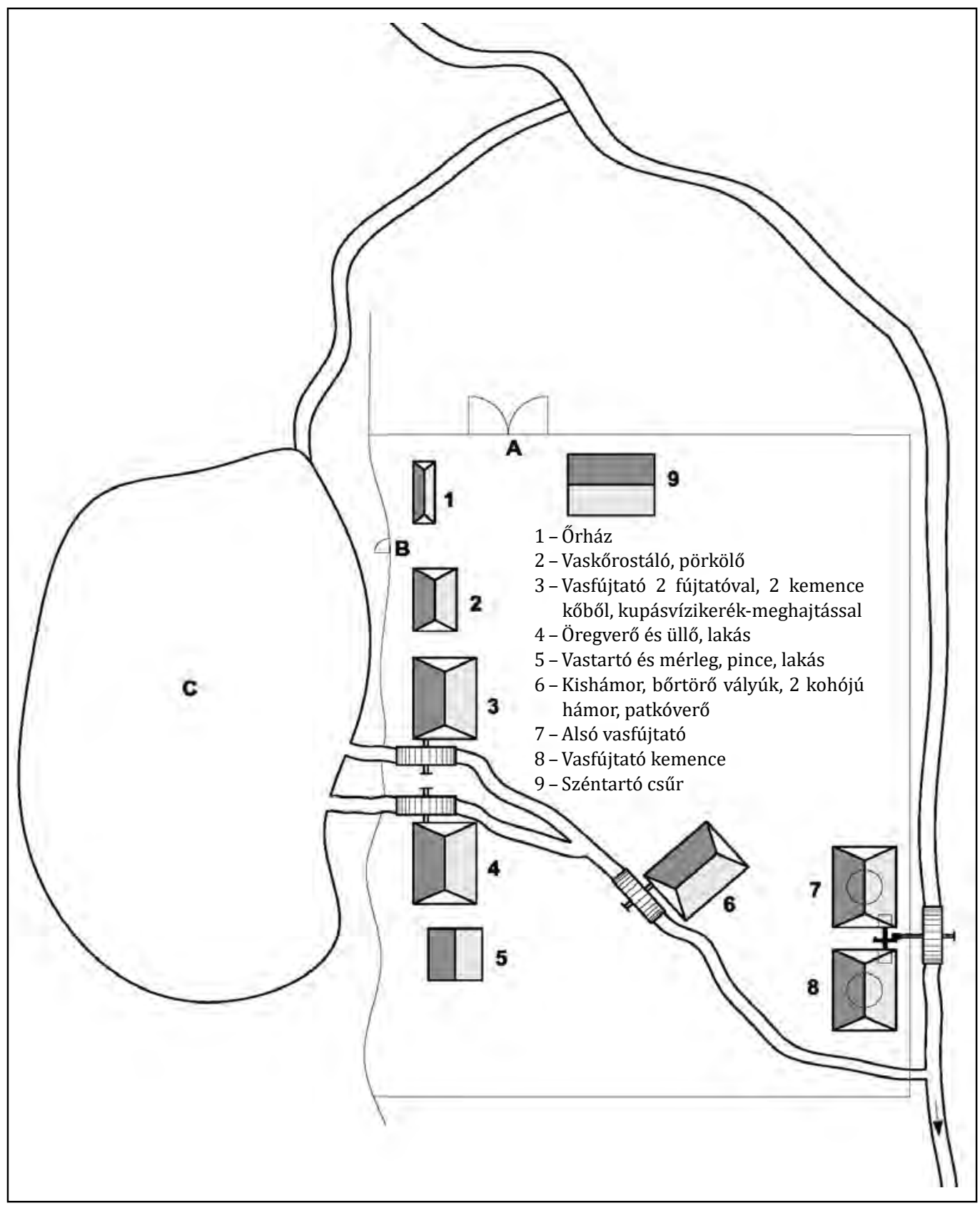

8. ábra. A csíkmadarasi vashámor lehetséges helyszínrajza egy 1677-ből származó leltár-leírás alapján 


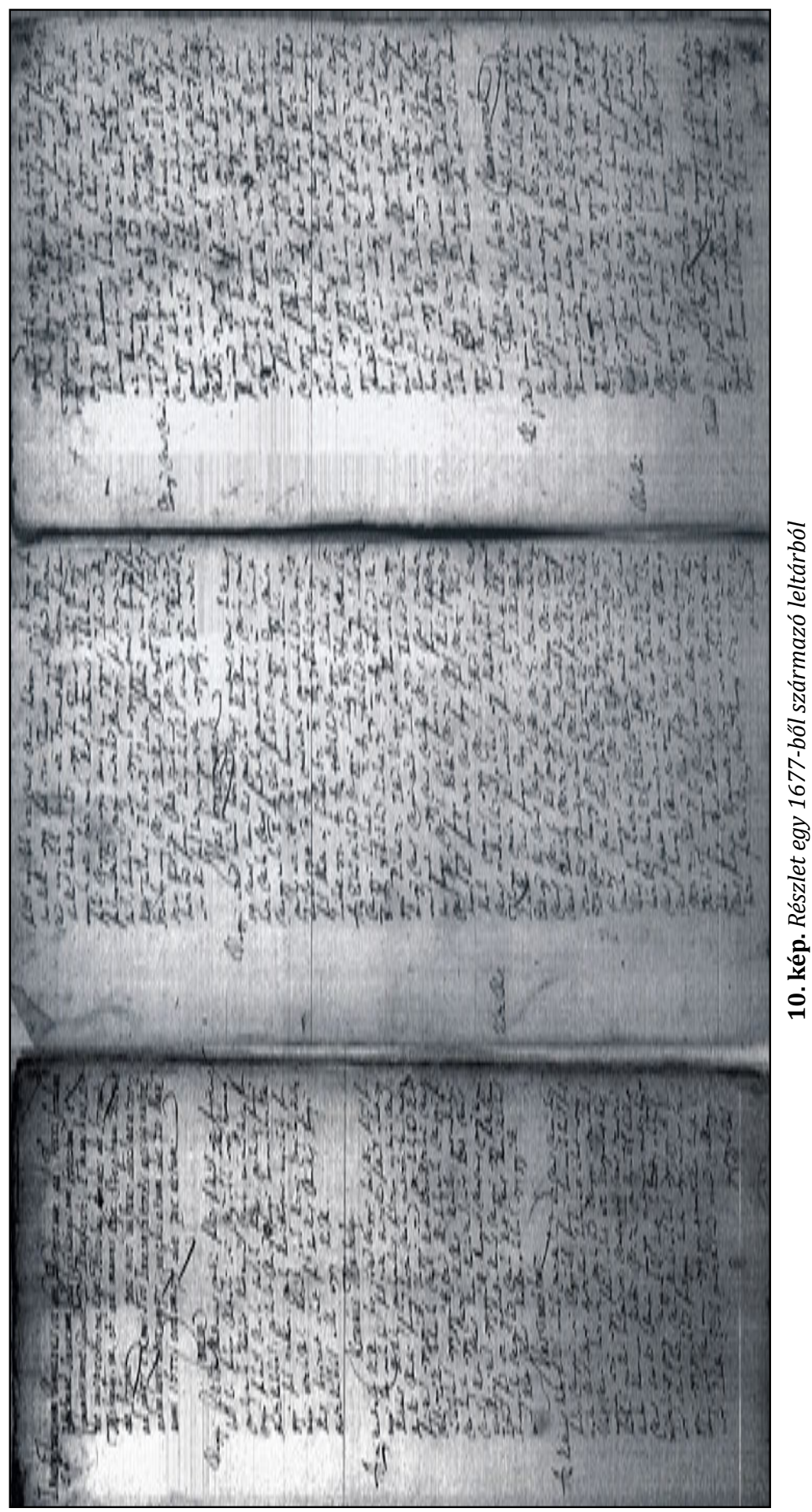


A 16. század közepén egy időben két műszaki könyv lát nyomdafestéket a bányászat és kohászat témakörében. A De re metallica, Georgius Agricola műve latinul és a $D e ~ l a$ pirotehnia, Vannocio Biringucio munkája olasz nyelven. A két mű korszakalkotó, és több nyelvre is lefordították. Mindkettő világos képet nyújt koruk bányászati és kohászati technikájáról. Ezek birtokában fejlődött a következő századokban különösen a kohászat technológiája, a bányászat gépesítése.

A 16-17. században az Erdélyi Fejedelemség vasszükségletének kielégítésére három vasgyártó központot működtetett. Vajdahunyadon és környékén, Torockón és Csíkmadarason fejedelmi vashámorok termeltek, feldolgozva a környékén található vasércet. Az erdélyi vasipar kibontakozásának minden feltétele adva volt. Közel voltak a vasérclelőhelyek, a salakképző mészkő, a fa tölgy-szén alapanyagát adó nagy kiterjedésű erdők, a vízenergia hasznosításának lehetősége, és munkaerőben sem volt hiány. Nem elhanyagolható tényező az sem, hogy a középkori vasgyárakat megelőző évszázadokban bucaeljárásos vasgyártás is létezett.

A fejedelemség korában létező vastermelésről korabeli források is tanúskodnak, ugyanis Csíkmadaras már jövedelmező vasipari központként szerepelt fejedelmi dokumentumokban. Az sem elhanyagolható, hogy a madarasi hámornál Csíkszék tíz településének lakói dolgoztak, mentesülve mindennemű adóterhek alól. A vasgyártás jelentőségét az is alátámasztja, hogy az itt dolgozó csíki, gyergyói és kászoni személyek kiemelkedő munkájuk elismeréséül a lófőséget is megkapták Báthori Zsigmond fejedelemtől. Gyakorlatilag az egész felcsíki medence vasérclelőhelyeiből származó vasérc ide, a madarasi vashámorba került további feldolgozásra.

A vasgyár és a hámor jövedelmező tevé- kenysége volt a kincstárnak, értéke is jelentős volt. Ennek tulajdonítható, hogy a fejedelmi kancellária néha zálogba is adta a hámort nehéz gazdasági helyzetének feljavítása végett. A csíkmadarasi hámor a mindenkori erdélyi fejedelmi udvar fontos jövedelemforrása volt, tulajdonát képezte még akkor is, ha rövidebb-hosszabb időre bérbe adta.

A17. század első felében, 1610-ben Báthori Gábor fejedelem a vasérclelőhelyek egy részét, köztük a csíkszentdomokosit is Bethlen Gábornak, akkor Csíkszék főkapitányának adományozza, aki utóbb, fejedelemé választása után több intézkedést is hozott az erdélyi vasgyártás fellendítése érdekében (Pataki József 1971. 10.).

Ahányszor fejedelemváltás volt Erdélyben, annyiszor cserélt gazdát a csíkmadarasi vashámor, de többször is megtörtént, hogy fejedelmi rendeletre a csíki főkapitány fennhatósága alá került. Például Barcsai Ákos fejedelem a csíki főkapitánynak, Petki Istvánnak adományozta, Apafi Mihály fejedelem 1000 tallérért zálogba adta a vashámor fele részét Daczó Jánosnak, aki szintén Csíkszék főkapitánya volt abban az időben (1668). Apafi Mihály alatt a fejedelemasszony vezette a hámorral kapcsolatos gazdasági nyilvántartásokat.

II. Apafi Mihály apja halála után örökölte a hámor fölötti jogot, sajnos csak rövid ideig, ami a hámor életében rossz irányú fordulatot hozott. 1695-ben Lipót osztrák császár Bécsbe rendelte az ifjú fejedelmet, II. Apafi Mihályt és nejét, Bethlen Katát, akik nem térhettek vissza Erdélybe. Ezután megkezdődött a csíkmadarasi vashámor hanyatlása, egy 1703-ból származó leltári összeírás is például a hámor siralmas állapotát tükrözi. Rohamosan veszíti értékét, 40 forintér adták bérbe akkor, amikor egy ökör ára 10-14 forint volt. 
A hámor lassú haldoklása egy 1722-ben keltezett bérbeadási szerződésből is kiviláglik, amelyben már nem esik szó a vasgyártásról, csak a területek, valamint a még működő fürészmalom és a szénarétek jelentenek értéket.

\section{A vashámor anyagmaradványainak elemzése}

Többszöri terepbejárás eredményeként különféle anyagmaradványok kerültek elő: salakmaradvány, nyersvasmaradvány és acélmaradvány.

Ezekből az anyagdarabokból vizsgálati mintákat vágtunk ki, amelyeket Thermo Niton XL3T típusú röntgenfluoreszcencia spektrométerrel (XRF), SPECTROTEST TXC25 típusú optikai emissziós spektrométerrel és Zeiss EV010 pásztázó elektronmikroszkóp energiadiszperzív spektrométerével (EDS) vegyelemeztünk. A felkutatott anyagminták felületét, illetve metallográfiai csiszolatokon a belső szerkezetét iqualitrol iMet-Y400 és Olympus PMG-3 típusú fémmikroszkóppal, továbbá sztereomikroszkóppal és pásztázó elektronmikroszkóppal vizsgáltunk.

A 4. táblázat az XRF-es vegyelemzés eredményeit tartalmazza.
A táblázat három adatsorát elemezve a következőket állapíthatjuk meg:

1. Az anyagmaradványok vastartalma 38,374\% közé esik. Ebben csak az a rendhagyó a mai vaskohászati maradványok összetételi eredményeivel összevetve, hogy a salakmaradvány vastartalma $38,3 \%$, ami a gyenge kinyerés következménye. A salakban jelentős menynyiségü, értékes elemek, pl. $\mathrm{Zn}, \mathrm{Ni}, \mathrm{Sb}$ találhatók, ezek kinyerése a hámor működése alatt felhalmozódott salakhegyből időszerű feladattá válhat.

2. A nyersvasmaradvány-mintadarab természetesen már vasban dúsabb: vastartalma 62,1\%-ot tesz ki. Megjegyezzük, hogy a felmért 5,8\% Si-tartalom is jellemző az öntvényekre. A Cr- és Sb-tartalom nem túl nagy, de éppenséggel lehet a csíkmadarasi vasércek sajátossága. A metallográfiai vizsgálatra előkészített, csak polírozott, tehát nem maratott nyersvasmaradvány-mintában jól látható a grafit rozettás eloszlása.

3. Az acélmaradvány mintadarab XRFes elemzésében megjelenik a réz (290 ppm), ugyanakkor csökken a nikkel részaránya (38 ppm). A cink, alumínium, ón jelenléte komplex ércre utal, ugyan-

4. táblázat. $A z$ XRF-es elemzés eredményei (\%)

\begin{tabular}{|c|c|c|c|c|c|c|}
\hline \multicolumn{7}{|c|}{ Salakmaradvány } \\
\hline $\mathbf{F e}$ & $\mathbf{M n}$ & $\mathbf{Z n}$ & $\mathbf{N i}$ & $\mathbf{C u}$ & $\mathbf{A s}$ & $\mathbf{S b}$ \\
\hline 38,3 & 3,2 & 0,0712 & 0,0345 & 0,0092 & 0,0061 & 0,0077 \\
\hline \multicolumn{7}{|c|}{ Nyersvasmaradvány } \\
\hline $\mathbf{F e}$ & $\mathbf{M n}$ & $\mathbf{C r}$ & $\mathbf{S i O} \mathbf{2}_{2}$ & $\mathbf{P}$ & $\mathbf{S}$ & $\mathbf{S b}$ \\
\hline 62,1 & 0,75 & 0,0498 & 5,8 & 0,76 & 0,11 & 0,0109 \\
\hline \multicolumn{7}{|c|}{ Acélmaradvány } \\
\hline $\mathbf{F e}$ & $\mathbf{C u}$ & $\mathbf{N i}$ & $\mathbf{Z n}$ & $\mathbf{M o}$ & $\mathbf{A l}$ & $\mathbf{S n}$ \\
\hline 74 & 0,0290 & 0,0038 & 0,0100 & 0,0020 & 0,0100 & 0,0100 \\
\hline
\end{tabular}


akkor kuriózum, hogy a vas olvadási hőmérsékletén megmaradtak ezek az elemek. Az itt előállított acél foszfor- és kéntartalma az XRF-es vizsgálat szerint csekély (a spektrométer nem mutatta ki ezen elemeket), de a metallográfiai vizsgálat és a csiszolatok különböző pontjaiban végzett EDS-analízis világosan mutatja, hogy az összetétel az acélminta csiszolatának különböző pontjaiban változó volt. A szennyezők mennyisége jelentős, és az anyagra a durva salakosság jellemző, ami természetes velejárója a korabeli gyártási technológiának.

A korabeli vasművességre jellemző, többszöri felmelegítés és kovácsolás hatására a kezdetben nagyon inhomogén vasanyag homogenizálódhatott, kiégett a grafit, és kikovácsolták belőle a salakot; így vált igazi, használható acéltermékké. Ha nagyobb mennyiségben kerülne elő nyersvas és acéltermék, amit elemezni lehetne, az eredmények is nagyobb pontosságúak lennének. Talán egy átfogó ásatás hozhatna felszínre újabb vashulladékokat, bár a valószínűsége kicsi, tudva azt, hogy a leltárok pl. a bejárati kapu elemeinek rögzítésénél használt vasszegeket darabonként tartalmazzák.

\section{Az anyagmaradványok mikroszerkezeté- nek vizsgálata}

\section{A salakmaradvány vizsgálata}

A helyszíni gyưjtés során talált anyagmaradványok közül a salakmaradvány kémiai összetételét EDS-analízissel is meghatároztuk, a 11.a képen látható felületet vizsgálva, amely a salakdarabnak a belső töretfelülete. Az EDS-analízis intenzitásdiagramja és az abból meghatározott összetétel a 11.b képen látható. Az EDS-elemzést több területen is megismételve azt kaptuk, hogy tömegrészarányban a Fe-tartalom rendre $42-44 \%$, a Si-tartalom kb. 7\%, a Mn-tartalom 2-3\%, és 1\%-nál több alumínium is jelen van a salakban. Az XRF-es elemzéssel összevetve feltűnő, hogy az EDS-elemzés jóval nagyobb mennyiséget mér a foszforra (5-6\%); ez az eltérés rávilágít az XRF-es elemzés korlátaira (Borkhodoev 2016; Kadachi-Al-Eshaikh 2012; Liss-Levy 2016; Rousseau 2001).

\section{A nyersvasmaradvány vizsgálata}

A leletből kivett anyagvizsgálati mintából metallográfiai csiszolatot készítettünk, amelyet polírozott állapotban és 4\%-os Nital marószerrel marva is vizsgáltunk, fémmikroszkóppal és pásztázó elektronmikroszkóppal

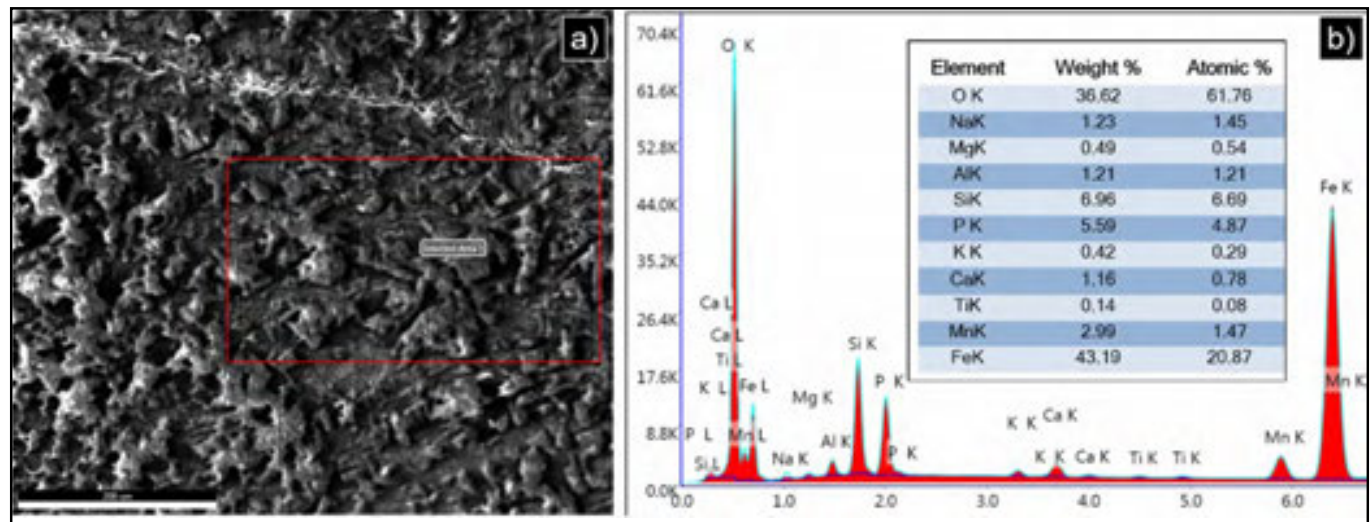

11. kép. A salakmaradék töretfelületének egy részlete (a), továbbá a rajta bejelölt területról felvett EDS-elemzés intenzitásdiagramja a kémiai összetétellel (b) 
egyaránt. A 12. képen az ISO 945-1:2019 szabvány szerint azonosítható a lemezes szerkezetű grafit alakja, eloszlása és mérete. A grafit alakja az I. és a II. osztály határára esik, eloszlását tekintve a B osztályba (rozettás grafit), mérete alapján pedig a 3 . és a 4. fokozat határára sorolható a nyolcfokozatú skálán. A fellelt minta felülete közelében a ferrit és a grafit fázishatára mentén széles sávban korrodálódott az anyag, ez látható a 12.c-d képen.

A polírozott állapotban végzett vizsgálat csak a grafit szerkezetének meghatározását teszi lehetővé, a mátrix azonosításához a maratás elengedhetetlen (Renkó-KeményNyirő-Kovács 2019). A maratás azonban roncsolhatja a felületközeli rétegben a grafit- lemezek határfelülete mentén korrodálódott részeket, ezért a maratás előtt végeztük el a pásztázó elektronmikroszkóp EDS-elemzőjével az anyag egyes, jellegzetes pontjai kémiai összetételének meghatározását. A 13. kép mutatja a polírozott állapotú minta szekunderelektron-képét. A 13.b képen látható felület egészét vizsgálva a fő öszszetevők mennyisége a vas és a szén nélkül: $\mathrm{Si}=0,77 \%, \mathrm{Mn}=1,17 \%, \mathrm{P}=1,72 \%$.

A felületközeli rész szövetképét mutatja a 14. kép. A grafitlemezek fázishatárán korróziótermék képződött, amelyben az EDS-elemzés atomrészhányadban $43 \%$ vasat és $56 \%$ oxigént mutatott ki, amely arány közel áll a magnetit $\mathrm{Fe} / \mathrm{O}$ arányához. A 14.b kép egy részletét kinagyítva mutatja a $\mathbf{1 5}$. kép,
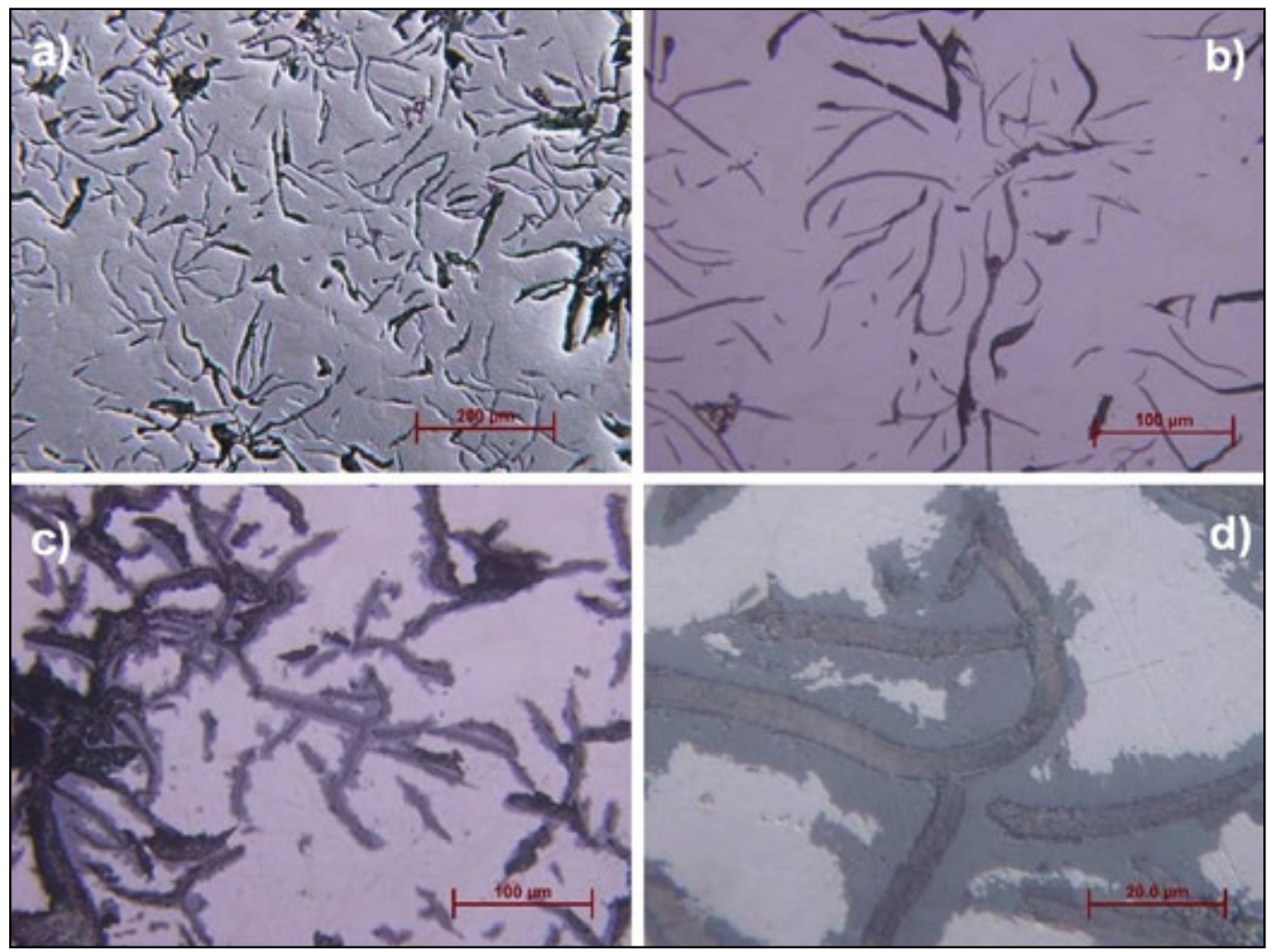

12. kép. A nyersvasmaradék mikroszerkezete polírozott állapotban, a minta belső részén ( $a-b)$, valamint a korrodálódott felület közelében (c-d) 


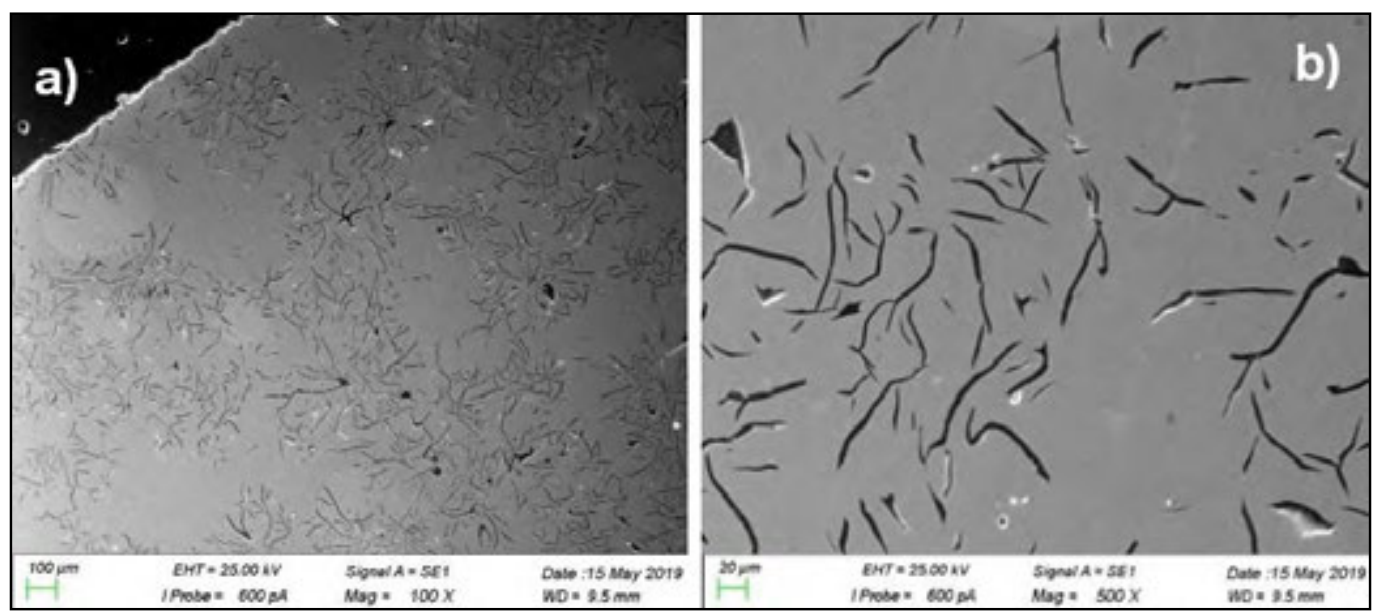

13. kép. A nyersvasmaradék szövetszerkezete polírozott állapotban, szekunderelektron-képen

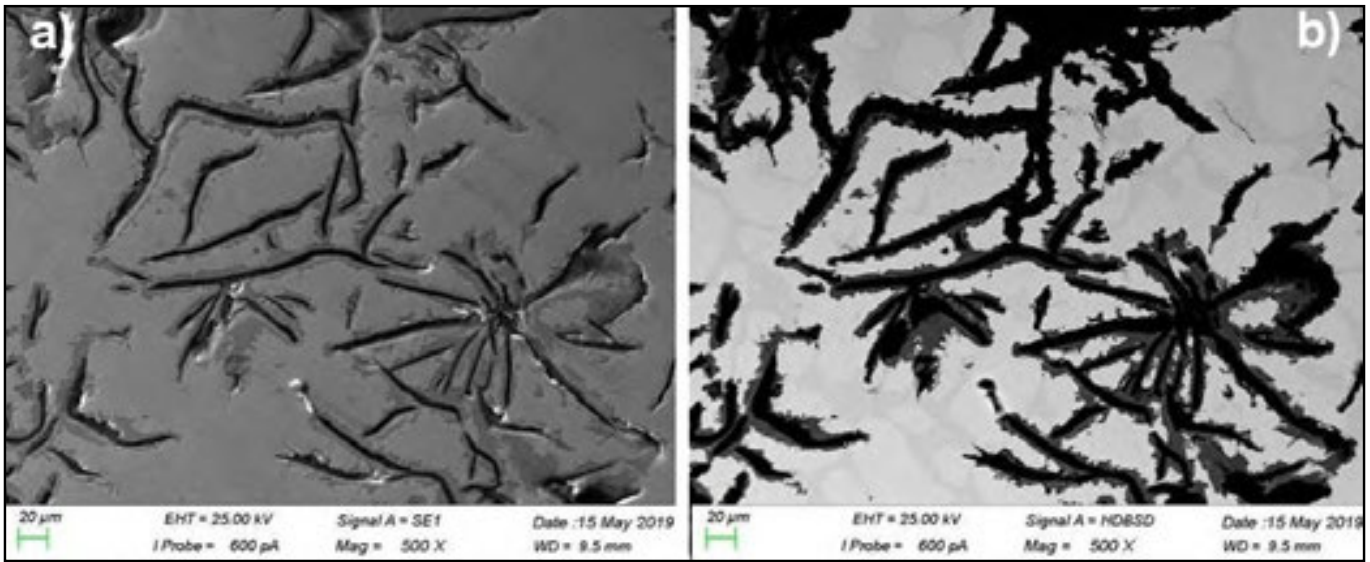

14. kép. A nyersvasmaradék felületközeli részének szövetszerkezete polírozott állapotban, szekunderelektron-képen

amelyen jól látható egy foszfideutektikumot tartalmazó rész. Az eutektikumban a foszfor atomi részaránya $17 \%$, a foszfidlemezben pedig 25\%.

A Nitallal végzett maratás kitűnően előhívta a szövetszerkezet vasdús szövetelemeinek morfológiai jellemzőit. A 16. kép szövetképeiből kitűnik, hogy a megszilárdulás során a rozettás grafit kiválása után az eutektikus hőmérsékletre hűlő olvadék mintegy háromnegyede ausztenitté alakult. Az olvadék maradékából lédeburit alakult ki. A lehűlés eléggé gyors volt, amit az jelez, hogy mind a lédeburit, mind pedig az ausztenitből keletkezett perlit szerkezete rendkívül finom.

\section{Az acélmaradvány vizsgálata}

Ebből az anyagvizsgálati mintából is metallográfiai csiszolatot készítettünk, majd polírozott állapotban és Nital marószerrel végzett maratás után is vizsgáltuk. A 17. kép szövetképei arról tanúskodnak, hogy a lelet anyaga jelentős átalakításokon esett át a nyersvassá alakítást követően. Az így kiala- 


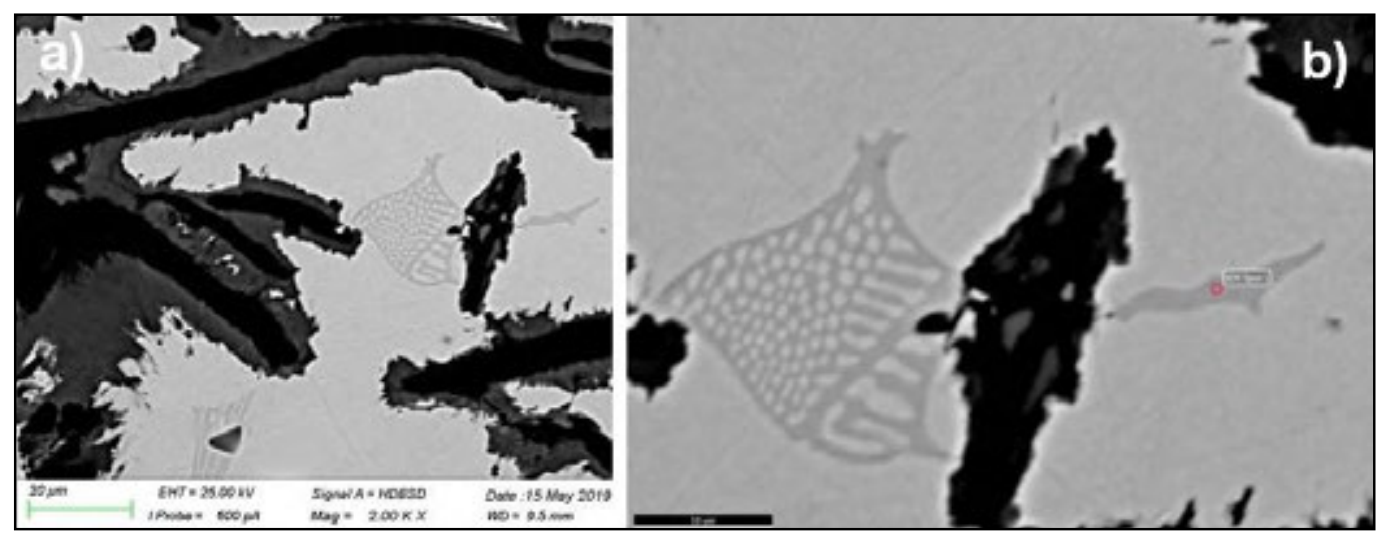

15. kép. A szövetszerkezet foszfideutektikumot tartalmazó részlete szekunderelektron-képen
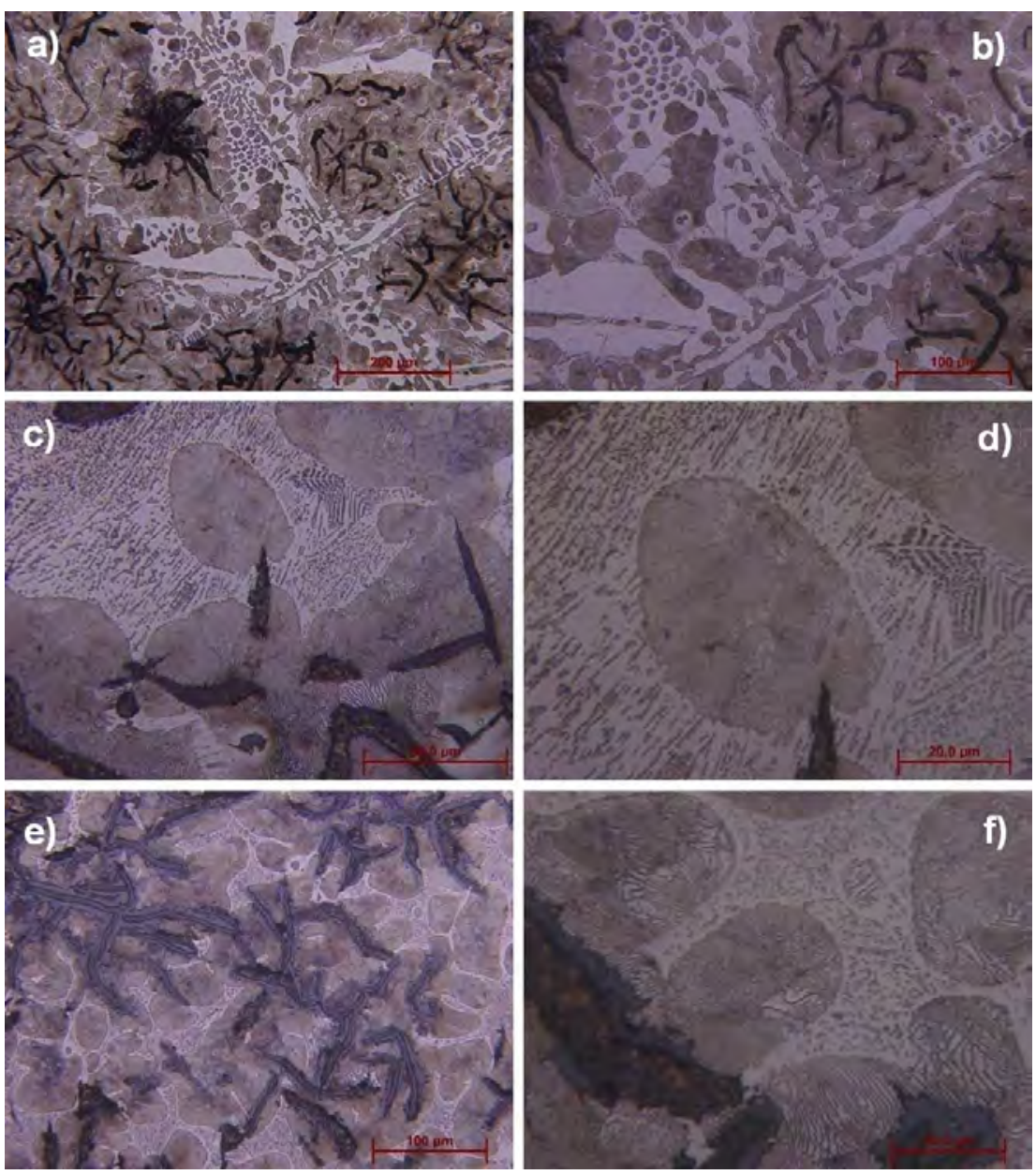

16. kép. A nyersvasmaradék mikroszerkezete polírozott állapotban, a minta belsô részén $(a-b)$, valamint a korrodálódott felület közelében $(c-d)$ 
kult szövetszerkezet fó jellemzői az alábbiak: a) Az anyag a vastagság mentén nagyon erősen eltérő széntartalmú zónákra tagolódik. A kis C-tartalmú részeken a csak a ferritszemcsék szemcsehatárai maródtak meg, míg a sötétre maródott zónákban nagy a C-tartalom, mivel itt csaknem teljesen eutektoidos az anyag összetétele.
A 17.e képen pl. a perlites tartományok alkotják a szövetnek kb. a 95\%-át, a proeutektoidos ferrit csak kb. 5\%-ot tesz ki.

b) Az anyag nagyon jelentős mértékben salakos, a salakzárványok főleg a felülethez közeli sávokban dúsulnak. Itt, a felületközeli zónában viszont a C-tartalom 0,037\%-ra csökkent a SPECTROTEST-es
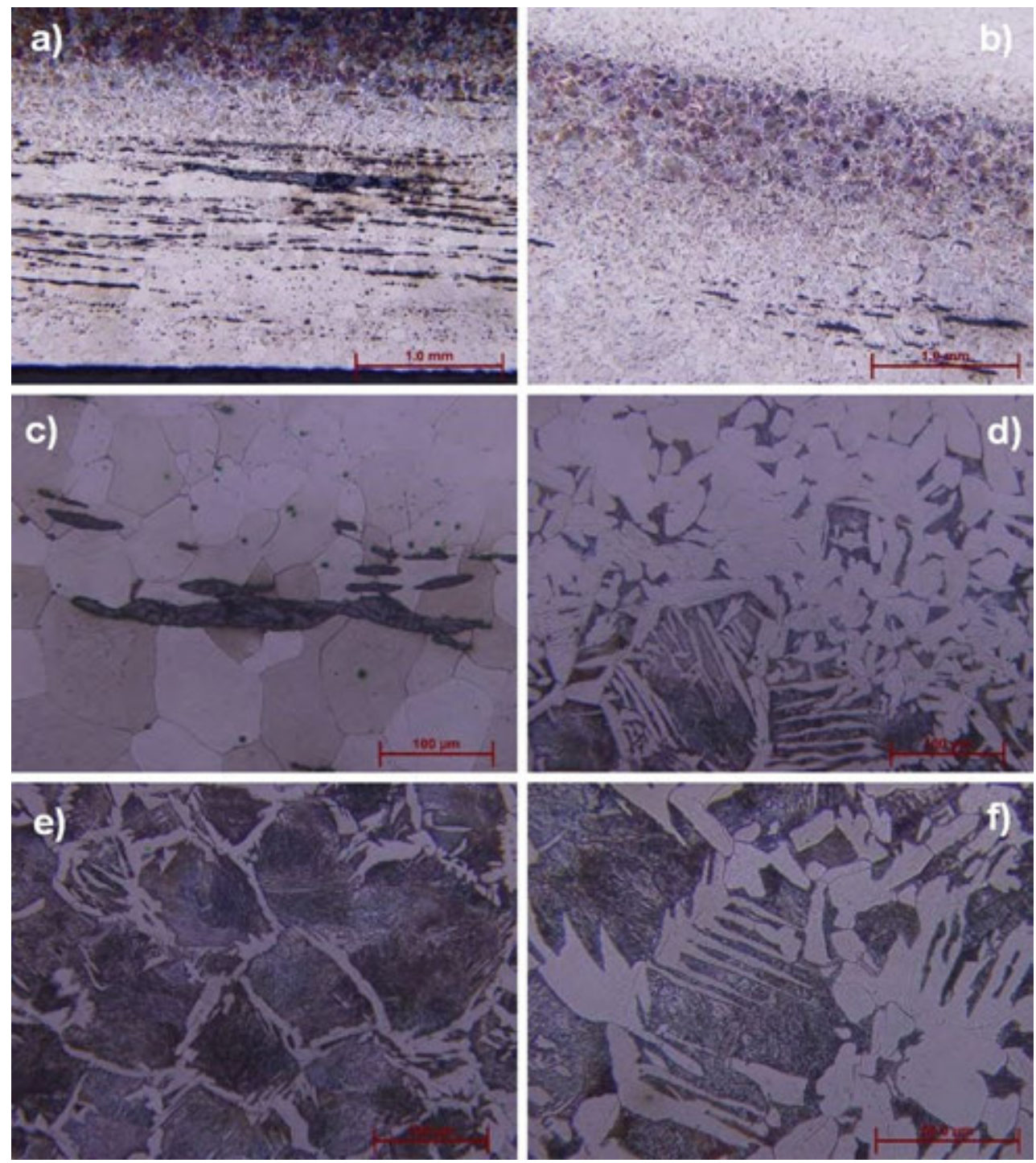

17. kép. Az acélmaradék minta mikroszerkezete a vastagság mentén kialakult egyes sávokban (marószer: Nital-4) 


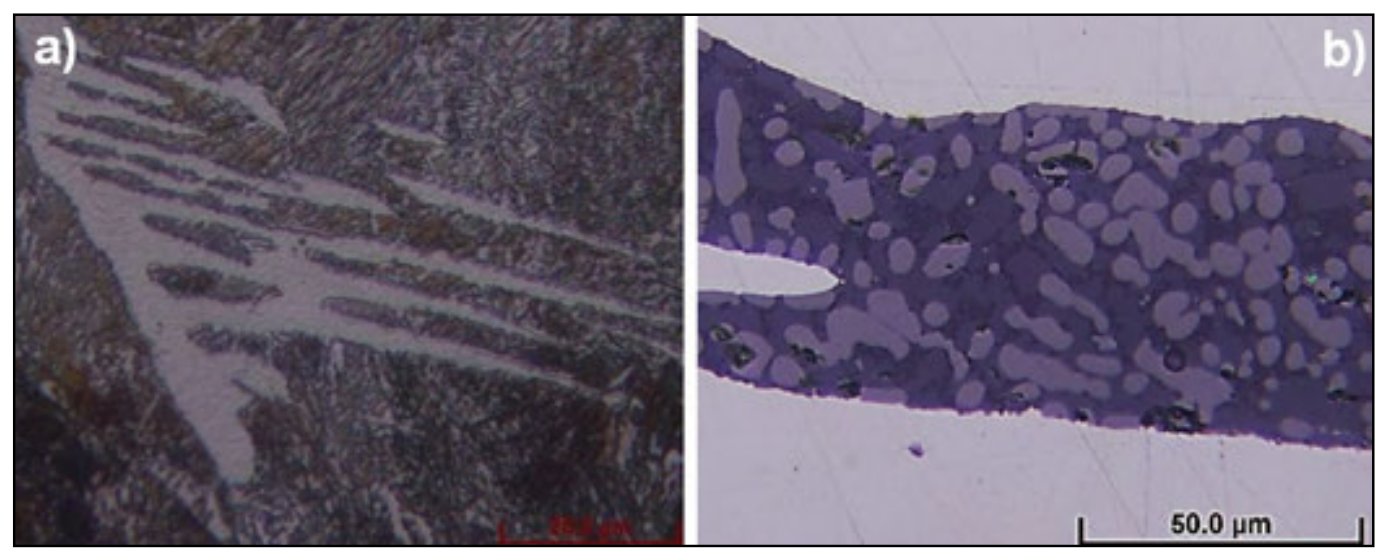

18 kép. a) Az acélmaradék minta mikroszerkezete a nagy C-tartalmú rétegben (marószer: Nital-4).

b) A salakzárvány mikroszerkezete polírozott állapotban

mérés szerint. A szén mellett a Si, a Mn és a kén szinte teljesen kiégett, és a P-tartalom is csak 0,079\%. Az összetevők kiégése és a jelentős mértékű salakosság arra utal, hogy a kovácsolást egészen nagy hőmérsékleten és hosszan tartó izzítással végezték, a felületet pedig nem tudták rendesen megvédeni a revésedéstől.

c) A kovácsolás okozta képlékeny alakváltozás mértéke jelentős volt.

d) A végső hőkezeltségi állapot a dekarbonizálódott részeken a teljes lágyításnak felel meg (17.c kép), a kb. 12 mm vastag minta nagy C-tartalmú rétegeiben (18.a kép) pedig a nem túl erélyes hűtés hatására kialakuló, tûs ferrites és finomlemezes perlites szerkezetnek. A 18.b képen egy vastag salakréteg belső szerkezete látható, a minta polírozott (maratlan) állapotában.

A vashámor folyamatos tevékenysége másfél évszázadon át, pontosabban 1567 és 1725 között nyomon követhető. Megszűnését a vasérc hiányának tulajdonították, de ez csak egyike azoknak a mondva csinált okoknak, amelyek első helyen a hámor gazdáinak téves szemléletét tükrözik.

\section{Lövétei vasgyártás}

A lövétei Szentkeresztbánya bányatelepe Bodvajtól 25 km-re, északnyugatra fekszik a Hargitától déli irányba lefutó Kis-Homoród patak völgyében, $720 \mathrm{~m}$ tengerszint feletti magasságban. A jellegzetes andezittuskók alatt, amelyek altalaját jellemzik, kavicsos szerkezetben szivacsos vas- és mangánérc található. Barnavaskő, vörösvaskő, opálvaskő, gyepvaskő, agyagvaskő, pátvaskő képezi a 2-6 m vastagságú tömzsöket.

Lövéte és Szentkeresztbánya kivétel a nagyszámú székelyföldi vasgyáralapítási kísérletek között, hiszen alapításától, a 19. század első felétől a 20. század végéig fennmaradtak, és eredményesen működtek. Vasgyártási kísérleteket, próbálkozásokat Homoródszentpálon, Kirulyban, Homoródalmáson, Madéfalván, Csíktaplocán, Csíkszeredában (a Vasfúvó-dombon), Csíkszentkirályon, Gyergyóbélborban (a Kelemen-havasok lábánál) is jegyeztek. Közös jellemzőjük a jelentéktelen eredmény volt. Jelentőségük csak ipartörténeti vonatkozású, hiszen a költséges, kis hatásfokú előállítási folyamat, a vasban szegény kőzetek csupán tiszavirág- életet nyújthattak ezeknek a kezdeményezéseknek. 
A Kis-Homoród völgyében létrejött vasgyártásnak a csíkmadarasi hámoréval hasonló története van. A kezdet itt is a 16. századhoz, az 1591 előtti időszakhoz kapcsolható, ugyanis ekkor adományozta Báthori Zsigmond erdélyi fejedelem a lövétei hámort főhadnagyának, Székely Mózesnek, a későbbi fejedelemnek szolgálatai jutalmául (Vajda Lajos 1983. 17.). Felszereltsége, műszaki színvonala is hasonló lehetett a csíkmadarasi hámoréval. Az egykori fejedelmi vashámor telephelyét ma is Hámorkertnek nevezik.

A szentkeresztbányai vasgyár, amelynek alapítása a 19. század harmincas éveire tehető, a fiatal kohó, és bányamérnök Gyertyánffi Jónás kezdeményezéseként indult egy olvasztókencével és egy vízzel hajtott kalapáccsal. Már a kezdetekor Gyertyánffi Jónás apjával, Gyertyánffi Dáviddal és Jónás testvérével Mártonnal megalakították a Lövétei Bányatársulatot, amelynek vezetését Gyer- tyánffi Dávidra bízták. Az új szervezési forma új lehetőségeket is jelentett, különösen szervezési, adminisztrálási vonatkozásban.

A vízenergia hasznosításának lehetőségeit kiaknázva a fújtatót és a kalapácsot az állandó hozamú, bő vizű egyesített Kis-Homoród, Vargyas pataka és Halaság vize múködtette (19. kép).

A szentkeresztbányai hámor működéséhez a vízcsatorna és a vízikerekek szolgálták az energiát. Mint a legtöbb újonnan alapított vasgyár esetében, Gyertyánffiék kezdeményezése is súlyos anyagi helyzetbe került, perek sorozata nehezítette a vállalat múködését. E nehézségek elhárításáért a család Demeter Miklós brassói pénzbeváltóhoz folyamodott hitelér,t aminek végeredménye az lett, hogy 1847-től a pénzember lett a bányavállalat igazgatója. Gyertyánffi Jónás kilépett a vállalkozásból, de részvényeit továbbra is megtartotta.

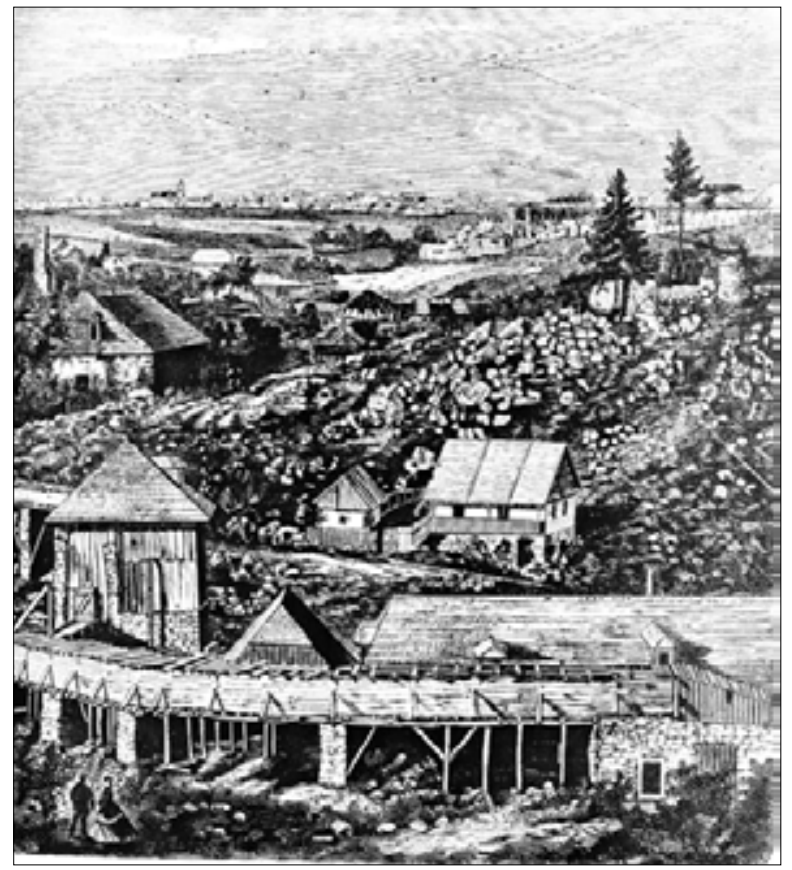

19. kép. Szentkeresztbányai hámor madártávlatból 
Beköszöntött az 1848-as esztendő, és a szabadságharc szele a kohó- és bányavállalatot is megérintette. Bár ágyút nem gyártottak, de a golyóöntés elindult. A Székelyudvarhelyi Haáz Rezső Múzeum féltve őrzi azokat az öntőmodelleket, amelyekkel a szabadságharc részére az ágyúgolyókat öntötték. A 20. kép ezeket a modelleket mutatja.

Az ágyúgolyóöntést a forradalmat leverő orosz és osztrák csapatok a gyár szétdúlásával torolták meg. A helyreállítás költségeit Demeter Miklós fedezte, aminek eredménye az lett, hogy a Gyertyánffi család részvényei mind a Demeter Miklós tulajdonába mentek át.

Demeter Miklós nagy lendülettel fejlesztésekbe kezdett, 1853-ban már 40000 bécsi mázsa vasércet dolgoztak fel, amelynek vastartalma 16-26\% között váltakozott. Új kohó építését is elkezdték, amely már a befejezés előtt nagy lelkesedést váltott ki, ám akkor Demeter Miklós hirtelen elhunyt. A folytatást egy gondnokság vette át, a gyár vezetését Rákovitz Albertre bízták. 1856-ban az öntöttvastermelés csupán 63,2\%-a volt a beindulási év eredményének. Bár jövedelmező termeléssel dolgozott a vasgyár, 1857-ben a gazdasági válság következtében nehéz anyagi helyzetbe került, amelyből a Brassói Bánya és Kohómű Rt. hozta egyensúlyba azzal, hogy 54000 forintért megvásárolta a szentkeresztbányai vasgyárat.

Ezután kezdődött az igazi korszerűsítés. Kúpolókemencét állítottak üzembe 1869-ben, a vízenergiával múködtetett kalapácsokat gőzkalapácsokkal cserélték fel, elindították a vasfinomítási technológiához vezető eljárást, új hengerművet állítottak üzembe, modellasztalos műhely segítette az öntödét könnyű és tartós modellek készítésével. Mindezek eredménye az lett, hogy 1858-ban rekordtermelést ért el a lövétei bánya, 30000 köbméter kitermelt vasércet dolgozott fel a vasgyár.

Az olvasztás energiahordozóját, a faszenet a homoródalmási erdőkben égették. 1863 az

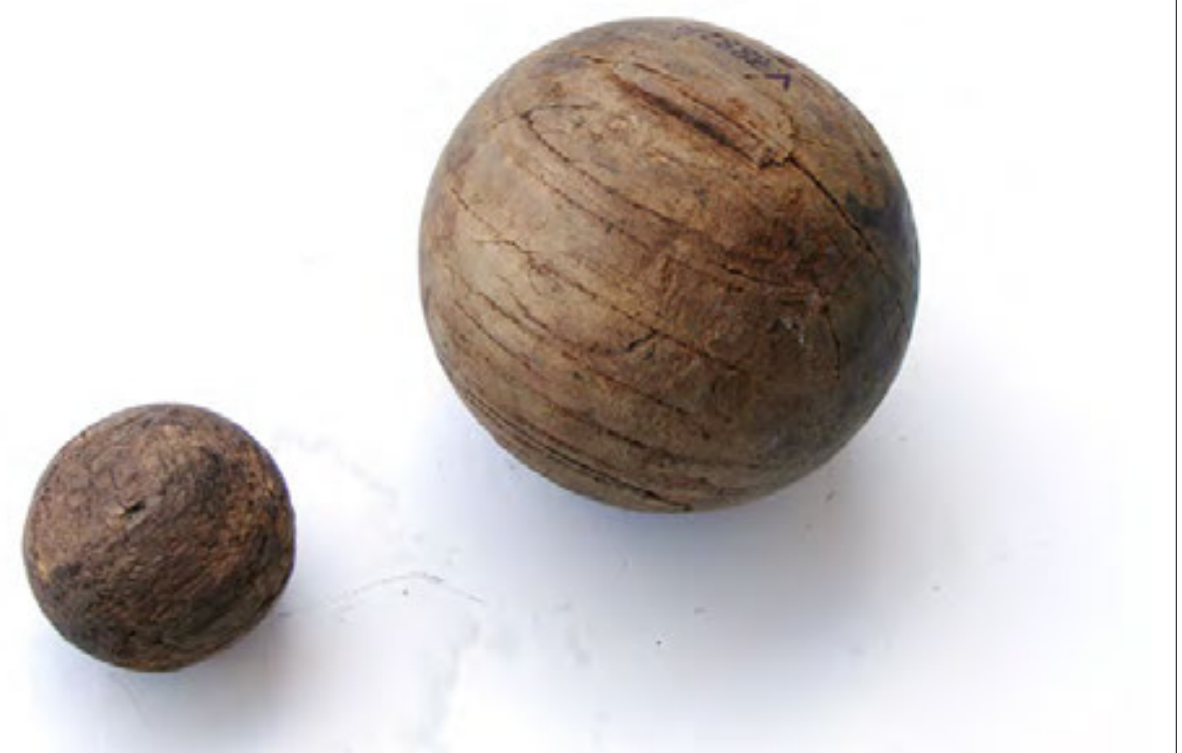

20. kép. Ágyúgolyó öntőmodellek öntőmodellek Szentkeresztbányán, 1848-49 ben 
átlagnál jóval aszályosabb év volt, ami érzékenyen érintette a vasgyártásban alkalmazott vízikerekek folyamatos működtetését. Ez a vízhiány 1866-ban kezdett helyreállni, ennek folyományaként természetesen a vasgyártás is újabb lendületet vett.

Nem sokáig tartott a kecsegtető állapot a szentkeresztbányai bánya és vasgyár történetében. 1867-ben megbukott a brassói vezetés irányítása, aminek az lett a hatása, hogy 1871-ben ismét vezetőcsere történt. Hrobonyi Adolf lett a nagy reményű vezető, akinek négy éven át sikerült egyensúlyban tartania a vasgyártást, míg végül 1875-ben a termelést beszüntetni kényszerült.

1878 után csökkentették a gőzgépek szerepét, és takarékossági meggondolásból viszszatértek a vízenergiára. A 21. kép a vízenergiával működő hámorbelsőt mutatja be.
Ekkor 12 vízikerékkel múködtették a vasgyártás technológiájának különböző fázisait, de a három beszerelt gőzgépből két gőzgépet is üzemben tartottak.

1885-ben Hrobonyi Adolf meghalt, igazgatói tisztségét Lántzky Sándor vette át, aki fiát, Lántzky Józsefet, a selmecbányai akadémia frissen végzett mérnökét nevezte ki a vállalat műszaki vezetőjévé. Sajnos az általános gazdasági helyzet, különösen a romániai üzlet hanyatlása kritikus helyzetbe hozta a vállalatot. Ekkor a termékskála mezőgazdasági gépekből, vaskályhákból, bográcsokból és egyéb hámortermékekből, lapátokból, ásókból stb. tevődött össze (22., 23. és 24. kép). A széles választékú termékskála sem hozott jelentős változást, ami a gazdasági mutatókat illeti. A tragédiák sora a Lántzky Sándor 1905-ben bekövetkezett halálával

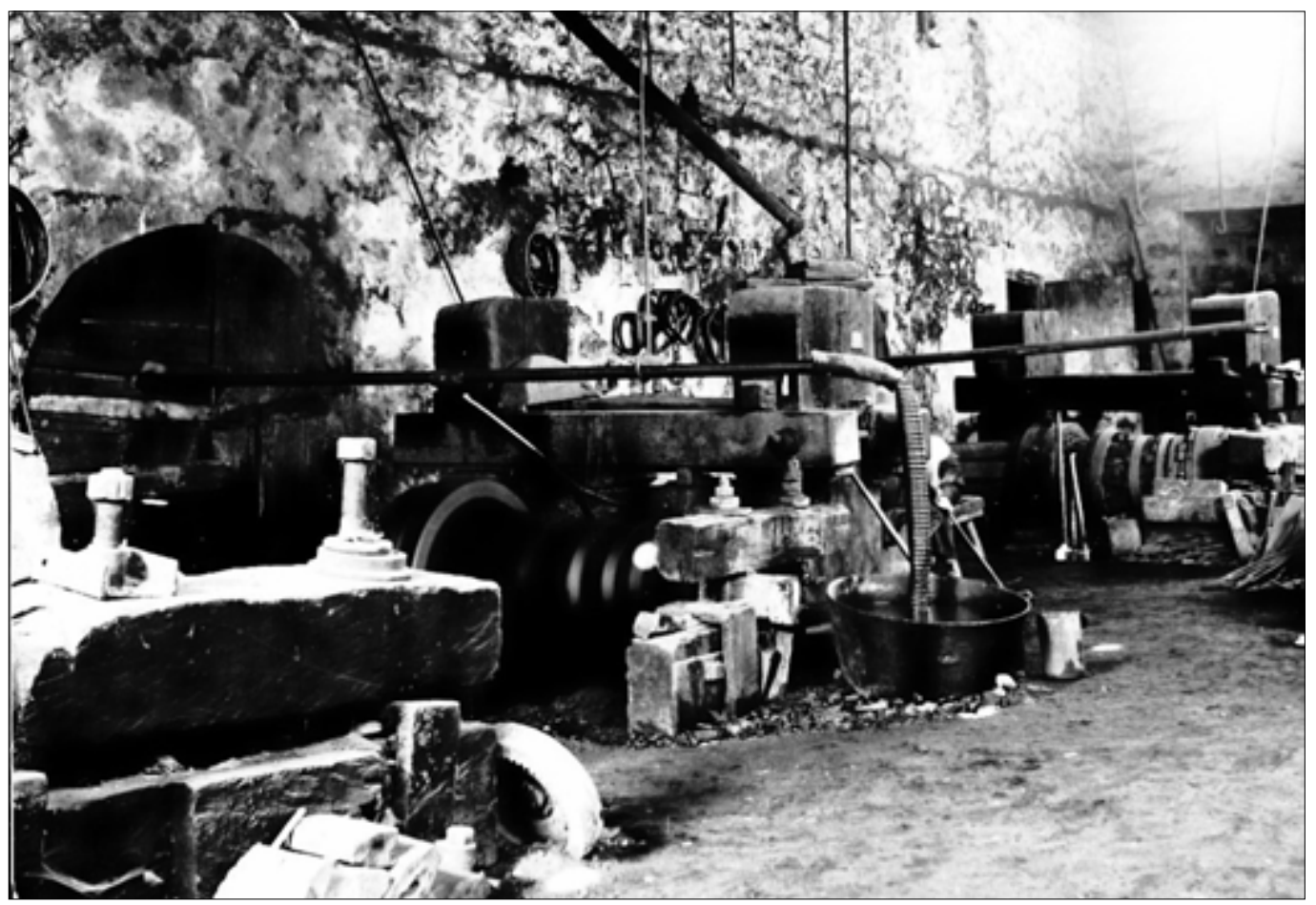

21. kép. A hámorbelső egykori látványa 
folytatódott. Helyét a vállalat vezetésében fia, Lántzky József bánya- és kohómérnök vette át, de a család nem akarta folytatni a vállalat múködtetését, ezért úgy határoztak, hogy bérbe adják. A jelentkező, aki folytatni kívánta a gyár múködtetését, a brassói Kamner és Jekelius vaskereskedő cég két tulajdonosa volt. Ekkor már a 20. század első évtizedében járunk. Ekkor a Szentkeresztbányai Vasöntöde és Szerhámorárugyár névvel indult újra a vasgyár, amelyben Lántzky József mérnök is szerepet kapott.

Az első korszerűsítési intézkedések között a kohó gőzerőre való átállítása szerepelt, ami meg is mutatta hatékonyságát. 1909-ben már 11823 mázsa vastermelést eredménye- zett, ami nagyon szép teljesítmény volt az előző évekhez viszonyítva. Sajnos a balsors egyre gyakrabban mutatkozott a vasgyár történetében. 1916-ban Lántzky József mérnök is meghalt, de ezzel nem zárult le a katasztrófák sora. Leégett a kohó töltőhídja, ami teljesen és évekre leállította, múködésképtelenné tette a gyárat. Az első világháború befejeztével a bérlő Kamner és Jekelius cég mindent elkövetett az üzem helyreállításáért, de már a megváltozott politikai körülmények között.

1924-ben véget ért a Lántzky család fél évszázados szerepe, a vasgyár részvénytársaság szervezési formában vívta harcát a nagy gazdasági válság éveiben.

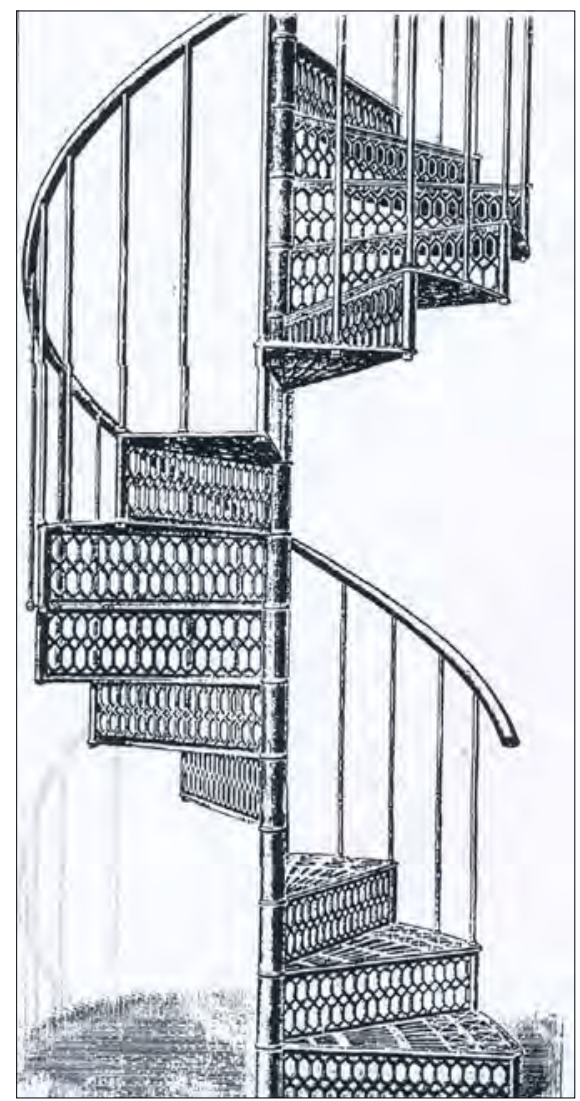

22. kép.Öntöttvas csigalépcső 


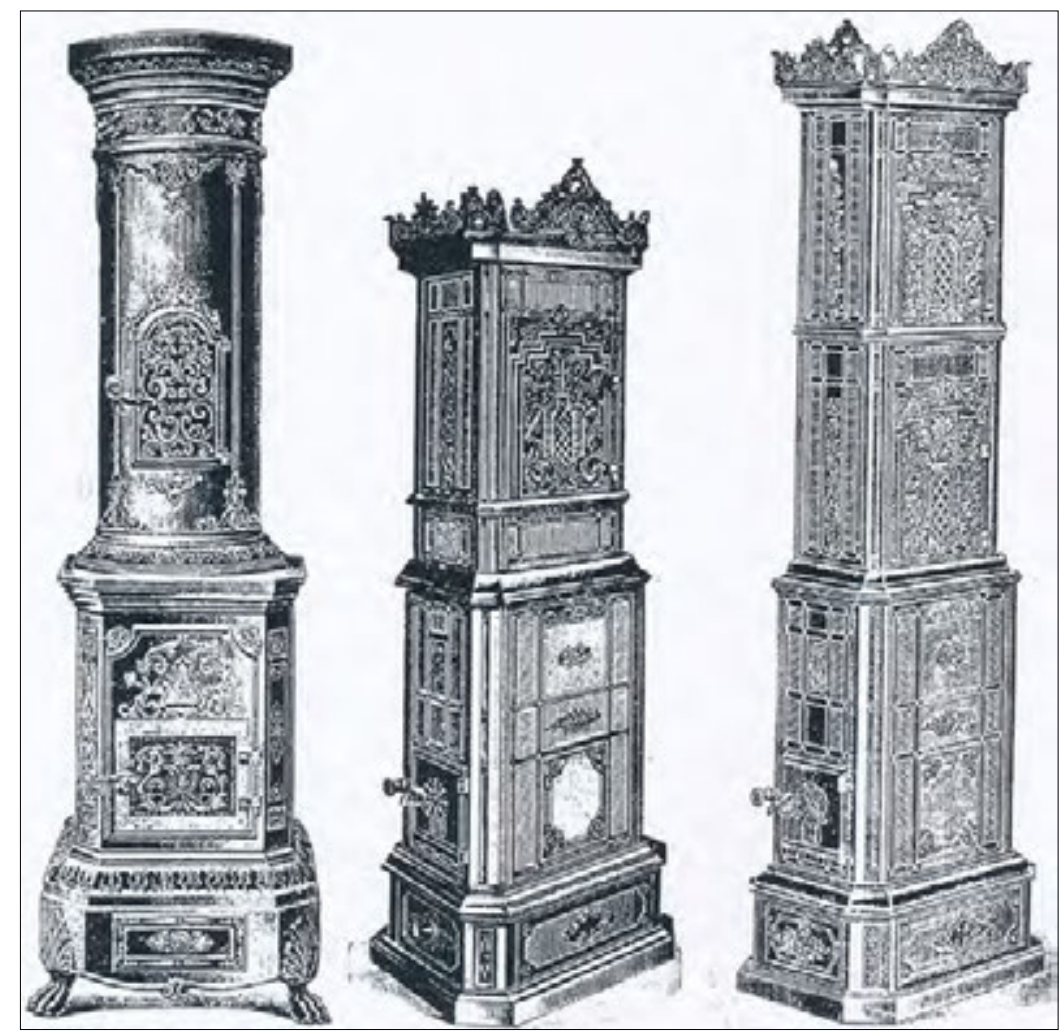

23. kép. Vasöntvény kályhák, Kamner és Jekelius tulajdonosok korából

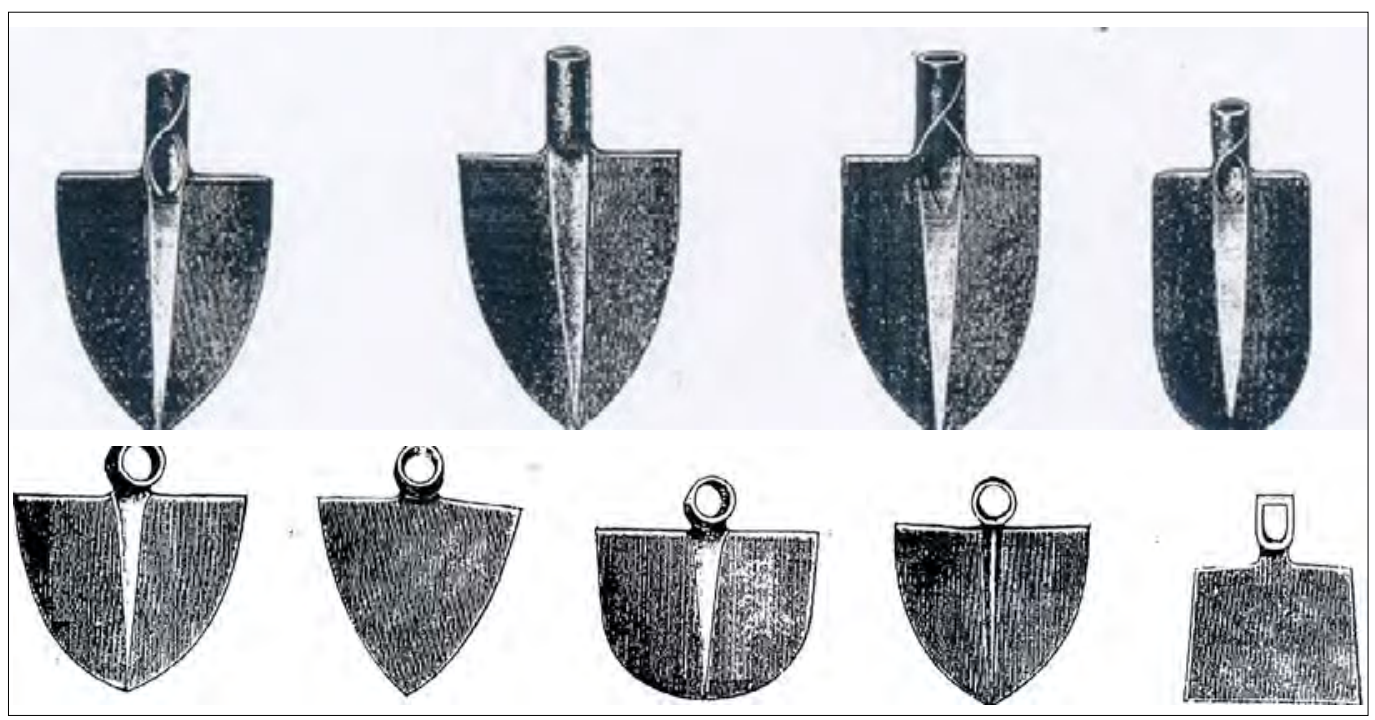

24. kép. Kamner és Jekelius vasöntödéjének termékei 


\section{Erdővidék vasgyártása}

A székelyföldi vasgyártás a Hargita-hegység vonulatának dél-délnyugati részére, Erdővidéknek nevezett területére is kiterjedt. Előző, a vasgyártás őskorát bemutató fejezetben, Székelyszáldobost is említettük, ahol a bucatechnológia maradványait tárták fel régészeti kutatások. A Székelyszáldobos szomszédságában található két település, Erdőfüle és Magyarhermány határához tartozó Bodvaj, ahol a 19. század elején a kor színvonalán működött vasgyártás és másodlagos megmunkálás. E két vasgyár és a lövétei, a hozzájuk tartozó magasolvasztókkal, hámorokkal a székelyföldi kohók néven váltak ismertté, és kielégítették vasból készült tárgyakkal, félkész termékekkel a régió ez irányú szükségletét.

A hámor Magyarhermány határában található, a Bodvaj-havas közelében, a Fenyős patak völgyében. 1831-ben kezdte müködését, bár Benkő József (1999. 83.) a vasbányát, ennek működését a század elejére teszi. A
„Század eleje”, amelyre az előbbi szöveg hívatkozik, a 18. századot jelenti, pontosabban 1768-ra tehető. Orbán Balázs is megemlíti a vasgyárat, amit személyesen is meglátogatott, és ekképpen értékeli a látottakat: „mert vasa föként öntvényekben, jobb a fülei vasnál, $s$ amellett a dústartalmú vaskő, vízerő a tüzanyag mind közel és kifogástalan mennyiségben jön elő itt; hozzá még jó közlekedő útja is van Nagy Baczon felől" (Orbán Balázs I. 1863. 213.).

Mátyé János a Háromszék napilapban megjelent írásában (2006. október 31.) szintén Benkő Józsefre hivatkozva úgy véli, hogy a „Szászhermányi vasmü 1720-ig múködött, akkor felhagytak vele, majd 1768-ban kezdték újra a termelést". Nem lehet tudni, mikor és miért hagytak fel a bányászással az 1768-i újrakezdés után. Egyértelmű, hogy a kitermelt ércet fel is kellett dolgozni, amiről csupán a feltételezések szintjén lehet gondolkodni.

A balánbányai rézmű tulajdonosa, Zakariás Antal 1831-ben kezdett tevékenykedni a vasmű elindításán, miután Balánbányáról átvit-

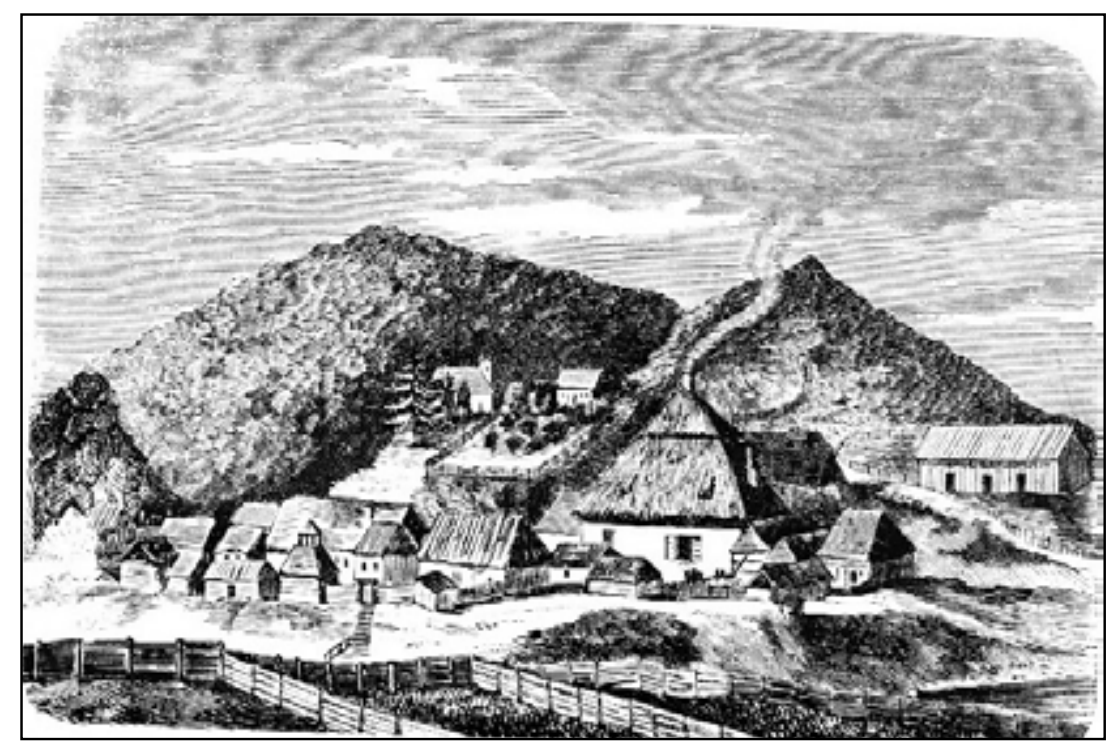

25. kép. A bodvaji vashámor, ahogy Orbán balázs látta 


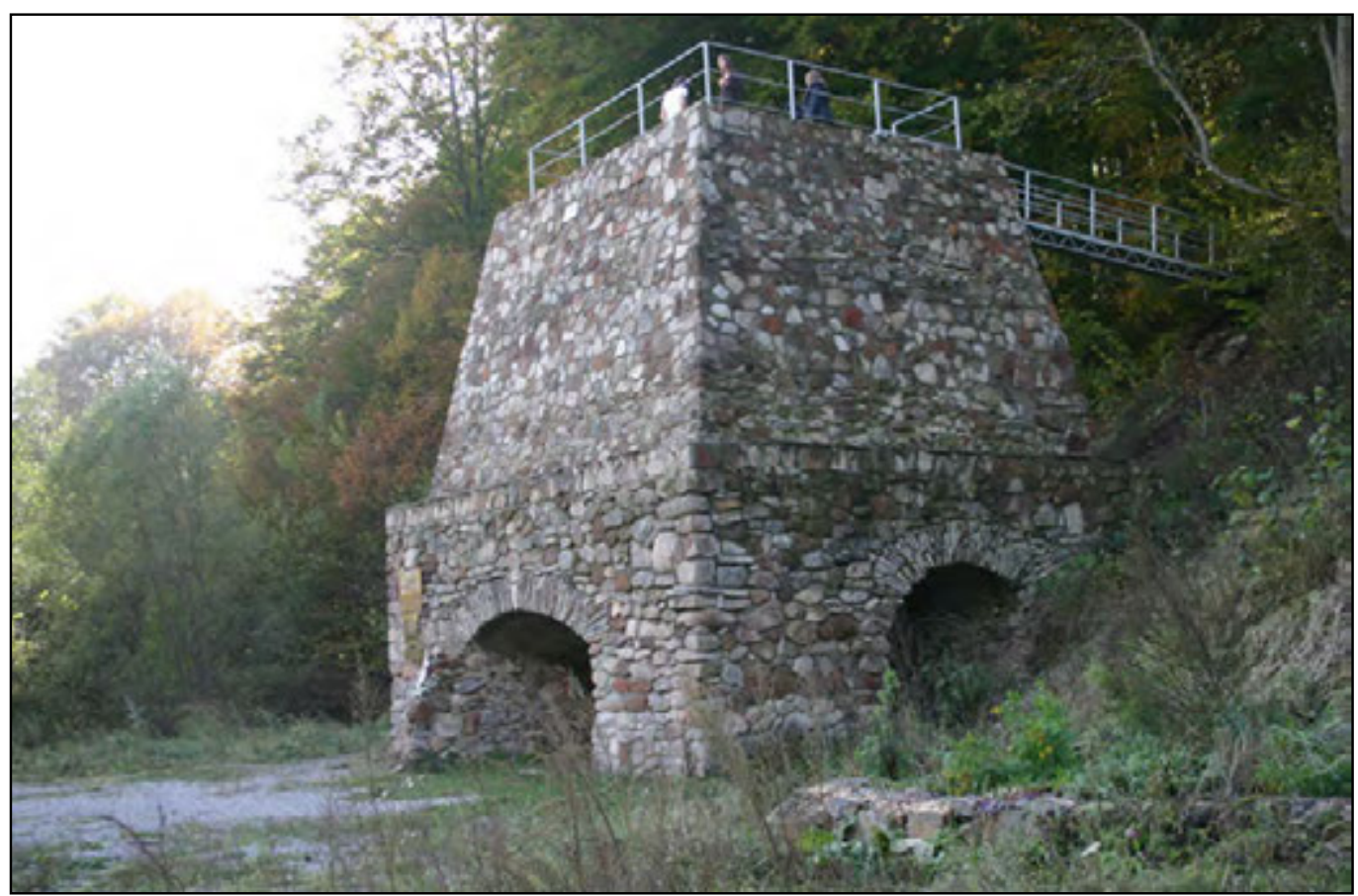

26. kép. A felújított olvasztókemence

te Bodvajra a bányászatban és vaskohászatban is jártas főmérnökét, Bodor Ferencet és jó néhány bányász és kohász szakemberét. Bodor Ferencet ezután is gyakran foglalkoztatta Bodvajon, a vasmúnél. Bodor Ferenc jól ismerte korának bányász-kohász technológiáját, ő ugyanis az Európa-szerte híres Selmecbányai Akadémián szerzett mérnöki oklevelet.

A vasgyár műszaki színvonala megegyezett a kor Kárpát-medencei vasgyárainak műszaki színvonalával. A bástya alakú, kőből épített, magas olvasztókemence belsejét hőálló burkolattal, agyag és homok keverékével kitapasztották, majd kerámia minőségre kiégették. A lövéteihez hasonlóan terhelték, rétegesen faszénnel, vasérccel és salakképző anyaggal. Faszén égetésével, ennek izzásával érték el az érc olvadási hőfokát, miközben többletlevegő befújásával növelték az olvasztási hőfokot.
A levegőtöbbletet szekrényes fújtató alkalmazásával nyerték. A fújtatót meghajtó vízikereket a folyóvíz hozamához, áramlási sebességéhez méretezték. Az olvasztókence vagy huta falának alsó felén kerámia fúvócsövön át vezették be a levegőt a szén égési terébe.

A kemence mellső falán volt egy másik nyílás, amely a megolvadt salak és folyékony vas csapolását, kieresztését tette lehetővé. Olvasztás alatt ezt a nyílást agyagdugóval elzárták.

A vasérclelőhely a vasüzem szomszédságában volt, így a kitermelt ércet csillékkel, közvetlenül a feldolgozás színhelyére, az olvasztókemencéhez szállították.

A faszenet a környező bükkerdők fájából égették. Bár jó fütőértékű a bükkfaszén, 1000 kg nyersvas előállításához 200 köbláb $^{9}$ szénre volt szükség. Ez óriási mennyiségű bükkfa szénné égetését jelentette. Ezért a környező erdők egyre fogytak, ugyanakkor a vasüzem fenntarthatósága a széntől függött. 
Egyre távolabbi erdőket kellet kitermelni, szénné égetni. A szén szállítási költségeinek növekedése a vas árában is tükröződött. Csupán a felidézés kedvéért említjük, hogy a bodvaji vasérc, a hematit $32-35 \%$ vastartalmú.

A kohóból közvetlenül szekrényes formákba vagy gödrökben kialakított formákba öntöttek. A nyersöntvény egy részét további felhasználásra, például kovácsvas gyártásárra tartalékolták. A megszilárdult, primer öntvényt újra megolvasztották a frisstűzben, másik olvasztókemencében. Ennek hőmérséklete magasabb lévén, mint az első, olvasztásnál, a nyersvas széntartalmának bizonyos százaléka kiégett. A második olvasztásnak éppen az volt a várható hatása, hogy a széntartalom, ami eredetileg 2-7\% volt, 0,5\% alá kerüljön. Így a törékeny, kovácsolásra alkalmatlan nyersvas szívós, kovácsolható acéllá alakult.

Ezt követte a feldolgozás következő fázisa, a kovácsolás, ami többszöri újramelegítéssel történt. Az első kovácsolás alatt, amit a nagyverőn végeztek, a szabálytalan tömbvasat rúdvassá alakították. Az izzítást és kovácsolást frissítésnek hívták. Egy második szakaszban, amelyet egy újabb izzítás előzött meg a kovácsvasat késztermékké, mezőgazdasági eszközökké, szerszámokká kovácsolták. A késztermékhámor termelését növelte a közben üzembe helyezett nagybaconi szerhámor, amelyet szintén a bodvaji hámor látott el nyersanyaggal.

A bodvaji hámornak jelentős szerepe volt az 1848-1849-es forradalom és szabadságharc erdélyi eseményeiben, ugyanis itt, Bodvajon öntötték az első három ágyút, vasból, de az ágyúgolyók öntésében mindvégig kivette részét a vasgyár és személyzete. A vasüzemet 1848 decemberében a császári csapatok feldúlták, de az akkor már a közel száz személyt foglalkoztató vasgyárat rövid időn belül ismét üzemképes állapotba viszszaállították dogozói. A vasüzem körül kialakult kis lakótelepre a tulajdonos Zakariás Antal 1852-ben kápolnát is építtetett. Egy évtized folyamán, szomorú, de egy temető is kialakult. Mára a gondozatlan kápolna eltűnt, a temetőt belepte az erdő, de a fák között a sírkeresztek őrzik, hírmondókként, a múlt emlékét.

1874-ben Zakariás Antal eladta a vasüzemet testvérének, Zakariás Andrásnak, aki nagy reményekkel és lendülettel fogott munkához, az üzem teljesítményének növelését célzó intézkedéseivel. A termelékenységet az olvasztási hőfok növelésével, a gyártási idő csökkentésével próbálta növelni. Az épületeket is mind rendbe tette. A kialakult kis bányász-kohász telepen 1875-ben már 21 lakóház állt. Ez volt a bodvaji bánya és vasgyár történetének fénykora. Ennek ellenére az új tulajdonos nem volt szerencsés, mint Antal testvére. Hatalmas adóságba keveredett, nem tudta bevezetni azt az irányvonalat, ami kora vasgyártóiparában már észlelhető volt. Ekkor már megjelenik a kúpoló kemence, a vasfinomítás új eszköze, amit Zakariás Andrásnak nem sikerült bevezetnie.

A román vámháborúként ismert, 1884-ben tapasztalható megszorítások következtében beszűkült a vasáru piaca. Megszűnt a Havasalföldre irányuló kereskedelem, ami fó felvevőpiaca volt a székely hámorok termékeinek. A dolgozók jelentős része 1886-ban átköltözött Szentkeresztbányára. 1894-ben már csak 15 személy dolgozott a vasgyártásban. A 19. század végén, 1884-ben a vasgyárat Lántzky Sándor, Szentkeresztbánya tulajdonosa megvásárolta, de ez sem állíthatta meg azt a folyamatot, ami a lassú sorvadáshoz vezetett, olyannyira, hogy 1897 őszén a bányászást beszüntették. Az addig kibányászott vasércet 1905-ig feldolgozták, ezt köve- 
tően az alkalmazottak szétszóródtak. Lántzki halála után, 1914-ben az örökösök eladták Bodvajt és a többi Lánczky-érdekeltséget a Magyar Kincstárnak.

Az első világháború alatt a gyár múködése szünetelt, csak 1945-ben került ismét a figyelem központjába, amikor megkezdték a bánya és a kohó helyreállítását (Máthé János 2006). A vasgyárat 1950-ben államosították.

Bár a vasgyártás újból elindult, korszerű berendezésekkel kiegészítették a gyár felszerelését, a vízenergiát gőzkazánnal helyettesítették, villanyáram-fejlesztőket szereltek fel, a közel fél évszázados szünetelést nem tudták áthidalni. 1951-ben a bányászást leállították. A vasgyár olvasztókemencéjének tüze 1954 tavaszán örökre kialudt.

Bodvaj ma ipartörténeti műemlék. Az újjáépített huta azokra az évtizedekre emlékeztet, amelyekben a Székelyföld vasgyárai,
Szetkeresztbánya, Bodvaj és Erdőfüle a békés idők termékeit, ásót, kapát, kaszát, számos szerszámféleséget előállítva a térség fejlődését képviselték, és amikor kellett, a forradalom és szabadságharc égisze alatt fegyvergyárrá átalakulva reménységgé nőtték ki magukat az egész magyar nemzet számára.

\section{Vasgyártás a Kormos völgyében, Erdőfülén}

„A falutól 10 percnyire van a Kormos völgyében regényesen fekvő fülei vashámor rendszeresen épült bányatelepével. Ott vannak azon roppant hámorok, öntödék, zúzdák, amelyek rémes zajjal töltik el a vidéket, s melyek évenként 20.000 mázsa nyers vasat, 7000 tonna öntvényt állítanak elō." (Orbán Balázs I. 1863. 224.) Így jellemezte Orbán Balázs a 19. század hatvanas éveiben az akkori Erdély egyik jelentős vasgyárát, a székelyföldi Erdőfülét.

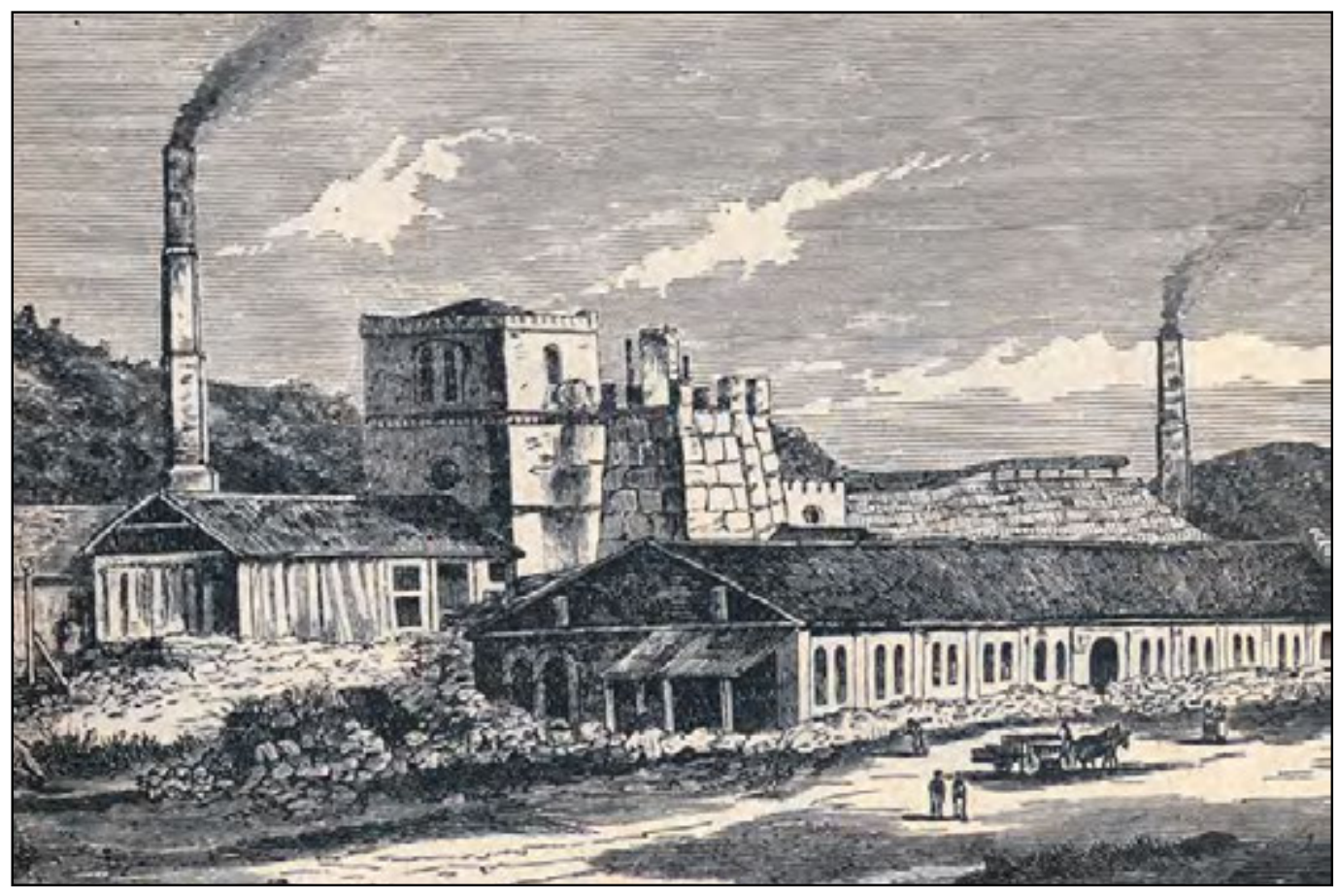

27. kép. Erdôfüle, a Székelyföld jelentős vashámora, ahogy Orbán Balázs látta 
A Hargitáról észak-dél irányú völgyben jelentős mennyiségű üledékes, vaskőmálladék található, 30-33\% vastartalommal. Gyepvasérctelepek is előfordulnak, amelyeknek vastartalma a 33-43\%-ot is eléri. Helyenként a gyepes mészkő képződmények gyengítik ezt a koncentrációt. Ezen a vidéken, vagyis Erdőfüle környékén, a 19. században budapesti és berlini vállalkozók kutatói száznál is több kutatási ponton találtak kitermelhető vasércet. Az Erdővidéki Bányaegylet kutatásai is hasonló eredményre vezettek. Amint megállapítják: „Különösen a száldobosi vasérctelep értékes, amely két méter vastagságban, köpenyszerüen borítja a hegyet, az itt talált gyepvasérc fémtartalma az elemzések szerint az 50\%-ot is eléri."(Pap Károly 1914. 376.)

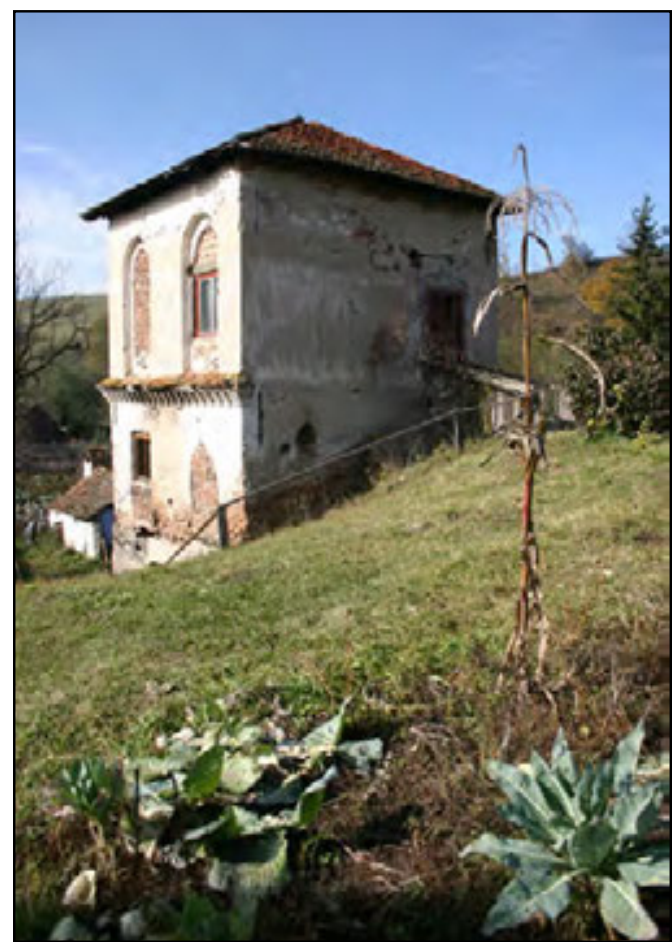

28. kép. Máig megmaradt épületrészlet az egykori hámorból.
A hámor fénykorát az 1848-49. évi forradalom és szabadságharc erdélyi hadszíntereinek idején élte, amikor a szabadságharcban részt vevő Gábor Áron szervezésének köszönhetően megszületett a háromszéki ágyúöntés és puskaporgyártás. Erdőfülén öntötték az ágyúgolyók tetemes részét. A győztes osztrák és orosz csapatok lerombolták ugyan a vasgyárat, de 1856-ban újra működött a felújított hámor. Működése kisebb-nagyobb megszakításokkal a 20. század közepéig tartott. Ekkorra olyannyira elavulttá és gazdaságtalanná vált működése, hogy végleg leállították. Mára a hámor épületegyütteséből csupán egy lakóépületnek átalakított toronyszerű épület (28. kép) meg az idő múlását tükröző hámori temető néhány elhagyatott sírhantjával, düledező síremlékével (29. kép) utal az egykori virágzó

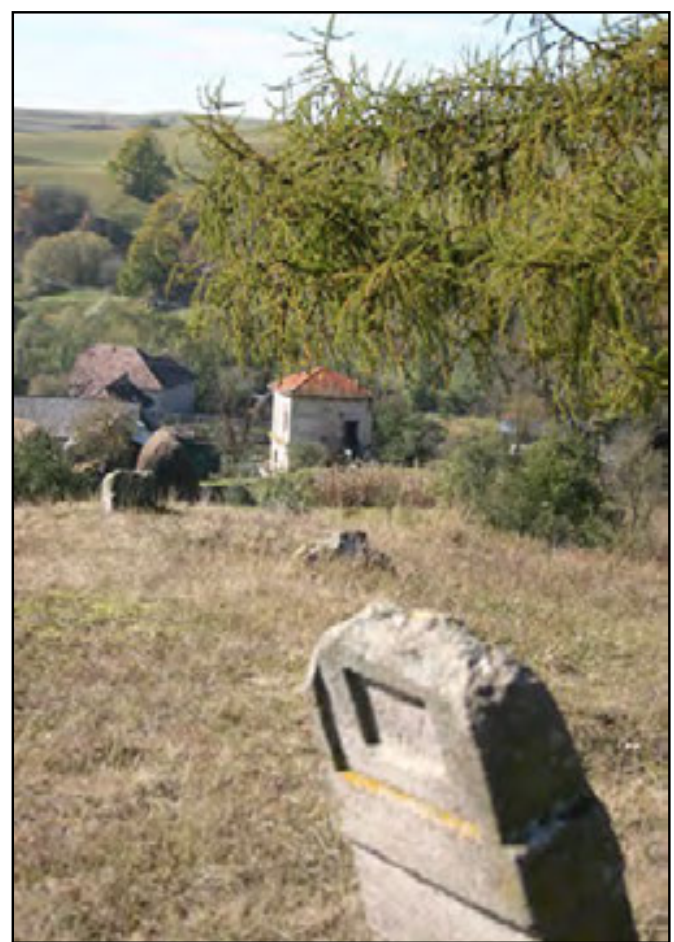

29. kép. Elhagyott temetô a hámor egykori dolgozóinak sírhelyeivel 
székelyföldi vasgyártás színhelyére. Az erdőfülei vashámornál is, akárcsak a kor más vasgyáraiban, a gyártás folyamata a kibányászott vagy patakok medréből összegyűjtött vaskő szárításával, aprításával és pörkölésével kezdődött, ami tulajdonképpen szárítását és az elgázosítható anyagoktól való megtisztítását jelentette. Ezt követte az olvasztás művelete, amely a kőből rakott és agyaggal kitapasztott, 8-10 méter magas, csonka kúp belsejü kemencékben ment végbe. Az $1500{ }^{\circ} \mathrm{C}$ fölötti olvadáspontot faszén égetésével, többletlevegő befújásával érték el. A többletlevegőt vízkerekekkel működtetett bőrfújtatók adták. A vasérc megolvadt állapotában szétvált folyékony vasra és salakra. Az így nyert nagy széntartalmú vasat közvetlenül formákba öntötték. Ezt többszöri hevítéssel és kovácsolással rúdvasakká alakították, melyeknek széntartalma a hevítések következtében egyre alacsonyabb lett, kovácsolható, képlékeny vassá alakult. Ezeket a rúdvasakat forgalmazták a vasgyárak, s belőlük a mindennapi élethez szükséges eszközök készültek.

Az erdőfülei vasgyártás egy öntvénydarabjának korszerű laboratóriumi eszközök, a FUNDARI MASTER PRO spektrométer használatával készült vegyi összetételének elemzését mutatja be első ízben korszerű laboratóriumi eszközöket használva az 5. táblázat.
Az összetételből látható, hogy a darab nagyobb szilícium- és foszfortartalommal rendelkezik, amely ötvözők elősegítik a grafit képződését, grafitosító hatásúak. A foszfor ilyen mennyiségben kedvezően hat az öntöttvas hígfolyósságára, javítva a formakitöltő képességét. A nagyobb foszfortartalmú öntöttvasat főleg vékony falú, bonyolultabb öntvények esetén használják. A további elem század, illetve ezred mennyiségben található. Minimális mennyiségben van az összetételben réz, ami arra utal, hogy valószínúleg nem használtak fel ócskavasat, hulladéköntvényeket a gyártáshoz. Elsődlegesen ércekből előállított öntöttvasról lehetett szó.

A szövetszerkezeti vizsgálatokon (30. kép) jól felismerhető a szürke töretű öntöttvas grafitja, amely részben rozettás elhelyezkedésű.

A mintát 1,5\%-os Nital oldattal gyengén maratva a mikroszkópi felvételeken láthatóvá vált a ledeburitos szövetszerkezet (31. kép).

Az erősebben maratott mintán a grafit mellett felismerhetők a további szövetelemek is. A 32. képen látható mintán a grafit mellet a ledeburit-, a perlit-, illetve a nagyobb foszfortartalom miatt a szteadit (foszfideutektikum) is megjelent.

Ma is használatos, hiteles erdőfülei termék, öntöttvas üst látható a 33. képen.

5. táblázat. $A$ vizsgált minta anyagösszetétele

\begin{tabular}{|c|c|c|c|c|c|c|c|c|c|}
\hline $\mathbf{F e}$ & $\mathbf{C}$ & $\mathbf{S i}$ & $\mathbf{M n}$ & $\mathbf{P}$ & $\mathbf{S}$ & $\mathbf{C r}$ & Mo & Ni & Al \\
\hline 91,2 & $3-4^{*}$ & 0,566 & 0,889 & 0,798 & 0,111 & 0,0117 & 0,0015 & 0,02 & 0,001 \\
\hline \multicolumn{8}{|c|}{} \\
\hline $\mathbf{C o}$ & $\mathbf{C u}$ & $\mathbf{M g}$ & $\mathbf{N b}$ & $\mathbf{T i}$ & $\mathbf{V}$ & $\mathbf{W}$ & $\mathbf{P b}$ & $\mathbf{S n}$ & $\mathbf{B}$ \\
\hline 0,0015 & 0,046 & 0,0005 & 0,0022 & 0,0074 & 0,0613 & 0,0118 & $<0,0025$ & 0,0052 & 0,0022 \\
\hline \multicolumn{8}{|c|}{} \\
\hline $\mathbf{C e}$ & $\mathbf{Z r}$ & $\mathbf{Z n}$ & $\mathbf{B i}$ & As & Se & Te & Sb & La & \\
\hline$<0,004$ & 0,0073 & 0,0002 & $<0,005$ & 0,0303 & $<0,0035$ & $<0,002$ & $<0,003$ & 0,0023 & \\
\hline
\end{tabular}

*A nagy széntartalom meghatározása bizonytalan. 


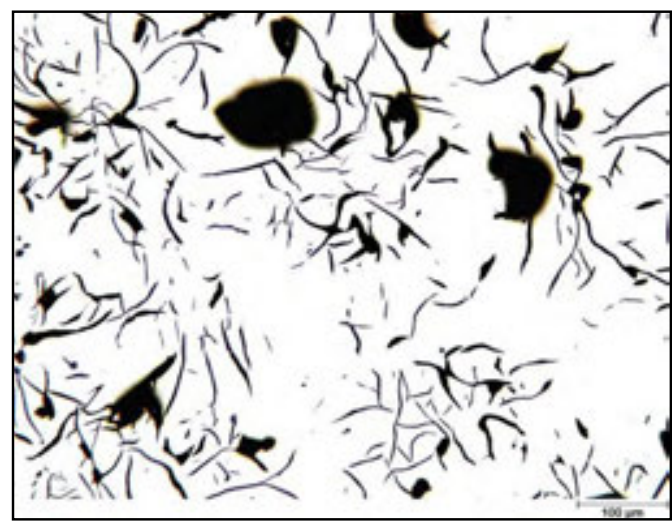

30. kép. A vizsgált minta szövetszerkezete (szürketöretü öntöttvas grafitja)

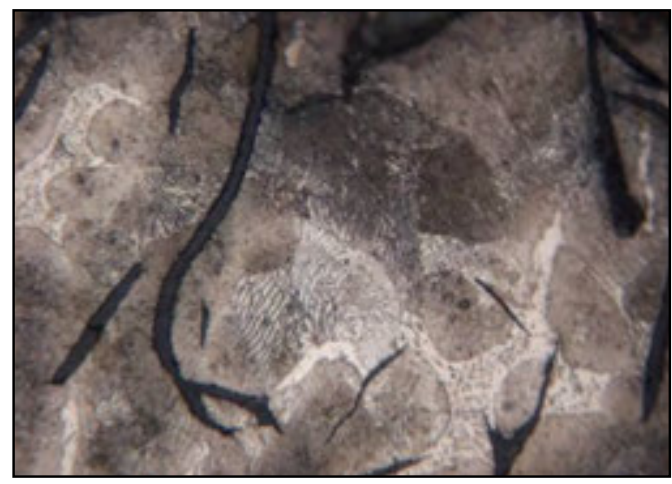

32. kép. $A$ vizsgált minta szövetszerkezete erôsebb maratás után (grafit, ledeburit, perlit, szteadit)

\section{Vasgyártási kísérletek}

\section{Kovászna}

A 19. század ipari forradalma, a vasúthálózat kiszélesedése a vas felhasználásának addig nem tapasztalt lehetőségeiben is megnyilvánul. A bucaeljárás régészeti maradványai jelzői lettek egyrészt a vasgyártás múltjának, másrészt a lehetséges vasérctelepeknek.

A Székelyföld területén, a helyi adottságok figyelembevételével kezdeményezések sora született vasérclelőhelyek feltárására, vasgyártás indítására, amelyek ipartörténeti szempontból tanulmányozva megfelelő he-

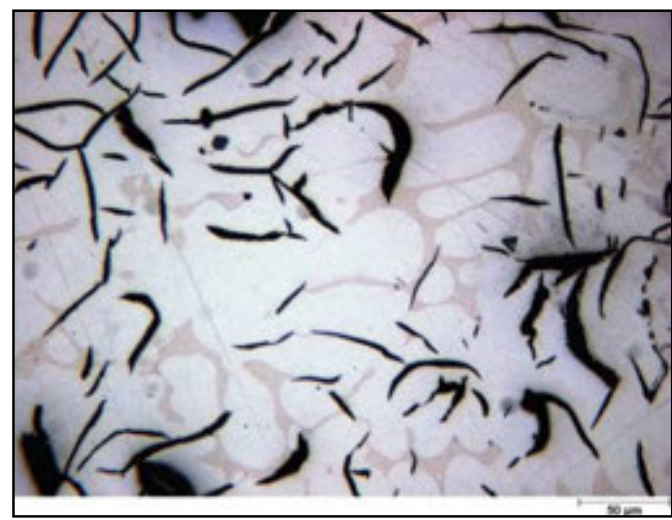

31. kép. $A$ vizsgált minta szövetszerkezete maratás után (ledeburitos szövetszerkezet)

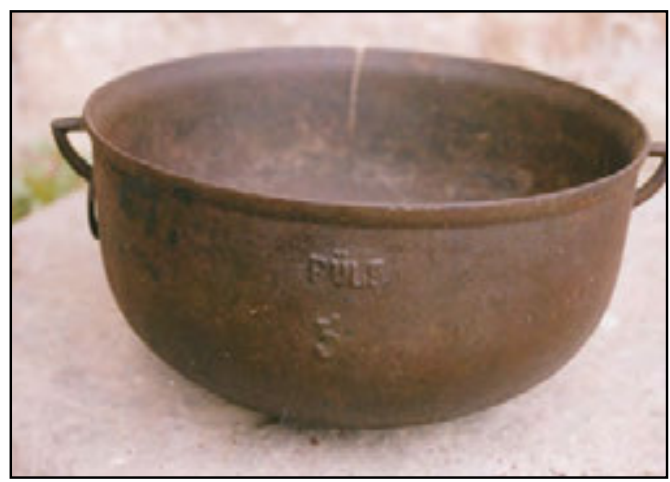

33. kép. Ma is használatos, Erdőfülén készült öntöttvas üst. A Székelyudvarhelyi Haáz Rezsô Múzeum tulajdona

lyet kapnak a térség fejlesztésének történetében. Ide tartozik Kovászna vasgyártásának története is.

Kovászna vasérctelepe viszonylag nagy területen, Zágonig nyúlik, ahol egyenlőtlen minőségű vasércrétegek bukkannak elő. Ezeket Bernhard von Cotta osztrák geológus négy minőségi osztályba sorolta a következő sorrendben:

1. tökéletes tiszta szferosziderit-rétegek,

2. kevésbé tiszta szferosziderit-rétegek, agyag tartalmúak, ezért agyagvaskövek, 3. igen csillámdús és agyagtartalmú vasérc, 4. agyagvaskő palák. 
Ezek alapján megállapította, hogy „ezen a helyen huzamos ideig tartó magas kemencei üzemre könnyen lehet böséges ércet nyerni" Megállapítását 1861. szeptember 10-én írásban is közölte. 1861-ben a Zeitschrift für Berg und Huttenwessen című folyóirat IX. évfolyamában részletes leírását adja a kovásznai vasérctelepnek. Ezt a leírást fordította magyar nyelvre Roediger Lajos ${ }^{10}$, melynek alapján fény derült a kovásznai vasgyártás lehetőségére.

Kovásznát említve ma már aligha gondolunk másra, mint a város és környékének gyógyhatású klímájára, gyógykezelésre szakosodott intézményeire. Véletlenül sem jut eszünkbe a 19. századi település, az akkori Kovászna, ahol a század hatvanas éveiben nagy reményű tervek születtek a helyi vasérc, a szferosziderit kitermelésére, feldolgozására, vasgyár létesítésére.

Az érdeklődés és a konkrét kutatás a vasérclelőhelyek tekintetében a 19. század közepén, pontosabban 1853-ban kezdődött, és Nagy Ezékiel nevéhez füződik.1860-ban már bányászatban jártas munkásokat is alkalmaztak. A helyszíni felméréseket, terepszemlét Herbricht F. térképe alapján kezdték, aki $A$ Székelyföld földtani és őslénytani leírása című műve 183-186. oldalán a kovásznai szferosziderit típusú vasérc előfordulását mutatja be.

Nem hagyhatjuk ki Orbán Balázsnak a kovásznai vasércről tett említését, amely szerint: „...az egész helység sphaerosiderit és agyag vaskő-rétegekből áll, mely feldolgoztatva 50-70 százalék vasat ád, oly finom minöségüt, mely a legfinomabb angol vassal is kiállja a versenyt" (Orbán Balázs I. 1863. 153-154.).

A hámor 1861-ben még dolgozott, a második negyedévben 2006 bécsi mázsa ércet termeltek ki. Ugyanazon év október 11-én már siralmas képet mutat a hámor, bár három hónappal korábban még 596 bécsi mázsa ércet fel is dolgoztak.

Bernhard von Cotta mint szemtanú ekképpen emlékezik az olvasztásra és a megmunkáló üzemre: „Vízerő által hajtott négy óriási kovácsfújtató szolgáltatta az olvasztáshoz a légáramot." A termékskála háztartási cikkekből, üstökből, sótörő mozsarakból, kisebb kovácsoltvas eszközökből tevődött össze.

Közben másoknak is megtetszett a kovásznai vasgyártás gondolata, mert még működött Nagy Ezékiel vashámora, amikor megalakult a Transsilvania Bányatársulat, amely magasolvasztót épített, és ugyanazokat a termékeket gyártotta, mint Nagy Ezékiel vashámora. Méreteiből következően különleges terméknek számított az öntöttvasból készült hamuzsírfőző üst (33. kép).

1865 körül a Transsilvania Társulat vasgyára is megbukott, dolgozói felgyújtották a telepet, és szétszéledtek, elvándoroltak Kovásznáról.

1881-ben a korabeli krónikás Kovásznán járt és ekként mutatja be a vasgyár állapotát: „...még állott az olvasztó alapja és szanaszét hevertek a nagy hamuzsír föző üstök" (Roediger Lajos).

A vasgyár újraindítását célzó próbálkozást is feljegyeztek (1907-ben, 1908-ban). 1914 például újabb terepszemlékkel, ércmintadarabok gyűjtésével, az újrainduláshoz szükséges tőke előteremtésével telt el. Közben kirobbant az első világháború, aminek következtében évekre leállt a vállalkozói kedv, de a lehetőség is szertefoszlott.

1919-ben román állami adminisztráció alá került Székelyföld, és csak a hivatalos szervekhez közel álló személyek próbálkozhattak újabb felmérésekkel az újraindítás reményében. „Ez idő után is jönnek, mennek a bányász és geológus urak, de nem tudunk öntésben gyönyörködni" - írja Roediger Lajos 1928. október16-án. 
Kovászna az évtizedek folyamán más irányú fejlődést tűzött ki célul magának. A vasérckitermelés és -feldolgozás még a gondolat szintjén is megszűnt, de pótolja, talán még sok évszázadon át, az a természeti adottság, ami több ezer ember egészségét szolgálja.

\section{Papolc}

A vasércbányászat és kohászat nem csupán Kovásznához köthető. 1860 októberében Papolc Községi Gyűlése bizottságot alakít azzal a céllal, hogy tárgyalásokat folytasson Nagy Ezékiel kovásznai vállalkozóval, aki vasércbányát szándékszik nyitni a Papolc községhez tartozó Borostyán patakán, egy akkor már vízenergiával működő vízi fürész szomszédságában. Nagy Ezékielnek ebben az időben már működött a tulajdonát képező, kovásznai vasgyára. Valószínű, hogy a Papolc környéki dús vasércet szándékozott kiter-

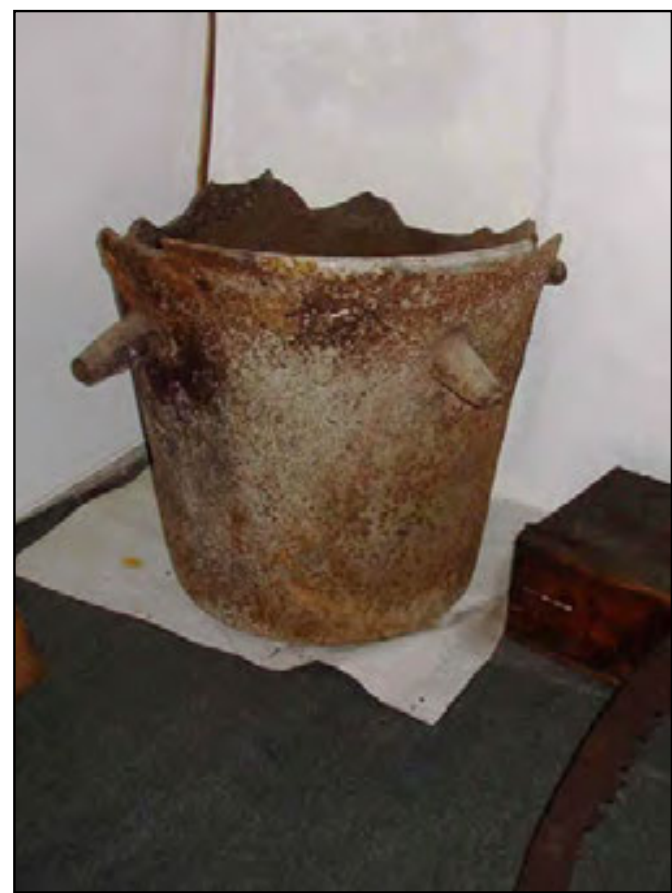

34. kép. Hamuzsírföző vasöntvény üst. A komandói falumúzeum tulajdona melni és kovásznai vasgyárában feldolgozni. A Községi Bizottság a jelen lévő Bányász Comissarius jelenlétében tárgyalt Nagy Ezékiellel, és tizenkét pontban rögzítették a terület bérbe adásának feltételeit. ${ }^{12}$

Az előbbiekből ismeretes, hogy a kovásznai vasgyár 1861 októberében beszüntette tevékenységét, így a Papolc határában található vasérc kitermelése örökre elmaradt, bár a kitermeléssel kapcsolatos megállapodás három évre szólt.

\section{Bereck}

Mint láttuk, a korabeli Háromszéken már 1845-től követhetők a vasgyártás elindítására irányuló törekvések. Bereck város ügyintézési iratai között található az a két brassói kereskedő, Nika György és testvére kérelmével kapcsolatos határozat, amely szerint a kérelmezők a Bereck határában található Luptyán patakon vashámort szándékoznak létrehozni, és ezért bér fizetésére kötelezik magukat. A kérést huzavona nélkül, már a beadvány napjától egy hétre a város 1845 . augusztus 1-jén megtartott közgyúlése elé terjesztették, s a határozatba a következőket foglalták: „Tanátsunk Esküdt s Városi Közönsége ezen üdvös intézkedéseket a Nika Testvéreknek méltányolván - a kért helyet meg adni határozta s a szerződés elvi megállítására a teljes Városi Közönség megbízta - úgy annak megkészítésére Tanátsos Trefás Josef, Bara János, s Jegyző Finta György akfia az esküdés részérôl pd. Orator Hankó András - esküdt reszerolpd. Orator Hanko András - Esküdt Foris Josef és Farkas Antal. Evenkent 130 pengő Taxa fizetés rendeltetett." (Arhivele Naționale, Serviciul Covasna (Román Nemzeti Levéltár Kovászna megyei kirendeltsége) Fond 357. 481., 483.).

Még egy nagyreményű próbálkozás, amely zsákutcába torkollott. Okai a tőke és a meg- 
felelő szakértelem hiánya, ami nélkül elképzelhetetlen egy vasgyár felépítése $\mathrm{s}$ a háttér vasércbánya hatékony működtetése.

\section{Vasgyártási kisérletek a Gyergyói- medencében}

\section{Gyergyócsomafalva}

Természeti adottságainak köszönhetően a hegyekkel körülhatárolt Gyergyói-medence déli-délnyugati részén a Görgényi-havasok vulkanikus eredetű vonulatának vastartalmú ércei késztethettek vállalkozó szellemű személyeket, hogy vasbányászattal, vaskohászattal foglalkozzanak ezen a vidéken.

Gyergyócsomafalván a Sólyom patak, amely a Délhegy lábánál bővizű patakká duzzad, adhatta a 18. század vasgyártásának egyik feltételét, a vízenergiát, ami az olvasztókemence fújtatójának működtetésénél volt nélkülözhetetlen. Együtt volt az érc, a vízenergia, a hatalmas erdőségek és 2-3 órányi járásra a salakképző anyag, a mészkő.

Egy 1741-ből származó dokumentum szerint „quondam Lázár István uram idejében vasat fúvattanak"11 (Tarisznyás Márton 1982. 150.). Ha ez valóban így volt, oka lehetett, hogy megszakították a vasgyártást, mert 1750-ben a csomafalvi lakosok újra megtalálták a régi bánya maradványait, és 1764ben elkezdődtek a tárgyalások a helyi lakosság és a hatalom képviselői között a bánya és a vasolvasztó újraindításának engedélyezése céljából.

A Magyar Országos Levéltár Erdélyi Fiscalis levéltárában található latin nyelvű beszámoló, amelynek eredetijét fakszimilében közöljük (F234, fasc. 356, V. szekrény), betekintést enged a kor iparosítási törekvéseibe a székelyföldi vasgyártási próbálkozások egyik színhelyén, Gyergyócsomafalván. Az említett okírat nem tartalmazza a tárgyalások ered- ményét, a döntéseket. Újrakezdték-e, vagy sem, miért szűnt meg a gyergyócsomafalvi vasgyártás, ha egyáltalán létezett, az idő homályába vész.

Az 1820-ban keltezett parasztvallomások Gyergyóra vonatkozó kötete (Csík-, Gyergyó-, Háromszék és Aranyosszék parasztvallomásai 1820-ból) Gyergyócsomafalvára vonatkozó forrásanyaga említést sem tesz az egykori vasércbányászatról, vasgyártásról.

A 20. század hetvenes éveiben a Gyergyószentmiklósi Múzeum feltárási munkálatokat végzett a feltételezett vashámor egykori helyszínén, ahol vasérc olvasztásából származó salakot is találtak. Ennek szakszerü elemzése nem történt meg. Szintén a hetveneses-nyolcvanas években szakosodott geológiai feltáróvállalat végzett fúrásokat az említett területen, de kitermelésre érdemes vasércet nem találtak. Alighanem az alacsony vaskoncentráció lehetett az egykori vasgyártás megszűnésének oka Gyergyócsomafalván.

\section{Gyergyóditró}

A 19. század első felében, 1847-ben Fülöp Ferenc (Fülök András) vállalkozó szellemű székely gazda vasgyártási kísérleteit jegyzik. Csupán mint rövid életű próbálkozás maradt meg feljegyzésekben, a félbemaradás okát a pénzhiányban és a szakmai tudás alacsony színvonalában kell keresnünk (Tarisznyás Márton 1982. 150; Vitos Mózes 2002. 259; Józsa Sándor 2004. 28.).

Hasonló, rövid életű vasgyártási kísérletekről szájhagyományok Gyergyótölgyes, Gyergyóbélbor környékére visznek. Itt sem alakult ki ipari méretű vasgyártás, feltehetőleg ugyanazon okok miatt. 


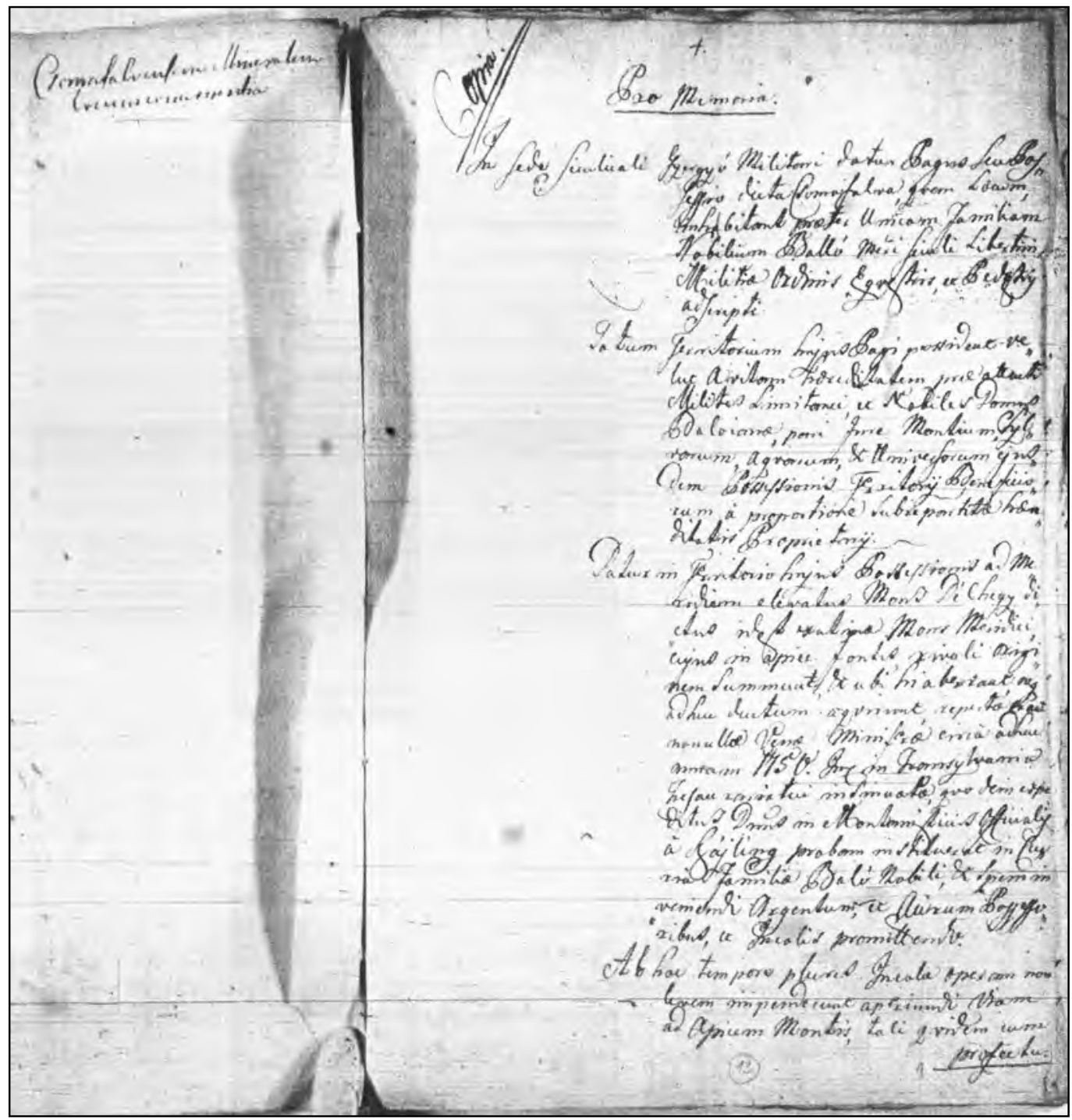

35. kép. Magyar Országos Levéltár, Erdélyi országos kormányhatósági levéltárak, Erdélyi kincstári levéltár, Erdélyi fiscalis levéltár, F 234, fasc. 356, V. Szekrény - Csomafalvi vashámor (részlet) 


\section{Jegyzetek}

1. Ha elfogadjuk, hogy székelyeket a 12-13. században telepítették be a mai Székelyföldre, azt is tudnunk kell, hogy a régészeti ásatások ezen a területen a betelepítés előtti időkből számos nép és népcsoport egykori jelenlétét igazolják. A római közigazgatás megszűnése után vizigótok, gepidák, avarok, onogur-bolgárok, szlávok váltották egymást, vagy olvadtak eggyé az idő nagy olvasztótégelyében.

2. A tellúr kémiai elem. Az elemek periodikus rendszerében (Mengyelejev-táblázat) az 52. rendszámnál Te vegyjellel szerepel. Ezüstös színű félfém, csak kismértékben vezeti az elektromos áramot, félvezető. Komplex színesfémércekben fordul elő. Ipari felhasználása festékanyagok előállításában az üveg és kerámia színezékeként vagy félvezető elektromos áramköri elemek gyártásában is használatos. Erdélyben 1782-ben a zalatnai aranyércekben fedezték fel. Felfedezője Franz-Joseph Müller von Reichenstein. Erdélyen kívül az Amerikai Egyesült Államokban, Ausztráliában, Kanadában található. Tiszta tellúr ritkán fordul elő. Arannyal, ezüsttel vagy mindkettővel együtt alkot vegyi kombinációt.

3. A termésréz rézércekben (kuprit, malachit, kalkopirit stb.) előforduló tiszta vörösréz fém, ami hidrotermás folyamat vagy másodlagos cementezés eredményeként keletkezett. Könnyen megmunkálható kalapálással, jól vezeti a hőt és az elektromos áramot. Kémiai elem, rendszáma 29, vegyjele $\mathrm{Cu}$. Az egyik leghasználatosabb fém, amit tisztán vagy ötvözőelemként alkalmaznak. Az elektrotechnikai iparban nélkülözhetetlen.

4. A rézércek redukciója az a magas hőmérsékleten végbemenő folyamat, amelynek során faszén égetésével $700{ }^{\circ} \mathrm{C}$ körül az érc oxigénje vegyi reakcióba lép az izzó szénnel, a rézérc ezáltal redukálódik. Az eredmény szén-dioxid gáz és tiszta réz.

5. Az ötvözés két vagy több, különböző olvadáspontú fém vagy nem fém olvadékának összekeverése. Például a réz és ón, a réz és ólom, a réz és cink megszilárdult keveréke. Ezek bronz néven ismert ötvözetek.

6. A csíkszentkirályi ezüstkincs 1953-ban a Csikzsögöd-Csíkszentkirály határában levő szoros andezitbányájában, kitermelés közepette került elő. Összsúlya 3650 gr, 15 kupát, egy fibulát, 2 pénzérmét tartalmaz. Dák vagy szkíta eredete nem egyértelműen tisztázott. A kincs egy a dák korra jellemző kerámiaedényben vészelte át az évszázadokat. Jelenleg a bukaresti Nemzeti Történelmi Múzeumban őrzik.

7. A csigafúvót ércek megolvasztásánál használták, az olvadási hőmérsékletet többletlevegő befúvásával lehetett vele elérni. Ezt korábban vízikerekekkel hajtott bőrfúvók alkalmazásával oldották meg. Ezeket helyettesíti a csigafúvó. A csigafúvó a 19. század végéig használatos volt. Debreczeni Márton bánya- és kohómérnök, Magyargyerőmonostor szülöttének találmánya, olyan levegőbefúvó szerkezet amit deszkából ácsoltak, zárt kamrákból és változó keresztmetszetű levegőcsatornákból tevődött össze. A zárt kamrát, amely levegőt tartalmazott, vízzel töltötték fel, ami kiszorította a levegőt a kamrából. A kiáramló levegő az összeszűkülő csatornában egyre növekvő sebességgel és nyomással hatolt be a kemence olvadási terébe, növelve a faszén égési hőmérsékletét. A víz-levegő kamrák felváltva működtek, ami a folyamatos levegőnyomást és hozamot biztosította.

8. Szérelés az a technológia, amelynek segítségével a zúzott ércliszt fémzúzalékát a meddő iszaptól elválasztják. Az elválasztást kivitelező eszköz, a szér egy ferdén elhelyezett deszkalap, amelynek dőlési szöge változtatható a szérelőre vezetett 
ércőrlemény fémszemcsetartalma függvényében. Lassú vízáram hordja be a ferde deszkasíkra az érclisztet, amit a zagyosztó a deszkalap teljes szélességében szétterít. A vizes érczúzalék sebességét a ferde síkon úgy szabályozzák, hogy a különböző fajsúlyú zagyösszetevők szétváljanak a ferde deszkalapon való áthaladásuk során. A könnyebb fajsúlyú meddő gyorsabban, a fémszemcsék lassabban haladnak, miközben a ferde lapra rakodva összegyűlnek. A meddőt a kifolyócsatornán a folyóba vezették. A fémszemcséket vízsugárral ismételten, többször is a ferde deszkalapra vezették, és az eljárást addig ismételték, amíg a kifolyó víz teljesen tiszta maradt. Ez azt jelentette, hogy a lerakódott fémszemcsék nem tartalmaztak meddő iszapot.

9. Egy köbláb 0,0283 köbméterrel egyenlő.

10. Roediger Lajos (1854-1941) torjai szüle. ésű muzeológus. A 20. század elején bekapcsolódott a Székely Nemzeti Múzeum tudományos munkásságába. Néprajzi és művészettörténeti írásai az egykori Háromszék kultúrtörténetébe engednek betekintést. Cotta tanulmányáról készített magyar fordítása kéziratban maradt fenn.

11. A gyergyószárhegyi Lázár István gróf 1642-ben meghalt.

\section{Felhasznált irodalom}

Ágyúcsőéspuskapor. BodorFerenc, a csíki 48-as ágyúöntő és lőporgyártó. Sajtó alá rendezte Pál-Antal Sándor. Mentor Könyvek Kiadó, Marosvásárhely, 2017.

Barabási László: Balánbánya története. Csíkszereda 1996. 36, 40, 70.

Benkő Elek: A középkori Székelyföld. Budapest 2012. 12.

Benkő Elek: Bronz és történelem. In: Emlékkönyv Kiss András születésének nyolcvanadik évfordulójára. Kolozsvár, 2003. 46-58.

Benkő Elek - Oborni Teréz. (szerk.): Székelyföld története. I. 150. Szerk. MTA, BTK-
EME-HRM, Székelyudvarhely, 2016.

Benkő József: Transsilvania specialis. Erdély földje és népe. Fordította, bevezető tanulmánnyal és jegyzetekkel közzéteszi Szabó György. Első kötet, Kriterion Könyvkiadó, Bukarest-Kolozsvár, 1999.

Bitay Enikő: Mûszakitudomány-müvelés Erdélyben. In: Csibi Vencel-József (szerk.): XXV. Nemzetközi Gépészeti Találkozó OGÉT 2017., Kolozsvár, 18-21.

Bitay Enikő - Márton László - Végvári Ferenc: $A$ székelyföldi vasgyártás történetéből. Lövéte múlt és jelen. In: Kása Zoltán Wanek Ferenc (szerk.): VIII. Tudomány-és Technikatörténeti Konferencia, Belényes, Románia, 2015. június 18-21., Erdélyi Magyar Műszaki Tudományos Társaság, Kolozsvár, 2015. 9-14.

Bitay Enikő - Márton László - Végvári Ferenc: $A$ székelyföldi vasgyártás történetéből. Erdőfüle. In: Kása Zoltán - Wanek Ferenc (szerk.): VII. Tudomány- és Technikatörténeti Konferencia, Szilágysomlyó, Románia, 2014. június 26-29., Erdélyi Magyar Műszaki Tudományos Társaság, Kolozsvár, 47-53.

Bitay Enikő - Márton László - Talpas János: A Csíkmadarasi vasgyártásból visszamaradt veletek anyagszerkezeti vizsgálata. Acta Materialia Transylvanica, 2/1. (2019) 79-86.

Borkhodoev, V. Y.: Estimation of limits of detection and determination in X-ray fluorescence analysis by the dependence of the relative standard deviation on analyte concentration. Journal of Analytical Chemistry, 71/9. (2016) 872-877.

Botár István: Germánok Csíkban. Magyar Régészet Online Magazin, 2015. 1-4.

Botár István: Népvándorláskori vaskohászat nyomai Csíkszentsimonban I. Acta Siculica, 2001. A Sepsiszentgyörgyi Székely Nemzeti Múzeum kiadványa, 2001. 165-162.

Darvas Lóránt: Raport de cercetare arheologică preventivă Şumuleu, strada Szék nr. 155. 
Csíki Székely Múzeum, Csíkszereda, 2018.

Dumitrescu, Ioan - Pastiu, Ioan: Metalurgia metalelor neferoase. Editura Didactică și Pedagogică, București, 1969. 117-118.

Erdélyi Magyar Szótörténeti Tár. II. Anyagát gyűjtötte Szabó T. Attila. Szerkesztette Vámszer Márta. Kriterion Könyvkiadó, Bukarest - Akadémiai Kiadó, Budapest Erdélyi Múzeum-Egyesület, Kolozsvár. 2004. 441.

Ferenczi István: Az ôs- és ókori vasmüvességről Erdélyben. In: Hagyományok és újítások a korai középkori vaskohászatban. Szerk. Gömöri János. Kiadja: A Dunafer-Somogyország Archeometallurgiai Alapítvány és MTA VEAB Régészeti és Aechiometriai Munkabízottság. Sopron-Somogyfajsz, 1999. 105-128.

Gabler Dénes: Ferrariae et ars ferraria. A vas kitermelése és feldolgozása a római korban. In: A vasmüvesség évezredei a Kárpát-medencében. Szerk. Nagy Zoltán - Sulovszki János, Szombathely, 2009. 45-53 .

Gimpel, Jean: Revoluția industrială în Evul Mediu. Editura Meridiane, București, 1983. 37.

Glodariu, Ioan - Zrinyi, Andrei - Gyulai, Paul: Le dépôt d'outils romains de Marculeni. Dacia. Revue d'archeologie et d'histoire ancienne. Nouvelle Serie XIV. Editions de l'Academie de la Republique Socialiste Roumanie, 1970. 207-231.

Józsa Sándor: Emlékeim Ditró székely község életéből. Mark Hause Kiadó, Gyergyószentmiklós, 2004.

Kadachi, A. N. - Al-Eshaikh, M. A.: Limits of detection in XRF spectroscopy. X-ray Spectrometry, 41/5 (2012) 350-354.

Kerpely Antal: Vasbányászat és vaskohászat. In: Magyarország az ezredik évben. VII. Budapest, 1896. 210.

László Gyula: Vértesszőlőstől Pusztaszerig. Élet a Kárpát-medencében a magyar államalapításig. Gondolat Könyvkiadó Budapest, 1974. 127.
Lestyán Ferenc: Megszentelt kövek. Glória Kiadó, Kolozsvár, 1996. 215.

Liss, B. - Levy, T. E.: Using X-Ray Fluorescence to Examine Ancient Extractive Metallurgy Practices: A Case Study from Iron Age Khirbatal-Jariya. Jordan. Journal of Powder Metallurgy \& Mining, 5/1. (2016) 1-5.

Magyar Országos Levéltár, Erdélyi országos kormányhatósági levéltárak, Erdélyi kincstári levéltár, Erdélyi fiscalis levéltár, F 234, fasc. 356, V. szekrény - Csomafalvi vashámor.

Magyar Országos Levéltár, Erdélyi országos kormányhatósági levéltárak, Erdélyi kincstári levéltár. Erdélyi fiscalis levéltár, F 234, fasc. 376, V. szekrény - Csíkmadarasi vashámor.

Magyar Országos Levéltár, Erdélyi országos kormányhatósági levéltárak, Erdélyi kincstári levéltár, Erdélyi fiscalis levéltár, F 234, fasc. 4, VI. A. szekrény - Csíkmadarasi vashámor.

Márton László - Talpas János - Bitay Enikő: A balánbányai rézérc (kalkopirit) felhasználhatóságának kérdései a bronzkori eszközök előállításánál. Műszaki Tudományos Közlemények 8. (2018) 57-64.

Orbán Balázs: A Székelyföld leírása. I. Pest 1868. 93.

Pap Gábor: Kitaibel Pálnak az erdélyi termésteluron végzett vizsgálatai. Múzeumi füzetek, Új sorozat, EME Kiadása, Kolozsvár, 2001/10. 56-59.

Rakoczi Sámuel: A bányászat múltja. Pallas Részvénytársaság nyomdája, Budapest, 1910. 18.

Renkó József Bálint - Kemény Dávid Miklós Nyirő József - Kovács Dorina: Comparison of cooling simulations of injection moulding tools created with cutting machining and additive manufacturing. Materials Today: Proceedings, 12. (2019) 462-469.

Renfrew, Collin: A civilizáció előtt. A radiokarbon-forradalom és Európa őstörténete. Osiris Kiadó, Budapest, 1993. 177. 
Roska Márton: A Székelyföld őskora. In: Emlékkönyv a Székely Nemzeti Múzeum 50 éves Jubileumára. Az SzNM Kiadása, Sepsiszentgyörgy, 1929. 216-326.

Rousseau, R. M.: Detection limit and estimate of uncertainty of analytical XRF results. The Rigaku Journal, 18/2. (2001) 33-47.

Szathmári Béla - Moly Sándor: Fémbányászat és kohászat. Pesti Könyvnyomda Részvény-Társaság. Budapest, 1898. 126.

Székely oklevéltár. Új sorozat. Közzéteszi Demény Lajos és Pataki József. Kriterion Könyvkiadó, Bukarest, 1983. 40.

Székely Zsolt: Csernáton község régészeti monográfiája. Státus Kiadó, Csíkszereda, 2007. 70-79.

Székely Zsolt: Háromszék őskora, ókora és kora középkora. Régészeti át- és kitekintő. In: Háromszékiek Háromszékrôl. Status Kiadó, Sepsiszentgyörgy-Csíkszereda, 2007. 24, 70-86.

Tarisznyás Márton: Gyergyó történeti néprajza. Kriterion Könyvkiadó, Bukarest 1982. 150.
Theophilus Presbyter: A különféle mûvességekről. Műszaki Könyvkiadó, Budapest, 1986. 115-116.

Tichi Géza: Fizika a vasgyártásban. Természet világa, 2007/7. 315.

Vitos Mózes: Csíkmegyei füzetek I-II. Adatok Csíkmegye leírásához és történetéhez. Hargita Kiadóhivatal, Csíkszereda, 2002. 244, 300.

Vörösvári Béla: A csíktaplocai Vasfúvó-domb. Acta Siculica 2009. 123-126.

Weisz Tádé: Az erdélyi bányászat rövid története. Oravicza, 1891. 148-149.

Zagreanu, Radu - Nyárádi Zsolt: New date about the Roman Settlement from Odorheiu Secuiesc. Marisia. Studii și materiale, XXXI arheologie. Tg. Mureș, 2011. 264-266.

Zsigmond Árpád: A balánbányai és zámi rézbánya és az ottani rézolvasztók. Bányászati és kohászati lapok, 1909. 42. II. kötet, 500-504. 


\section{SZÉKELYFÖLDI HARANGÖNTÉSZET}

A harang közösségeket összetartó, bronzból öntött, jellegzetes formájú egyedi zengésű hangszer, szakrális kelléke a keresztény liturgiának. Az élet hírnöke, tömegekhez szóló zengésének örök érvényű aktualitása napjainkban is él a tömegkommunikációs eszközök használatával egy időben, és remélhetőleg fenn is marad az idő végezetéig.

Jelzi az ünnepet, a bánatot, és mintha érezné, átélné az eseményeket. Zengése ünnepélyes vagy bánatos az alkalomnak megfelelően, mintha csak lelkéből jönne hangja.

Szakrális tárgyként sajátos díszítéssel, feliratozással magas hőfokon olvadt fémből, formába öntve, bronzból ${ }^{1}$ készül a harang. Szertartási használatát Fabianus pápa rendelte el, az utasítást betartotta a katolikus egyház, reggel és este áhítatra hívta a szerzeteseket és a vallásos érzelmű embereket. 1455. április 8-án III. Calixtus pápa rendeletével bevezeti az újabb harangozási szabályt, mely szerint „háromszor kongassák meg a harangokat”. ${ }^{2}$ Az imára felszólító harangszó több mint félezer éve zeng szerte a világon.

Az egyház és a vallásosság terjeszkedésével, terjedésével erős templomépítési folyamat indul Európa-szerte, de nem csak Európában. Ahol templom épül, ott harangra is szükség van, hiszen nehéz elképzelni keresztény szertartást harang nélkül.

A Kárpát-medence keleti részén, Erdélyben sem volt ez másként. Egyre több és egyre nagyobb templom épült, egyesek erődként, mentsvárként is szolgáltak háborúk idején a híveknek. Így volt ez szűkebb pátriánkban Székelyföldön is, ahol a várfallal kerített erődtemplomok védelmet biztosítottak a helyi lakosságnak portyázó török és tatár hordák támadásaitól.

Erdély nagy városaiban, Brassóban, Nagyszebenben, Segesváron, Aradon, Temesváron igazi harangöntő központok, híres mesterek gyártották a templomi bronzharangokat a megrendelők igényeinek és fizetési lehetőségeinek megfelelően.

Az első harangok Segesváron Joannes de Segisvár öntödéjében készültek 1430-ban, majd Nagyszeben harangöntő mestere, Andreas mester következett 1462-ben. Az elkövetkező 300 év alatt több száz harang készült az említett városokban. Egy részük ma is létezik Erdély templomtornyaiban, és századok óta végzik azt a feladatot, amelyet a legszebb harangfelirat ekképpen adja tudtunkra:

„Vivos voco

Mortuos plango

Fulgura frango"

(Az élőket hívogatom

A holtakat elsiratom

A villámokat eloszlatom)

Székelyföldön a templomi harang a 13-14. században a települések kialakulásával, az első templomokkal egy időben jelenik meg (Márton László 2001). Példa erre a csíkszentléleki (1502), csíkszentkirályi (1562), csíkszentmártoni (1495), csíkszenttamási (1491), homoródszentpáli (1542), medeséri (1496) Hargita megyéből, az erdőfülei 
(14. századból), szotyori (1426), olasztelki (1437), eresztevényi (15. századból), a sepsikőrispataki (1512), a nagybaconi (1575) Kovászna megyéből, a marosszentannai (1497) stb. Maros megyéből. Ekkor Székelyföldön nem létezett harangöntő műhely. Csak két évszázad múlva, a 18. században jelennek meg az első harangöntők és termékeik. Mi lehetett az oka ennek a hosszas késésnek? A harang nagyon bonyolult alakú bronzöntvény, aminél csak akusztikai tulajdonságai bonyolultabbak. Gyártását az öntőmester féltve őrzött titkaként kezelte, ezek a titkok, szakmai fogások apáról fiúra öröklődtek. Amelyik családban nem volt fiúgyermek, ott a vő örökölte a harangöntés mesterségét, de még így is maradtak olyan szakmai fogások, amelyeket az ifjú harangöntő maga kellett kiderítse. A legbonyolultabb feladat a pontos, előre meghatározottzengés elérése volt, összhangban a harang méreteivel, netán a már meglévő harangtárs zengési frekvenciájával.

Tudott, hogy a legegyszerűbb, rezgésbe hozható test a kifeszített rezgő húr. Ennek alaprezgése és a felharmonikusai közötti arány mindig 1: 2: 3: 4, míg a harangok alaprezgése (alaphangja) és felharmonikusai között ez az arány nem egyszerû számtani aránypár.

A harang hangja, amit fülünkkel hangként felfogunk, sohasem egyetlen rezgésszámú hanghullám, hanem olyan hangkeverék, amely az uralkodó alaphangból és a mellékhangokból tevődik össze. A mellékhangok nem befolyásolják az alaphang magasságát, de számuk, rezgési frekvenciájuk és erősségük (intenzitásuk) az alaphang sajátos színezetét alakítja ki. Ha két hangrezgés számának aránya $1: 2$, akkor az utóbbit az alaphang nyolcadának (oktáv) nevezzük, ugyanis a két említett hang közé még hat olyan hangot illeszthetünk, amelyeket, ha egymás után következve hallunk, kellemes zenei hangzásként érzékelünk. Ez a nyolc egymás után következő hang alkotja a diatonikus hangskálát. Ebben a hangskálában a hangok rezgésszámának aránya:

$$
\begin{array}{cccccccc}
1 & 9 / 8 & 5 / 4 & 4 / 3 & 3 / 2 & 5 / 3 & 15 / 8 & 2 \\
\text { C } & \text { D } & \text { E } & \text { F } & \text { G } & \text { A } & \text { H } & \text { C }
\end{array}
$$

vagyis ezek: alaphang (1), szekund, nagyterc, kvart, kvint, szext, szeptim, oktáv (2).

Két szomszédos hang arányát képezve, vagyis a magasabb hang rezgésszámának arányszámát elosztva az előtte álló, kisebb rezgésszámú hang arányszámával, az egymást követő hangok intervallumai:

\section{$\begin{array}{lllllll}9 / 8 & 10 / 9 & 16 / 15 & 9 / 8 & 10 / 9 & 9 / 8 & 16 / 15\end{array}$}

Ha két hang intervalluma $9 / 8$ vagy $10 / 9$, akkor azt mondjuk, hogy a második hang egy nagy, illetve egy kis egész hanggal magasabb, mint az első. A 16/15 intervallumot nagy félhangnak nevezzük.

Az említett nyolc hang nem elég, különösen zenei művek létrehozásánál. Ezért a diatonikus hangskála minden olyan két hangja közé, amelyek intervalluma egész hang, még egy-egy hangot - összesen ötöt - iktatunk be. Ezáltal létrejön a 13 hangot tartalmazó kromatikus hangskála: C, Cisz, D, Disz, E, F, Fisz, G, Gisz, A, Aisz (vagy B), H, c. A 13 hang 12 egyenlő intervallumot képez. Ennek a hangskálának egy-egy intervalluma $\mathrm{x}$, vagyis $\mathrm{x}^{12}=2$ (a C és a c közötti rezgésszámok aránya). Kettőnek a 12-ik gyöke 1,05946. Ennyivel nagyobb egy hang rezgésszáma az előtte levő hang rezgésszámánál egy oktávon belül. Ha több hang együtt megszólaltatva a fülnek kellemes hangzást ad, azt mondjuk, hogy összhangba (konszonanciában) vannak. Ha a fülnek kellemetlenül hangzanak, széthangzók (disszonánsak). Három hang is alkothat kellemes összhangot, egy akkordot. Ilyen például a tercből, kvintből és szeptimből lét- 
rehozott akkord, amelynél a rezgésszámok aránya 10:12:15. Ez komor jellegű akkord, és moll akkordnak nevezzük. A prím, nagy terc és kvint a dúr vagy vidám jellegű akkordot alkotja.

Nemzetközileg a másodpercenként 437,5 rezgésszámú hangot számítják alaphangnak. A többi hang rezgésszáma az intervallumszorzószámok segítségével határozható meg. Az így kapott eredmény értékét a harangborda vastagsága, rugalmassága, fajsúlya és még számos tényező befolyásolja. Ezért hát harangtervezés akusztikai alapismeretek nélkül nem végezhető el.
Ehhez a bronzötvözet, ötvözés technológiája is hozzáadódik, nem is beszélve a harangborda tervezésének módszeréről. A középkori grafikus tervezési módszert az olasz Vannoccio Biringuccio De La Pirotechnia című könyvéből sajátíthatta el az ambiciózus harangöntő. Hogyan juthatott a könyv birtokába a székelyföldi mester, szinte elképzelhetetlen a 14-15. században. Az 1. és 2. ábra középkori, grafikus harangborda-tervezés módszerét mutatja be. Nyugat-Európában a hajlított bordájú harangoknak két változata terjedt el. A két változat a francia és a német harangborda. A kettő közötti kü-

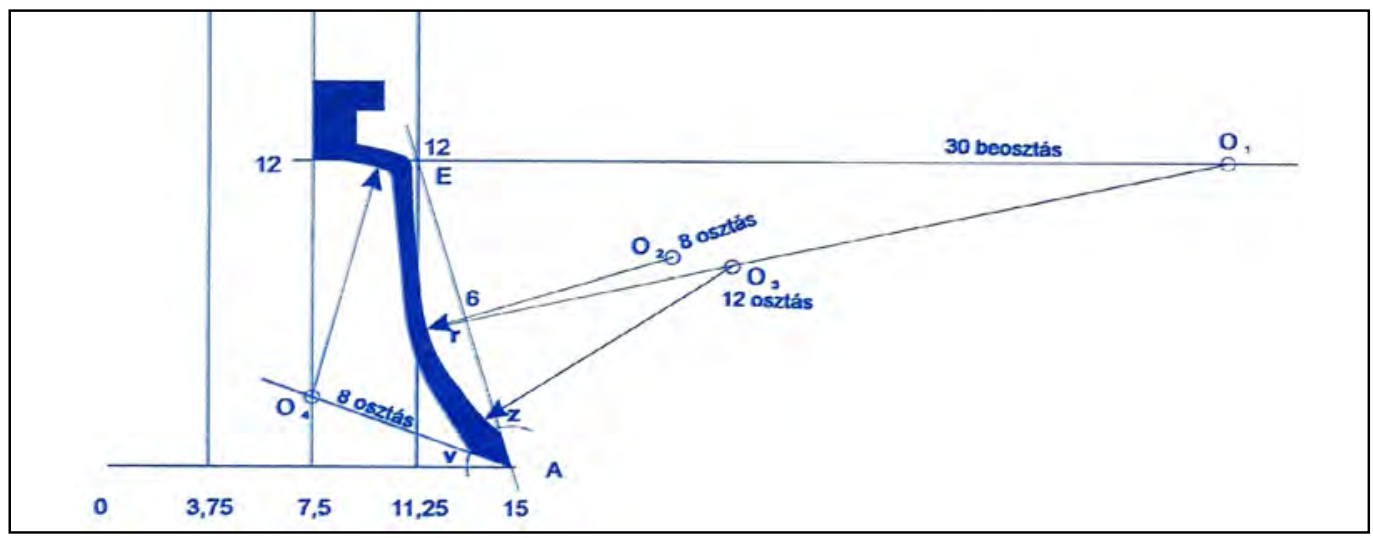

1. ábra. Francia harangborda grafikus tervezése

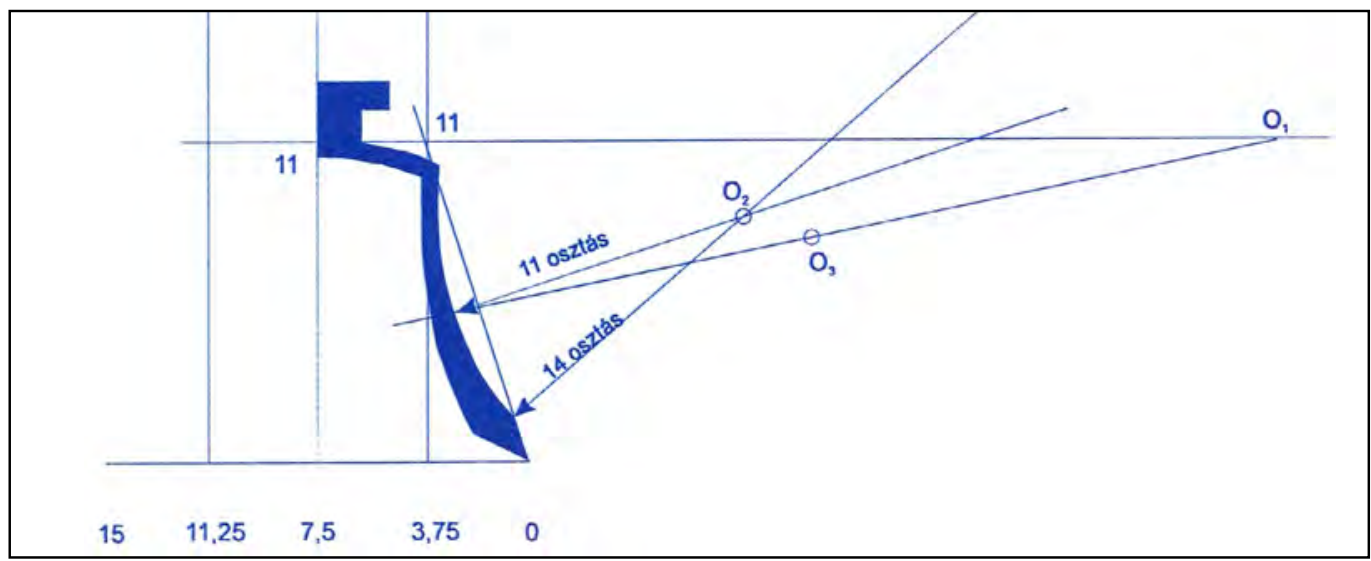

2. ábra. Német harangborda grafikus tervezése 
lönbség a harang magasságából adódik. A francia harangborda hosszabb, karcsúbb, míg a német harangborda zömökebb, alacsonyabb. Mindezt a székely harangöntő aligha tudhatta, ha előzetesen nem dolgozott volna például szászföldi mestereknél. A szászföldi mesterek (Dávid László 1998) nyugat-európai kapcsolataik révén elsajátíthattak olyan tervezési-kivitelezési módszereket, amelyek segítségével 4, 5, 6, akár több harangból öszszetett harangegyüttesek megvalósítását is vállalhatták. Arra is képesek voltak, hogy dúr jellegű zengést vagy mol összhangzású harangegyüttest alkossanak. Ilyen például C D- E dúr hangzású vagy C - D - Disz mol hangzású, három harangból álló együttes zengése.

Hol tart ma a harangöntés lehetősége? Jó példa a bécsi Szent István-dóm 11 harangból álló együttese, amely a következő zengést szólaltatja meg: G - C - Disz - F - G - B - C - D F - A -C (Jörg Wernisch 2006).

A székelyföldi harangöntés kezdeteit gyakorlatilag a 18. század végére tehetjük. Ekkor már múködött Johannes Küs, vagyis Kis János bronzöntödéje. A múhely 1791-ben öntött, máig fennmaradt harangja Homoródkarácsonyfalva unitárius templomának tornyában található. Körirata: I. Leopold Császár uralkodása idején Demjén József inspekciója a H. Karácsonyfalvi Unit. Eclezsia öntette A. 1791. Kis János. Kis János harangja található Bibarcfalván is, annak körírata: Dum. Trabor. Audite. Vocovos. AD. Sacra Venite. Sum. Eclae. Ref: Bibortz falutensi 1797. Me futzit Johanes Küs. ( Kisgyörgy Zoltán 2010).

A Kis család valóságos harangöntő dinasztiává vált, hiszen 1791-1872 között három tagja volt harangöntő. Kis János 1791-1815 között, fia Kis István 1822-1848 között és az unoka, a második Kis János 1856-1872 között, összesen 81 éven át. Tevékenységüket 24, ma is fellelhető harang fémjelzi. Ezek:
1794 Sepsimartonos, 1793 Fotos, 1781 Laborfalva Szentivány, Bodok stb. A három mester alkotásait mesterjegyük után is megkülönböztethetjük. A 3. ábra a három mesterjegyet ábrázolja (Kisgyörgy Zoltán 1996).

Szintén a 18. században született Árkos (Kovászna megye) unitárius templomának harangja, amelyet 1788-ban öntött Lakatos Mihály harangöntő mester, a falu lakosa. A harang körirata: In gloriam unius veri dei et fili Ejus Jesu Cristi. Refusa semptilus generosi domini Danielis Kontz pro ecclesiae unitariorum in Arkos Anno 1788. Egy másik Lakatos Mihály-harang a nagypataki ortodox egyház tulajdona. Körirata: Lakatos Mihály öntötte Anno Domini 1763. Egy harmadik Lakatos Mihály-mú is ismeretes, a sepsibikszádi gróf Mikes Ármin Általános Iskola előtti harangtartó szerkezeten. Körirata: Gróf Mik. Istv. Anno 1772.

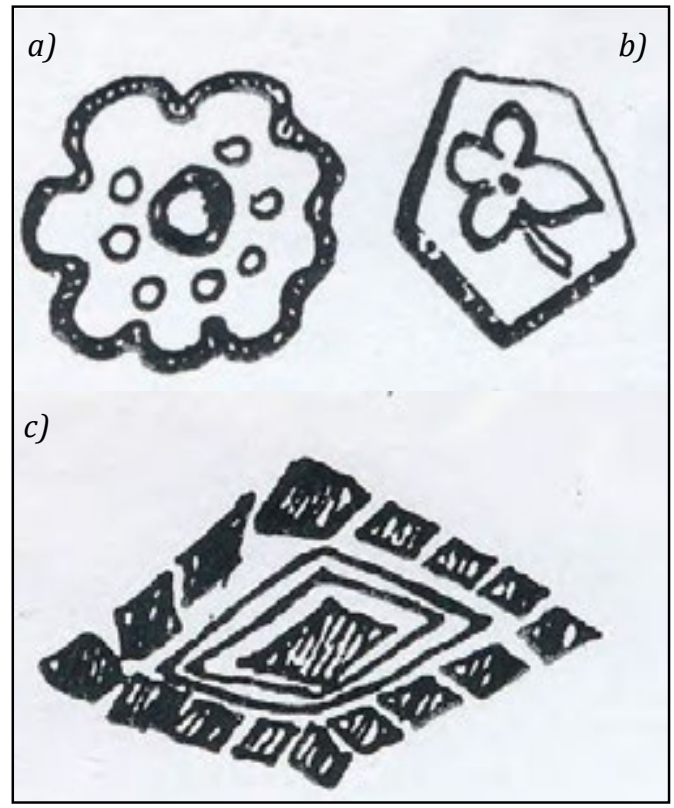

3. ábra. Mesterjegyek (Kisgyörgy Zoltán 1996, 24.)

a) Kis János mesterjegye (1815

b) Kis István mesterjegye (1835)

c) Kis János (az unoka) mesterjegye (1868) 
A 18. század végén, pontosabban 1790-ben, Kis Jánossal egy időben, az akkori Udvarhely vármegyéhez tartozó Korond községben is öntöttek harangot. A harangöntő Stephanus Maté, vagyis Máté István. Kilétéról keveset tudunk, amit az is fokoz, hogy Köszvényesnek öntött harangján a latin felirat azon részét, amelyik az öntés helyét és mestere nevét Fusa in Korondper Stephanum Mate formában adja, vagyis a Korond helynevet a latin per prepozícióval összeírva, félreértették, és Brassó egykori nevével (Corona) hozták összefüggésbe, azt sugallva, hogy Máté István brassói harangöntő volt és harangját is Brassóba öntötte (Szőcs Lajos 2006). A harangot 1916. szeptember 20 -án több haranggal együtt leszerelték, elmenekítették a vallás és közoktatási minisztérium 11792/1917. október 19. számú rendelete alapján.

A harang megmenekült a beöntéstől, ma az esztergomi bazilika harangkiállításában található.

A tévedést Szőcs Lajos a Csíki Székely Múzeum nyugalmazott munkatársa tisztázta levéltári dokumentumok alapján, és ezt a Hargita Népe 2007. február 10-i számában közzé is tette, megerősítve, hogy nyílván Korondról van szó, itt élt és alkotott Máté István, akinek öntödéje 1784-ben indulhatott, és 1790-ig dolgozott itt testvérével, Sámuellel. (Szőcs Lajos 2006)

Csíkszereda Zsögöd részén a Harom hegy és az Olt folyó közötti keskeny földsávon létesítette színesfémöntödéjét Tusa István, aki az
1946-1968 időszakban harangokat is öntött. ő öntötte az erdőfülei harangot, Homoródújfalu unitárius egyházközsége rendelésére $90 \mathrm{~kg}$ súlyú harangot öntött, továbbá Kápolnás falunak 1965-ben, Csíkzsögöd katolikus templomának kisharangját 1940-ben.

Aránylag termékeny harangöntőműhelyt üzemeltetett Rácz Sándor és fia Marosvásárhelyen. 2000-ben ők öntötték a csíkszeredai református templom két harangját. Szintén Marosvásárhelyen öntötte harangjait Kiss Endre. Itt öntötte újra Magyargyerőmonostor (Kolozs megye) 1778-ban öntött nagyharangját. Az új harang 1988. május 1-jén szólalt meg először.

Csíkajnád kisharangján olvasható Bíró Sándor öntő neve, aki 1727-ben múködtetett harangöntő múhelyt Homoródszentmártonban. Kilétének, munkásságának megismeréséhez további kutatások szükségesek.

A gyergyószentmiklósi Mechanikai Vállalat színesfémöntödéjében készült harang Síkaszó (Hargita megye) számára, egy másik a marosfői temető Tinkák (Tincani) településrész harangjaként elsiratja a holtakat. Bajtalan István öntőmester munkája az említett két harang.

Székelyföld egész területén fellelhető számos felirat nélküli harang, amelyeknek öntési helyét, az öntőmester nevét teljes bizonyossággal lehetetlen megállapítani. Ezért nem is szerepelnek Székelyföld harangnyilvántartásában. 


\section{KÉSZÜLT SZÉKELYUDVARHELYEN, LÁZÁR IMRE ÖNTÖDÉJÉBEN}

A Hargita déli oldalán, ahol bővizű patakok habjaikba burkolózva, sziklás partok között rohannak Erdély nagy folyói felé, valahol a kirulyi tanyavilágban élte mindennapjait egy négygyermekes bányászcsalád. Az apa, a lövétei vaskőbánya bányásza nap mint nap elbúcsúzott népes családjától, mert hát ilyen a bányász élete. Nem véletlen köszöntés a Szerencse fel! Mert valóban szerencse kellett a szüntelenül leselkedő veszélyek túléléséhez. Boldog volt a család, mert az esti harangszó hazahozta azt, akit egész nap vártak, az apát a családfőt.

A távoli harang hangja a családi összetartozás és szeretet szakrális szimbólumává vált számukra mindörökké. Az egykori négy gyermek egyike, ma Lázár Imre mérnök a Székelyföld egyik nagyvállalkozója, ismert harangöntőműhely tulajdonosa. Harangjai, kétszáznál is több, az élet tanúi a Kárpát-medencében Ipolyságtól Kárpátalján át Ópusztaszerig és több tucat erdélyi helységig.

Szilárd eltökéltsége harangöntővé érlelte az egykori álmodozó kisfiút. Harangjainak zúgása átível a Kárpát-medencén, s a kongó bronzú gong, a székelyudvarhelyi harang nemzedékeket összetartó zúgása a szülőföld szeretetét, az ősöktől örökölt földhöz való ragaszkodást, a megmaradást, a hitében erős embert hirdeti időtlen időkön át.

„Mérnök vagyok, és megtanultam, hogy minden építmény csak akkor szilárd, ha a szerkezet jó, az anyagok megfelelőek, a munka becsületes" - írta Kós Károly Reményik Sán- dornak 1925-ben. Ez szakmai hitvallása Lázár Imrének is. Sikeres vállalkozó, mert csapatmunkában gondolkodik, olyan csapattal dolgozik, amely vállalja a helyi hagyományokat, magáévá teszi a vállalat célkitűzéseit, és tudása legjavával valósítja meg ezeket. Lázár Imre harangjai a világ több ezer harangjával együtt hívogatják az élőket, elsiratják a holtakat, s villámok eloszlatásával óvják népüket. Déli zengésükkel emléket állítanak annak a nagy csatának s a győzelemnek, amelyet $\mathrm{Hu}$ nyadi János vívott Nándorfehérváron.

Első harangját 2000-ben öntötte, azóta az eltelt 19 esztendő alatt már 200-nál is több harang dicséri a székelyudvarhelyi harangöntést. Igazi rekorderedmény nemcsak a székelyföldi harangöntés történetében, de Erdély-szerte is csak többgenerációs harangöntő-dinasztiák munkássága valósított meg hasonló eredményt.

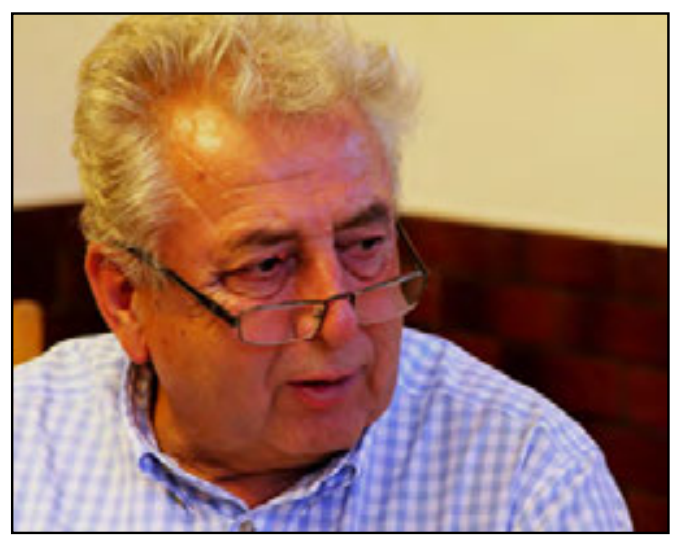

1. kép. Lázár Imre mérnök, az egykori kirulyi kisfiú 
Kommentár nélkül bemutatjuk egy általa öntött harang öntési technológiájának mozzanatait, egy 2200 kg-os harang születését, amelyet a gyergyóditrói neogótikus templom tornyába helyeztek el, és amelynek szava:

URADAT ISTENEDET IMÁDD, ÉS CSAK NEKI SZOLGÁLJ.

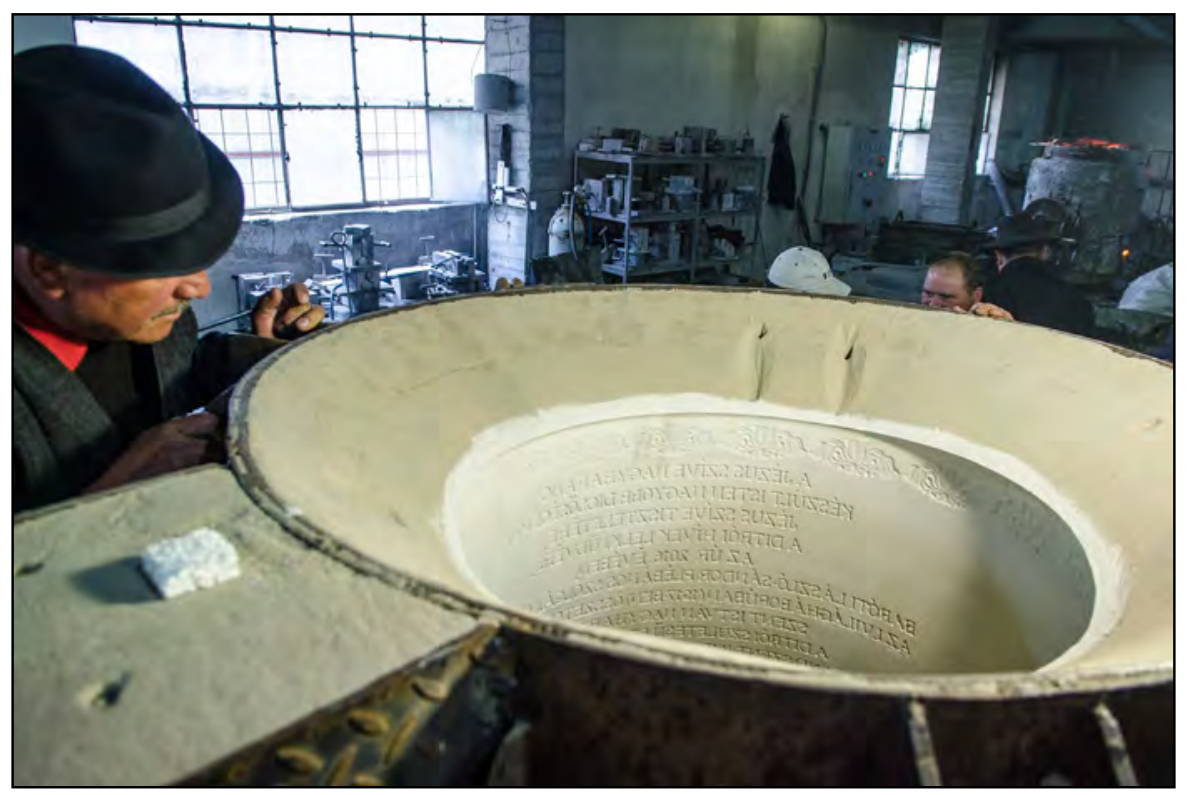

2. kép. $A$ harang öntőmodellje

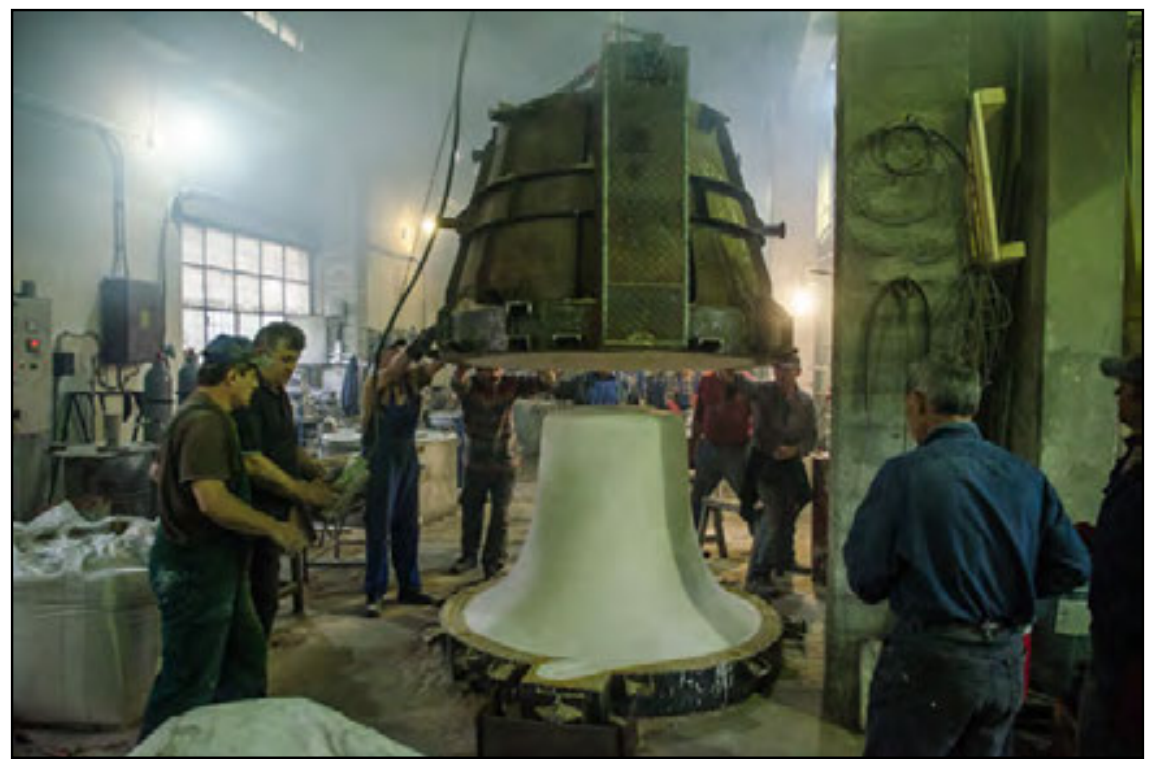

3. kép. A formaszekrény összeszerelése öntés elött 


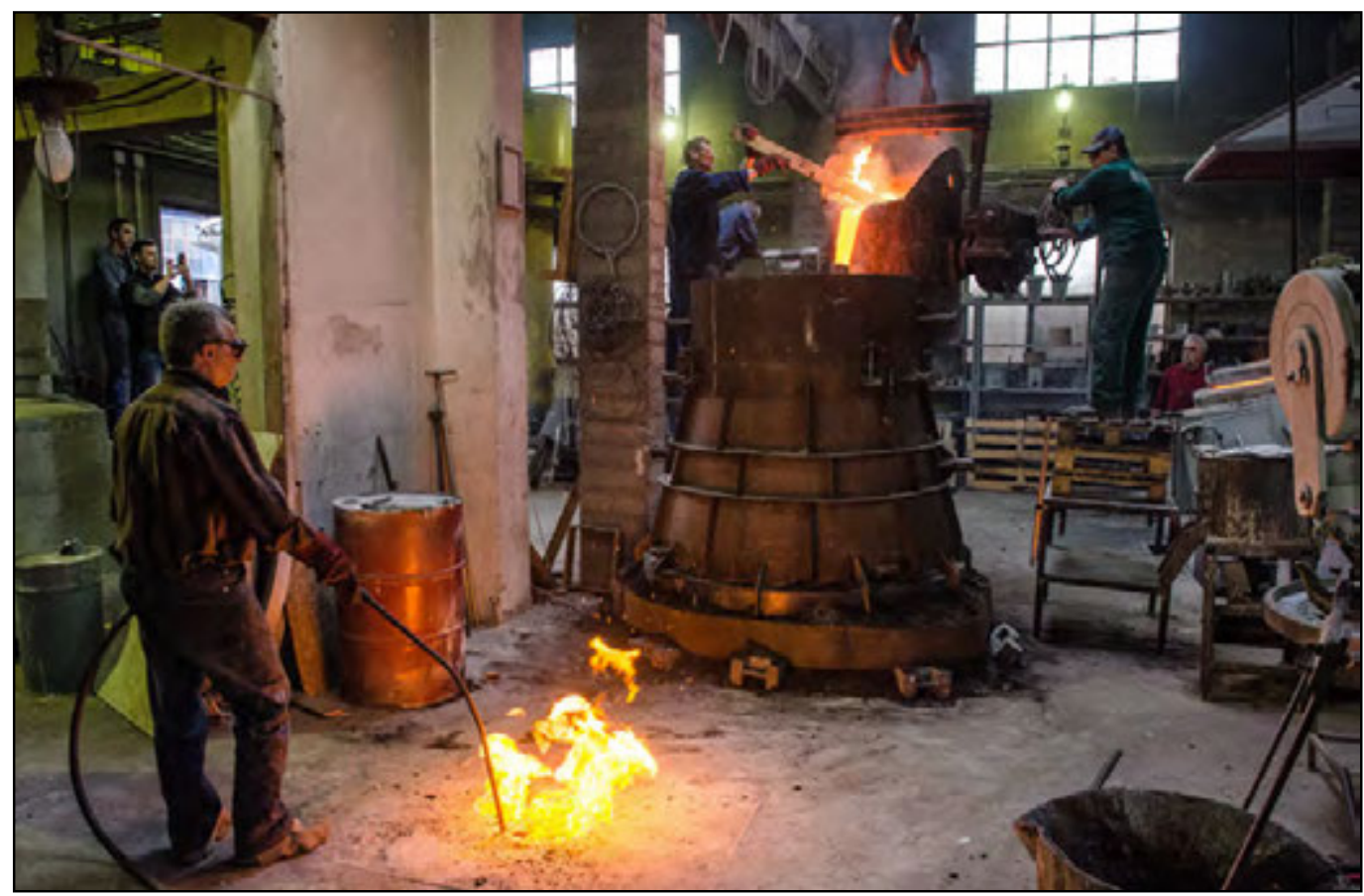

4. kép. Az öntés

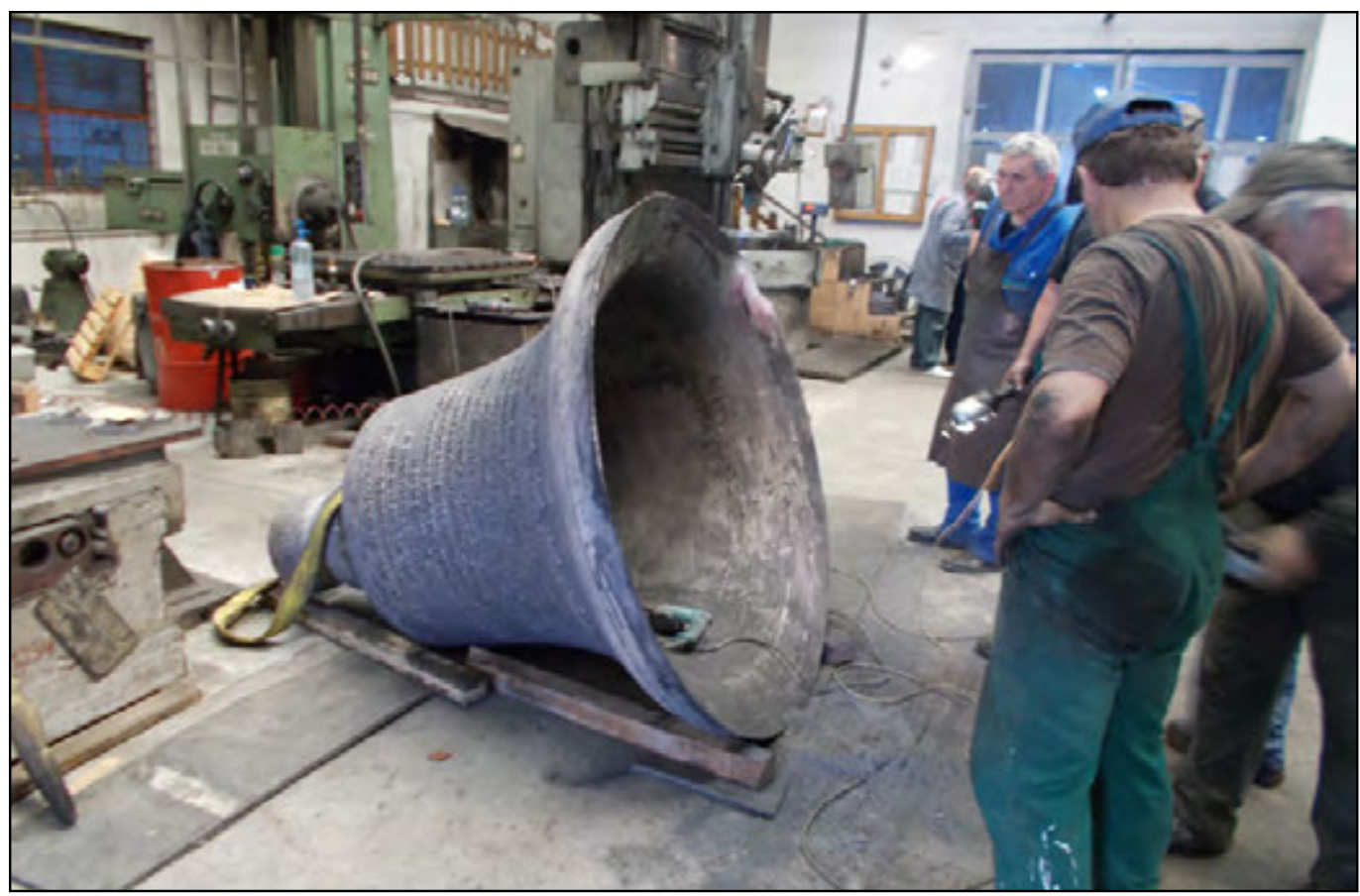

5. kép. A harang tisztítása, csiszolása 


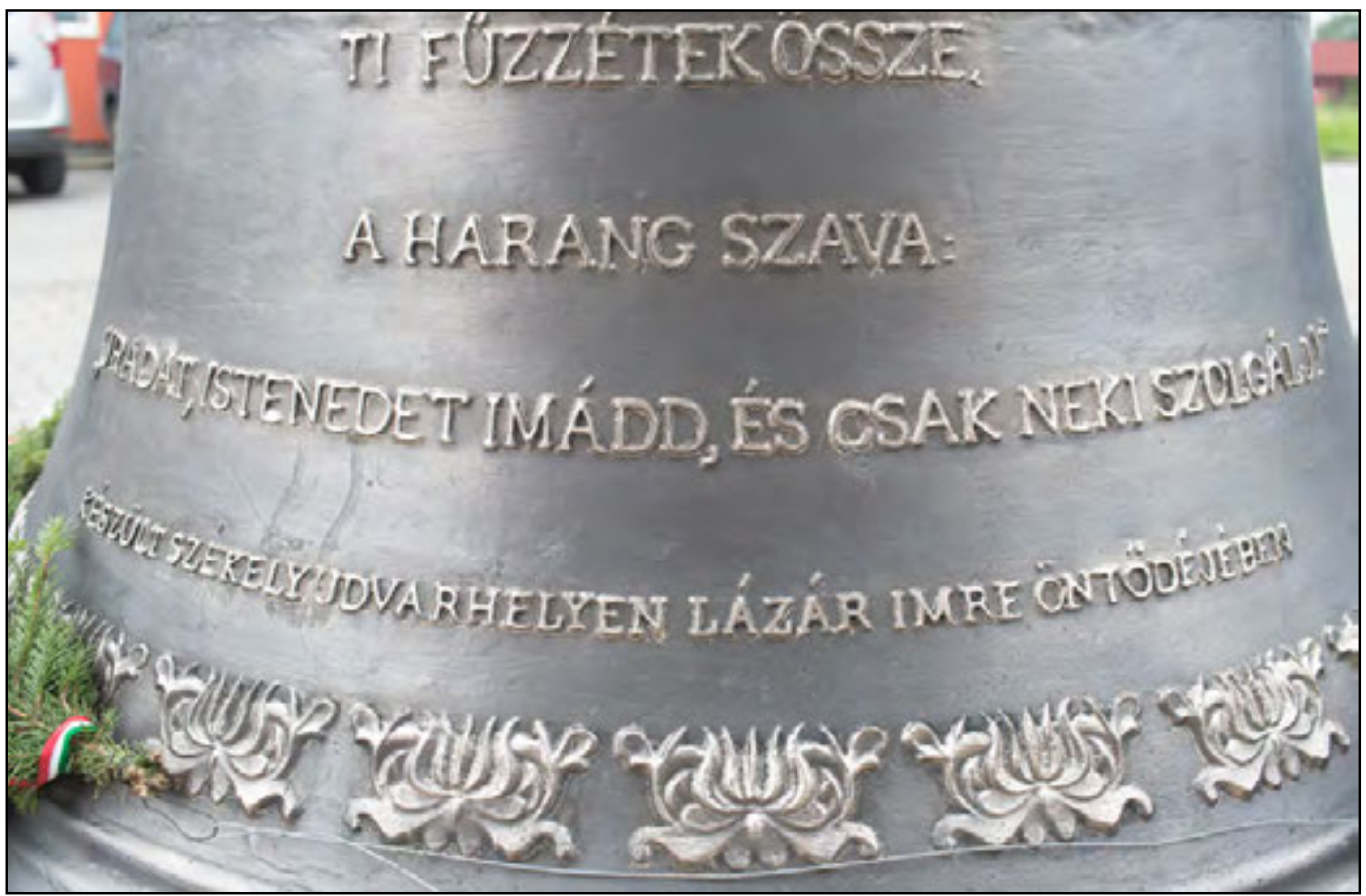

6. kép. $A$ harang feliratozása

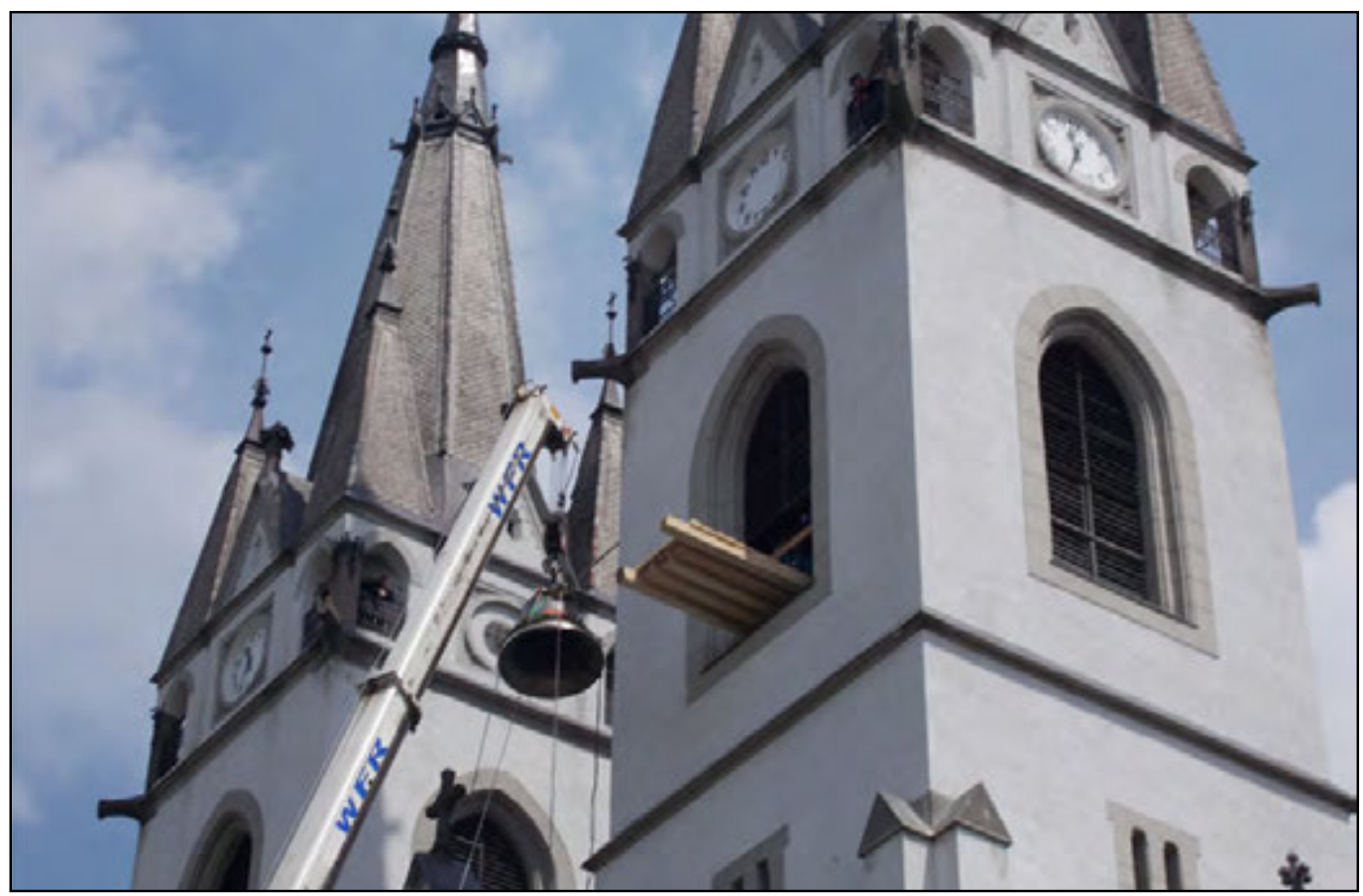

7. kép. A harang elhelyezése a gyergyóditrói neogótikus templom tornyába 


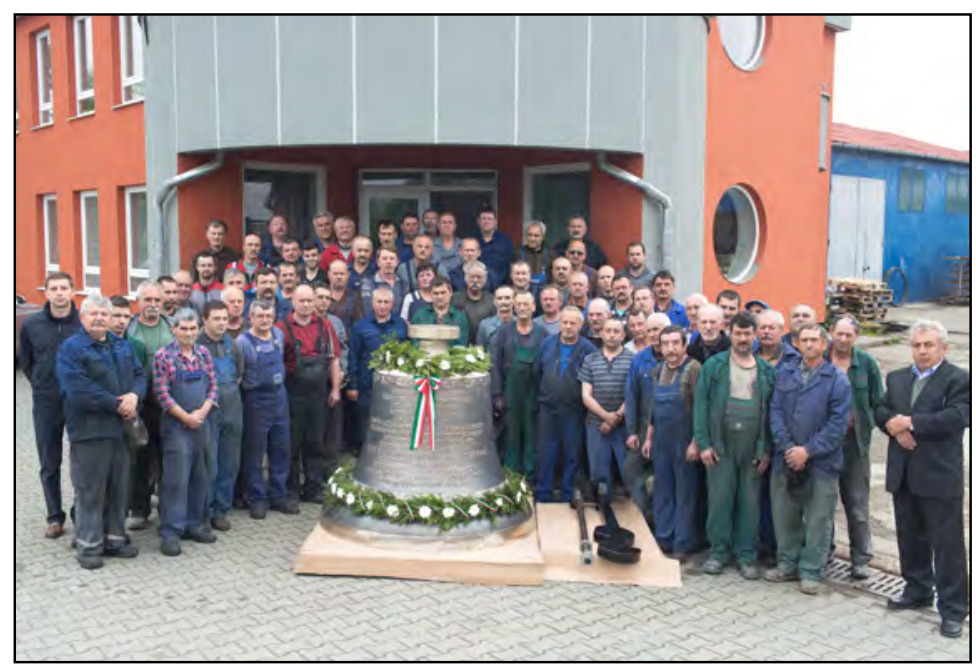

8. kép. A harang megalkotói, a Csapat

\section{Jegyzetek}

1. A harangbronz drága nyersanyaga a harangnak, réz és ón ötvözete. E két fém olvasztása által létrejött fémkeverék, amelynek alapfémje a réz. Rézben keveredik olvadása alatt az ón a harangöntő egyéni tapasztalatai szerint 20-22\% részarányban. Káros ötvözőelem az ólom, amely csökkenti a bronzharang csengését. Az ezüst, bár ritkán használták ötvözőelemként harangbronzban, javítja az ötvözet csengési tulajdonságait.

2. III. Callixtus pápa ambiciózus terve volt Konstantinápoly visszafoglalása. Haditervét 1455-ben kellett volna véghezvigye, ami viszont pénz és hadsereg nélkül nem valósulhatott meg. 1456 májusában a török hadsereg 90000 katonával hadműveletekbe kezdett. A hír hallatán június 29-én bullájával a híveket imára buzdítja, és harangozást rendel el, mondván, háromszor kongassák meg a harangokat déltájban. A pápa még nem tudta, hogy Hunyadi János 6000 zsoldossal és 2025000 keresztesből álló seregével már elindult Nándorfehérvár védelmére. A csatáról sem tudhatott, amely július 22én a magyar csapatok győzelmével végző- dött. Callixtus pápa csak augusztus 6-án értesült a magyar seregek győzelméről. Minden győzelmet a kor szokása szerint harangszóval ünnepeltek. Utólag maga a pápa hozta kapcsolatba a déli harangozást a győzelemmel.

3. A győzelem egyéves évfordulójának tiszteletére a pápa újabb rendeletet is kiadott, amelyben augusztus 6-át, az Úr színeváltozásának napját a keresztény világ ünnepévé tette.

\section{Felhasznált irodalom}

Dávid László: Harangok, harangöntők. Székelyföld, 1998. április, 116-119.

Kisgyörgy Zoltán: Harangoskönyv. Tortoma Könyvkiadó, Barót, 2010. 68-79.

Kisgyörgy Zoltán: Háromszéki harangok. Publisher Kiadó, Sepsiszentgyörgy, 1996. 24.

Márton László: Harangok. Pallas-Akadémia Könyvkiadó, Csíkszereda, 2001. 5.

Szőcs Lajos: Gondolatok egy KORONDPER harangfelirat kapcsán. Székelyföldi harangok Esztergomban. Hazanéző, 2006. 9-12.

Wernisch, Jörg: Glokenkunde von Österreich. Jurnal Verlag, Wien, 2006.78. 


\section{SZÉKELYFÖLDI SÓBÁNYÁSZAT ÉS SÓKERESKEDELEM A KEZDETEKTŐL A 17. SZÁZAD ELEJÉIG}

Székelyföld egyik legjelentősebb ásványi kincse a só, mely az Erdélyi-medencét egykor borító belső tenger elpárolgása következtében képződött sórétegekből a medence és a Keleti-Kárpátok közti törésvonal mentén különféle formákban tört felszínre, oly egyedi képződményeket hozva létre, mint a sófalviparajdi Sószoros vagy a szovátai Medve-tó.

A székelyföldi sóbányászatot és sókereskedelmet a történelem folyamán mindig kettős tényező határozta meg. Egyrészt a felszínen vagy a felszínhez közel található só bősége a Sóvidéken, illetve a Homoród mentén a sókitermelés legegyszerűbb munkamódszereivel könnyen és hatékonyan lehetővé tette e létszükségletű ásványkincs megszerzését. Másrészt az Erdélyi-medence keleti peremén felszínre bukkanó só elsősorban a helyi szükségleteket elégítette ki, ugyanis a földrajzi adottságok megnehezítették a távolsági szállítást, nyugat felé a hajózható folyók hiánya, keleten pedig a havasok képeztek akadályt, ráadásul Erdély többi részein bőséges sót adott a természet, a hegyeken túl pedig úgyszintén voltak sólelőhelyek.

\section{Előzmények}

Írott források hiányában régészeti módszerekkel kísérelhető meg a késő középkor előtti sóbányászat és sóhasználat közvetlen és közvetett nyomainak a kimutatása a régióban. A jelenleg rendelkezésünkre álló tudományos ismeretek e vonatkozásban még nem teszik lehetővé egy átfogó kép kialakítását, mind- össze egy-egy korszak vonatkozásában tudunk néhány észrevételt megfogalmazni. Sóvidéken a Korond-pataka völgyének - melyet északnyugatról a sósziklák zárnak le - elsősorban magaslati pontjain több mint féltucat olyan lelőhelyet ismerünk, melyek a középső bronzkori Wietenberg-kultúra népességének hagyatékát képezik. E településmaradványok viszonylag nagy száma feltevésünk szerint a közeli sóelőfordulásokkal hozható kapcsolatba, azaz a korabeli népesség a helyi sókitermeléssel (is) foglalkozott, bekapcsolódva a regionális sóellátásba. ${ }^{1}$ Homoródkeményfalván a Sóskút környezetének kutatása hasonló eredményeket hozott, itt a felszínen gyűjthető középső bronzkori leletek (Wietenberg-kultúra) közvetve jelzik a korabeli só, illetve sós víz használatát (Kavruk-Ştefan 2014. 21-25.).

A római korban a Sóvidéken nem folyt sóbányászat intézményes keretek között, ugyanis a kisrégió kívül esett néhány kilométerrel Dacia provincia határain. A sófalvi-parajdi Sószoros, a szovátai Földvár, illetve az itteni sósziklák környékéről nem ismerünk hiteles korabeli tárgyi maradványokat, a Firtos-hegy-Küsmödi-kő-Siklódi-kő-Bekecs vonalától keletre előforduló római kori régészeti szórványleletek mindössze a tartomány és a Barbaricum közti kapcsolatokat jelzik, ugyanis a két terület között értelemszerűen nem húzódott hermetikus határvonal. ${ }^{2} \mathrm{Ez}-$ zel szemben a provincia területére eső homoródszentpáli Sóskúton talált Kr. u. 2-3. 
századi fogadalmi oltár (1. ábra), melyet a bányabérlő tiszteletére állítottak, és még a sókitermelést irányító hivatalnok nevét is megőrizte, igencsak beszédes emléke a Homoród menti római kori sóbányászatnak (Wollmann 1996. 249.). Valószínű, hogy a provincia keleti részének szószükségletét a szentpáli castrum közelében található sóaknától fedezték.

\section{Sóbányászat és sókereskedelem a középkorban}

A továbbiakban a középkori székely sóbányászat és sókereskedelem kérdéseit elemezzük az írott források, nyelvészeti adatok és a régészeti topográfiai adatok segítségével. ${ }^{3}$ A szabad sóhasználati jog a középkorban a székely kiváltságok és önigazgatás legfőbb ismérvei közé tartozott. A székelyföldi sólelőhelyekről - a Sóvidékről és a Homoród mentéről - ingyen hordható só a kollektív „nemesi” szabadság egyik jelképe és jellegzetes megtestesítője volt. Horderejét mi sem mutatja jobban, mint hogy a középkori Magyar Királyság területén egyetlen más közösség sem rendelkezett ilyen teljes körú sóhordási joggal (kivételt csak a Német Lovagrend 13. század eleji állami szintű kiváltságai jelentettek).

Írott források hiányában e jog kialakulásának eredete és folyamata homályban marad az utókor számára. Az Erdélyi-medence peremterületein található sólelőhelyek jelentős része a királyi magánbirtok részét képezte a kora Árpád-korban. Nem lehet véletlen, hogy az egyik ilyen birtoktest a kelet-erdélyi (sóvidéki és Homoród menti) sókibúvások tágabb környezetében jött létre (1. kép). A királyság legkeletibb magánuradalma - melynek központja, udvarhelye névadója lett a későbbi Udvarhely városnak - az udvari szervezet

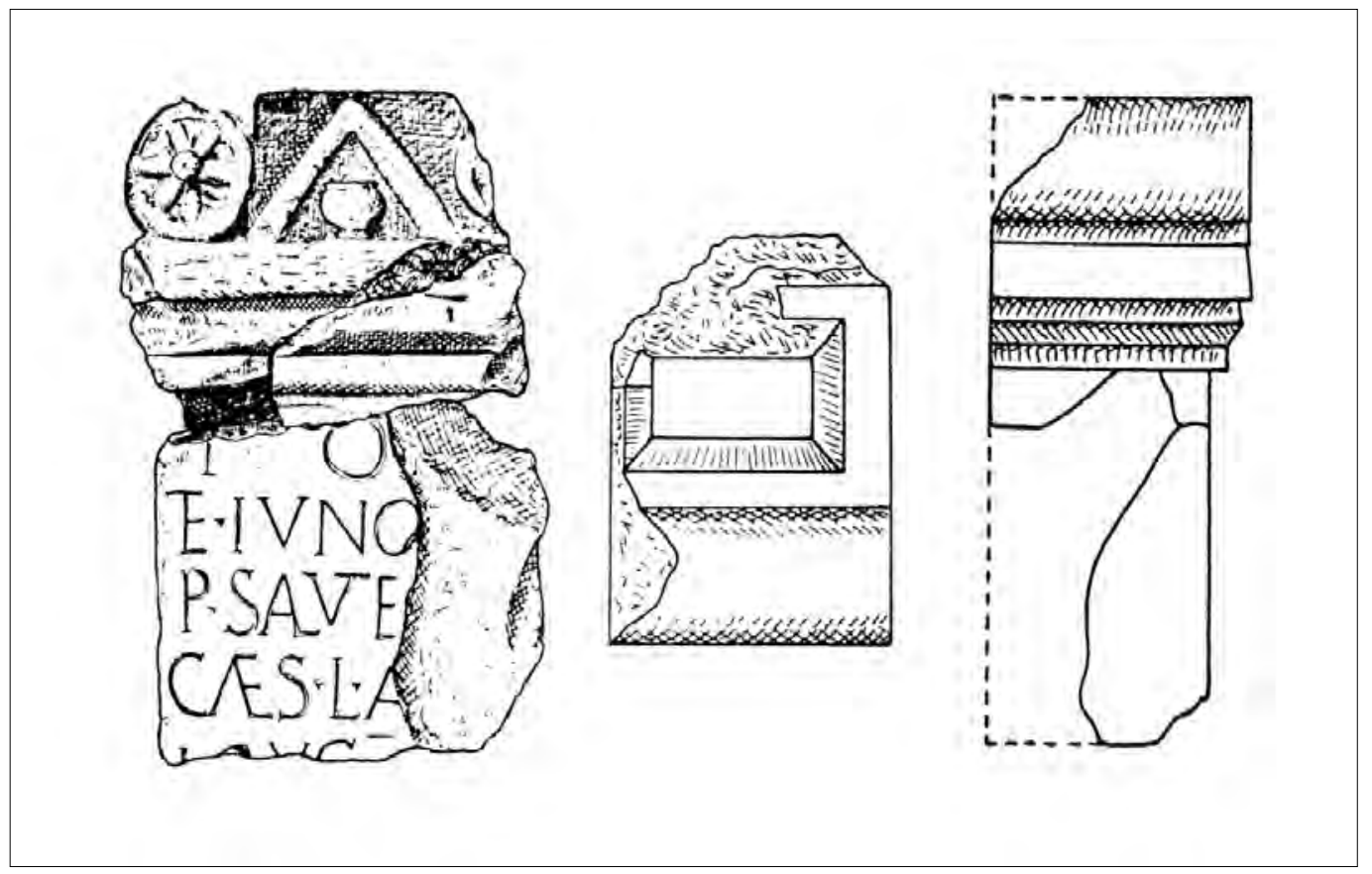

1. ábra. Római kori fogadalmi oltár töredéke Homoródszentpálról (Ferenczi-Ferenczi 1970) 
hatáskörébe tartozó, szolgáltató népekre utaló szórványos helynevek (Daróc, Solymos, Lövéte) tanúsága szerint nagyjából a későbbi Udvarhelyszék területét foglalta magába, ám helyenként túlnyúlt azon (pl. a rikai erdőuradalom, ennek területén királyi várak is épültek). A székelyek Árpád-kori, kiemelkedő szerepe abban is megnyilvánult, hogy katonai szolgálataik fejében uralkodóink lemondtak az Erdélyi-medence két jelentős tegyük hozzá, periferikus fekvésű - sólelőhelyéről, amelyek fölött a székelység teljes körű tulajdonjoga érvényesült a továbbiakban. Összehasonlításképpen érdemes kiemelnünk, hogy a Szászföld által körülölelt Vízakna sosem lett a szintén jelentős kiváltságokat élvező szászok birtoka (ennek megfelelően sóhordási joguk is korlátozott volt, és évente három alkalommal mehettek sóért). Az uralkodói jövedelmek jelentős hányadát ké- pező só (III. Béla idején azok 6,6\%-a ebből származott) bányászata és értékesítése fokozatosan átalakult a késő Árpád-kortól, és a 14. századra királyi monopóliummá vált (Paulinyi 1923-1924. 627-647.). A szebeni prépostság tulajdonából a királyi sókamara igazgatása alá került Vízaknával ellentétben a kelet-erdélyi sólelőhelyek megmaradtak a székelyek birtokában. Fontos továbbra is hangsúlyoznunk a székelyföldi sóaknák kedvezőtlen közlekedés-földrajzi állapotát (a vízi útvonalak hiánya eleve kizárta a távolabbi szállítást), amely meghatározó volt a 20. század előtti székelyföldi sókereskedelem vonatkozásában.

A székely sókitermelésről - noha kezdetei egyidősek a népcsoport Székelyföldön való megtelepedésével - mindössze a késő középkortól maradtak fenn írott dokumentumok. Ismereteink szerint a bakonybéli

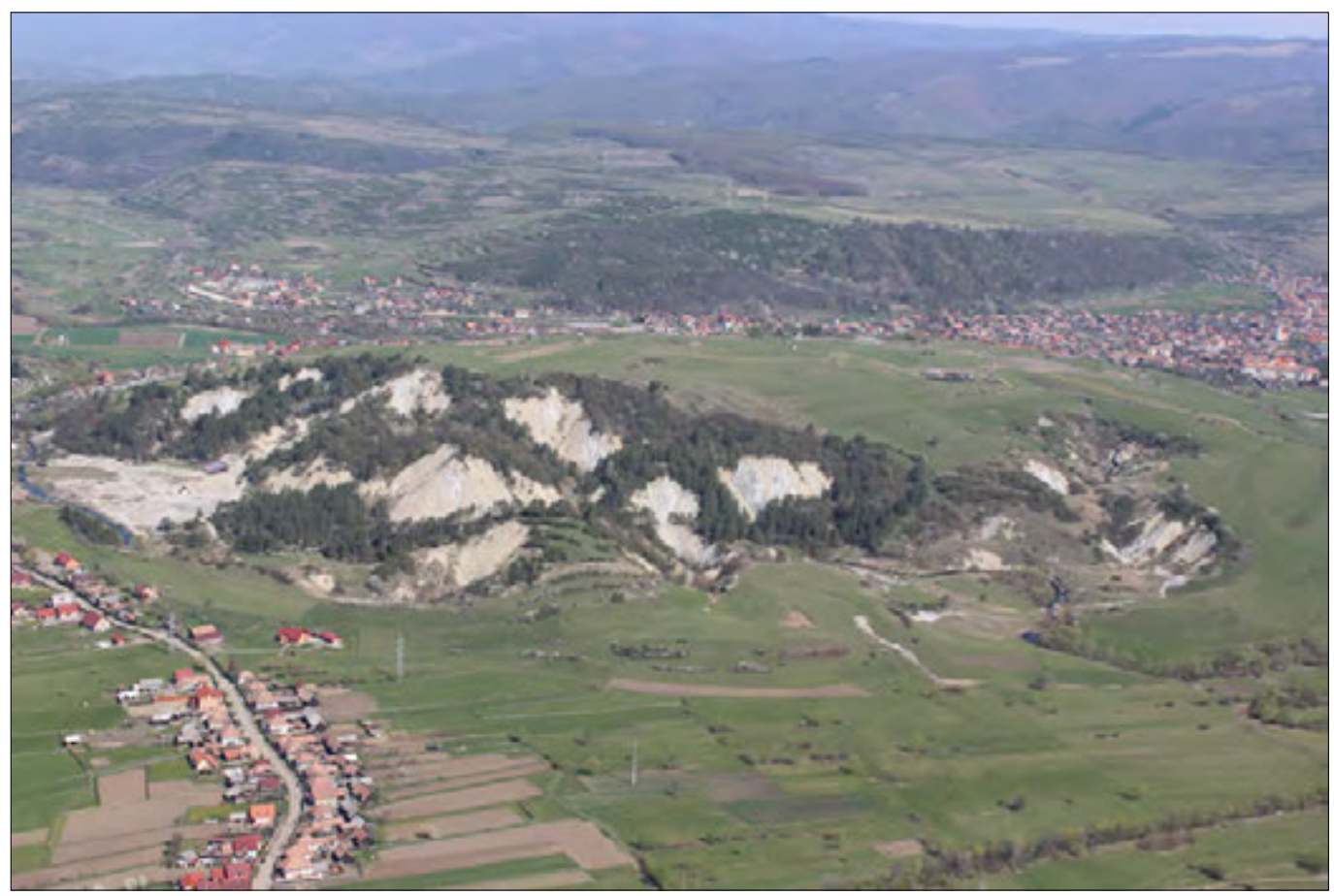

1. kép. A sófalvi-parajdi sósziklák a levegőből (a szerző felvétele) 
apátság 1131 körül keletkezett oklevelében említett Székely (Scichul) (Középkori székelység 15.) nevezetű szolgarendû sószállító személy nem hozható kapcsolatba a kelet-erdélyi sóbányászattal. A székely közösség szabad sóhordási jogát legfelső szinten - a nemzetgyűlésen - rögzíthették, ugyanis az ásványkincs, a só a székelység tulajdonát képezte, ennek kitermelése, valamint az elosztás módozata feltehetően a sólelőhelyekkel rendelkező székek hatáskörébe tartozott. A középkori sóvidéki sóbányászat szervezeti kereteinek kialakulása máig ható településtörténeti, közigazgatási következményekkel járt. A nyelvjárási kutatásokból tudjuk, hogy a Sóvidék településeinek (a Sóváradtól Korondig terjedő, a Kis-Küküllő felső vízgyűjtő területéhez tartozó kistájról van szó) lakói ugyanazt a - településtörténeti előzményekre visszavezethető - dialektust beszélik, mégis más-más szék joghatósága rendelkezett fölöttük (Benkő L. 1989. 354.). A terület közigazgatási - Udvarhely- és Marosszék közti - felosztása nagy valószínúséggel éppen sóelőfordulásainak tulajdonítható. A régió székely megszállása után, a helyi adottságok jelentőségének felismerésével, a székszervezet kialakulásával párhuzamosan mindkét szék igényt tartott egy-egy sólelőhelyre, és a 13-14. század folyamán Udvarhely- és Marosszék megosztotta a sókibúvásokban gazdag területet (Vö. Sófalvi 2005. 175.).

Az Árpád-kori, majd Anjou-kori sóbányászatot és sószállítást szabályozó uralkodói rendeletekben nem találjuk írott lenyomatát a székely sónak egészen addig a pillanatig, amíg ennek kereskedési hatósugara nem lépteát a Székelyföld határait. 1453-ban V. László utasította a széki és dési sókamarák ispánjait és azok hivatalnokait, hogy Segesvár város és -szék lakosait Zsigmond és Albert királyok óta gyakorolt kiváltságukban - mely szerint a székelyföldi sót az éves és heti vásáraikon szabadon árusíthatták - ne zavarják (SzOkl. III. 63-65.). Az oklevélből megtudjuk, hogy a szabadalom Ozorai Pipo országos sókamaraispán hivatalviselésének idejére (1400-1426 között töltötte be a tisztséget) nyúlik vissza, akinek tevékenysége meghatározó volt a sómonopólium rendszerének kiépülésében (Draskóczy 2008. 151.).

Az oklevél jelentőségét az adja, hogy ez a székelyföldi só legelső hiteles dokumentuma, mindemellett világosan tükrözi a szomszédos szászok növekvő sóigényét, akik ily módon rendszeres - és minden bizonnyal olcsó - sóellátásban részesültek. Ezt a tendenciát jól jelzi a továbbiakban az a tény, hogy a kedvezményezett segesváriak után negyedszázaddal már Brassó városa is székely sót forgalmazott: 1487-ben az uralkodói monopóliumot sértő székely só importja és árusítása ellen lépett fel Tárcai Márton erdélyi sókamaraispán (SzOkl. III. 112.). A rendelkezés záró része - miszerint a jövőben az ispán elegendő sót fog küldeni a város számára megtévesztő lehet, ugyanis azt sugallja, hogy a kamarai sóhiány késztette a brassóiakat székely só beszerzésére, ám ez kevéssé valószínű a sóbányákkal sűrűn behálózott Erdély területén.

A székely só feltűnése az oklevelekben a szászok só iránti keresletének a lenyomata. A 16. századi forrásokban a Székelyföldről származó sóval 1521-ben találkozunk, az év decemberében a segesváriaknak korábbi kiváltságaik - bemutatva Mátyás királytól kapott oklevelüket - alapján sikerült újra megerősítést kapniuk II. Lajostól (SzOkl. III. 214-215.), történt ez annak ellenére, hogy az év elején átfogó rendelet tiltotta meg a székelyek sóárusítását határaikon kívül, illetve 
minden nemest, polgárt és paraszti sorban lévőt intett attól, hogy székely sót használjon (Iványi 1911. 191.). 1536-ban Maylád István erdélyi vajda és székely ispán megparancsolta Erdély hatóságainak, hogy az udvarhelyszéki előkelőket (egregios et agiles) Segesvár és Kőhalom székekben való szabad sókereskedésükben - melyet „de vetusta et aprobata consuetudine" gyakorolnak - ne háborgassák. A tevékenység, mint az oklevél további soraiból kiderül, a szék összes lakói számára engedélyezett, azaz bárki által végezhető, Udvarhelyszék mellett Keresztúrszéket is beleértve (SzOkl. II. 40-41.).

A 16. század közepén Erdély megszerzésével I. Ferdinánd biztosai részletes helyzetfelmérést készítettek a tartomány gazdasági állapotáról, és figyelmüket nem kerülte el a székelyföldi „fehér arany” sem. A Bornemissza Pál és Werner György császári biztosok által 1552 tavaszán összeállított jelentés viszont elnagyoltan jellemezte a Székelyföld és térségének sólelőhelyeit, valószínű, hogy nem is jutottak el a székely sóaknák helyszíneire (vö. Szekeres 2007. 77.). A leírás a székely ispán birtokában lévő görgényi uradalom területén, illetve a közeli (Sós)Szentmártonban említ sóvágó helyeket (SzOkl. II. 95, 98-99.). Sóaknák még sok helyen találhatók - írják a küldöttek -, a székelyek földjén annyi só van, hogy szinte ingyen lehet kapni. „A székelyeknek a sójukat csak háztartásukban szabad használni és nem szabad nekik a sót a meghatározott területen túl, a melyben a szászoknak egy része Segesváron túl a Barczaságon át egészen Brassóig és Fogaras földje bennfoglaltatik, árusítani, mindamellett Erdélynek többi részeibe is becsempészik."(SzOkl. II. 96; Connert 1901. 105.) Tehát sókereskedésük körzetét a székelyek ekkora már Fogaras és Brassó vidékére is kiterjesztették, ez elsősorban a török okozta zavaros gazdasági és államigazgatási helyzet következménye lehetett. Ferdinánd intézkedése az ügyben nem maradt el, egy évvel később (1553 júniusa) a király arra utasította Haller Péter erdélyi kincstartót, hogy akadályozza meg a só kivitelét Székelyföld határain túlra, a törvényt megszegő kereskedő sóját kobozzák el, és szabjanak ki büntetést rá (SzOkl. II. 105; Oborni 2002. 176, 188-189.). Megszerzett kiváltságukhoz a székelyek viszont ragaszkodtak, azt rögzítették is 1555 . évi törvényeik között, leszögezve, hogy a királybírótól illeték fejében váltott pecséttel (engedéllyel) bármely székely kereskedhet sóval Segesvárés Kőhalomszékben, illetve Fogaras földjén (SzOkl. II. 125. 73. art.).

$\mathrm{Az}$ áttekintett forrásokból egyértelműen kiderül, hogy a 16 . század második harmada előtt nem beszélhetünk székely sókereskedelmi kiváltságról, és az 1536-os oklevél egy több mint százéves, többé-kevésbé megtűrt gyakorlatot hagyott jóvá. A Székelyföld határain kívüli sóárusítást korlátozó vagy tiltó uralkodói oklevelek, rendeletek jól tükrözik azt a gazdasági problémát, amelyet a székely sókereskedés jelentett a királyi sókamara számára.

Anélkül, hogy számszerű ismereteink lennének a sókivitel volumenéről, egy fokozatosan felívelő kereskedelemről szerzünk tudomást a késő középkori írott forrásokból, melyet az 1562-es felkelés derékban tört meg. A 15-16. században a székely társadalom felső rétege, majd 1536-tól a közszékelyek által is űzhető sókereskedés nem jutott el olyan szintre, hogy gazdasági-társadalmi viszonylatban maradandó nyomokat hagyjon maga után. Negatív tanúbizonysága a településhierarchiában is megfogható, a Sóvidéken vagy a Homoród mentén egyetlen olyan települést sem ismerünk, amely a késő középkorban a mezővárosi fejlődés fokára eljutott volna. 
A Sóvidék társadalmi tagozódását sem befolyásolta érdemlegesen a föld kincse, 1562 előtt nem tesznek említést primorokról a források. A késő középkori - kora újkori népességösszeírások társadalmi és demográfiai mutatói úgyszintén alátámasztják ezt a negatívumot, a sóvidéki vagy Homoród menti települések az átlagos lélekszámú udvarhelyszéki falvak sorába illeszkednek (vö. ImrehPataki 1979. 180-183.). A székely sóhasználat és sóhordás szokásjoga feltehetően eleve tiltotta a sóval való kereskedést a korai századokban. A forrásokból nem tudjuk meg, kik voltak a „külföldre” (azaz Szászföldre) vitt sószállítás kezdeményezői, gyanítható, hogy a szék politikai-társadalmi-gazdasági életében vezető szerepet betöltő főemberek és tehetôsebb lófők.

A középkori székely sóbányászat technikáit illetően mindössze az 1552. évi jelentés szűkszavú tudósítására vagyunk utalva. Ferdinánd biztosai megjegyezték, hogy a székelyek a nap világánál, azaz a felszínen bányásszák a sót, hasonlóképpen tudta ezt a kortárs Verancsis Antal is. A sókitermelés munkamódszere még két évszázadon át változatlan maradt a Székelyföldön, Fridvalszky János így írt erről a 18. század közepén: „sóbányát itt egyet sem látni, hanem a bányászást négyszögletes gödrökben végzik, s ezeket annyira ássák mélyre, hogy vállukon könnyen kihozzák a sót". A felszínen található só bősége hosszú időn át nem indokolta, hogy mélyebb tárókat nyissanak. Marosszéken a szovátai sóbányánál, Udvarhelyszéken Sófalván, a Homoród mentén Szentmártonban, Szentpálon, Szentpéteren, illetve Lövétén fordul elő kősó a felszínen vagy ahhoz közel (sóskutakat Korondon, Fiatfalván, a Homoród mentén Szentpálon, Szentmártonban, Keményfalván, Almáson és Lövétén múködtettek) (2. és 3.kép). A középkort illetően hasonló technikai vi- szonyokkal számolhatunk, valószínű, hogy az újkorból ismert nyomfejtésnek vagy kagylós fejtésnek valamilyen formáját alkalmazták. A sóelőfordulások környezetének intenzív hatású felszínalakító tényezői - a tektonikai mozgások és a víz - az egykori sókitermelő gödrök morfológiáját jelentősen átalakították vagy elpusztították. A középkori sóbányászat felszíni maradványai Sófalva határában nagyrészt megsemmisültek, ugyanis a sókitermelés helyszínén - a mai Sószorosban - egy sóstó alakult ki az évszázadok folyamán, melynek gátját átszakította a Korond-vize, elpusztítva az emberi tevékenység nyomait (a Sószoros két oldalán látható dolinák feltehetően szintén a sóbányászat hatására alakultak ki). Ugyanez történt a szovátai sóaknákkal. Homoródszentmárton középkori sóaknáját 1590-ben már nem művelték, a „Holt Akna” (SzOkl. ú.s. II. 116.) feltöltődött bányahelye napjainkban is jól felismerhető a falu Udvarhely felőli bejáratánál.

A középkori székely sóelosztás ügyeit a szokásjog szabályozta, így nem maradt nyoma az oklevelekben. Egyedül a helynevek bírhatók szóra e vonatkozásban, melyek hűen megőrizték a sószállítás nyomvonalait. Noha kései lejegyzésű, 16-18. századi helynevekről van szó, tanúságuk a legtöbb esetben középkori lehet, ugyanis 1562 után megszűnt a szabad sóhordás széles körű és szerteágazó joga, illetve lehetősége.

A sólelőhelyek többsége fölött rendelkező Udvarhelyszék sóvidéki aknájától több irányba vezettek a sóhordó utak. A Kalondán átkelve Udvarhelyig, a Gagy mentén pedig Keresztúrig követhetők a legfóbb sóutak, kisebb elágazásaik a Küsmöd-patak völgyében, illetve a Nyikó mentén tûnnek fel a helynevekben (Sófalvi 2017. 57.). A sószállításnak viszont alig maradt nyoma a Homoród menti 
toponímiában, melyre az itteni sólelőhelyek területi szóródása, illetve a sós források jelentősége adhat magyarázatot (a sós víz távolabbra szállítása nehezen volt kivitelezhető). A Kőhalomszékben vagy a Barcaságban forgalmazott székely só a Homoród menti utakon jutott el Szászföldre.

A sóaknáktól távolabb fekvő székekbe irányuló sószállítás útvonalai - Gyergyószéket leszámítva - nehezebben rekonstruálhatók. A gyergyóiak ingyen sója a sófalvi sóaknától induló, a Görgényi-fennsíkon átkelő sóúton ért el rendeltetési helyére. Csíkszék és Háromszék sószükségletének jelentős része Udvarhelyről, illetve a Homoród mentéről vezető utakon jutott tovább, helynévi lenyomat nélkül (a sólelőhelyektől, a centrumtól távolodva feltehetően egyre inkább elhalványult a sószállítás névadó jellege). A külső medencék sóellátásában helyi szinten fontos szerepe lehetett a sós forrásoknak, főként Háromszékben (pl. Kovászna, Sósmező) gyakoriak a konyhasós vízfeltörések. ${ }^{5}$

A székely sót a középkortól egészen a 20. század elejéig tengelyen szállították. Ferdinánd 1553-ban Haller Péter kincstartónak adott utasításában meghagyta, hogy a Székelyföldön kívül kereskedő székelynek a sóján kívül - ökreit is kobozzák el. (Oborni 2002. 176.). A székely nemzet 1555-ben írásba foglalt törvényei a sóval való szekerezés illetékét hat ökör után három pénzben (dénárban), két lóval való szekerezés esetében két pénzben állapították meg. Ha a székely pecsét nélkül kereskedett a sóval, marháját és áruját a királybíró elvehette (SzOkl. II. 125. 73. art.).

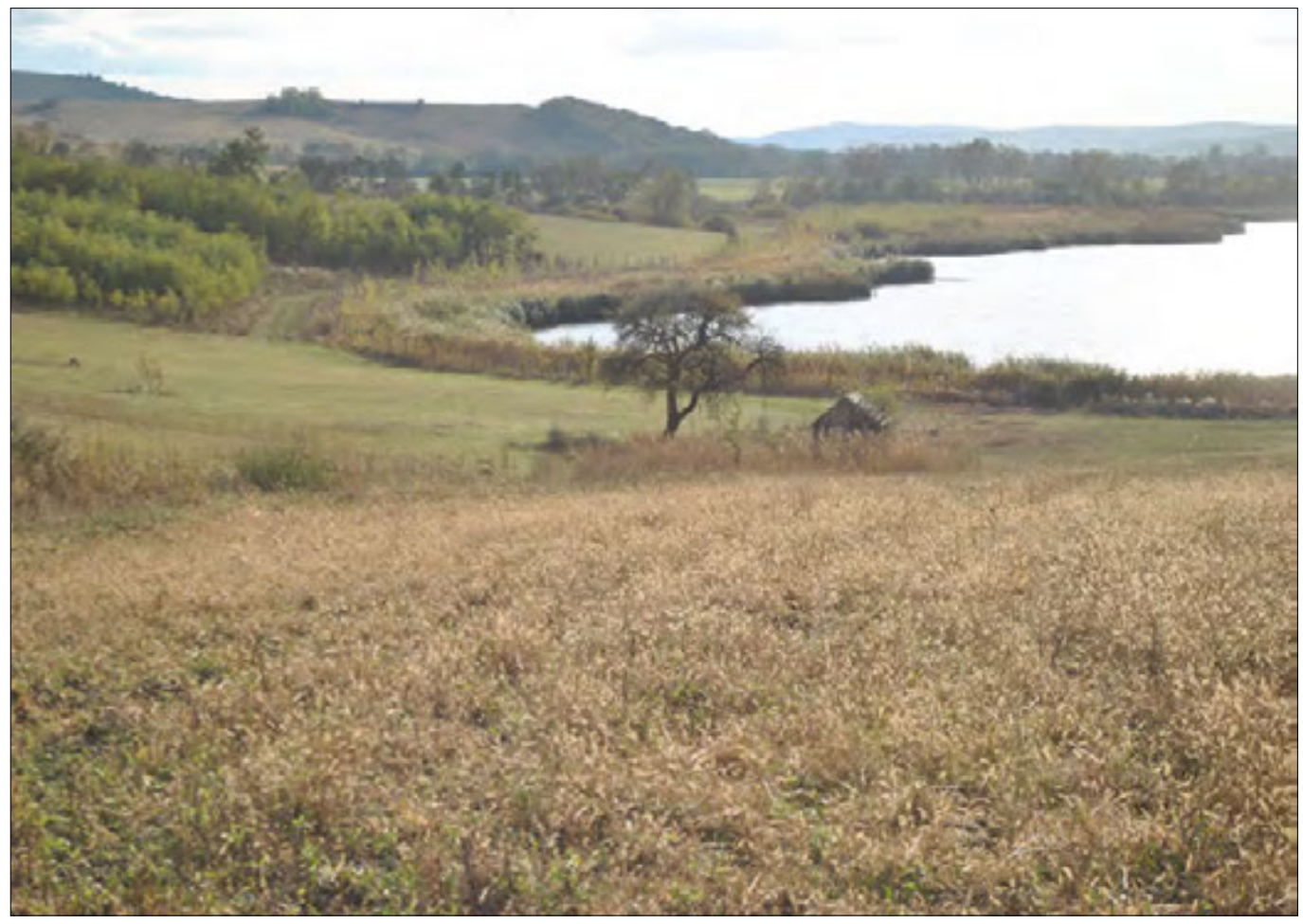

2. kép. Sós kút Homoródszentpálon (a szerző felvétele) 


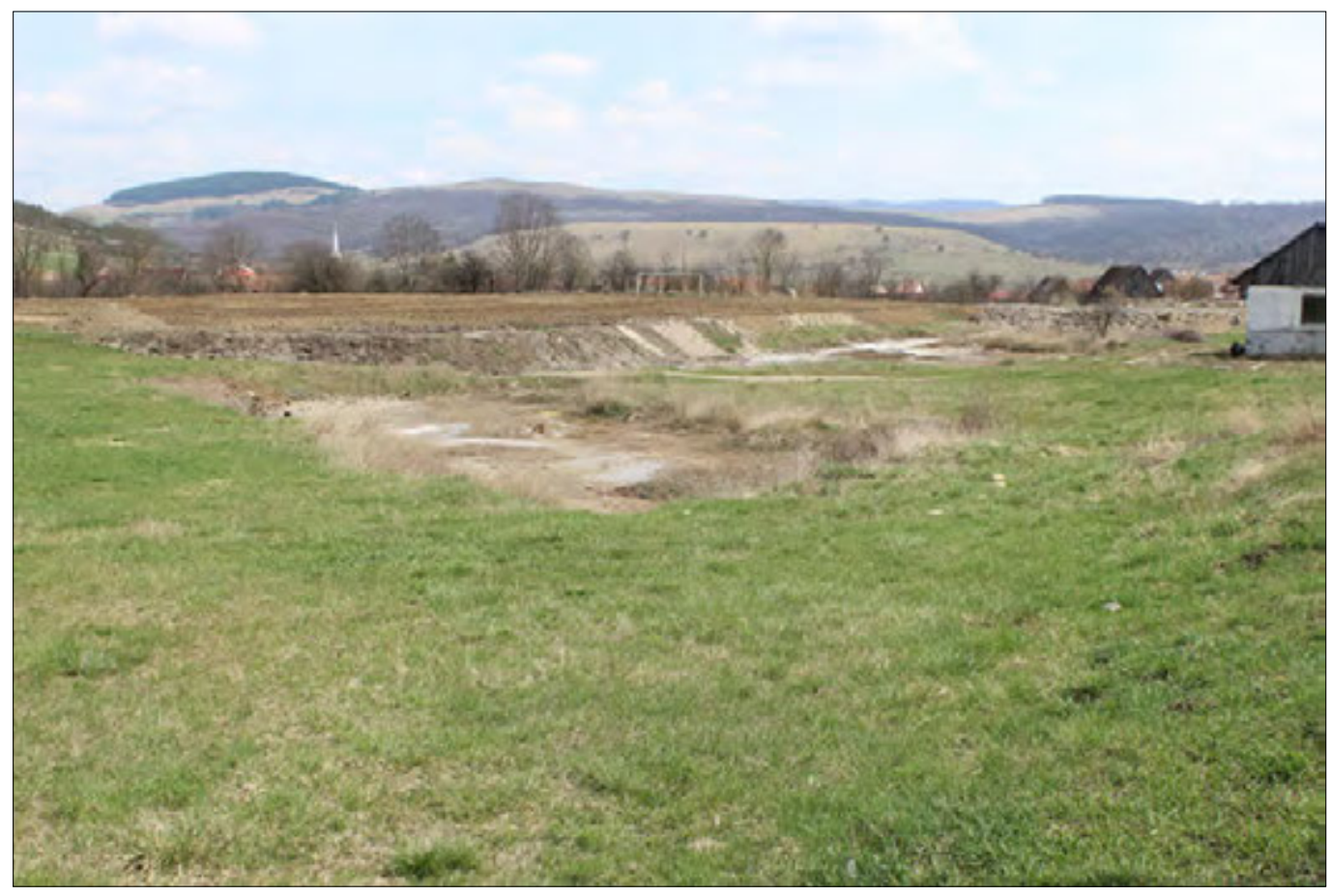

3. kép. Homoródszentmárton, a középkori sóbánya helyszíne (a szerző felvétele)

\section{A székelyföldi sókitermelés az Erdélyi Fejedelemség korszakának kezdetén}

A székely szabad sóhasználat vonatkozásában fordulópont az 1562. évi felkelés, ugyanis megtorlásának jogi következményei közt szerepelt az ingyen sóban való részesedés megszüntetése, és a segesvári országgyúlés kimondta, „hogy minden országokban a sókamarák császároknak, királyoknak és fejedelmeknek tárházokra néznek, azért a székely földén való sót a mü tárházunkhoz végeztük foglaltatni: de az fó népeknek házok szükségére való sót adatunk, mint az nemességnek régi szokás szerént só adatik" (SzOkl. II. 166.). A szabad székely jogból nemesi kiváltság lett.

A székelyföldi sóaknák egy részét bezárták, a tovább működőket pedig a sókamarai szervezetbe tagolták bele, Sófalván sóka- mara-hivatalt hozva létre. A szovátai sóaknák őrzésére és művelésére Báthori Kristóf 1578 előtt jobbágycsaládokat telepíttetett Szováta mezejére (Királyi könyvek 2005. 109. sz. regeszta, 68.), mely lényegében egy új település születését jelentette a Sóvidéken. 1583-ban Báthori Zsigmond fejedelem 50 marosszéki sóvágót minden adó és szolgálat alól felmentett, kivéve a sóbányában teljesítendő szolgálatot, ennek fejében 100 darab kősó után a kamarás 20 denárt kellett kifizessen számukra (Királyi könyvek 2005. 188. sz. regeszta, 93.). A Homoród mentén a sóaknák állandó működése megszűnt. Úgy tűnik, hogy a szentmártoni aknát többé már nem művelték, Szentpálról viszont vannak adatok sóvágásra a következő századból is. 1614-ben Bethlen Gábor engedélyezte Kornis Ferenc udvarhelyszéki fókirálybírónak, hogy Koncz Boldizsár sófalvi kamarás felügye- 
lete és ellenőrzése mellett 400 forintot érő sót vágasson egy zálogba vett birtok megváltásának fejében (SzOkl. IV. 192-193.). Homoródszentpéteren hasonló a helyzet a sóaknák használatát illetően, 1673-ban a fejedelem vargyasi Daniel István számára tette lehetővé, hogy itt sót vágasson udvarházai szükségletére (Daniel Lvt. 1894. 298-299.). Hogy a Homoród mentén a székely sókamara-hivatal folytatott-e mindemellett más jellegű sókitermelést, arra nincsenek adataink. (Pl. nem tudjuk, hogy a szentmártoni templomvár építésére sóadományt kiutaló Bethlen Gábor fejedelem rendelete melyik aknára vonatkozik.)

A sóügy a fejedelmi kancellária hatáskörébe tartozott, amely a sókamaraispánok tevékenységét felügyelte. Az első hiteles forrásból ismert székely sókamaraispán János deák (1568) (SzOkl. II. 225-226.), Székely Mózes édesapja volt, a későbbi erdélyi fejedelem is betöltötte mintegy évtizedig a tisztséget. A kamarás (más forrásokban gondviselő) hatáskörébe tartozott többek közt a sóaknák és azok jövedelmeinek kezelése, illetve a nemeseknek járó ingyen só kiadása.

A sókitermelés kezdetben a fejedelmi jobbágyokra hárult, a 16. század végétől viszont elsősorban a bányák környékén lakó falvak szabad székelyei végezték a sóvágást (helyenként egy-egy lófőt is találunk soraikban), és ismereteink szerint ebben az időszakban sem alakult ki egy kifejezetten sóbányászatra szakosodott társadalmi réteg a Székelyföldön, mint Erdély sóbányavárosaiban. A sókitermelés ősztől tavaszig folyt, a mezőgazdasági munkálatok idején többnyire szünetelt. A kamara által eladásra szánt sót a 18. századi forrásokból ismert ún. szekeresek fuvarozták a megrendelt helyre. 1595 őszén a székelyeknek ígért szabadság feltételei közt az is szerepelt, hogy „a só- és vasbányákat a fejedelem kapitányai gondozzák, de a közös kincstár költségeivel fogják müvelni, kivéve az ötven sóvágót és vasbánya mestert". ${ }^{6} \mathrm{~A}$ félszáz marosszéki és feltehetően ugyanennyi udvarhelyszéki sóvágó számát a későbbiekben a kiszolgált vagy a hadkötelezettség alól kibúvó székelyek sora gyarapíthatta, mint elszórt 17. századi adatok utalnak rá.

A székelyföldi sóbányászat a fejedelemség korában is felszíni fejtéssel folyt, mint Fridvalszky fentebb idézett leírásából kiderül. Az újkori forrásokból ismert kagylófejtés során ún. alaksót termeltek ki, a kagylóformán kinyert sót réseléssel repesztették fel a sótömzsből (helyi szóhasználatban: anyasóból), a múvelethez faékeket és fabotokat használva (Ld. P. Madar 1988. 224-226.). Elgondolkodtató az 1614. február 23. - március 16. közötti medgyesi országgyúlés 35 . artikulusának azon része, mely előírja, hogy „a székely sóaknára az régi szokás szerint való zab is megadassék" (EOE. VI. 422-423.), mert ez közvetve arra utal, hogy a sókitermeléshez már ekkoriban használtak lovakat, ugyanis a sószálításhoz általában ökröket vettek igénybe.

A 16. század második felétől fejedelmi igazgatás alá került székelyföldi sókitermelés tehát főképpen szervezetében különbözött a középkoritól, és a 18. századig a korábbihoz hasonló munkamódszerekkel és eszközökkel folyt.

\section{Jegyzetek}

1. Ld. részletesebben Sófalvi 2005. 164-165.

2. A probléma taglalását lásd bővebben Sófalvi 2005. 164-169.

3. A kérdésre összefoglalóan lásd még Sófalvi 2016. 295-301.

4. Fridvalszky 1767. 169. Magyar fordítása: Benkő J. 1999. II. 57.

5. Ld. Horváth 1998. 12.

6. Baranyai Decsi János históriája. In: Erdély öröksége. II. 119. 
lyuk óldảlábol, vért ont az mivefnek meg-fáradt tagiábol, bádgyadva vonfzák ki kớtélen az lyukbol.

Sótállando akoát nem mindgvárt találnak, fokat az viz mi. att kételen el-hadnak, vayki fok kốltéçge vagyon az aknának, az mig derckafon belo̊lók Sót vágnak.

Igen fok fzolga kel penig o̊ melléje, az bo̊lts elme ko̊zel ballagion fciéıe, az Sóvágonak. is légyen jo ereje, igen nehéz az Só,bajos emelnic.

Az fzép Deákság is fzolgál az aknákoak, Deákul kell tưuni az Kamora Lípannak, fzámot az magláfot nem. is adharnának, Ded́ktalanoknak ta találtatnának.

Az jo Kótél-gyártok, és az gyertya mártok, az jo hám tfinálok, az fendely faragok, feyfzével furoval, nagy bárdal az Atsok, aknákaak fzolgálnak az erós Kovátsok.

Az jeles Sóvágok cgéfz tárfasággal, aknáknak fzolgálnak crôis fảratsággal, ugyan meg-kúzdenck az nagy kemény Sóval, fokfzor munkájok-is elegy koporfoval.

Mert némely Sóvago az aknában talált, igen véletlenúl rettenetes halálte, kit az le efet Só mikor -gyon talált, egy f́zempillantárban ez világrol meg. vált.

Az Laytorárol is némeliyck le efnek, az nagy méleçg miat mert meg-iietkezack, az mozgo Laytorán avagy el fzédúlnck, fzórnyú halálokkal az aknában do̊lnek.

Mikot ezer ót fzáz hatván hatban irtak, Colofon egy aknát még akkor ifináltak, az údo̊tồl fogván abbol mind Sót, vágtak, gondold-meg azólta mely mélyf̣cget váytak.

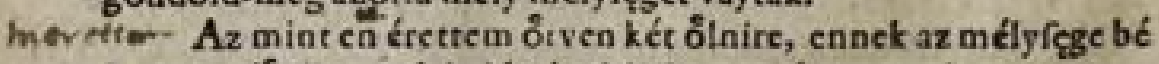
hator az fóldbe, tsak beić nézni-is illyen mély verembe, nagy posdultât fzerez ąember frivébe.

Azt mêtem mondani bátorsággal s-nyilván, találncék oly cm. bert az Varmegyetáján, hogy fzáz ház jobbágyért à fzerentfe fzárnyáa, aknába aem meane az mozgo laytorjan.

Az Sóvágo penig éyielis lemegyen, az ơ fẹrtállyának hogy héia ne légyen, hogy az fizctéfre mikor elómégyen, kalodázás nélkál bériben fel vegyea.

Nints.

4. kép. Szentmártoni Bodó János (1600?-1648): RMK I. 796. Az sonak ditsiretiröl valo magyar rythmusok a Johanne B. Szentmartoni. Nota: Meg adgya még Isten örömét, etc. Ez mellé adatott az Áts Mesterek ditsireti-is. Löcsén [Löcse]. 1647 (10. oldal) 
Nints illyen nagy dolog hegyben az kapálảs, az nyári kafzálto fem fzéna takarás, aratás, fem t fiplés, fem az buza fzórás, minden dolgozásnál nagyob az Sóvagás.

Még-is ennél foha óltsóbbat nem vefanek, probállyák mégh az kik menyegzốt fzereznek, kilentz pénzára Só hufz afztal vendégnek, igaz elég léfzen kit fel feai fôzhetnek.

Tiz pénzára jo két meg. súlt tyukmonyra, kõnnyen fel-vehetni az fzomjugyomorra, tiz pénzára Sót, (vigyék bár probára,) nem fóshatni mind fel tiz ezer tyukmonyra.

Ha penig mott nekem valaki igy fzolna: Im hallom az Sónak hogy vagyon fok hafzna, igen bajos penig vigafra az akna, oltsofaga tehát az Sónak hogy volna?

Hald-meg, az kérdéfre illyen az felelet : minden orfźagokat Iften bo̊vo̊fithet, gazdag tłrházábol mind ez világ élhet, onnat nemzettúnk-is az Sóban merithet.

Némely orfzágokat bõvófitet borfal,velentzét Czitrummal pomagránatokkal, Anglianak fóldét kies Rozmarintal, Tranfylvaniat-is meg.áldotta Sóval.

Szép ditfiretirồl ez nemes Erdélynek, Mufaim bõvebben énekelhetnének, mert nyilván eztárfa Chana sam fóldének, de mo. ftan fzemeim tsak az Sóra néznek.

Jolleher Cyrene fổldén fok Sót irnak, ugy hogy Kuñyotskákat az Sóbol tfinálnak, itt nállunk tornyokat Sóbol rak hatnainak, de pufzeta titulns nem keíl mi hazánknak.

Erdélynekálláfat ha confideralom, az jo Sónak erit magamban fzàmlálom, oly igen gazdagnak ez fóldet találom, nagy réfzro cz Orfzág Són fekfzik azt mondom.

Sok belyen találni Erdélynek határán, igen bỏvo̊n termet Colofon és Thordin, fok vagyon Défen-is, fzéken, és viz-aknán, Görgény vára mellet, s-Paraydon, Só falván.

Ne tsodallya tehát ezt az emberifzú, hogy fok hafzna vagyó, gond vágni, s-még. is bư, mert az mellyik alddás reánk Iftentől jú, oly fok mint tavafźzal áz súrún jốt zo̊ld fú.

Ez Orizágának penig kegyes Fejedelmi, nem akarjik árrát az $\mathrm{B}_{2}$

fónak

5. kép. Szentmártoni Bodó János (1600?-1648): RMK I. 796. Az sonak ditsiretiröl valo magyar rythmusok a Johanne B. Szentmartoni. Nota: Meg adgya még Isten örömét, etc. Ez mellé adatott az Áts Mesterek ditsireti-is. Löcsén [Löcse]. 1647 (11. oldal) 


\section{Felhasznált irodalom}

Benkő József: Transsilvania specialis. Erdély földje és népe. I-II. Fordította, bevezető tanulmánnyal és jegyzetekkel közzéteszi Szabó György. Bukarest-Kolozsvár, 1999.

Benkő Loránd: Maros- és Udvarhelyszék település- és népiségtörténetéhez. Századok 123 (1989). 3-4. sz. 342-358.

Connert János: A székelyek intézményei a legrégibb időktől az 1562-iki átalakulásig. Kolozsvár,1901.

Daniel Lvt. 1894

A vargyasi Daniel család közpályán és magánéletben. Szerk. Vajda Emil. Budapest, 1894.

Draskóczy István: Só a középkori Magyarországon. In: Gazdaság és gazdálkodás a középkori Magyarországon: gazdaságtörténet, anyagi kultúra, régészet. Szerk. Kubinyi András - Laszlovszky József - Szabó Péter. Budapest, 2008. 147-161.

Erdélyi országgyűlési emlékek. (EOE) I-XXI. Szerk. Szilágyi Sándor. Budapest, 1875-1898.

Erdély öröksége

Erdély öröksége. Erdélyi emlékírók Erdélyrôl. I. Tündérország. Szerk. Makkai László. Reprint kiadás. Budapest, 1993.

Géza Ferenczi - István Ferenczi: $O$ nouă mărturie epigrafică în legătură cu activitatea împăratului Lucius Verus în provinciile de lîngă Dunărea de Jos şi în Dacia. Sargetia 7 (1970). 59-78.

Fridvalszky János: Minerologia magni principatus Transilvaniae seu Metalla, semi-metalla, sulphura, salia, lapides \& aquae conscripta. Kolozsvár, 1767.

Horváth István: A székely sóbányászat rövid története. Parajd, 1998.

Imreh István - Pataki József: A székely falu gazdasági-társadalmi szerkezete a XVI. század végén és a XVII. század elején. In: Székely felkelés 1595-1596. Elözményei, lefolyása, következményei. Szerk. Benkő Samu - Demény Lajos - Vekov Károly. Bukarest, 1979. 146-190.

Iványi Béla: Két középkori sóbánya statútum. Századok 45 (1911). 1. sz. 10-30; 2. sz. 98-113; 3. sz.187-195.

Valeriu Kavruk - Maria-Magdalena Ştefan: Situl arheologic Comănești - La Fântâna
Sărată. In: D. M. Cioată - N. Man (eds.). Protejarea monumentelor saline de pe valea Mureşului Superior. Ghid de bune practici. Tg. Mureş, 2014.

Királyi könyvek

Az erdélyi fejedelmek királyi könyvei I. Báthory Zsigmond királyi könyvei 15821602. Erdélyi történelmi adatok VII. 3. Mutatókkal és jegyzetekkel regesztákban közzéteszi Fejér Tamás - Rácz Etelka Szász Anikó. Kolozsvár, 2005.

Középkori székelység

A középkori székelység. Krónikák és oklevelek a középkori székelyekrôl. A szövegeket válogatta, a kísérő tanulmányokat és a jegyzeteket írta Kordé Zoltán. Csíkszereda, 2001.

P. Madar Ilona: Adalékok a parajdi sóbányászathoz és sókereskedelemhez. Ethnographia 99 (1988). 2. sz. 213-236.

Oborni Teréz: Erdély pénzügyei I. Ferdinánd uralma alatt 1552-1556. Budapest, 2002.

Paulinyi Oszkár: A sóregálé kialakulása Magyarországon. Századok 57-58 (19231924) 1-6. sz. 627-647.

Sófalvi András: Sóvidék a középkorban. Fejezetek a székelység középkori történelméből. Székelyudvarhely, 2005.

Sófalvi András: Sóbányászat és sókereskedelem 1562-ig. In: Székelyföld története. I. kötet. Szerk. Benkő Elek - Oborni Teréz. Székelyudvarhely, 2016.

Sófalvi András: Hadakozás és önvédelem a középkori és fejedelemség kori Udvarhelyszéken. Kolozsvár, 2017.

Szekeres Lukács Sándor: Székely Mózes, Erdély székely fejedelme. Székelyudvarhely, 2007.

Székely Oklevéltár. I-VIII. Szerk. Szabó Károly - Szádeczky Kardoss Lajos - Barabás Samu. Budapest-Kolozsvár, 1872-1934.

Székely Oklevéltár. Új sorozat. I-VIII. Közzéteszi Demény Lajos - Pataki József - Tüdős S. Kinga. Bukarest-Kolozsvár-Marosvásárhely, 1983-2006.

Wollmann, Volker: Mineritul metalifer, extragerea sării și carierele de piatră în Dacia Romană. Der Erzbergbau, die Salzgewinnung und die Steinbrüche im römischen Dakien. Biblioteca Musei Napocensis XIII. Cluj-Napoca/Klausenburg, 1996. 


\section{FA ÉS FELDOLGOZÁSA}

\section{A KOMMANDó-KOVÁSZNA SIKLÓPÁLYA}

Hivatalos források szerint a Kommandó ${ }^{-}$-Kovászna ${ }^{2}$ siklóvasút a franciaországi Lyon és a magyarországi budavári sikló után a harmadikként épült Európában ${ }^{3}$ (Rosta István 1995). Sajtóinformációk szerint ez volt az egyedüli kitérőkkel épült gravitációs siklópálya, amely a legtovább üzemelt (1999. nov. 1.) jelentősebb átalakítás nélkül. Okkal állíthatjuk, hogy ez a szerkezet a 19. század mérnöki zsenialitásának egyik remeke, amely relatív 400 méteres szintkülönbséget leküzdve egy szédítően magas hegyen, kitérőkkel ellátva működött. Valamikor sok hasonló siklópálya létezett, de ez élt a legtovább, ezért vitathatatlan, hogy európai szinten egyedi ipartörténeti műemlék lehetne, ha megőriztük volna. A kommandóiak szemszögéből nézve közel 110 évig a sikló létfontosságú szerkezet volt, hiszen rajta szállították le és fel a rönköket, a szelvényárut, az élelmet, a gépeket, az utasokat, postai küldeményeket, pénzt, beteget, egyszóval mindent. A helybeliek sokáig csuszlónak nevezték, ez a népies megnevezés ma a múlt emlékei közé tartozik, és sajnos, lassan a szerkezet is oda kerül. A siklót Horn Dávid ${ }^{4}$ építette, majd a tulajdonosváltás után Groedelék ${ }^{5}$ tökéletesítették, úgy, hogy hozattak Bécsből egy kerekes fékezős álló szerkezetet. Gyakorlatilag a kerekes gépezettel együtt ismert a formája, működése. Tény, hogy 1890-től 1999-ig ez adott munkalehetőséget az évek hosszú során több száz munkásnak, akik közül sokan napjainkban is könnyes szemmel mesélnek azokról az évekről, amikor a siklói személyzet körébe tartoztak.

\section{A siklópálya szerkezete, működése}

Előzetesen olvassuk el a szerkezetről azt a leírást, ami különlegességnek számít:

„Térrét-Gyulafalvi ${ }^{6}$ sikló, tervezte Lux Emil, épült 1888-1890-ben, építette: Horn Dávid budapesti faiparos, tulajdonosa: Erdélyi Erdôipar Rt, az építkezési/kivitelezési munkálatokat Lux Emil és Tuñsek Pál vasúti mérnökök vezették." (M.O.L. 1891. P.111. A /4, 12,7fm.)

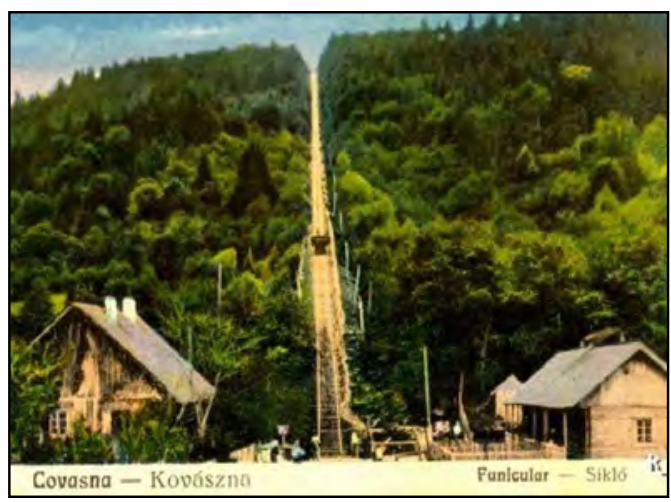

1. kép. A siklóópálya legszebb fotója (1925-ös felvétel) 
Az alábbiakban közöljük a szerkezetről azt a leírást, amit napjainkban, többnyire minden írott forrásban megtalálunk. Ez a leírás egykor ki volt függesztve a siklótetőn a gépházban. Állítólag még az 1960-as években is ott volt. Az eredeti nem tudni hogyan, de eltűnt, mert 1983-ban - Drunek igazgató idején - a vasutasok feldíszített mozdonynyal, állványkocsival ${ }^{7}$, ünnepi díszbe öltözve, fúvószenekarral tartott ünnepség keretében (7 évvel korábban) megtartották a 100 éves évfordulót. Viszont akadt olyan ember, aki lemásolta és megőrizte a leírást, mert 2004-ben Péter János (szül. 1953) kommandói adatközlő jóvoltából hozzám került. Íme, a másolat:

„Kovászna - Kommandó siklópálya, tervezte Lux Emil, épült 1888-1890, építette az Erdélyi Erdőipar Rt. A dán gyártmányú sikló adatai:

*Hossza: 1268 m

*Az állványkocsik nyomtávolsága: 1445 mm

*A felső állomás tengerszinttől számított magassága: $1013 \mathrm{~m}$

*A középső állomás tengerszinttől számított magassága: $853 \mathrm{~m}$

*Az alsó állomás magassága: 686 m

*A felső szakasz emelkedése: 268\%o
*Az alsó szakasz emelkedése: $280 \%$ o

*Menetidő: 15 perc

*Szintkülönbség siklóalja és siklótető között: $327,7 \mathrm{~m}$

*Az 1236 m hosszú sínpáron két állványkocsi található, amelyeket egy $28 \mathrm{~mm}$-es acélkötél köt össze. Az acélkötél 6 ágból áll, minden ág 19 különböző méretű drótból áll: 1.- 2,7 mm; 2.- 2,3 mm; 3.-1,3 mm, összesen: 114 szál drót.

*Szakítási próba: 54000 kgs.

*A gépezet: TH OBACH / Masinenfabrik Wien

*A pálya lejtése: 28 - 40 fok." (Szabó Mária 2004. 45-46.) (1. és 2. ábra Péter Klára dolgozatából)

Mivelhogy ez a szerkezet egyedinek számított, s a későbbiekben a folyamatos javítások, felújítások, siklótüzek és különböző változtatások miatt az idők során többször módosítottak rajta, úgy véljük, hogy fontos az első, pontos szakirodalmi leírás közlése mind a gépezet összetételéről, mind annak a működéséről. Az első leírást a frissen tökéletesített siklópálya szerkezetéről, működéséről, a kötelekről és a sínekről Sümegh Ignác 1898-ban tette közzé az Országos Erdészeti Egyesület közlönyében, az Erdészeti Lapokban.

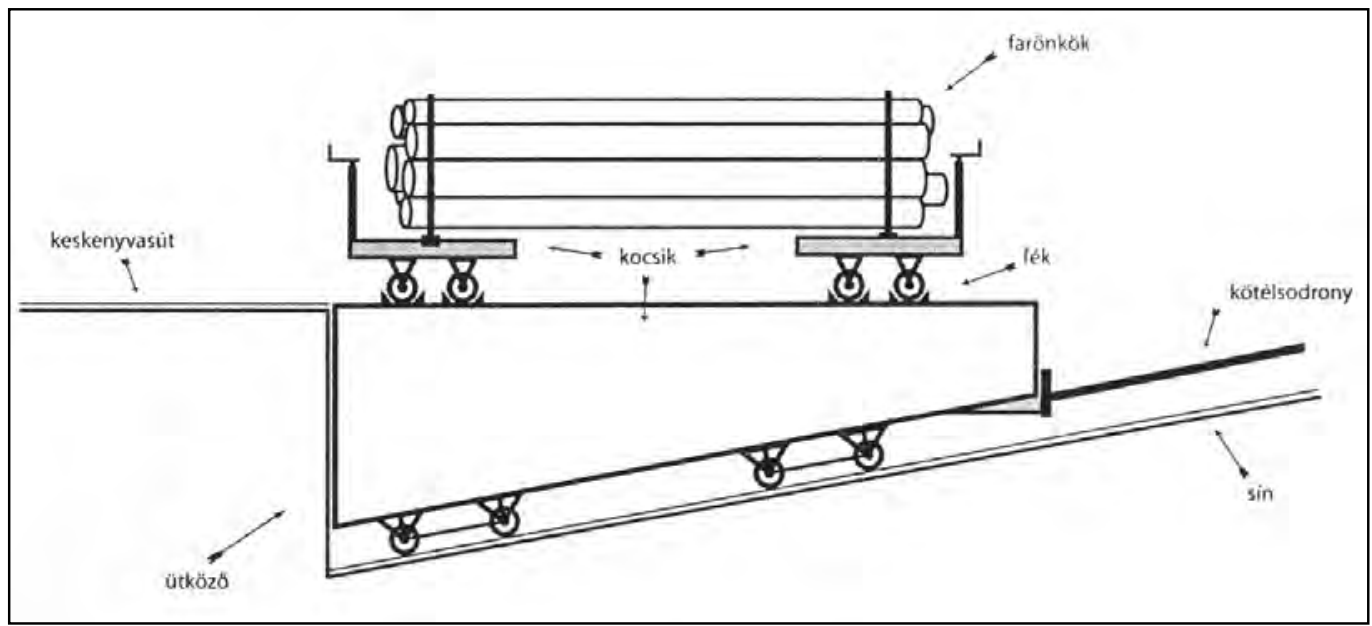

1. ábra. Vázlatrajz az állványkocsiról (Péter Klára dolgozata) 


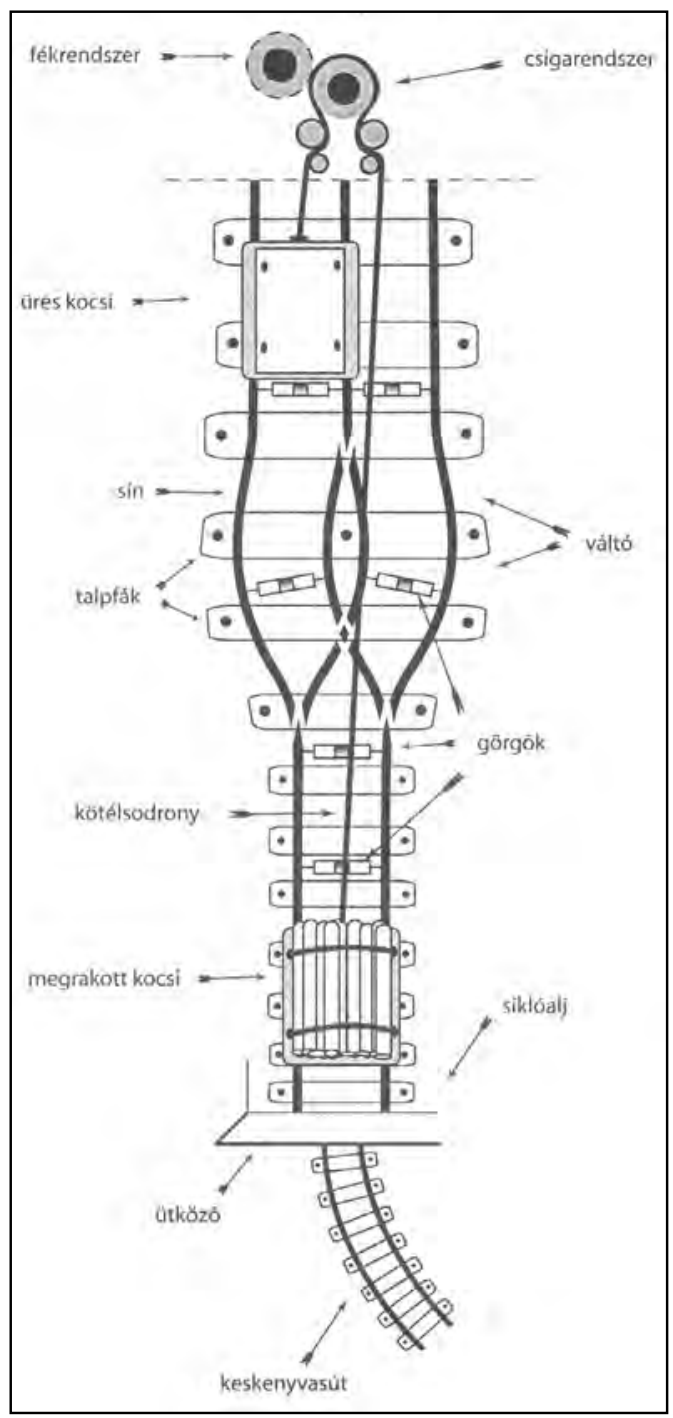

2. ábra. A sikló múködése (Péter Klára dolgozata)

„A sikló szerkezete Th. Obach bécsi cégtől származik. A vállalat a siklót kisebbített méretében szerkesztve az ezeréves kiállításon bemutatta. A sikló förészeit képezik: a) siklópálya, b) a felsősiklón alkalmazott gépezet, melynek fóbb részei a kötéldobok és fémkorongok, c) siklókötél, d) két sikló-állványkocsi, melyekre az üres, ill. a megrakott kocsikat kell rátolni. A pálya hossza $1258 \mathrm{~m}$. Legnagyobb esés-emelkedés: 345\%o, legkisebb esés-emelkedés: 220\%o, átlag esés-emelkedés: 268\%o. A sínek Bessemer-acélból készültek, súlyuk folyóméterenként $15,7 \mathrm{~kg}$. Nyomtáv normális 1,435 méter. A sikló viszonylagos magassága 328,54 méter. Minthogy a teher felülről lefelé szállíttatik, erőfejlesztő gép teljesen szükségtelen, és a sikló a ferde síkon való esés törvényén alapszik, a kötél felsô végéhez a teherkocsi, alsó végéhez pedig az üres kocsi van erôsítve. A kötél a sikló felső részén elhelyezett dobokra úgy van körülcsavarva, hogy a jobb oldali dobról 3-4 szeres körültekeredés után egy merôleges tengelyü vízszintesen forgó kerékdobra, onnan egy bal oldali kerékdobra csap át, erre ismét 3-4 szeresen feltekeredik. A kötélnek a bal oldali dobon túl haladó vége a megterhelt sikló állványkocsihoz köttetik. A teherkocsi kikötése esetén, önsúlya következtében lefelé haladván, forgásba hozza a kötéldobokat és húzza fölfelé az üres kocsit. A siklókocsi sebessége a dobokhoz alkalmazott, előbbieket körülfoglaló fémkorongok össze, vagy széthúzással szabályozható. [...] A sínek Bessemer acélból készültek, súlyuk folyóméterenként $15,7 \mathrm{~kg}$, a nyomtáv normális. [...] A vállalat eddig kétféle szerkezetű siklókötelet alkalmazott, az Obach félét és a Wakefieldi George Crafdock félét. Az Obach-féle kötél áll: 114 szál 1,6 mm vastag tégelyacél sodronyból és úgy van szerkesztve, hogy a 114 szál sodrony 6 kötegre osztva egy kenderbél körül van fonva. A kötél $25 \mathrm{~mm}$ vastag, és súlya folyóméterenként 2,08 kg. Mindegyik sodrony keresztmetszete 2,01 $\mathrm{mm}^{2}$. E szerint tehát az egész kötélnek keresztmetszete 002,01 $\mathrm{mm}^{2} \times$ $114=229 \mathrm{~mm}^{2}$. A kötélanyag a legkitünőbb tégelyacélból áll és $1 \mathrm{~mm}^{2}$-kint $180 \mathrm{kilog}$ ramm ellenálló képességgel bír, tehát a kötél ellenálló szilárdsága $229 \times 180=41.220 \mathrm{~kg}$. A megterhelt sikló állványkocsi súlya mintegy $13.000 \mathrm{~kg}$. És a siklópálya (hosszmetszetének 
átalakítása elött) legnagyobb esése 410\%o volt. A kötélhúzó feszültsége $4940 \mathrm{~kg}$. Ez a feszültség a rendes üzemnél mutatkozik, mely azonban vigyázatlan gyors fékezés folytán $9000 \mathrm{~kg}$-ra is emelhetô. Ez utóbbi esetben a kötél biztonsága 41.220: $9000=4,59$ azaz a kötél 4,59 szoros biztonsággal bír. Az angol kötélnek következő a szerkezete: áll 6 kötegböl, mindegyik 7 belső 1,2 mm és 8 külső 2,3 mm vastag tégelyacél sodronyból, tehát összesen 90 sodronyból kátrányozott kenderbéllel. A kötél átméróje $27 \mathrm{~mm}$, súlya $30.000 \mathrm{~kg}$, ezzel a kötéllel 10.000-11.000 kocsi lebocsátható. A vasúti kocsik közül kétféle van alkalmazásban 5000 és 6000 kg raksúllyal, e szerint a fürészárukból 10-12 $\mathrm{m}^{3}$ rakható. Naponta 50-55 kocsi ereszthető le, ami 400-450 $\mathrm{m}^{3}$ szelvényárunak és 5-10 kocsi bükkárunak felel meg." (Sümegh Ignác 1898. 1009-1010.)

$\mathrm{Az}$ alábbi ismertető a sikló múködésének utolsó 55 éves időszakáról (1944-1999) forrásmunkák és az adatközlők - javítók, karbantartók, utazószemélyzet, munkások visszaemlékezései alapján készült.

A sikló vasútpályája tulajdonképpen két részre osztható, az alsó és felső pályára, amiket a középállomás választ el egymástól. A felső pálya háromsínes rendszerű, amelyből a középső sínszálat mindkét állványkocsi használja. Az alsó pálya hagyományos kétsínes. A középállomás félkör alakú sínpárokkal van kiépítve, a völgy felőli részén található a kocsikísérők által állított váltó, a hegy felőli részen a belső sínszálak összefonódásával alakult ki a háromsínes vágány. A sikló felső állomásához kapcsolódva, a kocsik rendezéséhez 4 vágányos végállomást építettek, melyből kettő fut be az állványkocsikhoz. Innen indul a kisvasút felső 10 km hosszú fővonala Kommandóra (Nagy Jenő 2002. 10.).

Az állványkocsi, amely a siklótetőtől a sikló aljáig közlekedik, két részből áll: az alvázból és a fedélzetből. Az alváz vasból készült, és négy keréken mozog. Az alsó két kerék nem illeszkedik közvetlenül a vázhoz, csak vasrudak segítségével, s ez biztosítja, hogy a fedélzet mindig biztonságosan álljon. A fedélzet vastag pallódeszkából készült, a szélén vaskorlát van, a közepén pedig sínpár, ugyanis erre húzzák rá ló segítségével a kocsikat. Az egész építményt acélkötél tartja, s ezért a két vasúti sín között rolnik ${ }^{8}$ vannak, amelyeken a kötél gördül. Ha a kötél a földön csúszna, nagyon gyorsan elkopna (elmondta Biloklávek Mátyás).

Az állványkocsikra széles talpú síneket szereltek, amelyeket széles fém alátétlemezekkel és tirefon ${ }^{9}$ csavarokkal fogattak fel a talpfákra.

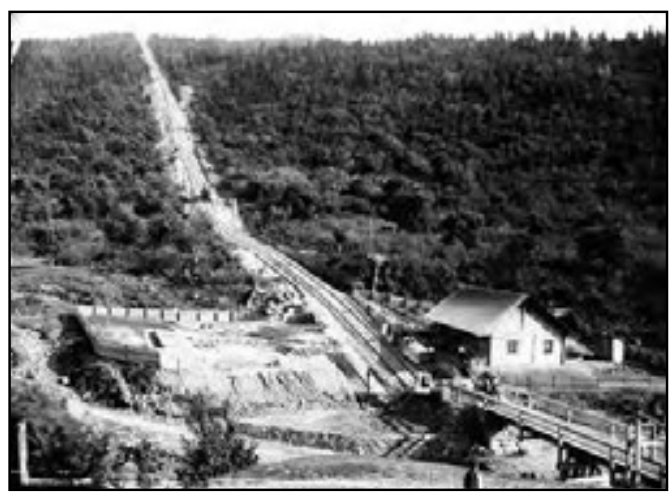

2. kép. Ismert felvétel a régi siklóról (Adler L.,1924.)

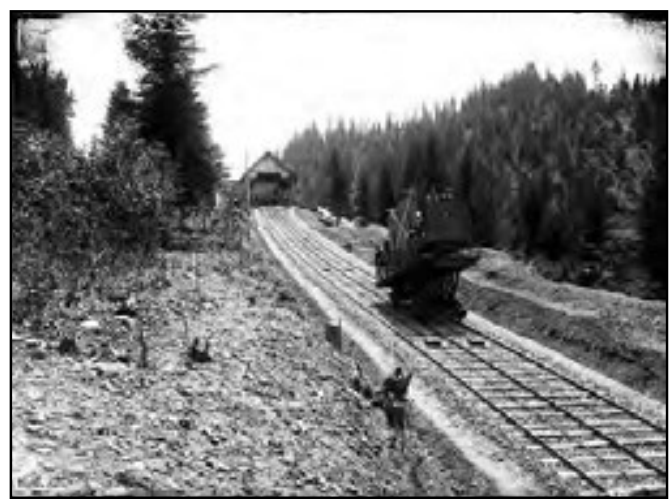

3. kép. Kovászna-Kommandó gravitációs siklópálya (archív felvétel) 
Fontos volt a sínszerkezet stabilítása és keménysége, ellenkező esetben nem bírta volna meg a rakományt. A góri siklónál ${ }^{10}$ még ennél is szélesebb volt a sínek talapzata, ezeket góri sínnek vagy talpas sínnek ${ }^{11}$ nevezték, ugyanis itt nem volt állványkocsi, és ilyen talpas sínekből állt az egész siklópálya. Az emlékek szerint még a kommunista rendszerben is volt arra példa, hogy ilyenekből javították ki a kovásznai siklón az állványkocsi sínszerkezetét. Sajnos, hogy még az ilyen talpassín-maradványokat is eladták ócskavasnak (elmondta Biloklávek Mátyás).

A két állványkocsira fel volt szorítva az acélkötél, amely a sínpár közepén vezetett végig. A kötelet kívül öntvény, belül rézgörgők segítségével rögzítették. Körülbelül 200 darab kisebb-nagyobb rézgörgő volt a siklópályán, amelyek pörögtek menet közben, és megadták a kocsik sebességét, azonkívül ezek védték a kötelet az esőtől, hótól, sártól. A szálak központi része a tetőn felállított gépházban volt. A sikló az egyensúly alapján működött. Motorra és üzemanyagra nem volt szükség, mert a vontatáshoz szükséges energiát a megrakott kocsi adta, a terhelt kocsi egyszerűen kihúzta a völgyből az üreset. A sebességet fékrendszerrel szabályozták, volt olyan eset is, hogy füstölt a rendszer, mert a nagy sebességtől és a súrlódástól felhevült, ilyenkor vízzel locsolták (elmondta Biloklávek Mátyás).

A csuszló „szívéről”, vagyis a kerekes szerkezet későbbi működéséről olvassuk el az adatközlésen alapuló ismertetőt.

A gépházban a szerkezet alatt volt egy jókora pincehelyiség, ahová lépcsőn lehetett lemenni. A pince csapóajtóval volt ellátva, ezt csak akkor tartották nyitva, amikor dolgozott az álló szerkezet. A látvány lenyűgöző volt. Középen egy hatalmas vízszintes állású csillagkerék forgott, ez öntvényből készült, és hasonlított a gőzgép lendkerekéhez, egyszerü, vájat nélküli, sima kerék, amely körülbelül 5 tonnát nyomott, rá volt szerelve hat darab félhold alakú acéldob, ezek vájatokkal voltak ellátva, ugyanis a kötél ide volt bevezetve. Az acéldobok egyenként másfél mázsát nyomtak. Ezt a központi kereket dobkeréknek vagy csillagkeréknek nevezték.

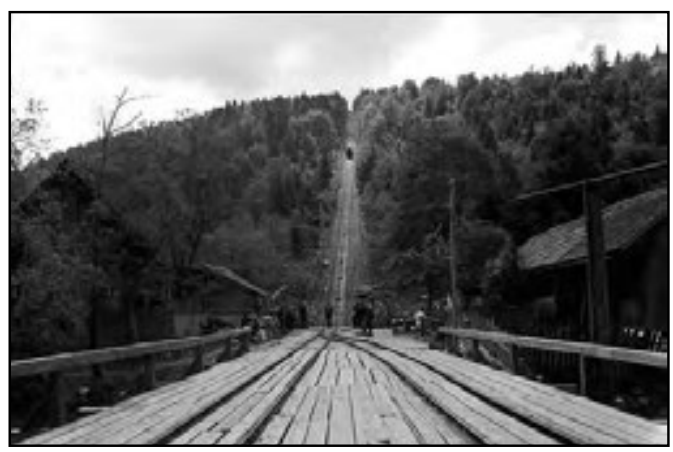

4. kép. Alsósiklón a híd 1924-ben

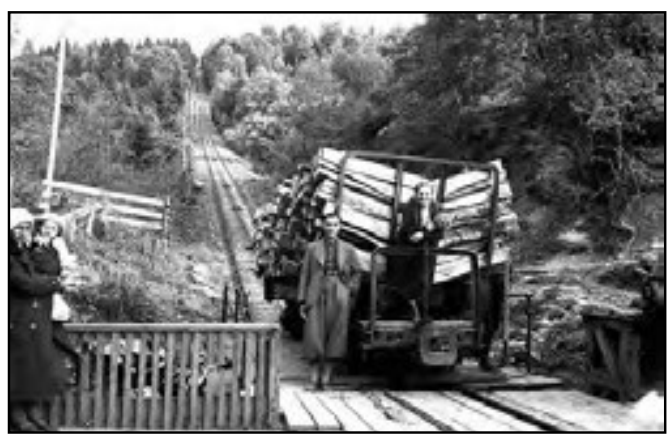

5. kép. Rakott állványkocsi (1924)

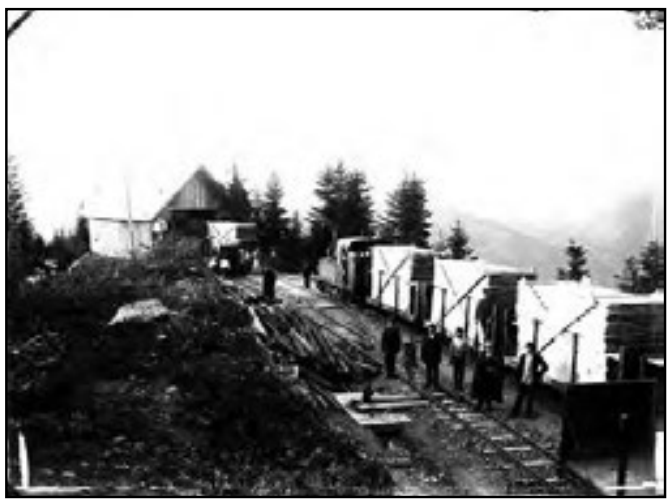

6. kép. Rakott kocsik a siklótetőn (archív felvétel) 
„Tegnap nyílt meg a Kovászna-Térrét-Gyulafalvi iparvasút, melyet Horn Dávid és társai építettek a papolci határban fekvő fenyőerdők kihasználása végett. Szavahihető emberek szerint széles e hazában, sôt azonkívül is messze körben ritkítja párját ezen merész és mégis kitünően sikerült vállalat, legföképpen pedig annak vasúti része. Kovásznán felül a Horgász nevü gyógyforrás közelében levő Térrét nevü helyrôl indul a pálya. Kezdetben pár kilométernyi síkságon halad át. Azután 1870 méter hosszan egy szédítöen meredek oldalon, melybe 345 m magas sodronykötél által vont sikló van beiktatva olyanképpen, hogy a terhelt kocsi felülről jôve saját súlyával felhúzza alolról az üres kocsit olyanképpen, hogy a két kocsi középen találkozva az e célra berendezett készülék segítségével kitér egymás elől. Azután újból rendes pálya következik, mintegy odaragasztván a meredek kősziklaoldalhoz, gyönyörü kilátást nyitva a szép háromszéki síkságra. Végül a fenyvesek végeérhetetlen tömkelege jön, szebbnél szebb allékat képezve a helyenként nyílegyenesen haladó pálya két oldalán, míg végre a „Gábor-fürész " nevü felső telephez ér, ahol egy egész kis helység képződött alig egy év leforgása alatt. Ezen áthaladva újból gyönyörü síkságon halad tovább, mindig és mindig fenyvesek között a Nagy-Baszka-patak bal partján a Györke-patak torkolatáig, hol a »József-fürész «fekszik, melyet közel két évvel ezelőtt avatott fel közönségünk lelkes öröme és részvétele között az akkor még egyedüli Horn Dávid tulajdonos[...] Azután következett a beszentelés [...] a beszolgáló zágoni róm. kat. lelkész és a kovásznai református, evangélikus és görögkeleti lelkészek tartották meg azt a villanyfénnyel világított gépházban az összes vendégek és gyári munkások jelenlétében, majd a Gábor-fürész feletti magaslaton álló vendégszálló villa éttermében folytatódott az ünnepség."

(Székely Nemzet 1889.3.)
A visszaemlékezők szerint a csillagkerék egy darabból állt, és valamikor lovakkal vontatták fel a siklótetőre a pályatest melletti rövidítő útszakaszon, amelyet később az utasok is használtak, ha nem engedték felszállni őket a siklóra. A kereket egyesek „vájat nélküli keréknek" is nevezték (elmondta Biloklávek Mátyás).

A dobkerék alá fel volt szerelve az orsósfék muffal ${ }^{12}$ ellátva, és a tengely acélból volt öntve, a forgórész csapágyai valamikor bronzból voltak esztergálva, később a bronzot rézzel helyettesítették (ezen forgott a dobkerék). A dobkerék mellett még volt két kisebb függőleges fekvésű fogaskerék, jobb és bal oldalon: a bevezető és kivezető kerék, ezeken volt keresztülvezetve a kötél, s a kerék rakta egymás után a kötelet a százötven kilós dobokra, amelyekbe be volt vezetve a kötél. A bevezető kerékről ment a kötél a dobkerékre kétszer megcsavarodva, hogy fékezéskor ne csússzon, egyszer bejött onnan a fordítókerékre, tehát bal oldali kerék, dobkerék, jobb oldali és vissza a kivezető kerékre. A bevezető és kivezető kerekekre voltak felszerelve a különböző drótterelő szerkezetek, valamint itt voltak a siklócsapágyas csigák is (elmondta Péter János).

A dobkerék szélére volt felvezetve $2+2$ fékcsintura ${ }^{13}$, erre jöttek rá a szilfatuskók ${ }^{14}$. 32 darab ilyen szilfa féktuskó volt egy-egy fékcsinturán. A fék tolatószerkezetéhez (hátramenethez) réz, majd elkopás után vas csapágyak járultak hozzá. A kötél vastagsága 30 mm. Egy új kötél 22000 kocsit bírt meg cserélés nélkül, és $25 \mathrm{~mm}$-ig volt szabad elkopnia. A dob átmérője, ahova a kötél jön, $1550 \mathrm{~mm}$, a féké $2010 \mathrm{~mm}$, a csinturák háza 8 darab 7/8-as csavarral volt rögzítve. A fordulatszám matematikai számítás szerint: $1550 \times 3,14=4,887 \mathrm{~m} / \mathrm{m}$ - fordulat, vagyis 267-et fordult egy kurszában ${ }^{15}$. Súlykülönb- 
ség $6500 \mathrm{~kg}$, felül $12000 \mathrm{~kg}$ a pőrekocsi ${ }^{16}$ súlyán kívül. A kötél szakítószilárdsága 55000 kg. Érdekességként eláruljuk azt a titkot is, hogy a kötél közepébe csihányspárga ${ }^{17}$ volt belefonva, azért, hogy a dobra csavarodva a dob ne vágja el. Az állványra helyezett kocsi hossza 6,30 m (ekkora volt a rajta levő sínpár), a rönk vagy a rakomány lehetett hosszabb. Az adatközlők szerint a dobfalak 1942-ben és 1981-ben voltak kicserélve. A fából készített sámlik csúszásgátló szerepet töltöttek be (elmondta Ferencz János és Jenei Gyula).

Ha már kikopott, a kötelet lecserélték, de általában nyáron szükséges volt vízzel locsolni, hogy a nagy súrlódástól felmelegedett kötél nehogy meggyúljon. A fékorsó végétől lánc jött fel a kormánykerekekre, amelyen két mánus ${ }^{18}$ volt, ami mutatta a kocsik helyzetét. A vezérmű két darab, hajókormánykerékhez hasonló fogantyús kerék segítségével múködött, ezek egymással párhuzamosan voltak felszerelve. Az acéldobokat négyszög alakú szilfából készült sámlival ${ }^{19}$ (fékcsintura, féktuskókkal) biztosították le, ezeket fékpofáknak nevezték, amelyek a felső kerekek szorításával, illetve lazításával fékezték vagy engedték a kocsit. Az adatközlő szerint - aki valamikor a gépészt helyettesítette - azért volt két fékcsintura, mert mindkét felső kormánykeréknek külön-külön megvolt a saját szerkezete, az egyik kerék a felső állványkocsi, a másik az alsó állványkocsi irányítására szolgált. Rendszeresen az alsó kocsit irányító kereket eléfelé hajtották, vagyis eresztették a kocsit, mert a felső kocsi a gravitációnak megfelelően önsúlyától fogva lejtőre jobban ment, ezt a kereket inkább szorították, de volt olyan eset is, hogy mindkettőt visszafelé kellett húzni, vagyis fékezni kellett, mert nem volt szabad túl gyorsan engedni a kocsikat, hiszen nagyon könnyen elszabadulhatott a pokol (elmondta Biloklávek Mátyás és

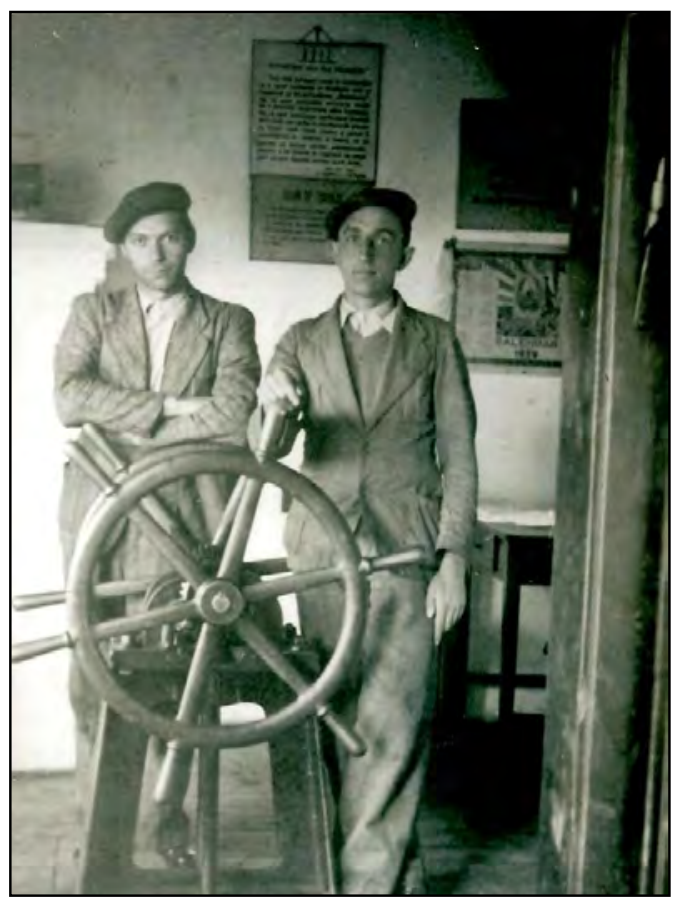

7. kép. A gépház az 1930-as években, Jenei Gyula és Fejér András

Jeney Gyula).

A szerkezet gépésze - a siklópálya legfontosabb személye - a nyitott pincéből látta a szerkezet működését, a mánusok mutatták a kocsik helyzetét, s a lánc pörgéséről tudta, hogy mikor kell szorítani, illetve lazítani a kerekeket. Ha könnyű volt a kocsi, többször kellett fékezni, ha nehezebb, kevesebbszer. Ha a kötél megnyúlt a nagy súlytól, a pincében vágtak ki belőle. Leszerelték a felső kocsiról, és megrövidítették, majd újrafonták a kibomlott részt, ehhez Bandi bácsi (Fejér András) értett a legjobban. Az acéldobokat a kikopás után újjal cserélték ki, és a selejtezettekre kétfelől fogantyút hegesztettek, ezekből készült a dobfal (aggfal), amelyet ellensúlynak használtak. Valamikor 40 darab ellensúlyt tartottak a siklótetőn. Lehet, ma már egyet sem találnánk meg belőlük (elmondta Biloklávek Mátyás). 
Az alsó siklót és a tündérvölgyi vasúti szakaszt egy merész patakvölgy választotta el egymástól. Ezt a részt egy gerendákból és pallókból készült híddal kötötték össze, aminek a közepén vasúti sínpár helyezkedett el. A könynyűszerkezetű híd hossztartói, kereszttartói rönkből készültek, és az ívviszonyok miatt csak lóvontatással vagy emberi erő segítségével lehetett a kocsikat továbbítani. A kovásznai hídfőnél volt a Térrét vasúti állomása.

Az évek során nagy hangsúlyt fektettek az sikló alatti híd karbantartására, mert ez képezte a fó kapcsot a sikló és a vaspálya között. A szokásos kopáson kívül sokszor volt árvíz vagy tűzeset, ami miatt újra kellett a hidat építeni (nagyon sok színes felvételen látszik az új híd), 1999-től, vagyis miután a siklópálya leállt, a híddal sem törődött senki, folyamatosan romlott, végül 2006 tavaszán a Kovászna-pataka ismét megáradt, és elvitte a maradványokat is.

\section{A siklópálya üzemeltetése és karbantartása}

A sikló üzemeltetéséhez külön személyzet tartozott. Állványkocsinként két fő, továbbá a felső állomáson egy gépkezelő, aki egyben a telefont is kezelte, 2 revizor, 2 fékező, 4-6 tolató és pályamunkás. Az alsó siklón egy forgalmista, 2 revizor, 2 fékező, 4- 6 tolató és pályamunkás. Az 1970-es évektől a személyzetet lassan leépítették, az utolsó években összesen 10 fő dolgozott a siklón.

Az állványkocsik személyzete (a tolatók) a következő feladatokat látta el: a lovak és lószerszámok gondozása (esetleges patkolása is), a tolatási műveletek elvégzése. Mind a felső, mind az alsó siklón volt ló és lóistálló. A húzató lovak általában apró, mokány termetű vagy herélt, béketűrő állatok voltak. A legendás fehér lovat - számtalan fotón látható - a magyarok Jancsinak, a román munká-

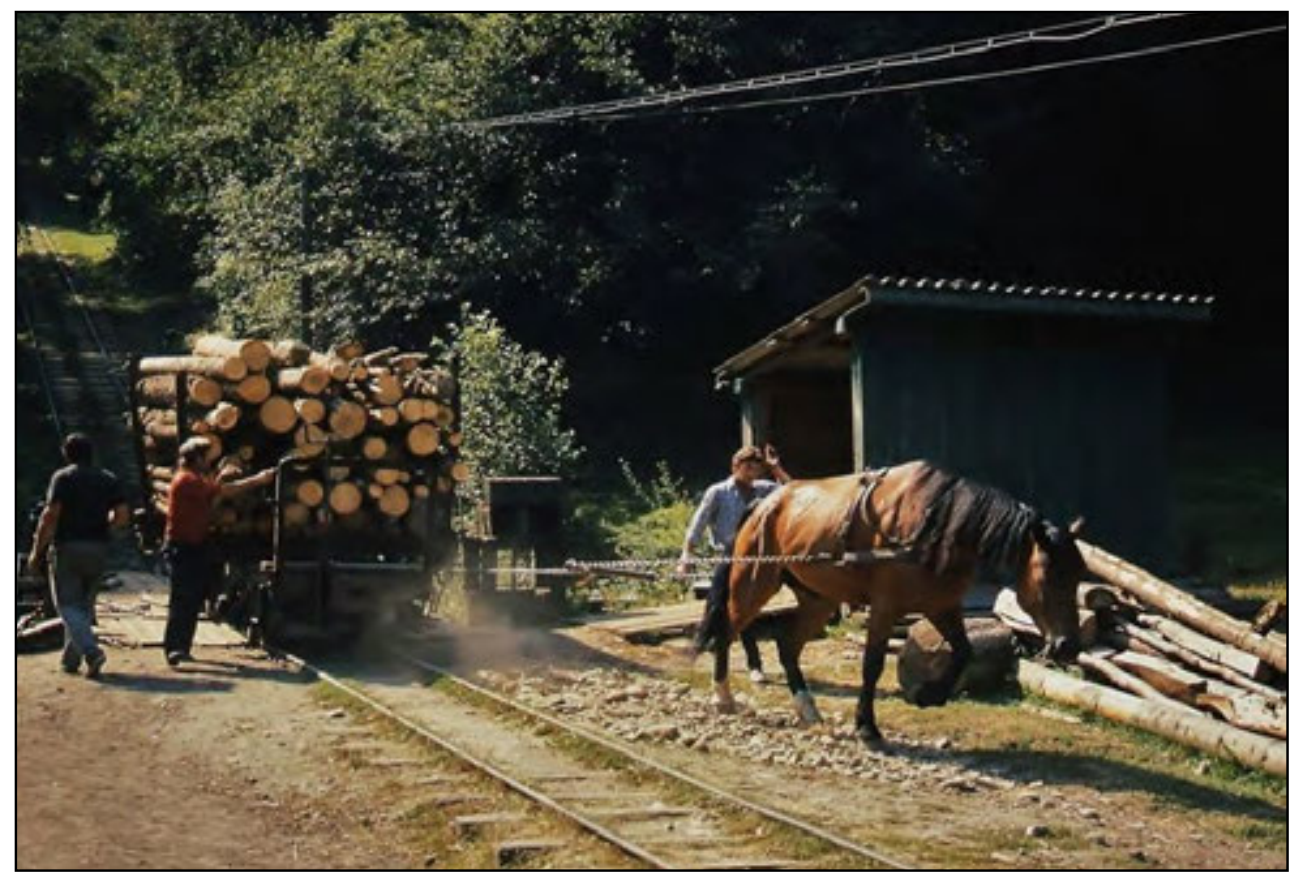

8. kép. Lóvontatás az alsó siklón (1999-es felvétel) 


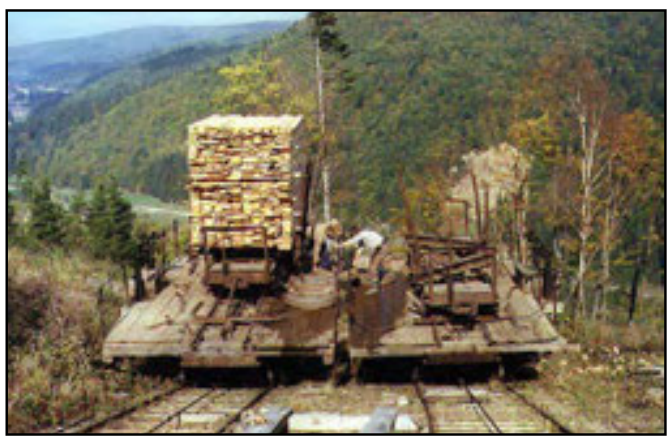

9. kép. Siklóközép ellensúlyokkal (Sáfrány Lajos, felvétele, 1996)

sok Ioanénak nevezték. Úgy beszélik, hogy ez a ló szolgált legtöbb ideig a siklópályán, még félig vakon is tudta a dolgát. A kocsi feltolása egyébként szalasztásos módszerrel történt, a hámot egy horoggal a drukk alvázához ${ }^{20}$ kötötték, a személyzet egyik tagja a lóval megindította a kocsit, a másik pedig a fékálláson állt. Amikor a kocsi kellőképpen felgyorsult, a horgot kiakasztották az alvázból, a kocsi felgurult az állványkocsira, a fékező pedig időben megállította azt (elmondta Gál Sándor és Szabó Csaba).

A deszkákkal, rönkfákkal, szelvényáruval, tűzifával stb. rakott kocsit lóval vagy emberi erővel ráállítják az állványkocsira a felső állomáson, az alsó állomáson pedig az üres truckpárt (pőre kocsi) vagy a hamburgot ${ }^{21}$ (platós kocsit), miután feltolták a kocsikat, rögzítik. Majd ha a rögzítés megtörtént, következett a csöngetés, illetve telefonos engedélykérés, ezután kioldották az állványkocsikat rögzítő reteszeket, ugyanakkor a fenti fékező oldotta a kötéldob fékjeit, s ezzel a rakott kocsi súlya a felső állomásról elindította az állványkocsit lefelé, a másik állványkocsit a völgyből fölfelé. A két kocsi a középállomáson találkozott, platójuk ${ }^{22}$ pereme szinte összeért. Mivel a kilométernél is hosszabb drótkötél súlya mindig az alsó kocsi súlyához adódott hozzá, ezt ellensúlyozandó a felső kocsin ezzel egyenértékű kiegyenlítő súlyokat kellett tartani (ezek voltak a dobfalak fogantyúval felszerelve). Ezeket minden egyes menetben kézi erővel át kellett rakni a középállomáson a lefelé tartó kocsiról a felfelé tartóra. A tolatószemélyzet tagjai mindig a saját pályaszakaszukon dolgoztak a siklón, mert a középállomási váltás után vissza kellett térniük a pályarészletükhöz, valamint az általuk jól ismert és megszokott lóhoz (elmondta Biloklávek Mátyás és Jeney Gyula).

Az adatközlők úgy mesélték, hogy az 1950es évek elején az alsó siklónál a munkások a hídon kézi erővel dolgoztak, mert a második világháború után évekig nem volt ló. A sikló alatt akkoriban minden kurszánál ${ }^{23}$ hat ember tolta a rakott kocsikat a híd tulsó oldalára, utána pedig az üres kocsit rátolták az állványra, a kocsikat talaborok ${ }^{24}$ segítségével lefogatták, majd ficérre ${ }^{25}$ meghúzták, ez volt a kocsi rögzítésének az elmaradhatatlan munkafázisa, ami nagy felelősséget igényelt. Volt rá eset, hogy a drukk nem volt eléggé rászorítva az állványszerkezetre, és emiatt leesett; olyan nagy volt a zuhanási sebesség, hogy darabokra törött, ilyenkor a munkások fizetése bánta a tévedést. Miután a kocsit ráerősítették, két szerelőmunkás lement az alvázra $^{26}$, és felengedte a kocsit, vagyis ficérrel meglazították, és a csapszeget kihúzták. Ezután a sikló aljáról (alsó sikló) telefonáltak a középsiklóra, ahol szintén telefon volt, és váltóőr, majd hármat csengettek a siklótetőre (felső sikló), ami azt jelentette, hogy készen vannak. A tetőn ugyanilyen múveletet végeztek a szerelőmunkások, csak ők rakott kocsit toltak az állványra. Miután minden készen állt, indultak a kocsik. Középen a váltóőr váltók segítségével irányította a kitérést, és áthúzta az ellensúlyokat a felső állványkocsiról az alsóra. Mikor elindultak a kocsik, mindkét 
féket fellazította a gépész, majd a sebesség szerint fékezet, illetve lazított. Nagyon pontos munkát igényelt ez a feladatkör, mert a nagy sebességtől hamar kisiklott az állványkocsi (elmondta Biloklávek Mátyás).

A sikló karbantartását teljesen a kommandói műhelyesek végezték, sőt a személyzet is a kommandóiak köréből verbuválódott. Olajozták a görgőket, a dobokat, javították az állványkocsikat, cserélték a talpfákat, a hevedereket. Tudták, hova kell sínszeg vagy síncsavar, ők voltak a váltókezelők, tolatók, kisérték a szállítmányt, húzogatták a dobfalakat. Említésre méltó, hogy a fakitermelő vállalat a meglévő két siklópályán kívül még két siklópályát építetett a vranceai havasokban, neruzsai siklók ${ }^{27}$ néven, ahol szintén kommandói munkások dolgoztak. Ezek az ingaforgalmú siklók 1907-1944 között üzemeltek. A munkások rátermettségéről Látó Anna szubjektív monográfiájában az alábbi sorokat olvashatjuk:

„Rendkívül ügyes fickók voltak, helytállni, ugrani egyformán vakmerő büvészmutatvány volt számukra. S még örömük is telt bátorságukban. Nem kevesebb buzgalommal, de kevesebb veszéllyel dolgoztak a góri és kovásznai sikló kocsitologatói is, a „kuplizók”, akik menetidő alatt pihentek ugyan, és történetekkel szórakoztatták egymást és önmagukat, de ha dolgozni kellett, beleadtak apait, anyait." (Látó Anna 1981. 84.)

A kovásznai sikló üzemelése változatos volt. A legforgalmasabb időben, vagyis az első világháborúig, valamint a második világháború utáni gazdasági fellendülés következtében a nagy kihasználtság miatt előfordult, hogy 24 órában üzemelt, akár hétvégén is. Az adatközlők szerint ebben az időszakban napi 60-70 rakott kocsi is leszaladt. Egy menet 15 percig tartott, amelyből 7-8 perc a középsiklón való pontos fékezéshez, valamint a súlyok átrakásához volt szükséges (elmondta Ferencz János)

Nem volt könnyű az emberek élete. Azonkívül, hogy egész héten az ideiglenes barakklakásokban aludtak, mindig kellett vigyázniuk a zavartalan működésre is. Az autonóm tartomány megszűntével a község közigazgatásilag átkerült Szilonhoz ${ }^{28}$. 1960-ban Romániában is megszűnt a gőzmozdonyok építése, a resicabányai gőzmozdonyjavító műhelyeket bezárták. Az emlékek szerint ekkortól, ha elromlott a mozdony, Szászrégenbe kellett küldeni főjavításra, a siklón engedték le, s a leküldés nem is jelentett nehézséget. De amikor vissza kellett húzni, az ellensúlyok sem bizonyultak elegendőnek, így még a tetőről is lementek a munkások, hogy szétbontsák a mozdonyt. Darabokban szállították fel. A szállítás úgy történt, hogy a mozdony fökerete külön ment „lábon” a tengelyekkel, víztartályokkal és a sátorral, valamint külön pőrekocsin a kazánja. Történt olyan eset is, hogy minden előkészület ellenére nem sikerült még ebben a formában sem felszállítani a gépet, mert a felső állványkocsi minden nehezékével együtt nem bírta. Ekkor olyan leleményes megoldást találtak ki, hogy a siklótetőre érkező mozdonyhoz hosszú drótkötelet akasztottak, a másik végét ráakasztották az állványkocsi drótkötelére. A mozdony az egyik szabad vágányon elindult Kommandó irányába, így a gép gyakorlatilag besegített a gravitációnak, és felhúzta a lentről érkező mozdonyt. Az utolsó ilyen jellegű szállítás 1993-ban történt, amikor a '47-est, vagyis a Krauss ${ }^{29}$ mozdonyt hozták Kommandóra. A kisebb testű gépezetek felhozatalánál nem volt nehézség, mert a siklón a felső kocsit 20 tonnáig meg lehetett rakni, de a nehezebbekkel sok baj volt. Amikor az utolsó gőzgépet hozták, egy-egy darabja olyan súlyos volt, hogy köveket kellett bányásszanak a kör- 
nyékről a vasutasok, mert fentről a negyven darab másfél mázsás dobfallal megterhelve sem bírta kihúzni a kocsi, és a kövekkel nehezítettek rajta (elmondta Biloklávek Mátyás és Ferencz János).

1944-ben a második világháború végén a visszavonuló német katonák úgy akarták megakadályozni a szovjet haderő előrenyomulását, hogy fel akarták robbantani a siklót. Akkoriban s talán azután is a személyzet olyan önfeláldozó magatartásról és szolidaritásról tett bizonyságot, ami párját ritkította. Szervezetten kifigyelték a hadicselt, így vérontás nélkül megakadályozták a robbantást, megmentve az egyetlen kapcsolatot a lenti és fenti világ között.

1947-ben hatalmas szárazság nyomorította meg még jobban a falut és az embereket, s mintha minden összeesküdne ellenük, még a sikló is lángba borult. A száraz avar lángra lobbant, és alulról fölfelé terjedt a tűz. Mire a munkások, a tűzoltók odaértek, az acélkötél elégett, a gépház lángokba állt, az alsó sikló épületei leégtek, és a dobok megsérültek. Hiába védték meg, most mindez kárba ment. De mivel nagyon fontos volt minél hamarabb feljavítani, 14 nap alatt elkészültek vele.

1955-ben a siklótűz megismétlődött, ekkor még a másfél mázsás dobfalnak nevezett ellensúlyok is megsérültek. Valamennyi műhelyi dolgozó és pályaőr ott dolgozott két hétig. A dobfalak javítását Romániában nem vállalták. A műhelyvezető (művezető) rögtönzött esztergapadot szereltetett fel a siklótetőn, a kopásokat feltöltötték, és ott helyben Kerekes Lajos a padon esztergakéssel eldolgozta. Bíró Endre főmérnök Marosvásárhelyről érkezett, hogy hamar megoldja a dolgot. A sikló fontos volt, kellett a fa, mert a háború sok kárt okozott. Akkoriban Kommandó a Maros Magyar Autonóm Tartományhoz tartozott, ami gyakorlatilag kedvezett az ittenieknek,
„A sikló a múlt század utolsó évtizedében készült el, építését Horn Dávid kezdte és Groedelék fejezték be. Túlságosan is siettek a Dániából rendelt, nem épp első rangú, de viszonylag olcsó gépezet felszerelésével és üzembe helyezésével. Magát az alépítményt sem képezték ki a kötélgörbének megfelelően, ami Lux Emil mérnök hibájából, de inkább a kicsinyes takarékosság és sietség miatt történhetett, és súlyos balesetet okozott. Az Angliából hozatott drótkötél elszakadt. A baleset századunk elején történt. Azóta is emlegetik. Részletekkel gazdagon megtűzdelt legenda lett belőle. Aki életében elöször utazott a siklón, annak a kötélszakadás történetét, megfelelően adagolva, mint keserü orvosságot, le kellett nyelnie. Spontán és eleven elöadásban, úgy, mintha a tegnap történt volna, söt ma is megtörténhetne. És mindig a legmeredekebb részen, a legfeszültebb pillanatban, mielött a kocsi elérkezett volna a sikló közepére, a szétágazó sínpárhoz és az utast megnyugvással tölthette volna el a helyén álló, fenséges nyugalommal tisztelgő váltóőr látványa. A siklón utazó újonc kimeredt szemmel figyelt. Ekkor valaki megszólalt tünődő hangon: - Furcsa természetû ez a kötél, nagyon furcsa, el is szakadhat. Megtörtént már. - Mire más hozzáfüzte: - Nem lehet azt kiszámítani, nagyon ravasz. - És kezdetét vette a tökéletes összjáték: abból az egyetlen kötélszakadásból három lett, négy, minden halottból öt-tíz-tizenöt, szaporodtak a rémtörténetek, gyorsuló ütemben elbeszélve, levágott lábak, kerékbe tört derék, esetleg törzsről lenyisszantott fej. Brrr, borzalom! Így ugratták a székelyek a gyanútlan idegent, és úgy belemelegedtek, mintha maguk is hinnék, amit kitaláltak - ... de aztán én úgy szöktem le a kocsiról, bé egyenesen a fák közé vagy tizenkét méterre, éppeg itt, ehelyt... -Több mint húsz éven át rendszeresen utaztam a siklón, efféle történeteket is gyakran hallottam, de katasztrófa soha nem ért. Lehet, hogy elfogult vagyok[...] de én a siklót azóta is a világ legbiztosabb járművének érzem." (Látó Anna 1981. 21.). 
mert a gépeket itt helyben javították ki. Bíró mérnök a dobok kicserélését lelevelezte valakivel, és fizetség helyett egy vagon sót ígért, ami miatt majdnem bezárták, de a dobokat kicseréltette. Megrendelték az új acélkötelet, de amikor felszerelték, sehogysem akart müködni. Akkor derült ki, hogy fordított fonással kell készítetni, hogy ne tudjon kitekeredni. Még a gépész, Fejér Bandi bácsi sem tudta ezt, pedig 1932-től itt dolgozott. Egyébként Bandi bácsi volt a legjobb gépész, és nagyon értett a karbantartáshoz is. Ezenkívül soksok évig ott dolgozott, és balesetmentesen kezelte a siklót (elmondta Jeney Gyula).

A kommunista rendszerben előre le kellett jelenteni, hogy milyen mennyiségű árut rendelt az élelmiszer-raktáros, mert fel kellett készüljenek a tetőn, vagyis úgy helyezték a rakományt, hogy tudja felhúzni az alsót. Sokszor megtörtént, hogy kevesebb szerepelt a bárcán ${ }^{30}$, s nem bírta a felső, ilyenkor a tetőről a munkások cipelték a dobfalakat, s ha már ez is elfogyott, addig mentek gyalog, ameddig elérték az alsó kocsit, és leszedtek a zsákokból. Ha netalán kilyukadt valamelyik, azt megfizettették velük. Amikor az acélkötelet ki kellett cserélni, főjavítást végeztek a szerkezeten - ezt meg kellett rendelni, s pár napba beletelt, amíg megjött az engedély, és végeztek a munkálatokkal. Ilyenkor gyalog közlekedtek az emberek, és annyira felgyűlt az áru, hogy még éjjel is engedték a kocsikat. Ha nyáron történt valami a siklóval, a bükkszállítmányt a kommandói vasútállomáson vízzel locsolták, mert ha megszáradt és elhasadozott, visszaküldték, s ezt is a munkások bére bánta meg (elmondta Biloklávek Mátyás).

A munkások számára legnehezebb a téli időszak volt. Jó tudni, hogy Kommandón általában hat hónapig tart a tél, és nemegyszer 1,5-2,5 méteres hó esik. Ilyenkor minden

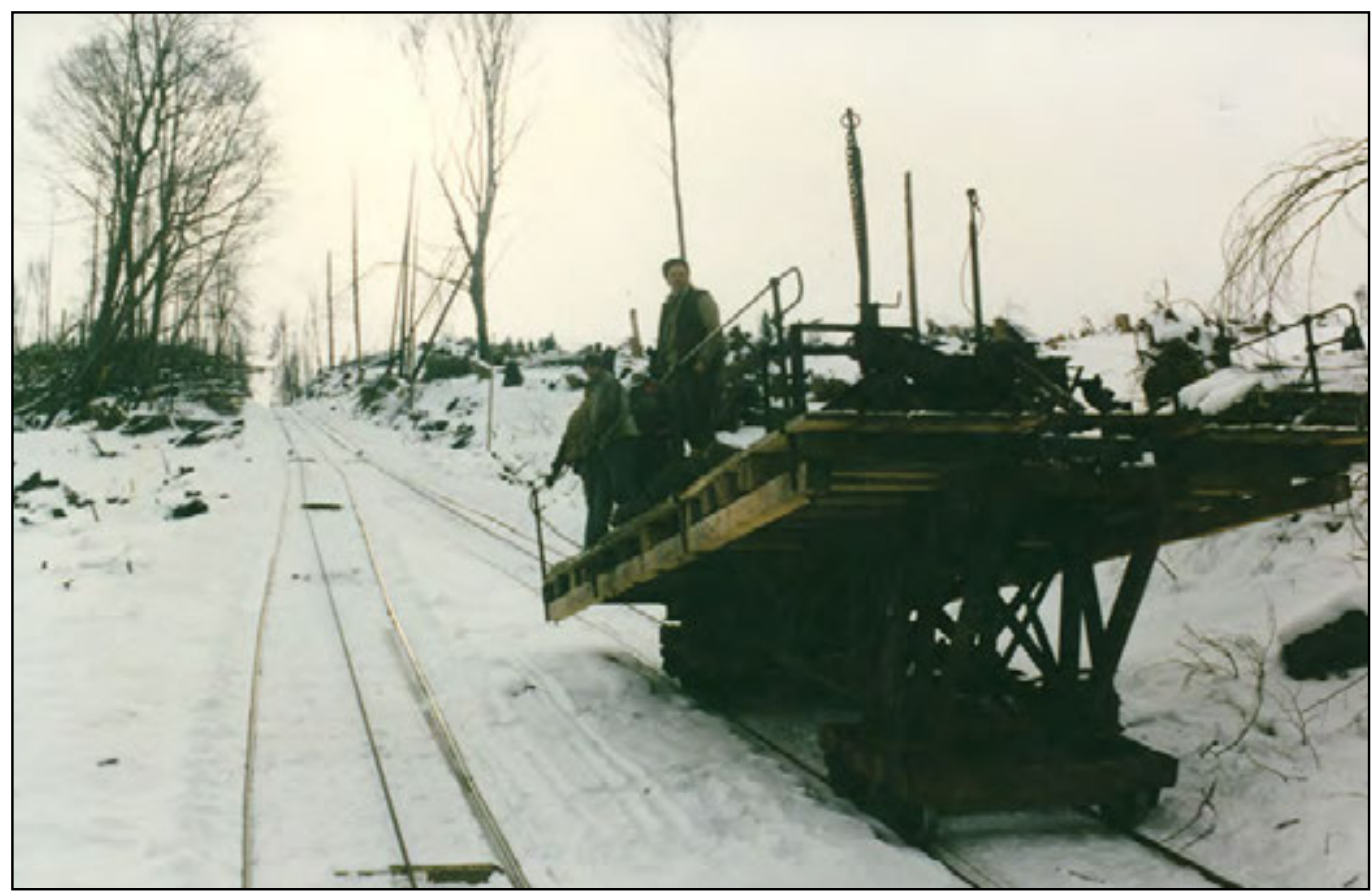

10. kép. A siklópálya 1999-ben 
munkás, beleértve a gépészt is, hólapáttal hajnalban kezdte a napot, mert amire megjött az első rakomány, a siklópályát ki kellett takarítani, a mozdonyra sokszor hóekét szereltek, de a siklónál ilyent nem lehetett alkalmazni.

Az 1960-as évek végén még állt a siklótetőn az a tábla, amelyen a következő felírat szerepelt: „Komandó-Kovászna sikló. Tervezte: Lux Emil. Épült: 1888-1890. A sikló napi teljesítménye: 30 kocsi rakomány, $10 \mathrm{~m}^{3} \mathrm{fa}=$ $300 \mathrm{~m}^{3}$."

A siklópálya világításával kapcsolatosan az adatközlőktől a következőket tudhattuk meg: kezdetben sötétedés után nem működött a sikló, az 1900-as évek elején fáklyákat helyeztek az állványkocsira, majd karbidlámpával világított a személyzet. A faipar fénykorában (1924) sötétedés után Petromax benzinlámpákat szereltek fel az állványkocsikra, és ezekkel világítottak a sötétben. Az 1950-es évek elején az alsó siklóra hozattak egy Rákosi motort kis generátorral, és megvalósították a villanyvilágítást a siklópályára. Az 1970-es években felhozták ide is a magasfeszültségű villanyhálózatot Kovásznáról (elmondta Biloklávek Mátyás).

Az 1947-es siklótűz alkalmával komolyan fontolóra vették azt (lévén, hogy sokan szenvedtek balesetet a siklón az évek során), hogy az utasok részére a szomszédos Kopasz nevű hegyre, amely sokkal lapályosabb, egy 13 km hosszúságú keskeny nyomtávú vasutat építetnek, amelyen „fogaskerekű” járattal megoldható lett volna az utasok biztonságos szállítása a siklótetőre (Kinda István Pozsony Ferenc 2007).

A kommunizmus éveiben már nem akadályoztatta a vezetőség a siklón a személyszállítást, s ezért a kocsirakományok súlya $10000 \mathrm{~kg}$-nál nem lehetett több (5 tonna drukkonként), mert kb. 2000 kg az emberek súlyára volt megengedve, ha nem bírta a felső kocsi az alsót (legtöbb esetben felfelé volt gond), leszállították az utasokat. Az adatközlő emlékei szerint egy pár drukk rakománya 10-12 $\mathrm{m}^{3}$ fa lehetett, s ennek megfelelő súlyarányban helyezték az alsó siklóállványra az üres drukkokat, platókat, hamburgokat, bárkákat. ${ }^{31}$ A drukkból általában egy pár elegendő volt, ha jó volt a fa. Az 1961-es széltörés után a száraz faanyagnak nem volt súlya, vagyis nem volt meg a fékszázalék, s ekkor három darab üres féldrukkot kellett rátenni az alsó állványra (ennyi fért fel összenyomva), ebből az egyiket mellékvágányra terelték (kézzel tolták) a tetőn, s miután meglett a párja, leellenőrizte a revizor, hogy megfelelö-e, ha nem, krétával megjegyezte, és kijavítás után

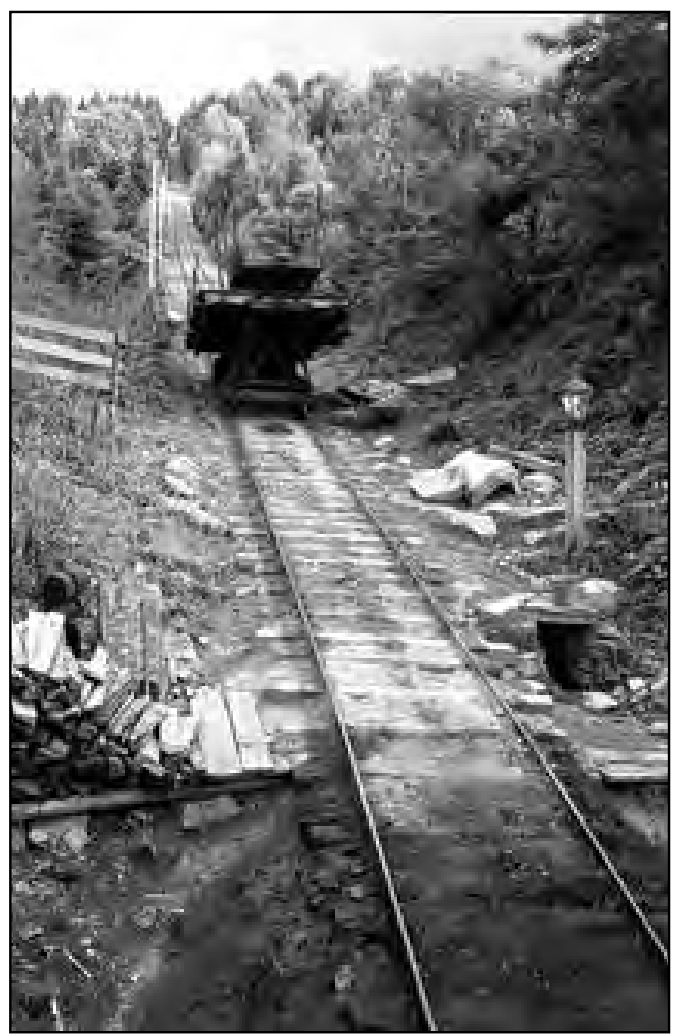

11. kép. Az első Petromax világítótest 
vitték fel a kommandói fürészgyárba. A hamburgokat meg kellett rövidíteni, mert nem fértek fel a siklóállványra. Ezekre főleg méterfarakomány került (elmondta Biloklávek Mátyás).

Még az 1970-es évek elején is közlekedtek a kommandóiak a siklón, aztán az út miatt - 1969-ben építették meg a Kovászna-Kommandó közötti makadámutat - ismét letiltották a személyszállítást, de sürgősség esetén még az 1980-as évekig bárki felülhetett az állványkocsira a szállítmány mellé. Természetesen mindenki vállalta saját magáért a felelősséget, ha baleset történt volna vele, senkit nem vontak volna kérdőre. Az elbeszélőnek és nagyon sok más kommandói embernek a sikló mindig biztonságos járműnek számított, hiszen itt nőttünk fel, évekig ezen utaztunk, és soha eszükben sem jutott a félelem.

Az utolsó siklótűz, vagyis a harmadik a sikló életében 1996. május 19-én tört ki. Jórészt minden megégett, de még ekkor is újjáépítették, mert az 1995-ös nagy széldöntés - 1995. november 5-én 2,5 millió köbméter szálfát döntött ki a szél - utáni fákat el kellett szállítani valahogy. Ekkor az újraépítésen az utolsó vasúti személyzet is részt vett, majd 1999. november 1-jén a szállítási vállalat csődje végleg megállította a siklót is. És ezzel az ipartörténeti jellegű sikló sorsa is megpecsételődött. Széthordták, tönkretették, a felszerelés nagy részét ócskavasnak adták el. Erről így ír a sepsiszentgyörgyi Háromszék címú napilap:

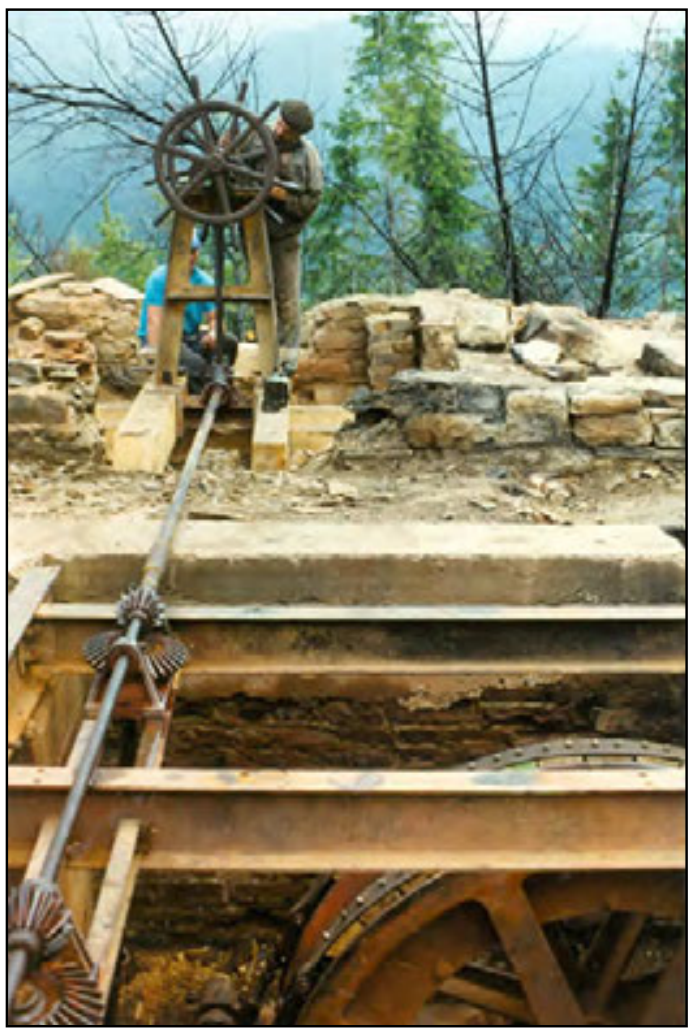

12. kép. A tû́z után, Debreczi Károly (1996. május) 


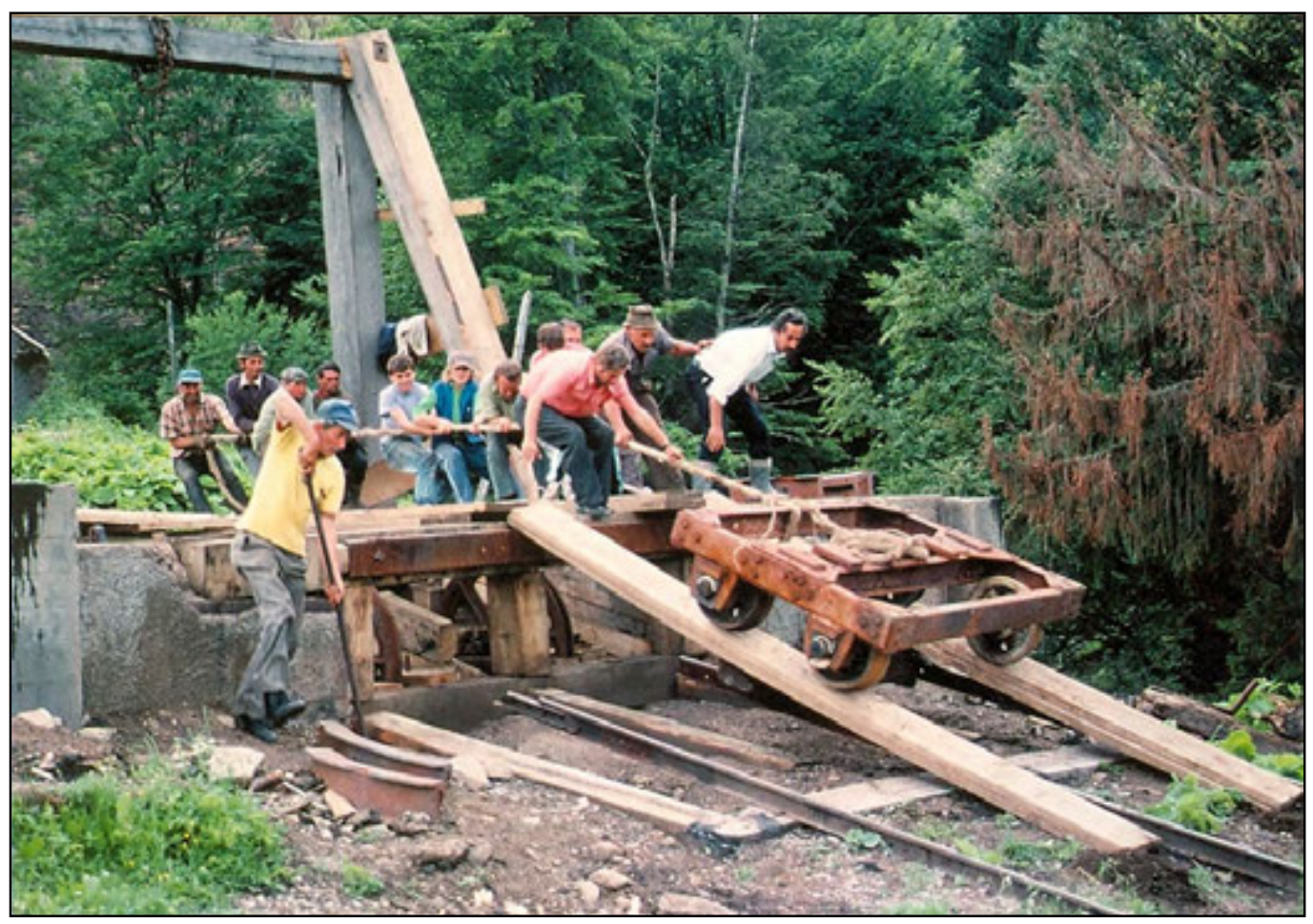

13. kép. Javítási munkálatok 1996-ban

„[...] patthelyzet alakult ki, ugyanis az Apor család a 10-es törvény értelmében vindikálja az ipartörténeti múemléket, így, amíg a per el nem dől, nem lehet lépni az ügyben. Ilyen körülmények között a sikló és a kisvasút ügyében pillanatnyilag nem tudunk egyebet tenni, csak azt, hogy ốrizzük. Ennek ellenére, amióta felemelték az ócskavas árát, minden mozgatható vasdarabot elloptak a feketézók. Pedig az örök folyamatosan terepen vannak, de a kovásznai vasútállomás és a sikló, illetve a sikló és Kommandó között nagy a távolság, s a tolvajok kilesik a megfelelő pillanatot, és úgyis ellopják, ami mozdítható. A gond az, hogy a hasznavehetetlen rozsdás bádogok mellett olyan pótolhatatlan alkatrészeket is elvisznek, amelyeket több mint száz évvel ezelótt gyártottak, s ma már nincs rajz, ami szerint újat lehetne készíteni."(Bodor János: Interjú Barthos Istvánnal, Háromszék, 2003. május 29. 3.)

\section{A siklópálya jelene}

Napjainkban, ha alaposabban szétnéznének a szakemberek, azt állapítanák meg, hogy az eltelt pár év alatt még a maradékot is széthordták, mert a sikló romokban hever, a híd beszakadva, az egyik állványkocsi évekig ott hevert a híd alatt, majd kiemelték, de jelenleg nem tudni, hogy hol van. A sínek lógnak a levegőben, elhordták a kötelet, a sínszegeket, az alátéteket, a hevedereket, az orsókat, a csapágyakat, sőt épületek is eltűntek, még a váltókat is kitépték, $\mathrm{s}$ a kommandói ember, ha arra jár, elfordítja a fejét, hogy ne lássa, mivé lett az, ami egykor a lételemünk, a büszkeségünk volt. Gyakorlatilag semmi nem maradt abból, ami Kommandót és Kovásznát 


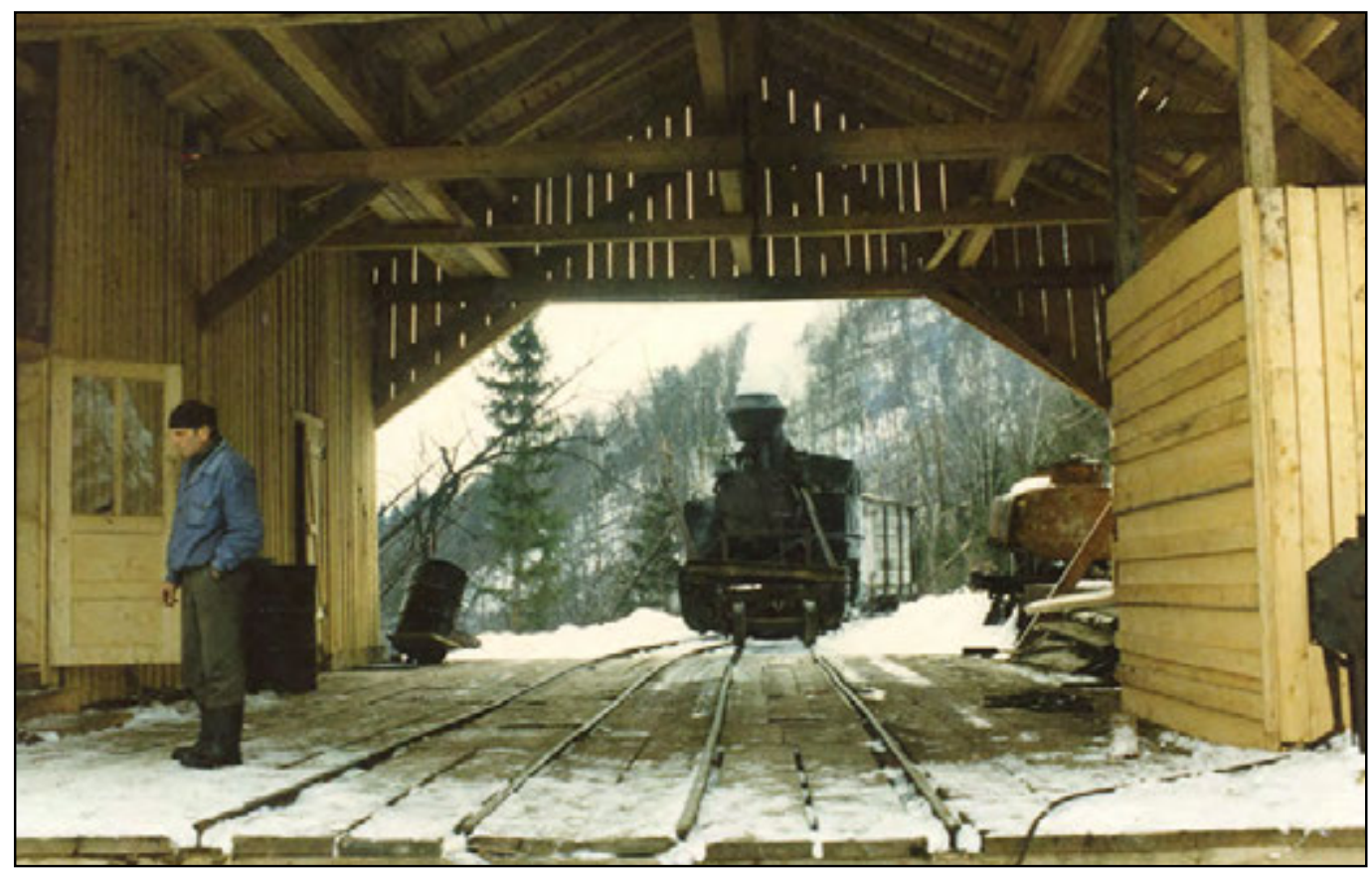

14. kép. Az újraépített siklótetô. 1999-es felvétel

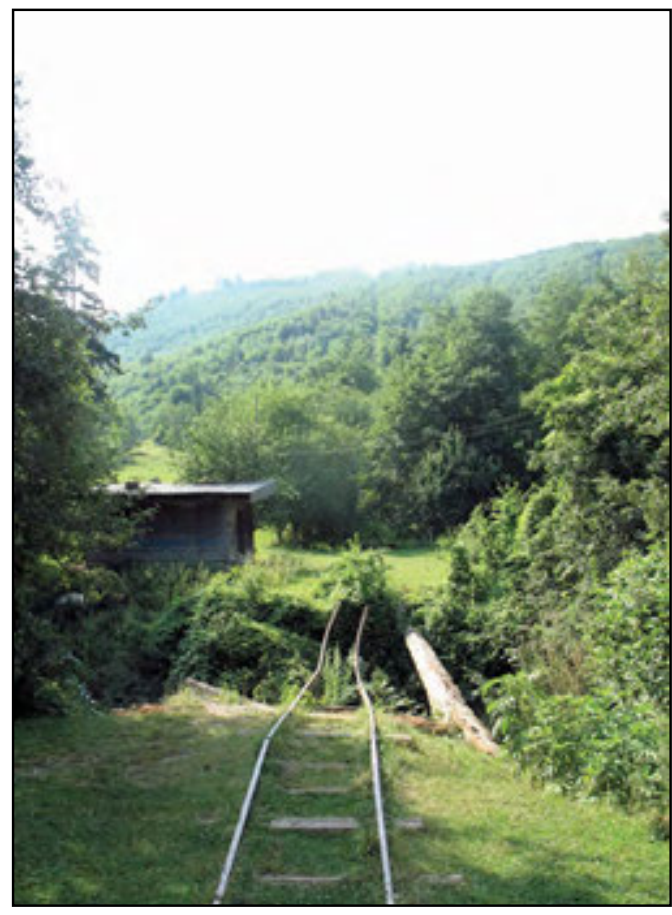

15. kép. Siklóalja 2008-ban az európai turisztikai vérkeringéshez kapcsolhatta volna. Hiába van műemlékvédelmi jegyzéken minden, a fémtolvajok még mindig dézsmálják az ipartörténeti maradványokat. A területi jogviszonyok még napjainkban is tisztázatlanok, ezért bármi megtörténhet.

Mindent összegezve attól kell félnünk, hogy addig tart ez az enyém, tied, övé, mienk jogvita, amire még a muzeális tárgyaknak sem marad nyoma. Sokan a kommandóiak közül, de mások is úgy jellemzik a sikló jelenlegi állapotát, hogy néhány évig megmarad a helye, mert erősen elkezdődött a pályatesten a természet regenerálódása. Az európai szinten egyedinek számító siklópályából gyakorlatilag semmi se látható - a kifüggesztett fotón kívül -, csak a sínszálak egy-egy része, s az is csak közelről és addig, ameddig az erdő visszaveszi azt, ami az övé volt. 


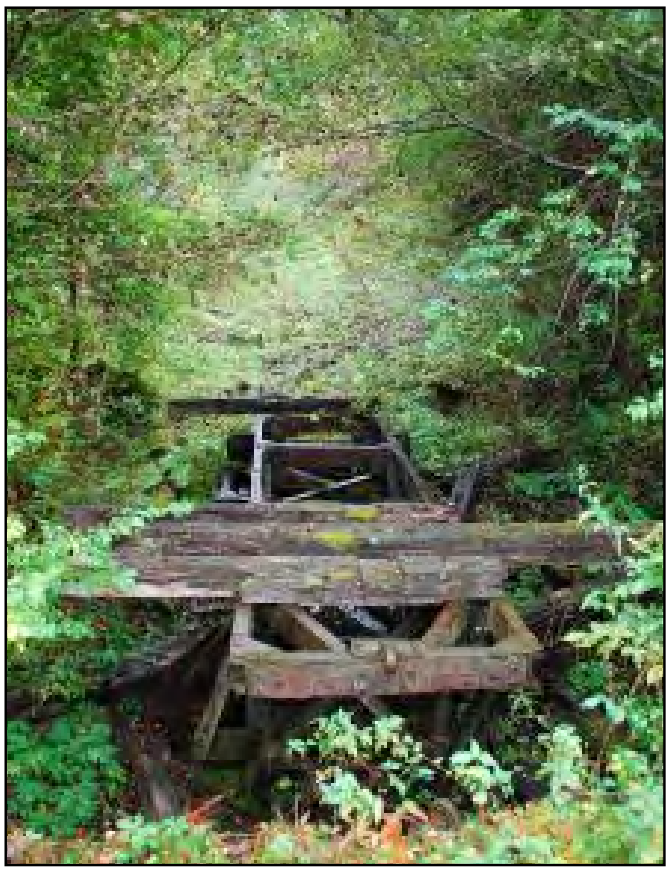

16. kép. A sikló maradványai, napjainkban

\section{Jegyzetek}

1. Kommandó község a hajdani Háromszék vármegye, ma Kovászna megye legmagasabban fekvő települése (tengerszint fölötti magasság:1068 méter), valamikor a 2. székely határőrezred állomáshelye volt, pontosabban parancsnoksági székhely, innen ered a megnevezése. A civilek lakta település 1889-ben ipartelepként létesült, egyszerre kezdett el lélegezni a gőzfürészgyárral, a kisvasúttal és a siklóval.

2. Kovászna - fürdőhely Kommandótól 18 km-re, 1952-től város, ma Kovászna megye harmadik legnagyobb települése.

3. Az elsőt Lyon és Croix Rousse között 1862ben építették - ez ingaforgalmú sikló volt -, a másodikat Budapesten 1868-1870 között, Budai Hegypálya néven (kétsínes, kötélvontatású, gőzhajtású sikló), tervezte Wolfahrt Henrik, a példa Lyonból származott, gróf Széchenyi Ödön építtette. (Acsárdi Ignác 1893. II. kötet 1560.)
4. Horn Dávid - felvidéki zsidó üzletember, mérnöki diplomával és sokoldalú nyelvtudással rendelkezett. 1886-ban 14582 kataszteri hold erdőt vásárolt Kommandó környékén. Ő rakta le nemcsak a település, hanem a háromszéki faipar alapjait is.

5. Groedelék - zsidó üzletemberek, akik megvásárolták Horn Dávidtól az Erdélyi Erdőipar néven működő iparvállalatot.

6. Gyulafalva - településnév. Kommandótól délkeletre, 1888-tól 1940-ig. Napjainkra csak a neve maradt fenn.

7. állványkocsi - a siklópályán közlekedő magas építmény megnevezése, két részből áll: állványból és padozatból.

8. rolnik - görgők, ez esetben rézből készültek.

9. tirefon - csapszeg.

10.góri sikló - az Erdélyi Erdőipar Rt. 1893ban a Górnak (1778 m) nevezett hegyre (Vrancea megye) siklópályát építtetett, amely 1931-ig működött. Ez egy kétsínes gőzhajtású sikló volt. 1904-ben készített színes képeslapokon a szerkezet úgy szerepel, mint Kommandó érdekessége.

11.talpas sín - hengerelt acélból készült, széles talpú Vignol-sín. Az egyes vasutak sajátosságai, illetve felépítményfajták szerint többféle sínrendszert használtak. A Vignoles széles talpú sín (a feltalálójáról van elnevezve) elterjedt volt Európában, másként Góliát-sínnek is nevezték, a síntalp szélessége $140 \mathrm{~mm}$, ez biztosította, hogy a sín stabilan álljon. Teherelosztó elemként a sínfej tetején keletkező igénybevételnek a töredékét adja az alátétlemeznek, illetve az aljnak (Urbán Lajos 1984).

12. muff - fékpárna (pamutból készült).

13. fékcsintura - fékszalag (vasból készül kb. $20 \mathrm{~cm}$. széles).

14. szilfatuskó - szilfából készített fékszerkezet (utóbb cserefából készítették).

15. kursza - itt: menetidő.

16. pőrekocsi - truck. 
17. csihányspárga - csalánból font vastag kötél, eredetileg lenből készült, később cserélték a csalánra.

18. mánus - mutató.

19. sámli - fékülés.

20. drukk (truck) - pőrekocsi.

21. hamburg - Hamburgból hozott vasúti kocsik egységes megnevezése, itt: deszkázott nagyobb kocsi.

22. plató (platós kocsi) - az angol platform után vasúti kocsik egységes megnevezése.

23. kursza - fuvar.

24. talabor - nagyméretű, láb alakú vas csapszegekkel ellátva.

25. ficér - csapszorító kar.

26. alváz - alépítmény, az állványkocsi alsó része.

27. Neruzsa (Naruja) - havas és településnév Vrancea megyében.

28. Szilon (Siriu) - község Szitabodza szomszédságában (Buzău megye).

29. Krauss - CFF 763-247-es pályaszámú mozdony, a müncheni Krauss \& Co. gyártotta 1916-ban (Papucs András 2011. 22.).

30. bárca - fuvarlevél helyies neve

31. bárka - szeneskocsi.

32. revizor - vagonellenőr.

\section{Felhasznált irodalom}

Acsády Ignác dr. (szerk.): Az Athenaeum kézi lexikona I-II. A tudományok enciklopédiája különös tekintettel Magyarországra. Az Athenaeum Irodalmi és Nyomdai Társulat kiadása, Budapest, é.n. (1893) II. kötet 1560.

A kovászna-gyulafalvi iparvasút megnyitása. Székely Nemzet VII. évf. 183. sz. 1890. november 27. 3.

Baross Gábor magyar kir. miniszter levelezése: Kérvények (1887-1892). Magyar Nemzeti Levéltár Országos levéltára, P. 111, $\mathrm{A} / 4,12,7 \mathrm{fm}$.

Bodor János: Interjú Barthos Istvánnal. Háromszék, 2003. május 29. 3.

Gyárfás Győző: Közlekedési viszonyok. In: Pótsa József (szerk.) Háromszék vármegye. Emlékkönyv Magyarország ezeréves fenn- állása ünnepére. Jókai Nyomda Rt., Sepsiszentgyörgy, 1899.

Györffy Kálmán: A sikló egykori gépésze. Komandói képeslapok. Megyei Tükör, Sepsiszentgyörgy, 1975. június 6. 4.

Látó Anna: Honvágyam hiteles története. Kriterion Könyvkiadó, Bukarest, 1981. 84.

Monografia Intreprinderii Forestiere din Comandău până la 13 noiembrie 1958. (Magántulajdon)

Nagy Jenő (szerk.): A Kovászna-Komandó Erdei vasút és siklópálya. Mester Nyomda, Budapest, 2002.10.

Papucs András: Erdei iparvasutak Orbaiszéken. In: Kinda István-Pozsony Ferenc (szerk.): Orbaiszék változó társadalma és kultúrája. Cova Print Nyomda, Sepsiszentgyörgy, 2007. 127-140.

Papucs András: Vasúti vontatójármúvek Kovásznán és Kommandón. Tipographic Nyomda, Csíkszereda, 2011. 22.

Rácz István (szerk.): Tanulmányok Erdély történetéról. Szakmai Konferencia Debrecen 1987. okt. 9-10. Csokonai kiadó, Debrecen, 1998.

Rosta István (szerk.): Fejezetek a magyar technika történetéből (Szent István korától a XX. századig). Nemzeti Tankönyvkiadó, 1995.

Sümegh Ignác: Erdei iparvállalatok Háromszék Vármegyében. Erdészeti Lapok 1898. Szerk. Dr. Bedő Albert - ÁK. 1249 (Országos Erdészeti Egylet könyvtára) Budapest, 37. évf. X. füzet, 1909-1910.

Szabó Mária: Kommandó monográfia. T3Könyvkiadó, Sepsiszentgyörgy, 2004. 47-48. Urbán Lajos: Vasúti Lexikon. Műszaki Könyvkiadó, Budapest, 2004.

\section{Adatközlők}

Biloklávek Mátyás (1935-2014) - Kommandó Ferencz János (1937) - Kommandó Gál Sándor (1959) - Kommandó Jeney Gyula (1927-2015) - Kovászna Péter János (1953-2016) - Kommandó Szabó Csaba (1955) - Kommandó 


\section{TEXTIL- ÉS BŐRIPAR SZÉKELYFÖLDÖN}

\section{A CSERGE KÉSZÍTÉSÉRőL}

\section{Mi a cserge?}

A cserge gyapjúból szőtt, két, három vagy négy szélből összevarrt vastag takaró, amely ványoláskor hosszabb szőrt - ún. lomot ereszt, és ekkor nyeri el végleges formáját. Kecske- vagy marhaszőrből (maszókból) szőtt változatát széjas csergének nevezték. Készítése és használata nem terjedt el az egész magyar nyelvterületen. A Kárpát-me- dencében Erdélyben és a moldvai magyarok között volt ismert és használt szőttesfajta. De nem csak náluk. Az erdélyi és a Kárpátokon kívül élő románok körében is nagy hagyományokra tekint vissza. Különösen nevezetesek és kedveltek voltak a máramarosi románok által készített csergék (Gönyey Sándor 1960; Farkas Irén 2008; Kerekes Ibolya 2008.).

Cserge szavunkat $A$ magyar nyelv történeti etimológiai szótára vándorszóként definiálja.

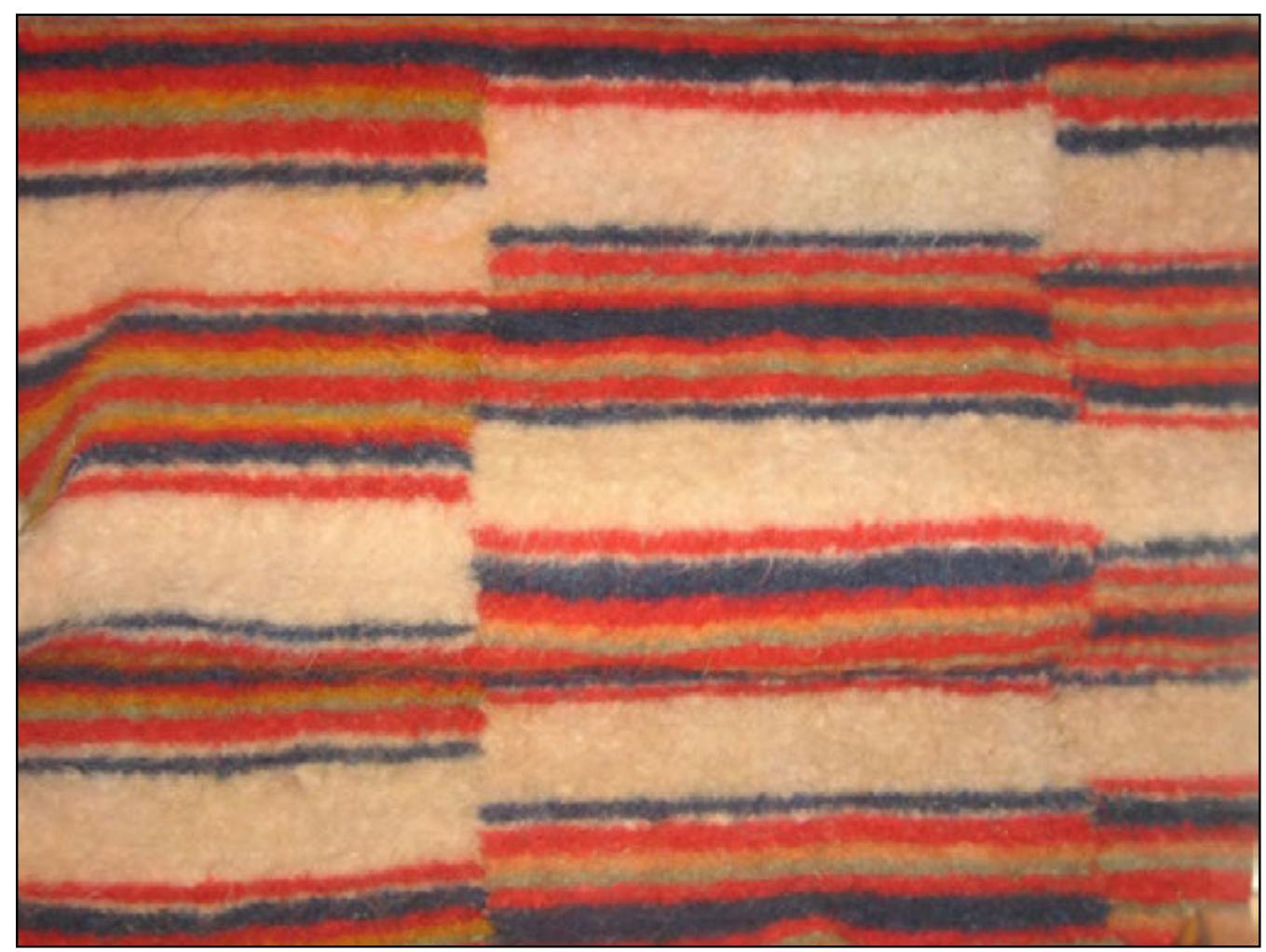

1. kép. Cserge (Kerekes Ibolya felvétele) 
Az oszmán çerge sátrat, a román cergă takarót, pokrócot, az albán cergë durva gyapjútakarót, sátrat, a bolgár чергa vastag gyapjúszőttest, szőnyeget, cigánysátrat jelent, a régi szerb nyelvben pedig a čêrga szónak takaró, pokróc jelentése volt (TESZ 1967. 510-511.). Az Erdélyi magyar szótörténeti tár meghatározása szerint „lompos szövésü gyapjúpokrócfajta" (EMSZT 1978. 115.). A magyar nyelvben a 14-17. században még az állati szőrből, gyapjúból készült sátorponyvát is csergének nevezték, később jobbára már csak a takaró, pokróc, takarózásra használt ágyneműféle jelentésével találkozunk (Palla Ákos 1958; K. Csilléry Klára 1977; EMSZT 1978. 116.). Magyar nyelven első írásos említése 1585-ből való. A későbbiekben feljegyzések egész sora tett említést új és jó öreg, viseltes és egész jó, lyukas és kopott, fehér és fekete, veres csíkos és fehér csíkú csergékről. Megörökítették azt is, hogy még a 15-16. században is voltak olyan egyszerűbb emberek, akik a középkorra jellemző módon, lepedő nélkül, földön vagy padon fekve, csak gyapjúlepedóbe vagy csergébe burkolódzva aludtak. Akik pedig ágyban aludtak, lepedőt terítettek maguk alá, úgy takarództak a vastag, meleg csergével (EMSZT 1978. 115-116; K. Csilléry Klára 1977; Kardalus János 2000. 219; Flórián Mária 2001. 165; Zentai Tünde 2002. 101-102, 149, 268.). Főként Csíkban, Udvarhelyen és Brassó környékén készítették. (Szőcsné Gazda Enikő 2007. 168, 182-182.). ${ }^{1}$

Az évszázadok során Erdély számos vidékén a férjhez menő leányok hozományának egyik alapvető darabja lett. A házasságba vitt cserge mennyisége, nagysága, színe, mintáinak kidolgozottsága a leány vagyoni helyzetét is mutatta (Fél Edit - Hofer Tamás 1969; Kerékgyártó Adrienn, U. 1984). Elsődleges, meleget adó takaró funkcióját a legtöbb helyen mára elveszítette ugyan (szerepét a pap- lan vette át), de lakásdíszként, ágytakaróként számos otthonban napjainkban is találkozhatunk vele (vö. Farkas Irén 2008).

\section{Nyírás}

A juhtartás egyik fontos haszonvétele a gyapjú (Thiering Oszkár 1925. 19-23.). Feldolgozásának rendjében egyes mozzanatoknál tájegységenként, falvanként, sőt falurészenként előfordulhattak különbségek, de a folyamat egésze egységes képet mutat az egész Székelyföldön.

Az erdélyi juhos gazdák jobbára cigáját vagy rackajuhot tartottak. A havasokon május közepéig meglehetősen hidegek az éjszakák, ezért a hagyományosan Szent György-napon (április 24.) felgyüjtött juhsereg téli, vastag bundában vonult föl a havasi legelőre. ${ }^{2} \mathrm{~A}$ sereg összegyűjését mágikus cselekedetek is kísérhették. Az egyik bánkfalvi asszony elmondása szerint ők láncot kötöttek a kapu alsó részére, közepébe ollót szúrtak. Ezen léptek át a juhok, miközben „Isten vigye szerencsésen, s hozza vissza szerencsésen! Óvja meg a bajtól!" szavakkal szentelt vizet hintettek az állatokra. Más olló helyett fejszét említett, hogy az állat lába erős legyen, elkerülje a baj. Volt, aki zöld ággal hajtotta ki a kapun állatait, hogy jól szaporodjanak (vö. Bálint Sándor 1977. I. 308.).

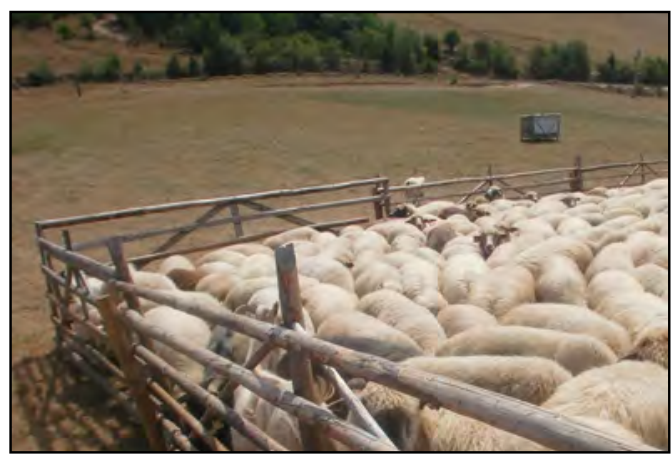

2. kép. Juhok a havasi esztenán (Kerekes Ibolya felvétele) 
A vastag gyapjú segítette a fagyok átvészelését, ám a hidegek elmúltával igyekeztek minél előbb megnyírni a juhokat. Egyrészt, mert vastag bundában könnyebben megrühösödtek, másrészt a meleg elleni védekezésül kezdtek volna megvetkezni, szőrüket elhullatni. A juhnyírás hagyományos ideje május végén, leginkább Orbán napján (május 25.) volt (Szentimrei Judit 1972. 157; Nagy Ödön 1992. 26-27.).

Az öregek emlékezetében sok helyütt még élénken éltek az Orbán-napi havasi nyírő élményei. A reggeli fejés és az otthoni állatok ellátása után a havasi legelők felé vezető út mentén, az esztenabíró által meghatározott helyen és időben találkoztak a családok. Szekerekkel mentek fel az esztenára. Mivel mindenki elsősorban a maga juhait nyírta, és adott időre el kellett készülniük a munkával, ha szükséges volt, a férj és feleség a gyerekek mellett felnőtt segítséget is vitt magával a nyírôbe. A néha két-két és fél órás úton jócskán megehültek, ezért érkezéskor először a tarisznyák kerültek elő. Ettek az otthonról hozott kenyérből, túróból, szalonnából, a pálinkát is „megkóstolták".

Amikor a déli fejésre megérkezett a sereg, akkor kezdődhetett a nyírés. Az emlékezők többsége a déli fejéssel egy időben zajló nyírásról számolt be, de előfordult olyan esztenaközösség is, ahol a fejés befejezése után kezdték nyírni a juhokat. Füljegyek alapján a családok kiválasztották a seregből a maguk juhait. Mindenkinek megvolt a szokása, hogy az állat hasán vagy hátán kezdi a munkát. Aki a hasán kezdett, az lefektette a juhot, egyik kezével az ajakát szorítva földre nyomta a fejét, másik kezében a juhnyíró ollóval a hasától indulva haladt körbe. Ha jól sikerült, akkor egyben teríthette ki a gyapjút. Aki a hátán kezdett, az a lábon álló juhot fogta meg erősen, előbb a gerinc vonalán haladt végig, majd a jobb és bal oldaláról külön-külön nyírta le a gyapjút.

A munkához kétféle ollót használtak. Az egyik típust főként helybeli kovácsok készítették, a másik, ún. csattanósat cigányoktól vásárolták, később mindkettőt boltból szerezték be (vö. Tagán Galimdsán 1939. 233. I. tábla, 2. ábra; Szentimrei Judit 1981. 193; Szolnoky Lajos 1991. 366.). Különösen a csattanós olló használata kívánt ügyességet. Vigyázni kellett ugyanis, hogy a felső él mindig az alsó elé kerüljön, máskülönben az élek eltávolodtak egymástól, s ahelyett, hogy a gyapjút nyírták volna, az állat vagy épp a nyíró bőrét csíphették ki vele. Mivel a juh könnyen szökött, lefogásában a gyerekek is segédkeztek. Ez általában az állat erős megfogását jelentette, de lehetett földre szorítás, a lábak összekötése, illetve cüvekhez vagy a kosár oldalához való kikötés. Tíz-tizenkét éves koruktól a gyerekek már maguk is nyírték a juhot.

Nyírás után színenként elkülönítették a gyapjút. Tartottak ugyanis a fehérek mellett fekete vagy vörösesbarna színű juhokat, hogy ezek szőréből fekete, szürke, illetve barnás árnyalatú fonalat fonhassanak. Ez az elkülönítés a gyapjú feldolgozása során mindvégig megmaradt. Külön áztatták, mosták, tépték,
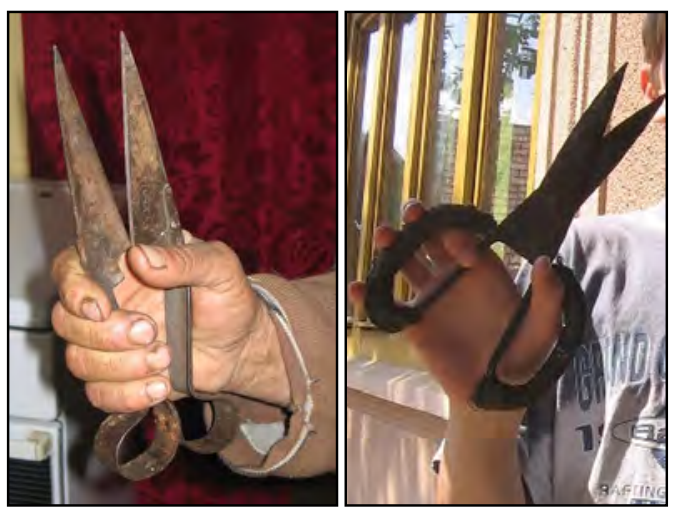

3. kép. Juhnyíró olló (Kerekes Ibolya felvétele) 
fonták a fehér, a fekete és a vörösesbarna színű gyapjút. Külön-külön összecsongolyították, a magukkal hozott zsákokba jó szorosan betưrték a frissen lenyírt gyapjút, és gondosan bekötötték a zsák száját. Egy-egy zsákba öt-hat állat gyapja is belefért. Ezekben a zsákokban tárolták aztán a gyapjút mindaddig, míg el nem érkezett a mosás ideje. Ily módon igyekeztek távol tartani a molyokat, mivel azok nem szeretik, nem eszik a piszkos, ganéjos, zsíros gyapjat. Aki a nyírók közül egy kicsit elmaradt, azt a többiek kisegítették, mert a közös ebéd és a mindenki által várt majálisszerű vigasság csak akkor kezdődhetett, ha minden család befejezte a nyírást (vö. Tagán Galimdsán 1934. 105; 1939. 231233; Timaffy László 1987; Ujváry Béla 1993; Szabadfalvi József 2001. 733.).

Volt társulat, ahol ebédre is ki-ki a maga tarisznyájából ett, másutt készülettel voltak, az otthon már előzőleg megfőzött, szekéren magukkal hozott ételt (leginkább töltelékes káposztát, kalácsot) ették. Több helyütt volt közös főzés, vagyis amíg a többiek nyírtek, addig az adott közösség szokásai szerint meghatározott személyek - leginkább az esztenabíró és a pásztor felesége - az esztenán levágott juhból tokányt fóztek a többieknek. Ilyenkor a juhot a pásztor adta a magáéból a közösségnek, cserébe pedig az esztenabíró töltelékes káposztát és kalácsot vitt a pásztor családjának a közösség nevében. Az ebédhez való pálinkáról szintén a bíró gondoskodott. Ebéd után kezdődhetett a vigasság. Előbb csak beszélgettek, énekeltek, majd a párok összekapaszkodtak, és (többnyire) a maguk énekére táncoltak. A férfiak a pásztor szállásának tűzhelyéről kormot szereztek, azzal kergették meg és igyekeztek összekenni az asszonyokat, nagyobb lányokat, akik nagy sikongatás közepette próbáltak menekülni. Válaszul ők is megkergették, vízzel locsolták le a férfiakat (vö. Hajdú Farkas-Zoltán 1993. 99.). A gyerekek ezalatt cekapecceztek (Utolsó pár előre fuss!-t játszottak), fogócskáztak, s különféle dobálós játékokkal szórakoztatták magukat. A havasi vigasság nem tartott túl sokáig, hiszen időben haza kellett érni az állatok ellátására, az esti teendők elvégzésére. Szekerekre ültek tehát, maguk alá tették a gyapjúval teli zsákokat, s indultak vissza a faluba. A hazafelé vezető utat végigénekelték, és a hegyek visszhangozták az énekszót.

Az 1960-as évek elejétől - a kollektivizáláshoz köthetően - megváltozott a nyírás helye és ideje. A juhtartás a szocialista időszakban is megmaradt, a családok viszont nem tudtak már hátramenni a havasra, ezért eltűnt az Orbán-napi közös nyírés és az azt követő ünneplés. A gazdák otthon nyírtak, saját elfoglaltságuktól függően választva meg az időpontot. Napjainkban továbbra is leginkább otthon nyírnak. Februárban, hidegebb esztendőben március első napjaiban kerülnek kézbe a juhnyíró ollók, hogy mire elcsapják a juhokat, már legyen valamennyi sarjúdzott gyapjúk, ne fázzanak meg a havason.

A 20. század végén, az esztenagazdaságok megújulásával a Székelyföldön is feléledt a havasi juhtartás rendjének egyik kiemelkedő mozzanata, a juhlátogatás, esztenalátogatás, vagyis az esztenára felhajtott állatok közösségi felkeresése (vö. Szebeni Géza 1962. 82.). A juhbíró hívására húszan-harmincan szekérrel, traktorral, autókkal mennek föl a közösség esztenájára. A látogatás célja elsősorban a tejbemérés, de aki nem nyírta meg otthon az állatait, az ekkor pótolja. Ilyenkor levágnak egy, a pásztor által felajánlott bárányt, és paprikást főznek belőle. A régi hagyományoknak megfelelően a legtöbb helyen a bárányért cserébe a bíró egy fazékban töltelékes káposztát visz a pásztornak. 


\section{Áztatás, mosás, szárítás}

A csergének szánt gyapjú mosásával mindig megvárták a júniusi, júliusi melegebb idők beköszöntét, amikorra a patak vize meglangyosodott. Egy szép, meleg napon az asszonyok előszedték a zsákokból a gyapjút, átnézték, kiszedegették belőle a nagyobb piszkokat, szénát, szalmát, ganés bogokat. Kisebb darabokra tépték, hogy a mosáskor majd könnyebben bírjanak vele. A ház udvarán langyos vízbe áztatták, néhányszor átdörzsölték, hogy a zsír, piszok hamarabb felpuhuljon, kioldódjon belőle. Volt, aki esővizet fogott reá, mert annak lágy vizében még hamarabb tisztult, puhább lett a gyapjú. Ügyeltek, hogy a víz napközben nehogy reáhúljön, mert akkor a kioldódott zsír visszatapadt a szálakra. Ezért, ha kellett, tűzhelyen melegített vízzel langyosították az áztatóvizet. Ezt aztán nem öntötték ki azonnal, mert ebben a síkos, lúgos, lanolinos lében tisztultak igazán jól az elpiszkolódott gyapjúholmik, posztódolgok, tarisznyák, harisnyák, gyapjúlepedők, takarók, csergék. Hamar híre ment, ha a közelben valaki zsíros gyapjat készült áztatni. Ilyenkor más asszonyok is odakéretôztek, hogy a maguk gyapjúholmiját odavihessék, a zsíros gyapjú vizében kimoshassák. Ennek a víznek aztán már különösebb jelentőséget nem tulajdonítottak, általában a patakba eresztették. Voltak, akik a ganéjdombra vagy a pallagra (a kert füves, kaszálónak hagyott részére) öntötték, mert a jó zsíros víztől a fü is szebben nőtt.

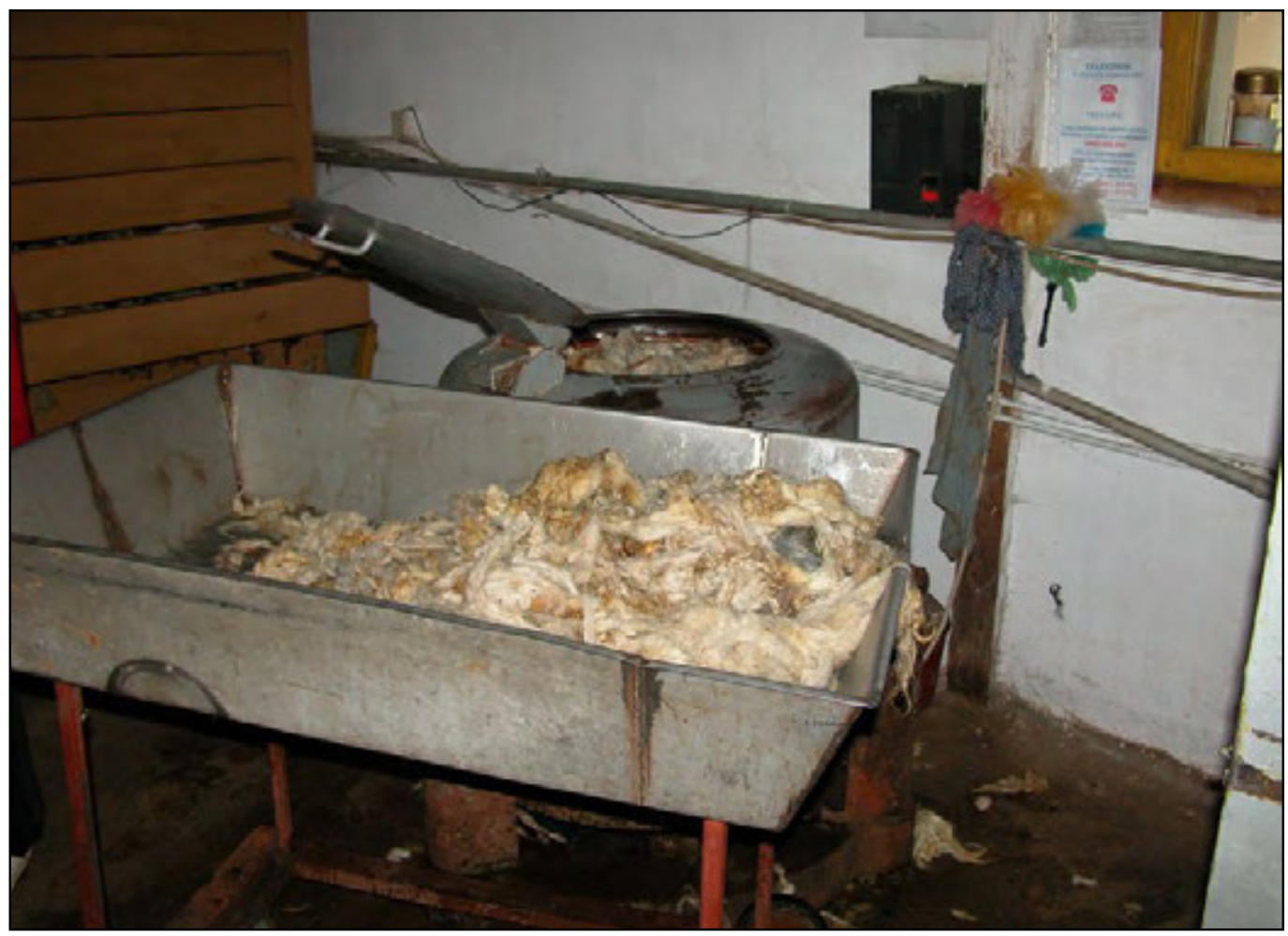

4. kép. Gyapjúmosás a Mózes Gyapjúfeldolgozó Manufaktúra csíkkarcfalvi műhelyében (Kerekes Ibolya felvétele) 
A kiáztatott, átdörzsölt gyapjút még aznap délután, esetleg másnap délelőtt vitték le a patakhoz. Ha sok gyapjú volt, az is előfordult, hogy mosókalákát szerveztek az asszonyok. A vízben kialakított gübóbe beleállították a mosópadot, lábához kosarat kötöttek, hogy abba dobhassák a mosás során leszakadó kisebb darabokat. Sulyokkal jó erősen átkopogtatták, hol lapjával, hol élével ütve a gyapjút. Közbe-közbe kosárba téve belegübbögtették a patak vizébe, újra és újra kiöblítették, kihabarták, megtisztálták. Voltak települések, ahol inkább otthon vagy az utcán lévő vajorokban mosták, tisztálták ki a gyapjút. Ilyenkor a kút, a közös kifolyó vagy forrás vizét használták. Amikor teljesen tiszta víz jött a gyapjúból, akkor csavarták ki alaposan, s vitték vissza a ház udvarára ki-

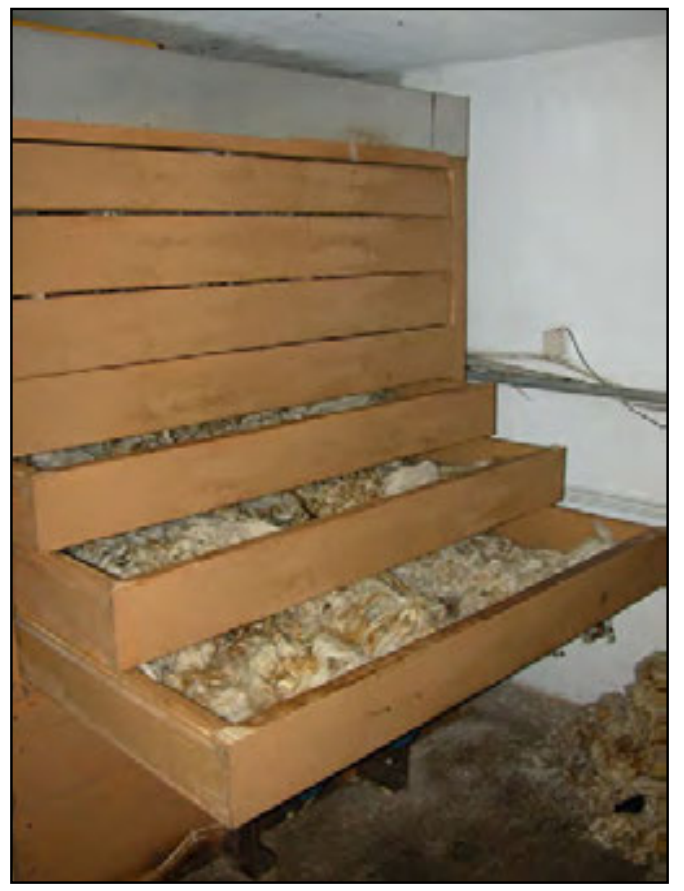

5. kép. Mosott gyapjú tárolása a Mózes Gyapjúfeldolgozó Manufaktúra csíkkarcfalvi mühelyében (Kerekes Ibolya felvétele) teregetni. A nagyobb darabokat kerítésre, a kisebbeket drótra, kifeszített kötélre, felfordított kosárra, tyúkborítóra, ajtóra, deszkára, rácsra, létra fokaira terítették, úgy, hogy a levegő átjárhassa, szárítani tudja a gyapjút. A teljes száradás után színenként elkülönítve kosarakba gyűjtötték s újra zsákokba tették a mosott gyapjút (vö. Benda Judit 2014. 27; Palotay Gertrúd 1937. 273; Szentimrei Judit 1972.157-158; Uő. 1978. 147-148; Szolnoky Lajos 1979).

\section{Tépés, fésülés}

Mosás után hamarosan elkezdték a tépést és a fésülést, mert a tiszta gyapjút a moly is szerette, könnyen rátalált. Amelyik háznál kevesebb gyapjú volt, ott többnyire már nyáron elvégezték ezt a munkafolyamatot. Elsősorban az öregek és a kisebb gyerekek csinálták, akik nem jártak mezei munkára. Kiültek a tornácra vagy egy szélvédett helyre, a zsákból elővették a gyapjút, szétlazították, majd kisebb kupacokat téve maguk mellé finom puhára tépegették. Ha nem volt öreg vagy kicsiny gyermek a háznál, akkor az asszony végezte ezt a munkát is. A színenként különválasztott gyapjút ekkor is külön kezelték. Ha szürke fonalat akartak fonni, akkor fehéret és feketét vegyítettek össze. Akinek volt vörösesbarna gyapjúja, az általában meghagyta azt a maga színében. A tépett gyapjút ölükbe, kötényükbe vagy maguk elé a földre ejtették. Időnként fölállva összegyűjtötték, belerakták az előre odakészített tiszta zsákokba. Az adatközlők emlékei szerint kisgyermekkorukban egy idő után meglehetősen unalmasnak találták ezt a munkafolyamatot. Mégsem hagyták abba, főleg azért, mert édesanyjuk, nagyanyjuk utána cukros törökbúzát (cukros vízben főtt csöves kukoricát) készített nekik, vagy valamilyen más finomsággal, figyelmességgel köszönte meg segítségüket. 
Akinek több gyapjúja volt, az a lerekedés (a juhok őszi hazahajtása) után tépőkalákába hívta magához az ismerősöket, baráti házaspárokat. A megbeszélt estén összegyűlt aszszonyok karimóba ültek, és a középre öntött tépetlen gyapjút elosztották maguk között. A székük mellé húzták vagy egy zsákba gyürték a nekik jutott részt. Innen szedegettek ki egy-egy maroknyit, s puhára tépve kötényükbe gyűjtötték. Ha tele volt a kötény, akkor középre öntötték a tépett gyapjút. Időnként megálltak, a háziak főtt szemes törökbúzával, piskótával, egy-egy pohár pálinkával kínálták meg a jelenlévőket. A férfiak eközben hátul kártyáztak, beszélgettek, pálinkáztak.
A tépés után rövidesen következett a fésülés. A megkérdezettek jó része még emlékezett arra, hogy egykor otthon kézzel is füsültek. Férfiak, nők, gyerekek egyaránt foglalatoskodtak ezzel. Minden családban volt, aki szívesen végezte ezt a műveletet. Az ehhez használt füsülőt brassói szász mesterek készítették, és vásárokban szerezhették be. Maga az eszköz két különálló darabból állt: egy-egy kb. $15 \times 20 \mathrm{~cm}$-es nyeles deszkalapból, amelyre sűrű, finom acélfogazat volt rögzítve. A fogazat szegecsei nem merőlegesen álltak ki az alapból, hanem kissé megdöntve előre, illetve hátra. Az alsó részt bal kézben tartva, a fogazatba szorítottak egy jó maroknyi gyapjút, és a jobb kézben tartott

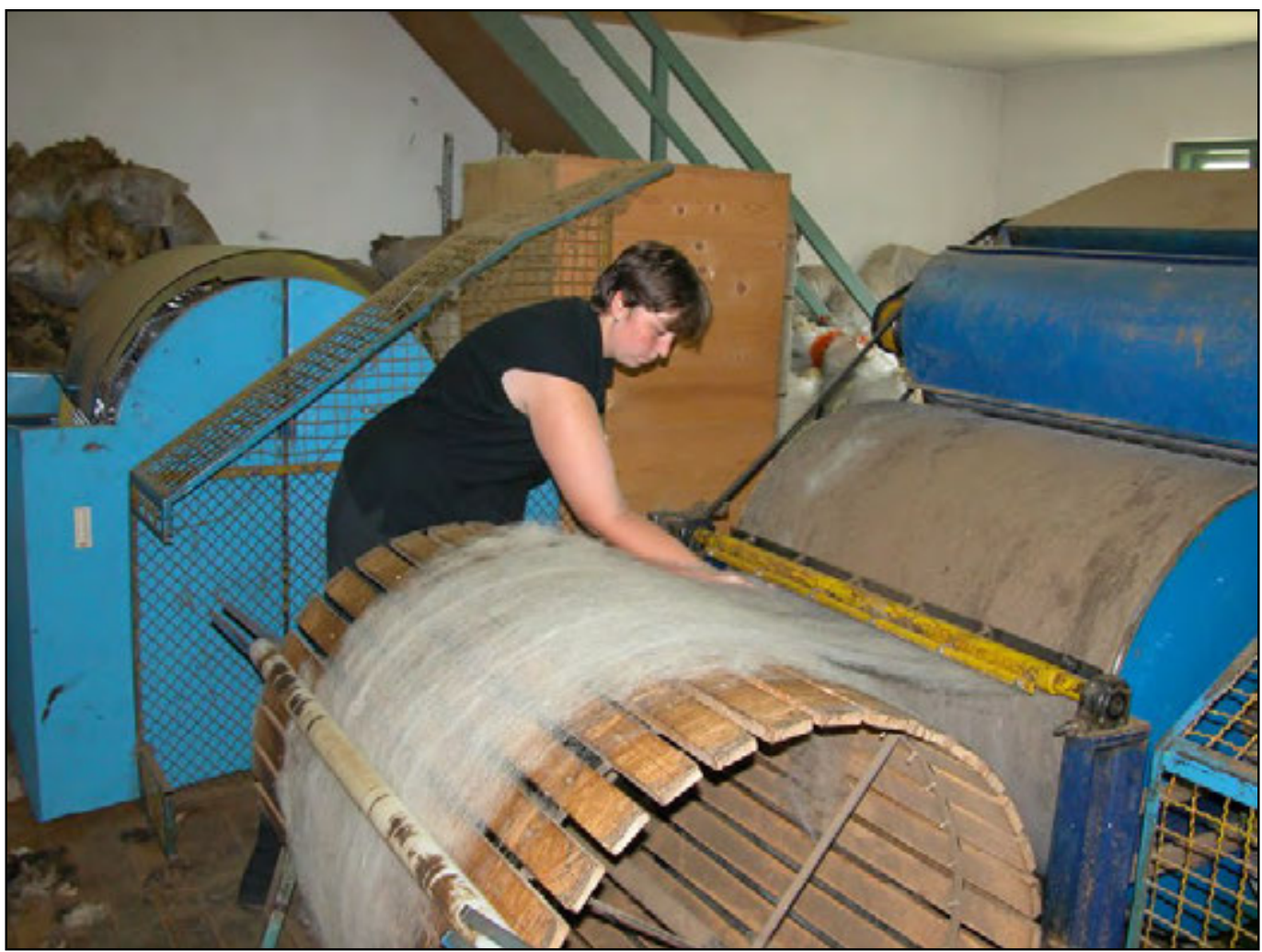

6. kép. Gyapjúfésülő gép a Mózes Gyapjúfeldolgozó Manufaktúra csíkkarcfalvi mühelyében (Kerekes Ibolya felvétele) 


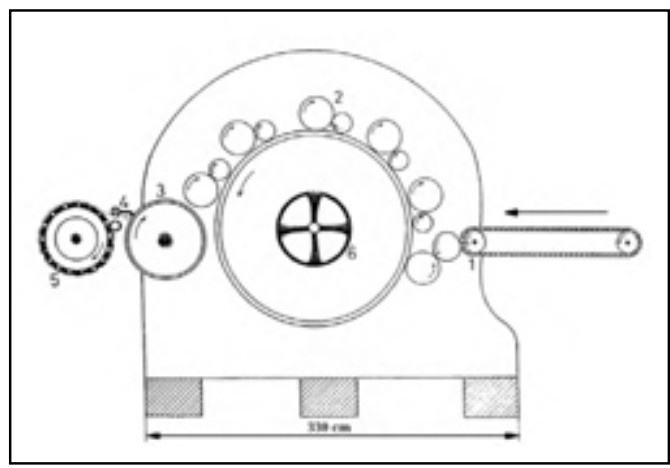

1. ábra. Mosott gyapjú tárolása a Mózes Gyapjúfeldolgozó Manufaktúra csíkkarcfalvi mühelyében (Kerekes Ibolya felvétele)

másik deszkát többször végighúzogatták rajta. Az alsó és felső rész fogazata ellentétes dőlésszögben állt, ezért a gyapjú jól beletapadt, szép szálasra lehetett húzni. Voltak olyanok is, akik a mosópadra kötötték rá a fésülő egyik részét, így azt nem kellett tartani. A másikkal húzogatták, fésülték a gyapjút (Palotay Gertrúd 1937. 273.).

Mivel időt, türelmet igénylő, haladatlan, sok szállongó szösszel járó munka volt, a gyapjúfeldolgozásnak ez a fázisa sok helyen kikerült a házból. Erre szakosodott, vízierővel vagy később villanymotorral hajtott füsülóbe vitték a gyapjút - még ha fizetni is kellett érte. A gépi fésülés jóval gyorsabban ment (egy óra alatt kb. 8-10 kg gyapjút tudtak földolgozni), s az otthon, kézzel füsültnél finomabb, lazább szerkezetű, egyenletes minőséget eredményezett.

A fésülőműhelyben az előkészített, mosott gyapjút előbb a tépetóbe, gyapjútépóbe tették. A kézi fésülőhöz hasonlóan ez is két fó részből állt, de ez a két rész egyetlen, lábakon álló, rögzített szerkezetet alkotott. Egy csónakszerűen, enyhe hajlással készített alsó elemből és egy - ebbe a csónakszerű, alsó hajlásba illeszkedő - felső elemből állt. Az alsó elemet tartó keretbe jobb és bal oldalról egy-

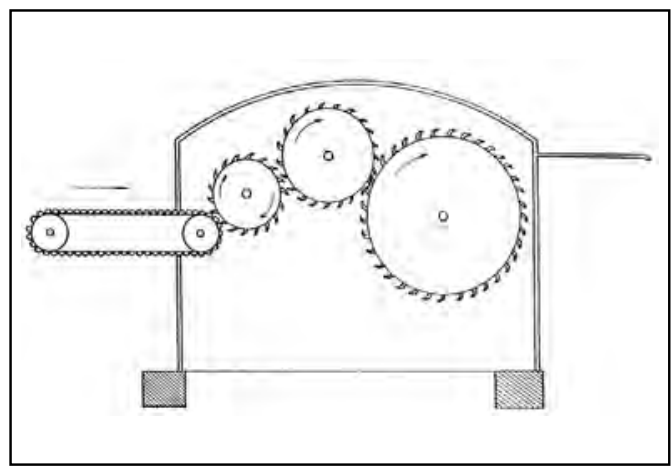

2. ábra. Gyapjútépő gép müködési vázlatrajza. A rajz a kibédi Szilveszter család gépéról készült. In: Márton Béla 1995. 124.

egy függőleges állványt is rögzítettek, amelynek a felső végén egy-egy mély vájat volt. E vájatok tartottak meg egy keresztbe fektetett, négyszögletesre faragott, erős rudat. Ehhez a vájatokban szabadon elforduló rúdhoz volt hozzáerősítve a tépetô csónakszerű alsó részébe illeszkedő felső elem. Az állvány tartotta keresztrúd mint egy vízszintes tengely működött. Segítségével a felső elem el tudott mozdulni, előre- és hátrairányuló lengőmozgást tudott végezni a rögzített alsó elem fölött. Mindkét elemrészbe (a kézi fésűhöz hasonlóan) sűrűn egymás mellé ellentétesen hajlított, farkasfogszerűen elvékonyodó acéltüskéket helyeztek. A felső rész mozgatásával ez a fogazat fellazította, puhította a tépetőbe helyezett szálakat. A kézi füsülóhöz hasonló elven müködött tehát ez a szerkezet is, ám mivel nagyobb felülete volt, hamarabb kész lett vele a munka. A tépetôt alapvetően kézi vagy vízi erővel mozgatták, de a 20. századra ez a szerkezet sem kerülte el a gépesítést.

A tépetés után vitték át a gyapjút a patakvízzel vagy motorral hajtott fésülőgép asztalára. Ez a gép már gyárban készült, bonyolult, több egymásra helyezett hengerből álló vasszerkezet volt. Fésülő, puhító és simító 


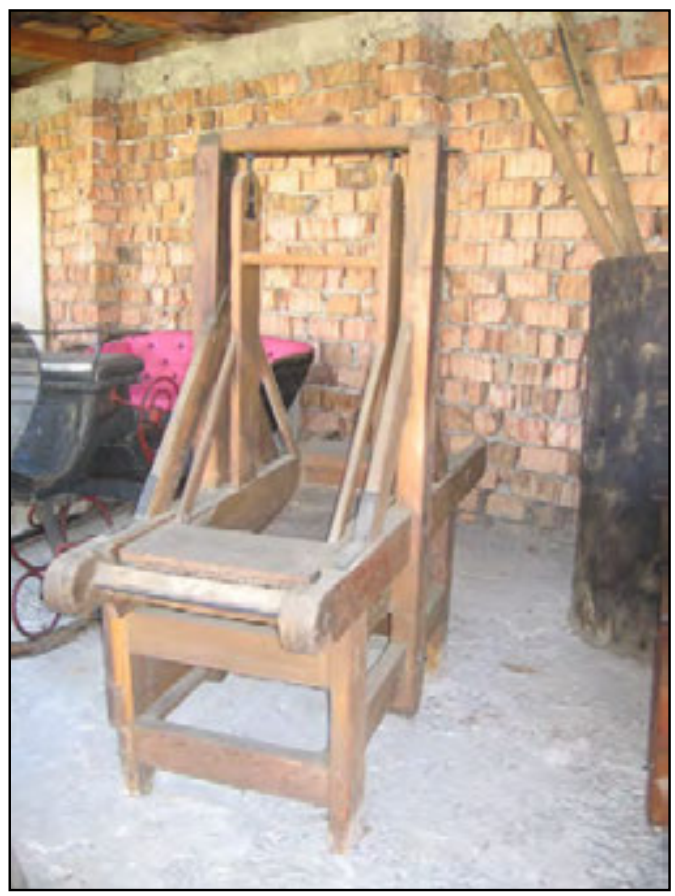

7. kép. Gyapjútépő a gyergyószentmiklósi Tarisnyás Márton Múzeum udvarán (Kerekes Ibolya felvétele)

hengerek sora. A gép elejét képező asztalról adagolták a hengerek közé a fellazított, tépett gyapjút. Az elöl lévő hengereken még nagyobb tüskék voltak, amelyek vékony szálakra szedték szét a tépett gyapjút. Az egyre kisebb tüskéjű hengerek egyre finomították, a simító hengerek puhították, rendezték a szálakat. Az utolsó fésűsor leválasztotta a hengersorról és a feltekerődobra irányította a gyapjút. A hengereket borító, hengerenként egyre finomodó apró tüskék tehát lágy, egyenletes paplanná kártolták (Gáspár Gyula 1939. 660; Márton Béla 1995. 122-125.). A fésülőről lekerült „gyapjúpaplant" egyes helyeken a gép kezelője végül még guzsalynyi egységekbe, félkilós, kilós bundákba is osztotta, feltekerte, s így tette vissza az otthonról hozott zsákokba.
A gép tulajdonosa a gyapjú súlya alapján határozta meg a munkadíjat, a fésülés árát. Ezt elsődlegesen pénzben kellett leróni, de egy részét gyapjúval is meg lehetett váltani. Általában a gyapjú súlyának 10-20 százalékát hagyták ott vámba. A fésülő tulajdonosa ezt a gyapjút legtöbbször eladta olyanoknak, akiknek a szükségesnél kevesebb gyapjújuk volt (vö. Márton Béla 1995). Volt olyan füsüloos is, aki a vámba hagyott gyapjú jó részét kötőfonalnak dolgozta fel, és a környékbeli asszonyok tőle vásárolták a szvetternek való fonalat.

Az 1960-as évek elejétől kezdődően lassan eltűntek a családi vállalkozásban múködtetett kisebb fésülők, szerepüket a háziipari szövetkezetek fésülőgépei vették át. (Bár azért, ha csak mutatóba is, de a szocializmus évtizedeiben is maradt egy-két, magánháznál működtetett fésülő.) Az 1989-ben bekövetkezett politikai változások a gazdaság átalakulását is magukkal hozták. Ennek egyik következménye volt, hogy Erdély-szerte fölszámolták a háziipari szövetkezeteket, felszerelésüket - jó esetben - magánvállalkozók vásárolták meg. Közülük néhányan újra elkezdték múködtetni a régi fésülőgépeket, így ma is vannak olyanok, akik vállalják az otthonról hozott gyapjú fésülését.

\section{Fonás}

A fésülés után igyekeztek minél előbb megfonni a gyapjút. Amíg a kendert és a festékesnek, rakottasnak félretett gyapjút többnyire külön erre a célra szerveződött fonókban, hosszú őszi, téli estéken dolgozták fel, addig a cserge fonala fóleg nyáron készült, és otthon, maguknak fonták. Amint a nyári munkák közben egy kis időt tudtak lopni reá, vagy épp esős napok köszöntöttek be, azonnal elővették, s fontak, durgáltak (vö. Hajdú Farkas-Zoltán 1993. 92.). 
A fonás két ősi kelléke az orsó és a guzsaly. Az orsó keményfából készült, 40-50 cm hosszú, mindkét végén hegyes, tetejétől kezdődően fokozatosan vastagodó, alsó részén hasasra esztergált egyszerű eszköz. A Székelyföldön használt guzsaly elterjedt típusa majd két méter hosszú, általában nyolcszögletűre faragott rúd, amelyet egy talpba illesztettek bele. Az egyszerűbb talp egy akkora deszkacsík, amelyre a fonást végző kényelmesen rátehette a lábát, hogy a guzsalyrúd fonás közben biztosan álljon. Ügyes kezű férjek, apák, legények, utóbb helybeli asztalosmesterek készítették. A guzsalyrudat nemegyszer meg is cifrázták, volt, aki színesre (pirosra, zöldre) festette. Előfordult, hogy a talpat is díszítették: kerekre, szív alakúra, vagy herelapi (lóhere) formájúra faragták, aljába pedig 4-6, alig néhány centis lábacskát tettek (bővebben: Kós Károly 1980; Nécsey István 1900; Domokos Pál Péter 1930; Gönyey Sándor 1943; Nagy Jenő 1947).

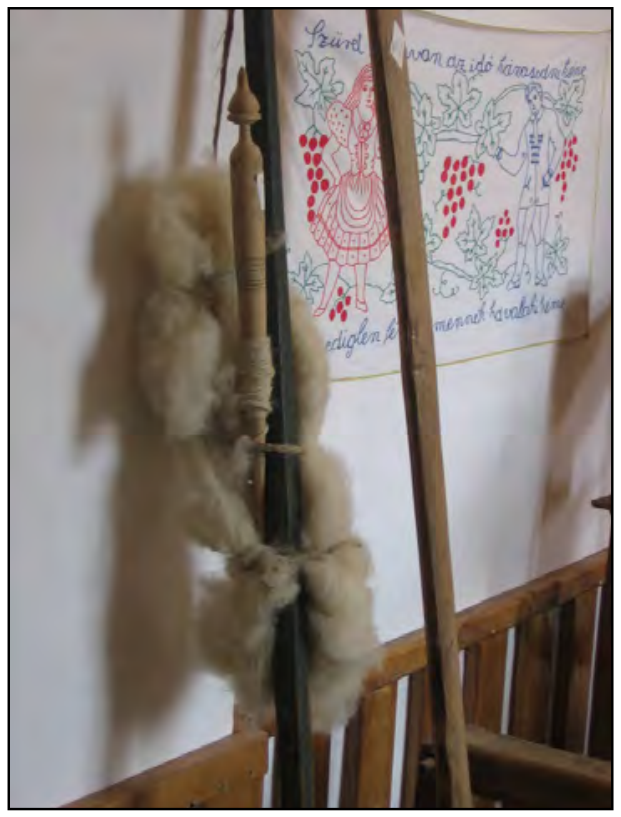

8. kép. Guzsalyra kötött gyapjú és orsó (Kerekes Ibolya felvétele)
A fonó kisujjnyi széles pamutszalaggal, kenderből sirített vastagabb fonallal erősítette fel a gyapjút a guzsalyrúdra. Ezután székre ülve, guzsalyát maga mellé téve vagy két térde közé szorítva, lábát a guzsalytalpra téve elkezdte a fonást. A gyapjúból óvatosan húzta ki a kezdőszálakat, s ujjai között sodorva jó félméternyi fonalat készített. A fonal végét az orsóra kötötte, majd ettől kezdve bal kezének mutató-, középső- és nagyujjával folyamatosan húzta ki a gyapjúszálakat, jobb kezével pedig az orsót pörgette, hogy arra tekeredjen a fonal. Amikor úgy érezte, hogy megvan egy duvaszka - azaz tele lett az orsó, nem tudta már ujjaival sem tartani, sem pörgetni -, akkor rövid időre abbahagyta a fonást. Fölállt, fölmatollálta a fonalat, különben a lazán megsodort fonal az orsóról lehúzva azonnal szaladt, összegabalyodott volna. Ha kész volt a matollálással, akkor ült le ismét a guzsaly mellé, s folytatta tovább a fonást.

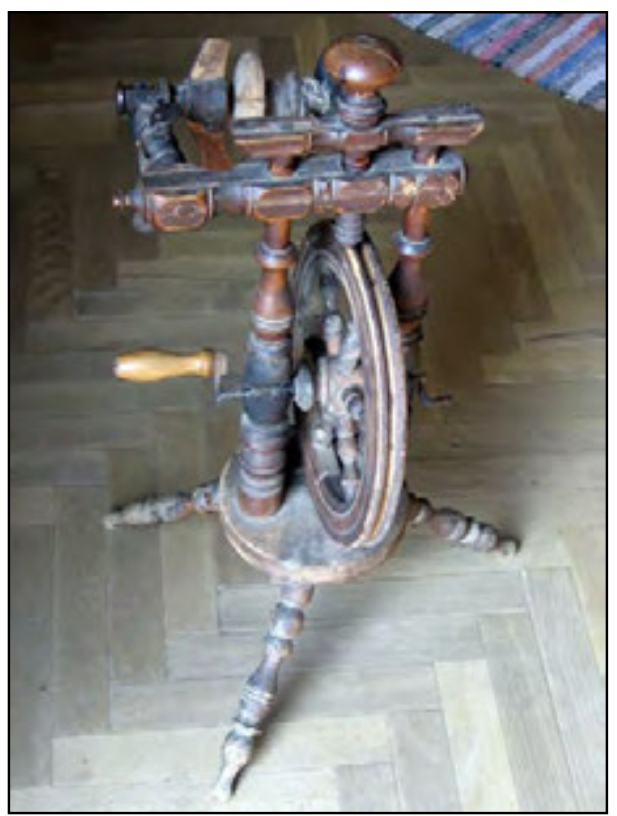

9. kép. Fonókerék, rokka (Kerekes Ibolya felvétele) 
A 20. század közepén terjedt el a Csíki-medence falvaiban a fonókerék (rokka) használata. Helybéli asztalosmesterek készítették megrendelésre. A szerkezet függőlegesen álló kerekét egy fogantyú segítségével a fonó hajtotta. Ez hozta mozgásba a vízszintes vaspálcára illesztett vékony, csőszerű orsót, amelyre föltekeredett a guzsalyról eresztett gyapjúszál.

Egy csergére kb. 6-8 kg fésült gyapjút számítottak. Ebből kétféle vastagságú fonalat készítettek. Hüvelykujjnyira húzták, s alig sodorták a leverôszálat, ontokot (vetüléket). Valamivel vékonyabbra durgálták, jobban sirítették (sodorták) a mellyéknek (felvetőszálnak) szánt fonalat. Volt olyan asszony, aki a vetüléket talpas guzsallyal, a felvetőszálat pedig fonókerékkel fonta. Az utóbbival ugyanis erősebb fonalat lehetett sodorni. Nyugodalmas, esős napon akár egy csergére valót is meg tudtak egyszerre fonni. Ilyen alkalom azonban gyéren adódott. Jobbára néhány nap alatt, kicsidenként fonták meg a csergének való fonalat.

\section{A szövés előkészületei}

Egyenesen az orsóról matollálták föl tehát a fonalat. Ennek eszköze egy T-alakú, fejes vonalzóra emlékeztető, alul villában végződő kézi matolla. Hossza általában 1,75-2 m, szélessége 8-10 cm. Tetején keresztben egy 40-45 cm-es, kissé elvékonyodó fejben végződött, alsó villája 5-7 cm magas. Az eszközt matolláláskor keresztbe fektették az asztalon, úgy, hogy mindkét vége kissé lelógjon, szabadon maradjon. A fonal végét az alsó villa egyik ágára kötötték, majd a fejrészen lévő T-nek felváltva hol az egyik, hol a másik oldalát kerülték meg a fonallal, s tértek vissza az alsó, villás véghez. Ha az orsóról elfogyott a fonal, folytatták a durgálást. A matollán időnként megolvasták a feltekert szálakat, hogy megfelelő mennyiségű fonalat készítsenek elő a szövéshez. 3 szálat mondtak 1 igének, 20 igét (60 szálat) 1 zserébnek. ${ }^{3}$ Ha 3-4 zserébet (180-240 szálat) fölmatolláltak, akkor a villánál egy kis darab fonallal összekötötték, matollástul levitték a patakhoz, esetleg egy előre odakészített, vízzel teli cseberhez, belemártották, s a matollát villájára állítva hagyták megszáradni. Az így előkészített fonalat előbb a T-alakú fejrész két oldaláról, majd az alsó villáról lehúzva már sokkal könnyebben tudták kezelni, nem bedrett, nem sodródott össze.

A matolláról leemelt fonalat legtöbbször festetlenül hagyták, a maga természetes színében használták. Akik viszont a fehér, szürke, vörösesbarna szín mellett más árnyalatokat is szerettek volna beledolgozni a csergébe, azok festőanyagokat használtak. A bolti festékek elterjedés előtt ezek különféle növényi részekből készültek. A fekete színt például cserefahéjból/egerhéjból tudták előállítani. Egy idős adatközlő emlékei szerint az egerfa kérgét nyáron - „amikor a mézga ott van a kéreg alatt" - meghántották, megszárították. Felhasználás előtt kézzel törték apróbb darabokra, majd kis fabottal megütögették, megtörték. Boltban vásárolt gálickővel keverték össze, vizet öntöttek rá, és egy nagyobb fazékban fölforralták. Eközben egy üstre botokat tettek keresztbe, ezekre bojtokat, hajlát (fenyőágakat) fektettek. A sűrűn egymásra helyezett ágak tűlevelei szűrték meg a festőlevet. Ebben a lében áztatták aztán a festésre szánt fonalat. Kihűlés után hideg vízben tisztálták meg. Hasonlóképpen jártak el a dióhéjjal, amelyből barna színt nyerhettek (Vö. Bartha Károly, N. 1937. 19-22; Palotay Gertrúd 1937; Szentimrei Judit 1972. 168-171; Miklóssy V. Vilmos 1978. 91-100.). 
A 20. század első felétől terjedtek el a boltban vásárolt, az asszonyok által pilifuxiaként, vagy egyszerüen csak fuxiaként emlegetett bázikus festékek, amelyeket a sokféle szín könnyű előállítása és jó színtartósága tett közkedveltté. Főként a festékesek fonalának előkészítésénél használták, de utóbb már a csergeszövők is alkalmazták néhány színét. A II. világháború után egy másik, Galos, illetve Gallus néven említett textilfestéket tudtak beszerezni. Ezt használták, ha a juhok fehér, fekete, vörösesbarna színű gyapjának öszszevegyítésén túl valamilyen más színnel is szerették volna díszíteni a csergét. ${ }^{4}$

A matollálás, és ha kellett, a festés után az összekötött szálakat kézzel összefogták, $\mathrm{s}$ átemelték a tekerőlevelre. Ennek felső része két, 1-1 méter hosszú, tenyérnyi széles, keresztben összeilleszthető deszkából, ún. levelekből állott. A közepükön lévő lyukba helyezett vékony, esetenként egyszerű faragással díszített pálca segítségével lehetett egy kereszt alakú talpban végződő rúdhoz rögzíteni. A felső kereszt deszkáinak végére készítője két-három furatot is tett. A megfelelő furatba illesztett pálcákkal akkora méretet állíthattak be maguknak az asszonyok, amekkora a matolláról lekerült fonalköteget feszesen tartotta. Mivel csak a középső, vékony pálca tartotta a talpazathoz a felső keresztet, e tengely körül könnyen el tudott fordulni, s kényelmesen lehetett róla letekerni, gombolyítani a fonalat. Ha leverôfonalnak (vetüléknek) való szálakat tettek a tekerőlevelre, akkor azt kézzel tekerték föl több, egyenként 35-50 cm hosszúságú, 6-8 cm széles, két végén ívesen bevágott, vékony falapra, csépre. A mellyéknek való fonalat csöllőkerék segítségével a vetélők lyukas közepűre esztergált pálcáira csöllötték, tekerték fel (Szolnoky Lajos 1991. 366-367; Kardalus János 2000. 221.).

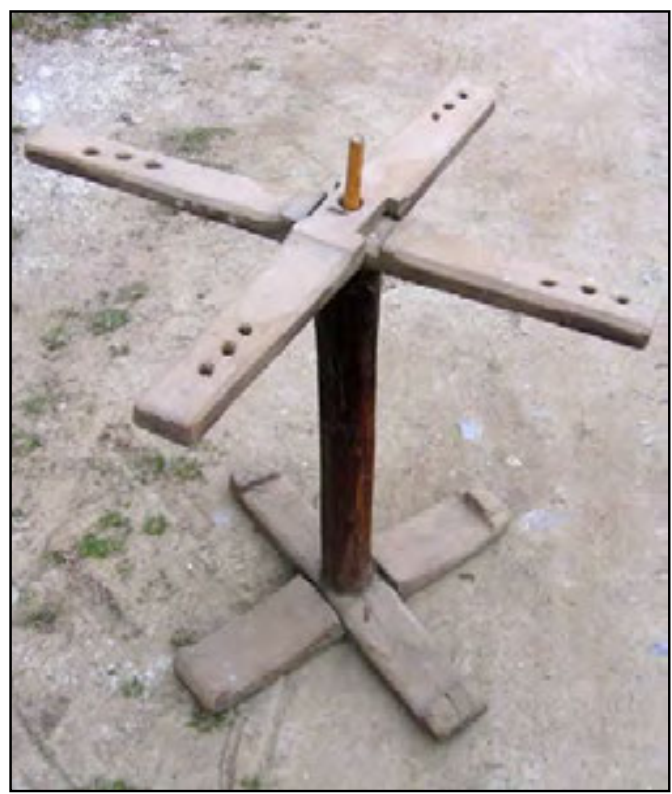

10. kép. Tekerőlevel (Kerekes Ibolya felvétele)

Ezután vetőfára tekerték föl a szálat, ami már a szövőszékre való fölvetést készítette elő. Attól függően, hogy milyen hosszú csergét akartak szőni, a hossz kétszeresét vágták le először a gombolyagról. A levágott szálat a vetőfa alsó részéhez kötötték, majd spirálisan tekerték föl az oldalsó léceken. Ez a szál volt a mérték, ehhez képest számlálták a szükséges szálmennyiséget. ${ }^{5}$

A fonalak előkészítése után következett a szövőszékre való fölvetés. Szövéshez ugyanazt a szövőszéket (osztovátát) használták, mint a kender- és gyapjúszőttesekhez, csak a bordában volt különbség. A csergéhez való borda furatai ugyanis gyérebben voltak, és akkorára készítették, hogy azokon a mellyék vastag szálai átférjenek. (A felvetés mozzanatairól részletesen: Csókos Varga Györgyi 1992. 107-113; 1998. 112-126; Márton Béla 1993. 22-23; vö. Tagán Galimdzsán 1935. 85-86.).

Néhányan próbálkoztak azzal, hogy a $r a-$ kottashoz hasonlóan a csergéhez is az erő- 


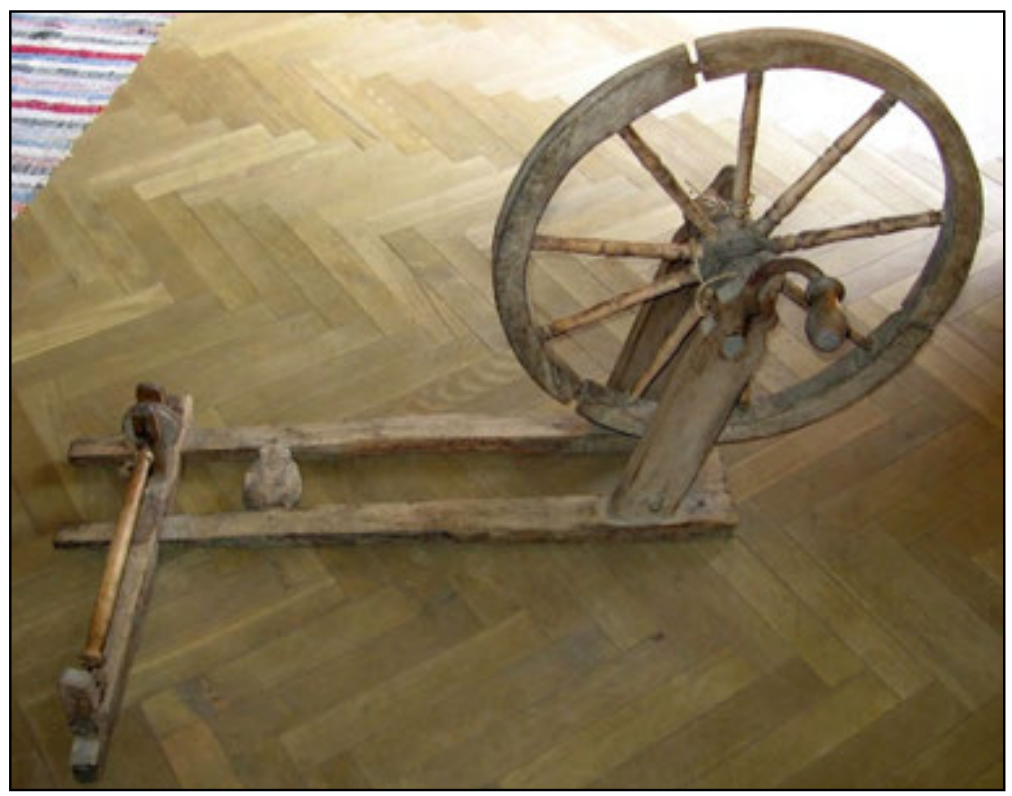

11. kép. Csöllőkerék, durgálókerék (Kerekes Ibolya felvétele)

sebbnek tartott pamutfonallal vessenek föl. Az újító próbálkozás azonban nem mindenütt vált be. Az így készült szövet ugyanis már az osztovátáról levágva is gyưrüsödött, hullámosodott, főképp pedig a ványolás után vált egyenetlenné a felülete, mert a vízre és a mechanikai ráhatásra eltérően reagált a kétféle alapanyag. A cserge felvetőszála - az újító kísérletek sikertelensége miatt - általánosan a gyapjú maradt a Székelyföldön. Az 1950-1970-es években azonban - amikor a kötelező leadások miatt időnként meglehetősen gyapjúszúkében voltak - előfordult, hogy a mellyék gyapjúszálai közé minden harmadik vagy negyedik szálat kenderből vetették.

\section{Szövés}

A hosszadalmas előkészületek után a szövés már gyorsan ment, mert a vastag fonallal szaporán haladtak. A csíki asszonyok, házasságra készülő leányok általában kétnyüstös osztovátán, kettős lábítóval szőtték a csergét. ${ }^{6}$
Jó esetben egy, kevésbé jó esetben két nap alatt készültek el vele. Leggyakrabban egyszínű fehér vagy szürke csergét készítettek. Ezzel hamar elkészültek, hiszen a felvetőszálak között csak a csépre tekert leverőszálat kellett átvezetni hol az egyik, hol a másik oldalról, és a bordával ráverni. Az osztovátán általában 60-100 cm széles gyapjúszövetet tudtak szőni. Ettől függően két, három vagy négy ilyen szél (szövetcsík) összeöltésével állították elő a megfelelő méretű - általában 3-3,5 méter hosszú, 1,6-2,4 méter széles szốtteményt. Ha cifrázni is akarták, akkor a szürke, illetve fehér alapszínbe csíkokat, négyzetet, ritkábban rombuszt szőttek. Az alcsíkiak fehér, szürke, fekete, piros, a felcsíkiak ezenkívül még kék, sárga, esetleg zöld színt használtak díszítésre. ${ }^{7}$ Azzal már a szövéskor számoltak, hogy ványoláskor felére, harmadára apad a cserge. A kisebb csíkokhoz ezért legalább 5-10 cm-t, a nagyobbakhoz legalább 30-60 cm-t szőttek. A mintával díszített csergék szövése több figyelmet igé- 


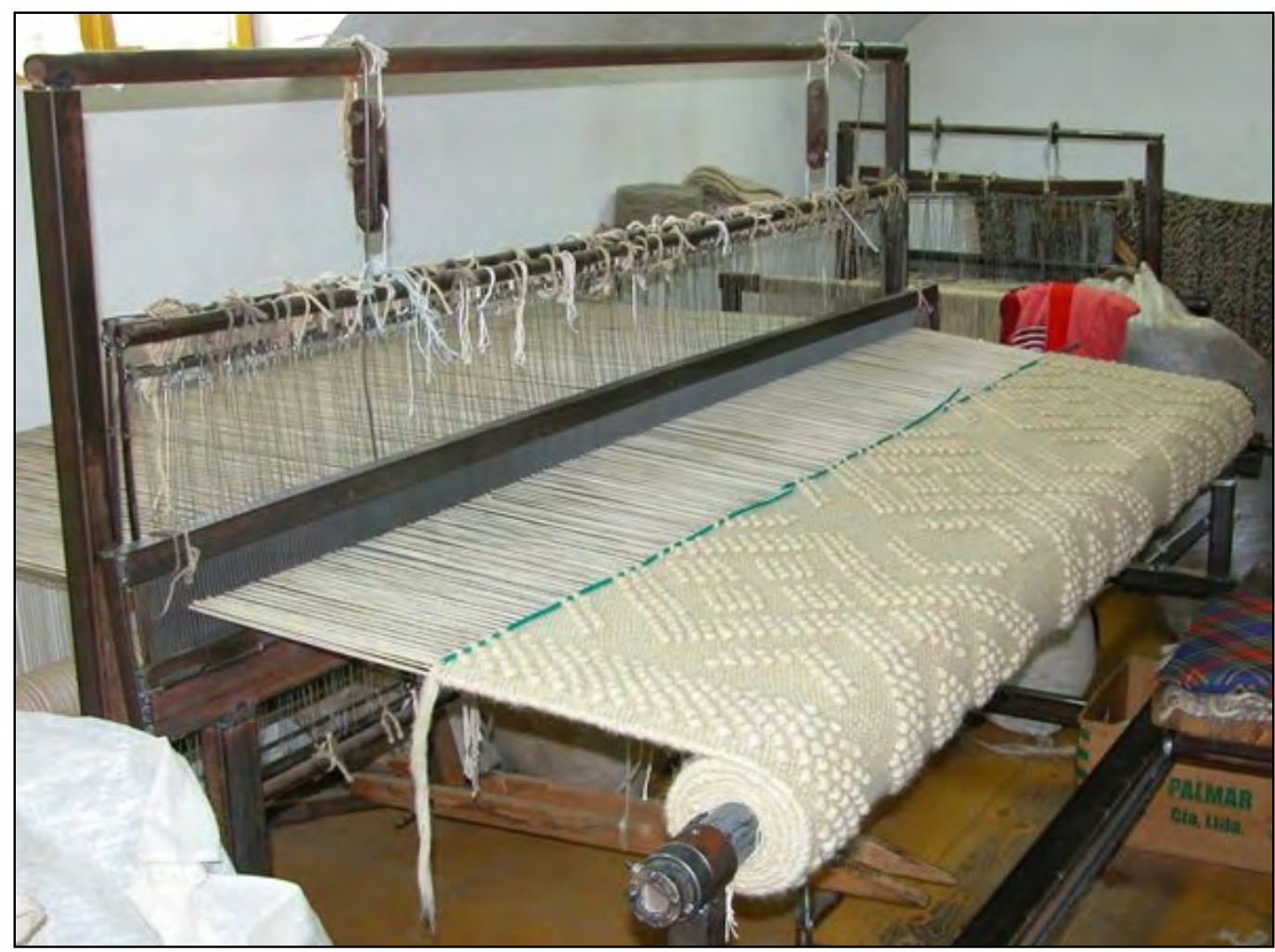

12. kép. A csíkkarcfalvi Mózes Gyapjúfeldolgozó Manufaktúra szövőszéke (Kerekes Ibolya felvétele)

nyelt, mert pontosan kellett számolni ahhoz, hogy majdan a takaró összeállításakor, a szélek összeöltésénél a minták találkozzanak, illetve a kívánt ritmust adják ki. Ha megvolt a megfelelő hosszúság, a gyapjúszövetet levágták a szövőszékről. Az egymás melletti felvetőszálakat jó erősen összekötötték, és visszafüzték, vagy rojtnak hagyták meg (vö. N. Bartha Károly 1932. 19-23.).

Az egyes csíkok szélein, ahol a csépen vezetett fonal átfordul egyik sorból a másikba, egy kicsiny rés marad. Egy arasznyi hosszú, vastag tűbe a mellyékből maradt fonalat füztek, s ezekbe a szélső kis résekbe szúrva a tűt egyszerűen összevarrták a két szélt. Az egyszínűre szőtt csergék összeöltése gyorsan ment. A csíkozottaknál vagy a cifrázottnál kellett figyelni arra, hogy a megfelelő sorok a megfelelő helyen találkozzanak, s így szépen jöjjön ki a minta.

Júniusban, augusztusban a legtöbben készen voltak a cserge szövésével és összeállításával. Mivel ezután egy időre kikerült a házból, jegyet varrtak bele (Kardalus János 1977). Ez legtöbbször a cserge egyik sarkára varrott, a családnév kezdőbetűjét formázó textildarab volt. Ezután következhetett a ványolás.

\section{Ványolás}

A csergekészítés munkafolyamatának ezen a pontján a cserge egyébként is vastag szövete még inkább összesűrűsödött, tömörült, lomot eresztett, erős és tartós lett.

A ványolás „szezonja" május végétől szeptemberig tartott. A nap melegétől a patak 
vize is meglangyosodott, és ebben a lenge nyári vízben tudott igazán jól ványolódni a cserge. Éppen ezért a legtöbben a nyári melegben, júliustól augusztus végéig (csipkerózsanyílástól Szent Istvánig) vitték, küldték ványoltatni a csergét.

Egykor sok székelyföldi település határában ott voltak a ványolókádak. A tiszta vizü, gyors folyású hegyi patakok vize mellé több helyen is vízimalmok települtek. E malmok a víz erejét - a gabonaőrlés, gyapjúfésülés mellett - ványolásra is felhasználták (Gáspár Gyula 1939. 661-663; Ozsváth Gábor Dániel 2011. 137-141; 2014). A malom melletti mederbe 2-3 méter átmérőjü, 1,5-2 méter magas, kerek, alul keskeny, fölfelé bővülő csonka kúp vagy tölcsér alakú fakádat, ványolókádat helyeztek, amelyet a meder köveivel körbe is raktak, hogy ne tudjon elmozdulni. Dongáit korábban füzvesszővel fonták körül, utóbb fa- és vasabronccsal fogták össze. Mivel tartósan, folyamatosan mozgó, nagy víztömeget kellett megtartaniuk, erős támasztólábakkal is megerősítették, alátámasztották az abroncsot.

A patak vizét fából készített vályúval (lajjal) terelték a ványolókádhoz. A laj készítésénél figyeltek arra, hogy a víz kb. 1, 2, 2,5 méterrel magasabbról induljon a kád felé, és fölötte, kb. 30-50 centiméterrel beljebb érjen véget. Ezzel a szintkülönbséggel és a viszonylag keskeny vályúval biztosították, hogy a víz nagy sebességgel zúduljon a kádba. A laj beállításakor arra is figyeltek, hogy a lezúduló víz úgy érkezzen a kádba, hogy lehetőleg az óra járásával ellentétes irányú, örvénylő mozgást alakítson ki. Ez az örvénylő mozgás ragadta magával újra és újra a csergét.

A kádba eresztett cserge először vizet szívott magába, és merülni kezdett a kád alja felé. Mivel a patak vize folyamatosan és felülről érkezett nagy sebességgel a kádba, így nemcsak a laj beállításának köszönhető ol- dalirányú örvénylés, hanem egy fentről lefelé és lentről felfelé tartó, folytonos keringés is kialakult a kád belsejében. Ez a lentről felfelé irányuló mozgás újra és újra felszínre vetette a csergét. Az pedig a felszínre érve megint átvette az oldalirányú, keringő mozgást, majd az örvény holtterébe kerülve a nagyméretú, vízzel átitatott gyapjút ismét lefelé húzta súlya. A felülről érkező és a szintkülönbség hatására nagy sebességgel lezúduló víznek akkora ereje volt, hogy a kád aljára került víz szinte azonnal elkezdett nagy erővel fölfelé sodródni. Ez a fölfelé irányuló vízmozgás ismét felszínre vetette a csergét, amely fent újból belekerült az oldalirányú keringésbe. Lemerülés, felszínre vetődés és oldalirányú forgás. Ezzel a folyamatos mozgással teltek az órák, napok. Éppen azért kellett a kádnak megfelelő formájúnak és méretűnek lennie,

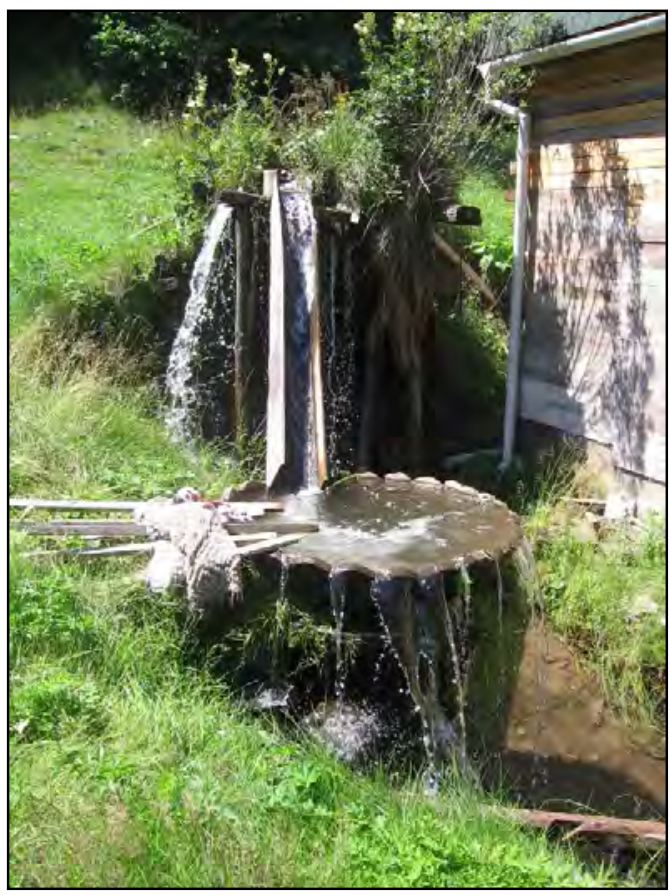

13. kép. Ványoló Székelyvarságon (Kerekes Ibolya felvétele) 
hogy a cserge elférjen benne, és legyen helye a folyamatos forgó, örvénylő mozgásra. E mozgás során tömörültek össze a gyapjúszálak, vált erőssé és lomossá a cserge anyaga.

A kádban lévő víz mennyiségét és a fölösleg elvezetését a dongák felső végének kialakításával, valamint a dongákba fúrt lyukakkal tudták szabályozni. A dongák felső végének kialakításában három típussal találkozhatunk. Az egyiknél a dongák vége egyenes, a szélektől 40, 50 vagy 60 centiméterre lyuksor található. A másiknál a végek lekerekítettek, a felső végek alatt körben, azonos magasságban ugyancsak megtalálható a lyuksor. A harmadik típus dongáinak végét fent szögletesre faragták, jobb és bal oldalon pedig - a tetejétől kb. 40-50 centiméterre - háromszög alakban bevágták. A dongák összeillesztése után ennél a típusnál is egy szögletes lyuksor alakult ki a felső széltől egyenletes magasságban. A felső lyuksor biztosította a fölösleges vízmennyiség elvezetését, a dongák végének gömbölyű vagy csúcsos kialakítása pedig azt akadályozta meg, hogy a nagy sebességgel kavargó, örvénylő vízzel a cserge átbukjon a ványolókád peremén. Előfordult, hogy néhány dongán lejjebb is fúrtak egy-egy lyukat. Ezek bedugásával, illetve megnyitásával lehetőség nyílt a kád vízmagasságának szabályozására.

Legalább egy teljes napon keresztül mozgott, kavargott a vízben a cserge, de ha mód volt rá két-három napot is hagyták. Időnként a ványolós is odament a kádhoz, egy hosszú rúddal, horgasbottal belenyúlt, átforgatta a szőtteményeket. Volt, hogy ki is vette a kádból, hogy megnézze, hol tart a cserge tömörülése, lomosodása. Éppen ezért volt, ahol a kád mellé egy asztalt is beállítottak, ide emelhették ki a csergét. Amikor már késznek ítélték, kivették a kádból. Mivel maga a cserge nagyméretű volt, ráadásul vizesen még a súlya is megsokszorozódott, a kádból való kiemelése nehéz munkát jelentett. Ha csak lehetett, nem is egyedül végezte a ványolós, hanem segítséget hívott. Szakaszosan húzták ki, és hagytak egy szusszanásnyi időt, hogy a kihúzott részből kicsoroghasson a víz. Ha a kád mellé volt asztal állítva, akkor oda emelték ki a csergét, ha nem, akkor a ványoló melletti füves területre vitték, és terítették ki, ahol kifolyhatott belőle a víz nagy része. Kicsiny idő múltán külön erre a célra használt, lehetőleg napos, szellős helyen álló szárítóállványra terítették át. Ez az állvány erős lábakból és egy szintén erős, rendszerint 5-8 m hosszú, 10-12 cm vastag, hengeresre faragott, sima felületű keresztrúdból állt. Az állvány magassága akkora volt, hogy a félbehajtott cserge ne érjen földet, ki tudjon folyni belőle a víz. A rúd azért volt olyan hosszú és erős, hogy egymás mellett akár két-három cserge is száradni tudjon rajta. A vastagsága pedig azért volt fontos, hogy a rétegek között a levegő tudjon járni, mihamarabb meg tudjon száradni a cserge (Gáspár Gyula 1939. 661-663; Nagy Mari Vidák István 2014).

Száradás után még átfésülték, mert a vízben mozogva a szálak megbolyhosodtak, lomot eresztettek. A ványolt cserge megapadt, legalább harmadával lett kisebb az eredetileg szőtt és több szélből összeöltött mérethez képest, de vastagsága hozzávetőlegesen megduplázódott. A tömörülés hatására a szélek közötti összeöltés sem látszott már.

Létesültek kifejezetten a posztónak szánt gyapjúszövetekkel iparszerűen foglalkozó, egész évben működő ványoló- vagy kallómal$m o k$ is. Itt is vállaltak csergeványolást. Ezekben ütőbotokkal és melegített vízzel segítették a szálak tömörülését. Mivel katlanokban melegített vizet használtak, egész évben tudtak ványolni. Müködésükhöz itt is a patakok vize biztosította az energiát. A víz ereje egy 


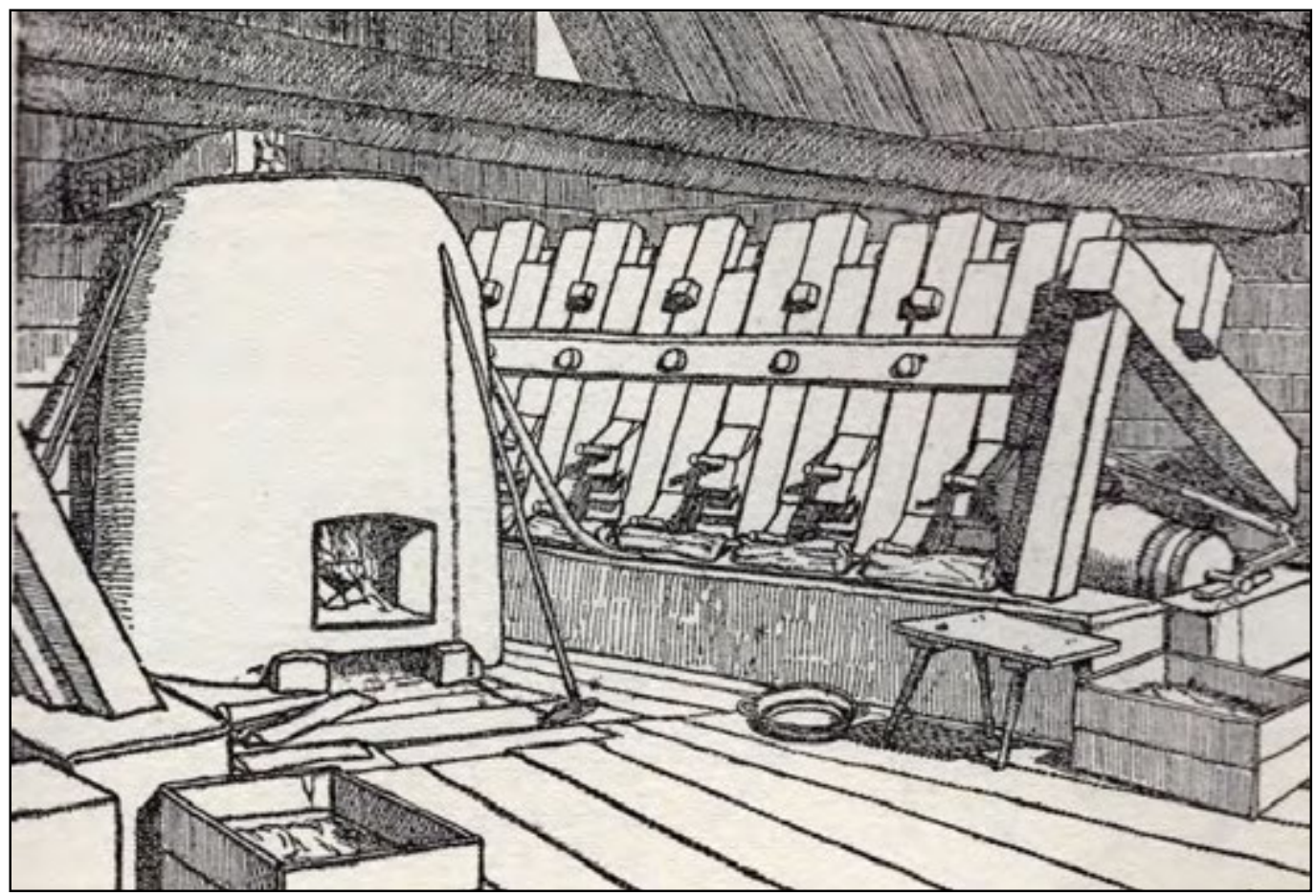

3. ábra. Ványolómalom belseje In: Bátky Zsigmond - Győrffy István - Viski Károly 1933. I. 335. 989. kép (Lásd még Haáz Ferenc Rezső 1931. 3. ábra)

fogas hengert mozgatott, ez emelte, majd ejtette vissza a langyosra melegített vízben ázó gyapjúszövetekre az ütóbotokat ${ }^{8}$ (vö. Endrei Walter 1984. 25-26, 48; Benda Judit 2014. 29; Haáz Ferenc Rezső 1931). Ettől a folyamatos, erős dürücköléstől a cserge szálai összetömörültek és meglomosodtak. Azért, hogy a botok egyenletesen érjék a szövetet, és ezáltal az egyenletesen menjen össze, ványolás közben háromszor (reggel, délben és este) meghányták, azaz szétbontották, majd újra összehajtogatták. 24 óra elteltével bő vízben kimosták, majd a szárasztóra terítették. Száradás után szálhúzató hengeren vezették át a csergét. Ez átfésülte és föllazította a ványolás közben kialakult 5-6-7 centiméteres lomot. Végső mozzanatként rövid időre egy belülről faszögekkel tüskézett forgódobba tették, amelybe kb. $50^{\circ} \mathrm{C}$-ra melegí- tett vizet öntöttek. Ebben az ún. melegítóben forogva a szegecsek hatására a lomok töve is megerősödött, tartósabb lett, a használat során még nehezebben hullott el. Szárítás után a cserge visszakerült gazdáához (Haáz Ferenc Rezső 1931; 1939; Bátky Zsigmond - Györffy István - Viski Károly 1933. I. 345347; Bartha Károly, N. 1932. 22-23; Gáspár Gyula 1939. 661; Szentimrei Judit 1972. 183-184; Szolnoky Lajos 1991. 367-368. vö. Gönyey (Ébner) Sándor 1946. 86-87; 1954. 43-45; 1960. 351; Tagán Galimdzsán 1935. 86; Ozsváth Gábor Dániel 2011. 126-140).

$\mathrm{Az}$ asszonyok - a környékbeli ványolók mellett - messzebbre is elvitték csergéiket ványoltatni. (Az egyik leghíresebb a lövétei ványoló volt. Már Orbán Balázs is megemlékezett róla. - Orbán Balázs 1868-1873. I. 83.) Még akkor nyáron feltekerték, zsákba vagy 
nagy, ún. vékás posztótarisnyába tették a megszőtt takarót, egy alkalmas napon hátukra kötötték a darabonként jó hat-hét kilós terhet, s gyalogosan keltek vele útra. Utóbb már voltak olyan ványolósok, akik szekérrel járták be a vidék falvait, havonta összegyűjtötték, majd vissza is szállították az elkészült csergéket. Ezt mindenütt hamar megkedvelték az asszonyok, mert sok fáradtságtól kímélte meg őket. Minden faluban volt olyan gazda, aki a vállalkozóval megegyezve, a maga portáján gyűjtötte össze a ványolnivalót. A ványolósok alkalmanként 15-20 települést is végigjártak, ezért pontos nyilvántartást kellett vezetniük arról, hogy az egyes szöveteket mely faluból hozták el, s hová kell visszavinniük. Egyenes és kör alakú vonalakból, illetve bevágásokból és lyukakból mindegyikük maga alkotta meg (vagy vette át elődjétől) az egyes falvak jegyeit, amelyeket a szôttemény szélére tettek (vö. Kardalus János 1977; 1980). Az elkészült darabokat e jegyek alapján csoportosítva rakták szekérre, és vitték vissza a falvakba. Az asszonyok vagy családtagjaik aztán a ványolóssal egyezségben lévő házhoz mentek el, s ott a saját maguk által belevarrt jegy alapján keresték ki a maguk csergéjét.

\section{A cserge használata, ápolása}

A ványolóból hazakerült, hozományba szánt csergét eltették. Legtöbbször abban a ládában vagy ágyban tartották, amelyben a kelengye többi darabját is gyűjtötték. A hozományba adott cserge mennyisége, nagysága, színe, mintáinak kidolgozottsága mind-mind a lány vagyoni helyzetét mutatta. Úgy tartották, ha egy nő megbecsüli, rendben tartja a csergét, akkor az élethosszig is eltart. Amikor asszony lett a lányból, akkor vették használatba, tették bele a vetett ágyba, s takarództak vele. A használatra váró vagy egy időre félretett csergébe diófalapit, dohánylevelet, később naftalint raktak a molyok elleni védekezésül.

Évente egyszer, nagypéntek reggelén, a nagyheti takarítás részeként mindenféle gyapjúból készült holmit (csergét, gyapjúlepedőt, párnákat, derékaljakat stb.) kihordtak a házból, kerítésekre, kifeszített kötelekre, drótokra teregették, s estig ott szellőztették. Azt tartották (és tartják ma is), hogy a nagypénteken meglevegőztetett gyapjút nem eszik meg a molyok.

A használat során természetesen a cserge is elpiszkolódott, időnként ki kellett mosni, hogy felfrissüljön. Évente, kétévente kerítettek erre sort. Egy nagy cseberbe tették, langyos vizet öntöttek rá, és megáztatták. Áztatóvíznek - ha csak lehetett - frissen fogott esővizet használtak. Ezzel legalább egy napot vártak, hogy leülepedjen, és csak azután öntötték rá a mosásra váró csergére. Ennél is jobbnak tartották a zsíros gyapjú levét, mert - tapasztalatuk szerint - abban tisztult, lúgozódott ki legjobban a gyapjúholmiba rakódott piszok. A jól megáztatott csergét átdörzsölték, majd a patakra vitték, és a mosópadon alaposan átsulykolták. Mosás után a nagyméretű és a víztől még inkább megnehezedett csergével egy ember nehezen tudott bánni, segítség kellett a kicsavarásához és a kiterítéséhez is. A segítővel otthon rúdra vagy kerítésre tették az udvaron, ahol a nap érte, és a levegő átjárhatta. Ott száradt meg és frissült fel. Mosásra és szárításra, ha csak lehetett, meleg, napsütéses időt választottak. A nagy, vastag csergét ugyanis a házban csak nehezen tudták szárítani. Az volt a tapasztalat, hogy a kényszerűségből benn a házban, tűz mellett szárított cserge lomja a használat során megtört, majd maga a szövet is hamarosan meglyukadt.

Ha nem volt mód a mosásra, akkor az elpiszkolódott csergét a posztóharisnyákhoz 
hasonlóan az udvar füves részén terítették ki, illetve egy szélesebb asztalra fektették fel, puliszkaliszttel behintették (utóbb boltban vásárolt benzint is adtak a puliszkaliszthez), a lisztet tenyérrel besúrolták a szövetbe, majd szárítókötélre vagy drótra emelték át. Itt aztán egy pálcával jól megverték, hogy hulljon ki belőle a liszt s vele együtt a rátapadt piszok. Akár mosták, akár puliszkaliszttel tisztították a csergét, befejező mozzanatként gyér fogú fésűvel fésülték át a lomját, s utána vitték vissza a szobába, vették újra használatba. Ha már évek óta használták, többször tisztították, megkopott a lom. Ilyenkor újra megványoltatták és tépették, hogy újra meglomosodjon. A jó lomosra ványolt csergét tartották ugyanis igazán becsüsnek.

A csergék sem örök életűek. A régóta használt, esetleg az elhalt szülőktől örökölt, megkopott, lomjukat vesztett csergék kikerültek a családi ágyból. Előbb szénacsináláskor vitték magukkal takarónak, ha azokra a távoli, havasi kaszálókra mentek föl, ahonnan nem jártak haza mindennap. Aztán a szekérre került át, s hideg időben ebbe burkolództak az úton járók. Ha végképp megkopott, lópokrócnak használhatták, de olyan asszony is volt, aki a falut járó öreg koldusnak adta oda.

\section{A cserge készítésének átalakulása}

A kommunista-szocialista rendszer által a lakosságra erőltetett kollektivizálás az élet számos területén jelentős változásokat hozott. A családi juhtartás - ha nem is szűnt meg - lényegesen visszaszorult. Ennek következtében a gyapjú házi feldolgozása szinte teljesen eltűnt. A II. világháborút követő években a kötelező beszolgáltatás miatt kialakult gyapjúszúke hatására a 3-4 év alatt összegyưjtögetett gyapjúból inkább posztónak való szövetet szőttek, hogy a férfiak az abból készült ruhában tudjanak az erdőre járni. A lányok kelengyéjét ez idő tájt apránként összerakosgató családok jórészt csak pénzért tudták megvásárolni a különböző tárgyakat. Az anyáknak, nagyanyáknak kevesebb módjuk volt otthon szőni, ezért ezzel foglalkozó helybeli specialistával vagy a háziipari szövetkezetek valamelyikében készíttették el a szőtteseket.

Ha volt otthon összegyűjtött gyapjújuk, akkor azt elvitték magukkal. Ha találtak kedvükre való kész szőttest a szövetkezet boltjában, lerakatában, már vihették is, ha nem, akkor meg kellett rendelni, s az igényeknek megfelelőt szőttek a bedolgozók. A késztermék árának egy részét a magukkal hozott gyapjúval rótták le, a munkadíjat mindenkor pénzben fizették. $1 \mathrm{~m}^{2}$ szôtteményre $1 \mathrm{~kg}$ gyapjút számoltak. Akinek nem volt gyapjúja, természetesen a teljes összeget pénzben fizette ki.

A házasuló fiatalok igényei időközben megváltoztak, már nem a hagyomány, hanem a kor divatja volt a meghatározó. A szövetkezetek bedolgozói igyekeztek a régi hagyományok megőrzése mellett az új elvárásoknak is megfelelni. Ezért az 1950 után készült csergéken is az adott időszak egyes divatszínei és a külvilág hatására változó egyéni ízlés is nyomon követhető. Adatgyűjtésem során annak idején ilyenekkel is találkoztam. Az egyik háznál például a háziasszony megmutatta féltve őrzött, 1954-ben a háziipari szövetkezetben szövetett csergéit. Mindkettőt hozományba hozta magával. Az egyik hagyományos fehér-szürke, kockásan szőtt, a másik teljes egészében narancssárga színű.

A Székelyföldön ma sok háznál találkozunk az újabb típusú, vastag fonalból szőtt, bedolgozók, illetve specialisták által készített szőttesekkel. Ezek ványolva nincsenek, de mivel fehér, szürke vagy barna színű, vastag gyapjúfonalból készültek, ma ezeket is csergének 
mondják. Ezek három, egymástól jól elkülöníthető csoportot alkotnak.

Az elsőbe azokat sorolom, amelyek mintakincse és szövési technikája a hagyományos székely festékesekkel, rakottasokkal egyező, de a gyapjú természetes színeit használják benne, és vastag fonalból készítik. Van, aki ágy előtti szőnyegnek, van, aki ágytakarónak használja.

A második típus az ún. lomos vagy lombos cserge. Szövéstechnikája emlékeztet a gubakészítésre (vö. Luby Margit 1927; Flórián Mária 1997. 629-632; 2001. 165-168.). $\mathrm{Az}$ egyes sorok leverése után ugyanis a juhok oldalán nőtt, hosszú, erős szálú gyapjúból, külön erre a célra durgált, alig sirített gombolyagot raktak maguk mellé a szövők. Három ujjukat összecsippentve egy 10-12 centiméteres tincset téptek ki belőle. A szélső szálakat kihagyva ujjukkal megemeltek négy felvetőszálat, és behúzták alá a tincset. Ezután téptek egy újabbat, ismét megemeltek négy másik felvetőszálat, $s$ behúzták alá. Amikor végigértek a soron, a tincseket lekísérték, azaz a cséppel átvezették fölöttük a vetülékszálat, és a bordával jó erősen rávertek. A tincsek végei kilógtak a szövetből, gubára emlékeztető felületet képeztek. A lombos csergét általában egyszínű fehérre szőtték, de itt is előfordult a már említett geometrikus díszítés: a tincsekből vízszintes csíkozást, a sarkokra vagy középre négyzetet, rombuszmintát, esetleg a négy szélen körbefutó szélesebb keretet készítettek. Az elkészült cserge lombját átfésülték, hogy a tincsek eligazodjanak, szép szálasak legyenek, és már használhatták is - elsősorban ágy- és foteltakarónak.

A harmadik csoportba az ún. bogos vagy bogyós csergék tartoznak. Ezeknél is ujjnyi vastagra durgált, alig sirített, általában nyers és szürke színű fonallal dolgoznak. A bogok ki-

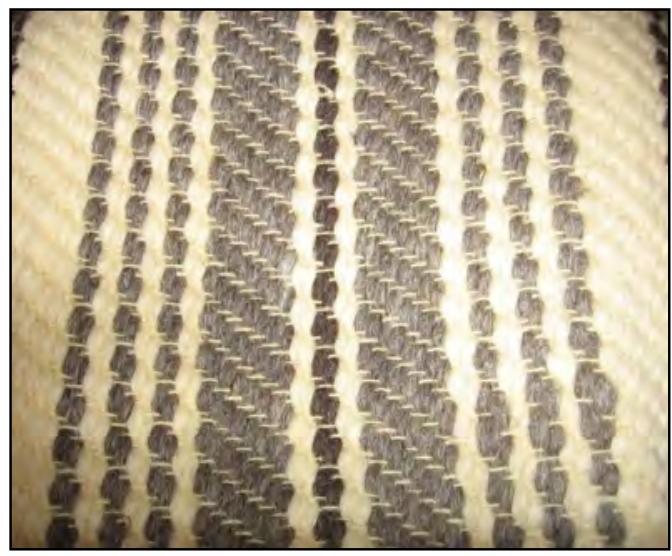

14. kép. Vastagra durgált fonalból szőtt ágytakaró, „cserge" (Kerekes Ibolya felvétele)

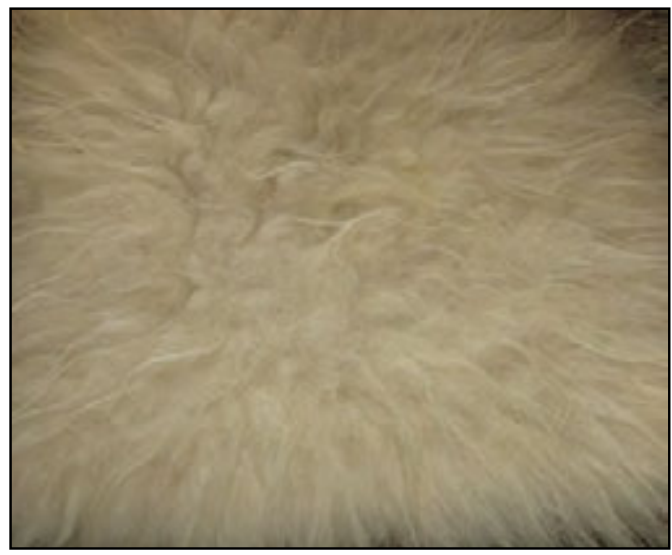

15. kép. Lomos cserge (Kerekes Ibolya felvétele)

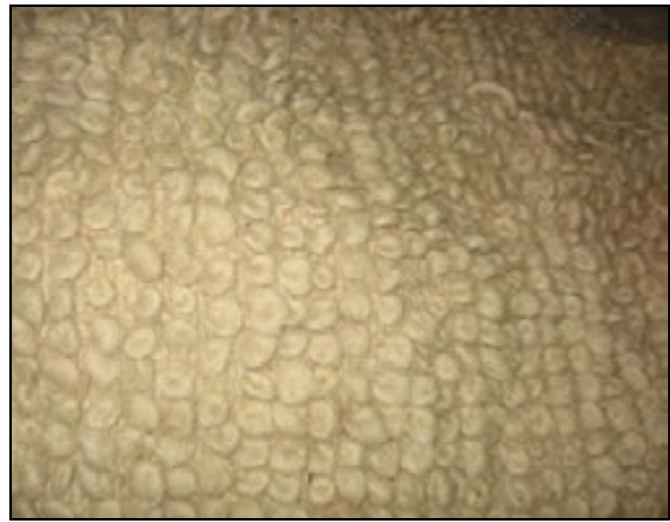

16. kép. Bogosan szőtt ágytakaró „cserge"(Kerekes Ibolya felvétele) 
alakításához egy vékony (általában múanyag borítású) vaspálcát használnak, amely valamivel hosszabb, mint a szövőszéken készíthető szövet szélessége. A legegyszerűbb mintázat kialakításához három-négy sor leverése után a következő sor fonalát minden negyedik-ötödik felvetőszál között benyúlva kihúzogatják, s a fonal alá csúsztatott vaspálcára emelik rá. Attól függően, hogy hányadik felvetôszál után nyúltak be, s emelték meg kissé a fonalat, sűrübben vagy ritkásabban sorakoztak a bogok. A sor leverése után kiveszik a pálcát, három-négy simán levert sor után veszik ismét kézbe, hogy ráemeljék a bogokat. Hasonló technikával készíthetnek négyzet, illetve rombuszmintákat is a szövetbe. Találkoztam olyan asszonnyal, aki „a forradalom után", 1991-ben tanulta meg a technikát. Ő vaspálca helyett a kicsid ujját használja a bogok kiemelésére. Szőtteseit a nála megszálló magyar turisták vásárolják meg, s viszik magukkal mint „eredeti erdélyi csergét".

Az új típusú „csergéket" nem ványolják, s az utóbbi két típusról az is elmondható, hogy a II. világháború előtt férjhez ment asszonyok egyike sem emlékezett arra, hogy akár ők, akár környezetük szőtt - vagy akárcsak látott - volna ilyet. Készítésükről a csak „fiatalabbak" tudtak beszámolni. Ebből arra következtethetünk, hogy ezek a háziipari szövetkezetek létrejötte után terjedtek el a Székelyföldön (vö. Márton Béla 1993. 23.).

\section{Összegzés}

Századokon át generációk adták át egymásnak a csergekészítés ismeretét. Minden csíki leány anyjától, nagyanyjától tanulta el a mozdulatokat. Hozományuk része volt egykét maga szốtte cserge. A kelengyébe vitt ágy felszereléséhez ugyanúgy hozzátartozott, mint a szalmazsák, lepedő, derékalj, párna, később a paplan. Férjhezmenetelük után vették használatba, s takarództak vele. Különbséget tettek a gyapjúpokróc és a cserge között. Csergének csak az alig sirített, ujjnyi vastagra durgált fonalból készített, ványolt $\mathrm{s}$ a ványoláskor meglomosodott, vastag, puha, meleg takarót nevezték.

A 20. század közepén hatalomra jutott kommunista-szocialista vezetés a Székelyföldön is minden eszközzel igyekezett felszámolni a hagyományos paraszti kultúrát. De - mint oly sok területen - itt sem jártak teljes sikerrel. Az élet jelentősen átalakult ugyan, de a közösségi munkamegosztásnak ez a sok emberöltő alatt kialakult formája búvópatakként a szocialista időszakban is tovább élt. Mindvégig voltak olyanok, akik - ha kevésbé nyilvánosan is - nemcsak önellátásra fontak, szőttek gyapjút. Egyes falvakban a családi bevételek kiegészítésére több asszony specialistaként foglalkozott a csergekészítéssel, ezzel egészítve ki a szűkös családi bevételeket. Munkájukkal tovább éltették a kézmüvességnek ezt az ágát. Náluk meg lehetett rendelni a hozományba szánt csergét vagy pótolni az elhasználódott takarót. Legfőképpen télre vállalták a szövést. A megrendelő hozta a megfelelő mennyiségű füsült gyapjút, a specialista pedig megdurgálta és megszőtte. Egy-egy ügyesebb asszonynak hamar elterjedt a híre, többen is fölkeresték. Mivel a munkáért kapott pénzből nem fizettek adót, olcsóbban is dolgoztak, mint a háziiparban, nehogy valaki följelentést tegyen.

Mások „hivatalosan", az 1950-es évektől létrejött háziipari szövetkezetek bedolgozóiként vállaltak munkát. E szövetkezetek mára mindenütt fölszámolódtak. Elvétve akad csak olyan, amely az egyéni vállalkozók befektetésének és igyekezetének köszönhetően túlélte az 1989-et követő gazdasági változásokat. A csíkkarcfalvi az egyik ilyen kivétel. Gépeit 
1991-ben egy vállalkozó szellemű, fiatal házaspár - Mózes Csaba és felesége, Annamária - vette át, s kezdte el újra működtetni. Kezdetben csak fonalelőkészítéssel (mosással, tépéssel, fésüléssel, fonással) foglalkoztak. A gyapjúfonalat az akkor még múködő csíkszentdomokosi szövetkezet vásárolta meg tőlük. A domokosi vállalkozás azonban lassan hanyatlani kezdett, végül csődbe ment. Mózesék továbbra is láttak viszont fantáziát a nagy múltú csíki székely festékesek készítésében, ezért 1997-ben Segesvárról régi, használt gépeket vásároltak részletre, megtanulták a gépek kezelését, karbantartását, munkatársakat vettek fel, s lassan bővíteni tudták vállalkozásukat. Mára egész Csíkban ismert a Mózes család gyapjúmanufaktúrája.

Ahol nem élték túl a rendszerváltást a hajdani szövetkezetek, és nem volt, aki tovább működtesse őket, ott is megmaradt az egykori bedolgozó szövőasszonyok tudása. Néhányan közülük újra elővették szövőszékeiket, családjuknak vagy egyéni megrendeléseket teljesítve újra szőnek.

Amíg régen a hagyományos lomos csergékből általában egyet vagy kettőt adtak hozományba, addig az 1960-1970-es években elterjed új típusokból garnitúrát rendeltek a férjhez menő leány szülei. Egy ágytakaró, két foteltakaró, egy falvédő és egy asztalra való terítő alkotja ma is a garnitúrát. A felhasznált fonal vastagsága és az alkalmazott színek magyarázhatják azt, hogy ezeket is csergének mondják. Az új típusok azonban elsősorban lakásdíszítő funkcióval bírnak. Ezekkel a „csergékkel" (vastag fonalból szőtt, dísztárgyként használható szőttesfajtákkal) találkozhatunk ma a kirakodóvásárokon, turisták által látogatott idegenforgalmi nevezetességek közelében, frekventált főútvonalak mentén létesült bazársorok pavilonjaiban.

Napjainkban azokat a régi, egykor hozo- mányba készített lomos csergéket, amelyeket jó állapotban örököltek meg az utódok, többnyire nagy becsben tartják. Néhol annyira, hogy nem is használják, szekrények, ágyak mélyén őrzik, csak a nagypénteki szellőztetésre viszik ki a házból. Ahol nem féltik annyira, ott főleg ágytakaróként találkozhat velük a betérő. Használatban leginkább azoknál láttam, akik az 1950-es évek előtt kötöttek házasságot. Ma már ők is főképp ágytakarónak használják. Vannak, akik az ágyban terítik maguk alá, erre teszik a lepedőt - így melegítve fázós lábukat, fájós derekukat. Néhány olyan öreggel találkoztam csak, akik takarózásra használják régi csergéjüket, ők is jobbára az ebéd utáni pihenés idején. A cserge eredeti (meleget adó takaró) funkcióját az 1950-es évektől mindenütt egyöntetűen a paplan vette át. Az egykori ványolt, lombos csergék lassan kikopnak a mindennapos használatból. Napjainkban csupán néhányat láthatunk, „hírmondóikkal" találkozhatunk a Székelyföldön.

\section{Jegyzetek}

1. N. Bartha Károly az Udvarhely megyei Bágy község csergekészítéséről írt közleményének elején megjegyzi: „A cserge készítése csak Bágyban van szokásban, sem a szomszédos vidéken, sôt más székely megyében sem foglalkoznak vele, csupán bent Csíkban." Bartha Károly, N. 1932. 19.

2. A juhtartó családok kisebb-nagyobb esztenagazdaságba (esztenaközösségbe, esztenatársulatba) szerveződtek, egyéni tulajdonban lévő állataikból közös juhnyájat hoztak létre. A gazdasági együttműködésnek ez a formája Erdély egész területén ismert. Az esztenagazdaság élén az esztenabíró állt, akit tagjai közül választott a közösség. Feladatai közé tartozott a különféle hivatalos fórumokon saját közösségének képviselete, érdekérvényesítése, pásztorok fogadása, a legeltetés fi- 
gyelemmel kísérése, a tejfeldolgozás és a tejtermékek elosztásának szabályozása, a szükséges közösségi munkák megszervezése, lebonyolítása. Egy faluban több ilyen társulás is működhetett. Szerveződésének alapja általában az adott település hagyományos közigazgatási egysége volt, de előfordulhatott, hogy a falun belüli egyéb területi egység, illetve rokonsági kapcsolatok révén alakult juhtartó közösség (vö. Paládi-Kovács Attila 2001. 613-614.).

3. 1 ige kb. 12 méternyi fonalat jelent. Vö. Szolnoky Lajos 1950; 1991. 359.

4. Felcsíkon például a nyers és a szürke mellett öt színt kedveltek: pirosat, fehéret, zöldet, sárgát és kéket. Az alcsíkiak többnyire szürke, fehér, piros színből szőtték csergéiket.

5. Csak egy példa: a csíkszentgyörgyi Jenőfalva tizesben élő Vitos Erzsike (Vitos Gyuláné Basa Erzsébet) sok csergét szőtt eladásra. 80 centiméter széles bordájába 140 szálat tudott befüzni. Elmondása szerint két, $3 \mathrm{~m}$ hosszú szél elkészítéséhez $2 \times 6 \mathrm{~m}$, azaz összesen $12 \mathrm{~m}$ fonalat tekert fel a vetőfára. Kis ráhagyással ehhez mérte hozzá 140-szer a mellyéknek font szálat. Ezt a fonalmennyiséget vetette föl aztán az osztovátára.

6. Az egyik idős asszony elmondása szerint ő két csergét szőtt életében. Azt a kettőt, amelyet hozományként hozott magával 1941-ben. Szövésüket akkor kezdte el, amikor menyasszony lett.

7. Láthattam olyan, még a kicsi magyar világ előtt, 1937-ben készült takarót is, amelynek széleit piros, fehér, zöld csíkozással szőtték. Mégsem „nemzeti zászló" lett belőle, mert készítője a két szélsőnek szánt szövetet piros fonallal kezdte, a középső csíkot viszont fehérrel. Így a szélek összeöltése után az egyes színek mozaikszerūen helyezkedtek el a cserge felületén, diszkréten, mégis egyértelműen kifejezve készítője és használója nemzeti hovatartozását.
8. Jó illusztrációkat láthatunk erről a $M a$ gyarság néprajza I. kötetének 989. és 991. ábráján. Bátky Zsigmond - Györffy István - Viski Károly 1933. I. 335, 336.

\section{Felhasznált irodalom}

Bálint S.: Ünnepi kalendárium. A Mária ünnepek és jelesebb napok hazai és közép-európai hagyományvilágából. I-II. Szent István Társulat, Budapest, 1977.

Bartha Károly: A cserge készítése az udvarhelymegyei Bágy községben. Néprajzi Értesítő XXIV. (1932) 19-23.

Bátky Zsigmond - Györffy István - Viski Károly: A magyarság néprajza. I. kötet. (1. kiadás) Budapest, 1933.

Benda Judit: Posztókereskedelem és posztóboltok a későközépkori Budán. In: Szulovszky János (szerk.) A textilmüvesség évezredei a Kárpát-medencében. Az anyagi kultúra a Kárpát-medencében 5. MTA VEAB Kézművesipar-történeti Munkabizottság, Budapest, 2014. 2742.

Benkő Loránd (főszerk.): A magyar nyelv történeti-etimológiai szótára. 1. Akadémiai Kiadó, Budapest, 1967.

Csókos Varga Györgyi: Tárgyi anyanyelvünk. Szent Gellért Egyházi Kiadó, Szeged, 1992.

Csókos Varga Györgyi: Fonás, vetés, szövés. Planétás Kiadó, Budapest, 1998.

Domokos Pál Péter: A kender feldolgozása és eszközei Menaságon. Néprajzi Értesítő XXII. 3-4. (1930) 145-149.

Endrei Walter: Patyolat és posztó. Magvető Könyvkiadó, Budapest, 1989.

Farkas Irén: Hagyományos népi gyapjúszőttes Csíkban: a cserge. In: Murányi János (szerk.): A Csíki Székely Múzeum Évkönyve 2007-2008. Humán- és Természettudományok. Csíki Székely Múzeum - ProPrint Kiadó, Csíkszereda, 2008. 127-150.

Fél Edit - Hofer Tamás: A kalotaszentkirályi kelengye. I. Néprajzi Értesítő LI. (1969) 15-36. 
Flórián Mária: Gyapjúszövet, szürposztó ruhák. In: Balassa Iván (főszerk.): Magyar néprajz IV. Életmód. Akadémiai Kiadó, Budapest, 1997. 616-632.

Flórián Mária: Magyar parasztviseletek. Planétás Kiadó, Budapest, 2001.

Gáspár Gyula: Abaposztó, cserge, lomospokróc. Búvár V. 9. (1939) 659-664.

Gönyey (Ébner) Sándor: Gyapjú- és kenderguzsaly a Radnai havasok alján. Ethnographia LIV. 1943. 191-192.

Gönyey (Ébner) Sándor: A gyimesi csángók gyapjúmunkája. Ethnographia LVII. 1946. 86-87.

Gönyey (Ébner) Sándor: Nagybajomi kapcások ősi gyapjúkallója. Néprajzi Értesítő XXVI. 1954. 43-45.

Gönyey (Ébner) Sándor: Ôsi gyapjúványoló a mezôségi románoknál. In: Gunda Béla (szerk.): Műveltség és hagyomány. I-II. Tankönyvkiadó, Budapest, 1960. 351-357.

Haáz Ferenc Rezső: $A$ székely ványoló. Néprajzi Értesítő XXIII. 1931. 55-62.

Haáz Ferenc Rezső: Udvarhelyszéki mesterségek. Erdélyi Múzeum XLIV. 1939. 365-370.

Hajdú Farkas-Zoltán: A csíki kaláka. Pro Print, Csíkszereda, 1993.

K. Csilléry Klára: Cserge. In: Ortutay Gyula (főszerk.): Magyar Néprajzi Lexikon. I. 1977. 498.

Kardalus János: A Homoród menti posztóványolók íratlan nyilvántartása. Művelődés XXX. 7. (1977) 53.

Kardalus János: Posztó- és csergeványolás a Kis-Homoród mentén. Acta Hargitensia 1. 1980. 223-234.

Kardalus János: Maszók szőnyeg és gyapjú-cserge készítése Bágyban. In: Cseke Péter - Hála József (szerk.): A Homoród füzes partján. Dolgozatok a Székelyföld és Szászföld határvidékérôl. Pro-Print, Csíkszereda, 2000. 219-224.

Kerekes Ibolya: A csíki cserge. Libelli Transilvanici 5. Kecskemét, 2008.
Kerékgyártó Adrien: Csíkmenasági leltárak (1779-1930). Néprajzi Értesítő LXIII-LXVI. 1984. 71-163.

Kós Károly: Erdélyi guzsalyok. In: Kós Károly: Eszköz, munka, néphagyomány. Dolgozatok a munka néprajza köréből. Kriterion Könyvkiadó, Bukarest, 1980. 108-130.

Luby Margit: A guba készítésmódja és a gubásmesterség. Néprajzi Értesítő XIX. 4. (1927) 144-154.

Márton Béla: A parajdi csergeszövés. Hazanéző IV. 2. (1993) 22-23.

Márton Béla: Gyapjúfésülés a Maros megyei Kibéden. Néprajzi Látóhatár IV. 3-4. 1995. 122-127.

Miklóssy V. Vilmos: Festőnövények a csíki háziiparban. In: Kós Károly - Faragó József (szerk.): Népismereti dolgozatok. Kriterion Könyvkiadó, Bukarest, 1978. 91-100.

Nagy Jenő.: Orsófaragás a kalotaszegi Magyarvalkón. Ethnographia LVIII. 1947. 264-266.

Nagy Mari - Vidák István: Csergeványoló kádak a Székelyföldön. Ház és Ember, 26. 2014. 159-171.

Nagy Ödön: A havadi juhtenyésztés. In: Keszeg Vilmos (szerk.): Kriza János Néprajzi Társaság Évkönyve 1. Gloria Kiadó, Kolozsvár, 1992. 24-36.

Nécsey Isván: A gyapjúguzsaly és orsója. Néprajzi Értesítő I. 4. (1900) 39-50.

Orbán Balázs: A Székelyföld leírása. I-VI. Pest, 1868-1873

Ozsváth Gábor Dániel: Patakmalmok a Kárpát-medence keleti felében. Terc Kereskedelmi és szolgáltató Kft., Budapest, 2011.

Ozsváth Gábor Dániel: $A$ vízerő hasznosítása a Kárpát-medence népi textilmunkáiban. In: Szulovszky János (szerk.): A textilmüvesség évezredei a Kárpát-medencében. Az anyagi kultúra a Kárpát-medencében 5 . MTA VEAB Kézművesipar-történeti Munkabizottság, Budapest, 2014. 143-154. 
Paládi-Kovács Attila: Állattartó gazdaságok. In: Paládi-Kovács Attila (főszerk.): Magyar Néprajz II. Gazdálkodás. Akadémiai Kiadó, Budapest, 2001. 599-616.

Palla Ákos: A szkíta cserga. Az Országos Orvostörténeti Könyvtár Közleményei 8-9. (1958) 218-232.

Palotay Gertrúd: A gyapjú fonása és festése Csíkszenttamáson. Néprajzi Értesítő XXIX. (1937) 273-274.

Szabadfalvi József: Juhtartás. In: PaládiKovács Attila (fószerk.): Magyar Néprajz. II. Gazdálkodás. Akadémiai Kiadó, Budapest, 2001. 732-736.

Szabó T. Attila (főszerk.): Erdélyi magyar szótörténeti tár II. Kriterion Könyvkiadó, Bukarest, 1978.

Szebeni Géza: A csíki juhászat. Ethnographia LXXIII. 1. (1962) 54-89.

Szentimrei Judit: Szôttes és varrottas munkák. In: Kós Károly - Szentimrei Judit Nagy Jenő (szerk.): Kászoni székely népművészet. Kriterion Könyvkiadó, Bukarest, 1972. 157-216.

Szentimrei Judit: Szőttesek és varrottasok. In: Kós Károly - Szentimrei Judit - Nagy Jenő (szerk.): Kis-Küküllő vidéki magyar népművészet. Kriterion Könyvkiadó, Bukarest, 1978. 145-255.

Szentimrei Judit: Szőttesek, varrások, hímzések. In: Kós Károly-Szentimrei Judit-Nagy Jenő (szerk.): Moldvai magyar népmüvészet. Kriterion Könyvkiadó, Bukarest, 1981. 177-359.

Szolnoky Lajos: Minőségi csoportok, mennyiségi egységek és a fonalrendezés számolási rendje a kenderfeldolgozásban. Ethnographia LXI. 1-2. (1950) 29-54.

Szolnoky Lajos: Gyapjúmosás. In: Ortutay Gyula (föszerk.): Magyar Néprajzi Lexikon. II. 335.

Szolnoky Lajos: A kender, a len és a gyapjú népi feldolgozása. In: Domokos Ottó (főszerk): Magyar Néprajz. III. Kézművesség. Akadémiai Kiadó, Budapest, 1991. 341-368.

Szőcsné Gazda Enikő: Erdélyi levéltári források felhasználási lehetôségei az építészet és lakásberendezés rekonstruálásában. Ház és Ember 20. (2007) 159-202.

Tagán Galimdsán: Baskír gyapjúmunka. Néprajzi Értesítő XXVI. (1934) 105-108.

Tagán Galimdsán: A baskír posztókészítés. Néprajzi Értesítő XXVII. (1935) 85-87.

Tagán Galimdsán: A gyapjú feldolgozása a kisázsiai törököknél. Néprajzi Értesítő XXXI. (1939) 231-238.

Thiering Oszkár: A textilipar. A szövés-fonás anyagai és technikája. Kultura Könyvkiadó és Nyomda Részvénytársaság, Budapest, 1925.

Timaffy László: Juhászat az Alsó-Garam mentén. In: Balázs Géza - Voigt Vilmos (szerk.): Arator. Dolgozatok Balassa Iván 70. születésnapja tiszteletére. Magyar Néprajzi Társaság, Budapest, 1987. 111-123. 58. Ujváry Béla 1993

Ujváry B.: Juhtartás Csíkmenaságon. Néprajzi Látóhatár II. 1-2. (1993) 83-94.

Zentai Tünde: Az ágy és az alvás története. Pro Pannonia Kiadói Alapítvány, Pécs, 2002. 


\section{GYERGYÓSZENTMIKLÓSI ÖRMÉNY TÍMÁROK HÍRNEVES TERMÉKE: A KORDOVÁN}

Az örmény iparosok két kedvenc szakmája a mészárosság és a tímármesterség volt. Egy 1820-ban végzett felmérés jól tükrözi a 19. század eleji nagyközség, Gyergyószentmiklós társadalmi, gazdasági, szakmák szerinti összetételét. A felmérés szerint: „Vagynak ezen faluban mindöszvességgel kisebbel, nagyobbjával öszvevéve 15 kereskedő boltok[...] Mesterséget üzố emberek e következendô számmal: kenyérsütők a piac számára vannak 25, zsemlesütő 2. Mészárosok vannak 40. Korcsomárosok vannak - nagyobb részüek -10. Csizmadiák vadnak 30, suszterek 2. Szabómesterek 10, Kovácsmesterek 12, lakatos 2, asztalos 10, ács 2, kerekes 2[...], Kömives mesterek vannak, numero 6. Kádármesterek 13, malommesterek 20, üveges mesterek 4, füsüs- mester 1, kéményseprö 1 , serfőző 1, szatler 1, szíjgyártó (!) 2, talpérdő tímár 2, chirurgus 4, borbélymihely 2, kordovány csináló tímárház 6 . Nota bene: de egy házban 10-en, s többen is dolgozni szoktak." (Csík-, Gyergyó-, Kászonszék és Aranyosszék parasztvallomásai 1820-ból)

A kérdőív 13. pontjában a „hasznos fabrikák" szomszédságáról kérdésre adott válasz: „Az említett kordovány készítő fabrikákon, a borszéki üvegcsúri fabrikán kívül (!) itt egyebek nincsenek."

A tímárság mint önálló kézműipar aránylag későn, a 18. század közepén jelent meg Gyergyóban. A nyers bőrök kikészítését a helyi lakosság végezte szükségletei szerint. Miért éppen az örmény iparosok lettek a tímár- ságnak mint önálló iparnak megteremtői, művelői? Az örmény kereskedők közép-keleti, oroszországi kapcsolatai, forrásai lehettek az új szakma, a kordován készítő tímárság megismerésének, elsajátításának. Érdekük volt, hogy termékeikkel a piaci versengésben is megállják helyüket, hogy a legjobb minőségú áruval jelenjenek meg a piacon, ahol már jelen voltak a Konstantinápolyból, Cordobából, Avignonból, Párizsból és Európa más részéből származó gyártmányok (Möller János 1818).

A kordovánt gyártó kézmúipar mennyiségi és minőségi árutermelése, jelenléte külhoni piacokon egyik fontos tényezője lehetett a gyáripar kialakulásának. Hogy valóban a bőrkikészítés kézműipari fázisa volt a kezdetleges gyáripar kialakítója, mi sem bizonyítja jobban, mint a tímárházak száma és a mesterséget gyakorló személyek, akik egy tímárházban dolgoztak. Ha csak egy tímárház dolgozóinak számát vesszük számításunk alapjául, ami tíz vagy még több személyt jelent, Gyergyószentmiklóson 1820-ban a hat tímárház dolgozóinak létszáma jóval meghaladja bármelyik kézműipar foglalkoztatottjainak számát.

A gyergyói bőripar nem a mai ipari szemléletünknek megfelelő méretű és müszaki felszerelésű tevékenység volt. Ezt azok a rendelkezések is tükrözik, amelyek a tímárházak létrehozását és múködését szabályozták. Tímárház csak a településen kívül múködhetett, a vegyi anyagokkal telített szennyvizek- 


\begin{tabular}{|c|c|}
\hline 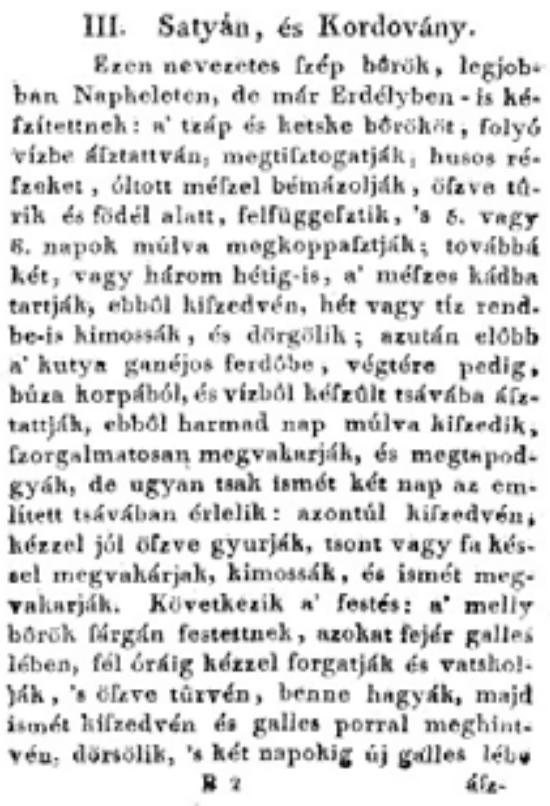 & 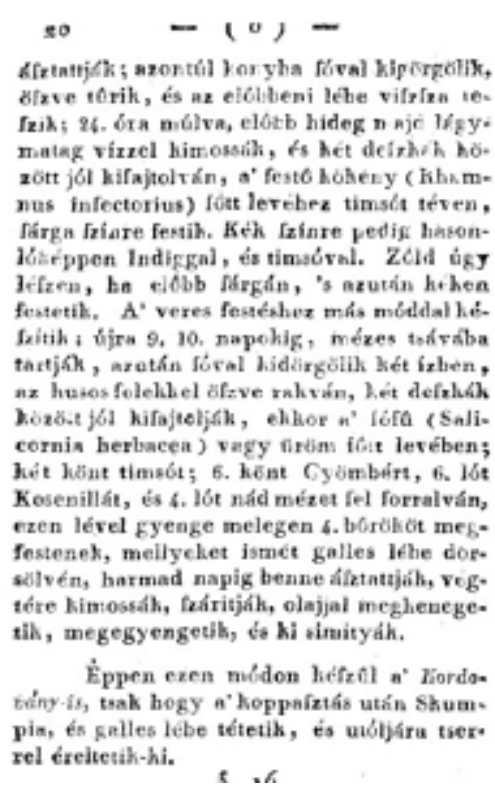 \\
\hline
\end{tabular}

1. kép. Gergelyffi András könyvének 19. és 20. oldala a „Satyán és Kordovány” készítéséről

tisztítása, ülepítők építése és használata kötelező volt. A rendelkezések be nem tartását szigorúan bírságolták, eljárásokat indított a helyi hatóság azok ellen, akik az ülepítőket kiiktatták, vagy nem takarították rendszeresen. Így próbálták tisztán tartani a patakok vizét, amelyekből a helyi lakosság állatait itatta.

A kordován gyártásának technológiáját korabeli dokumentumok, könyvek szúkszavúan tárgyalják. Azt vitathatatlanul leszögezik, hogy bakkecske bőréből „tsaknem azon módon készítetnek valamint a szattyánok; mindazonáltal nem kutya rezelettel hanem tserrel". (Gergelyffi András 1809)

Teljesebb képet nyújt a kordovángyártásról Gergelyffi András 1809-ben Pozsonyban kiadott műve, amelynek 19-20. oldala részletes leírását tartalmazza az egykor keresett bőripari termék, a kordován gyártástechnológiájának.
Mindkét említett forrás, bár megjelenésük között kilenc év különbség van, leszögezi, hogy eltérően a szattyán kikészítésétől a kordovánnál nem használtak kutyaürüléket. „E helyett skumpia és galles lébe tétetik, és utoljára tserrel éreltetik-ki."

Mint általában lenni szokott, minden terméknek van életútja. Az elején felugrik a kereslet, majd egy idő után hanyatlásnak indul, a termék iránti érdeklődés lecseng. Ez tapasztalható volt a kordovánnál is. 1800ban Gyergyószentmiklóson a kordován fabrikák száma 20, 1820-ban 10, két év múlva, 1822-ben ez a szám már csak 6 volt. ${ }^{4}$

A kordován többféle finomságú és színű, nagyon finom tapintású bőripari termék volt. Az örmény kordovánkészítők jobb időkben 1000 köteg kordovánt is gyártottak, minden egyes köteg hat darab bőrt tartalmazott, négy feketét, egy pirosat és egy más szinüt. Ezt az 1000 köteget el is adták, nehézség nélkül. A 
hatezer bakkecskebőr beszerzése nagyobb gond volt, mint a késztermék értékesítése.

A kordován gyártástechnológiájának olyan részletei is vannak, amelyeket a mesterek féltve őriztek, noha az előbbiekben bemutatott gyártási eljárás mondhatni minden tudnivalót tartalmaz ahhoz, hogy bárki kordovángyártó legyen. Természetesen ez nem így volt. A titkok, a mesterfogások, mint pl. a cserző- és csávázóanyagok arányos keverékei, ezek vizes oldatának koncentrációja, a folyamatok pontos időtartama, hőmérséklete megannyi apró részletkérdés, amiket kizárólag a mester birtokolt. Ezek a szakmai titkok és sok más tapasztalati tényező, amiket nem írtak le, apáról fiúra szálltak, a fiú vagy vő örökölte ezeket, ha folytatták apjuk, apósuk szakmáját. Csak nagyon ritkán avattak be családon kívüli személyt féltve őrzött szakmai titkaikba. Az ilyen szakmai titoktartás a kézműiparok összességére jellemző volt.

A kordovángyártást az ipar fejlődése során a bőrgyárak váltották fel, a cipő felváltotta a csizmát, a bőrkabátot az ipari textíliák világa követte. Lassan, de biztosan fogyatkozott, majd megszűnt egy székelyföldi örmény kézműipar és az örményekre jellemző, mindennapjaikat meghatározó tevékenység, hagyomány és ezzel együtt maga a gyergyói örménység is. Ma már alig van néhány család, amely tisztán örménynek vallhatja magát Gyergyóban. A kordovángyártás eltűnt. Az örmények egykori jelenlétét a településkép meghatározó elemei, az épített örökség, a templomok őrzik, hírmondóiként egy sokat szenvedett, tevékeny, városalakító népességnek.

\section{Felhasznált irodalom}

1. Csík-, Gyergyó-, Kászonszék és Aranyosszék parasztvallomásai 1820-ból. A forrásokat sajtó alá rendezte és kiadja Takács Péter. Debrecen, 2002. 98.

2. Möller János: Az erurópai manufaktúrák és fabrikák. Mesterség Míveik. Pesten 1818, 397.

3. Gergelyffi András: Technologia, vagyis a mesterségek és némely alkotmányok rövid leírása. Pozsony 1809. 19-20.

4. Tarisznyás Márton: Gyergyó történeti néprajza. Kriterion Könyvkiadó, Bukarest, 1982. 99. 


\section{A KovásZnAI POSZTógYÁR}

Kovászna a Háromszéki medencében, a Kárpátok lábainál fekszik 550 méter magasan a tengerszint fölött. Az egykori Orbaiszék központja, 1876-tól járási székhely, 1952-től város, 1968-tól Kovászna megye névadó települése. Az idők során Vajnafalva olvadt bele. (Benkő-Fábián 2007. 11.).

A gyapjúfeldolgozás a kezdetekben házi mesterségként létezett. A gyapjút megmosták, ványolták, fonták, festették és megszőtték, mindez többnyire a nők feladata volt. Köztudott, hogy a gyapjúval, miután a juhról lenyírták, azonnal dolgozni kezdtek, mert a gyapjú, ha nem dolgozzák fel időben, veszít a minőségéből. Kezdetben a megmosott, szárított gyapjút kézi orsóval fonták, a szövőszékek is általában kisméretű, házi készítésű szerkezetek voltak. A gyapjúfeldolgozással kapcsolatosan olvassuk el az alábbi szakirodalmi bejegyzéseket:

„Kovásznán a többségében (71\%) magyar lakosság mellett románok is éltek, feltehetően a XVIII. század közepétől. [...] A juhtenyésztő vajnafalvi románok messze földön ismertek voltak jó minőségű készítményeikről. Nemcsak a tejtermékek (túró, sajt, orda, sós tej) tették híressé őket, hanem a gyapjúfeldolgozás is, amit házilag végeztek, kézi erővel megfonták, majd megszôtték. A kovásznai posztó mindenfelé keresett termék volt, különösen a második világháború után." (Dr. Benkő Gyula - Fábián Ernő 2007. 22-23.)

Kozma Ferenc 1879-es leírásában az áll, hogy Kovásznán 12-en állandóan, 16-an ide- iglenesen foglalkoztak gyapjúfeldolgozással. „Az 1885-ös budapesti országos kiállításon mint fontos terméket szerezték be a kovásznai híres halinaposztót és pokrócokat. Ez jórészt fehér és szürke, durva posztó volt, amelyet elsôsorban a felsô ruházathoz vásároltak a vidék kereskedői. [...] A marosvásárhelyi kereskedelmi és iparkamara 1899-es felmérése Kovásznán 4 posztóverōt tartott nyilván és a helység híres csergéjét e neves ipari fórumon is számon tartotta. A millenniumi évkönyv két posztóványolót tartott nyilván Kovásznán és azt is jelezte, hogy igény volt a századfordulón a gyapjúszőttesek finomítására. Az 1907-es sepsiszentgyörgyi székely kiállításon is részt vettek a vajnafalvi román gyapjúszövők." (Szőcsné Gazda Enikő 2007).

A kisipari egyesületek létrejöttét az 1910-es években jegyzik, ekkor 3 gyapjúfeldolgozó működött: a Mioriţa Vajnafalván, valamint a Hangya és a Szorgalom szövetkezet néven Kovásznán. A tulajdonképpeni gyáripar 1923-ban jelenik meg, ezeknek az egyesületeknek a folytatásaként.

A kereskedelmi kamara bejegyzése szerint Kovásznán 1926-1952 között működött a Kisipari mesterek általános testülete, amelyhez 4 takácsmester csatlakozott (Ioan Lăcătuşu 2009. 165.).

Dokumentumok szerint az ún. első román világban már három posztógyár üzemelt a városban, de az adatközlők emlékei szerint a „fileturában” nem szőttek, csak előkészítették az anyagot, pontosabban ványoltak, fes- 
tettek, fontak. Ez a gyár később Prázsmárhoz tartozott, és az 1980-as években a kommandói „perzsaszövődét” is innen látták el gyapjúval (Bede Levente).

Jelenleg Kovászna megyében sehol nem ványolnak. A kovásznai gyapjúgyár részére Bákóban végzik el a munkálatokat (Bede Levente).

1930-1944 között Vajnafalván Papuc Gheorghe, Maria Jurebita (Teaca), Ioan Rusu és Raveica Urzică üzemeltette a Buru néven ismert posztógyárat - jelenleg is ezen a néven ismerik, ahol 4 fonógép, 3 ványoló és 4 szövőszék volt üzembe helyezve (Ioan Lăcătuşu, 2009, 168.).

Itt jegyezzük meg, hogy ez a gyár a Horea, Cloşca şi Crişan utcában az államosítás után 2001-ig működött.

A Kereskedelmi Kamara és Ipartestület bejegyzései szerint 1934-től 1948-ig üzemelt Péterffy Adalbert posztógyára, a Petőfi utcában, amely jelenleg is Filatura néven ismeretes.

Ugyanott jegyzik Csutak Lajos és Csutak Ferenc szövő- és fonógyárát a Gábor Áron utcában, amelyik később Béke gyár néven vált ismerté. Ez kezdetben takaros kisüzem volt. A szövőszékeket gőzüzemű meghajtásra szerelték fel. A gőzgépek transzmissziós szíjakkal voltak ellátva, amelyeket a tetőtéri padláson vezettek át.

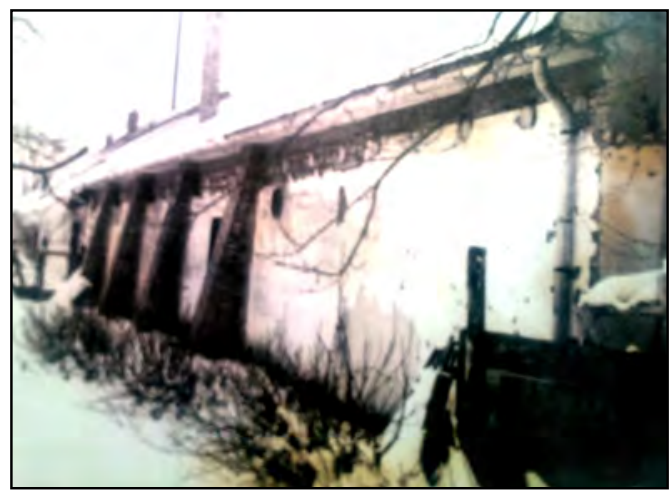

1.kép. Posztógyár 1936-ban (archív felvétel)
A kezdeti időszakból fennmaradt egy Németországban gyártott kártológép és egy előfonalgyártó.

Valószínű, hogy a szövőszékek is Németországból érkeztek, de bővebb információval nem rendelkezünk. Az adatközlők szerint a kommunizmus éveiben már „EVELINA” és „MUGUREL” cégjegyzésű vetélős szövőgépekkel dolgoztak.

Ekkoriban sokféle anyagot szőttek, például: posztót, szőnyeget, pokrócot, törülközőanyagokat, szőttesféleségeket, sőt egész vékony szálú ún. „ije” anyagokat is szőttek az „aba” posztón kívül. A kovásznai háziiparosoknak köszönhetően a posztógyártás kisipari jellegét a gyáripar megjelenése után is megtartotta. Az adatközlők emlékei szerint az államosítás után egyesítették a háziipart a gyárakkal, mindenki bevitte a gépeit, a nyersanyagot és a szaktudását a közösbe. Innen ered a sokatmondó Béke gyár megnevezés. Voltak bedolgozó munkások, akik otthon dolgoztak (Bede Levente).

Beke Ernő munkájában a kovásznai posztókészítésről az alábbi bejegyzést olvashatjuk:

„Kovászna talán leghíresebb kisipari termékei a különféle posztók és gyapjúszövetek voltak. Nyersanyag bőségesen és olcsón állt rendelkezésre. Szinte nem volt ház, ahol ne foglalkoztak volna szövés-fonással mind a románok, mind a magyarok. Voltak olyan kisüzemek, ahol már árutermelés folyt. A finom négy-hat-, söt nyolcnyüstös szöveteket nagyvárosok (Brassó, Bukarest, Kolozsvár) kereskedői forgalmazták. Fésülők, préselők és ványolók müködtek a szövőmühelyek kiszolgálására. Legjelentősebbek a Péterffi (volt Pálmay), Csutak Lajos és Csutak Ferenc fonóés szövőgyárai, de rajtuk kívül voltak olyan háziipari mühelyek, mint Bogyó, Cseh, Bede és Orbán (finom vásznakat is készített) szövődék 


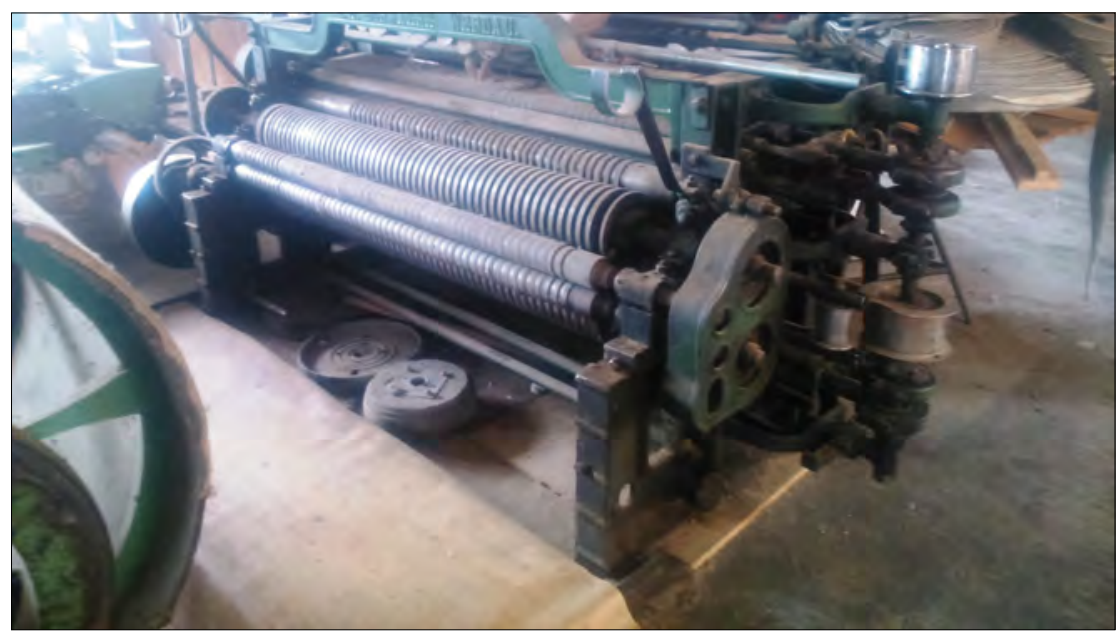

2. kép. Egy 1901-ben gyártott tépetőgép

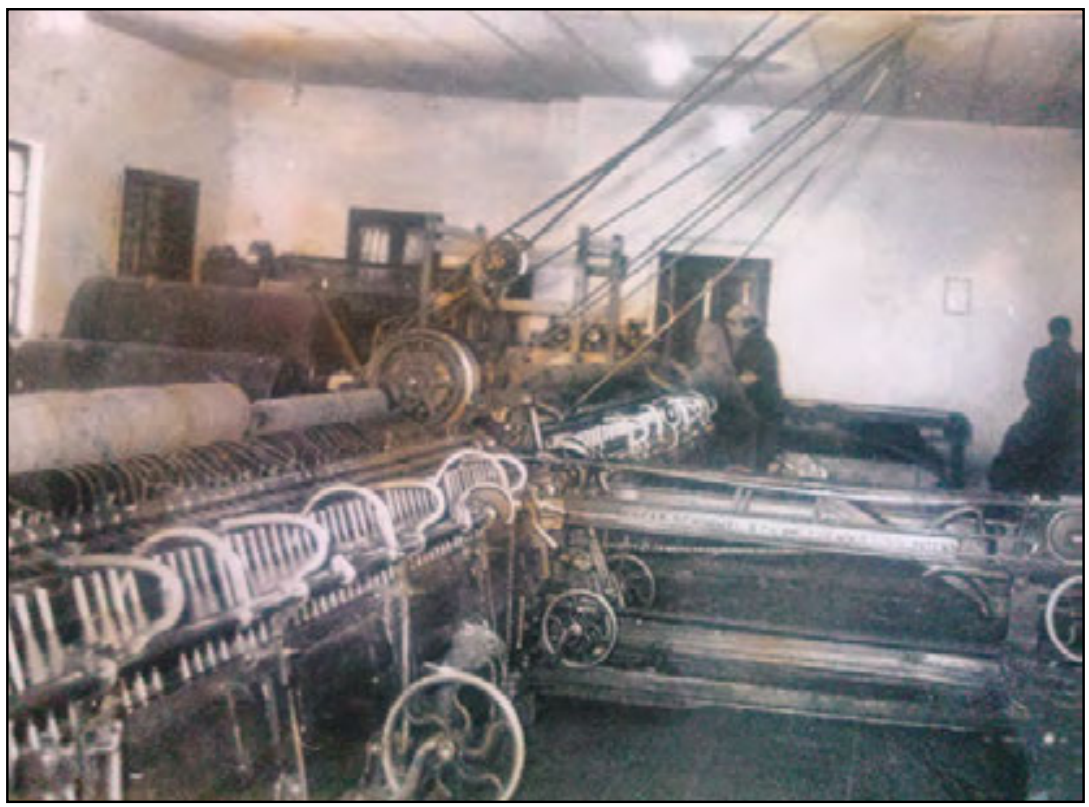

3. kép. Szövőszékek anno (archív felvétel)

és fésülő-ványolók, ahol szintén minőségi árut termeltek." (Beke Ernő 2005, 10.)

A kovásznai posztógyárakat 1989 után apránként felszámolták, jelenleg a hajdani Béke gyár épületében egy magánvállalkozó (Ciambur Dan) öt emberrel dolgoztat, és csak ha- gyományos, eredeti színű abaposztót szőnek. Az adatközlők szerint napjainkban senki más nem foglalkozik gyapjúfeldolgozással, sem posztószövéssel. A vállalkozó a régi gépeket megtartotta, jelenleg is üzemképesek és megtekinthetők. 


\section{Felhasznált irodalom}

Beke Ernő: Üdvözlet háromszékrőll. Charta ki- Szőcsné Gazda Enikő: Gyapjúfeldolgozás, adó, Sepsiszentgyörgy, 2005.

Benkő Gyula - Fábián Ernő: Kovászna. Charta kiadó Sepsiszentgyörgy, 2007.

Lăcătuşu, Ioan: Personalități ale Oraşului Covasna. Studiu monografic. Editura Eurocarpatica, Sf. Gheorghe, 2009.

kendertermesztés. In: Kinda István - Pozsony Ferenc (szerk): Orbaiszék változó társadalma és kultúrája. Sepsiszentgyörgy, 2007. 155.

Adatközlő: Bede Levente, Kovászna. 


\section{SZÉKELYFÖLDI VIZIMALMOK TÉRBEN ÉS IDŐBEN}

A vízimalom romantikát sugalló műszaki alkotás. Romantikája mögött az alkotó géniusz egykori termékét csodálhatjuk. Gyökerei az ókor távolába vezetnek, de romantikán innen és túl, figyelembe véve a felhasználási területek sokaságát vagy a szerkezetek különbözőségét, megváltozik véleményünk arról a korról és a kor emberéről, amelyben éppen a vízzel hajtott szerkezetek voltak a műszaki fejlődés csúcsteljesítményei.
Ki ne csodálna meg festői környezetben vízcsobogás kíséretében forgó vízikereket, amelyhez a szokásostól eltérő épület is társul? Nem kétséges, hogy a folyó víz hajtotta szerkezetek leglátványosabb része a vízikerék a vízvezető csatornával, a kerékről alázuhogó vízeséssel, gyermekkorunk kedves fürdőzőhelyével (1. kép).

Minden vízimalom közös eleme a hidromotor, a vízikerék, turbinás malmoknál a turbina-

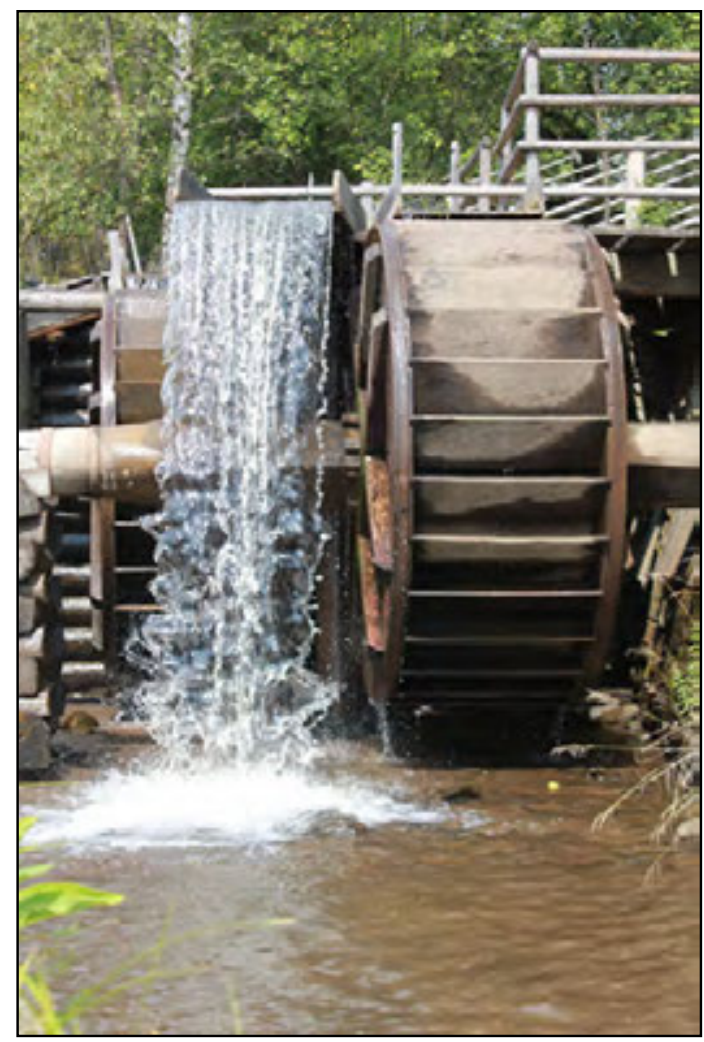

1. kép. Gyermekkorunk kedves fürdőzőhelye, a kerékről alázuhogó vízesés 
kerék, amely forgása közben a vízenergiát mechanikai energiává alakítja át. „Minden malom volt a középkorban, amit folyóvíz müködtetett, a lisztelō, a vizifúrész, a ványoló, az érczúzó, az olajütő, a papirkészitő, a vízemelő, minden, amit a víz energiája hozott mozgásba és dolgoztatott az ember hasznára." (Ádám Gyula-Cseke Gábor 2009. 24.)

A székelyföldön, a domborzati-vízrajzi adottságok, a tájegység gazdag folyóvízhá- lózata kedvező feltételeket teremtett a vízi szerkezetek elterjedéséhez (1., 2. ábra). Hegyek koszorújába zárva, 4,5 Celsius-fok éves átlag hőmérsékletével az ország leghidegebb vidéke Gyergyó, ahol a napi 10-15 Celsius-fokos hőingadozás sem ritka. Sokan nem is sejtik, hogy Erdély egyik nagy folyója, a Maros, a Gyergyói-medence délkeleti csücskében, a Gyergyói-havasokban ered, és délről északnyugat irányba áthaladva szülőföldjén,

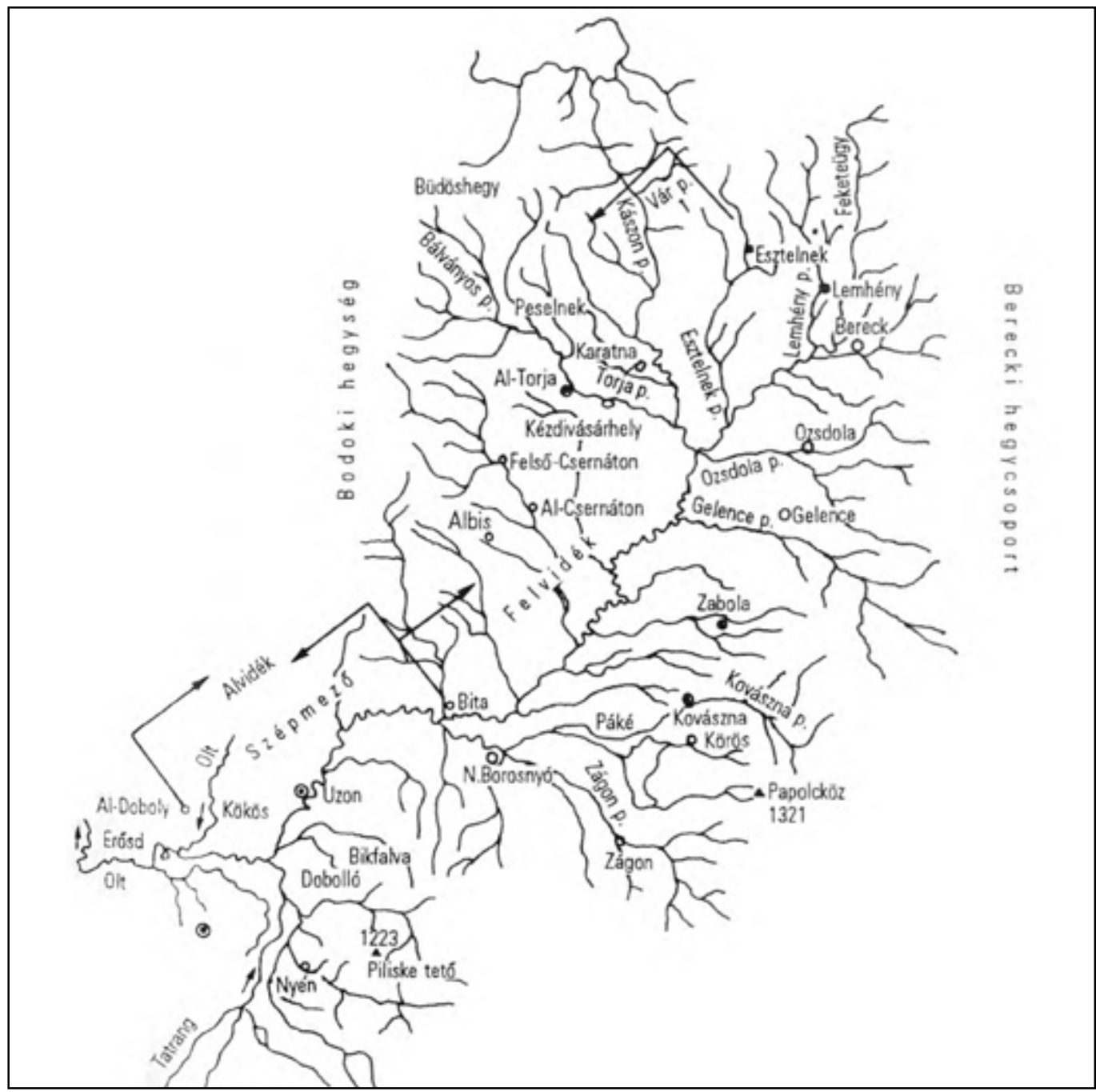

1. ábra. A Feketeügy folyó vízhálózata (Kv.) (Kádár Zsombor 1999. 439.) 
a Gyergyói-medencében összegyüjti a hegyekről tajtékozva alásiető kis testvérei, a hegyi patakok vizét, tekintélyes folyóvá gyarapodva. És mintha búcsúzni akarna e mesebeli tájtól, az emberektől, zúgva tör át a Szalárdi-szoros sziklái között, majd kiterebélyesedve, lelassulva folytatja útját a sík vidéken. Talán bánja is, már időtlen idők óta, hogy elhagyta szülőföldjét, ezt a tündérországot.

A Maros vízgyűjtő medencéjéhez hasonlóan az Olt, a Kis-Küküllő és Nagy-Küküllő, Kis- és Nagy-Homoród, a Feketeűgy felső szakaszának vízgyűjtő területe a hozzá tartozó, számos gyors vizű patakkal kiváló feltételeket teremtett a vízimalmok működéséhez Erdély keleti részén, a Székelyföldön.
Noha a székelyföldi települések többsége már a 14. század közepén fellelhető a „pápai dézmák regesztrumában”, malmokról, a malomhasználatról csak a 16. század végéről, 1589-ből származó, máig fennmaradt udvarhelyszéki törvénykezési jegyzőkönyv tesz említést (Székely Oklevéltár, Új sorozat, 1983. 88.). Székelyföldön, ebben az időben, a mezőgazdasági termelés fejlettsége jóval kezdetlegesebb volt, mint a szomszédos Szászföldön, ennek ellenére ebből a korszakból, az 1589-1591-es évekből fennmaradt több tucat oklevél, törvényszéki jegyzőkönyv is a malmok nagy számára utal. A századok folyamán a Székelyföld egész területére a népesség számbeli növekedése volt jellemző, ezt a növekedést a vízimalmok elterjedése is igazolja.

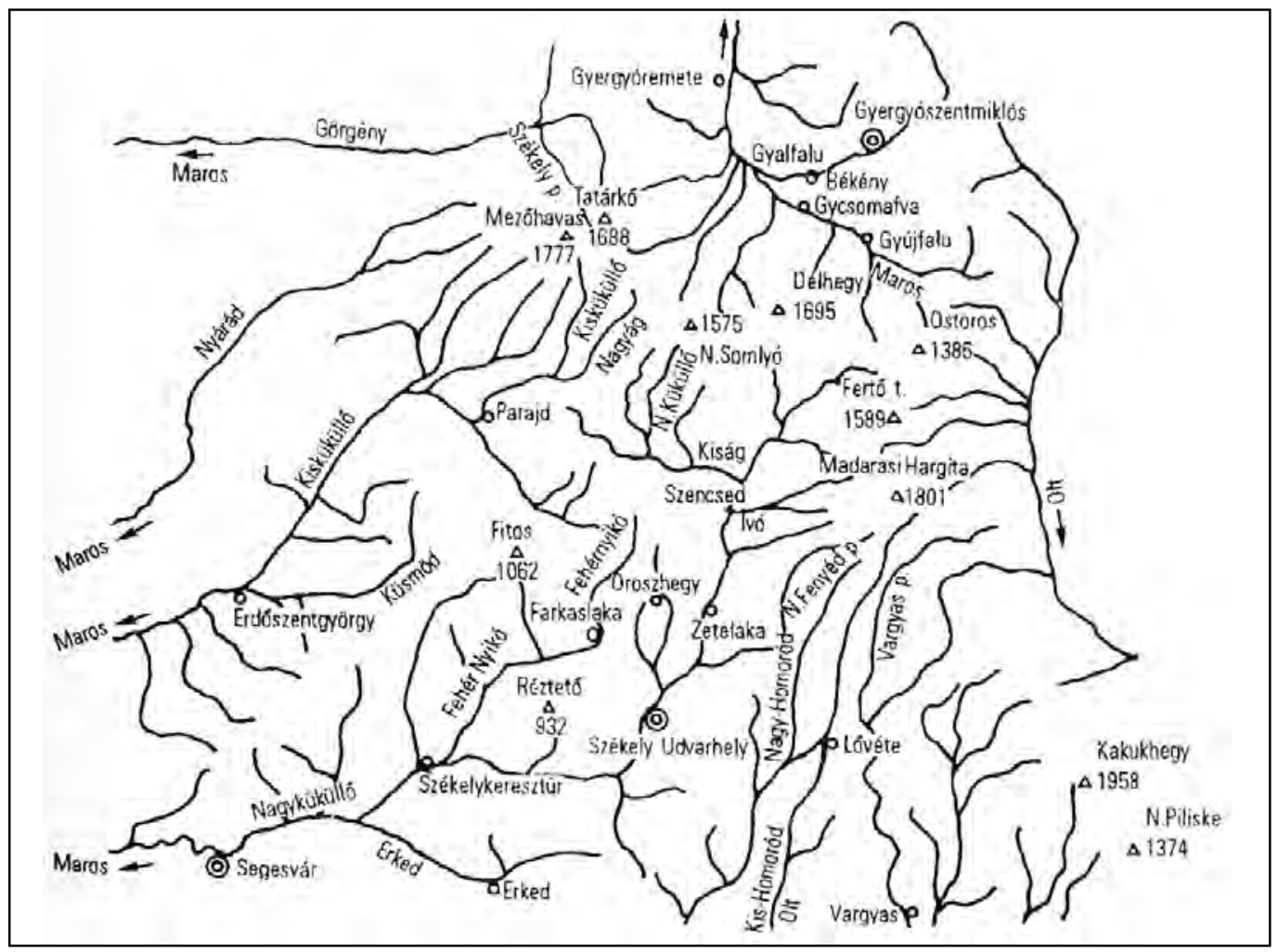

2. ábra. A Nagy-és Kis-Kükülő vízhálózata (Kádár Zsombor 1999. 457.) 
A mindenkori, élénk erdélyi kereskedelem egyik láncszeme a Székelyföld volt, ami egyrészt a mezőgazdasági termények szükségszerű behozatalának, másrészt a vidék legjelentősebb árucikkeinek, az élő állatok, a bőr és a fa kivitelének köszönhető. Az itt élő nép rákényszerült, hogy a vidék természet adta lehetőségeit kiaknázza, termékeivel kereskedjen. E vidék sajátosságait ismerve Erdély fejedelmei jövedelempótló foglalkozásokat elősegítő kiváltságokkal segítették a székelyföldi településeket. 1622ben Bethlen Gábor Erdély fejedelme az udvarhelyszéki Zetelakának olyan kiváltságokat biztosított, amelyek lehetővé tették a település rohamos fejlődését. Egy passzus a fejedelmi rendeletből: „minden census, taksa és úgy rendes, mint rendkívüli adó alól, segély és kamarai hasznok, tizedek, kilencedek és minden szolgálmányok alól, úgy minden lustra és minden rendes és rendkívüli hadi szolgálatok alól kivesszük..." szögezi le a kiváltságlevél. Ezt a kiváltságot Apafi Mihály 1662-ben, majd Lipót császár 1701-ben megerősíti. A kiváltság meghozta gyümölcsét: „Azért Zetelaka egy nagy gyár-falu, hol minden ház egy zsendely mühely; a Küküllőn megszámlálhatlan fürész metszi a deszkát", jegyzi a nagy székely, Orbán Balázs (Orbán Balázs 1868. 65.). Természetes, hogy a kiváltságok hatása nem késlekedik. Zetelaka például, a 15. századra 3000 lélekszámú településsé nőtte ki magát. Ebben a népességnövekedésben jelentős anyagi hátteret jelentettek a vízimalmok.

Hasonló kiváltságokat adományozott a Nagy Fejedelem az oláhfalviaknak is 1614-ben, amit 1618-ban megerősít azzal a feltétellel, hogy kötelesek fejedelmi fürészt építeni és évente kétezer szál deszkát szállítani Gyulafehérvárra a fejedelmi udvar részére. Az említett kiváltságot I. Rákóczi György 1631-ben megerősítette. Orbán Ba- lázs Oláhfaluban tett látogatása alkalmából megjegyzi, hogy itt „csaknem annyi fürészmalom van, mint ház”.

A fafeldolgozással párhuzamosan, a szükségeknek megfelelően épültek a lisztelőmalmok, a ványolók, dürückök. Utóbbiak száma a Kis-Homoród mentén olyannyira megnőtt, hogy e vidék hírnevét éppen ványolóinak, dürückölőmalmainak köszönheti. A Homoród menti ványolósok ismertekké váltak a Küküllő menti településeken, Erdővidéken, Háromszéken, Alcsikon, de Gyergyó vidékére is kiépítették kapcsolatrendszerüket. Egyegy begyűjtőúton 150-200 vég ványolni valót is összegyűjtöttek, amelyeket ványolás után visszavittek az illető településekre. A ványolók szakaszosan múködtek, egy-egy ványoló évente 1000-1500 vég posztót is megványolt, ami nem kevesebb, mint 15 000-30 000 méter posztószövetnek felelt meg (Kardalus János 1980. 224.).

A Kis-Homoród völgye nem csak a deszkametsző fürészmalmairól és dürückölő-ványoló malmairól volt híres. A Hargita-hegységben feltárt vasérc új ipar lehetőségét nyújtotta a Kis-Homoród menti települések lakóinak. Erre vonatkozó feljegyzések már a középkorból is fellelhetők. A vidéknek évszázadokra visszanyúló hagyománya van a vasgyártás terén. Erről tanúskodik Báthory Istvánnak, Erdély fejedelmének 1591ből származó adománylevele, miszerint a lövétei vashámort szolgálati jutalomként Székely Mózes főhadnagynak adományozza. A vasgyártásnak folytatása van a Kis-Homoród völgyében. Homoródalmás határában 1811-ben hámor működött, Homoródszetpálon 1770-1771 között vashámorról tudósítanak a feljegyzések (Vajda Lajos 1983. 18.). Lövétén a 19. század elején is, pontosabban 1829-ben rúdvasat kovácsoltak a helyi olvasztók nyersvasából. 
Talán fölösleges is megemlítenünk, hogy a vasgyártás abban az időben elképzelhetetlen volt vízenergia felhasználása nélkül, bár az ókorban is gyártottak vasat, de ez menynyiségileg, sőt minőségileg sem hasonlítható össze a viz hajtotta fújtatókkal müködtetett olvasztók és vasverők termékeivel.

Továbbhaladva a Hargita hegyvonulata mentén déli irányban újabb vasfeldolgozó központok sora bontakozik ki Erdővidéken, pontosabban Bodvajon és Erdőfülén. Mindkettő a vízenergia hasznosításának iskolapéldája, ugyanis mindkét helyen bánya, olvasztó és hámor is működött. Bodvajon 1831-ben létesítenek vasércbányát és hámort, Erdőfüle bányája, kohója és hámora 1842-ben kezdi el működését a bővizű Kormos-patak mellett. Kisebb-nagyobb megszakításokkal üzemelt, majd 1874 után végleg beszüntetik működését. Szintén a térséghez tartozik Bibarcfalva és Nagybacon, e két helység ugyancsak a vasgyártás-kísérletek színhelye volt a 19. századi Székelyföldön. A legjelentősebb azonban a Lövétén és Szentkeresztbányán 1836-1844 között épült vasolvasztó és hámor volt, amelynek pusztuló részeit a mai napig megtaláljuk (2. kép). A Kid-Homoródból a hámorra vezető vízcsatorna 150 év múlva is lenyűgöző látvány. Fénykorában országos jelentőségű vasgyárként tartották nyilván, ekkor a lövétei vasgyár a bodvaji hámorral és néhány kisebb vasgyárral együtt 10308 mázsa vasat állított elő (Vajda Lajos 1983. 24.).

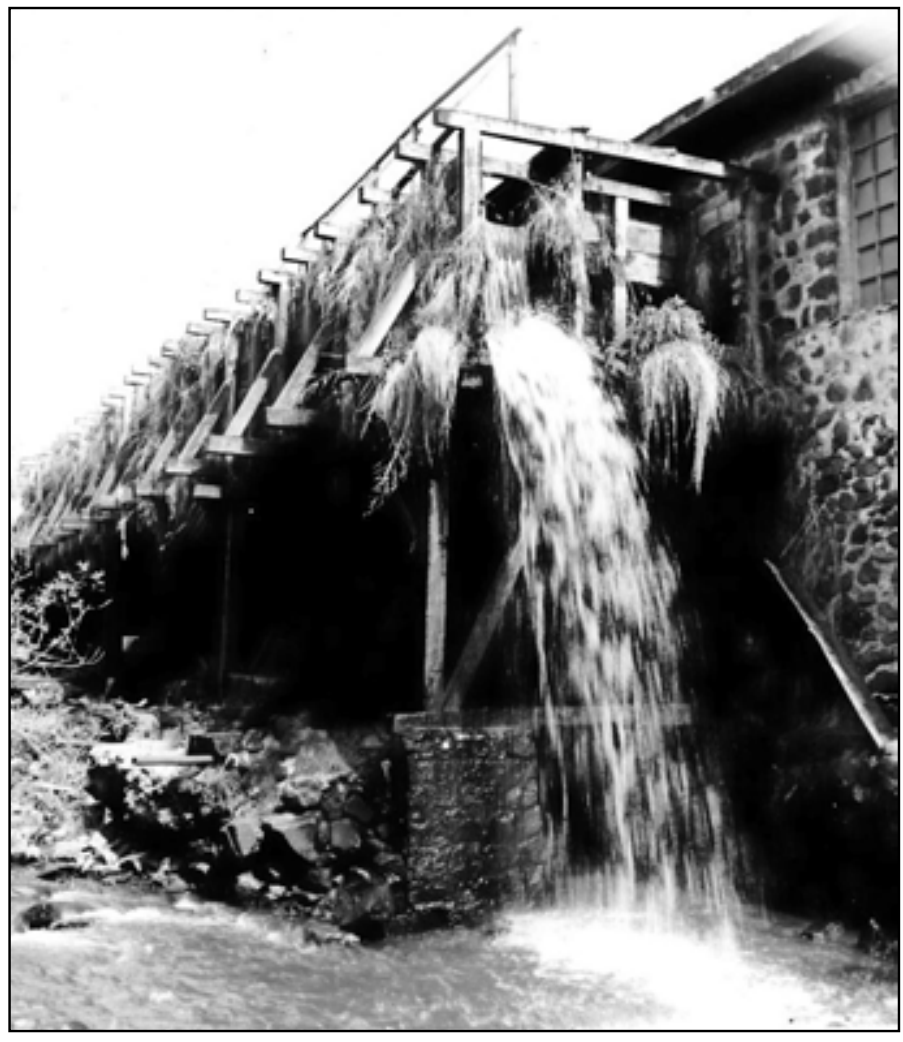

2. kép. Pusztuló vízcsatorna Szentkeresztbányán (Hr.) 
A vízimalmok széles skálájához tartozó, kevésbé ismert szerkezetek a máz és festékőrlő malmok, amelyeket a Székelyföld régi kerámiaközpontjában, Korondon állítottak üzembe a helyi fazekasok vagy molnárok. Ezek a vízimalmok abban különböznek a lisztelő malmoktól, hogy a felső kő meghajtását nem alulról, a bélkeréktől a korongkeréken át, tehát hagyományos módon oldották meg, hanem felülről, megfelelő áttételek alkalmazásával. Ez szükségessé vált, mert hatására a nedvesen őrölt festék és máz anyaga nem folyt át a tengely és az álló kő közötti résen. Az első vízhajtású mázőrlő malmot a 20. század elején építették Korondon.

A másik sóvidéki malomjellegzetesség a sóőrlő vízimalmok, amelyeket ugyancsak Korondon működtettek a parajdi só őrlésénél. Szerkezete megegyezik a lisztelő malmok szerkezetével.

Korondon a vízimalmok sűrű hálózata alakult ki az évszázadok folyamán a Korond vizének és mellékpatakjainak, a malomárkok vízenergiájának hasznosítása nyomán. Harminchat vízimalmot tudnak felsorolni a korondiak, ezek mind lisztelő malmok voltak. Ezek sorát számos ványoló, dürück, fürészmalom egészíti ki.

A Székelyföld egyes tájegységein a kis vízhozamú patakok energiájának felhasználásával is kísérleteztek helyi mesterek. Az Udvarhelyszékhez tartozó Havasalja néhány településén: Tibódon, Ülkén, Oroszhegyen és Szentkirályon építettek lisztelő malmokat kis hozamú patakokra.

A vizenergia-hasznositás következő, jelentős tájegysége Csik-, Gyergyó- és Kászonszék területére tehető. A Gyergyói-medencét minden irányból a Marosba beleszaladó bővizű patakok szelik át, mindez kitűnő körülményeket teremtett a gyergyóiaknak a vízenergia hasznosításához.
Gyergyó falvai már a középkorban is népes településeknek számítottak, ami a lisztelő malmok gyakoriságával is igazolható. Egy 1721-ből származó összeírási adat minden településről egy-egy molnárt jegyez, kivételt képez Gyergyószentmiklós három, Alfalu és Újfalú két molnárjával. A gyergyói vízimalmok első, máig fennmaradt írásos emléke egy 1627-ben keletkezett tanúvallomás, amelyben a Lázár grófok birtokán található régebbi, 1570-ben a Békény partján létező malomról tanúskodnak. Ugyancsak 1627-ből Ditróból, majd 1637-ből Alfaluból, 1667-ből, Újfaluból, 1669-ből Szárhegyről léteznek malmokkal kapcsolatos okleveles feljegyzések (Tarisznyás Márton 1982. 112-121.).

A 19. század végén, az akkori Csik vármegye területén 626 vízimalom üzemel, ebből 1341700 előtti, 64 a 18. században épült. A 19. században tehát újabb 428 malom kapcsolódott be a vármegye lisztszükségletének előállításába. Még a 20. század első évtizedeiben is nagy szerep hárult a lisztelő és fürészmalmokra, amiből például Gyergyószentmiklóson a 8-9 km hosszúságú folyószakaszon 34 víz hajtotta szerkezet működött. Hasonló a helyzet a Gyergyói-medence többi településén is. Alfaluban 22, Güdücön 17, a Remetéhez tartozó Eszenyőn 13 vízimalmot tartottak üzemben. Gyegyócsomafalván 1869-ben több fürészmalomról, és ami ritkaságszámba megy, árpakását őrlő malomról tesznek említést korabeli dokumentumok. Ha a ványolókat is figyelembe vesszük, Csomafalva Somlyó pataki része igazi molnártelepülésként írta be nevét a székelyföldi vizenergia-hasznositás történetébe. A kezdetleges vasgyártás nyomai is megtalálható Gyergyócsomafalva határában, a Somlyó patak vízenergiájának hasznosításával.

Újfaluban az első vízimalomról egy 1667-ből származó oklevél tanúskodik. 
A 20. század elején már 14 víz hajtotta szerkezetet jegyeznek a Maros, a Visszafolyó újfalvi szakaszain. Vasláb és Marosfő sem képez kivételt a Gyergyói-medence vízenergiájának hasznosításában. A pár éve még működőképes vaslábi vízifürész háromszáz éves múltat igazol. A Gyergyói-medencén kívül fekvő Gyergyótölgyes vízenergia-hasznosítási adottságai kiválóak. A 18. századtól kezdődően 18 lisztelő és fürészmalom szolgálta itt a tájegység lakosságát.

A Gyergyói-medencét a Felcsíki-medencétől elválasztó Gréces-tetőn áthaladva az Olt felső folyása és mellékpatakai által alakított vízrajzi területre érkezünk, amelyen régi települések sora helyezkedik el. Csikszentdomokoson egy 1867-ből származó egyházi felmérés szerint 2323 lélek élt abban a korban. A középnagyságú település liszt-, ványolt posztó- és deszkaszükségletét a településen áthaladó Olt vize által hajtott malmok biztosították. Ami viszont igazi hírnevét adta Csikszentdomokosnak, az nem más, mint a balánbányai rézbányászat és olvasztó. A mai bányaváros keletkezése, írott története 1802-ben kezdődik, amikor hivatalosan bejegyzik az első táró megnyitását a zalatnai bányakapitányságon. A 19. század közepén Balánbányán 19 nyilú zúzda, olvasztók és kohók működnek. Kétségtelen, hogy a zúzónyilakat és az olvasztók fújtatóit vízikerekek működtették. Érdekes megjegyeznünk, hogy mig 1811-ben az itt előállított tiszta réz 116 mázsa, 1823-ban több mint ötszörösére növekedett a termelés, és elérte az évi 624 mázsát.

Csikszentdomokoson már a 17. században is állítottak elő vasat, amiért az itteni hámoroknak Bethlen Gábor kiváltságlevelet is adott. Továbbhaladva az Olt folyása mentén Szenttamáson kilenc lisztelő és egy fürészmalom, Madarason hét lisztelő és egy fürészmalom létezéséről vannak feljegyzések még a 20. század közepén is. Ugyancsak Madarason az 1930-as években a meglévő 32 vizifürésznek van pontos és részletes termelési nyilvántartása. Ezek egy része az Olt, másik része a Hargitáról aláhömpölygő Madaras patakán épült. A 17. században fénykorát élő, Erdély-szerte ismert madarasi vashámor fújtatóit, kalapácsait is a Madaras pataka látta el vízenergiával. Csikkmadaras a székelyföldi ipartörténet, az erdélyi vasgyártás kiemelkedő létesítménye volt a 16. század közepétől a 18, század kezdeti évtizedeiig. És mindez a helyi adottságok szerencsés ötvöződésének köszönhetően. A hargitai vasérc, az erdő közelsége és a Madaras patak gyors folyású, bő vízhozama megannyi tényezője volt a középkori vasgyártás kialakulásának Csikkmadarason. Ma már alig azonosítható az a hely, ahol egykoron pezsgő ipari tevékenység folyt. A korabeli Erdély legjelentősebb vastermelő központja Vajdahunyad volt, a váruradalom vasszükségletét több hámor termelése biztosította. A csikmadarasi vasgyár csak 25,5 mázsa vassal és 25 laposvassal termelt kevesebbet, mint a hunyadi hámorok bármelyike (Pataki József 1971.32.).

Alcsíkon is számos vízimalom, vizifürész „zajongott”, ahogyan Orbán Balázs jellemzi a vizi szerkezetek működését. A népességgyarapodás jeleire utal az egyre növekvő számú vízimalom a Szépvíz patakán, a Fiságon vagy Tusnádon. Menaságon még a 20. század közepén is üzemelt négy lisztelő malom.

Kászonszék négy falujában az 1703. évi összeírás szerint - nem kevesebb, mint 31 malom működött, de már 1691-ben is számos ványolóról és vizifűrészről tanúskodnak korabeli feljegyzések. Orbán Balázs is arról tudósit, hogy a Kászon vizén fürészmalom fürészmalmot ér, és ez jelenti a lakosság legjelentősebb jövedelemforrását. 


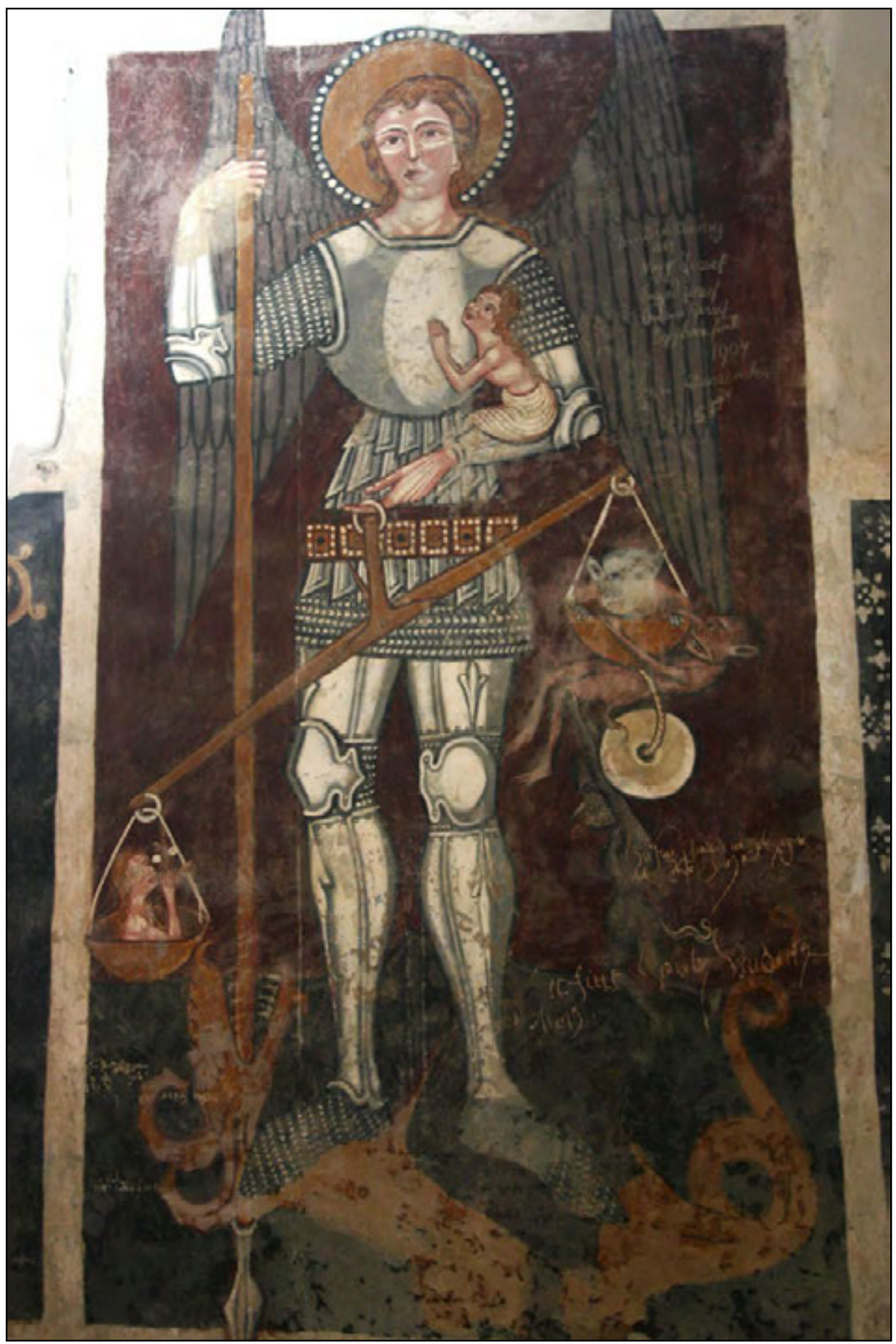

3. kép. Legkorábbi székelyföldi malomkő ábrázolás (1419), Székelyderzs, unitárius erődtemplom 
Háromszék kedvező vízrajzi adottságainak jelentős szerepe volt e tájegység malomiparának alakulásában. A Feketeűgy, valamint Csernáton, Torja, Ozsdola és Gelence patakainak, a Kormos, Vargyas és az Olt vízi energiáját hasznosította a malmok sűrű hálózata. A 20. század közepén még közel 60 vízimalom szolgálja a települések lakóit. $\mathrm{Az}$ élvonalban 11 malommal Felsőcsernáton vezet, ezt követi Torja 10 malommal, de Lemhény és Ozsdola 8 malmával, Gelence 5 működő malmával előkelő helyet foglal el a székelyföldi vízi energia hasznosításában (Márton László 2003. 134.). A magyar királyi Országos Statisztikai Hivatal kimutatása szerint 1885 elején Háromszéken 198, Csík vármegyében 344, Udvarhely megyében 122 vízimalom volt nyilvántartásban (A brassói kereskedelmi és iparkamara jelentése 1889). A Székelyföld, Csík, Gyergyó, a Gyimesek, Háromszék és Udvarhely környéke különleges vízrajzi adottságai szinte kínálták a lehetőséget a víz energiájának hasznosítására. Az itt lakó népek már a középkorban, a 15. században felismerték ezt, és a szükségleteknek megfelelően a viz hajtotta szerkezetek egész hálózatát, hozták létre. A vízenergiát tudatosan felhasználták, ennek érdekében újabbnál újabb szerkezeteket alkottak. Bár ezek szerkezetileg alig különböznek egymástól, a különböző tájegységek mesterei tapasztalataikat, örökségüket alkotó módon alkalmazták, ezért a malmok tájegységenként is egyedieknek minősíthetők.

A Székelyföld legkorábbi malomkő-ábrázolása a székelyderzsi unitárius erődtemplom 1419-ben készült falfestményén látható.

\section{(3. kép).}

A malomépítés helyének vízrajzi-vízenergetikai adottságai döntő tényezői voltak egy malom telepítésének. Az állandó vízhozamú, gyors folyású hegyi patakok voltak alkalma- sak vízimalmok, vízzel hajtott szerkezetek telepítésére. A telephelyet körültekintéssel választották ki, amit vízügyi mérnök helyszíni felmérése követett. Malomépítési engedélyt csak olyan személy kaphatott, akinek tulajdonában volt az a földterület, partszakasz, ahová malmát építeni szerette volna. A malom működéséhez szükséges vízhozamot az erre a célra létesített malomárok biztosította, figyelembe véve, hogy árvizek idején a kiáradó patak és malomárok minél kevesebb kárt okozzon a malom környezetében található szomszédos területekben. A 3. ábra Ferenc Áronnak a Nagy-Küküllő zetelaki szakaszára elképzelt malmának vízrajzi tervrajzát tartalmazza. A terv 1942 tavaszán készült, és magában foglal minden olyan adatot, ami a malom kivitelezésében nélkülözhetetlen, a malomárok vízellátó gátjának építési helyétől a vízikerék helyéig. A tervező a vízikerék méreteit is megadta tervében, amit két méter vízesésre és 0,70 méter vízmagasság-változásra számított.

A Tudományos gyűjtemény nevű folyóirat 1832-ben közreadott 16. évfolyama, amelyet a költő Vörösmarty Mihály szerkesztett, a következőképpen ír a malomépítésről: „Hogy az emberi erôtlen kezeknél a folyóvizek sikeresebb szolgálatot tehetnének, e jóltevő felfedezésre tsak Krisztus urunk születése táján bukkantak az emberek, egy feltalálta, próbálta, százan követték s tökéletesítették. Az így készült vízi-malmok azon nemét tették az örlő malmoknak, mellyek sebes folyók partjára építtetnek még ma is, úgy hogy csak a nagy vizes kerék ért a vízbe, mellyre később a víz ereje, kivált víz-apadáskor zsilipek által szorittatott, a lisztelő kövek és garad pedig a szárazon feküdt. Látni való tehát, hogy ezen malmok sem nagyobb és partosabb folyóknál sem kissebb patakoknál nem voltak alkalmaztathatók." 


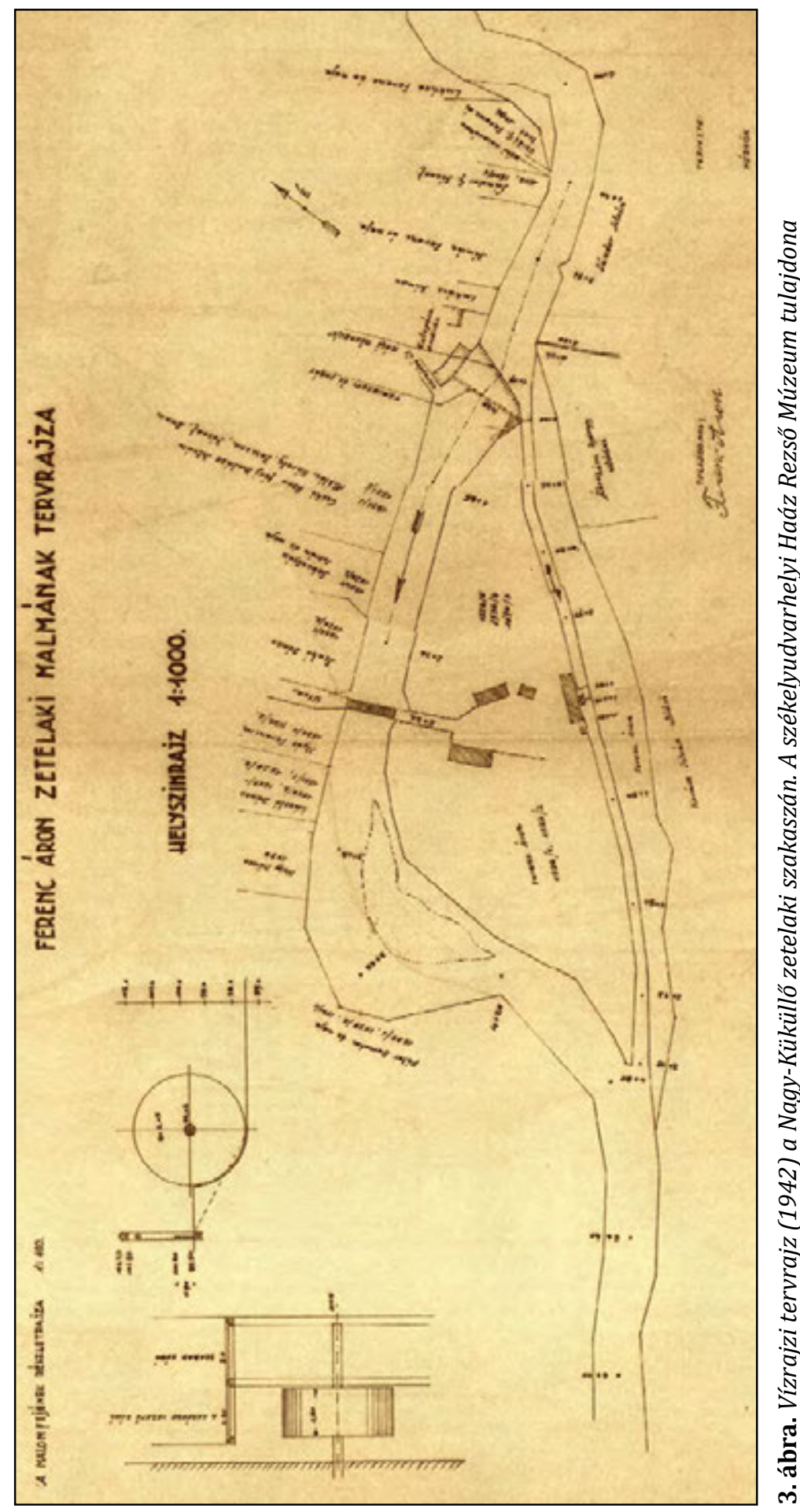


A molnár sokoldalú tudását, ami kiérdemelt tekintéllyel járt, így dicséri Szentmártoni Bodó János ${ }^{1}$ a 17. század közepén $A z$ malom és ács mesterségnek dicsiretirôl való ének című versében:

Sok szép mívöket az faragó rendnek,

Nézd elméjüket az ács embereknek,

Csodáld erejét az malom-mesternek,

Mert Isten után parancsol a víznek.

A 17. században, amikor a vízimalom volt a kor egyik legbonyolultabb mechanikai szerkezete, és a molnár a kor műszaki zsenije, nem csoda, hogy ekképpen vélekedik a költő erről a mesterségről és művelőjéről.

A vízimalmokat maguk a molnárok építették. A vízimolnár több mesterségben is járatos volt, csupán a szerkezet fém alkatrészeit, a gerendely ${ }^{2}$ csapjait és a bélkerék ${ }^{3}$ szorító karikáit, a perpencét ${ }^{4}$, a függőleges tengelyét készíttette helyi kovácsokkal. Így, önerőből, megszerzett szaktudását, kreativitását gyakorlatba ültetve építette malmát. A malom talán legfontosabb alkotóelemét, az őrlőköveket megvásárolta vagy megrendelte kőfaragómesterektől. Malomkő-kereskedések különböző méretű őrlőköveket, zömében a csicsókeresztúri gyártmányokat, de Székelyföldön gyártott malomköveket is forgalmaztak. A tölgyesi, a csomafalvi, a Hargita szikláiból származó gyártmányokat értékelték a molnárok, ezeket keresték. Egy pár kő ára egy szarvasmarha árához közelített, 1750-ben 12-60 dénár volt, 1900-ban akár 15-20 forintot is elkértek érte. A malomköveket a fejtés színhelyén faragták, csiszolták. Nehéz fizikai munka a malomkőfaragás, szakértelmet feltételező művelet volt. Az is megtörtént, hogy a többnapos faragás után valamilyen rejtett repedés miatt a malomkő kettétört, és kárba ment az egész munka.

A székelyföldi népi építészetet a helyi adottságok, a helyi építkezési anyagok felhasználása jellemzi. A gerendaház vagy a gerendavázas, deszkával borított épület volt a legelterjedtebb malomépület típus (4., 5. kép).

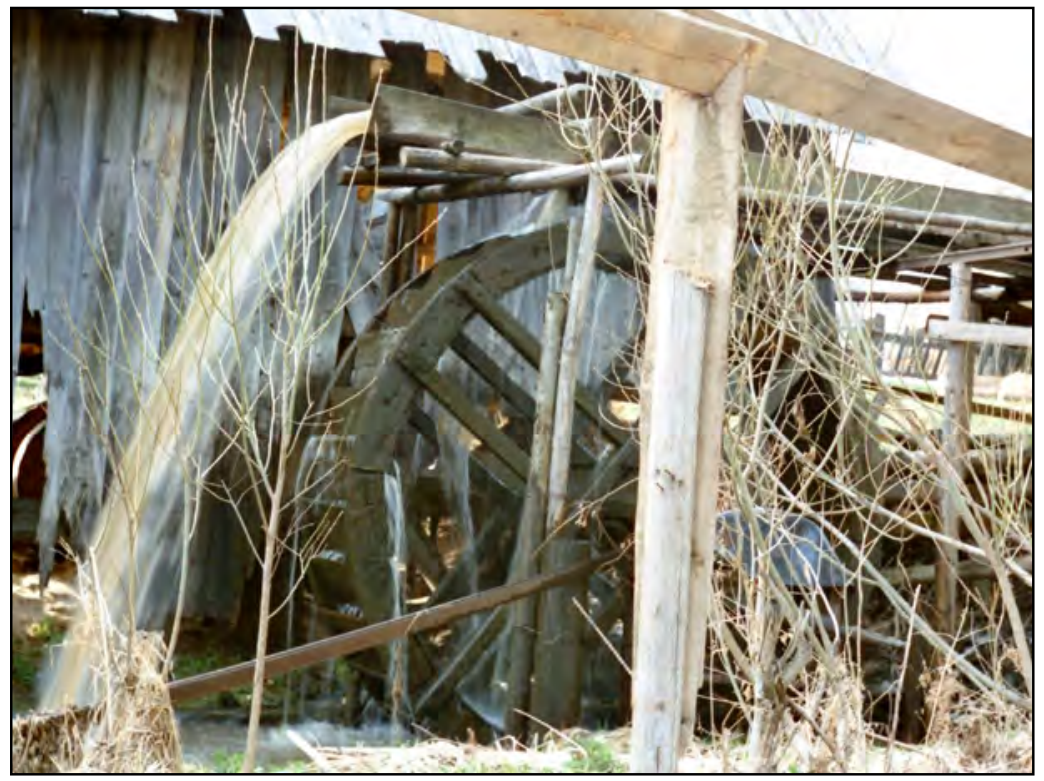

4. kép. Deszkával borított malomház 


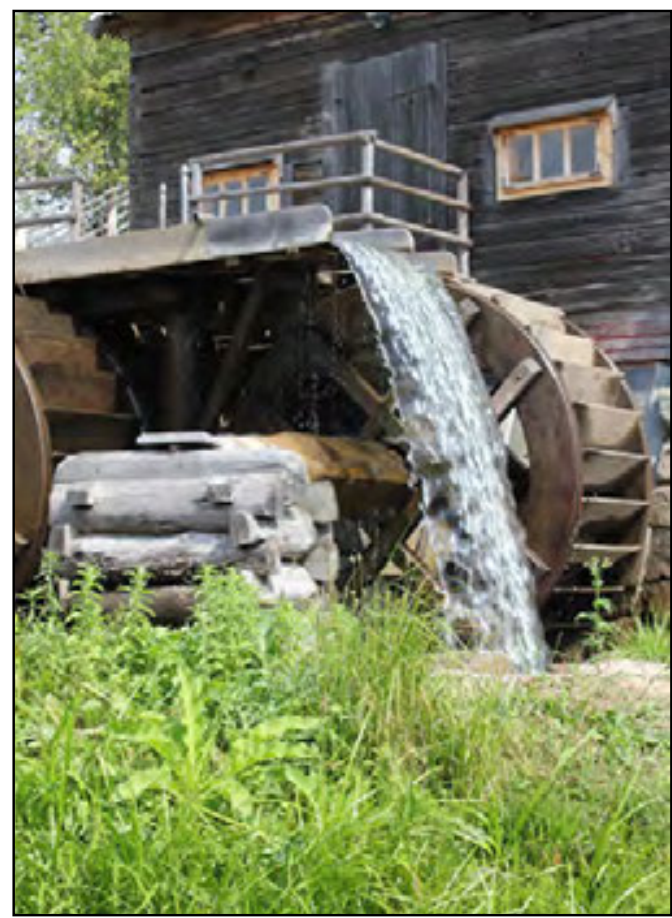

5. kép. Gerendából épült malomház

Malomépítéskor a folyó víz jellemzői, mint sebessége, hozama, éves hozamváltozásai játszottak fontos szerepet a telephely kiválasztásában.

A vízimalmok szerkezetének látványos része a vízikerék. Ennek méreteit a folyó víz hozamához, a vízfolyás sebességéhez méretezte építője úgy, hogy a legjobb hatásfokkal alakítsa át az áralmó víz potenciális energiáját mechanikai energiává. A víznek a vízikerékre vezetési módozatai három változatát alkalmazták székelyföldi vízimalmoknál. Így felül-, középen és alulcsapós vízimalmok működtek, mindhárom típus létezett, és még napjainkban is létező hírmondói az egykor virágzó vízimalom-használatnak. E három vízvezetési módozatot mutatják be a 4-6. ábrák, valamint a hozzájuk tartozó képek.

A vízikerék méreteit eleinte tapasztalati adatok felhasználásával határozták meg.

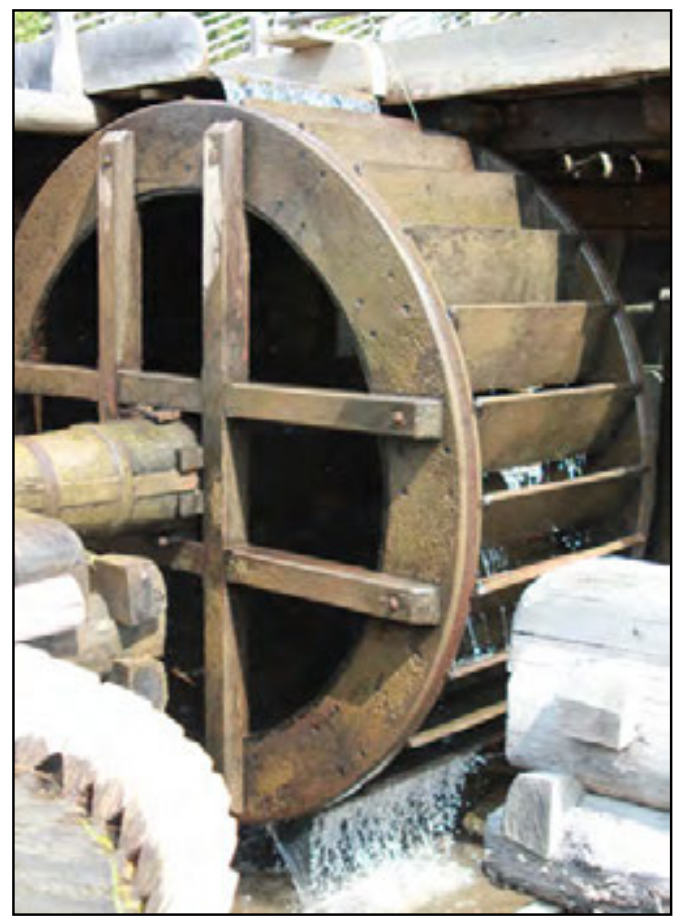

6. kép. A felülcsapós vízikerék felépítése

A molnár-ácsok akkor még nem ismerték azokat a számítási módszereket, amelyek alkalmazásával a malomkerék méreteit kiszámíthatták volna az illető folyó víz jellemzőit figyelembe véve. Ez érvényes volt a folyó víz energetikai jellemzőinek meghatározásában is. A molnároknak széles körű tapasztalati tudásuk volt. Hasonló természeti körülmények között működő malmok vízikerék-méreteit ismerve építették az új malmot. A 19. században már számos kiadvány ismerteti azokat a műszaki számításokat, amelyek alapján a vízhozamot meg tudták mérni, a vízikerék méreteit ki tudták számítani (Péch Antal 1869. 80.). A 6. kép egy felülcsapós vízikerék részleteit mutatja.

Legelterjedtebbek a lisztelő malmok voltak. Ez érthető, hiszen a népesség állandó számbeli növekedése az őrlési kapacitások növekedését is meghatározta. 


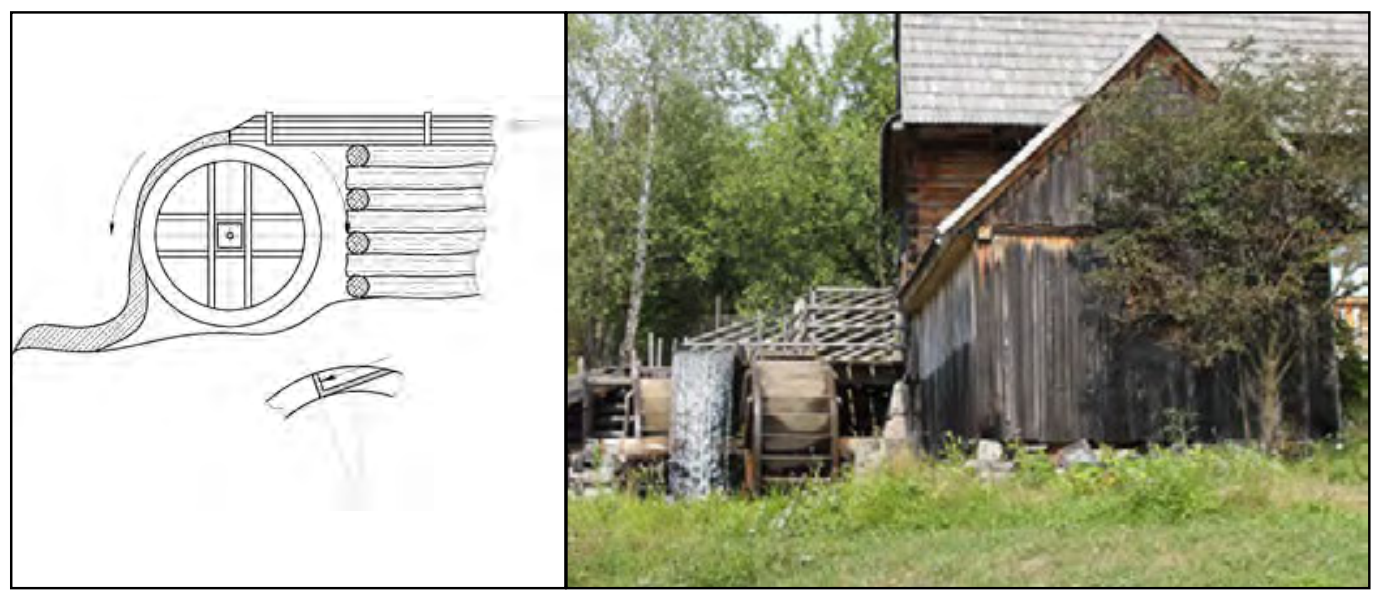

4. ábra. Felülcsapós vízikerék

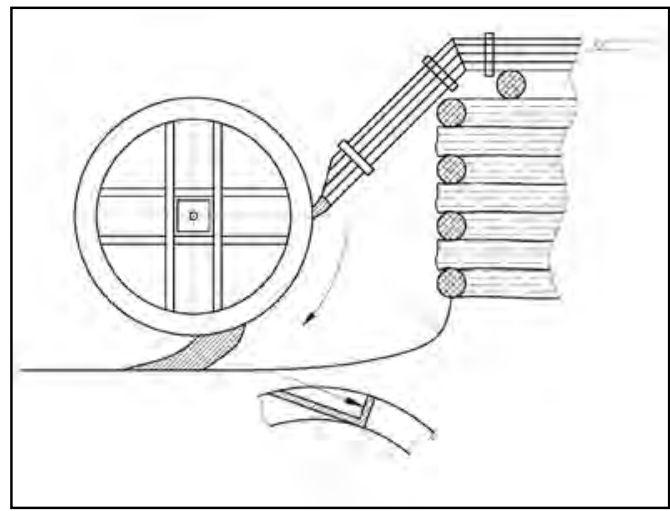

5. ábra. Középcsapós vízikerék

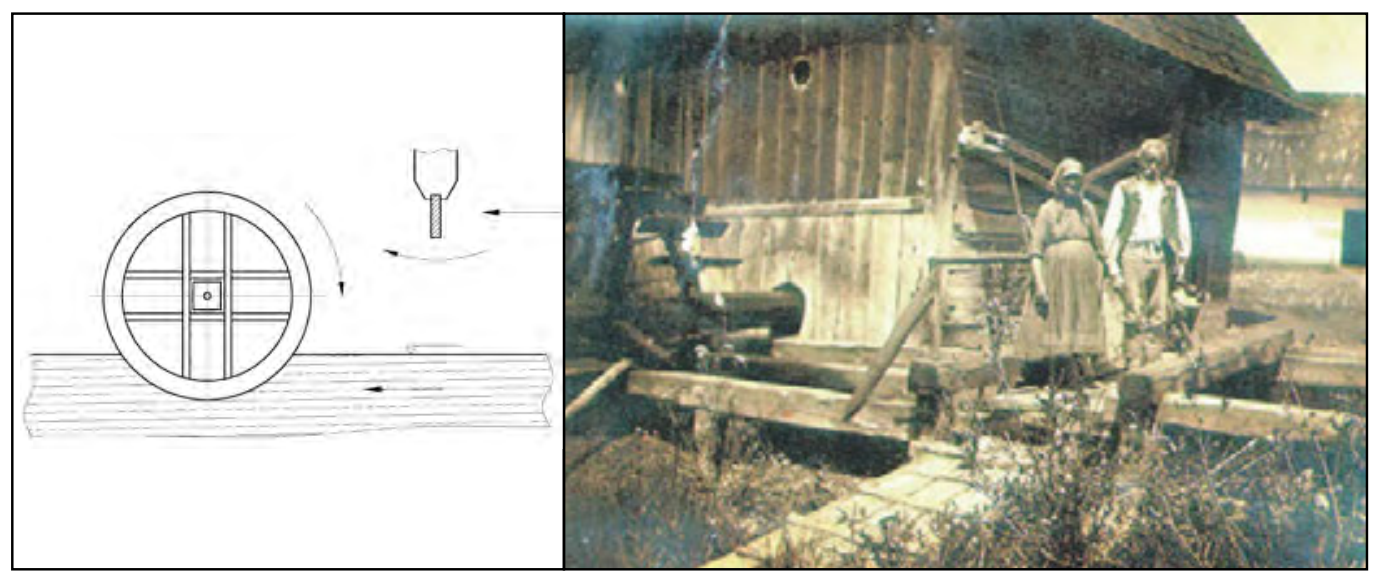

6. ábra. Alulcsapós vízikerék 

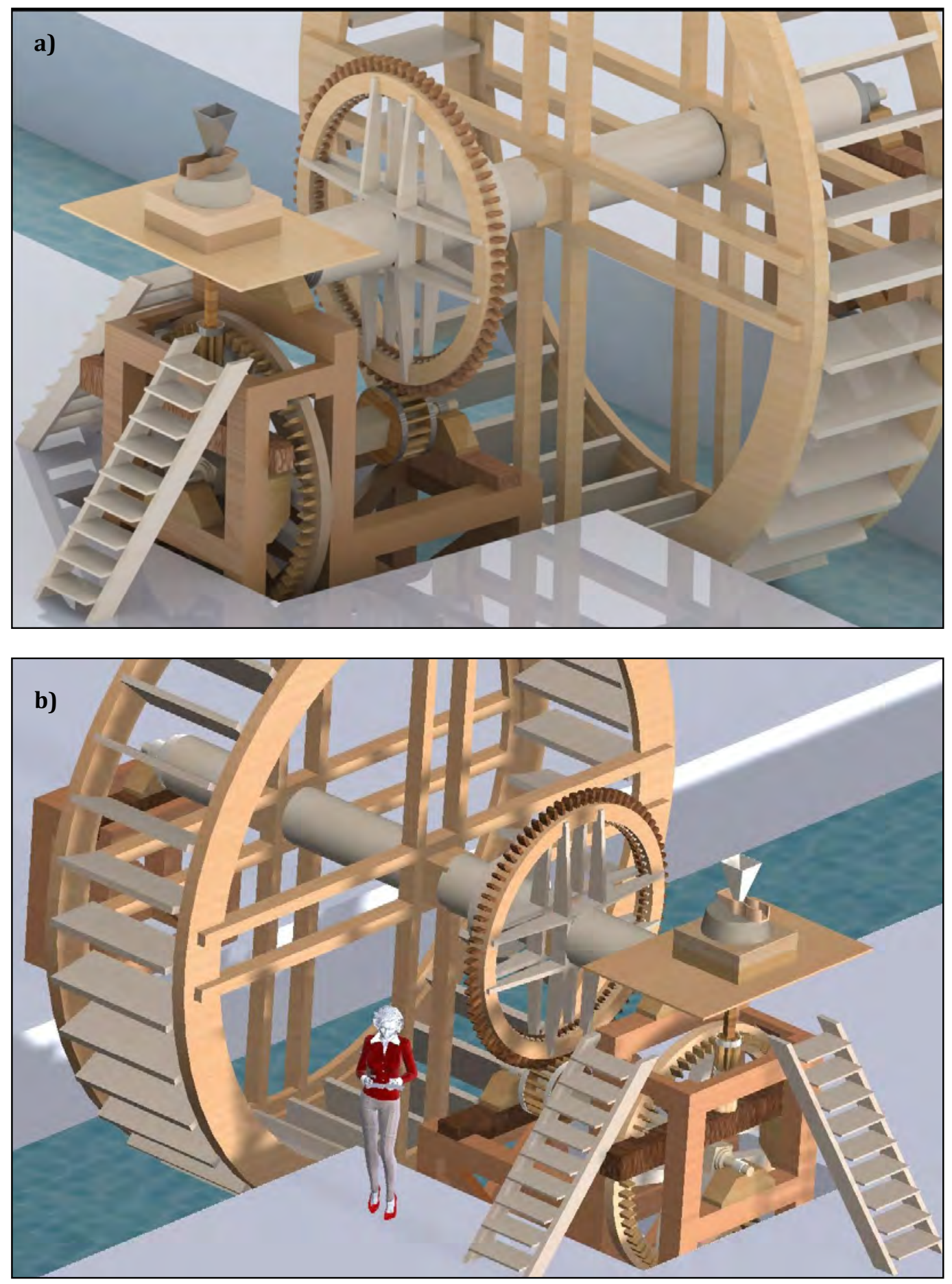

7. kép. Alulcsapós vízimalom 3D képe (készítette Angi Norbert) 
Múködési elvük a 7. ábra segítségével követhető:

Az vízvezető (laj) (1) csatornából a vízikerékre (2) ömlő víz kettős hatással, egyrészt a víztömeg impulzusával, másrészt a vízikerék fiókjait feltöltő víz súlyhatásával forgásba hozza a vízikereket. A kerék forgását a tengely (gerendely) (3), amelyet a csapágyazás (4) tart, továbbítja az első pár $(5,6)$ homlokfogazatú fogaskerékpárhoz. Ez az első gyorsító fokozat. A fogaskerék (6) tengelyén található az oldalfogazatú fogaskerék (bélkerék) (7), amelynek párja az orsó fogaskerék (8). A fogaskerékpár alkotja a második gyorsító fokozatot, ami gyors folyású patakok esetében fölöslegessé is válhat. Ebben az esetben csupán egy gyorsító fokozat szükséges ahhoz, hogy a vízikerék fordulatát a forgó kő 120-130 fordulatára gyorsítsa. Az orsókerék fordulatát a kőszálvas (9) továbbítja a felső, vagy forgó őrlőkőnek (10). A garat (11) fogadja az őrlésre szánt gabonát, az őrleményszemcse méreteit a kövek közötti távolsággal, a vashíd (12) emelésével vagy aláeresztésével lehet változtatni.

A kőszálvas, amelyen az orsó fogaskerék található, talpcsapágya a vaspadba van beágyazva. A vaspad gerendájának egyik vége V alakú párnában végződik, és egy szintén $\mathrm{V}$ alakú élre támaszkodik. A vaspadgerenda másik végén szabályozó orsó található. Az orsó kézi kerekének elfordításával a kőszálvas emelkedik vagy ereszkedik. A kőszálvas felső vége a forgó kő tartója, egy a köbe bemélyített fém alkatrész segítségével. Ez a fém alkatrész a perpence.

Idővel, használatuk következtében az őrlőkövek felülete kopik. Az őrlőfelületbe bevágott őrleménykihordó csatornák mérete kopásuk következményeként csökken, de csökken a malom őrlési kapacitása is. Ilyen esetben a forgó követ kiemelik a 8. ábrán látható kőemelővel, és a molnár kőfaragó-szerszámaival újra vágja, újra élezi a kövek őrlőfelületeit.

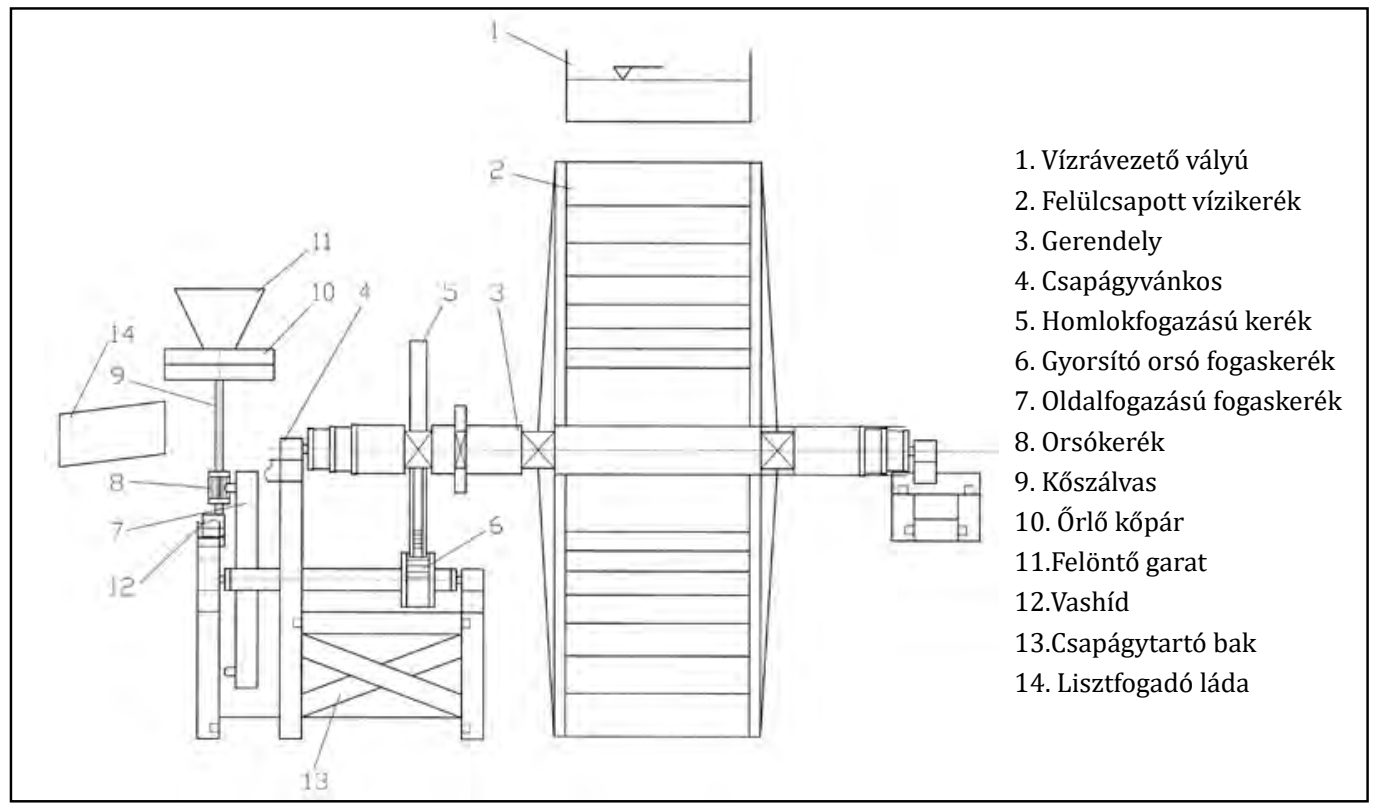

7. ábra. $A$ vízimalom múködési elve 


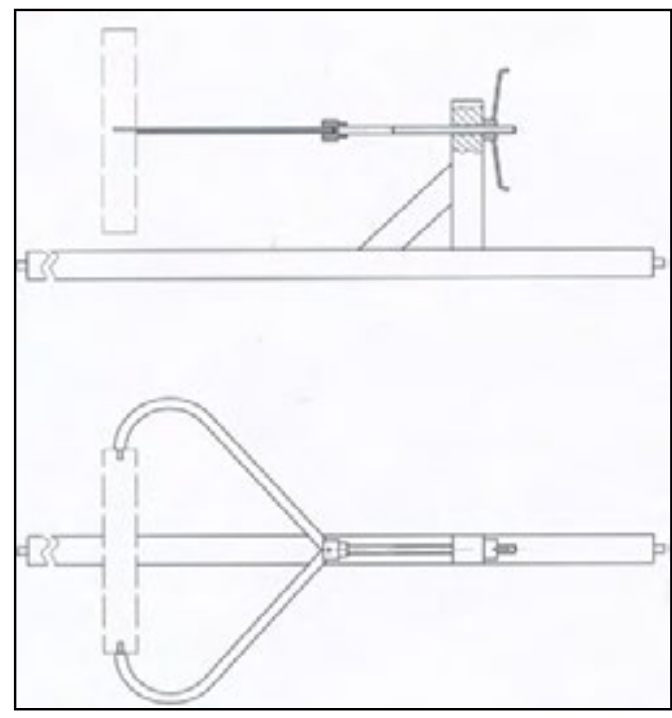

8. ábra. Kőkiemelő
A 8. kép a kövek újravágását mutatja. Szakértelmet feltételező, nehéz fizikai munka volt a kővágás. A kővágás minőségétől függött a malom teljesítménye és az őrlemény mino"sége is.

Hegyvidék vízenergiáját hasznosító szerkezet a fa deszkává metszésének több évszázados múltra visszavezethető gépe a fürészmalom. Szerkezetileg különbözik a lisztelő malom szerkezetétől, bár közös eleme is van a két vízi szerkezetnek. A vízikerék és a forgómozgást továbbító gépelemek mindkét malomnál megtalálhatók. Míg a lisztelő malom szerkezeti felépítésében a malom gépelemei mindvégig forgómozgást végeznek, a fürészmalom szerkezeti felépítésében a forgómozgást váltakozó irányú szakaszos mozgássá átalakító szerkezet is megtalálható.

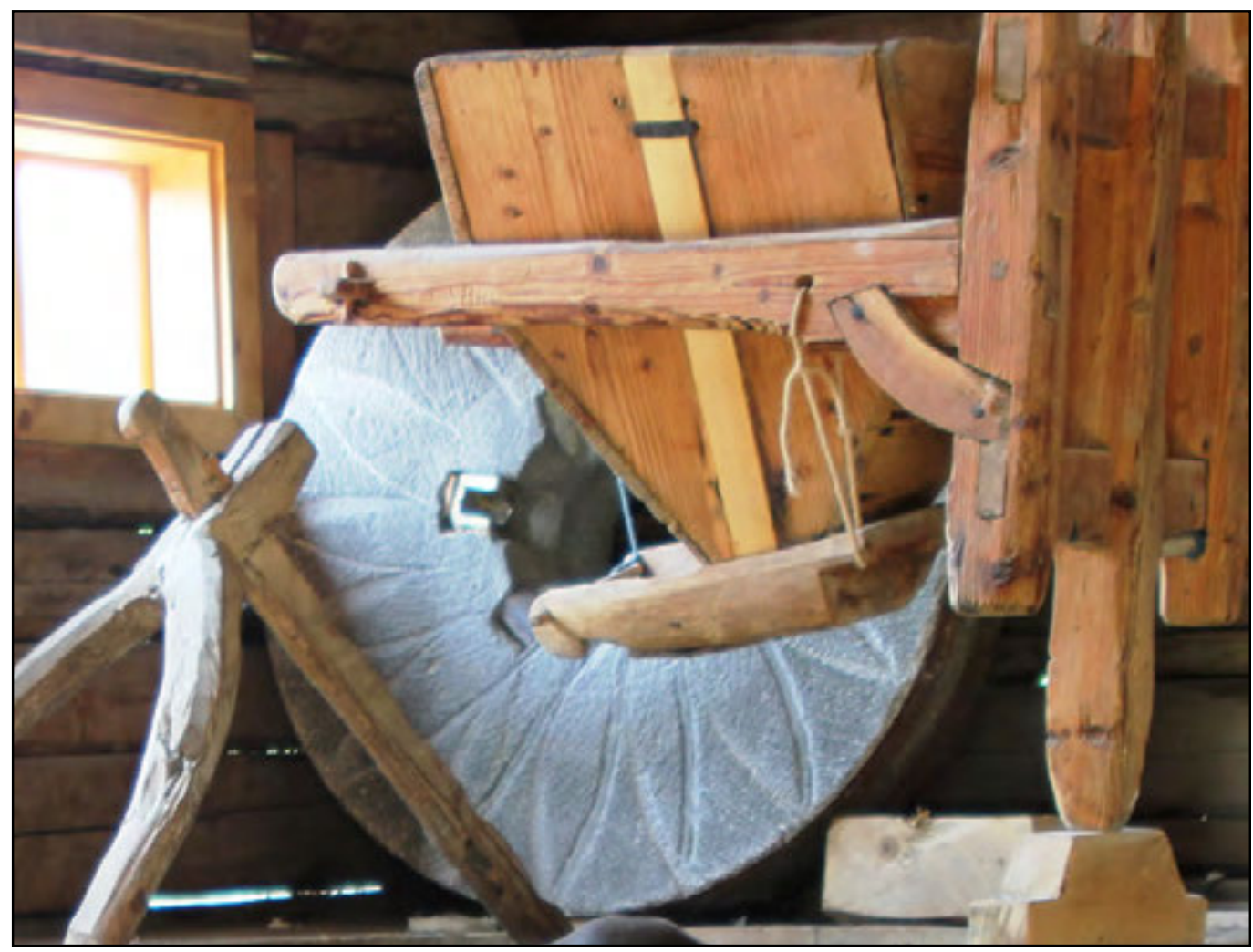

8. kép. Újravágott malomkő őrlő felülete 
Ez a forgattyús tolattyú, ami magát a fürészlapot magában foglaló keretet váltakozó irányban mozgató szerkezet. A székelyföldi fürészmalmok döntő többsége függőleges síkban elhelyezett fürészlapokkal metszi a deszkát.

A fürészmalmot a lisztelő malomhoz hasonlóan két szintre építik. Az alsó szinten a vízikerék és tengelye, a forgómozgást közvetítő áttételekkel, valamint a forgattyús tolattyú található. A felső szinten, ami a tulajdonképpeni technológiai szint, a rönktartó szekér és megvezető pályája, maga a keretfürész és a deszkametszést folyamatossá tevő előtolást létrehozó szerkezet található. Lisztelő malmoknál a kőpad kiemelkedő felépítése hozza létre a felső szintet. Ebből a kettős szintű elhelyezésből az is következik, hogy a fürészmalmok telephelyének megválasztásánál figyelembe kell venni a kettős szintű felépítés lehetőségét, mert ha ez nem természeti adottság, a rönköt fel kell vinni a felső szintre, a keretfürész szintjére, ami meglehetősen bonyolult művelet, és csörlőberendezést követel.
A telepítési feltételeket és a rönkszállítás nehézségeit is figyelembe véve a fürészmalmokat a kitermelés helyszínéhez közel építették, arra is számítva, hogy a beütemezett famennyiség fogytával más telephelyre költöztetik a deszkametsző malomszerkezetet.

A fürészmalom épülete fa oszlopokra épített, oldalain bedeszkázott, deszkával, jobb esetben zsindellyel fedett egyszerű épület, amelynek a vízikerék oldalával ellenkező oldala nyitott, ahol a méretre szabott rönköket a technológiai szintre gördítették.

Bő vízhozamú, gyors folyású patakokra kisebb átmérőjű kerekeket alkalmaztak, gyorsító áttételek alkalmazása nélkül. Kis hozamú patakokra nagyobb átmérőjű vízikereket építettek, és gyorsító áttételekkel növelték a technológia szükségleteinek megfelelő forgattyú fordulatszámát. A 9. ábra egy fürészmalom felépítését szemlélteti, a kinematikai rajz segítségével követhető működési elve.

A tanulmányozott fürészmalmok a rönknek a deszkametszés ideje alatti előtolását megvalósító szerkezetük szerint három cso-

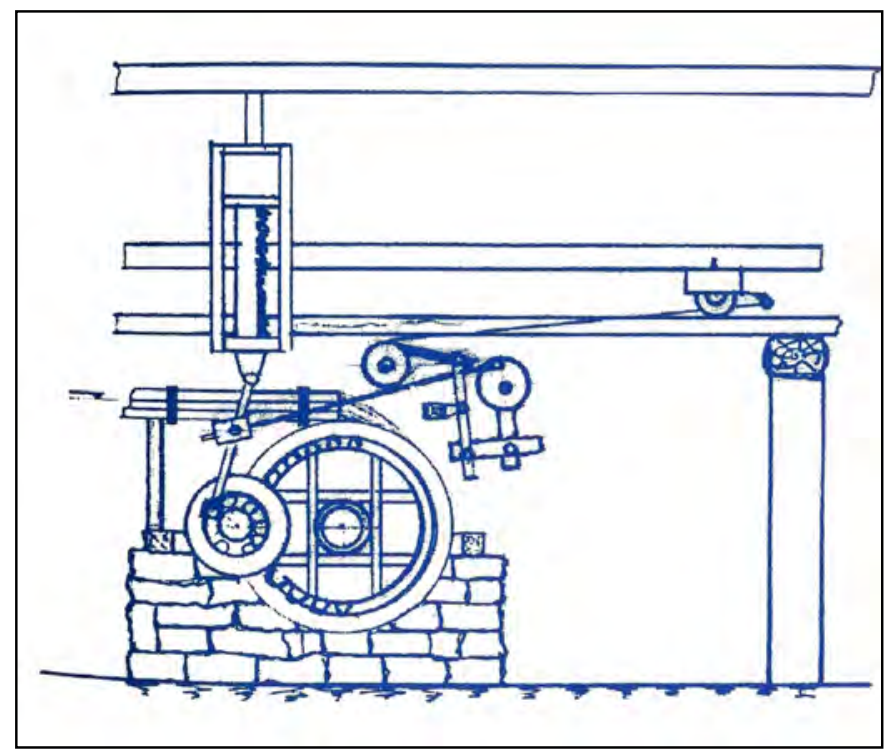

9. ábra. Fürészmalom felépítésének elvi rajza 
portba sorolhatók. A legkezdetlegesebb a rönktartó kocsi folyamatos húzása emberi erővel, csörlő segítségével (9. kép). A csörlő kötelének egyik végét a rönktartó kocsihoz kötötték, másik végét a csörlőhöz. Emberi erővel minden egyes rönköt valósággal áthúztak a keretfűrészen, mindaddig, amíg az egész rönkből deszka nem lett. Minden metszés után a rönktartó kocsit visszatolták eredeti helyére, ezalatt a csörlőről lecsavarodott húzókötél készen állt a következő metszési ciklusban való részvételére.

A századok deszkametszési technológiája nem állt meg a csörlős keretfürészeknél. A cél az emberi erővel működtetett előtolás gépesítése volt. Ez sikeresen megoldódott a dörzskerekes, valamint a racsnis előtolás (10. ábra) bevezetése által.
Mind a racsnis, mind a dörzskerekes előtolásnál a mozgást létrehozó szerkezeti elem, ami átveszi a racsnis kerék szakaszos mozgását, és a fürészlap irányába mozgásba hozza a rönktartó kocsit a rönkökkel együtt, nem más, mint a rönktartó kocsi egyik tengelye. Mindkét előtolást végző szerkezetnél tolórúd veszi át a keretfürész mozgását a dörzskerékhez vagy a racsnis kerékhez. Az előtolás a fürésztartó keret felfelé irányuló mozgása alatt jön létre. A tolórúd kinematikai rajza racsnis szerkezethez kapcsolódva a 11. ábrán látható.

Újabb keletű a fogaskerék-fogasléc szerkezet alkalmazása a keretfürészek rönktartó kocsijának előtolást létrehozó mechanizmusaként. A gyakorlatban a rönktartó kocsinak egy póttengelye van, ennek egyik végén a

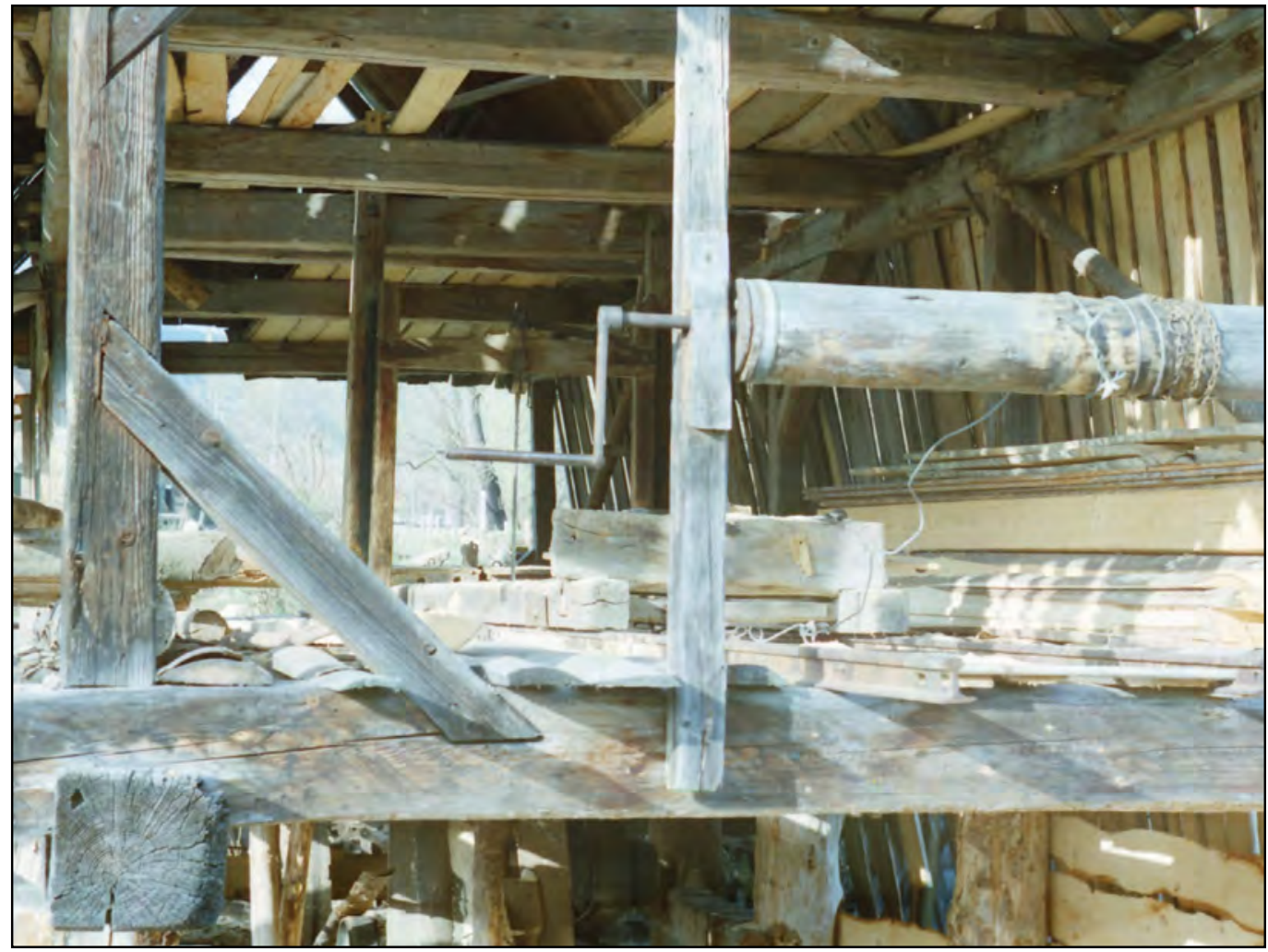

9. kép. Emberi erővel működtetett csörlős előtolás (húzás) 


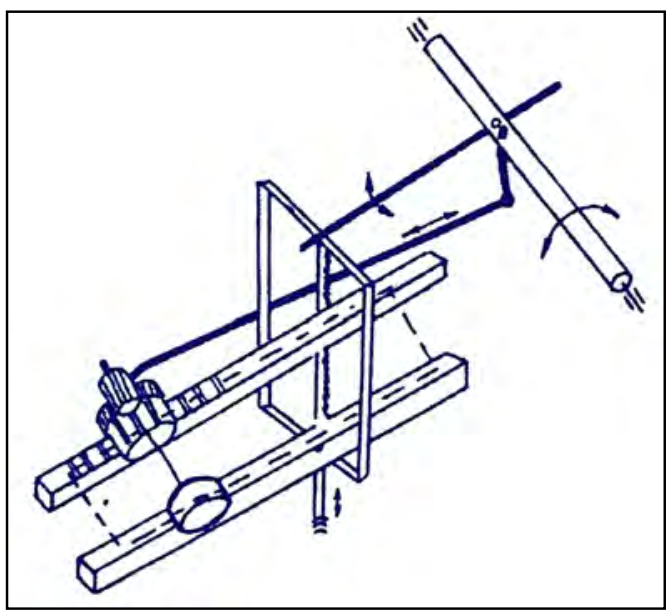

10. ábra. Racsnis előtolás

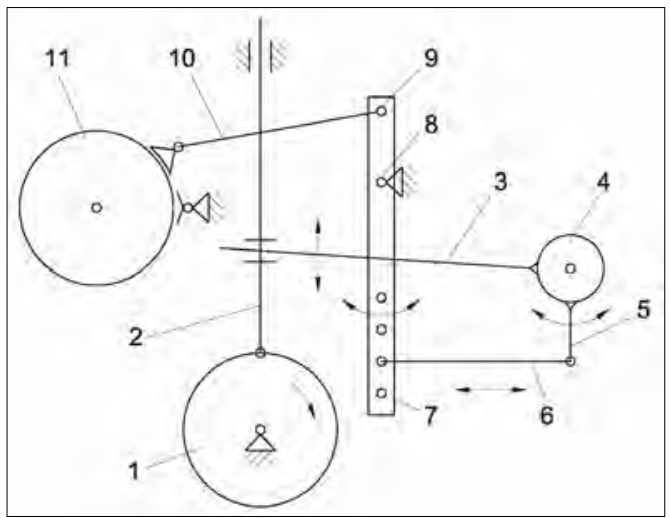

11. ábra. A tolórúd kinematikai rajza

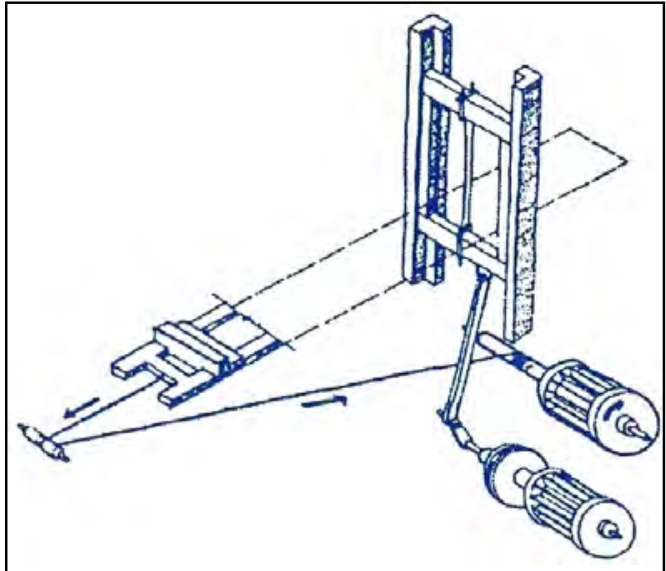

12. ábra. Rönktartó kocsi visszahúzása vízikerékkel racsnis szerkezet, másik végén a fogaskerék-fogasléc található. Minden fürésznyom után a racsnis szerkezetet feloldották, a rönktartó kocsit visszataszították kiinduló helyzetbe. A racsni visszakapcsolásával indították a következő deszka metszését.

Még korszerübb megoldás a vízikerék hajtású visszahúzó szerkezet. A rönktartó kocsi kiindulópontjába való visszavitelét erre a célra egy második vízikereket is beiktatnak, ami csak a visszahúzás idején lép be a szerkezetbe (12. ábra).

A fürészmalmok több évszázados múködésének a nagyobb termelékenységű gőzgépekkel működtetett fürészüzemek elterjedése vetett véget a 20 . század kezdeti éveiben. Ezek a fürészüzemek már nem az egykori romantikus, vízhez kötött fürészmalmok voltak, amelyeknek kétségkívül jelentős szerepük volt a fafeldolgozás gépesítésében.

A lisztelő és a fürészmalmok szerkezetével és működésével kapcsolatos tapasztalatok alapul szolgáltak azokhoz az alkalmazásokhoz, amelyeket a textilipar, élelmiszeripar hasznosított, könnyítve vagy teljesen kiiktatva a nehéz fizikai munkát. A gyapjú és kender feldolgozása egykorú a gazdálkodó, állattartó ember múltiával. A gyapjúból készült termékek iránti kereslet növekedése egyre nagyobb mennyiségű nyersanyag feldolgozását igényelte. A gyapjú tisztításától a kártoláson át a fésülésig, majd a félkész termék, a posztó, cserge, szőnyeg tömörítése, lomozása mind nehéz fizikai munka volt. Ezt helyettesítette a vízikerék meghajtású kártoló, kalló, ványoló, lomozó malom.

A gyapjúfeldolgozás a mosással kezdődik, szárítással folytatódik, majd a fonást megelőző kártolás következik. A kártolás a gyapjúszálak párhuzamosító művelete, az összekuszált gyapjúnak fonásra alkalmas állapotba hozása. 
A vízenergiával múködtetett kártoló elvi felépítése a 13. ábrán látható.

A gyapjúkártolást egy álló és az álló keret fölött, ezzel párhuzamosan lengő keretből kialakított szerkezet végzi. Mind az álló, mind a lengőkeret körív alakú. A lengőkeretet lengőkarok tartják, amelyek egy tengely körül elfordulva lengőmozgásba hozzák a lengőkeretet. A lengő- és az állókeret görbülete megegyező, a köztük levő rés mindkét felületét szegekkel verték ki. A szegeket úgy görbítették, hogy a két felület között a gyapjú csak egy irányba haladjon, mialatt szálai párhuzamosodtak. Így kialakult a fonásra alkalmas gyapjúpaplan. A kártolót egyenletes vastagságú, mosott és szárított gyapjúréteggel etették. A kártoló szakaszosan működött, a gyapjúnak a szeges felületek közötti előtolását egy elmés szerkezet végezte. A kártoló szélességével egyenlő szeges henger és két párhuzamos bőrszíjra szegezett lécek szállítószalagot képezve végezték az előtolást. A szeges henger egyik végén egy racsnis szerkezet, a másik végén pedig egy tárcsa található. A tárcsára bőrszíj van rácsavarva úgy, hogy a szíj egyik vége a lengőkarhoz, a másik végére egy súly van rögzítve. A lengőkar egyik irányú lengése alatt a bőrszíj rászorul a tárcsára, és fordít egyet rajta, aminek megfelelően a szeges henger is fordul, magával húzva a szegekbe akadt gyapjút.

A lengés másik irányában a feltekert bőrszíj fellazul a tárcsáról, a szeges henger másik végén található racsni kitámaszt, aminek következtében a szeges henger csak egyik irányban tud elfordulni. Így a gyapjú csak szakaszosan mozdul a szeges léc mozgásának ütemével a lengő és álló keretek közé.

A kártolt gyapjúpaplant szétosztották, és kézi fonással gyapjúfonalat sodortak belőle.

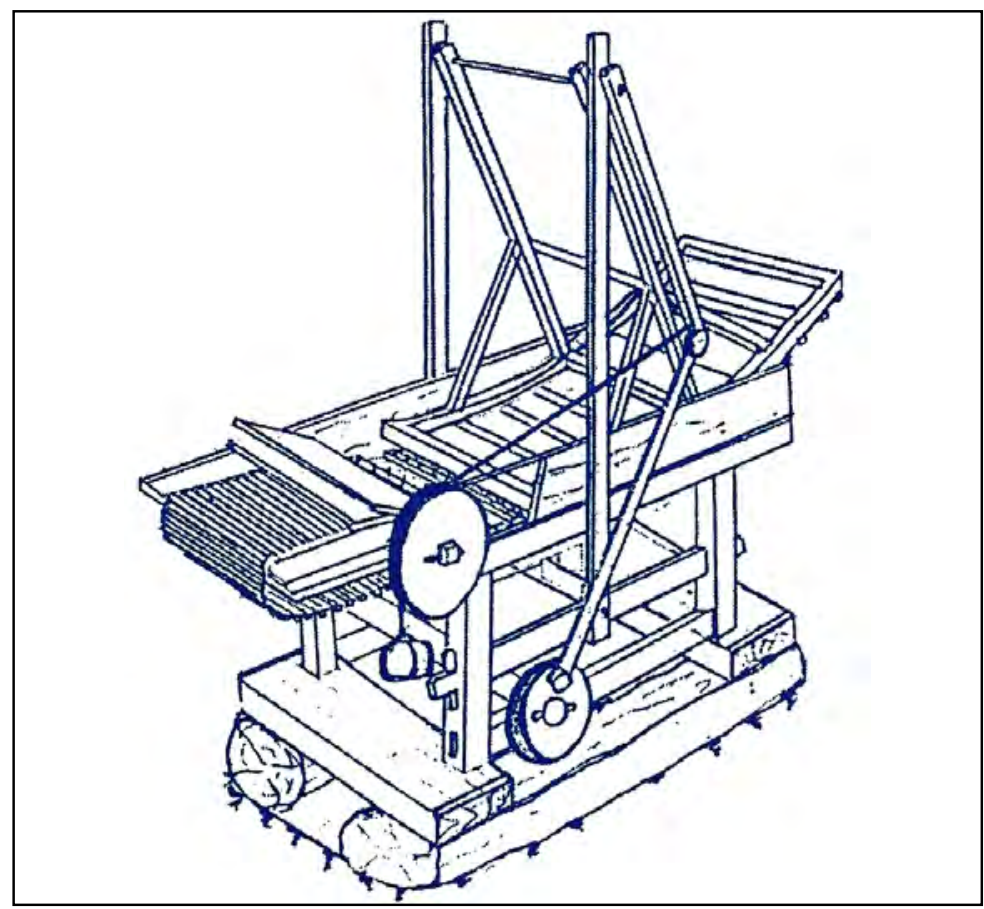

13. ábra. Vízenergiával múködtetett kártoló 
Ebből készültek a gyapjúszövetek kézi szövőszéken. A műveletet $A$ cserge készítésérôl fejezet részletesen ismerteti. Az így nyert gyapjúszövet egyenlőtlen, nem elég tömör. A ványolás és a kallás az a múvelet, amelyeket vizes technológiával a szövetek tömörítésére, egyenletessé tételére alkalmaznak.

A Székelyföldön majd minden lisztelő vízimalom mellett ványolókádak is léteztek. A ványolókád (10. és 11. kép) csonka kúp alakú faépítmény, a csonka kúp kis alapjával a föld felőli részén. A csonka kúpba érintőlegesen vezették be a hegyi patakok tiszta vizét úgy, hogy a kúp belsejébe helyezett szövet a vízzel együtt forgómozgást végzett. A ványolókád, így nevezték ezt az eszközt, palástját alkotó deszkák között réseket hagytak, így a befolyó víz folyamatosan cserélődött. A forgás következtében a szövet a ványolókád oldalához és saját maga rétegeihez súrlódva

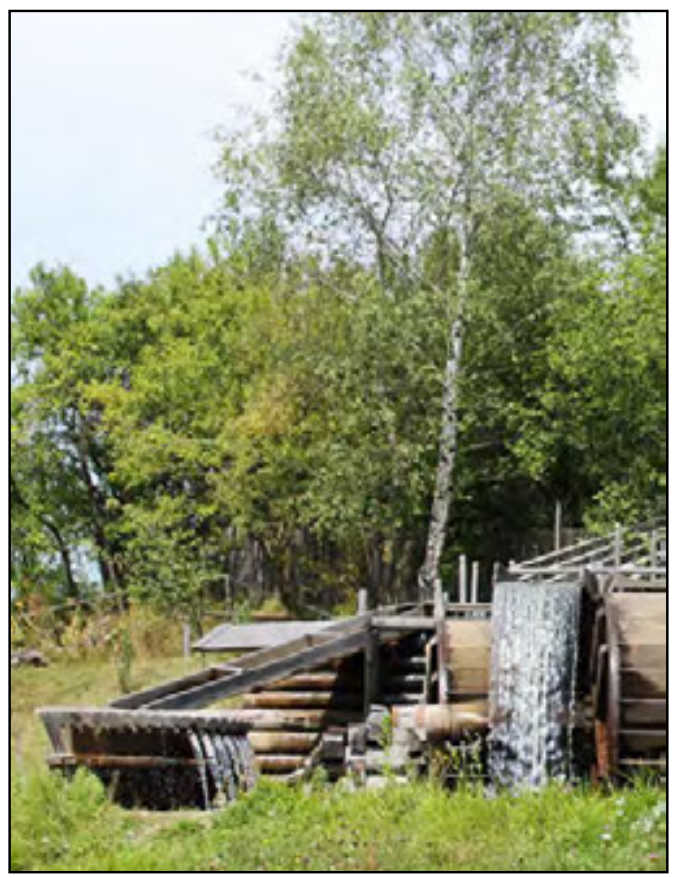

10. kép. Ványolókád

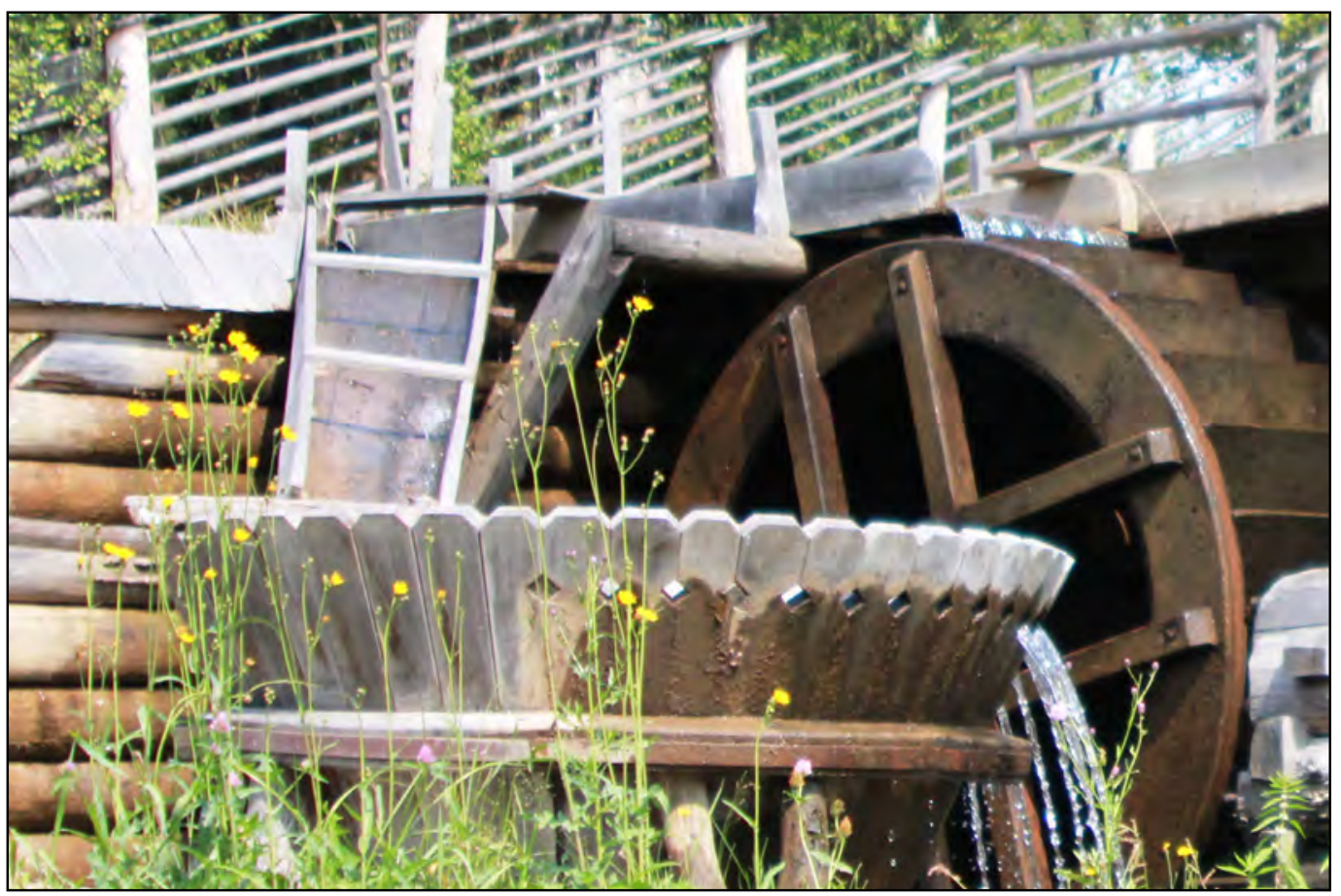

11. kép. Ványolókád (részlet) 
tömörült, lomosodott, egyenletesebbé vált.

A ványolás művelete 10-24 órát is igénybe vett, a szövet hosszának és a kívánt tömörítésnek megfelelően. Csak tiszta vízben és csak nyári hónapokban ványoltak.

A kallás a ványoláshoz hasonló eredménynyel járt, a szövet tömörítődött, lomosodott, egyenletessé vált. A kallás erőteljesebb művelet volt, hiszen kalapácsos szerkezettel végezték. A kalapácsokat vízikerék meghajtású bütykös tengely emelgette. A kallás alatt a szövetet meleg vízben tartották, és közben ütögették. A kalapácsok ütőfelületének és a kallókád belső felületének alakja az ütés alatt fordított a szövetnyalábon. Egy kádban egy időben 15-25 méter hosszú szövetet dolgoztak fel 4-6 óra alatt. Jelentősége volt a víz hőmérsékletének, mert a forró víz tömörített és zsugorított, a hideg víz pedig lomosított.

A kalló ütőbotjait (kalapácsait), amint már említettük, forgásban lévő bütykös tengely emelgette. A felső holtpontról a botok viszszaestek a szövetre, tömörítve azt. A kallóknak, bár a művelet eredménye ugyanaz volt, három szerkezeti felépítését használták. A különbség a kallóbotok emelgetésének módjában nyilvánult meg. Az alkalmazott emelés három változatát a 14., 15. és a 16. ábra szemlélteti. A 14. ábra a nyél nélküli kallóbotokkal működő szerkezetet mutatja, amely esetben a botok egyenes vonalú mozgást végeznek, a 15. ábrán látható nyeles botok körív mentén haladva zuhannak a vályúban található szövetre. A lengőkalapácsos kalló (16. ábra) vízszintes síkban lengve üti a szövetet a különleges üregelésű kádban.

A nyél nélküli kalló felépítése egyszerűbb a nyeles kallókalapácsénál. Utóbbit akkor részesítették előnyben, ha a meghajtó bütykös tengely nem a kalapácsok közelében volt. Ekkor a kalapácsok nyelének meghosz-

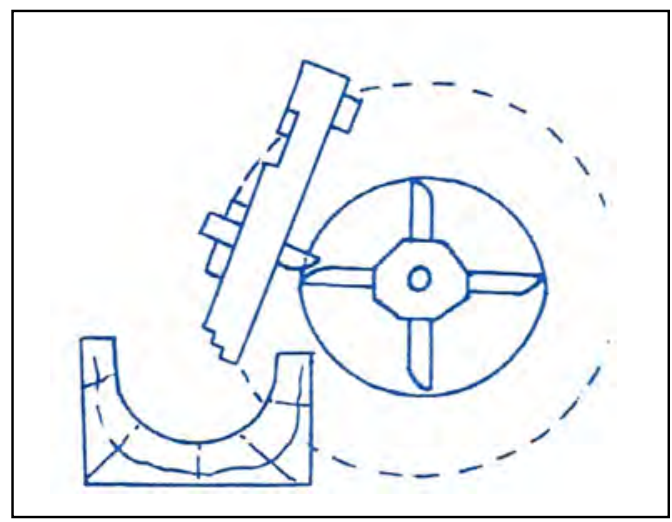

14. ábra. Kallónyilak emelése nyél nélkül

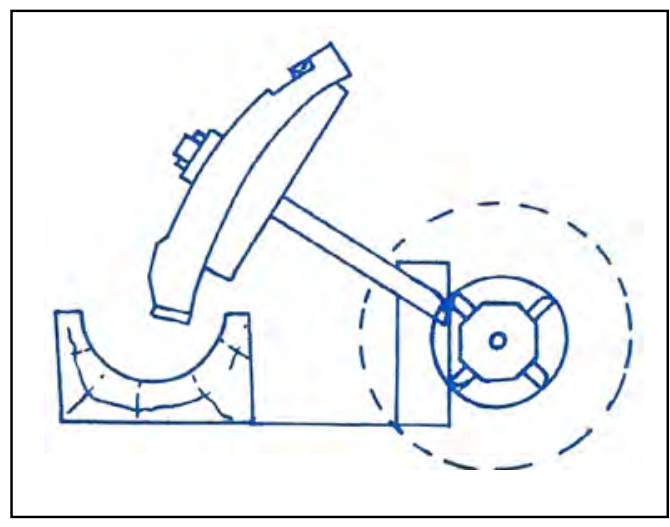

15. ábra. Kallónyilak emelése nyeles szerkezettel

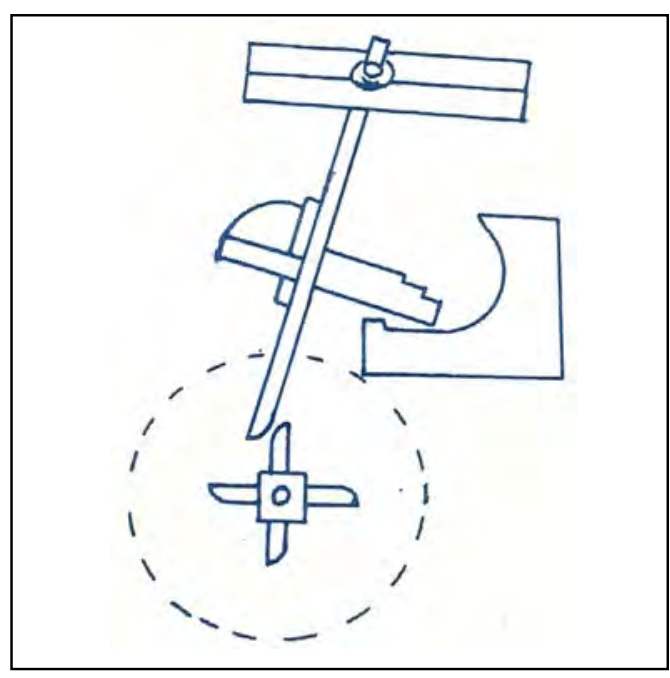

16. ábra. Lengőkalapácsos emelés 
szabbításával érték el az emelőbütyköket. A ványolás és a kallás jó egyéni tapasztalatot feltételezett. A kallómalmot, akárcsak a ványolókádat, csak fagymentes hónapokban működtették.

Hasonló eredményeket lehet elérni egy másik, egyszerű, mondhatni primitív eszközzel, a vesszőből font, henger alakú forgódobbal, a ványolókosárral. A vesszőhenger belső felületén fából kiképzett szegekhez és a vesszőfelülethez súrlódó szövet és a szegek kölcsönhatásának eredményeként tömörítés és lomozás egyszerre keletkezik. Ezt az egyszerű technológiát szintén a vízikerék felhasználása tette gépesítetté. Egész évben használható volt, mert a ványolókosár meleg vizes medencében forog.

A ványolás és a kallás technológiailag rokon szakma az olajütő kezelő tevékenységével. Az olajütés technológiája a következő lépcsőzetben követhető:

- a magvak szárítása;

- a magvak pörkölése;

- a magvak törése és gyúrása;

- préselés.

Ezekből a törés és a préselés fázisában lehet vízenergiát, vízikereket alkalmazni. Az olajütő is szakaszos működésű szerkezet. A kalapácsot bütykös tengely emelgeti, a kalapács a zuhanásából keletkező ütőerő széttöri a pörkölt magvakat. A nagyobb számú kalapács a hatékonyság és a termelékenység növelését eredményezi.

Az olajütés végső mozzanata a megtört magvak préselése, sajtolása. A sajtolás gépesített változata szintén a vízikerékhez kapcsolódik.

\section{A vízenergia jelentősége a bányá- szatban, kohászatban, fémfeldol- gozásban}

A bányászat, a kohászat és a fémfeldolgozás a 13. századtól már elképzelhetetlen volt a vízenergia adta lehetőségek hasznosítása nélkül. A vízikerék által működtetett bányavízszivattyúk, levegőbefújás, nagy kapacitású fújtatók és kalapácsok üzemeltetése jelentették a kor energiaforrásának, a vízenergiának hasznosítását, általa új utak nyíltak a középkor ipari fejlődésében. Három évszázadnak kellett eltelnie a vízikerék feltalálásától ahhoz, hogy a Székelyföld bányászata, kohászata és fémfeldolgozása alkalmazza a vízikerék energia adta lehetőségét. A 15. század közepén már szakkönyvek is segítik a kor műszaki szakembereit, hogy egyre szélesebb körben alkalmazzák az új lehetőséget, a vízikereket. A vízikerék és a bütykös tengely nélkülözhetetlen elemévé válik a műszaki fejlődésnek.

A 16. században Csíkmadarason a Madaras patak mellett és Lövétén a Nagy-Homoród bő hozamú patakán is elindul az ipari méretű vasgyártás, a kor műszaki vívmányainak alkalmazásával. Ebben a korban a kohók és a kalapácsok tűzhelyeinek fújtatóit vízikerekek működtették. A vízikerék az olvasztókemence fontos része volt, ugyanis a fújtatók többletlevegője biztosította az olvasztás folyamatához szükséges hőfok elérését és fenntartását, ugyanakkor a vas minőségét is befolyásolta. Több levegő magasabb hőfokú olvasztást eredményezett, ami magával hordozta az előállított vas szén-, kén- és foszfortartalmát, egy szóval minőségét. A fújtatókat marhabőrből készítették a fúvócsináló vargák. A csíkmadarasi hámornál tucatnyi fújtató működött, amelyeknek javítása, újak készítése két varga feladata volt.

A vasércet főleg felszíni fejtésekből nyerték, de föld alatti kitermelést is folytattak. A 16. századi székelyföldi bányák nem voltak olyan mélyek, hogy ezekben levegőbefújást is kellett volna alkalmazni. A 18. században beindult balánbányai rézércbányák bőrfúj- 
tatókat használtak, de a 19. században már Debreczeni Márton bánya- és kohómérnök találmánya, a csigafúvó is használatba kerül Balánbányán. A csigafúvó nemcsak müszakilag jelentett nagy teljesítményt, de a bőrfújtatók előállításának költségeit és a gyakori meghibásodásuk okozta javítási költségeket is nagymértékben csökkentette.

Balánbányán is vízikerekek működtették a fújtatókat, a rézércolvasztás és a hengerlés műveleteinél is a vízenergiát hasznosították. A villamos energia térhódítása aztán egyre inkább kiszorította a vízikereket mint energiaforrást.

Az utóbbi 40-50 esztendő közömbössége a székelyföldi vízimalmokat végzetes helyzetbe hozta, létszámuk alaposan megcsappant. A máig megmaradt néhány matuzsálem korú malom csupán hírmondója az egykori virágzó vízimalom-hálózatnak. Napjainkban elindult egy említésre méltó folyamat, amelynek eredményeként egyre több víz hajtotta szerkezetet felújítanak. Egyre inkább tudatosul, hogy ezek megőrzése, felújítása, a turizmusba való bekapcsolása, közkinccsé tétele a hagyományőrzés egyre aktuálisabb feladata.

\section{Jegyzetek}

1. Szentmártoni Bodó János (1590?-1648) - unitárius lelkész, költő, a verses oktatóköltészet művelője, a praktikus életszemléletű unitárius mesteremberek, városlakó polgárok költője. Az ácsmesterség és a kovácsmesterség hasznáról szólva a molnármesterség dicséretét is versbe foglalja.

2. gerendely - malomtengely, vízimalomban a száraz kerék tengelye.
3. perpence - az a kis pálca, amely a forgó malomkő lyukában zörög, és a szitát rázza.

4. bélkerék - a malom belsejében forgó száraz nagy kerék, megkülönböztetésül s vízben forgó külkeréktől.

\section{Felhasznált irodalom}

A brassói kereskedelmi és iparkamara jelentése. A brassói kereskedelmi és iparkamara kiadó tulajdona, Brassó, 1890.

Ádám Gyula - Cseke Gábor: Székelyfőldi vízikerekek nyomában. Hargita Megye Kulturális Központ - Pro Print Könyvkiadó, Csikszereda, 2009.

Kardalus János: Posztó és csergeványolás a Kis-Homoród mentén. In: Acta Hargitensia, Miercurea Ciuc - Csíkszereda 1980.

Márton László: Vízimalmok. Pallas-Akadémia Könyvkiadó, Csikszereda, 2003.

Orbán Balázs: A Székelyföld leírása... I. Pest, 1868.

Pataki József: A csíki vashámor a 17. század második felében. A Csíkszeredai Múzeum Kiadványa, Csíkszereda, 1971.

Péch Antal: Érczek előkészítésének elvei, gyakorlati szabályai. Khór és Wein sajátja és kiadványa, Pest, 1869.

Szabóki Zsolt: Nézd elméjüket az ács embereknek. Artunion Könyvkiadó, Budapest, 1987. 3.

Székely Oklevéltár. Új sorozat. Közzéteszi Demény Lajos és Pataki József. Kriterion Könyvkiadó, Bukarest, 1983.

Tarisznyás Márton: Gyergyó történeti néprajza. Kriterion Könyvkiadó, Bukarest, 1982.

Vajda Lajos: A szentkeresztbányai vasgyártás története. Politikai Könyvkiadó, Bukarest, 1983. 


\section{SZÉKELYFÖLDI ÜVEGHUTÁK}

\section{Kárpát-medencei üveghuták}

A Kárpát-medencében a rómaiaknak köszönhetően meghonosodott az üvegből készült tárgyak használata. Az első magyar üvegcsűr Sparrendorfi Krabath György szklenófürdői hutája volt. Itt gyártották 1450 körül a selmeci és körmöci bányáknak azokat az üvegeket, amelyekben az ezüst és arany szétválasztásához szükséges királyvizet tartották.

Újabban Pásztón egy 12. századból való üveghutát tárt fel dr. Valter Ilona, az Országos Műemléki Felügyelőség régésze. Ez két helyiségből álló, nyitott fedélszékes, ácsolt tetőszerkezetű műhely volt. A nyersanyagot előzetes tisztítás, mosás után, az ún. temperáló kemencében előmelegítették, illetve különböző adalékanyagok hozzáadásával tisztították. Agyag olvasztótégelyekben kb. 1400 C-fokon olvasztották, az ún. olvasztókemencében. Az üvegfúvók itt fújták ki, formálták meg tárgyaikat az üvegfúvócső („pipa”) segítségével. A hűtőgödör (hűtőkemence) szolgált a tárgyak hűtésére. Itt, 500-600 C-fokon feszültségmentessé tették.

A kora középkorban a szerzetesek műhelyei gyakorolták az üvegmesterséget. A legjelentősebbek a német bencés apátsági huták voltak. Ezeket követték a fóúri (uradalmi), illetve bányavárosi huták. Ezekre egyértelműen hatottak a velencei-muranói üvegesek.

Bethlen Gábor 1619-1620-ban a Velence melletti Muranóból hozatott üvegeseket Porumbákra (Szeben megye), ahol főleg a bányavárosok szükségleteire termeltek választó- és poncüvegeket, tégelyeket, no meg kristályüveget. Bethlen halála után, a rossz bánásmód miatt az üvegesek visszatértek szülőföldjükre. ${ }^{1}$

A 16-17. században a társadalom előkelőbb rétegei már megengedhették maguknak az ablak- és öblösüvegek használatát. Az ablaküvegek kerek vagy hatszögű tányérok voltak, amelyeket fa-, ólom- vagy ónkeretek segítségével illesztettek össze.

Pálffy Pál kamarai elnök is építtetett 1625ben üveghutát. Az udvari kamarának 1635ben azt írja, hogy Magyarországon több úrnak van üveghutája. Nem üzérkedés céljából, hanem saját gyönyörködtetésükre, illetve saját szükségleteik kielégítésére építtették ezeket az üvegcsűröket.

Az első üvegtáblákat 1685-ben Haller János hozta Bécsből Magyarországra. A magyar üvegcsűrök kb. az 1630-as évektől mind nagyobb mennyiségben termeltek használati, háztartási üveget (kotyogós és virágvíznek való üvegeket) és poharakat.

A hagyományos üvegipar Erdély szász városaiban,BrassóbanésSzebenben céhes keretek között működött már a 16. század elején. Marosvásárhelyen 1615-től tudunk üvegcéhről. „A szállítást, favágást, tüzelést jobbágyrobotban végeztették, a szakértelmet kívánó munkát bérmunkásokkal látták el." (Erdély rövid története 1993. 343.) Tömegesebb elterjedése azonban csak a 18. század kezdetétől indult. 
A mineralógia atyjának tekintett Georgius Agricola (1494-1555) már a 16. század közepén részletesen leírta az üveg előállításának technikáját. Részletesen vázolja az üvegcsűrök szerkezeti felépítését (lásd $A$ bányászatról és kohászatról írt könyvét, 1556). Bethlen Miklós az üvegofficinát üvegcsűrnek nevezi. Az officina vitraria szerszámai és munkaeljárásainak leírása már magyar, például „üvegcsőket forgató kétágú vas”, „üvegcifrázó" stb. Egyre növekszik a kereslet az üvegholmik iránt.

A 17. század második felére megjelentek a tréfás üvegek: kancsó, üveglopó, üveghordócska, gyertyatartó, lapos boroskancsó, mezei lámpás stb. Ebben az időben a porumbáki hutában készítettek csiszolt és gravírozott üveget is. Itt a palackfúváshoz 12 fajta faformát használtak. Készítettek hasáb alakú, négyoldalas üveget, kisméretű orvosságos, illatszeres és nagyméretű 1-1,5 l űrtartalmú, pálinka és bor tárolására használt üveget.

Készítettek pincetokpalackokat is több palack együttes tárolására, szállítására szolgált). Hat vagy tizenkét rekeszre osztott, belülről gyakran párnázott, posztóval bélelt, kívülről bőrrel bevont, fémveretes láda volt.

A 18. század közepétől Porrumbákon és Felsőárpáson (Szeben megye) készültek színes opak (átlátszatlan) zománcfestésű palackok, butykosok, butellák.

1860-tól Magyarországon meghonosodott az üvegfestészet. Róth Miksa „császári és királyi üvegfestô" 1900-ban a párizsi világkiállításon ezüstérmet nyert munkáival. 1860-tól kifejlesztették az ún. íriszes (csillogó) üveget. Pantocsek Leó Valentin (1812-1893) a magyarországi szecessziós üvegművészet egyik úttörője volt.

Ismereteink szerint üvegcsűr működött Száldobágyon (Bihar megye), Parádon (Heves megye). Ez utóbbinál emlékpoharak is készültek a fürdőt látogató vagyonosabb középpolgári vendégeknek. Ezek az emlékpoharak csiszoltak (vésettek) voltak, rajta sok esetben évszám és a gyártó szignója.

\section{Székelyföldi üvegcsürök}

Az üveghuták a fő közlekedési útvonalaktól távol eső, vízben és fában gazdag területeken létesültek. A 17. század második felében és a 18. század elején létrejöttek a földesúri huták (Görgényüvegcsűr, Zalánpatak, Bükszád stb.). A nagy erdőségekkel rendelkező földesurak (Bornemisza János, Henter család, Kálnoky Sámuel, Mikó Ferenc stb.) így értékesítették erdőiket. Ők látták el a közeli piacokat üvegtermékekkel. A fölösleget az Alföldön értékesítették. A legtöbb helyen kezdetben ablaküvegeket gyártottak, vagy ásványvíz-lelőhelyeken (Borszék, Málnás) a palackozáshoz szükséges tárolóedényeket. A magyar parasztság viszonylag hamar megbarátkozott a népi (rusztikus) üvegedényekkel. Ajobb módú polgáricsaládokotthonaiban általánossá vált a cseh díszüvegek használata, illetve az „úri” kristályüveg, amely áttetsző, színtelen üvegből készült (drágább is volt). A közhasználatra szánt üvegtermékek a piacon erdéli (erdélyi) név alatt kerültek be a köztudatba. A technika elmaradottsága miatt a produktumok minősége gyengébb volt az osztrák vagy a cseh-morva üvegipar termékeinél. Nagyon kevés üvegcsűr tudott átállni a modern technikára (Szelistye, Feketeerdő). Ezeket a hutákat 30-40 évenként új helyszínre kellett költöztetni, mert a közeli erdőket letarolták. Olcsóbb volt egy fában gazdag terepen újra felépíteni, mint a messzi távolból a fát az üvegcsűrhöz szállítani.

Viszonylagos visszaesést jelentett az 1886-tól 1893-ig tartó vámháború Romániával. A megegyezés után újra fellendült a cserekereskedelem. 
Háromszék területén a 17. század végétől sok vállalkozás született. A sepsiszentgyörgyi Henter család létesített üvegcsűrt a Bodza nevű lisznyói erdőrészen. A helyi lakosság lerombolta a jogtalannak ítélt erdőhasználat miatt.

1740-1750 között Zalán-patakán már volt egy üveggyár, Kovásznán és Zágonban 17601858 között működtek üveghuták. Málnáson 1770-ben, Bodzán 1790-ben létezett működő üvegcsűr (Veres L. 1989).

A zalánpataki (románul Valea Zălanului, Kovászna megye) a legrégebbi. Az oklevelekben 1692-től szerepel. Az első üvegcsűr Egyedmezején állt. Kálnoky Sámuel háromszéki főkirálybíró tulajdonában volt. Kálnoky bajor, cseh és olasz mestereket hívott. A szilikátot Csíkszentimréről, a Hargita-hegységből hozatta. Vízzel működő malom zúzta porrá, és hatalmas katlanokban készítették a szép üveget. Kezdetben csak ablaküveggyártással foglalkoztak. A kolozsvári Szent Mihály-templom színes üvegablakai mind itt készültek. Nemcsak színes hutaüveget, hanem művészeti kivitelezésű használati tárgyakat is készítettek. 1759-ig magánföldesúri kezelésben állott. Ezt követően bérlet útján üzemeltették. 1754 végén csehországi üveges bérli, aki tíz üvegest hozott magával. A 18. század utolsó harmadában 8-10 szakmunkás mellett 30-40 uradalmi jobbágy segédkezett. A modernizáció révén egykemencés 6-8 olvasztótégelyes technológiát alkalmaztak. Gyártottak patikai üvegeket, boros- és vizespalackokat (parasztüvegek vagy más néven népi üvegek), és csak alkalmanként készítettek finomüveget. 1832-ben Simonai János volt a bérlő. Ő hamuzsír helyett szódát használt (ez már környezetkímélőbb volt, hiszen nem tarolták le az erdőket). A termékek több mint 90\%-át Havasalföldre és Törökországba exportálták. 1771-1781 kö- zött Toma és Manole Calfocini brassói kereskedők értékesítették az üveghuta termékeit, később a szebeni Marcu üzletház tagjai.

„A finom üveg mellett változatos, sokféle funkciójú használati üvegeket gyártottak" (Bunta M.- Katona I. 1983).

A 18. század derekán Szilágycseh, Margitta, Nagykároly, Beszterce, majd a 18. század végétől Kolozsvár, Marosvásárhely, Szamosújvár és Beszterce voltak az üvegekkel megrakott szekerek célpontjai. Az itteni üveghuta 1860-ban szüntette be a termelést, egyrészt a versenyhelyzet, másrészt az erdők megcsappant faállománya miatt (Oláh-Gál Elvira 2011). Ehhez még hozzájön a tőkehiány és a képzés hiánya is (nem foglalkoztak szakemberképzéssel).

1979. áprilisában a huta területén Kisgyörgy Zoltán geológus és Karácsony Zoltán folyattak ásatásokat. 38-féle üvegtöredék került felszínre: öblös üveg, egyliteres fehér palacküveg, fehér színű söröspalack, hasáb- és hengeres testű orvosságos üveg, befőttes- és uborkásüvegek, légyfogók, lopók, tintásüvegek, talpas poharak, üvegtálak, korsók, vázák, kancsók.

Mikóújfalu (románul Micfalău, Kovászna megye) szintén az üveggyártásról volt nevezetes. Gróf Mikó Miklós 1750-ben, más források szerint 1763-ban alapította az üvegcsűrt. A Zsombor-tetőn létesített üvegcsűrhöz cseh, valamint német családokat telepített. Az itt működő kishuta 1782-ben áttelepül Sepsibükszádra, ugyanis fogytán volt a hamuzsírfőzéshez szükséges erdő.

Sepsibükszádon (románul Bicsad, újabban Bixád, Kovászna megye) az üveggyártás egy másik központja működött. „A 17-18. században a határban lévő hatalmas bükkerdők az akkor virágzásnak induló s a falut nevezetessé tevő üveggyártás áldozataivá váltak" - írják a szerzők a vidéket bemutató könyvükben 
(Váradi és társai 1994). Az első hutát Zsombor-tetőre (Mikóúffalu határában) építették. Német és cseh munkásokkal üzemeltették. Első neve Bükszádi üvegcsűr. A település a nevét az üveghutáról kapta, amely az Oltba ömlő Nagy- és Kis-patak völgyében épült. 1812-ben telepítették a végleges helyére. Tulajdonosa, gróf Mikó Miklós az üvegcsűrt később hozományként lányának, Eszternek adta. Így került 1847-ben gróf Mikes Benedek tulajdonába. Kezdetben 12 család dolgozott itt. 1850-ig közönséges parasztüveget gyártottak. Gr. Mikes Benedek üvegköszörülő- és festőműhellyel szerelte fel az üveghutát, ezáltal értékesebb tárgyakat tudtak készíteni. „Évenkint 6-8 hónapot dolgoztak, és 18 ezer schock ${ }^{2}$ üveget állitottak elô" (Orbán Balázs 1869). 1885-ben a huta leégett. Újjáépítése hosszadalmas volt. Modernizálták az üveggyártást. Két, egyenként 10-10 tégelyes faüzemeltetésű kemence szolgálta a folyamatos termelést. Évente 3 ezer mázsa közönséges és ezer mázsa öblösüveget gyártottak. Ebben az időben az „üvegcsüri munkások: székelyek, oláhok, németek és csehek" - írja dr. Hankó Vilmos: Székelyföld c. művében. Tőle tudjuk, hogyan is nézett ki. „A falu középpontjában nagy fekete faalkotmány emelkedik: gr. Mikes Benedekné üveggyára, a Székelyföld egyik legtekintélyesebb ipartelepe. A gyár ízléses készítményei, palaczkjai, köszörült, festett üvegtárgyai egyre nagyobb piaczot hódítanak itthon és a szomszédos Romániában." Az 1880-as években a termékeket szekérrel szállították a 60 km-re lévő brassói vasútállomásra, és onnan tovább a távolabbi piacokra. 1897-ben megépült a Brassó-Sepsiszentgyörgy-Csíkszereda vasútvonal, és így könnyebb és olcsóbb lett a szállítás. Egy újabb modernizálás következtében gázfütéses regenerátoros kemencét építettek, ami 12 órára csökkentette az alap- anyag olvasztási idejét (Cserey Zoltán 1994). 1898. október 15-én azonban az üvegcsűr ideiglenesen beszüntette a termelést. A mélypontról egy szlovákiai születésű szakember lendítette ki. Fénykorát is Sovánka István (1858-1944) üvegművész idejében élte. Sovánka István előzőleg (1881) a zay-ugróczi üveggyár tervezője volt. Az 1896-os millenniumi kiállításra egy keresztelőmedencét készített. Rendszeresen részt vett rangos hazai és nemzetközi kiállításokon. 1902-ben, a torinói világkiállításon érdemoklevelet kapott, 1904-ben Milánóban aranyéremmel tüntették ki. 1907-ben társbérlóként érkezett Sepsibükszádra. 1914-ig vezette az üveghutát. A huta utolsó tulajdonosa gr. zabolai Mikes Ármin, aki 1928-ban eladta a település lakóinak (lásd www.erdelykincsei. com). A huta 1918-ig üzemelt, akkor végleg megszűnt. A bükszádi üvegcsűr 1898-ban készült fotója látható Sepsiszentgyörgyön a Székely Nemzeti Múzeumban, az üveggyár termékei pedig megtekinthetők a bükszádi iskolamúzeumban.

Görgényüvegcsür (románul Glăjărie, Maros megye) Szászrégentől északkeletre, Görgényszentimrétől mintegy $11 \mathrm{~km}-\mathrm{re}$, egy mellékvölgyben fekszik. Első okleveles említése Görgényüvegcsűr néven 1760-ból származik (Buccow-féle összeírás). Hosszú ideig a görgényi uradalom része volt (kincstári birtok), majd 1719-től a Bornemisza család birtoka lett. Ifjabb báró Bornemisza János egy német barátjával a Görgény-hegységben vadászott, és gazdag kvarclelőhelyre akadtak. Az üveggyártás másik alapanyagát, a hamuzsírt a bőséges bükkerdő biztosította. Az irtást a mai Felsőlárga nevezetű völgyben kezdték. Itt épült fel a későbbi falu nevét adó huta - egy csűrre emlékeztető múhely -, ahol az üveget fújták. A tulajdonos Cseh-Morvaországból hozatott kilenc üvegfúvó szakembert. 
Erdőirtások és újabb - osztrák, német és olasz - mesterek alkalmazásával a település tovább bővült. Településként 1777-től említik. Kezdetben csak ablaktáblákat, palackokat és tányérokat, később díszített vizes-, boros- és pálinkáspoharakat készítettek.

A vállalkozás kifizetődő volt mindaddig, amíg helyben volt elegendő nyersanyag. Amikor az elfogyott, távolról kellett ideszállítani. A kvarcot Naszód környékéről (Beszterce-Naszód megye), a meszet eleinte Görgénysóaknáról, majd Homoródalmásról szállították a hutához. Így az előállított termékek költségesebbek lettek, kevesebb hasznot hoztak. A tulajdonos hatévenként bérbe adta. 1837-ben az üvegcsűr bérlője a szászrégeni Schuller Mihály volt. Évenként 4000 forint bérleti díjat fizetett, amiért 3000 szekérnyi fát is kapott. Nyolc üvegfúvót és kisegítő legényeket alkalmazott. Az üvegtábla-készítők napi 15 forintot, míg a kisegítők 7-8 forintot kaptak. Itt üvegmetsző is dolgozott, aki darabonként 2 krajcárért metszette az üvegeket. Az üveghuta 1870-ig múködött.

A 99 éves bérleti szerződés lejárta után a Bornemisza család megtagadta a görgényi birtok visszaszolgáltatását a kincstárnak, mindaddig, amíg az nem fogja visszatéríteni az e birtokon végzett befektetések költségeit, melyek között a görgényüvegcsűri üveggyár is szerepelt. Ennek következtében az osztrák állam 1835-ben bírósági eljárást indított a bérlő Bornemissza ellen. A birtok visszavásárlására és a befektetések megtérítésére indított eljárás 27 évig folyt, melynek végeredménye a bérlő Bornemissza 500000 forintos kártérítése, ugyanakkor a birtok újra az osztrák állam birtokába került. 1870-ben az osztrák állam bezárja az üveggyárat, épületeit elárverezi, ugyanakkor betiltja az erdőkitermelést is, ami a 600 görgényüvegcsűri lakost megélhetés és jövedelem nélkül hagyja.
A már nem jövedelmező üveghutát a tulajdonos felgyújtotta. Az üvegház szakemberei a Bihar megyei Feketeerdőben és Medgyesen kerestek munkát, a többiek átképezték magukat: kőfaragók, tutajosok, szénégetők lettek. A kincstár a görgényi uradalmat visszaváltotta. A település lakóit kötelezték, hogy telkeiket, földjeiket megvásárolják.

Az üveghuta termékeinek egy gyűjteménye látható az általános iskola múzeumában.

Megpróbáljuk csoportosítani az üveghuták termékeit:

a) Tárolóedények: palackok, ballonok, butéliák, tejes- és befőttesüvegek, kancsók, pincetokba való palackok, korsók stb.

b) Ivóedények: poharak, kancsópoharak, porciós és füttyös üvegek, butykosok, kulacsok, bokályok ${ }^{3}$, kotyogós üvegek, stb.

c) Vegyes használatú (háztartási célokra készített) üvegek: mécsesek, függő- és álló lámpák, gyertyatartók, tányérok, tölcsérek, dugók, köpülőfedők stb.

d) Különleges rendeltetésű üvegek: tréfás üvegek, görbebot, üvegpipa, cumisüveg, hímes tojás stb.

\section{A borszéki üveggyár}

(Borszék románul Borsec, Hargita megye)

A 18. század végén a Ditró határához tartozó Borszéken üveggyárat alapítottak, melyről a korabeli források a következőket jegyzik fel: „Vagyon ezen helység határán egy üvegcsináló fábrika, az úgynevezett Borszék nevü helyben, ahol vagyon a híres borszéki savanyóvíz is, némelyek szoktak ezen helység lakosai közül onnat borvizet kiszállítani, némelyek pedig az oda bémenni szokott nagyságokat vagy másokat alkalom szerént fizetésért oda bé szokták vecturázni ${ }^{4} \mathrm{~s}$ onnan is még fizetésért visszahozni." 
Daniel Scheint Borszék első fürdőorvosa címü 1833-ban Pesten megjelent könyvében jelzi, hogy az ipari termelés rohamosan fejlődik, és említést tesz a borszéki üveghutáról is (Scheint 1833. 543.).

A borvizes üvegekért nem fizet százezreket a cseh Siemens gyárának, hanem építtetett magának olvasztókemencét. Zimmethausen, a borvízforrás bérlője magával hozta Eisner üveggyárost, aki egyrészt felkutatta az üveggyártáshoz szükséges alapanyagot, másrészt megépítette az üveghutát. Borszék a legjobb kovahomokkal rendelkezik. Az egy sziksót (szódát), amit itt helyben nem leltek, Marosújvárról szállították. A nyers szóda mázsája 9, kristályosítva 12 pengő.

Az üzem Alsóborszéken, a mai polgármesteri hivatal és orvosi rendelő épületeinek helyén létesült 1806-ban, fenyőgerendákból. Az építkezési munkálatokat Hartwig Ferenc és Hartwig János porosz származású mérnökök vezették.
Az üveggyári munkásokat (cipszereket) Zimmethausen hozta magával. A régi Szepes vármegye német lakosai voltak. Miklós József nyelvész szerint „a mi szászainkhoz hasonlóan a magyar királytól kaptak földet, az ide telepített sziléziai és szász vendégek nagy szorgalommal és kitartással termékennyé varázsolták, rajta magas fokú civilizációt teremtettek, gyönyörü várak, kastélyok és pompás városok sokaságát építették fel, felvirágoztatták a kézmüvességet és a kereskedelmet." (Miklós József 2005) Leszármazottaik ma is Borszéken élnek: Birmanok, Eigelek, Foktok, Kamenitzkyk, Straffok, Wildek, Thiermájerek, Schillerek stb. Közel 200 családnak biztosított kenyeret az üveggyár (110 üvegcsűri olvasztó nevét ismerjük).

A termelés 1808-ban már három kemencében zajlott, 20-30 olvasztófazékkal. Orbán Balázs A Székelyföld leírása című műve második kötetének (1869) 118. oldalán látni a mellékelt korabeli metszetet a füstölgő üvegcsűrről (1. kép).

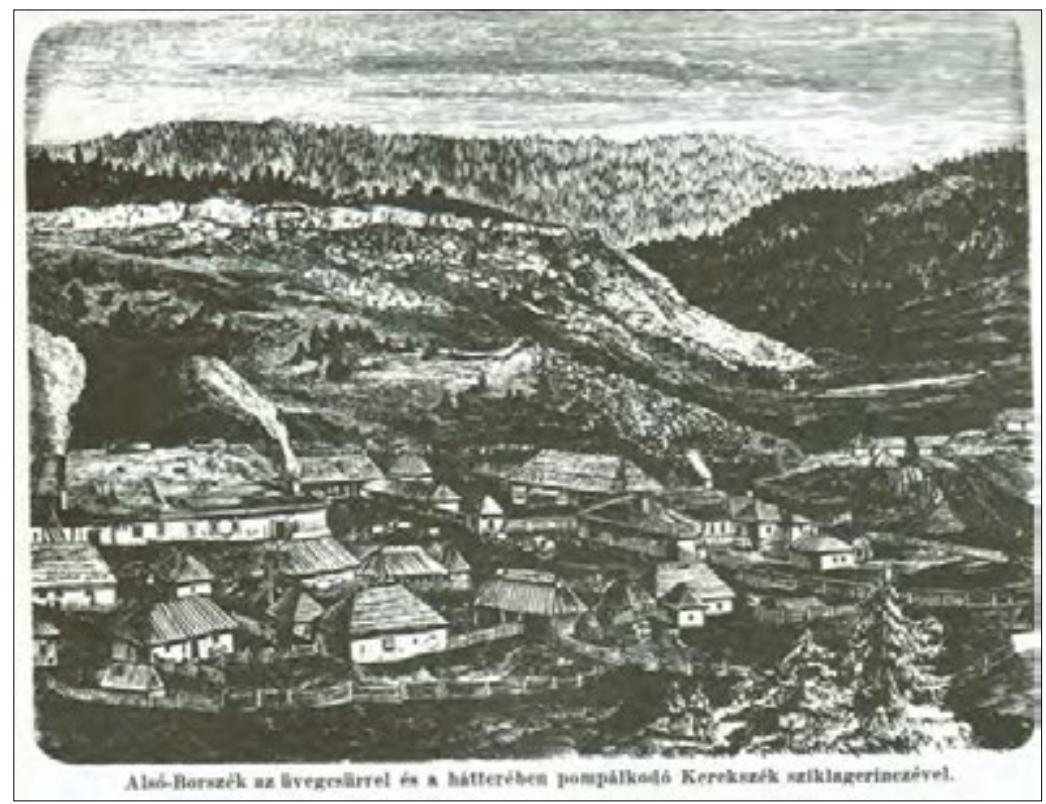

1. kép A borszéki üveggyár távlati képe Orbán Balázs A Székelyföld leírása c. múvében 
Az üveggyár nagymennyiségű tűzifát használt. Ezt a két község közeli erdeiből termelték ki és szállították ide. Kőváry László szerint „vagy 12 legény szüntelen fújja az üveget, és mégsem elég" (Kőváry 1984. 145-146.).

Boner leírása szerint: „nagy tömegben van itt vakító fehér homokkő, a legfinomabb üveget, a legjobb tükröt lehetne belőle készíteni, de csak üvegeket gyártanak a borvíz számára. Ezek az üvegek a lehető legcélszerütlenebbek, ugyanis nemcsak az a hiba, hogy az üveg rendkívül vékony, hanem amellett igen rövid az üvegek nyaka. Csak egy hosszú nyakú üveget lehetne jól bedugaszolni." (Boner 1865.)

Kozma Ferenc, a székelykeresztúri állami tanítóképezde igazgatója 1879-ben megjelent könyvében így ír: „A borszéki vízzel való kereskedéshez szükséges üvegeket a tulajdonos községek [Szárhegy és Ditró] saját gyárukban állíttatják elő, hol a lakosságnak több mint fele (60-70) nyer foglalkozást és keresetet. Az itteni üveggyártásnak az az elönye van, hogy a hozzá szükséges anyagok helyben nemcsak bőven vannak, de olyan kitünö minöségüek, hogy azokat a csehországi üveggyáros a híres cseh-üveg anyagainál részben kitűnőbbeknek állíttá. Ezt bizonyítja azon körülmény is, hogy a borszéki üveg, daczára a legprimitívebb gyártásnak, a legjobb színtelen üvegek közzé számítható. Hogy a borvíz-szállításhoz miért nem gyártanak kevésbé törékeny üvegeket, s czélszerü berendezés és szakképzett müvezető alkalmazása által a gyártást miért nem terjesztik ki másféle üvegek előállítására is, e kérdésekre feleletek a laikus birtokoktól hiába várunk!" (Kozma Ferenc 1879. 287.).

Egyed Ákos szerint a 19. század közepén 18 üveggyár működött a Magyar Korona országaiban, de az osztrák ipar versenye s a fa árának megdrágulása miatt a régi huták egymásután szűnnek meg.
Kőváry László már csak a tanulmányunk bevezetőjében felsorolt hét működő üvegygyárról tud. A bükszádi üveggyár gróf Mikes Benedek tulajdona volt, és évenként 18 ezer darabot gyártott. „Az üvegcsür különben általánosan kedvelt ipari üzem a székelyföldi földesurak között. Az ismert csíki, föleg borszéki üveghuták" mellett máshol is épültek hasonló létesítmények, például Bárkányban és a bodzaszorosi Krasznán.

Kőváry írja, hogy a borszéki üveggyárnak 10-12 munkása volt, és hogy az egész vállalkozás 60-70 ezer forint értékű forgalmat bonyolított le, valamint azt is, hogy ott „éjjel és napon, töltik egy csapon, néha kettőn is az üvegeket" (Kőváry László 1842. 195.).

A bérlőket kötelezték (1844), hogy a korhadó fenyőoszlopokat és a kötésükre használt deszkákat cseréljék ki kőfalra. Ez meg is történt alaprakás nélkül, felületesen.

Az üveggyár minden évben nagy mennyiségű tűzifát igényelt, és emiatt az erdőket kíméletlenül pusztították. A birtokos község 1863. november 10-én tartott gyűlésén elhatározták, hogy csak a lehullott és erdőégések által megperzselt fákat szabadjon kihordani. Ugyanebben az évben sikerült kitiltani az idegen gyárakból (pl. Porumbák) hozott üvegpalackokat. A borszéki üveggyárban elegendő palackot gyártottak. A borszéki hutában előállított üvegek olcsók voltak, az üvegtörések pedig gyakoriak. Annak bizonyítására, hogy mennyire törékenyek voltak az itt gyártott üvegek, álljon itt egy korabeli dokumentum „...a dugaszoló helyiség mellett ezer szám fekszik egymáson a dugaszolás közben eltört üveg..." (Pesti Napló 1880.).

Július 25-től a borszéki üvegekre M. D. (Mandel Dávid), és alája F. K. (Fő-kút) felirat került. Ezt meghirdették a fogyasztók tájékoztatása végett a hírlapokban is. Az üvegek szájára ólomkupakokat tettek. 
Az 1870-es években a birtokos községek újjáépítik az üveghutát. Dezső Mózes vállalkozó és Szász Ferenc ács-kőműves behelyezték a 3. olvasztókemencét és hűtőt. Egy új szárnnyal bővült az üveggyár, 13733 frt értékben. Közben megépítettek egy szint a kőszén tárolására. 1874-ben házi kezelésbe került a fürdő és a borvízgazdálkodás. Az üveggyár részére a békasó összetörésére malmok és égetőkemencék építését kezdték meg. 1876-ban elkészült egy üveggyári olvasztó- és hűtőkemence, amely borszéki kőszénnel működött.

1880-ban egy Dousa József nevű cseh szerencsevadász jelentkezett, „évi $1200 \mathrm{ft}$ fizetés, szabad szállítás, természetbeni tüzifa és világítás, s két marhatartási illetménynyel. Nagy későre készíttetett egy olvasztó és hütő kemencét kőszénneli hevítéshez, s még egy üvegtábla nyujót." (Puskás 1880. 155.) A hibás szerkezet miatt nem lehetett jó minőségű üveget gyártani, s Dousa a táblanyújtót is szűk helyre tervezte, a három hónapos próbaidőt meg sem várva, december 15-én távozott. A fizetéséből visszatartottak 113 forintot kártérítés címén.

Ezután egy Ulman Vilmos nevű személy jelentkezett gyárvezetőnek (1881), de hat hónap után felmondtak neki, mert az általa készített, kőszénnel működő kemence semmivel sem volt jobb, mint a régi fás kemence. Egy héten csak háromszor lehetett benne önteni, többet nem bírt meg. Tönkretette a régi olvasztófazekakat is. Három hétig szünetelt az üveggyártás, ami komoly termeléskiesést jelentett. Közben megépítettek egy szint a kőszén tárolására, az üveggyár melletti hegyoldalban pedig egy pincét építettek, ahol a petróleumot tartották.

1882 januárjában visszaállt a régi rend, és már működött két kemence, nemsokára a harmadik is beindult. Az igazgatóság dön- tése értelmében „minden időben legalább 60 olvasztó fazekat készenlétben kellett tartani" (Puskás 1882. 161.).

A palackozáshoz szükséges üvegeken kívül (hosszúkás zöld színű pintes üvegek) az ügyes kezű üveggyári munkások készítettek dísztárgyakat is: üveggyöngyöket, nyakláncokat, gyűrüket vagy más használati tárgyakat: virágvázát, cukortartót, sótartót, légyfogót stb. A borszéki üvegek színe világoszöld volt.

Vitos Mózes (1894) szerint „Borszéken Csíkmegye legnagyobb üveggyára van, az Európailag híres csehországi üvegrészeknél nem alábbvaló, sőt nagy része ennél jobb" - írja a Csíkmegyei Füzetek I. kötetében (240. old.).

Telkes Simon 1895-ben az Üvegiparunk. Ipari monográfia c. művében írja: „Gyergyó-Borszéken megkezdte múködését egy korszerünek tekinthető regenerátoros gázkemencével felszerelt öblösüveggyár. Speciális feladatköre volt: a borvízpalackozáshoz szükséges palackok gyártása. Évi 500 ezer darabot termeltek. 1884 után kétmillió egyliteres borvízpalackot készítettek."

De készítettek emlék- és fürdőpoharakat is. Ezek egy részén rajta van a település neve, esetenként évszám. Veres írja: „A borszéki fürdő aranyozással kombinált gravírozott látképével díszített egy magas talpból kinövő, ivelt oldalú és szájánál kiöblösödő testü rubinpácos pohár, amelyen a fürdőképpel átellenes oldalon képzett mezőben Borszéki Emlék felírat olvasható." (Veres 1989.)

1898-ban Erdélyben már csak négy üveghuta volt üzemben, köztük a borszéki. Ebben az időben az üveggyárban 86, a töltésnél 40 munkás, továbbá 3 munkafelügyelő és 3 kocsis dolgozott, felváltva, éjjel-nappal. Ezeken az állandó munkásokon kívül voltak napszámosok is, gyakorlatilag egész Borszék lakossága itt dolgozott. 14 tisztviselő volt állandó 
alkalmazásban, beleértve a papot, az orvost és a kertészt is.

Fekete Mór bérlő főjavítást végeztetett az üveggyárnál. Az újranyitásról tájékoztatott a korabeli sajtó. „A napokban kezdte meg müködését... Ünnepélyes istentisztelet és beszentelés után Fekete Mór társelnök és Sümegi Vilmos [országgyűlési képviselő] buzdító beszédet intézett. Az üveggyár készíti a híres borszéki és Erdély részi ásványvízhez szükséges több millióra menő üvegeket."

Hogy mekkora volt az itt gyártott üvegek űrtartalma, nem tudjuk pontosan. A korabeli dokumentumokban ilyen megnevezéseket találunk: „gömbélyeg borvíznek való kétkupás üveg”, „borvizes üres cilinder üveg”. Egy cilinderes üveg 4 krajcárt ért (Tarisznyás Márton). Használták a pint mértékegységet is, de ez is kétféle volt: magyar pint $=1,696$ liter és bécsi pint = 1,415 liter. Az üvegeket nagy ládákba rakták; ezek olyan nagyok voltak, hogy egy szekérre csak öt fért fel.

A borszéki üveggyár az első világháború előtt már üzemképtelenné vált. A Fekete Mórék Rt. bezáratta.

A későbbiekben a borszéki ásványvíz palackozásához szükséges üvegmennyiség egy részét (kb. 5 millió üveg) az ország különböző üveggyáraiból (Azuga, Medgyes, Dicsőszentmárton, Torda stb.) szerezték be.

\section{Üveggyári munkások}

A borszéki egyházközség anyakönyvei alapján sikerült összeírni az üveggyárnál dolgozókat. Sajnos a rendelkezésünkre álló dokumentumok csak keresztmetszetét adják az itt dolgozóknak. Áttanulmányoztuk a születési, halálozási és keresztelési anyakönyveket. A legtöbb esetben a nevek mellett feltüntették a foglalkozást is (üveggyári munkás, anyagvegyítő, üveggyártó, olvasztár, üvegcsűri olvasztó, vegyész, üvegfúvó kifeje- zésekkel találkozunk).

1805-ben veszi kezdetét az üveggyári mun-

kások letelepedése, írja Puskás Ferenc

Borszék története c. könyvében.

1835: Miller György üveggyári munkás, Vas

Mihály; (Gyergyóremetéről kaptak házhe-

lyet, írja Csiby Andor);

1879: ifj. Eigel Antal, Kolbert Ferenc, Schiller

János, Vild Ferenc;

1881: Dellarosa Antal, Ucseszánek Rudolf

anyagvegyítő, Molnár József, Vild Mihály;

1882: Straff Károly, Immermaier Károly, Siller

Péter, A(E)igel József, Vild Ferenc, id. A(E)igel Antal;

1883: Straff József, Fragell János vegyész;

1885: Plechinger János;

1886: Vild József; Krammer Ferenc üvegcsűri

olvasztó; Eigel Mihály, Straff Károly, Tiller

Károly, Kotczbacher Ferenc;

1889: Háring Ignácz üzemvezető, ifj. Wild Sándor;

1890: Vaszi Péter, Vaszi János, Vackon Antal,

Wild József;

1891: Schiller Pál, Straff Ferenc;

1892: Krammer Mihály, id. Vaszi János;

1893: Eigel Ferenc, Krammer Ferenc olvasz-

tár, Schneider Alajos;

1894: Id. Eigel Ferenc, ifj. Vaszi János, Straff István;

1895: Eigel András, ifj. Vakkon József, Kolbert Antal, Krammer István, Pechninger János, Ucseszánek József, Krammer Károly, Straff Károly;

1896: Krammer Ferenc, Straf József, Siklódi Imre szerelő, majd fő gyárvezető, Siller Frigyes gyári üvegessegéd, Cservenka Ferenc, Siller Károly;

1897: Fokt József, Eigel József, Eigel Károly, Sárpátki Mihály, Hauer Adolf, Eigel György, Kolbert József, Eigel Mihály, Schiller Ferenc tüzelő, Straff Sándor, Schiller Rudolf, Hartvig Ferenc al-gyárvezető, Kotczbakher 
Ferenc (37 éves), Schiller Károly;

1899: Vild Ferenc, Eigel Ferenc, Kolbert

Sándor, ifj. Váradi János;

1900: Fokt József, Ferencz József, Schiller Mihály;

1901: ifj. Eigel Károly, Czimbalmas István

főraktáros, Eigel György;

1902: Becze Péter, id. Vaszi János;

1903: Balázs Péter Miklós;

1904: Vild Gyula, Vild Sándor, Pallér István,

ifj. Eigel József;

1905: Vild András, Proff Vencel üveggyárvezető;

1910: Szalai Mór, Strul Farkas, Kozbacher

Ferenc (26 éves), Straff György, Kopacz

Ferenc üvegfúvó, Krammer Károly;

1911: Ilyés Ferenc, Siklódi József, Kolbert György;

1912: Starff Károly, Siller János, Vakkon József; 1913: Siller Ferenc;

1914: Krammer Ferenc üvegfúvó;

1919: Krammer Rudolf.

\section{A borszéki üvegek utóélete}

A palackozáshoz használt tárolóedények (palackok) a szállítás és használat során öszszetörtek. Sajnos a borszéki Borvíz Múzeum egyetlen példánnyal sem rendelkezik. Az egykori erdei hutából a paraszti igényeket is kielégítő használati és dísztárgyak is kikerültek. A megfáradt munkások pihenésképpen vagy szórakozásból családjuknak, rokonaiknak, barátaiknak készítették ezeket. A múzeum üvegtárgyai között találhatók borosüvegek dugóval, valamint pálinka és bor mérésére szolgáló mérőedények, továbbá kék pohár meg kiemelt díszítésű pohár, virágmintás, sőt gravírozott is.

A vegyes használati tárgyak közül kiemelem a légyfogót, a fedeles cukor- és sótartót. A légyfogó rendkívül szellemes készítmény, sokan megcsodálják. Színtelen, áttetsző, díszítés nélküli, szűk nyakkal, bő korongtesttel.
Az öblös rész alsó pereme visszahajló. Ebbe tették a cukros folyadékot, illetve a légyölő galócát (Amanita muscaria). A legyek az üvegtest alsó részén jutottak be. Onnan már nem volt visszaút.

Ezúton mondok köszönetet Soós Zoltánnak, a Maros Megyei Múzeum igazgatójának, hogy kölcsönadta a gyűjteményükben levő 15 népi üveget (ívó- és tárolóedények, vegyes használati tárgyak) (2-6. kép).

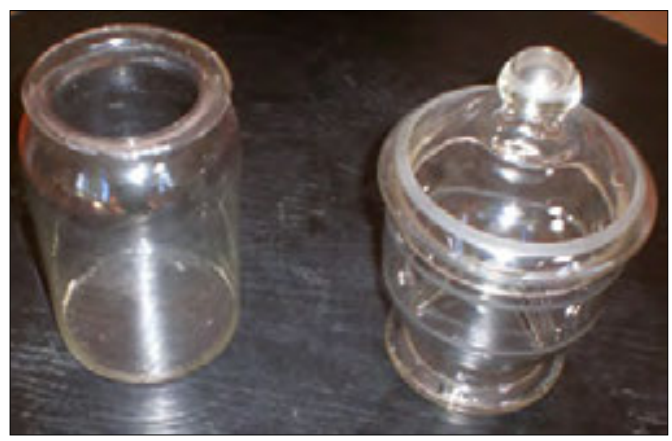

2. kép. Beföttesüveg és cukortartó

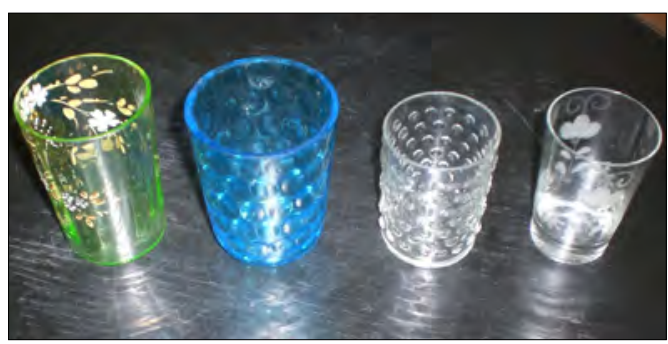

3. kép. Ívópoharak

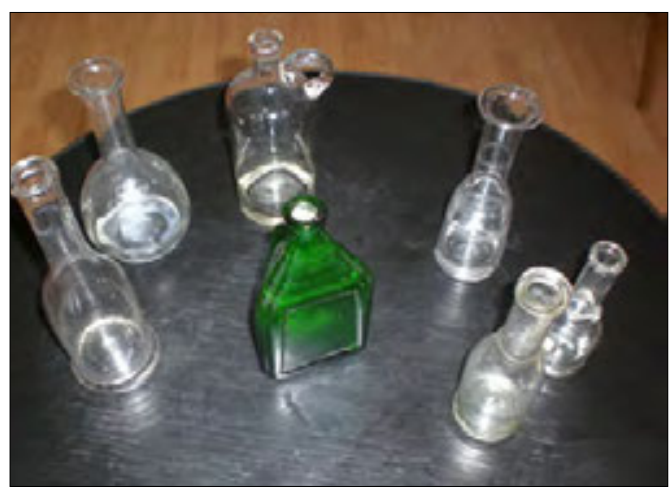

4. kép. Pálinkás- és borosedények 
Kamenitzky Antal borszéki lakos, a Borvíz Múzeum őre tulajdonában is van egy eredeti nagyméretű uborkásüveg és egy virágváza, amelyek szintén a borszéki üveghutában készültek (7. kép).

A Maros Megyei Múzeum kiállítótermében van egy 19. századi színes borszéki ivópohár. Hasonlóképpen a budapesti Iparművészeti Múzeum gyűjteményében is található egy ivópohár, valamint a Semmelweis Orvostörténeti Múzeumban berendezett Képek a gyógyítás múltjából. Fürdőügy Magyarországon
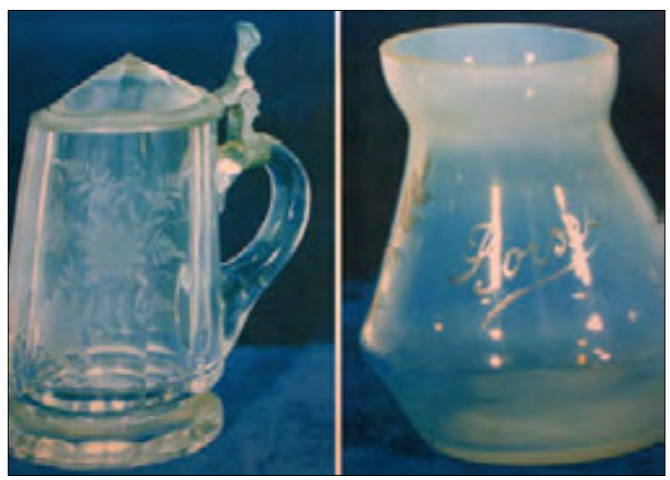

5. kép. Víztároló edények

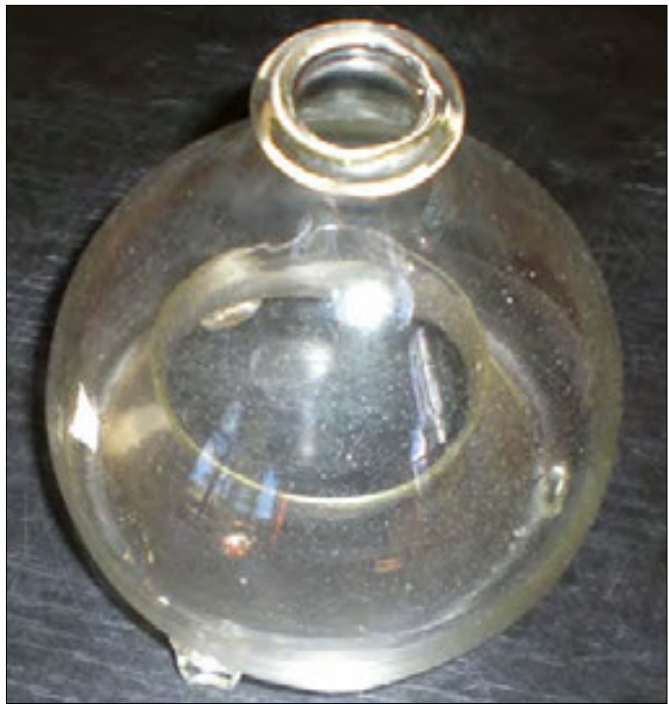

6. kép. Légyfogó kiállításon (IV. terem) látható két ivópohár (megtekinthetők a múzeum honlapján is).

A székelyföldi múzeumok a sok értékes tárgy között üvegtermékeket is tárolnak, esetenként kiállítanak. A Csíki Székely Múzeumban van egy 19. századi nagyon szép díszpohár és egy „rücskös” díszű kancsó, a sepsiszentgyörgyi Székely Nemzeti Múzeumban található egy 1898-ból való Bükszádi üvegcsűr ábrázolás. Bükszádon, az Iskolamúzeum is rengeteg tárgyat őriz az ottani üveghuta termékeiből.

\section{Az üveggyártás technikája}

Az üveg kovasav (kvarchomok) és alkáliák vegyülete. A kovasavat (kvarchomok) magas hőfokon megolvasztották (képlékennyé válik). Hamuzsír (szalakáli) hozzáadásával csökkentették a kvarc olvadáspontját. Más alkálifémek, amiket használhattak: szulfát, karbonát és nitrát (hozzáadásával csökkentették a kvarc olvadáspontját). Ezt a forró, folyó masszát fújták, formázták és mész segítségével szilárdították. A homok vastartal-

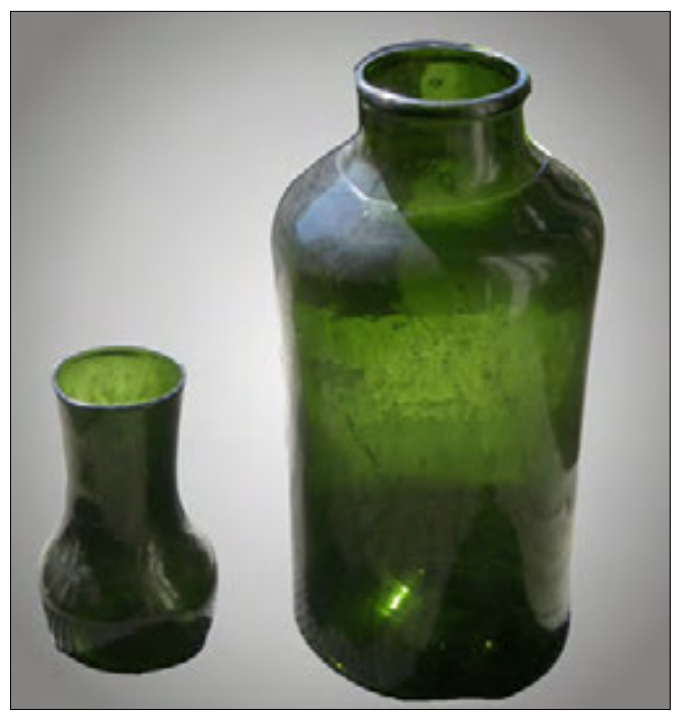

7. kép. Az üveggyár termékei 
ma adta meg az üveg szép zöldes „hutakék” színét. Minél tovább tartott az olvasztás, annál tisztább és hólyagmentesebb lett az üveg. Az üveggyártási folyamat több kemencét igényelt. Az elsőben összeolvasztották a nyersanyagot. A második kemencében forrón tartották, mert ebből dolgoztak az üvegfúvók. A harmadik kemence hütésre szolgált. Az üveg megszilárdulását a mész biztosította. A formázott tárgyakat itt hűtötték le.

Többféle technikát használtak:

1.Fúvás. Szíriában fejlődött ki. Az olvasztott üveg formázása levegő befújásával, fúvócső, ún. „pipa” segítségével történt. A fúvópipa kb. 1,75 m hosszú és 1,5 cm átmérőjű vascső. A kiszélesedő végével a forró üveget alakítják, a fával borított végét az üvegfúvó tartja. A kezdő üvegmennyiséget (banka) a fúvópipa segítségével kimerítik. Vaspálca segítségével leveszik a pipáról a fölösleges anyagot. A forró üvegcseppet vele viszik fel az üvegre, és készül a fül, nyak, szájperem stb.

2.Formákba fúvás. Egyiptomban alakult ki. A kezdő üvegbuborékot (hólyagot) formába fújják. Az üvegtárgy felveszi a forma alakját. Ezt a módszert használták a palackfúváshoz is. Más módszerek: préselés, formába öntés, formába olvasztás stb.

Díszítőtechnikák: csiszolás-gravírozás (vésés), maratás, homokfúvás, repesztés, melegen felcsavart (rátett) üvegfonalas díszítés. Az igények növekedésével újabb díszítőtechnikák jelentek meg: fémfóliás díszítés, üvegberakás, zománcfestés, aranyozás, lüszterezés (vékony, filmszerü, fémesen csillogó réteg).

Az üveg színezése többféleképpen történt:

1. az alkotórészek közé fém-oxidot kevertek,

2. a kolloidális állapotú anyagokkal való színezés,

3. a beágyazott színes anyagrészecskékkel történő színezés. Az üveg anyagát fém-oxi- dok hozzáadásával színezik. A vasvegyületek zöldre, a réz világoskékre és zöldes árnyalatúra, az urán sárgászöldre, a mangán a lilától a feketéig terjedő színárnyalatúra, a kobalt kékre, a nikkel szürkés-barnás színre, a szelén rózsaszínre színez.

Érdemes néhány szót ejtenünk a türelemüvegekről. A népművészet azon tárgyai, amelyeknél a fafaragványokat egy palack belsejében helyezik el. Hajókat, vallásos tárgyakat, bányászjelenteteket építenek be. Ilyen tárgyakat láthatunk Rudabányán is, a helyi Ércés Ásványbányászati Múzeumban, ahol Bics István restaurátor készítményei láthatók. Tanítómester Viktor Gyula; évente kb. 15 ilyen üveget készít.

\section{Jegyzetek}

1. Georg Kraus erdélyi szász krónikaíró Siebenbürgische Chronik című munkájában utal arra, hogy Bethlen Gábor 1619-1620ban a Velence melletti Muranóból üvegeseket hozatott Porumbákra, akik itt kristályt készítettek.

2. schock = mértékegység: öt tucat (60 darab).

3. bokály = karcsú, egyfülü, körte alakú edény (kancsóhoz hasonlít).

4. vekturázni = szállítás, hordás a latin vectura szóból.

\section{Felhasznált irodalom}

Agricola, Georgius: De Re Metallica Libri XII. A bányászatról és kohászatról. 1556. Magyar kiad. Budapest, 1985.

Benke István - Peter Huber: Palackba zárt bányászat. Magyarországi bányász türelemüvegek, Zalaegerszeg, 2006.

Benkő Aurora: Monografia Glăjăriei. Casa de Editură „Mureș”, Tg-Mureș, 2010

Boner, Charles: Transylvania, its Products and People. London, 1865.

Bunta Magda - Katona Imre: Az erdélyi üvegmüvesség a századfordulóig. Kriterion Könyvkiadó, Bukarest, 1983. 
Cserei Zoltán: Üveggyártás Háromszéken a 17-20. században. In: Industria et societas. Manufaktúrák Magyarországon. Szerk. Németh Györgyi, Miskolc, 1994.

Csiffáry Gergely: Magyarország üvegipara 1920-ig. Heves Megyei Múzeumi Igazgatóság, Eger, 2006.

Erdély rövid története. (Főszerk. Köpeczi Béla) Akadémiai Kiadó, Budapest, 1993.

Farkas Aladár: A borszéki ásványvíz-palackozás 200 éves története. Státus Kiadó, Csíkszereda, 2006.

Farkas Aladár: A borszéki üveggyár. Bányászattörténeti Közlemények XIV. Rudabánya, 2012.

Gálfalvi György: Szülöföldön, világszélen.Kriterion Könyvkiadó, Bukarest, 1974.

Hankó Vilmos, dr.: Székelyföld. Budapest, 1896.

Kozma Ferenc: A Székelyföld közgazdasági és közművelődési állapota. Budapest, 1879.

Kőváry László: Erdélyország statistikája. Kolozsvár, 1847.

Kőváry László: Tájképek utazási rajzokban (1837). Kriterion Könyvkiadó, Bukarest, 1984.

Kőváry László: Székelyhonról. Kolozsvár, 1842.

Miklós József: Nyelves Világ. Nyelvi ábrándozások Európában. Csíkszereda, ProPOS Könyvkiadó, 2005.

Oláh-Gál Elvira beszélgetése gr. Kálnoky Tiborral. Székelyföld 2011/május.
Orbán Balázs: A Székelyföld leírása történel$m i$, régészeti, természetrajzi $s$ népismei szempontból. 1868-1873. Reprint kiadása két kötetben. Babits Kiadó, Szekszárd, 2002.

Puskás Ferenc: Borszék története hiteles adatok alapján. Budapest, 1882.

Ruppert Ferencné: Az üveg története.Nemzeti Szakképzési és Felnőttképzési Intézet, Budapest, 2008.

Sághelyi Lajos: A magyar üvegesipar története. Budapest, 1938.

Scheint, Daniel: Das Land und Folk der Szekler in Siebenbürgen... Pest, 1833. Magyar fordítása Boér Laura munkája, Acta Siculia, 2007.

Szentiváni Mihály: Gyaloglat Erdélyben (1837). Európa Könyvkiadó, Budapest, 1986.

Telkes Simon: Üvegiparunk. Ipari monográfia. Budapest, 1895.

Váradi Péter-Pál - Gaál Anikó - Zsigmond Enikő - Lőwey Lilla: Erdély - Székelyföld Sepsiszentgyörgy és vidéke. 1994.

Veres László: Magyar népi üvegek. Herman Ottó Múzeum, Miskolc, 1989. (Internetes változata: www.hermuz.hu.)

www.gyergyoditro.ro/turizmus/a telepules tortenete

www.erdelykincsei.com/sepsiszentgyorgy-es-videke-terkepvízlat-tortenelmi hatterrel-harmadik resz-2011.09.17 


\section{Xateshedelemungy}

$a \mathrm{x}$.

UI I IS T E R.

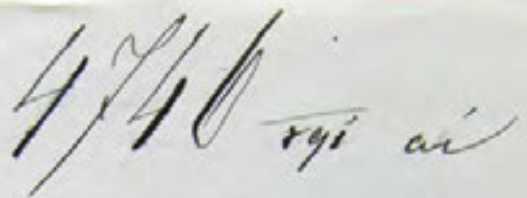

$320,09 / 2$.

(1) 10 sion

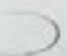

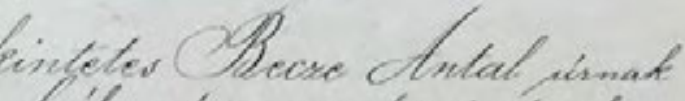

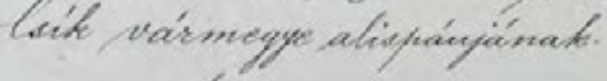

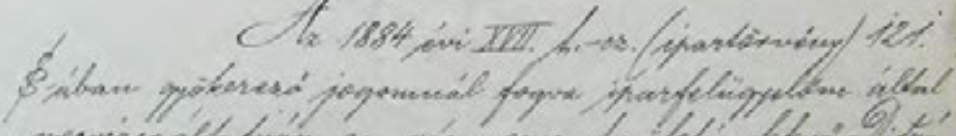

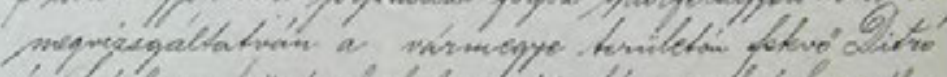

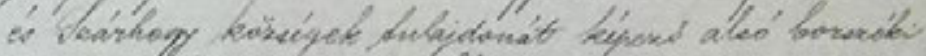

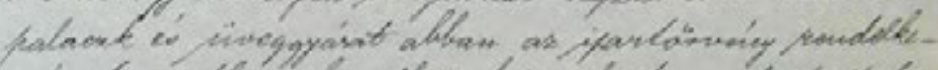

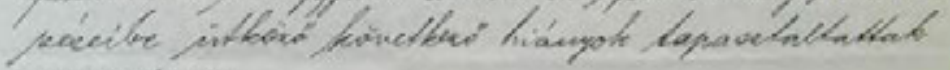
reverestaces:

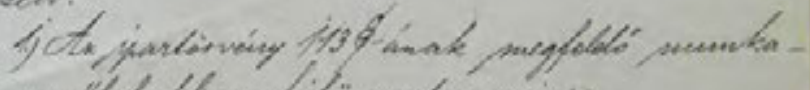

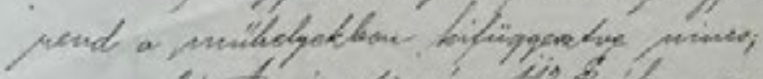

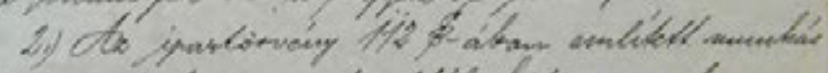

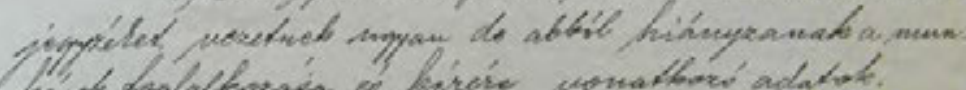

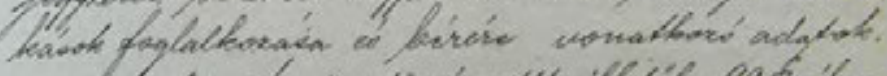

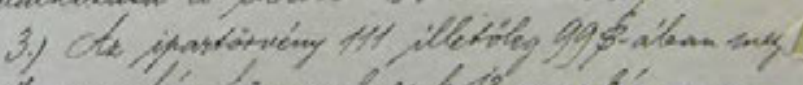

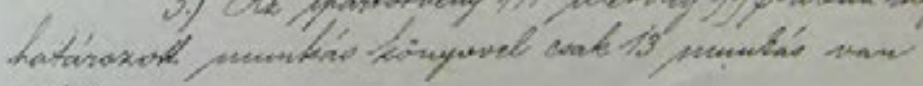
clatsa.

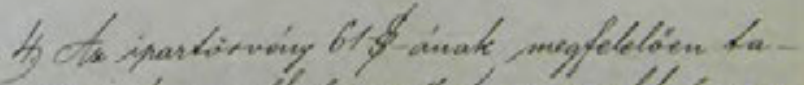

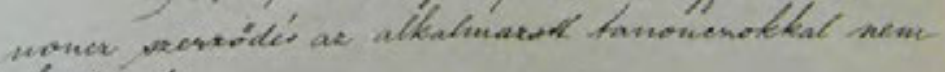
LWheKR.

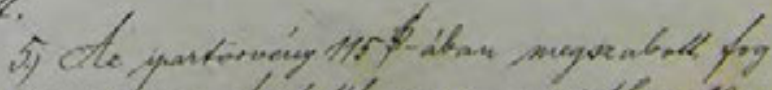

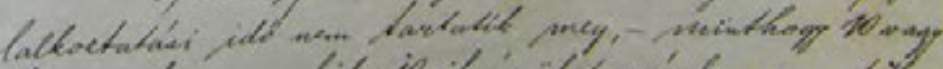

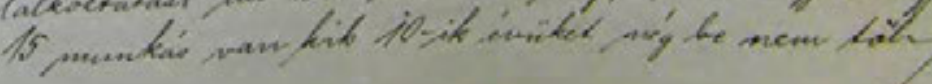




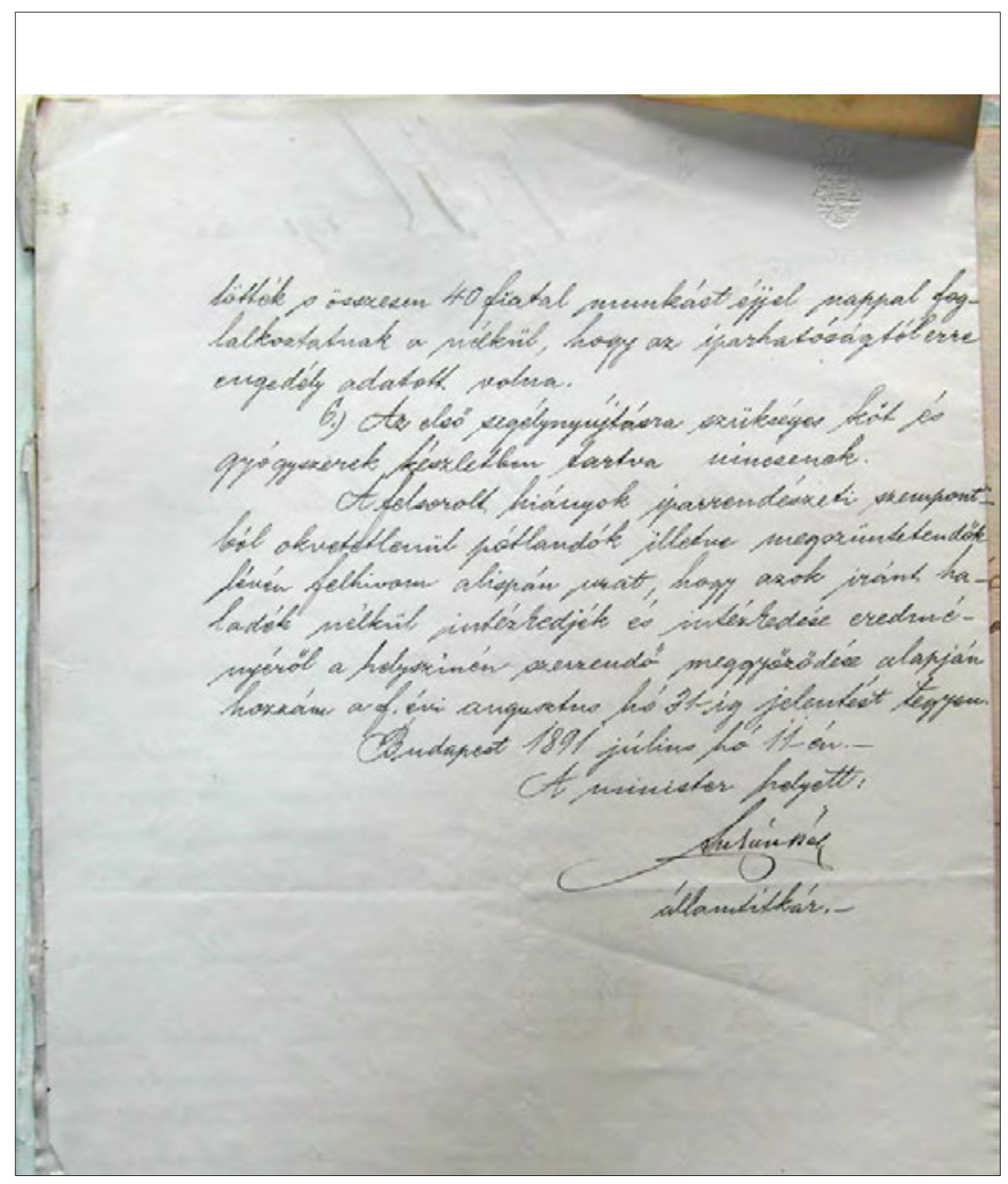

9. kép. Munkavédelmi ellenörzés észrevételei 1891-ből (verso) 


\section{MELLÉKLET}

\section{RÖVID TÖRTÉNETI ÖSSZEFOGLALÓ}

Az üveg első előfordulási helye Mezopotámia, kb. i. e. 3500-3000-től. Ásatások során üveggyöngyök és más üvegmaradványok kerültek felszínre.

$\mathrm{Az}$ i. e. 16. századból származó asszír agyagtáblák az üveggyártás nyersanyagait ismertetik. A 7. századi ninivei táblák már részletes „üvegtechnológiai” felvilágosításokat tartalmaznak.

Egyiptomban i. e. 1475-1450 körül megkezdték az üveg előállítását. Ismerték a formába öntés és a préselés technikáját. Jellegzetes tárgyaik: toalett- és illatszerek, olaj tárolására alkalmas edénytípusok, illetve a bor és más folyadékok tárolására alkalmas kétfülű edények (amfora). A formák a görög kerámiatárgyakat utánozták.

Szíriában i. e. 1500 körül készítettek üveget, amit a föníciai kereskedők értékesítettek egyre szélesebb körben.

Cipruson és Rhodoszon az i. e. 7. és 6. században kezdtek üveget gyártani. Az 5. századtól az Adriai-tenger mentén több helyen alakultak ki üvegelőállító központok.

Az alexandriai üvegközpontok i. e. 332-ben alakultak ki, míg az itáliai üveggyártás i. e. 100-ban indult meg.

Ebben az időben mát ismertek több üvegmegmunkáló technikát: a homokmag körüli formálást, a mozaiküveg, az öntés, csiszolás (köszörülés) csínját-bínját.
A korai időszak üvegei színesek, gyakran átlátszatlanok (opak). Egyre elterjedtebbek a római és szíriai üvegek (ivóserlegek, tárolóedények, palackok és flaskák, tábla- és tükörüvegek). Rómában és Alexandriában készítettek díszüveget is, amelyet csiszoltak, gravíroztak (véstek).

Az iszlám üveg az 661-675 közötti időszakban terjedt el. Zománcfestéssel és aranyozással díszített üvegek voltak (mecsetlámpák, rózsavízhintők, díszcsészék).

Kínában az 5. századtól beszélhetünk önálló üvegművességről. Nehezen hódított teret, hiszen itt elsődleges a kerámia volt.

A Római Birodalom bukása Európában az üvegművesség átmeneti megszűnését jelentette. Csak üvegablak-készítés és az üvegfestmény gyártása folyt.

Caius Plinius Secundus (23?-79) Naturalis Historia című enciklopédiájában (i. sz. 77) azt írja, hogy már a föníciaiak ismerték az üveggyártás titkát.

Veres László is azon a véleményen van, hogy „az ember több mint öt évezrede ismeri és használja az üveget”.

A velencei üveggyártás 450 körül terjedt el, Angliában 1240 körül, Spanyolországban, 1300-ban, míg Franciaországban a 14-15. században.

A középkorban német és cseh földön is teret hódít az üveggyártás. 


\section{A VILLAMOS ENERGIA HASZNOSÍTÁSÁNAK KEZDETEI}

\section{FEJEZETEK CSÍKSZEREDA VILLAMOSÍTÁSÁNAK TÖRTÉNETÉBŐL}

„1911. február 11-ike jelentös dátum Csíkszereda kultúrtörténetében, mert e napon adatott át a Ganz-féle városi villamosmú rendeltetésének. $A$ város közönsége jóleső örömmel gyönyörködött a Budapestre beilló fényárban, mely az egész várost elborította" - így üdvözölte a villanyfényt 1911 februárjában a Csíki Lapok újságírója, aki gyors összehasonlítást is tett más székelyföldi városokkal, megjegyezve, hogy „A leghatározottabban állíthatjuk, hogy a szomszéd Sepsiszentgyörgy, Székelyudvarhely és Gyergyószentmiklós városok villanyvilágítását túlszárnyaltuk, mi fóleg abban leli magyarázatát, hogy a villanyoszlopok az utcákon alig 30-35 méternyi távolságra nem 16-20-as, hanem 40-es körtékkel vannak ellátva mi pazar világításnak mondható." (Villanyvilágítás 1911. 2.) Nem volt véletlen a korabeli újságíró megjegyzése, így próbálta „menteni a mundér becsületét”, vagyis azt a tényt, hogy Csíkszereda jócskán lemaradt a villamosítási sorban, hiszen az akkor még nagyközségnek számító Gyergyószentmiklós nyolc évvel, Székelyudvarhely pedig három évvel előzte meg.

Jelen írásban elsősorban a korabeli sajtó és néhány levéltári dokumentum alapján foglaltuk össze Csíkszereda villamosításának első évtizedeit, emellett felhasználtunk adatokat Vofkori Györgynek a csíkszeredai villany- telepre vonatkozó írásából (Vofkori György 2007. 270-274.), de a kutatás korántsem teljes.

\section{A kezdetek}

Tivai Nagy Imre (1849-1931) jeles csíkszeredai közíró leírásából tudjuk, hogy tűz világánál, faggyú- vagy szurokmécses mellett, előkelőbb helyeken faggyúgyertya fényénél időztek, kézimunkáztak sötétedés után eleink, amíg 1870 körül Csíkban is megjelent a petróleumvilágítás. Volt időszak, amikor Csíkszeredában „petróleumlámpával világítottak az utcán is. Oszlopok voltak felállítva, amelyeknek tetején egy üvegfalú bádog doboz-szekrényke volt, benne a lámpa. Panni János városi alkalmazott minden reggel egy kis lajtorján felment sorban minden oszlop$r a$, levette a lámpát, megtörölgette az üveget, petróleumot töltött a lámpába és visszatette. Estefelé újra bejárta a várost, felment létrán a lámpafára, és kénköves gyufával, amelyet a harisnya fenekén gyújtott meg, meggyújtotta a lámpát." (Gál József 1970).

Ez viszont nem jelenti azt, hogy 1911 előtt Csíkszeredában meg sem fordult villanyszerelő, vagy nem hallottak a villamosságról. Az egyik első ajánlatot a város utcáinak és nyilvános tereinek villamos világítására 1897ben nyújtotta be Csíkszereda tanácsához egy vállalkozó (Villamos világitás Csik-Szeredában 1897.). Ugyancsak ő tett ajánlatot 
„Az esténként végzett munka tűzvilágnál, faggyú vagy szurok mécses mellett, avagy igen előkelő helyen faggyúgyertya világánál folyt, mert a petróleum világítás csak a hatvanas évek végén, inkább a hetvenes évek elején jött használatba. A lábakon álló csempés alatt a hasábfák szabad tűzön égtek, mely elég világosságot árasztott a tűzhely előtt folyó apró munkákra. Még a varrottasok is ezen világítás mellett készültek, miközben a góc lábánál avagy a sód mellett ülő egyik családtag állandóan el volt foglalva a tűz szításával. A cserépfáján vagy csempés oldalán álló, vékonyra hasogatott hosszú fenyőfa szálkák pipagyújtásra, vagy a szoba valamely zugában, a kamarában vagy pincében való keresgélés céljára gyújtattak és mindég készen állottak. Ugyanezen célt szolgálta a szurok-mécses, mely egy törött fazékba állított és beszurkozott csepűmadzagból állott s meggyújtott vége nagy lánggal és még nagyobb büdös füsttel égett. A gyertyaöntő bádog forma minden háznál készen állott, melyben vendéglátás alkalmával a gyűjtögetett juh- vagy marha faggyúból két-három szál gyertyát öntöttek. Ez volt a legelőkelőbb világítás. Stearin- vagy paraffingyertya csak a templomi luszterekben égett. A faggyúgyertya nélkülözhetetlen társa volt a koppantó, mellyel a gyakran megnőtt gyertyahamvat kellett levágni. Az ezzel való ügyes bánás majdnem az etikette szabályait igényelte, miért a házi férjhezadandó leány mindig reszkető kézzel nyúlt a koppantóhoz. A gyertya hamvához kézzel nyúlni a legilletlenebb cselekedet számba ment. Hogy milyen volt a koppantó, azt meg lehet látni majdan a csíkmegyei múzeumban, mert leírni bajos; Iegfennebb annyit jegyzek fel róla, hogy előkelő úri házaknál ezüstből volt és hosszúkás, kis ezüst tálcán állott, a több ágú ezüst gyertyatartó mellett." (Tivai Nagy Imre 1996. 73-74.) a „magánosok” részére a villany házakba és szobákba való bevezetésére. Ugyanebben az évben Herczka Gyula is ajánlotta szolgáltatásait (Herczka Gyula 1897.). Az ő neve azért érdekes, mert később Csíkszeredában telepedett le, és minden valószínűség szerint neki volt Csíkszeredában az első elektrotechnikai és műszaki szaküzlete, amely már jóval a villanyvilágítás bevezetése előtt működött: a korabeli sajtó híradásai szerint 1900-ban nyitotta meg (Elektrotechnikai és müszaki üzlet 1900), reklámjaival pedig több mint egy évtizedig találkozhatunk a lapok hasábjain (Herczka Gyula 1909). Szintén Herczka Gyulához kötődik egy különleges találmány is, a rádiumvilágítás, amelyről 1908-ban azt írta az újság, hogy „a budapesti m. kir. József müegyetem által engedélyeztetett, szabadalmaztatott és törvényileg védve lett” és „az összes eddigi világításokat végleg ki fogja szoritani” (Új világitás 1908).

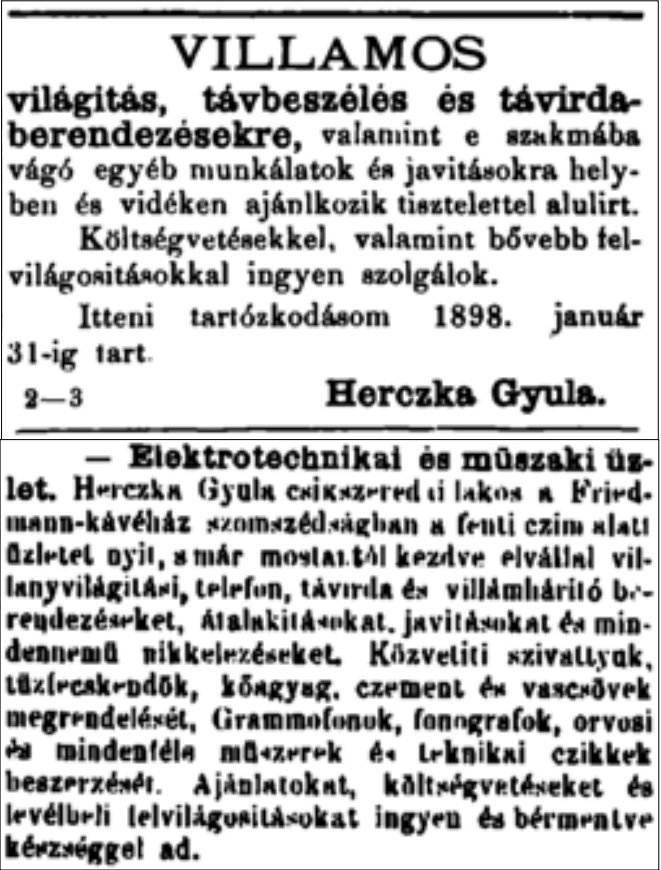

1. kép. Herczka Gyula reklámai 
1901-ben arról olvashatunk, hogy közelebbről Gyergyószentmiklóson lesz villanyvilágítás, Csík vármegyében elsőként (Villamos világitás 1901).

„Villámos világítás Csik-Szeredában. Alig hogy megindult nálunk a vasut, a modern technikának már is egy másik vivmánya is kopogtat ajtóinkon. Ugy tudjuk, hogy a városhoz ajánlat tétetett a város utczáinak, nyilvános tereinek villamos világitására és a munkaátviteli villamos vezetésre szolgáló sodronyok lerakására. Az utczai közvilágitás egyelőre 16 gyertyafényü izzólámpával eszközöltetnék egy meghatározandó átalány összegért, mig a magánosok a házakba és szobákba való bevezetés esetén egy16 gyertyafényü izzólámpáért óránkint 2 krt, 10 gyertyafényüért 1,32 krt és 5 gyertyafényüért 0,66 krt vagyis fél krajczárt fizetnének. Ezenkivül azonban a magánosok a fogyasztás mérvéhez képest engedményben is részesülnének, nevezetesen az összes berendezett lámpáknak évi 600 órán át való üzembe vétele esetén $5 \%$-ot. 1000 óránál $10 \%$-ot, 2000 óránál $20 \%$-ot és 3000 óránál $30 \%$-ot. Az ajánlat szerint a városnak jogában áll a villamvilágitási üzemet 25 év múlva becsáron, 30 év múlva becsáron alól $5 \%$ engedménynyel, 40 év múlva becsáron alól $15 \%$ engedménynyel, 50 év mulva becsáron alól 30\% engedménynyel mindenkor 2 évi felmondás kikötése mellett megváltani. Az érték meghatározásánál az anyagok értéke mintegy üzemben levő telep alkatrésze fog megbecsültetni. 70 év lejártával az egész áramfejlesztő telep az összes nyilvános vezetékkel és egyéb tartozékkal együtt ingyen fog a város tulajdonába bocsáttatni. Ezek szerint az első lépés, az ajánlat meg van téve, most jön a második lépés, a tanulmányozás." (Csíki lapok, 1897. április 21.)
„Villamos világitás. Csikmegyében is lesz már közelebbről villamos világítás. Az itteni viszonyokkal nem ismerős emberek bizonyára azt hiszik, hogy ezen czélszerü ujitást Csíkszeredában, a vármegye központján fogják létesíteni. Pedig, de hogy; ilyen kérdésekkel Csíkszeredában nem igen foglalkoznak, hanem igen is Gyergyó-Szentmiklóson, melynek életre való elöljárósága igyekszik haladni, a korral s nem zárkózik el még a nagyobb anyagi áldozatoktól sem, ha olyan dolgot kell létesíteni, mely ugy a községnek, mint a község polgárainak elönyére válik. Gyergyó-Szentmiklósnak már a közel jövőben villamos világitása lesz; erre mutat az, hogy az előmunkálatokat vezető Márk Etele a mult héten megkészítette a villamos világítás hálózatának térképét." (Csíki lapok, 1901. október 9.)

1902-ben báró Bánffy János folyamadott engedélyért villanyfejlesztő telep létesítésért a Maroson.

1904-ben szinte irigykedve ír a Csíki Lapok arról, hogy míg Csíkszeredában az utcai lámpákat sem gyújtják meg éjszakára, addig Székelyudvarhely képviselőtestülete már a villany bevezetéséről tárgyal. „Boldog város, hol éjjel is nappali fényesség lesz, bár nekünk állandóan egy pislákoló mécses jutna!" (Villámvilágitás és egyiptomi sötétség 1904)

1904-ben Keller J. budapesti vállalkozó intézett felhívást a lakossághoz az aerogéngáz-világítás bevezetése ügyében - ezt a világítási megoldást rendelte meg a vármegye az akkor épülő Vigadó részére is (Csíkszereda világitása 1904). Az elképzelés vitát kavart, a lapokban érvek és ellenérvek ütköztek: míg a Csíkszereda címú lap az aerogéngáz-világítást támogatta (Csíkszereda világitása 1904), addig kezdetben a Csíki Lapok úgy vélte, hogy 
„Ha már munkát végzünk, végezzünk egész munkát s várjunk jobb napokra. Kis városok is a villámra rendezkednek be s azt hisszük, az Olt vizi erejének s esetleg egy uj ipari telepnek a felállitása módot nyujthat, már a közelben a kérdés végleges és szerencsés megoldására." (Haladunk 1904) Később a Csíki Lapok is egy átmeneti időszakra elfogadhatónak tartotta volna az aerogén világítás bevezetését (Aerogén-gázvilágitás 1904).

A csíkszeredai villany ügye a továbbiakban is számtalanszor napirenden szerepelt, mígnem 1909. április 14-én úgy tűnt, hogy dr. Ujfalusi Jenő polgármester megvalósíthatja a „nagy reformot”, és a város kiírja a pályázatot a villanyvilágítás bevezetésére (Villanyvilágitás városunkban 1909). Ám a konkrét megvalósítás is számos akadályba ütközött, és további két évre volt szükség, hogy valóban kigyúljon a fény.
„Villanyvilágitás városunkban. Városunk agilis polgármestere nagy reformot valósit meg. Évek óta fáradozik, hogy a meg nem felelő világitást villanynyal cserélje fel. Őszintén szólva kétkedve néztünk fáradozásai elé, ismerve városunk szerény anyagi viszonyait. Amint azonban most értesülünk, az eszme testet ölt s már a közel jövőben megvalósulást nyer. A pályázatot közelebbről kihirdetik, mert a szükséges előfeltételek már biztosítva vannak." (Csíki Lapok, 1909. ápr. 14.)

\section{A megvalósítás}

„A várva várt villanyvilágítás teljesen a bizonytalanság kátyújába jutott" - írta a Csíki Lapokban 1911 januárjában „egy városi polgár”. „Legjobb értesüléseink szerint a Ganz-féle társaság építési vezetősége összes munkálataival egészen készen van és a villanykörték akár ma is kigyúlhatnának, ha a posta továbbra is nem kísérletezne. Arról van ugyanis szó,

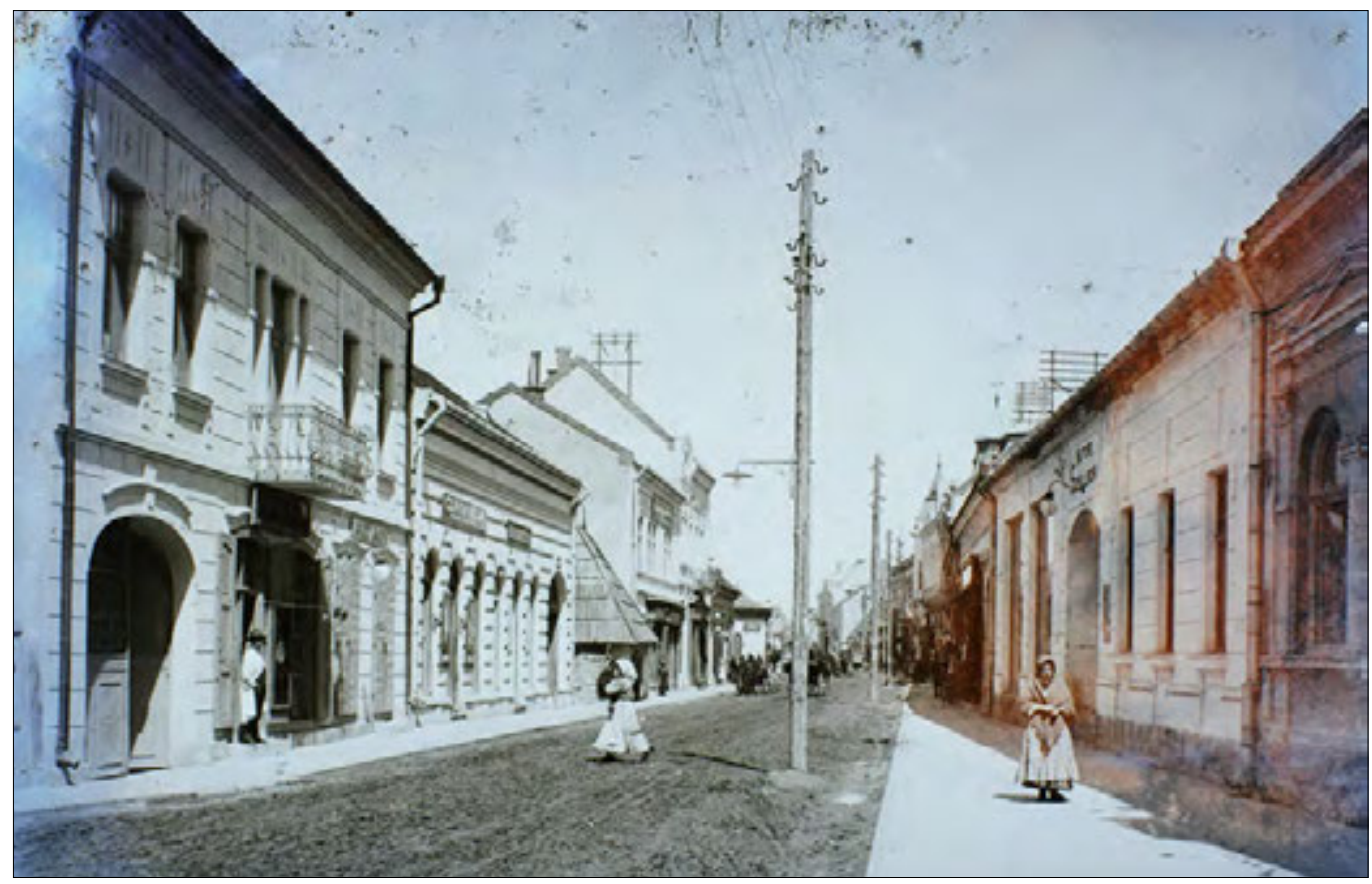

2. kép. Csíkszereda az 1910-es években (fortepan.hu) 
hogy a telefon kábelét Pototzky Pál és Nagy Gyula üzlete közé, az úttest alá behelyezzék és a vezetéket megfelelőleg áttegyék. A munkálatokkal Halász mérnök van megbízva, érthetetlen okból azonban a munkálatok oly lassan és nagy pausákkal haladnak, hogy kilátás van arra, miszerint azok még egy jó hónapig is eltartanak." (Villanyvilágitásunk 1911) Végül is a borúlátó polgárnak nem lett igaza: 1911. február 11-én mégis kigyúlt a villany Csíkszeredában. „Vasárnap már a magánlakásokban is a villany szórta a fényt, mely itt ép oly kifogástalan jó, mint az utcákon. Értesülésünk szerint eddig 2400 láng városunkban, de ez a szám rohamosan fog emelkedni, most igen sokan azt tartották, hogy előbb »lássuk a medvét«. Most mindenki megygyőződött a villany előnyeirôl és jóságáról, épen ezért kevesen lesznek, kik annak bevezetése elöl elzárkóznak. A villamosmü a Ganz cég szolidságát és megbízhatóságát dicséri." (Villanyvilágitás 1911)
A budapesti Ganz-féle villamossági Rt. 1910-ben építette fel Csíkszeredában áramfejlesztő telepét, és átadáskor két darab 40 lóerős dízelmotorral rendelkezett, generátorokkal együtt. A telep 3100 volt, 42 periódusú háromfázisú váltakozó áramot termelt.

Az első csíkszeredai villanytelep egyik áramfejlesztője az 1990-es években még Csíkszentkirályon, a malomban megtalálható volt, de nem múködött. Ma már nincs meg leadták ócskavasba.

A csíkszeredai elektromos művek első igazgatója a körmendi születésű Hodossy Kálmán (1882-?) volt, aki Pápán, majd Budapesten szerzett oklevelet, és Németországban, Gödöllőn és Gyöngyösön végzett szakmai gyakorlatot (Dávid József 1941). Hodossy Kálmán - megszakításokkal - évtizedekig vezette a vállalatot.

1913 elején megállapodás született az államvasutak igazgatósága és a város között a vasútállomás villanyvilágításáról. „A villany

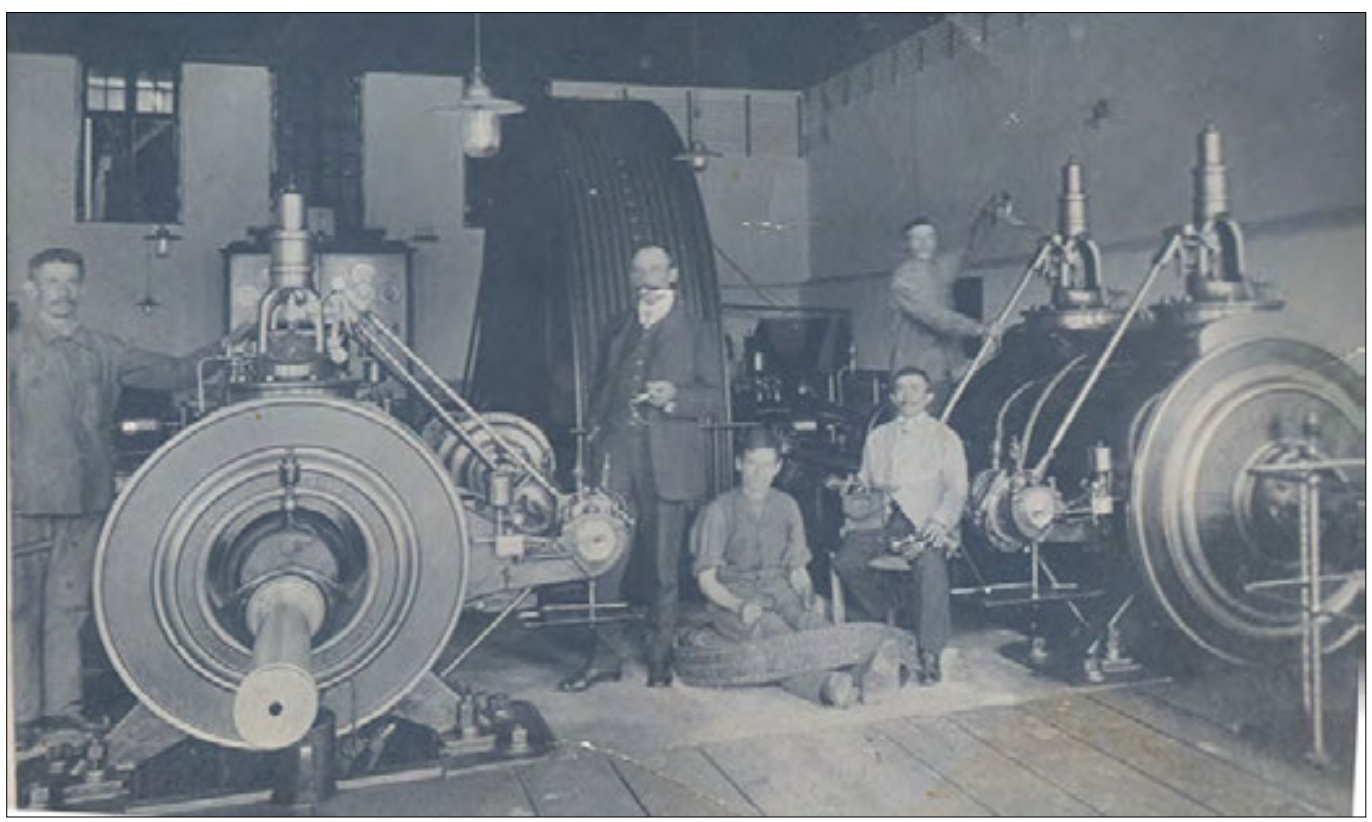

3. kép. A csíkszeredai villanyüzem (a fotó a Csíki Székely Múzeum tulajdona) 


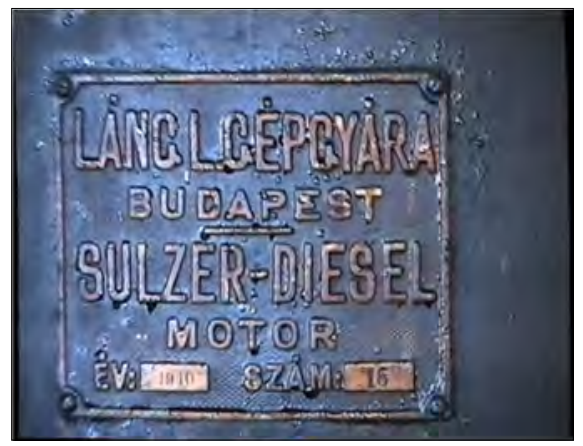

4. kép. A csíkszeredai villanytelep egyik első áramfejlesztőjének felirata (Daczó Katalin felvétele)

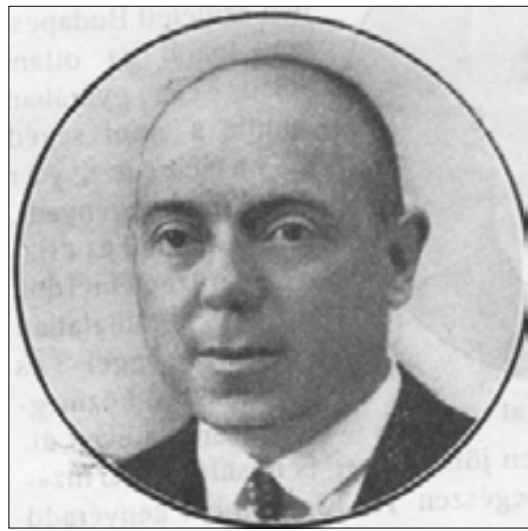

5. kép. Hodossy Kálmán, az első igazgató (Az 50 éves Ipartestület 1934)

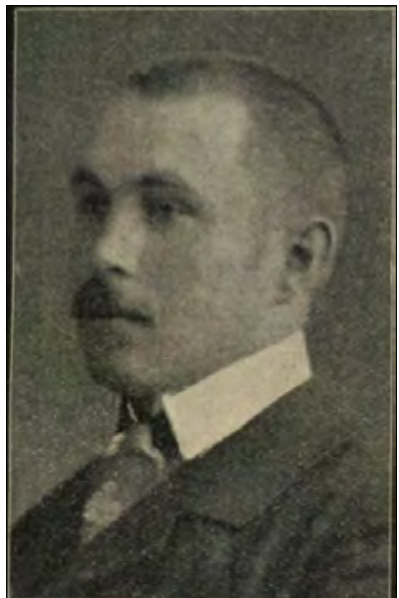

6. kép. Ujfalusi Jenő polgármester - akit dicsértek és kritizáltak a villany miatt az összes helyiségekbe bevezettetik, a pályaudvart pedig 8 darab ezer gyertyafényü Wolfram lámpa fogja megvilágitani" - adta hírül a Csíki Lapok. (A vasuti állomás villanyvilágitása 1913)

„Villanyvilágitás van-e, avagy faggyugyertyát égetünk?”- tette fel a kérdést ismét „egy polgár" 1913 júliusában (Villanyvilágításunk mizériái 1913). „Vagy van villany, vagy nincs?” - kérdezte „egy polgártárs” azok közül, akik röpke két év alatt hozzászoktak az elektromos áram áldásaihoz, de az áramszolgáltatás akad ozott, mert a két áramfejlesztő nem bírta a megterhelést, annak ellenére, hogy csak éjszaka volt áram. Éppen ezért 1913 szeptemberétől egy harmadik gépet is üzembe helyeztek, így már három darab dizelmotor szolgáltatta a villanyáramot 200 lóerő, illetve 136 kilovoltamper összteljesítménnyel (Vécsey Gyula 1938). Ettől a beruházástól remélték, hogy lehetővé válik a nappali áramszolgáltatása is 1914. augusztus 1-től (Villanyvilágítás Zsögödön 1914). „Sajnos azonban e feltétlenül jó hírrel szemben fel kell hívnunk Ujfalusi Jenő polgármester ur figyelmét azon általános és mindennapos panaszra, hogy az áram ereje annyira meggyöngült, miszerint kétszer oly erôs világítás sem éri el a fénynek eredeti erejét. Ezen segíteni kell, még pedig gyorsan és gyökeresen, mert ellenkezö esetben a villanymizeriákra irányuló panaszoknak állandó rovatot kell nyitnunk." (Nappali villamos áram 1913)

\section{Háborús idők}

Az első világháború idején gyakran esett szó a lapok hasábjain az elektromos áramszolgáltatás akadozásáról és drágulásáról. Az akkori állapotokról az egyik cikkből érzékletes képet kaphatunk. „Nagypénteken este megint megfenyegetett a sötétség. A lakásokban felgyúlt a villany este félhétkor és el- 
aludt 10 kor, az utcán egy percig sem gyúlt fel s elterjedt a vészhir, hogy ezután sötétben maradunk, mert elfogyott a benzin. - Nem azért említjük ezt, mintha olyan nagy veszedelmet látnánk abban, ha egy emberi alkotás egyegy pillanatig felmondja a szolgálatot, se nem azért, mintha a mi eredeti nagy sötétségünket kizárólag villannyal vélnók eloszlatni, hanem egyszerüen annak konstatálására, hogy a mi villanyunk nem egy mucsai nyegócás üzlet, hol a szappan, gyertya és bors árát azonnal felemeli, vagy az árulást rögtön beszünteti a mucsai boltos, ha a lova megsántul s az uj szállítmányt nem tudja e miatt a vasútról elhozni. Nálunk egy nagy világcég firmája alatt szolgáltatják a villanyt s el akarják velünk hitetni, hogy ennek a nagy cégnek a háború miatt épen csak Csíkszeredában fogy el a benzine $s$ ezen cimen nagy parlamentirozások után felemelik a villany árát 40\%-kal, sôt hogy ezt a fogást indokolják, néha sötétséget is rendeznek. Hát a mi boldog tudatlanságunk és hozza nem értésünk lehet világhírü, de azt az egyet még sem lehet nálunk mindenkivel elhitetni, hogy egy nagy világcég üzleti konjunkturái épen a csíkszeredai vállalat esélyei miatt forognának kockán, mert a Ganz cégnek minden órában módjában áll a csíkszeredai villanyvilágításhoz szükséges benzint a legkisebb lájbi zsebéből hozzánk liferálni. A 40\%-os árfelemelés indokául pedig ne akarják elhitetni velünk, hogy a nagy világcég a világításhoz szükséges benzint Szereda számára naponkint, vagy épen litrenként és a háború esélyei szerint szerezgeti be s annak konkurrens ára szerint kell a villany árát hol felemelni, hol leszállítani. Ez a feltevés szégyent vetne a nagy cégre, mely nem a mucsai boltos, s a mellett nagyban dehonesztálja azt a percentes hasznot, melyet a városi közjövedelmek között olyan nagy féltékenységgel szoktak védelmezni." (Megint a villany 1915)

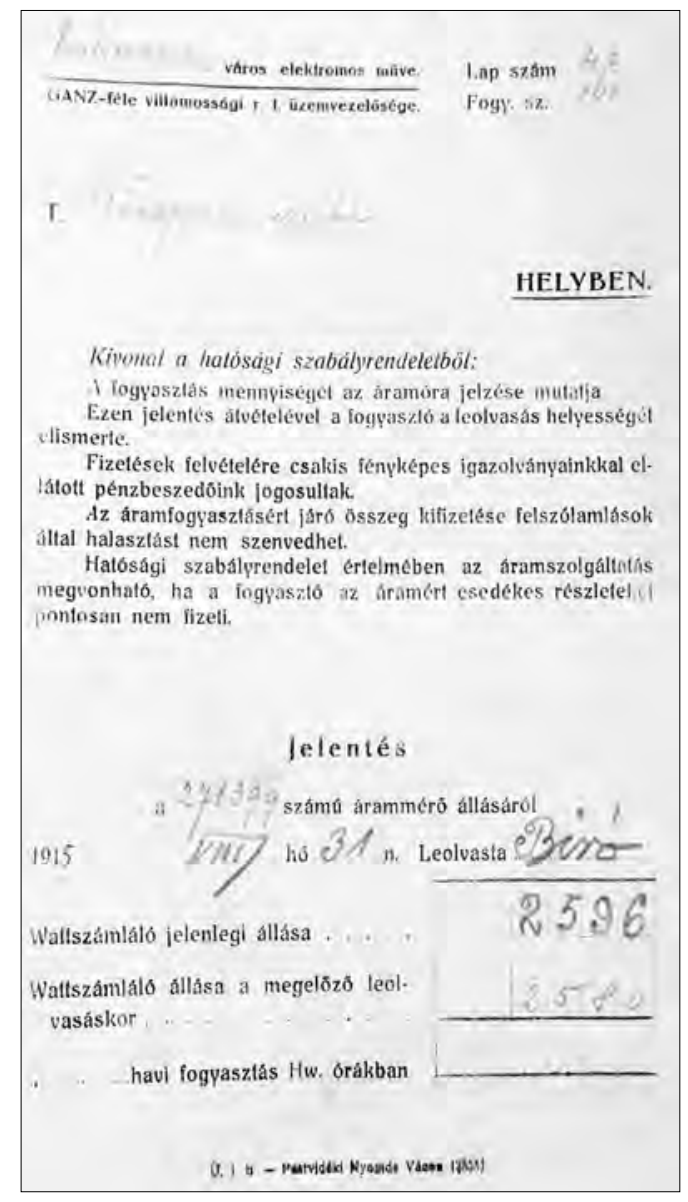

7. kép. Jelentés a főispáni iroda árammérőjének állásáról

A háború vége felé, 1918-ban minden fogyasztót villanyóra vásárlására köteleztek, ugyanis 49 órás fogyasztón kívül a korábban létező 338 átalányfogyasztó igen nagy égőket kezdett használni, és rendkívül megnövekedett a terhelés. Ezért „át kellett térni az órával való fogyasztás-mérésre és kényszeríteni kellett a fogyasztó közönséget óra vételre és ezáltal automatikusan a fogyasztás csökkenés állott elő, mindenki igyekezett takarékoskodni, mert az óra minden kis fogyasztást mutatott" (Vécsey Gyula 1938). 


\section{A villanytelep és a város}

A Ganz céggel 1910-ben kötött egyezség értelmében „a villanytelep évi tiszta nyereségén fele-fele arányban osztozott az rt. és a város”, azzal a kikötéssel, hogy ha „az üzemév veszteséggel záródna, azt egészében a város köteles fedezni". Az első éveket a villanytelep mérsékelt nyereséggel zárta, a háború éveiben viszont veszteségessé vált, és ez a város anyagi helyzetét is súlyosbította (Vofkori György 2007).

A háborút követően, 1920 novemberében Tetiu Aurel polgármester felmondta a szerződést, arra gondolva, hogy a város házi kezelésbe veszi a villanytelepet, és majd olcsóbban állítja elő a villanyáramot. Válaszul a Ganz cég táviratban értesítette a csíkiakat, hogy a felmondást - az aláírt szerződés értelmében - csak az 1921. december 31-i időponttól fogadja el. Hajlandó lett volna viszont a szerződés felbontásáról tárgyalni, ha a „300 000 koronát kivető tartozását a város rendezi" (Vofkori György 2007). Végül 1921. december 25-én arról adott hírt az újság, hogy „egy évig még a Ganz marad” (A villanyvilágitás ügye 1921), de az egy évből több is lett, bár elképzelhető, hogy egy kis kihagyással. „Bölcs városatyáink a villanytelepet 1929. január elsejétől számított 15 esztendôre Ganzéknak újból bérbe adták" (Legyen olcsóbb a világitás 1931) - jegyezte fel nem kis rosszallással Frank Miklós mérnök, és valóban, az 1940-es években még mindig a Ganz múködtette a csíkszeredai villanytelepet.

Néhány múködési adat: az 1934-ben megjelent ipartestületi emlékkönyv szerint ebben az időben az áramot oszlopokra szerelt szabadvezetékek juttatták el a város különböző részein múködő $17 \mathrm{db}$ transzformátorig, ahol a 3100 voltos primer áram 3-szor 110 voltos szekunder használati feszültségre alakult át. 1934-ben a primer vonal 6 km,

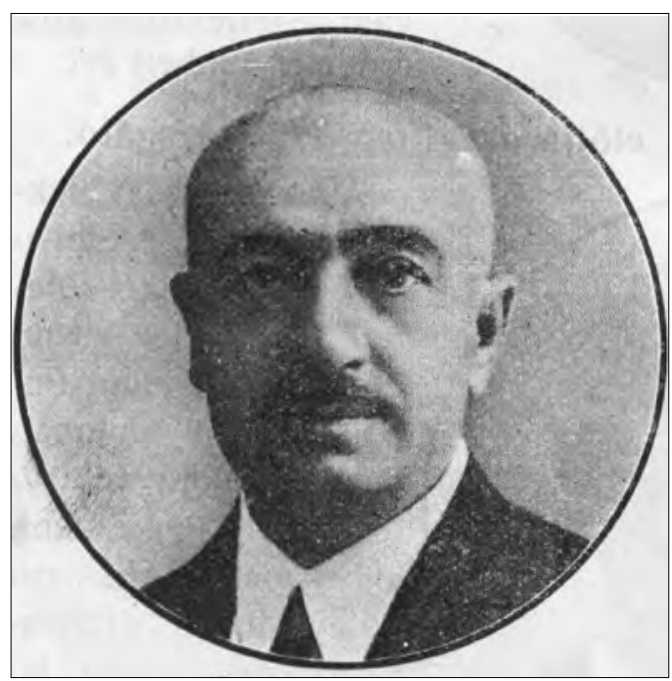

8. kép. Paulovits Antal villanyszerelö, vállalkozó

míg a szekunder huzalok majdnem 15 kilométer hosszan voltak beépítve. A Ganz cég vállalta világítási, erőátviteli berendezések tervezését, szerelését községek, gazdaságok és lakások részére. Saját gépjavítóműhelyt működtetett, és mérőberendezés állt rendelkezésére az árammérők, műszerek és áramfogyasztó tárgyak pontos ellenőrzése céljából (Csíkszereda város villamosmúve 1934).

Itt kell megemlítenünk a korszak egyik legismertebb szakemberét, Paulovits Antal budapesti születésű villanyszerelőt, aki 1912-ben jött Csíkszeredába a Ganz cég alkalmazottjaként, és akinek 1933-ban kenyéradó gazdái a gazdasági válságra hivatkozva felmondtak. Paulovits Antal 1884-ben született Budapesten, és a mesterséget ugyanott, a Ganz cégnél tanulta. Leépítése után Paulovits Antal villanyszerelési vállalatot alakított (Paulovits Antal villanyszerelő 1934).

\section{Kinek kellett a fény?}

A 20. század elején még igencsak megoszlottak a vélemények az egyes községek villamosításának kérdésében. A helyi tanácsosi 
testületek nehezen ismerték fel a villamos energia bevezetésének jelentőségét, a kezdeményezők ezért igyekeztek minél nyomósabb érvekkel előállni. A Csíkszentmárton és Csekefalva községek villamos közvilágításának létesítését felvállaló Alcsíki Bank Rt. képviselője így foglalta össze a villany bevezetésétől várható változásokat 1918-ban: „villany ég a szobában, istálóban, nem kell bajlódni a lámpa, lámpaüveg, bél és petróleum beszerzésének mind nagyobbá váló nehézségeivel, nincs lámpatakarítás, nincs korom, füst és rossz levegő a szobában, - nincs tűzkár, melyet nagyon sok esetben a petróleumlámpa és gyertya, ezek meggyújtásakor eldobott gyufa okoz. A kivilágított utcákon nagyobb a közbiztonság, és mert a villanyvilágítás óriási lépést jelent a fejlődés, a haladás útján, fejlettebb községekben pedig értékesebb minden, többet fog érni itt a közvagyon, magánvagyon egyaránt." (Alispáni iratok 1918)

A meggyőzés Csíkszereda közvetlen szomszédjainál sem ment könnyebben. A hálózat jövedelmezősége érdekében a Ganz gyár tisztviselői több ízben is tárgyaltak a ma Csíkszeredához tartozó, de akkor még önálló Csíktaploca, Csíkzsögöd és Csíksomlyó községek elöljáróságaival a villanyáram bevezetése ügyében (Villanyvilágítás Csíktaplocán 1914), de hosszú évekig elutasításba ütköztek. A csíktaplocai tanácsülés 1911ben egyhangúan úgy döntött, hogy: „a község anyagi helyzete a villanyvilágítás bevezetését nem engedi meg. - A jól értesültek még azt is tudják, hogy e határozat létrejöttét nagyban elösegítette az egyik képviselö-testületi tag következő érvelése: „Eddég es láttunk alunni villany nélkül: ezután es látunk!..." (Gál Sándor 1935).

1914-ben ismét felvetődött a villany bevezetésének ügye Zsögödön és Taplocán, s ezt valószínűleg az időközben kirobban vi- lágháború akadályozta meg. Így, a háborút követően, még 1921-ben is napirenden volt a Csíkszeredával egybeépült települések villanyhálózatának kiépítése, sőt 1931 novemberében még mindig csak arról olvashatunk, hogy Zsögöd területén a Ganz cég megkezdte a villanyhálózat kiépítését ( $A$ csíksomlyói községi tanács és a villanyáram 1933), majd 1932-ben bekapcsolódott a hálózatba (Szendy Károly 1941). 1933-ban a csíksomlyói tanács is határozatot fogadott el a villanyáram bevezetéséről. De nem ám egyszerűen - történt ugyanis, hogy negyven csíksomlyói polgár „beadványt intézett Csikszereda városhoz, a villanyvezetéknek Somlyóra való meghoszszabbítása tárgyában. [...] Hogy hogy nem a villanyáramnak mint kulturjelenségnek Csiksomlyóra való kivezetéséről tudomást szerzett a községi tanács is. Gyorsan összeült. Határozni afelől, hogy milyen álláspontot foglaljanak el ebben a roppant érdekes kérdésben. Engedjék vagy ne az áramot Somlyóra. És mit tetszik gondolni, egyhangúan, megható nagylelküséggel úgy határoztak, hogy megengedik. A község. Mert szerintük nekik semmi közük annak a negyven somlyói lakónak a privát kezdeményezéséhez, akik villany luxust akarnak üzni. [...] Azonban árat szabtak ennek az áldozatos határozatuknak. Közölték Csíkszereda városával, hogy a villanyt csak úgy engedik be, ha a város ingyen ellátja Somlyó községnek 8 lámpával való közvilágítását és a községházának gondoskodik az állandó díszvilágításáról. Természetesen Csíkszereda közölte a községi tanáccsal, hogy a közvilágitást a városnak is meg kell fizesse. A város szívesen támogatja a község lakosságának az áramnyújtásra vonatkozó kérését, azonban ezért ráfizető áldozatot a község nem kívánhat." (A csíksomlyói községi tanács és a villanyáram 1933)

Végül 1934-ben Csíksomlyón is kigyúlt a villanyfény (Szendy Károly 1941), és ün- 
„Bevezetik a villanyt a híres csiki búcsújáróhelyre. Mercurea-Ciuc (Csikszereda). Saját tud. A városhoz közelfekvő összeépült Ciucsumuleu (Csiksomlyó) községbe, az országosan híres Mária búcsújáróhelyre, a városi Ganz villanyüzem megkezdte a villanyvilágitás bevezetését, úgyhogy az a közel jövőben már meg is valósul. A hires búcsújáróhely és az ősrégi zárda, valamint az évszázados kegytemplom sokat nyer már idegenforgalmi szempontokból is a villanyvilágítással. Itt emlitjük meg, hogy Hodossy Kálmán villanyüzemi igazgató tervei szerint a zsögödi közvilágitási lámpák szaporitását és intenzivebb áramszolgáltatást is kilátásba helyeztek." (Csíki Lapok 1934. julius 22.)

nepélyesen megvilágították a csíksomlyói Szűzanya kegyszobrát is (A somlyói kegytemplomban 1934). 1938-ban a hargitafürdői villanyvilágítás bevezetésére tartottak árlejtést (Hargitafürdő villanyvilágítása 1938), tehát folyamatosan emelkedett a hálózatra csatlakozott személyek száma. „Jelenleg a helyzet 842 órás fogyasztó és 13 átalányos szerepel a kimutatásban és már $358 \mathrm{~kW}$ a beépített felvevő képesség. Mi lenne ha mindenki bekapcsolná összes lámpáit és motorait?A teljesítőképesség 106 kW és a fogyasztóképesség 358 kW. Szerencsére az egyidejü terhelés még 105 kW körül mozog" - foglalta össze Vécsey Gyula 1938 augusztusában, sürgetve új gépek vásárlását a villanytelep részére (Vécsey Gyula 1938).

1939 márciusában már azt adta hírül az egyik helyi lap, hogy új gépeket kap a villanytelep, mert „a városi villanytelep erôforrásához kapcsolt zsögödi és somlyói házak megvilágításával túlterhelt gépek már nem bírják a kellő mennyiségü áramot szolgáltatni" (Csikszereda város 1939).

\section{Új világ fényei}

1940 őszén, a második bécsi döntés után a lapokban megjelentek a Tungsram reklámok, hamarosan pedig megkezdődött a falvak villamosítása. „Dr. Varga József Ipar- és keresk. miniszter a tudós felkészültségével beszélt a megvalósítás előtt álló székelyföldi kérdésekről. A Székelyföld villamosítása rövid idő kérdése. Egy hónapon belül megalakul a részvénytársaság s 200 székely községet látunk el elektromos árammal. Ebben az évben már 15 községben égni fog a villany. Nem vizi erôtelepeket használunk. Gázkincs hasznosításán fog alapulni a Székelyföld villanyellátása." ( A magyar kormány csikmegyei látogatása 1942)

1942 októberében Csíkszereda tanácsa a villanyhálózat Zsögödfürdőig való meghosszabbításáról döntött (Csíkszereda költségvetési előirányzata 1943.). „Csíkmegye villamosítása Csíkszeredából kiindulva rohamlépésben érhet célba"- írta a Csíki Lapokban Ferencz Gyárfás 1943. január 17-én. Ekkor már hét alcsíki községben is égett a villany (Gyárfás Ferenc 1943).

1943. december 31-én, több mint 32 év után, lejárt a Városi Villamosmű üzembérletére vonatkozó szerződés a Ganz és Társa Rt.-vel, s mivel a Székelyföldi Villamosművek Rt.-vel folytatott megbeszélések 1944 februárjáig nem vezettek eredményre, Csíkszereda házi kezelésbe vette a villanyüzemet. A Csíki Lapok beszámolójából kiderül, hogy valóban megtörtént a házi kezelésbe vétel, s hogy egy „kivénhedt villamosműről” van szó, így fokozottan figyelni kell a takarékosságra, különben sötétben maradhat a város. A városnak viszont „minden körülmények között kötelessége, hogy a mozi vasárnap délután 3 órakor áramot kapjon" (Városi közgyülés 1944). 
Az 1944. augusztus végi kiürítéskor a németek állítólag felrobbantották az üzemet. A robbantást átvészelő egyetlen gép ezután csak a kórházba, az orosz parancsnoksághoz és a megyeházába tudta eljuttatni az áramot. 1944-45 után, a menekülésből hazatérve Fénya Károly és Vécsey Gyula vezetésével a megmaradt felszerelésekből, alkatrészekből újabb villanytelep jött létre a mai villamossági vállalat székhelyén, és ezzel új fejezet kezdődött a csíkszeredai villanyüzem életében, amely 1963 októberéig tartott. Közben, 1962-ben, Csíkszeredát bekapcsolták az országos hálózatba, de este, „csúcsfogyasztás idején a város villanytelepe egy rövid esztendeig beszolgált az országos hálózatba" (Vofkori György 2007).

\section{Felhasznált irodalom}

Dávid József (szerk.): Székelyföld írásban és képben. Budapest, 1941.

Gál József: Csíkszereda múltja és keletkezése. Kézirat, 1970.

Gál Sándor. Érdekességek Csiktaplocza község múltjából. Csíki Lapok 47. évf. 50. sz. (1935. december 15.) 2.

Gyárfás Ferenc: Csíklázárfalván minden házban villany ég. Csíki Lapok 55. évf. 3. sz. (1943. január 17.) 2.

Herczka Gyula: Villamos világitas... Csíki Lapok, 9. évf. 50. sz. (1897. december 15.)

Herczka Gyula: (reklám) Csíki Lapok, 21. évf. 16. sz. (1909. április 14.) 4.

Hodossy Kálmán In: Az 50 éves Ipartestület 1884-1934. Csíkszereda és Vidéke Ipartestülete, Csíkszereda, 1934. 65.

Szendy Károly (szerk.): Magyar városok. Vármegyei Szociográfiák Kiadóhivatal, Budapest, 1941.

Tirvai Nagy Imre: Emlékezés régi csíkiakról. 2. kiadás. Pallas-akadámia, 1996.

Vécsey Gyula: $A$ villanytelep ügye vagy karácsonykor vajjon petroleum-lámpával világitunk-e? Csíki Lapok, 50. évf. 30. sz.
(1938. aug. 21.) 3.

Vofkori György: Csíkszereda és Csíksomlyó képes története. Typografika, Békécsaba, 2007. 270-274.

A csíksomlyói községi tanács és a villanyáram. Csíki Lapok, 45. évf. 44. sz. (1933. okt. 29.) 2.

A föispáni iroda villamos világítási lámpáinak beszerzése. Direcția Județeană Harghita a Arhivelor Naționale (Román Nemzeti Levéltár Hargita Megyei Igazgatósága), Fond 7 Prefectura Județului Ciuc (Csík megyei prefektúra iratai) - Subprefect (inv. 4) Alispáni iratok (4. számú leltár) 978/1915

A magyar kormány csikmegyei látogatása. Csíki lapok - 54. évf. 25. sz. (1942. június 21.) 2.

A somlyói kegytemplomban. Csíki Lapok - 46. évf. 29. sz. (1934. julius 15.) 4.

A vasuti állomás villanyvilágitása. Csíki Lapok,. 25. évf. 16. sz. (1913. ápr. 16.) 3.

A villanyvilágitás ügye. Csíki Lapok, 33. évf. 52. sz. (1921. dec. 25.) 1.

Aerogén-gázvilágitás. Csíki Lapok, 16. évf. 42. sz. (1904. okt. 5.) 3.

Alispáni iratok. Direcția Județeană Harghita a Arhivelor Naționale (Román Nemzeti Levéltár Hargita Megyei Igazgatósága), Fond 7 Prefectura Județului Ciuc (Csík megyei prefektúra iratai) - Subprefect (inv. 4) (4. számú leltár) 13125/1918.

Csíkszereda költségvetési előirányzata. Magyar Országos Levéltár (K150. 3526. IV. 30. tétel) Városok ügyei - Csíkszereda. 239/1943.

Csikszereda város. Csíki Néplap, 9. évf. 9. sz. (1939. márc. 8.) 1-2.

Csíkszereda város villamosmúve. In: Az 50 éves Ipartestület 1884-1934. Csíkszereda és Vidéke Ipartestülete, Csíkszereda,1934. 104-105.

Csíkszereda világitása. Csíkszereda, 2. évf. 40. sz. (1904. szept. 25.) 2-3.

Elektrotechnikai és müszaki üzlet. Csíki Lapok, 12. évf. 29. sz. (1900. julius 18.) 
Haladunk. Csíki Lapok, 16. évf. 41. sz. (1904. szept. 28.) 2.

Hargitafürdő villanyvilágítása. Csíki Lapok, 50. évf. 24. sz. (1938. jún. 12.) 2.

Legyen olcsóbb a világitás. Csíki Lapok, 43. évf. 7. sz. (1931. febr. 15.) 2.

Megint a villany. Csíki Lapok, 27. évf. 14. sz. (1915. április 7.) 3.

Nappali villamos áram. Csíki Lapok, 25. évf. 48. sz. (1913. nov. 26.) 3.

Paulovits Antal villanyszerelő. In: Az 50 éves Ipartestület 1884-1934. Csíkszereda és Vidéke Ipartestülete, Csíkszereda, 1934. 66-67.

Új világitás. Csíki Lapok, 20. évf. 9. sz. (1908. február 26.) 2

Villamos világitás. Csíki Lapok, 13. évf. 41. sz. (1901. október 9.) 3.

Villamos világitás Csik-Szeredában. Csíki Lapok, 9. évf. 16. sz. (1897. április 21.) 1.

Villámvilágitás és egyiptomi sötétség. Csíki Lapok, 16. évf. 40. sz. (1904. szept. 21.) 3
Városi közgyülés. Csíki Lapok, 56. évf. 9. sz. (1944. február 27.) 1-2.

Városok ügyei - Csíkszereda. Csíkszereda költségvetési elóirányzata. Magyar Országos Levéltár (K150. 3526. IV. 30. tétel) 239/1943.

Villanyvilágítás. Csíki Lapok, 23. évf. 7. sz. (1911. február 15.) 2.

Villanyvilágitás. Csíki Lapok, 43. évf. 44.sz. (1931. november 1.) 4.

Villanyvilágítás Csíktaplocán. Csíki Lapok. 26. évf. 25. sz. (1914. június 17.).

Villanyvilágitás városunkban. Csíki Lapok, 21. évf. 16. sz. (1909. ápr. 14.) 2.

Villanyvilágítás Zsögödön. Tárgyalások. Csíki Lapok, 26. évf. 27. sz. (1914. július 1.) 3.

Villanyvilágitásunk. Csíki Lapok, 23. évf. 4. sz. (1911. január 25.) 2.

Villanyvilágításunk mizériái. Csíki Lapok, 25. évf. 31. sz. (1913. júl. 30.) 4. 


\section{A VILLAMOSÍTÁS ELSő ÉVTIZEDEI SZÉKELYUDVARHELYEN}

A 20. század kezdeti éveiben Székelyudvarhelyen a közvilágítást még mindig a petróleumlámpák kizárólagos egyeduralma jellemzi, ami nem volt kuriózum azokban az években a Székelyföldön. Faoszlopokra, épületek falára rögzített öntöttvas lámpatartó konzolokra szerelt, üvegablakokkal ellátott vaslemez dobozokban elhelyezett petróleumlámpák voltak a közvilágítás egyedüli eszközei. A lámpákat egy lámpagyújtó személy kezelte, ami abból állt, hogy szürkületkor, létra használatával felment a lámpához, kinyitotta a doboz ablakát, begyújtotta a lámpa kanócát (lámpabelet), ami a petróleumba merülve felszívta a világítva égő petróleumot. Ekkor már használatban volt a gyufa, amelynek meggyújtásához elegendő volt a ruházathoz súrolni, amitől lángra lobbant. Ezzel a gyufaszállal gyújtotta meg a kanócot a lámpagyújtó, majd becsukta a lámpatartó ablakát, leereszkedett a létrán, majd a következő lámpánál megismételte ugyanezeket a műveleteket.

Székelyudvarhelyen még 1904-ben is ezt a közvilágítást alkalmazták, és ehhez 165 darab utcai lámpát használtak (Udvarhelyi Híradó 1906. március 25.). Reggelig világítottak a lámpák, amikor a lámpagyújtó ismét végigjárta az oszlopokat, eloltotta a lámpákat feltöltötte tartályukat petróleummal, megtisztította a kormos üvegeket, majd visszacsukta a lámpatartó ajtaját. A lámpa készen állt az esti begyújtásra.

Az Udvarhelyi Híradó 1904. szeptember 11-i számában jelent meg az a hír, amely- ben a budapesti Ganz és Társa Rt. bemutatta ajánlatát a Polgármesteri Hivatalnak, és tárgyalásokat kezdeményezett villamos energia előállításával és felhasználásával kapcsolatosan Székelyudvarhelyen (Udvarhelyi Híradó 1904. szeptember 11.).

Az első ajánlat szerint az áramfejlesztő generátorokat vízenergiával, a régi malom helyén felállított törpe vízerőművel üzemeltették volna. A meghajtó erőforrás egy Francis típusú vízturbina lett volna. A $240 \mathrm{~V}$ hálózati feszültség egyenáramú rendszerben múködött volna, arra hivatkoztak, hogy a vízturbina kapacitása, az általa meghajtott generátor nem termeli azt a villamos energiát, ami abban az időben megfelelt volna a város szükségleteinek (Udvarhelyi Híradó 1904. szeptember 11.). A különbözetet akkumulátortelepek párhuzamos múködtetésével tervezték megvalósítani. Éjjel, amikor a fogyasztás csökken, töltötték volna az akkumulátorokat, majd a csúcsfogyasztás alatt kapcsolták volna ezeket a generátorokkal párhuzamosan a termelt elektromos energia kiegészítése céljából.

Számos elemzés és bírálat követte a Ganz és Társa ajánlatát, aminek az lett az eredménye, hogy a vízturbina kapacitását egy 60 LE-s gőzgéppel kiegészítve újabb energiatermelést reméltek, hiszen az újabb számítások szerint 150 LE primer energiaforrásra lett volna szüksége a városnak (Udvarhelyi Híradó 1904. szeptember 18.).

Ezt látva 1905. április 17-én a város tör- 
vényhatósága megsemmisítette a Ganz és Társa Rt. által előterjesztett és a város elöljárói által aláírt szerződést (Udvarhelyi Híradó 1905. március 19.). Újabb egy év telt el az új szerződés megkötéséig. 1906. június 12-én új szerződés aláírására került sor a Ganz céggel, megnövekedett energiatermelést előírva. Világítási célra 220 volt, ipari célokra 400 volt feszültségű egyenáramú rendszert terveztek.

1906. december 10-én ismét jóváhagyott a közgyűlés egy újabb szerződést a Ganz és Társa céggel. Ez a szerződés 1906. január 27-én érvénybe lépett. A villanytelepet a Nagy-Küküllő mellett, egy régi malom telkére építették. A három nagyobb helyiség 1908-ban készült el 396,9 m² beépített felülettel (Udvarhelyi Híradó 1906. június 10.).

A villanytelep felszerelése mindhárom helyiséget elfoglalta. Az első helyiségbe helyez- ték el a széngázt fejlesztő 2 darab generátort, valamint a két kompresszort. A kompresszorok az indításhoz szükséges magasnyomású levegőt állították elő. Ezzel hozták forgásba a motor lendkerekét, a széngázos motor indítását.

A középső helyiségben, a tulajdonképpeni gépteremben a 2 darab szívógázmotor és a velük összekapcsolt egyenáramú generátorok kaptak elhelyezést.

A harmadik helyiség az akkumulátortelepeket foglalta magában. Az akkumulátorok, mint említettük, akkor szolgáltattak áramot a városi villanyhálózatba, amikor a fogyasztás lecsökkent és leállították a generátoregységeket. Így takarékoskodtak a széngázzal. A két generátor 220/400 volt egyenfeszültséget fejlesztett. A két rendszer (két gázmotor, két generátor) egyszerre működött,

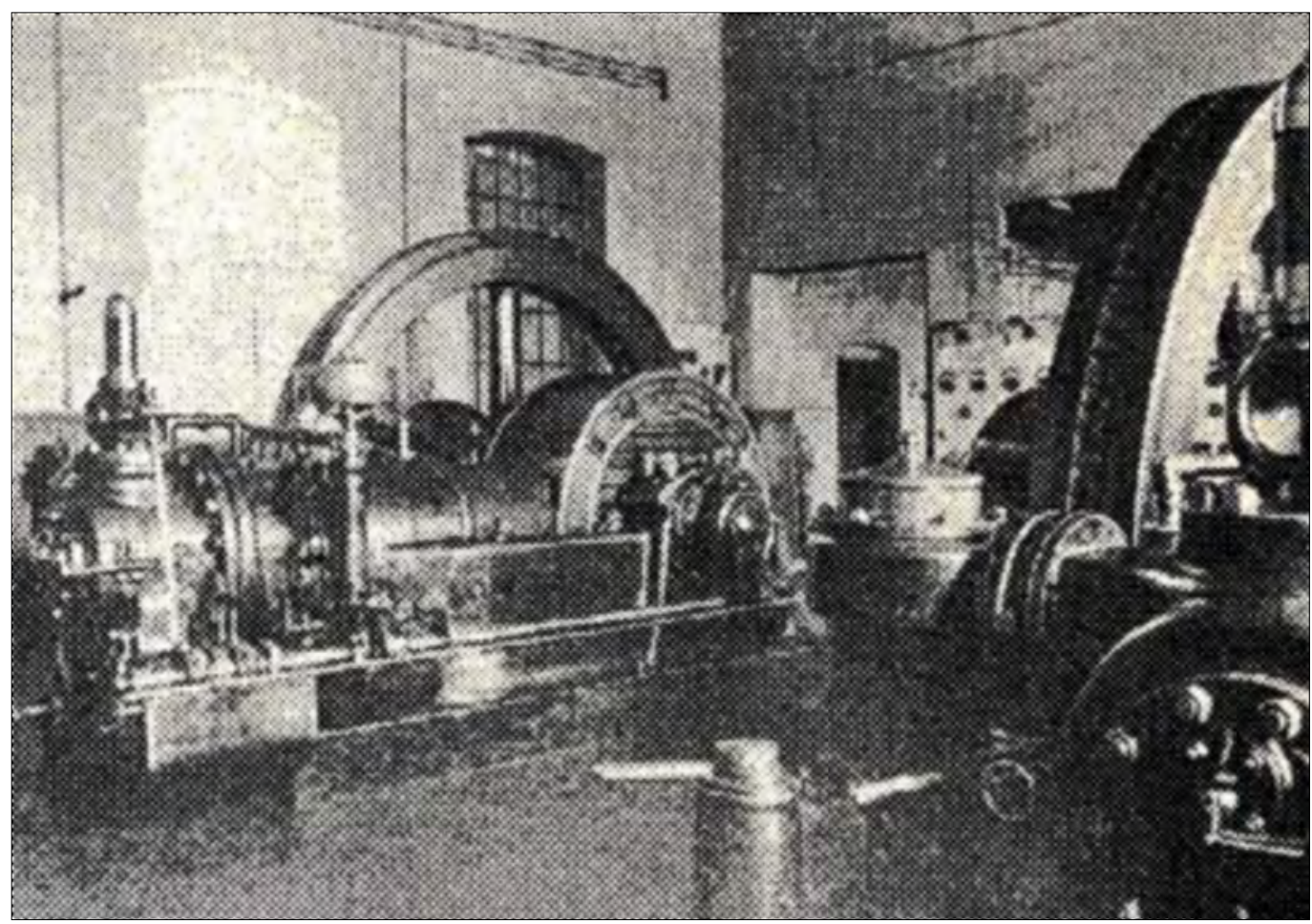

1. kép. A villanytelep gépterme a két szívógázmotorral 
párhuzamosan kapcsolva a városi hálózatra. A generátorokat a Ganz művek gyártották 1904-, illetve 1907-ben.

A közvilágítást első ízben 1908. május 24-én éjjel helyezték feszültség alá. Ebben a felállításban múködött a villanytelep kisebb-nagyobb üzemzavarokkal, tartalék kapacitás nélkül (Udvarhelyi Híradó 1908. május 31.).

1914-ben kitört az első világháború, amit a villanytelep is megsínylett. Hadi célokra, ólomtartalmának más rendeltetése kapcsán leszerelték az akkumulátortelepet. Így telt el a villanytelep első tízéves működésének időszaka.

A második évtized egyre több üzemzavarral, számos nem várt nehézséggel telt el. A megnövekedett igény kapcsán sürgősen bővíteni kellett a villanytelep kapacitását. Így az első fejlesztést 1930-ban végezték. Ekkor a Ganz cég egy 80 LE-s, kéthengeres dízelmeghajtású generátor üzembe helyezésével növelte a villanytelep kapacitását, remélve, hogy ekkora fejlesztés meghaladja a már megnövekedett fogyasztást. Az összteljesítmény a fejlesztés után 280 LE volt, ami 206 KW villanyenergiát jelentett.

Nagy fogyasztóként lépett be a városi mozi. Vetítőgépe ívfénylámpával működött, ami a bekapcsolásakor jelentős feszültségesést okozott a hálózaton. Ennek kompenzálására hoztak létre egy villanymotor-generátor csoportot. A motor a hálózati feszültségre kapcsolva meghajtotta a kis teljesítményű generátort, amelynek feszültsége kimondottan a mozigép ívfénylámpáját volt hívatott ellátni feszültséggel. Mindezek mellett egyre sürgetőbbé vált a villanytelep kapacitásának bővítése. Ezt indokolta az is, hogy az évek során

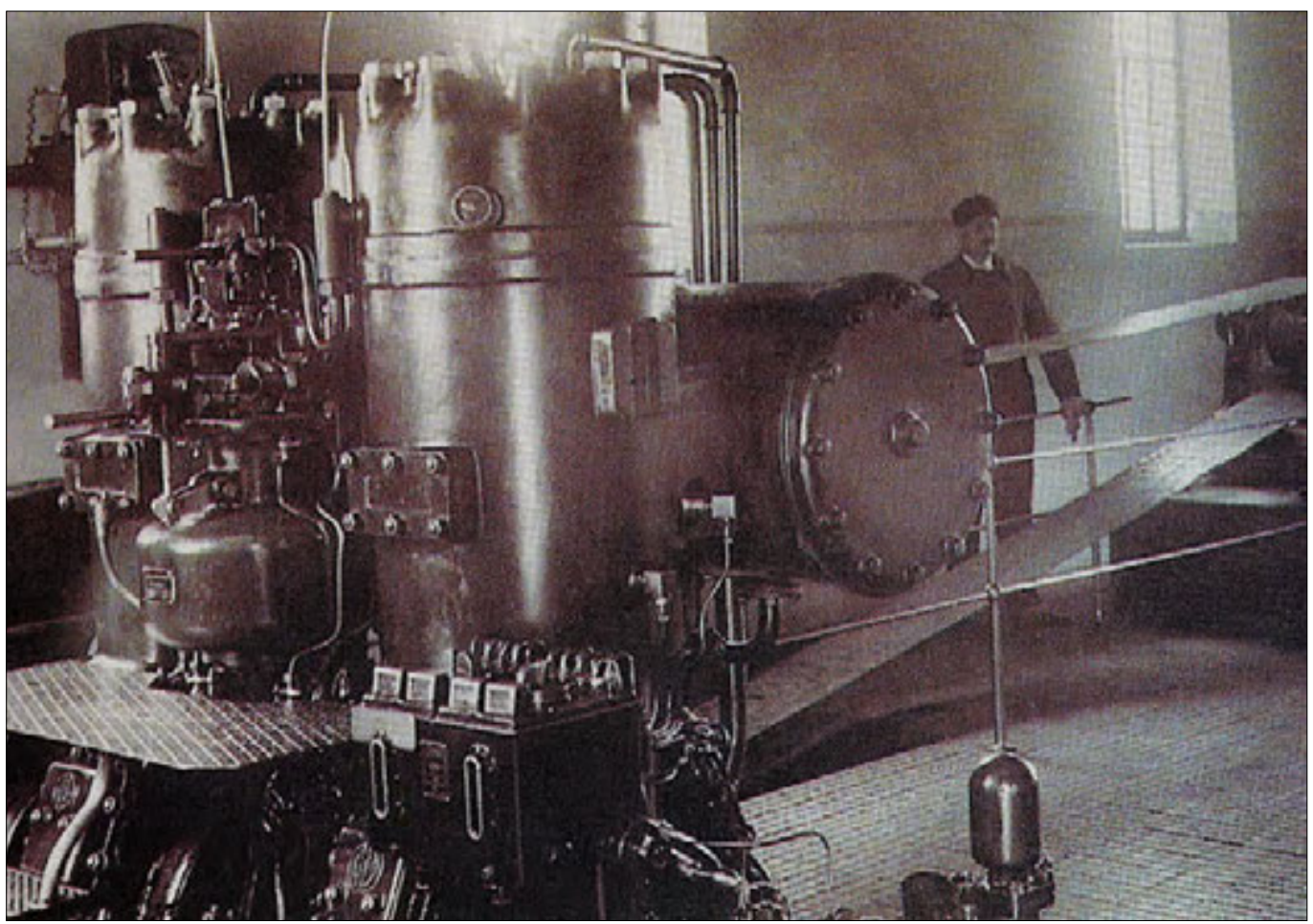

2. kép. Az 1930-as bővités a 80 lóerős, kéthengeres dízelmotorral és dinamójával 
a lakosság lélekszáma az 1930-as 8518 főről 1941-ben 11927 főre emelkedett (Péter Attila 1998, 40.).

1948-ban újabb fejlesztésre került sor, ami jelentős kapacitásnöveléssel jár. Újabb 220,8 KW teljesítménnyel bővült a villanytelep teljesítménye. Ezáltal a telep összkapacitása elérte a 426,88 KW teljesítményt. Megmaradt a két szívógázmotor, a dízelmotoros egység, ezekhez csatlakozott a 220,8KW új dízelmeghajtású egység. A fejlesztés itt sem állt meg. 1952-ben újabb 404,8 KW teljesítménnyel bővült Székelyudvarhely villanytelepének kapacitása. Az új egységet a 80 LE teljesítmény helyébe szerelték. A leszerelt 80 LE kapacitást Miklósfalvára szállították, ott helyezték múködésbe. A kialakult teljesítmény 610, 8 KW. Az utóbbi fejlesztést egy svéd gyártmányú Atlas Polar márkájú, dízelmeghajtású egység jelentette (Péter Attila 1998. 40-42.).

Ez a heterogén szerkezetű villanytelep sem tudta ellátni a város növekvő igényét villamos energiával. A hosszas túlterhelések egyre több üzemzavart okoztak, nem is beszélve az egyenáram alkalmazásának megannyi nehézségéről.

A végleges megoldást az 1959-es év hozta.. Ekkor csatlakozott Székelyudvarhely is az országos váltóáramú ellátórendszerhez. Az ötvenes években megkezdődött az Udvarhely környéki falvak villamosítása is.

Jelen összegzés a néhai Péter Attila székelyudvarhelyi tanár Volt egyszer egy villanytelep című tanulmánykötetének felhasználásával készült, a család utólagos beleegyezésével.

\section{Felhasznált irodalom}

Péter Attila: Volt egyszer egy Villanytelep. Infopress nyomda kiadása, Székelyudvarhely, 1998. 40-42.

Vofkori György: Székelyudvarhely. Várostörténet képekben. Polis Könyvkiadó, Kolozsvár, 1998. 85-88. Udvarhelyi Híradó, 1904. szeptember 1.

Udvarhelyi Híradó, 1904. szeptember 18.

Udvarhelyi Híradó, 1905. március 19.

Udvarhelyi Híradó, 1906. március 2. Udvarhelyi Híradó, 1906. június 10. Udvarhelyi Híradó, 1908. május 31. 


\section{A VILLAMOS ENERGIA HASZNÁLATÁNAK KEZDETEI GYERGYÓSZENTMIKLÓSON ÉS A GYERGYóI-MEDENCE TELEPÜLÉSEIN}

Már 1902-ben, Székelyföld városai és nagyobb települései villamosítása előtt Gyergyószentmiklós elsőként létesített villanyenergiát termelő villanytelepet. Ennek felszerelése két darab, egyenként 65 LE teljesítményű, Langfelder gyártmányú gőzgép, amelyeknek múködéséhez a szükséges hőenergiát két darab, 1902-ben gyártott, 10 légkör nyomást fejlesztő, $50 \mathrm{~m}^{2}$ fütőfelületű gőzkazán termelte. Mindkét kazán fa tüzelésű típus volt. A két gőzgép egy-egy elektromos áramfejlesztő generátort hajtott, amelyek akár a kazánok - szintén 1902-ben készültek. Ekkor már mindkét generátor háromfázisú, $50 \mathrm{~Hz}$ hálózati frekvenciájú, Siemens Halske gyártmányú volt. Ez azért említésre méltó, mert még a később létesített villanytelepek is egyenáramú generátorokkal dolgoztak. A gőzgépek laposszíj meghajtással csatlakoztak az áramfejlesztő generátorokhoz. A generátorok elektromos teljesítménye egyenként 40 kVA (kilovoltamper), összesen $80 \mathrm{kVA}$.

A kezdeti nehézségeket leküzdve a villanytelep egyre jobban, üzembiztosabban múködött. A villamos energia iránti igény viszont egyre nőtt, a $80 \mathrm{kVA}$ teljesítmény egyre inkább kevésnek bizonyult. Ezért már tíz év múlva, 1912-ben megtörténik az első teljesítménybővítés egy darab 165 LE teljesítményű, Schlick Nicholson gyártmányú gőzgép beszerelésével. Az új gőzgép egy 195 LE teljesítményű, háromfázisú, $50 \mathrm{~Hz}$ hálózati frekvenciájú, 210 volt üzemfeszültségű generátort hajtott. A gőzgép működtetéséhez szükséges gőzt egy 1912-ben gyártott Siemens Lanz gyártmányú, $150 \mathrm{~m}^{2}$ fütőfelületű, 12 légkör nyomással üzemelő gőzkazán termelte. A fejlesztés eredményeként az összes termelhető villamosenergia $175 \mathrm{kVA}$, míg a meghajtó gőzgépek összteljesítménye 295 LE. A fogyasztókat légvezetékek csatlakoztatták az elosztó kapcsolótáblákhoz. A légvezetékek hossza 18 km volt, de már 200 m föld alatti kábelt is beszereltek.

Rövid idő múltán annyira nőtt a villamos energia iránti igény, hogy a 275 kVA teljesítmény kevésnek bizonyult. Ez azzal is magyarázható, hogy nem csak világításra

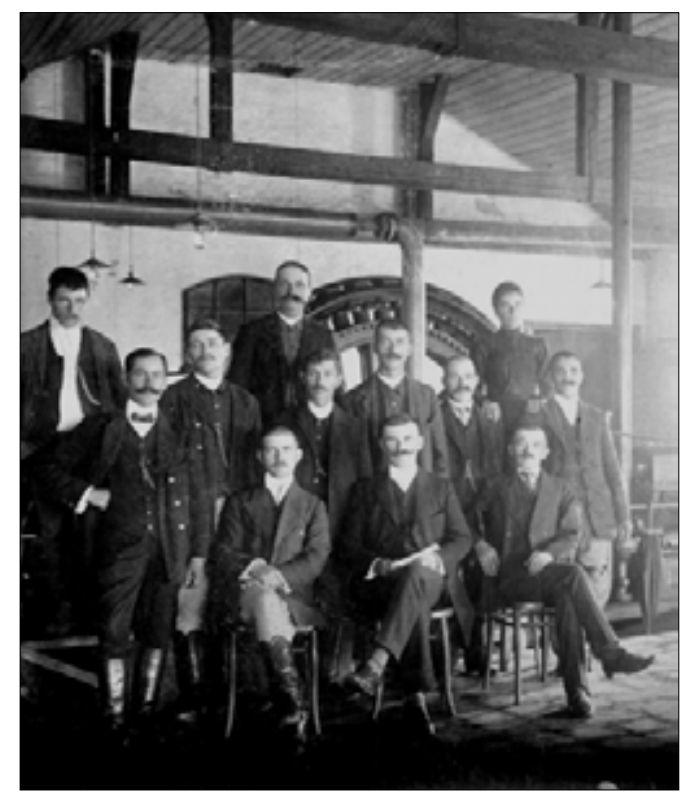

1. kép. $A$ villanytelep alkalmazottai az 1930-as években 


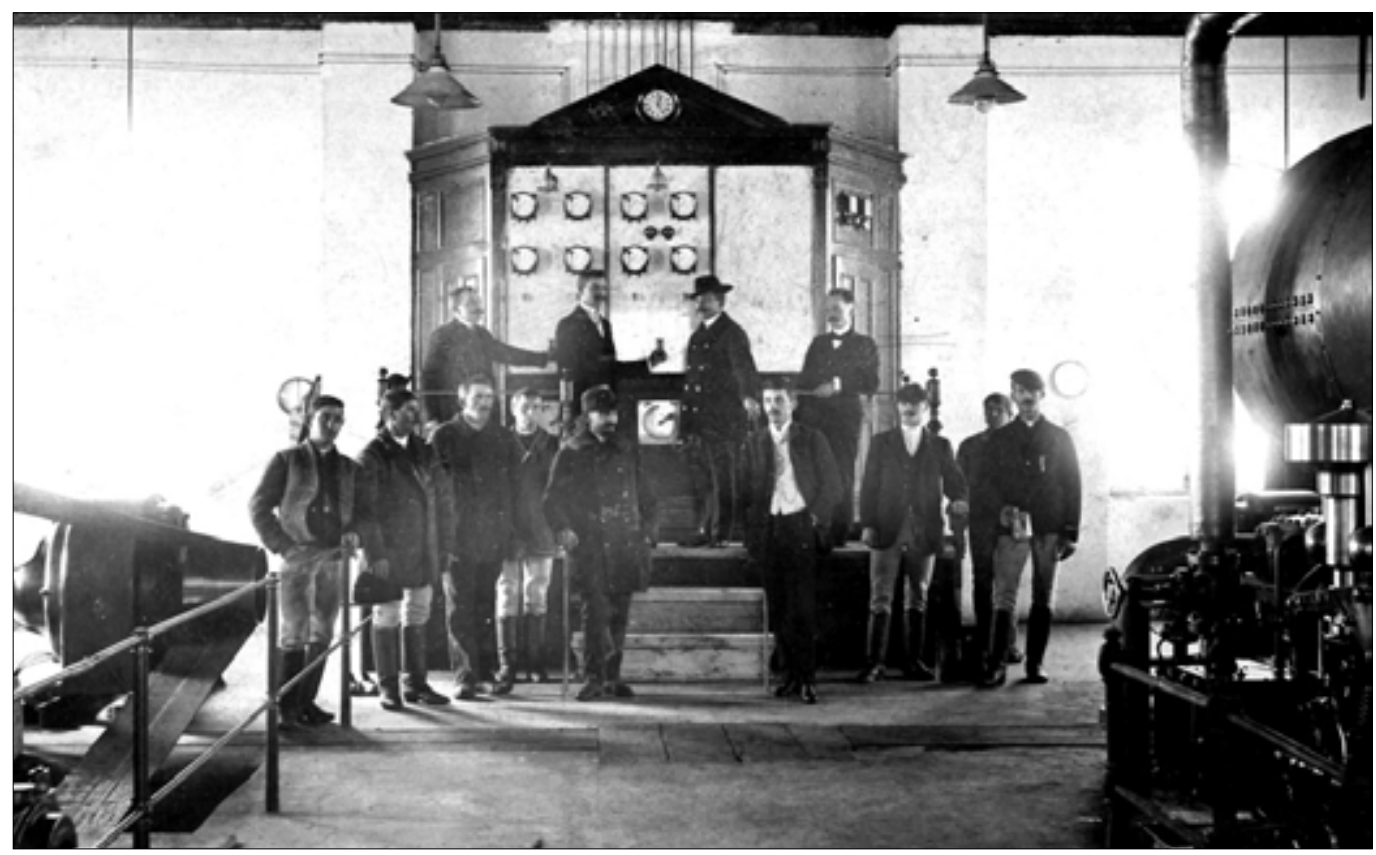

2. kép. A villanytelep alkalmazottai az 1930-as években

használták az elektromos energiát, ipari felhasználása is fokozatosan növekedett. Mindez megkövetelte a villanytelep termelőkapacitásának újabb növelését, a régi kapacitás felújítását.

1929-ben a tervbe vett megújítás a gőzkazánok cseréjéből, új generátorok beszerzéséből állt volna. Az is felmerült, hogy a gőzkazánokat, gőzgépeket dízelmotorokra cseréljék. Javaslat is született, hogy az energiatermelő kapacitást olyan mértékben növeljék, amely lehetővé teszi a Gyergyói-medence településeinek, a 9 községnek elektromos energiával való ellátását. A nagy reményű terveknek a közben bekövetkezett gazdasági válság vetett véget.

1939-ben egy új gondolat születik, amely a várostól 25 km-re fekvő Gyilkos-tó vízenergetikai hasznosítását tűzte ki célul, egy 500 LE teljesítményű vízerőmű felépítésével. Átdolgozták azokat a terveket, amelyeket már 1936-ban kidolgoztatott a város. Ekkor a teljes népességre és az egy főre eső éves fogyasztást az 1. táblázatban foglalt adatok szerint tervezték.

1. táblázat. A teljes népességre és az egy före esô éves fogyasztás 1939-ben

\begin{tabular}{|l|c|c|}
\hline Város vagy község & $\begin{array}{c}\text { Lakosok } \\
\text { száma }\end{array}$ & $\begin{array}{c}\text { Legnagyobb } \\
\text { terhelés } \\
\text { (kW) }\end{array}$ \\
\hline Gyergyószentmiklós & 11000 & 149 \\
\hline Remete & 8220 & 73 \\
\hline Ditró & 7842 & 70 \\
\hline Szárhegy & 4948 & 45 \\
\hline Gyergyóalfalu & 6743 & 60 \\
\hline Gyergyóújfalu & 3873 & 34 \\
\hline Csomafalva & 4706 & 42 \\
\hline Kilyénfalva & 1009 & 9 \\
\hline Tekerőpatak & 2939 & 26 \\
\hline Vasláb & 1351 & 12 \\
\hline Összesen & $\mathbf{5 2 6 7 1}$ & $\mathbf{5 2 0}$ \\
\hline
\end{tabular}


Az is felmerült, hogy a balánbányai rézmünek villamosenergiával való ellátása is megoldható lehetne a Gyilkos-tói vízerőmủ megépítése kapcsán. A legnagyobb szükséges terhelés becslése annak figyelembevételével történt, hogy Gyergyószentmiklósnak abban az időben a legnagyobb fogyasztása $100 \mathrm{~kW}$ volt. „A helyi viszonyok alapján legtöbb 50\% szaporulat várható a jövőbeni kihasználásnál."
A tanulmány leszögezi, hogy nem lehet szó nagyobb növekedésről, mert „Gyergyószentmiklós városnak nincsen semmi lényegesebb fejlődési lehetősége félreeső földrajzi és kedvezőtlen gazdasági helyzete folytán".

A tervek megvalósításának a megváltozott geopolitikai helyzet, a második világháború vetett véget. 


\section{GYILKOS-Tó, BÉKÁS-SZOROS HIDROELEKTROMOS ERŐMÜ ÉPÍTÉSÉNEK TERVEI ÉS KUDARCAI}

A gyergyószentmiklósi villamos hálózat bővítése, valamint a Gyergyói-medence kilenc településének villamos energiával való ellátásának gondolata lehetett az 1902-ben beindult villanytelep 1929-re tervezett megújításának, fejlesztésének indítéka. Az 1902ben múködésbe lépett villanytelep 1912-ben már átesett egy jelentős bővítésen, aminek az eredményeképpen kapacitása 295 LE-s gőzgépből és $275 \mathrm{kVA}$ összteljesítményű generátorokból tevődött össze. Az 1929-ben terveztetett újabb bővítés új gőzfejlesztő kazán beszerelésével egy időben új generátorok beszerzésének gondolatát is felvetette. Ebben az időben már gyakorlattá vált a dízelmotor energetikai alkalmazása. Ilyen háttérrel született a Gyergyói-medence kilenc települése villamosításának gondolata a már meglévő villanytelepre épülve. A terveknek sajnos véget vetett a bekövetkezett gazdasági válság. Ennek ellenére az általános villamosítás gondolata nem veszett el végleg Gyergyóban.

1935-ben a város vezetése egy újabb tervet dolgoztatott ki, ez alkalommal a várostól 26 km-re fekvő Gyilkos-tó környéki vízrendszer vízenergetikai lehetőségeinek hasznosításával. A tervezés indoklásában megfelelő hangsúlyt kapott a lendületes fejlődésnek indult Gyilkos-tó üdülőtelep villamosítása is. A tervek elkészítésére Dorin Pavel bukaresti mérnököt kérték fel, hogy kidolgozza az új energiaforrás hasznosítását. 1936. március 4-én a Közmunkaügyi Minisztérium Dorin Pavel tervét jóváhagyta, ami magában foglalta egy 500 lóerős hidroelektromos központ építését Gyilkos-tónál, a távvezeték építését Gyergyószentmiklósra és a kilenc községbe, valamint az elosztó transzformátorok telepítését ezekbe a helységekbe.

A gyergyószentmiklósi villanytelep a vízerőmű beindítása után továbbra is üzemben, működőképesen, tartalék energiaforrásként maradt volna. Gazdasági számításokat is készítettek, ezek szerint a vízerőmű 50 év alatt amortizálódot volna.

A város vezetése 1936-ban kisérletet tett a tervezett vízerőmű megépítésére koncessziós alapon. Megkereste az Italo-Belge társaságot, hogy ez vállalja el a Gyilkos-tói vízerőmű építését, és tegye meg ajánlatát ezzel kapcsolatosan. Megjegyezzük, hogy ez a társaság építette Brassó villanytelepét, tehát megfelelő gyakorlattal rendelkezett ilyen téren. A terveket a város eljuttatta $\mathrm{az}$ olasz-belga cég vezetőségének, ahonnan az igazgatóság két tagja mérnökeik kíséretében kiszállt a vízerőmű tervezett helyszínére, itt tanulmányozták a kivitelezés lehetőségét. A kiküldetést megismételték egy későbbi időpontban, ez alkalommal már vízhozammérő állomást is felállítottak a tó kifolyásánál. A Gyergyói-medence kilenc településén tanulmányozták a várható villamosenergia-fogyasztás távlatait, a kivitelezés lehetőségeit. Ezzel az ügy 1938 közepén lezárult, amikor is a brassói társaság közölte Gyergyószentmiklós vezetőségével, hogy nincs abban a helyzetben, hogy a vízerőmű megépítésével 
tovább is foglalkozhasson. Érthető döntés volt, ugyanis nemsokára kitört a második világháború.

A háború befejeztével ismét napirendre került, aktuálissá vált a vízerőmű megépítésének gondolata. Remélték, hogy „az olcsó elektromos energia biztos alapja és záloga lesz az egész gyergyói vidék iparosodásának" (László Antal 1940. november 26.).

1935-ben, amikor a Gyilkos-tó és környékének vízenergia-hasznosítási elképzelése megszületett, a város villamosítási foka alacsony szintű és kezdetleges volt. 1933-ban 10948 lakosra vonatkoztatott összfogyasztás $12 \mathrm{~kW}$ volt évente és személyenként, ami rendkívül alacsony fogyasztásnak számított. A környező falvak lakóinak száma: Remete 822, Ditró 7842, Szárhegy 4948, Alfalu 6763, Csomafalva 4706, Újfalú 3673, Kilyénfalva 1009, Tekerőpatak 2939 és Vasláb 1951, összesen 52671 fő Gyergyószentmiklóst is beleszámítva. Mindez indokolttá tette a meglévő villanytelep termelőkapacitásának növelését. Ekkor még egyetlen falu sem volt villamosított a Gyergyói-medencében.

A Gyilkos-tó turisztikai jelentőségét fokozza, állapítják meg a tanulmányok, hogy a tó vízgyűjtő kapacitása gyújtőtóként felhasználható a vízerőmú rendszerében. Az sem elhanyagolható, hogy a tó vízszintje alig változik, ezáltal mint energiaforrás gyakorlatilag állandó (1. kép).

Csupán érdekességként említjük meg, hogy a majdnem teljesen hiányzó villamos- energia-használat folytán a meglévő villanytelep termelése naponta néhány órán át állt, nyáron 5-14 óra között, télen 9-13 óra között. Gyergyószentmiklós legnagyobb terhelése ekkor $100 \mathrm{~kW}$, jóllehet a villamosítás csak részleges. Becslések szerint, figyelembe véve a helyi viszonyokat, legtöbb 50\%-os növekedés volt várható a következő évtizedekben.

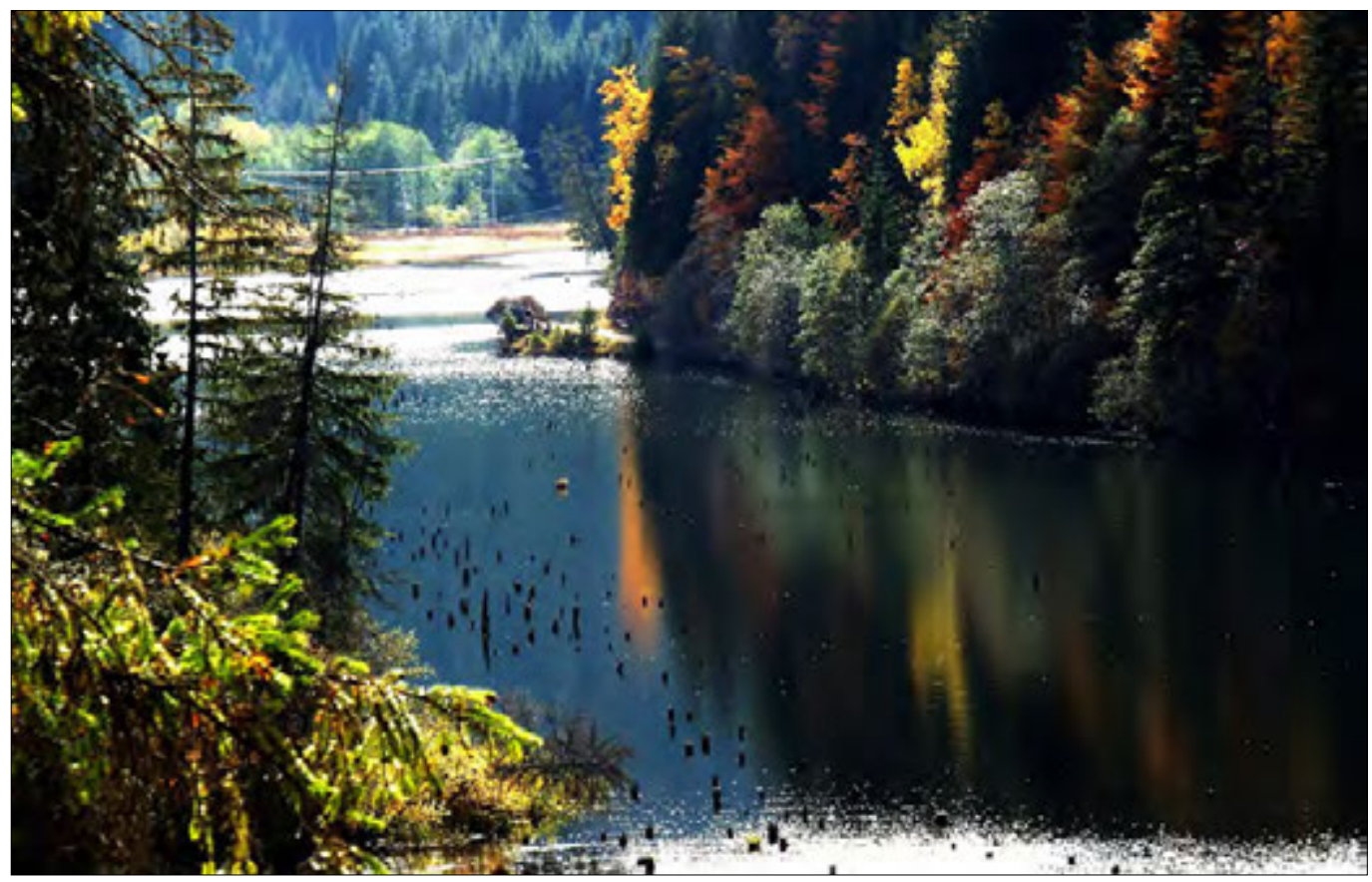

1. kép. A Gyilkos-tó ősszel (Kémenes Árpád felvétele) 
A bevezető tanulmány azt is megállapítja: „nem lehet szó nagyobb emelkedésról, mert Gyergyószentmiklós városnak nincsen semmi lényegesebb fejlődési lehetôsége félreeső földrajzi és kedvezőtlen gazdasági helyzete folytán". (Mily tévedés!). Ezt figyelembe véve, összevetve az éves $12 \mathrm{~kW} /$ év/személy fogyasztással, és amit a községekben nem fognak elérni, a termelendő éves energiamenynyiség $12 \times 52$ 671= $630000 \mathrm{kWh} /$ év kellet volna legyen.

Számítások szerint még ez az alacsony szintű fogyasztás is jelentős árbevételt eredményezett volna, ha megépül a vízi erőmű.

A városvezetés szakemberek bevonásával mérlegelte, hogy nem lenne-e hasznosabb a meglévő hőerőmű bővítése a vízi erőmű helyett. Végül azonban arra a következtetésre jutottak, hogy meghagyva tartalékként a meglévő hőerőművet fel kell építeni a vízi erőművet, mert ez lehetne a leggazdaságosabb, legelőnyösebb változat. Sokat nyomott a latban az, hogy a vízzel termelt energia olcsóbb, mert nincs megterhelve a tüzelőanyag költségeivel,... a jövőben a megnövekedett fogyasztás fatüzeléses rendszerrel nem lesz gazdaságos, ezért két dízel gépcsoport felállítása válik szükségessé. A nyersolaj ára azonban ezen a petróleumtermelő helyektől távol eső vidéken érezhetően magasabb, mint az ahhoz közelebb eső vidékeken.

Ezeket figyelembe véve a vízerőművet 500 LE teljesítményre tervezték, ami $330 \mathrm{kWh}$ elektromos energia lehetőséget biztosít. Ezt két Francis típusú turbina beszerelésével, üzemeltetésével érték volna el. A termelt energia 89\%-át vízi erőművel, 11\%-át hőerőművel nyerték volna. Az áramfejlesztés helyétől Gyergyószentmiklósra 15 kV-os távvezeték továbbította volna a fogyasztható elektromos energiát. A távvezeték hossza 21,4 km, ami követte volna az állami országút nyomvonalát, leszámítva a szerpentines szakaszokat. A $15 \mathrm{kV}$-os, $3 \times 16 \mathrm{~mm}^{2}$ keresztmetszetű távvezetéket vasbeton lábakra szerelt fenyőoszlopok tartották volna. A városi transzformátorállomás 15 000/6000 és 6000/2100 V lépcsőben szállította volna a felhasználók transzformátoraihoz az elektromos energiát, ahol 2100/220 V használati feszültségre csökkentették volna.

Mind a kilenc településen egy vagy két transzformátorállomást állítottak volna üzembe, a távolságok és a teljesítményszükségletek függvényében. Gyilkos-tó üdülőtelepet közvetlenül a vízi erőmű transzformátorállomásából látták volna el elektromos energiával.

Érdekességként említjük, hogy a vízi erőmű a tervek szerint $840 \mathrm{kWh} / \mathrm{nap}$ teljesítménynyel $0,30 \mathrm{~m}^{3} / \mathrm{sec}$ vízhozam felhasználásával működött volna. A $0,3 \mathrm{~m}^{3} / \mathrm{sec}$ vízhozam egy nap alatt a tó vizét $9160 \mathrm{~m}^{3}$ vízmennyiséggel apasztotta volna. Ezt a vízmennyiséget a tó felületére osztva, ami akkor $140670 \mathrm{~m}^{2}$ volt, 0,065 m tófelszín apadást jelentett, vagyis a tó felszíne 0,065 m-t fluktuált volna.

A $40 \mathrm{~km}^{2}$ vízgyújtő terület még a szárazságos években is biztosította volna az évi $0,877 \mathrm{~m}^{3} / \mathrm{sec}$ vízhozamot. Ez a vízhozam elegendő 500 LE erőkifejtésre, 353 KW generátorteljesítményre. Számítások szerint a gát 1 m-rel emelte volna a tó akkori vízszintjét.

A turbinához vezető vasbeton cső hosszát 1143,80 méterre, belső átmérőjét 900 mm-re tervezték. Az acél nyomócső 116,8 méter, belső átmérője $700 \mathrm{~mm}$ (1. ábra). Azt is figyelembe vették a kivitelezhetőségi tanulmány összeállításánál, hogy a vízgyűjtő terület 85\% a jól erdősített, ami kedvező feltételnek számított, mert ilyen helyeken nem alakulnak ki az esőzéseket követő vízmosások.

Több számítási módszer alkalmazásával, hasonlósági tanulmányokkal megállapították 
a több évre vonatkozó közép vízhozamot, hogy az eredmény a közép vízhozam esetében a lehető legnagyobb valószínűség határai közé kerüljön. A számítások az évi közép vízhozamra az $0,850 \mathrm{~m}^{3} / \mathrm{sec}$ értéket adták.

A vízmennyiség változhat évről évre a csapadékviszonyoktól függően. Ezt a változást 16 évre követve megállapították, hogy a legkisebb érték 620,5 liter/sec, a legnagyobb 1144 liter/sec volt. A hasznosítható vízhozam legnagyobb értékét 1000 liter/sec menynyiségre, míg az évi hasznosítható középértéket 700 liter/sec mennyiségre állapították meg (2. ábra).

Összehasonlító gazdasági számításokat is végeztek, hogy eldönthessék a fejlesztés irányát, vagyis hogy a meglévő hőerőmű további fejlesztésével vagy vízi erőmű építésével növeljék a villamosenergia-termelést Gyergyószentmiklóson. Megállapították, hogy hőerőtelep fejlesztéséról nem lehet szó, mert a teljesítmény kicsiny, és a szénhiány kedvezőtlen körülmény. Azt is leszögezték, hogy abban az esetben, ha a vízi erőmű nem valósulna meg, a dízel változat az egyedüli, amibe érdemes befektetni. A felszerelendő teljesítmény nagyságrendjét a meglévő teljesítmény hozzáadásával a vízi erőmű teljesítményéhez

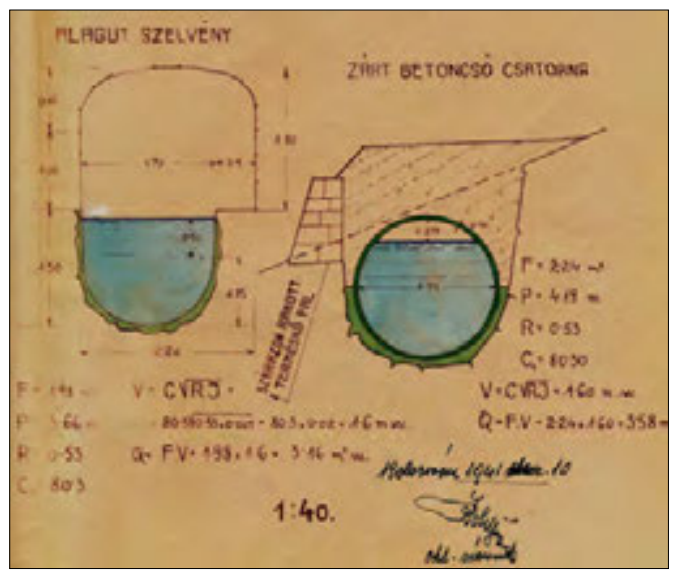

1. ábra. Felvízcsatorna részletrajzai
730 LE-t eredményezett volna. Ezt a teljesítményt három dízelegységgel, egyenként 250 LE-vel és közvetlen meghajtású generátorral tervezték.

A második világháború alatt mindenre lehetett gondolni, csupán vízi erőmú építésére nem, főleg a Gyilkos-tónál. A terület ez alatt az idő alatt katonai múveletek színtere volt.

1941-ben ismét terítékre kerül a vízi erőmű megépítésének terve, azzal a különbséggel, hogy ekkor már rájöttek, az 500 LE (330 kW), ami abból adódott, hogy az éves csúcs 520 kW teljesítményből 190 kW a hőerőmű teljesítménye, így a $330 \mathrm{KW}$ teljesítményt vízenergiából kell majd előállítani. Figyelembe véve a szállítási, transzformálási veszteségeket $330 \mathrm{~kW} \times 1,36$, ez osztva 0,893 hatásfoktényezővel 502 LE turbinateljesítményt eredményez. A nagyobb biztonság megvalósításáért két generátort szereltek volna be, amelyekhez két Francis-turbina kapcsolódott volna.

A befektetés mértékéhez viszonyítva, figyelembe véve az aktuális gazdaságpolitikai távlatokat, kevésnek tartották a $330 \mathrm{~kW}$ teljesítményt. Ezért újabb változatokat fontolgattak. Egyrészt hasznosítani akarták a Kis-Békás vízenergetikai kapacitását, másrészt összesí-

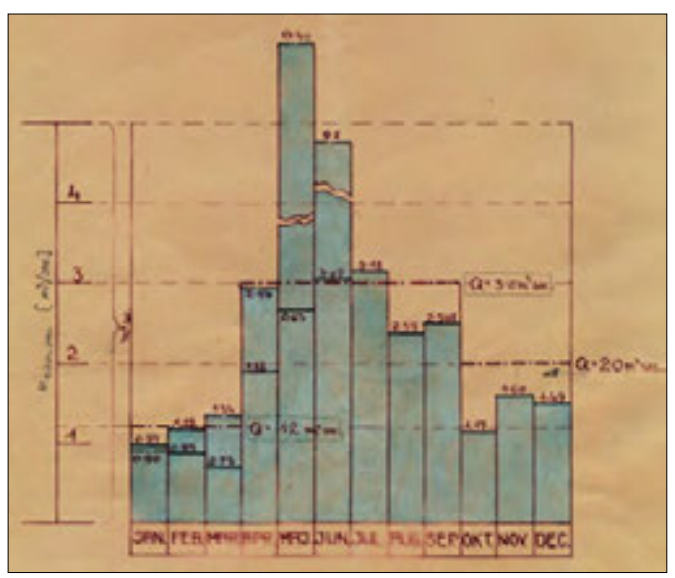

2. ábra. Víztömeg grafikon 
teni szerették volna a Békás és a Kis-Békás patakok energiatermelő adottságait.

Méréseket végeztek a Kis-Békás vízhozamviszonyainak megismerése végett, elkészítették a Kis-Békás tározómedencéjének részletes geodéziai felvételét.

Torkolati szakaszán a Kis-Békás patak meredek és magas sziklafalak között folyik. A torkolattól 1,2 km-re a vízfolyás völgye kitárul, a környező hegyek átlagosan 400 méter széles és mintegy $3 \mathrm{~km}$ hosszú, kis fenékesésü, így víztárózásra igen alkalmas medencét képeznek. E medence fölött a vízfolyás vadpatak jellegű. A völgy Szurdok nevü szorosában építették volna a zárógátat. A zárógát előtt a jobb oldalon lett volna a vízkivezetés. Innen a vizet alagút vezette volna a kiegyenlítő medencéig. Innen acél nyomócsövön a turbinatelephez. A turbinatelep, a Békás völgyében a két patak egybefolyásától kb. 800 méterre épült volna.
A Kis-Békás vízenergiájának hasznosítására két megoldás is megszületett. Az egyik változatnál csak a Kis-Békás vizét tárolták volna, a másik változat szerint a Kis-Békás és a Békás-patak vízenergiáját együttesen hasznosították volna úgy, hogy a Békás mellékpatakja, a Fügés-patak torkolata alatt létesített duzzasztómú közbeiktatásával alagúton átvezették volna a Békás és Fügés együttesét a Kis-Békás tározó medencéjébe. Ebben az esetben a Békás és Fügés együttesét két helyen tervezték hasznosítani: először a Kis-Békás tározójába való beömlése előtt, másodszor a Kis-Békás vizével együtt, a Békás-völgyi erőműnél (3. ábra).

A Kis-Békásnak 80,6 km² vízgyűjtő területe vehető számításba, bár e terület csapadékban meglehetősen szegény, az átlagos évi csapadék mintegy $600-700 \mathrm{~mm} / \mathrm{m}^{2}$. Ezt az értéket nem mérésekkel állapították meg, hanem összehasonlítással, közeli csa-

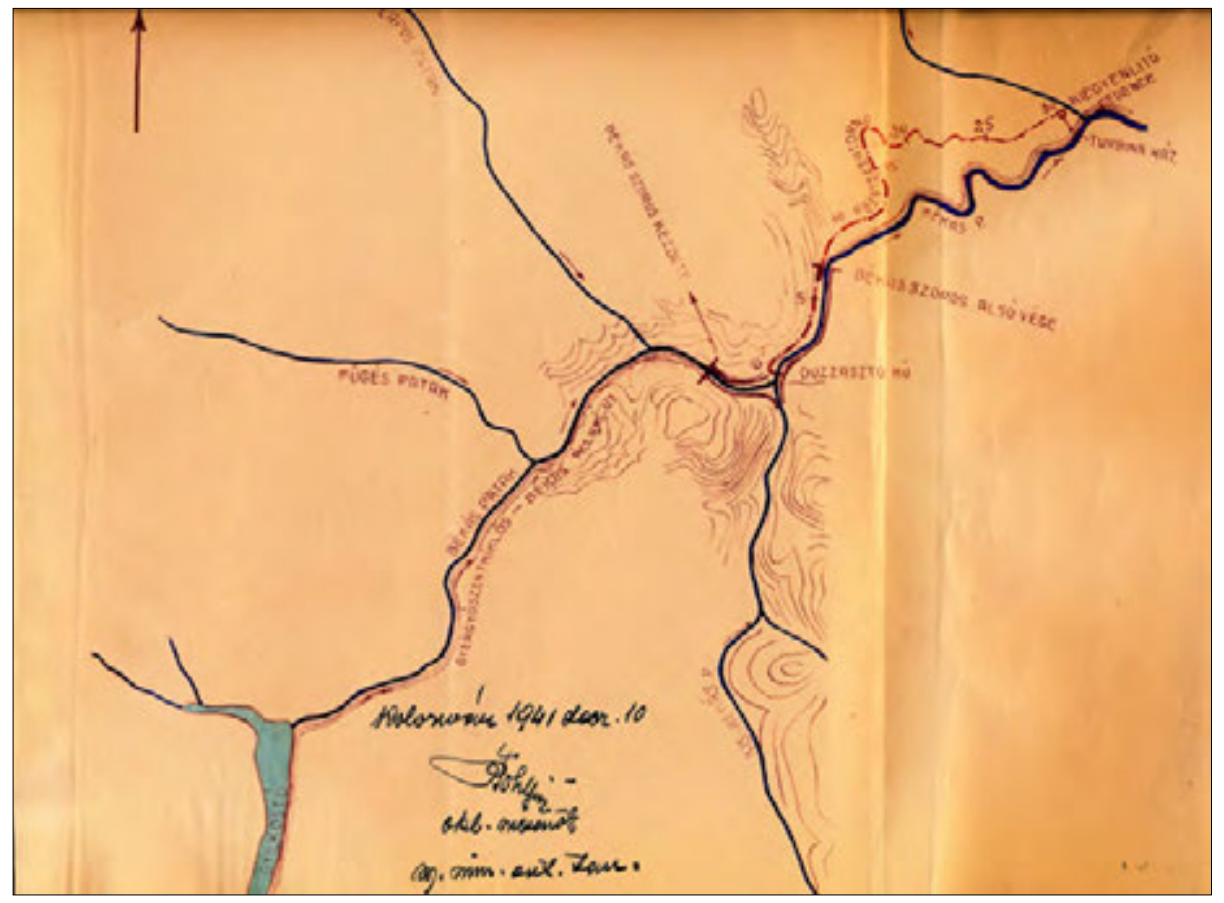

3. ábra. A Békás-patak és mellékpatakjai 
padékmérő állomások adataival (Balánbánya, Gyergyóbékás, Gyergyótölgyes, Gyimesbükk). Érdeksség ebben a témában, hogy az 1942-es év csapadékviszonyai megegyeztek az 1904. év csapadékával. Mindkét esztendő csapadékban szegényként szerepel a mérési adatok között.

A városvezetés 1941 októberétől tartott fenn rendszeres vízállásmérést a Békás-patakon, a Márk István villájánál található vízhozammérési szelvényben. Eddig a mérési pontig a Békás-patak vízgyűjtőterülete 41,0 km².

A Fügéssel egyesült Békás- és Kis-Békás-patak együttes tizenkét hónapi vízmenynyisége összesen 47,0 millió $\mathrm{m}^{3}$ az ebből adódó közepes vízhozam pedig 1,50 $\mathrm{m}^{3}$ / sec. Biztonságból az üzemvízalagút áteresztő kapacitását túlméretezték úgy, hogy az esetenként $1,50 \mathrm{~m}^{3} / \mathrm{sec}$ vízhozamnál nagyobb árhullámot is átvezesse a gyűjtőmedencébe túlterhelésmentesen.

A hidrológiai tanulmánnyal párhuzamosan a geológiai viszonyokat is tanulmányozták 1942 nyarán és őszén, a Földtani Intézet közreműködésével. Megállapítást nyert, hogy az alapkőzet ugyan mészkő, ezt azonban a medence majdnem egész kiterjedésében olyan vastag pala, illetve homokkő fedőrétegek borítják, hogy a víz elszivárgásától nem kel tartani. Ez a fedőréteg csupán a völgyelzárásra kiszemelt szorulat közelében vékonyodik el annyira, hogy ott esetleg kisebb területen cementbesajtolásra lesz szükség.

A gát végleges helyét a további, részletes kutatások eredményétől tették függővé, anynyit viszont megemlítettek, hogy a szorulat alkalmas lehet íves gát megépítésére. A gátat a mintegy 250 méter hosszú szoros felső végében célszerű elhelyezni.

Az íves gátnál az erőhatást oldalt, a vállak támasztópontjaiban veszi át a sziklafal, ugyanakkor a hőmérséklet-ingadozás okozta tágulás lehetősége is megoldott.

A völgyzárógát építésére megközelítőleg 2310 m3 faltérfogat volt szükséges. A tározótér befogadó képessége 13 millió köbmétert tett ki. Ebből következően 1 köbméter faltérfogatra 5628 köbméter tározótérfogat jutott.

A víznyomásból származó legnagyobb nyomófeszültség $12,5 \mathrm{~kg} / \mathrm{cm}^{2}$. A méretezés magában foglalta a jégnyomásból származó feltételezhetően kialakuló legnagyobb igénybevételt is. A jég vastagságát egy méterrel számolták és megállapították, hogy ezen a tengerszint feletti magasságon, amit 855,00 méternek vettek, a számított eredőfeszültség nem haladja meg a $12,5 \mathrm{~kg} / \mathrm{cm}^{2}$ igénybevételt.

Az előzetes, kivitelezhetőségi tervekben a tározó vízének az erőműhöz való vezetése módosított változatára is kitértek. Ezek szerint a gáttest előtt, a jobb oldalon 826,00 tengerszinti fenékmagasságból kiindulva mintegy $2 \mathrm{~km}$ hosszú üzemvízalagút vezetett volna, nyomás alatt a kiegyenlítő medencébe. Ezen a szakaszon egy ellenőrző aknát is létesítettek volna. A kiegyenlítő medencéből meredek esésű acél nyomócsövön jutott volna el a víz a Békás-völgyi turbinatelep gépegységeibe. Így a legnagyobb természetes esés, 160 méter, keletkezett volna.

Ha a másik változatot részesítették volna előnyben, a Békás vizét a magasságkülönbségeket kihasználva először a Kis-Békás tározó medencéjébe vezették volna mintegy $1 \mathrm{~km}$ hosszú üzemvízalagúton át. Innen a tározó mellékvölgyében létesített kiegyenlítő medencéből acél nyomócsövön, 36 méter természetes eséssel vezették volna a vizet a turbinatelephez. Ebből kitűnik, hogy minden változatot előterjesztettek, hogy a szakemberek mérlegeljék ezeket, és a leggazdaságosabb változat megépítése mellett dönthessenek (2. kép). 
A Kis-Békás patak vízerejének hasznosítása révén mindkét változat esetében „olyan nagy energiamennyiség termelhető, amekkora Gyergyószentmiklós város és a környező községek villamos árammal való ellátását lehetővé teszi" (Kanizsai Alajos D.C. 627.8.).

A tervek kivitelezésébe ismét beleszólt egy újabb, ezúttal a második világháború és annak következményei. Évek múltán bebizonyosodott, hogy a Gyilkos-tó és környékének vízenergetikai lehetőségei csak töredékét fedezték volna annak a szükségletnek, amelyet a vidék fejlődése megkövetelt.

\section{Felhasznált irodalom}

Kanizsai Alajos: A Kis Békás patak vízerejének hasznosítása. D.C. 627. 8.

László Antal: Átirat. Gyergyószentmiklós, 1941. december 13.

László Antal: Jelentés Gyergyószentmiklós és vidéke elektromos energiával való ellátásáról. Gyergyószentmiklós Megyei Város Mérnöki Hivatala. Gyergyószentmiklós, 1940. november 26.

Márton László: Változatok a Gyilkos-tó vízrendszerének hasznosításáról. Hargita, 1981. április 11.

Márton László: Változatok a Gyilkos-tó vízrendszerének hasznosításáról. In: Korunk évkönyv 1989. 39-42.

Pavel, Dorin: Memoriu asupra centralei hid-

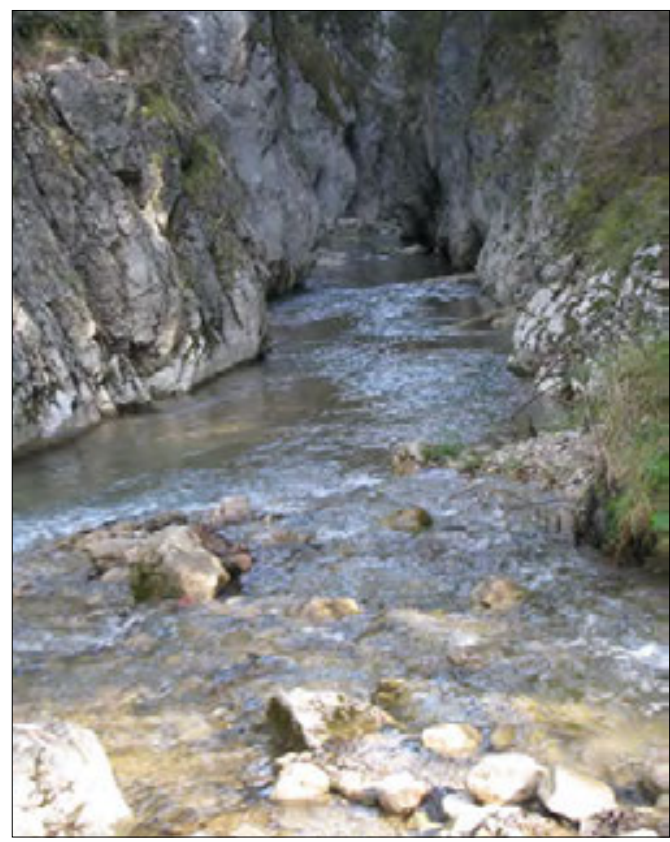

2. kép. A Kis-Békás patak, szurdok (Kémenes Árpád felvétele)

raulice Ghilcoş în legătură cu electrificarea oraşului Gheorgheni și a comunelor invecinate. București, 1935.

Pohl Béla: Gyilkostói vízierôtelep helyesbített vízmütani és gazdasági számításai. Kolozsvár, 1942. augusztus 20.

Vofkori György: Gyergyószentmiklós. Várostörténet képekben. Gyilkos-tó, Békás-szoros. Polis Kiadó, Kolozsvár, 2004. 136, 137, 216-243. 


\section{KOMMANDÓ VILLAMOSÍTÁSÁNAK TÖRTÉNETE}

A 19. század végén Háromszéken a fafeldolgozást csak házi mesterségként gyakorolták, bár Kommandón és környékén óriási őserdők álltak hasznosítás nélkül. Miután a vasút elérte Brassót, több iparmágnás szerette volna a környező erdőket kitermelni, de lehetetlen vállalkozásnak tűnt, ezért a kitermelés váratott magára. 1886-ban Horn Dávid felvidéki faiparos és üzletember megvásárolta Zathureczki Gyulától 14582 kataszteri hold erdő kitermelésének jogát, és ezzel megvetette a faipar alapjait itt a hegyek tetején, az egykori Háromszék vármegyében, a megye legmagasabban fekvő településén, Kommandón. Ekkor itt a kor legmodernebb technikáját alkalmazták, amiből a villamosenergiafejlesztés és hasznosítása sem hiányozhatott. Levéltári adatok, hírlapok és szakirodalmi feljegyzések igazolják, hogy az akkori Háromszék vármegyében elsőként alkalmazták a villamos energiát, amit helyben állították elő. Kommandótól 6 km-re, 1888. október 17-én, délelőtt 10 órakor Horn Dávid tulajdonos jeladására elindult a 8 keretfúrészes fürészgyár 900 munkással, akik Gyulafalván laktak. Számos tiszti (tisztviselőház) és mun-

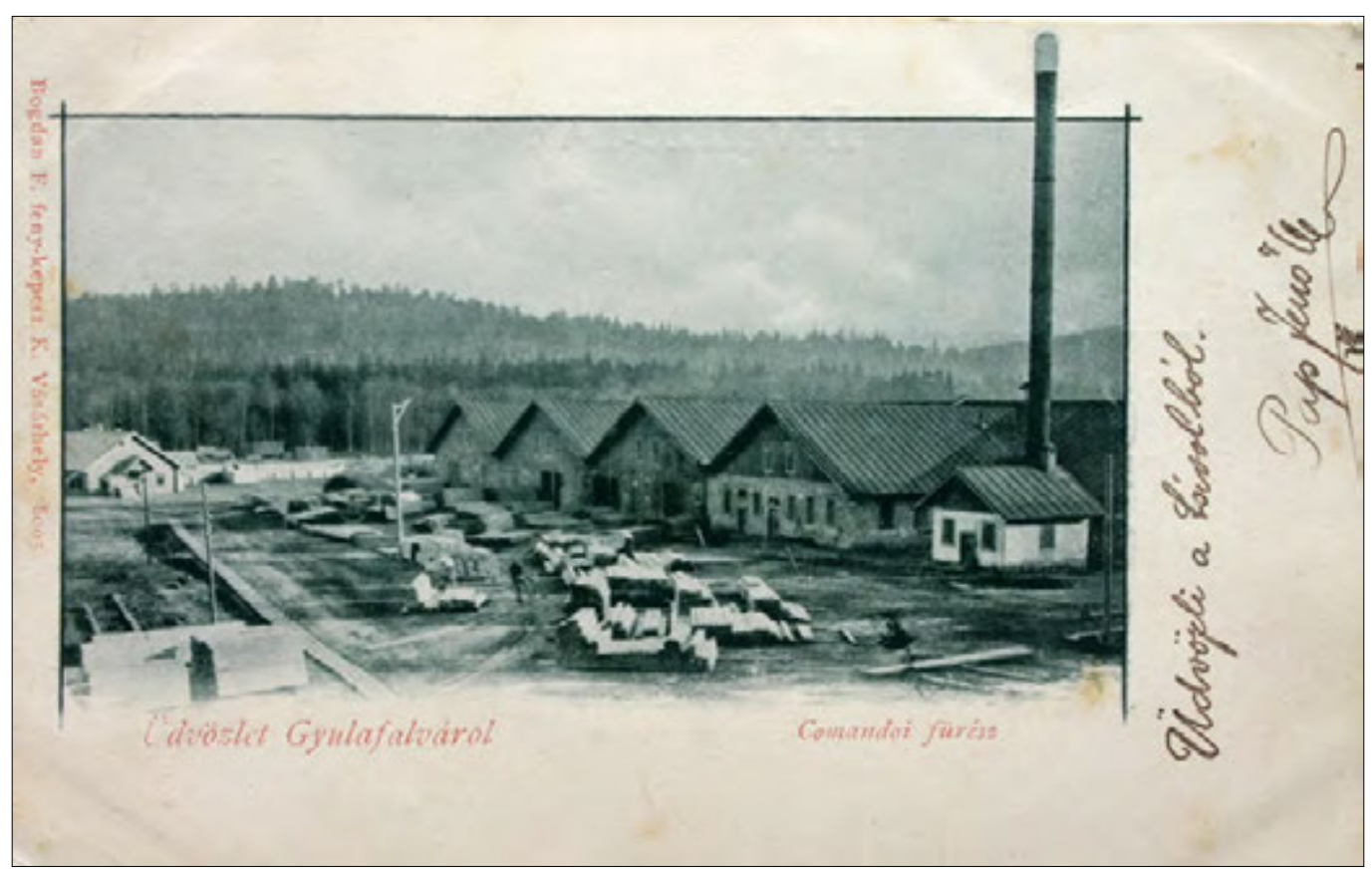

1. kép. A kommandói gyár 1899-ből 
káslakás adott otthont a faiparban dolgozó családoknak. A fürészgyárat vasúti sínekkel, úgynevezett lóvonatú vaspályákkal kötötték össze a vágterekkel, ahol lovak vontatták a kocsikat. Horn Dávid valamennyi elképzeléshez az ötletet Magyarországról hozta, hiszen ott már az 1800-as évek közepén léteztek hasonló vaspályák (Pótsa József 1899. 287.). Mindenből talán a legszebb és legegyedibb az volt, hogy a gyár elindulásával 1888. október 17-én kigyúlt a villanyfény is Kommandón. Az egyszerű emberek a földre borultak, és keresztet vetettek, mert azt hitték, hogy mennyei csoda történt. Valóban csoda történt, de nem égi csoda, hanem egy haladó eszméjű vállalkozó csodája, aki elérte azt, hogy országos szinten, Temesvár után Gyulafalván másodiknak, majd 1889-ben Kommandón gyúljon ki a villanyfény a közvilágításban.

Temesváron 1884-ben gyúlt ki először a villanyfény, ami akkoriban nem Erdély területéhez tartozott, tehát erdélyi szinten Gyulafalván gyúlt ki elsőnek a villanyfény, hiszen még Brassóban is gázzal világítottak. Dr. Rosta István azt írja, hogy Temesvár villamosítása volt a múlt század végén az első kiemelkedő technikatörténeti esemény. 1884-ben az angol-amerikai Brush Co. szállított oda hagyományos egyenáramú világítási rendszert.

Erdélyben 1888-ban megjelentek az első Ganz rendszerű váltakozó áramú berendezések, amelyeket közcélú világításra kezdtek üzemeltetni. A gőzgépek - nagy testű gépek voltak, amelyeknek a szállítása darabokban történt - összerakásához, kezeléséhez fejlett technikai tudás szükségeltetett (Rosta István szerk. 1995. 124.).

Ezzel az alkotásával diadalt aratott Horn Dávid, meghódította az őserdőt, és megmutatta azt, hogy az erdei fenyő igazi arannyá válik, ha megfelelő kezekbe kerül.
A gyulafalvi fürésztelepet 1888. október 17-én helyezték üzembe, de az avatóünnepségre csak 1889. január 15-én került sor. Az avatóünnepségre küldött meghívóban ez olvasható:

\section{„Meghívó}

Papolc község határában levő Zathureczky Gyula úr és társai-féle erdőben létesített (Gyulafalvi) gőzfürész gyártelepemnek 1889 évi jan. hó 13-án (vasárnap) du. 5 órakor a helyszínen leendő ünnepélyes felavatásához van szerencsém uraságodat meghívni, kérvén nagyra becsült megjelenésével az ünnepélyt megtisztelni.

Kiváló tisztelettel: Horn Dávid"

A vállalkozó nyilván büszke volt a sikerére, és ezt meg akarta osztani másokkal is. Az avatóünnepségre meghívott minden jelentős személyt, beleértve a sepsiszentgyörgyi Székely Nemzet lapszerkesztőjét is. 1889. január 15-én megjelent a tudósítás, amelyben többek között ez olvasható:

\section{„Az ipartelep felavatása Gyulafalván}

A gőzfürészgyár, mely Zathureczky Gyula tulajdonát képező tizenkétezer holdnyi erdőséget van hivatva 25 évi kihasználási idő tartamán belül feldolgozni, alig néhány hónap alatt bámulatos gyorsasággal épült fel. Papolc községtől 22 km-re fekszik, honnan egy a tulajdonos által jól járható közlekedési út vezet a telephez. Azon esetben, ha tervbe vett háromszéki vasút felépül, Horn Dávid úr egy pályát szándékozik építeni, mely Gyulától kiindulva Kovászna felé venné irányát, hol egy nagy raktár lesz berendezve az ide szállítandó anyagok számára. A telepre megérkezve újabb és kedves meglepetés várakozott a vendégekre. A bejáratnál lampionokkal s zöld fagallyakkal díszített diadalkapu volt felállítva: *Isten hozott* és *Éljen az ipar*. A megnyitón jelen voltak: Pótsa Józseffőispán, Szentkereszti 
Béla országgyúlési képviselő, Szentiványi Miklós megyei föjegyzö, Zathureczky Gyula földbirtokos és mások. A villanyvilágítás fénye mellett megszemlélték a Nedoma építömester által ügyesen és szépen felállított épületeket, a krompachi vasgyárból szállított és ugyanott készített gépeket, a Ganz féle villanygépeket, a múhelyeket, a raktárat és a kazánházat. Mindenki az emberi munka bámulatos alkotó erején csodálkozott, hogy e lakatlan, elhagyott erdőségben oly bámulatos gyorsasággal, egy ezreknek kenyeret adó óriási iparvállalat létesült." (Székely Nemzet 1889/6. 3.)

A gőzgép és az áramfejlesztő generátor a fatelepek legfontosabb részei voltak. Kommandón és környékén a faipar fénykorában három fürészüzem létesült: József-fürész (Gyulafalva), Gábor-fürész (Kommandó)
Brackó-Musa-Ghermani-fürész (Musa). Minden egyes fatelepnek volt gőzgépe és áramfejlesztő generátora. A keretfürészeket gőzerővel működtették. A gőzgépek transzmissziós szíjakkal voltak ellátva, a gyártelepeken alagútrendszert építettek ki, és szíjak segítségével vezették a gőzerőt a gépekhez. A kommandói adatközlők még napjainkban is emlékeznek arra, hogy az alagutakat akkor tömték be, amikor a régi gyártelep helyére tömbházakat építettek az 1980-as évek elején. Az alábbiakban olvassuk el Sümegh Ignác 1898-as leírását az Erdélyi Erdőipar Rt. (Horn Dávid fatelepei) gépeiről:

„Gábor-fürész (Kommandó): A hajtőerôt szolgáltatja egy 250 lóerejü magas nyomású vasmüvel ellátott (Meyer-féle) iker-gőzgép a Nicholsontól. Gőzfejlesztésre szolgál 4 henger-

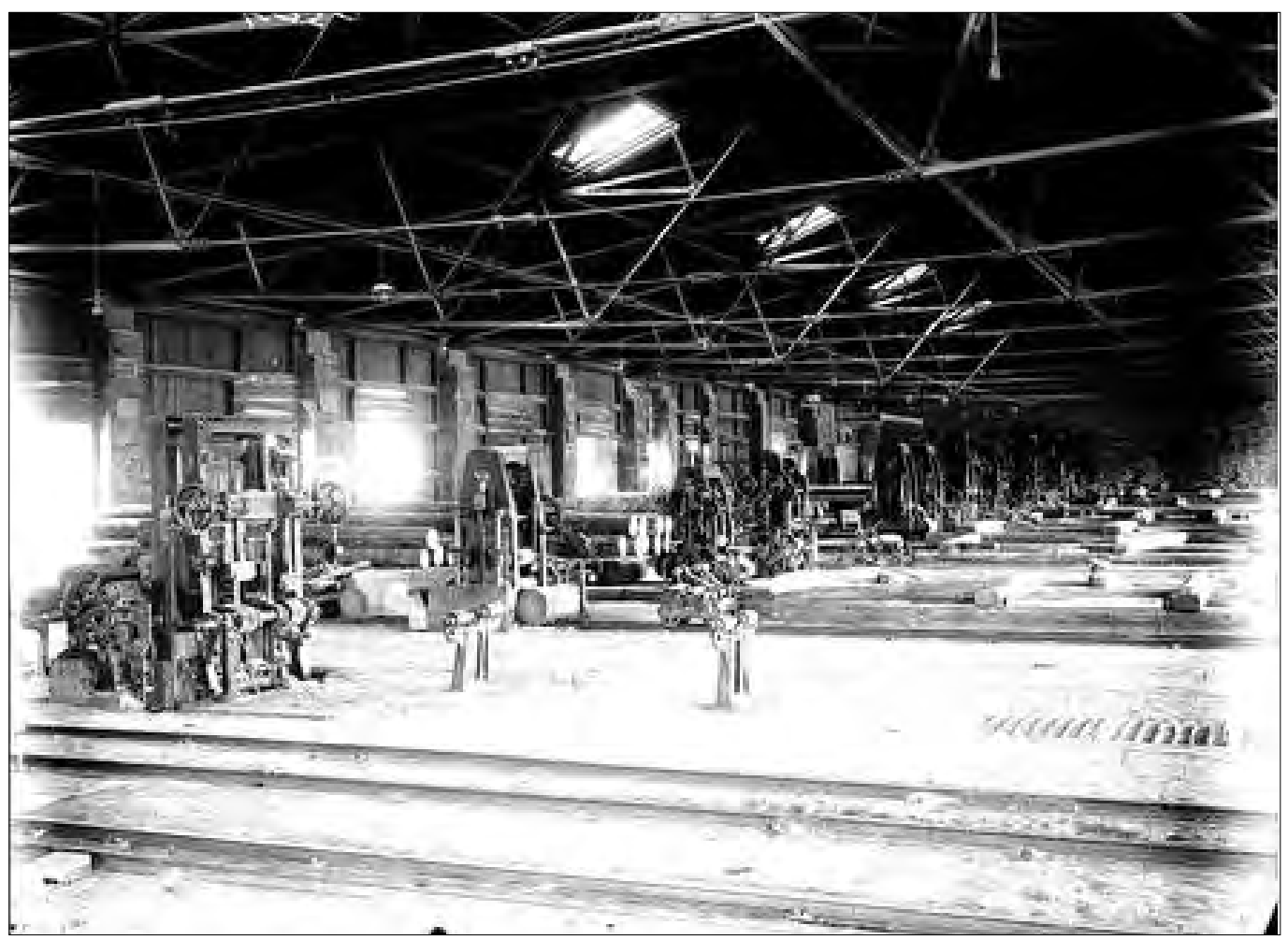

2. kép. Kommandoi gatterszín 1924-ben (Adler Leopold felvétele) 
kazán két elômelegítôvel $50 \mathrm{~m}^{2}$ fütôfelülettel a Nicholsontól. Villamos világításra szolgál egy 9 lóerejü gôzgép (Tangens-féle szabadalom), hajtja egy delta jegyü Ganz gyárban készült 100 amper és 110 volt feszültségü dinamógép. Előbbi tartalékul, utóbbi erőátvitelre szolgál.

József-fúrész (Gyulafalva): Gépházában van egy 150 lóerejü gőzgép fogaskerék átvitellel, egy szivattyú, ezenkívül van lakatos mühely egy esztergával és fúrógéppel.

Brackó-Musa-Ghermani nevü fürész berendezései: 250 lóerejú gőzgép Nicholsontól, 3 gőzkazán." (Székely Nemzet 1898.)

Az évek során változtak a gépek, a gyárak többször is leégtek, és köztudottan a történelem fordulatai, a háborúk, a határosztások mindenkor befolyásolták a vasútüzem sorsát. Tehát valószínű, hogy a későbbiekben is léteztek a fatelepeken hasonló gőzkazánok, generátorok, hiszen a kordokumentumok szerint 36 keretfürész múködött Kommandó fénykorában, vagyis 1924-ben, de források hiányában bővebb információt nem tudunk. Ugyanúgy arról sem tudunk, hogy a „Bükk-gyárban” milyen gépek voltak. A bükkfát feldolgozó gyár a második világháború után a kommandói központi gyár alegységeként saját kapcsolótáblával rendelkezett, mert a villanyáramot a fenyőt feldolgozó, puhafateleptől kapta.

Kommandón a gyár irányában volt a gépház, itt helyezték el a gőzgépet, az áramfejlesztő generátorokat, a kapcsolótáblákat, amelyek az 1889-1980 közötti időszakban a magasfeszültségi hálózat megjelenéséig az áramot szolgáltatták mind a gyáraknak, mint a településnek. A generátorok a kezdetektől a közvilágítást is ellátták, de háborús időkben a keretfúrészeket is villanyárammal működtették. Volt olyan időszak, amikor a faluban nem volt áram, mert a gőzgép teljesítménye nem volt elég a település és a gyár szükségleteinek ellátásához. A hangsúly mindig a vasútüzem megvilágítása volt. Az adatközlők emlékei szerint volt egy nagyméretű kapcsolótábla, amelyet a gépészek kezeltek. Kötelességük volt a villanyhálózat be- és kikapcsolása. Az utcákon villanyoszlopok voltak, amelyeken szintén kapcsolókkal indították a közvilágítást. Az utcai világítás ki- és bekapcsolása az éjjeliőrök kötelessége volt, de az éjjeliőrök óráit szintén a villanyoszlopokon található kulcs segítségével húzták fel, így igazolták szolgálatuk teljesítését.

Az alábbiakban Haszmann Pál visszaemlékezéséből idézünk egy rövid részletet:

„Mivel állandó éjszakai szolgálat volt, egy szoba az éjjeliöröknek volt fenntartva. Ezek vezetöje Török bácsi volt. Az öröknek börtokban tartott óra volt a nyakukba akasztva. Az óra úgy volt megszerkesztve, hogy abba egy papírszalagot helyeztek bele. A telep területén oszlopok voltak felállítva azokon egy bádogdobozban kulcs. Az órát megfelelő idôben csak azzal a kulccsal lehetett felhúzni, ami a szalagra rápontozta az idôt. E rendszerrel ellenőrizte az éjjeliôröket, hogy teljesítették-e a kötelességüket." (Haszmann Pál 1971.)

Az első, vagyis a Horn Dávid által hozatott csepeli gőzgép, amely 1957-ig múködött, kétkazános Ganz típusú hajógép volt. Ezt a gépet 1958-ban elvitték Piteşti-re, s ezután az áramot két August 23 és egy Škoda típusú dízelgenerátor biztosította. A mostani gőzgéproncs elődei: 1958-ban egy 70 lóerős Pojoriţa, 1961-ben egy 120 lóerős gőzgép Câmpulung Moldovenescről, amely 1967-ig működött, majd ócskavasba került. Az utolsó gőzgép, mely 1967-ben kezdte meg a múködését, egy kazános fürészkorpa üzemeltetésű volt. A generátor, amit 450 lóerővel hajtott meg, utolsó kezelője a nyugdíjas Zonda Jenő gépész volt. A gőzgép 1999-ig működött, ekkor eltörött a forgattyús tengelye, a javí- 
tásból már nem tért vissza Kommandóra. Valószínúleg ócskavasként végezte be pályafutását. A gyár órára pontosan 110 évig müködött (1889. október 17. 10 órától - 1999. október 17. 10 óráig).

A magasfeszültségű hálózat kiterjesztése után Kommandón egy ideig még élt a gőzgép. Kazánjában égették a hulladék fát és a fürészkorpát, de az áramfejlesztő generátor lendkereke csak akkor lendült működésbe, ha meghibásodott a magasfeszültségű hálózat, ráesett egy fa a vezetékre, vagy az erős szél összeverte a huzalokat, és rövidzárlat keletkezett. Ilyen esetben a helyi generátor csak a gyárat látta el villamos energiával. Megöregedett alkatrészei gyakran javításra szorultak, majd 1999. október 17-én 10 órakor a gyárral együtt végkép leállt. A fölöslegessé vált gépeket széthordták, napjainkban csak töredéke van meg az áramfejlesztő generátornak. A háromfázisos generátor a gyár leállásakor még működőképes állapotban volt, de a fémtolvajok a későbbiekben ezt sem kímélték, akárcsak a kapcsolótáblát.
Minden mozgathatót elvittek, széthordtak az élelmes fémgyűjtők. A régi, muzeális értékű WOLF típusú generátor 2006 márciusában (a gyár rövid üzemeltetésekor) még ott volt a pincében. Mostanra teljesen tönkrement az utolsó gőzgép is, akárcsak az áramfejlesztő generátor. Csupán roncsaik hevertek a félig összeomlott gépházban. 2012-2013-ban a fémtolvajok nemcsak a generátor roncsait, de még a mühely vasajtaját is elvitték. A két darab öttonnás öntvénykerék, vagyis a javításba vitt forgattyús tengely lendkerekei ott hevertek Kovásznán, a Perdi gyár udvarán. Miután ez a gyár is leégett, a lendkerekeknek is örökre nyoma veszett, bizonyára ezek is ócskavasként fejezték be életüket.

\section{Vízerőmű-tervezet}

A második bécsi döntés után Kommandó erdőterületeinek nagy része román területre került, ezért újabb módosításokat kellett figyelembe venni. Például vissza akarták állítani a katonai bázist, a turizmus lehetőségeit is latolgatták. A magyar állam a település

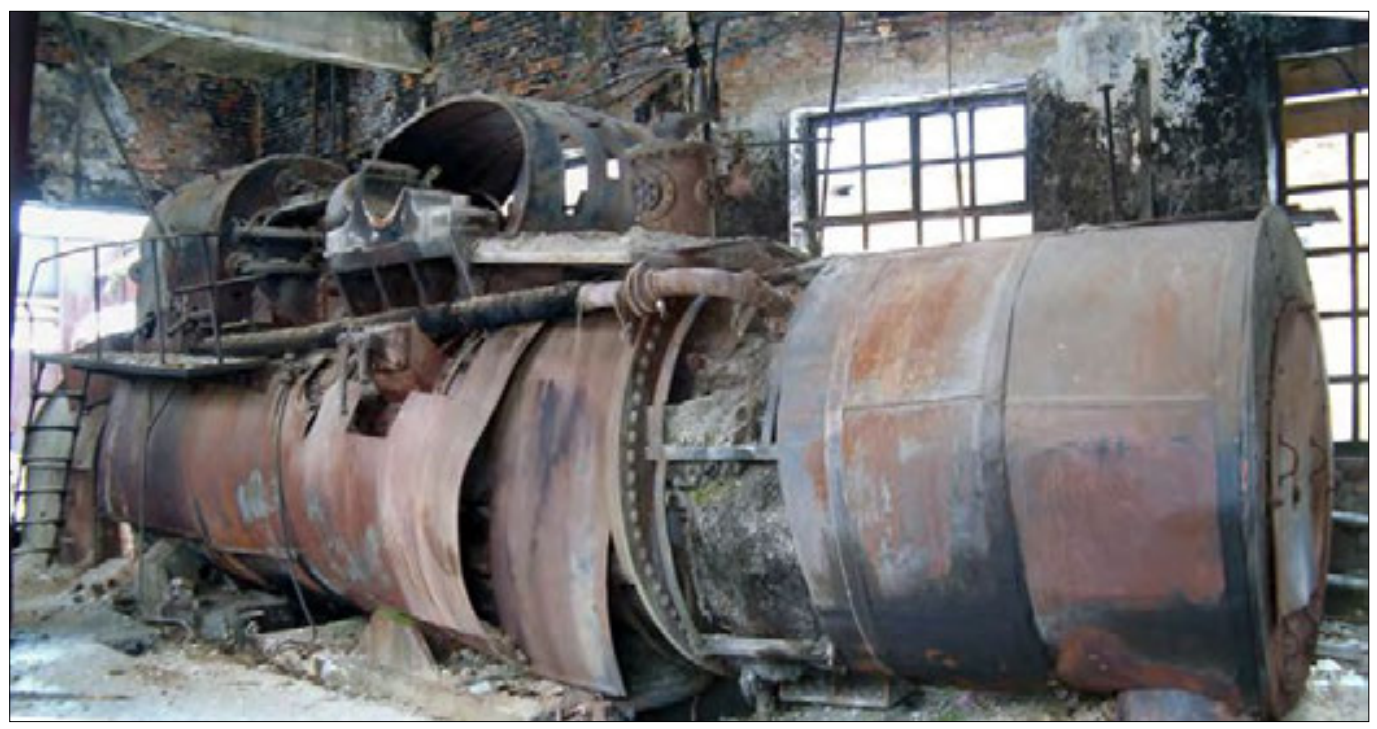

3. kép. Kommando. A gőzgép roncsai napjainkban 
másik természeti kincsét, a Bászka vizét akarta felhasználni, 1942-ben készült egy tervezet vízi erőmű építésére.

A Nagy-Bászka a háromszéki lapály fölött 550 méter magasságban folyik. Kedvező földtani helyzete révén a vízválasztót rövid alagúttal át lehetne törni, ami által a Nagy-Bászka vize a háromszéki lapály felé ömlene. Szakemberek szerint a víznek ide irányítása nem természetellenes, mert a környék vizei, amint megállapították, valamikor a háromszéki síkság felé folytak. Közben azonban földtani hátráltató erők támadtak, és a víz folyását Románia felé irányították. Tervek szerint a Nagy-Bászka völgye az Ölves- és Hagymás-patakok torkolata alatt gáttal elzárható. A mindenfelől körülzárt völgyben ezáltal tó keletkeznék, amely nemcsak a környékről jelentékeny tömegben lezuhogó vizekből, de a csapadékokból is meggazdagodnék. A tárolómedencébe 5 millió köbméter víznek kell beleférnie. Az ilyenfajta erőművek létesítésénél igen fontos az esés kérdése is. A lapály peremén elhelyezkedő előhegyek magassága nem éri el a Nagy-Bászka völgyének magasságát, ezt a rendelkezésre álló esését ilyenformán jól ki lehet használni, éspedig két lépcső beállításával. Egyik a kovásznai siklónál, a másik a Kapocs-hegynél lenne. Az előbbinél 400 m esés, a másodiknál 100 m állna rendelkezésre. Az erőműtelep évi erőtermelése 30 millió lóerő lenne. Háromszék falvai nagy részét villannyal lehetne ellátni a Nagy-Bászka vízerejének a felhasználásával, és ezáltal a jelenleg leállott üzemmel dolgozó kommandói munkások megélhetésre találnának.
A helyi adottságok olyanok, hogy az építésnél különösebb nehézségek nem merülnének fel. Az alapkövezet kárpáti homokkő, ez gátépítésre és víztárolásra alkalmas. A kiépítendő vízművek az iparvasút közelében lennének, tehát az anyag elszállítása is olcsón és könynyen történhetik. A vízmű kiépítése előzetes és hozzávetőleges számítás szerint 5 millió pengőt tesz ki. A nagyvonalú terv természetesen csak a háború után valósulhat meg. De az erőműteleppel nemcsak Háromszék falvainak a villamosítását lehetne megoldani, hanem üzemben tartásánál is hasznos lehetne (Szabó Mária 2004. 62.).

\section{Felhasznált irodalom}

Haszmann Pál: Kommandó. Megyei Tükör 1971.

Látó Anna: Honvágyam hiteles története. Kriterion Könyvkiadó, Bukarest, 1981.

Pótsa József (szerk.): Ezeréves Háromszék Vármegye. Emlékkönyv Magyarország fennállása ünnepére. Jókai nyomda, Budapest, 1889.

Rosta István (szerk.): Fejezetek a magyar technika történetéből. Nemzeti tankönyvkiadó, Budapest, 1995.

Szabó Mária: Kommandó monográfia. T3 kiadó, Sepsiszentgyörgy, 2004.

Székely Nemzet, VII. évf. 4. szám, 1898 jan. 6. Székely Nemzet, VII. évf. 6. szám, 1889 jan.15. Székely Nemzet, XVI. évf. 128. szám, 1898.

Székely Nép, LX. évf. 74. szám, 1942. április 1.

\section{Adatközlők}

Farkas Tibor (1952-2017) Kommandó

Szabó Dávid (1956) Kommandó

Zonda Jenő (1928-2010) Kommandó 


\section{A SZÉKELYFÖLDI CÉHEKRŐL}

„A város középpontján lévő nagy kiterjedésú piac egyike honunk legszebb vásárterének; kár azonban, hogy az oda épített városház, csizmadia- és tímárszínek által meg van szaggatva, stöbb részekre felosztva. Ennek északi részében van a Ferencrendiek kolostora nagy, kéttornyú templomával." (Orbán 1868. 52.)

Az elmúlt századokban a vásártereken találkoztak a vidéki lakosság mezőgazdasági termékei a város kézművesipari ${ }^{1}$ termékeivel. Szinte mindenki, aki megjelent a vásártéren, vásárló és ugyanakkor eladó is volt. Ezen túl az udvarhelyi vásártér jellegzetessége volt a sópiac ${ }^{2}$, ahol a parajdi bányában vásárolt sót adták tovább a sókereskedelemmel foglalkozó magánszemélyek. A „sópiac" rendezését 1670-ben az országgyülés törvény alkotásával kísérelte meg. ${ }^{3}$ A gabonapiacon az udvarhelyszékiek és a csíkiak vásárolhatták meg a város és a szék ellátásához hiányzó gabonát, ${ }^{4}$ a búzát a Szászföldről érkező gazdáktól, a rozsot a Hargitán átszekerező csíkiaktól. Ezek az egyszerűnek tűnő megállapítások a valóságban egy nagyon bonyolult, a privilégiumok sokaságában fuldokló, sok megkötöttséggel működő gazdasági rendszert takartak, amelyben az ipari termelést nagyobbrészt a céhek biztosították. „A városok piacterein álló »árulószínek « nyitását-zárását a szolgáló céhlegények kötelességévé tették a céhmesterek. Szigorú szabályok írták elő az eladás rendjét is: ki hol, mikor árusíthat, milyen árut és mennyit, és ezt felső fórumaik is gyakran megparancsolták, milyen árat kérhet termékeiért. Ezek a kőből rakott, fából ácsolt színek és sátrak voltak a hetivásárok, sokadalmak alkalmával, az országos nagyvásárokról nem is szólva, a földet müvelók ipari termékellátói. A különböző foglalkozási rétegek, hegybeli és síkföldi lakosok találkozási helyein - az árucsere forgalom empóriumain - tehát mind több és változatosabb árucikket igényelt a földet müvelö ember is." (Imreh 1979. 174-175.)

A vásárok vagy sokadalmak alkalmával a törvények, rendeletek és a helyi szokások betartatásáért a város felelt, amely rendszerint a vásárjog tulajdonosa is volt. A vásárjoggal rendelkező városokban a termelők (kézművesek, iparosok) mellett megjelentek a kereskedők. Nem tudjuk, hogy Székelyudvarhely mikor és kitől kapott vásárjogot. Az is lehetséges, hogy a székelyek letelepítésének forráshiányos időszakában a szükséglet hozta létre és szokások éltették tovább a vásárokat. $A$ vásárrendtartásokban írták le az időpontját, időtartamát. A vásárjog a városok egyik legfontosabb privilégiuma volt, bevételeket biztosított a közösség számára, és jövedelemhez juttatta a helyi lakosságot.

A városok arra törekedtek, hogy kiváltságaikat fejedelmi oklevélben biztosítsák. Bethlen Gábor a vásár jövedelmeit a városnak adta. I. Rákóczi György 1637-ben elrendeli, hogy idegenek 10 óra előtt gabonát nem vásárolhatnak az udvarhelyi piacon, ez a helybeli lakosságnak volt fenntartva. Ezért panaszkodtak is a csíkiak, akik innen pótolták a hiányzó termésüket. 

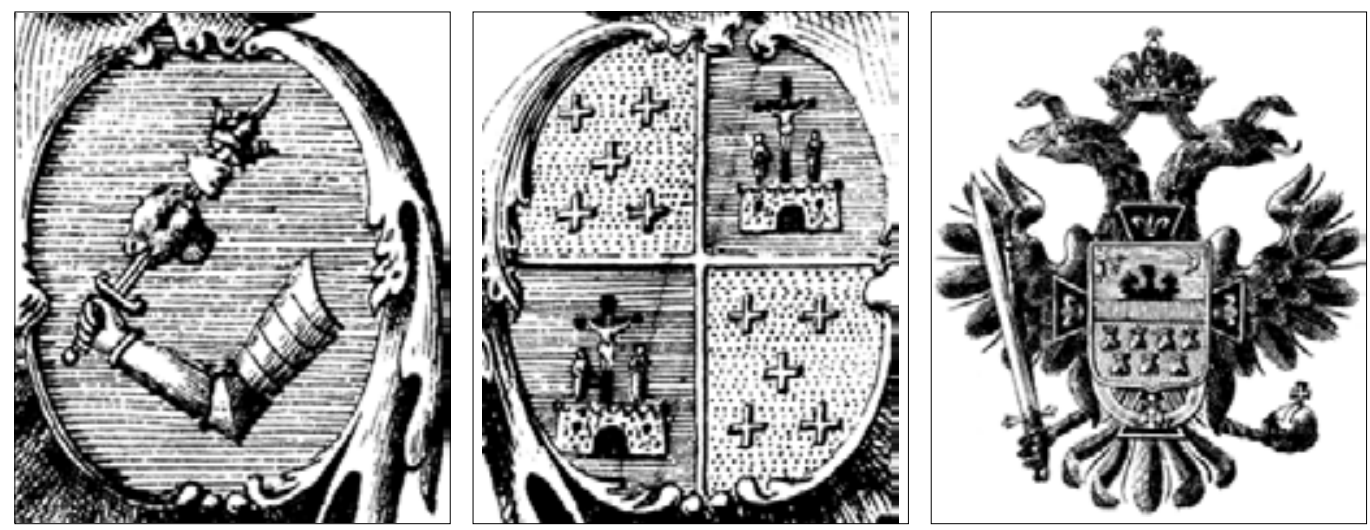

1. kép. Székelyudvarhely város, Udvarhelyszék és Erdély címere a mészáros céh I. Ferenc 1809. április 6-án adományozott statútumán (tusrajz)

Vásáros napokon a piactereket körülvevő állandó jellegű üzletekben is megnőtt a forgalom és vele együtt a bevétel. Ez történt a város vendéglőiben és a szolgáltatásokat nyújtó üzletekben (borbély) is. A piac közben differenciálódott. Külön területet kapott a fapiac ${ }^{5}$ vagy a baromvásár. A 19. század második felében egyre nagyobb súlyt kapnak a nagyállatvásárok.

Székelyudvarhely nagy központi terén és mellékutcáiban, a széles Botos utcában tartott vásárok regionális szempontból a termékek cseréjének legjelentősebb fórumai voltak. Lakatos István 1702-ben a Székelyföldről megjelent munkájában kiemelte a székelyudvarhelyi vásárok jelentőségét. Évente három országos vásárt tartottak, és minden kedden hetivásár vagy hetipiac volt. „Mind a kétféle vásáron dúskálni lehet csaknem mindenféle holmiban és pedig húsfélékben, fában, sóban, állatban, búzában, különféle hüvelyesekben, halakban, majorságban, az évszakhoz mérten más és más fajtájú gyümölcsökben, pogácsákban, portékákban és egyéb, az emberi élet fenntartásához és kényelméhez szükséges dolgokban." (Lakatos 1942. 12-13.) A templomukból kiszorult katolikusok a miséket a piacon tartották az iparosok sátrában.
Száz évvel később Szigethy Gyula Mihály, az 1670-ben alapított református kollégium neves tanára is megemlékezett a város és vidéke mesterségeiről: „ $A^{\prime}$ mesterségek $a^{\prime}$ nemes székben sokfélék, bővek, 's a székbeliek szüksége kielégítésére szinte elégségesek" - írta 1829-ben. - Udvarhelyen is vannak jó mesterek: „fáin selyem kalapokat készítő kalaposok; asszony s férfi köntös darabokat a legújabb módra csinálni tudó szabók, bör-leibit, ködmönt, kozsokat, bundát, kucsmát, börsapkát, kesztyüt készítő szőcsök, fényes módoson készült stibliket varró schusterek, kik külföldeken vitték mesterségbeli tanulságokat tökéletességre." Annak ellenére, hogy sok mesterember elhagyja mesterségét és kereskedelemre adja magát. Ennek oka „a pénznek szúkvolta, az életnek drágasága”, a mesterek viszonylag nagy száma a fogyasztók számához viszonyítva. A csizmadiák, szabók, vargák ronggyal, vassal, szalonnával, dohánnyal, borral, mézzel, bárány-, ló-, ökör-, juh- és kecskebőrökkel kereskednek. A báránybőröket szekérszámra adják el az örményeknek, vagy viszik Debrecenbe. A helyi mesterek csak másod-, harmadkézből jutnak hozzá, akkor is jó drágán. Legjobban jövedelmező mesterségek a kalapos, szappanos, a talpcsi- 
náló (érlelő) vargáké, a kenyérsütőké (pékeké), asztalosoké, akik „fáin rakott asztalokat, kaszteneket, divánokat, ládákat, töltött székeket sokszor válogatott fákból csinálnak", de sokszor készen is lehet ilyeneket találni. Az 1820-ban összeírt jobbágyvallomásokban a vásárokra is találunk kérdést és válaszokat. 1820-ban Udvarhelyszékben is végrehajtották a Cziráky-féle összeírást (Conscriptio Czirákyana) (Takács 2001). Az úrbéri összeírás egyik kérdése a látogatott vásárhelyekre vonatkozott. A kérdésekre adott feleletekből kirajzolhatjuk az egyes vásárok vonzáskörzetét. A székelyudvarhelyi vásárt elsősorban
Udvarhelyszék falvaiból látogatták. Vonzáskörzete gyakorlatilag lefedte az egész széket, kivéve az Erdővidéket és a Partiumot, a nyugati peremvidék falvait, ahol már gyengült a vonzereje. A vásárhiányos Kelet-Erdély „egyetlen fontosabb vásárközpontja Székelyudvarhely" (Sonkoly 2003. 168.).

Az udvarhelyi vásárt 1820-ban a városban lakó jobbágyok így jellemezték: „Itten esztendőnként négy sokadalmak és heti vásárok szoktanak esni, és ki-ki szabadoson mindenféle italt korcsomárolhat. Ezen conscribált részen ugyan a városnak boltok nincsenek, hanem lakosai nagyobbára mesteremberek,

1. táblázat. Udvarhelyszéki vásárok (Kozma Ferenc 1879; Kardalus János 1985; István Lajos 1977)

\begin{tabular}{|c|c|c|c|c|}
\hline Város, falu & Vásárjog & Országos vásár & Hetipiac & $\begin{array}{l}\text { Vonzáskörze- } \\
\text { tében lévő fal- } \\
\text { vak 1820-ban }\end{array}$ \\
\hline $\begin{array}{l}\text { Székelyudvarhely, oppi- } \\
\text { dum, taxás város, királyi } \\
\text { taxás város, r. t. város }\end{array}$ & eredete ismeretlen & $4+$ & kedd & 94 \\
\hline $\begin{array}{l}\text { Székelykeresztúr, mez̋ovvá- } \\
\text { ros, város, nagyközség }\end{array}$ & $\begin{array}{l}\text { 1. korai vásárjog-adomá- } \\
\text { nyozó ismeretlen } \\
\text { 2. Bécs }\end{array}$ & $\begin{array}{l}\text { február } 24 . \\
\text { május } 4 . \\
\text { szeptember } 14 . \\
\text { július } 7 .\end{array}$ & szombat & 44 \\
\hline Bögöz & 1868. március 12. & 4+1 marhavásár & & \\
\hline Etéd & $\begin{array}{l}\text { Báthori Zsigmond adomá- } \\
\text { nyozta 1593. április } 26 \text {-án }\end{array}$ & $4+1$ & egy & 16 \\
\hline Farkaslaka & & 2 & - & \\
\hline Homoródszentmárton & $\begin{array}{l}\text { I. Ferenc, Bécs, } \\
\text { 1808. január } 29 .\end{array}$ & $\begin{array}{l}\text { február } 24 . \\
\text { május } 16 . \\
\text { augusztus } 29 .\end{array}$ & 1 & 19 \\
\hline Korond & $\begin{array}{l}\text { Gróf Gyulaffy László } \\
\text { kérésére a szentdemeteri } \\
\text { vásárt tették át Korondra. } \\
\text { 1749. augusztus } 3 .\end{array}$ & $\begin{array}{l}\text { január } 25 . \\
\text { május } 13 . \\
\text { július } 4 . \\
\text { augusztus } 25 . \\
\text { november } 20 .\end{array}$ & szombat & 13 \\
\hline Oláhfalu & & & 3 & \\
\hline Oklánd & 1864 & & & \\
\hline Parajd & $\begin{array}{l}\text { Ferenc császár, } 1802 . \\
\text { november } 11 . \\
\text { A júliusit I. Ferdinánd } \\
1847\end{array}$ & $\begin{array}{l}\text { március } 19 . \\
\text { október } 15 . \\
\text { december } 17 . \\
\text { július } 26 .\end{array}$ & csütörtök & 13 \\
\hline Zetelaka & & & & \\
\hline
\end{tabular}




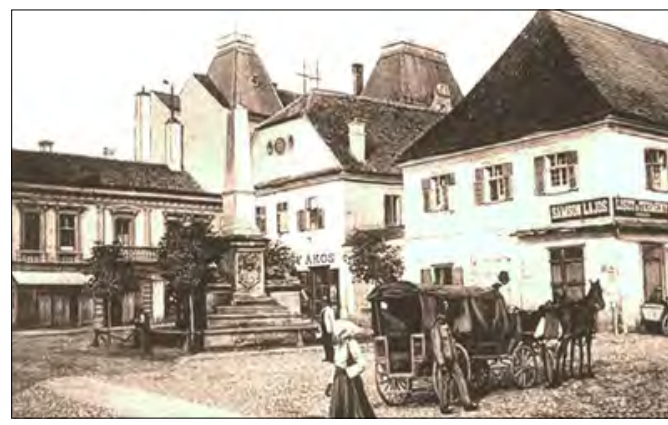

2. kép. Székelyudvarhely piactere a 20. század elején a millenniumi emlékoszlop és a városháza látványával. Háttérben a „barátok” temploma

akik taxát fizetnek. Hanem, mivel ezen része a városnak a többi részével egy contiquitásban vagyon, a városi boltok és céhok hasznaival élnek. Ugyanazért azok, s egyéb beneficiumot importálók is felvétetvén. Vagynak a városon nagyobb kereskedőboltok 5, apróbb boltok 22, vasáruló boltok 2, borbélymühely 2. Mesteremberek többnyire lakosai, kiknek vagynak cehái: 1-o. csizmadia, 2-o. talpkészítő tímár, 3-o. kordovány készítő tímár, 4-o. szabó, 5-o. szőts, 6-o. kalapos, 7-o kovács, lakatos, 8-o. szígyártó, 9-o. kőmíves, 10-o. mészáros céhok 11-o. két szappanyföző, 12-o. egy takács, 13-o. sok ács mesterember, 14-o. serföző 3" vallották a székelyudvarhelyi vallomástevők (Takács 2001. 158.). „Udvarhely városa ide gyalog fél óra. Ökörrel menve egy óra járó distantia, ahová mindenütt csinált, töltött úton visszük a természetnek minden jovait, és minden vásárvám nélkül commoda distrahálylyuk." (Takács 2001. 161.) Bethlenfalva lakói jól kihasználhatták a piac közelségét és a kövezett út előnyeit.

Az 1895-ben a városba kebelezett Szombatfalva számára is előnyös a város közelsége. „Udvarhely városában ki-ki szabadon hordja a tüzifát, feleségeink tejet, tojást, vajat, tyúkot, csirkét és veteményt hordanak eladni.

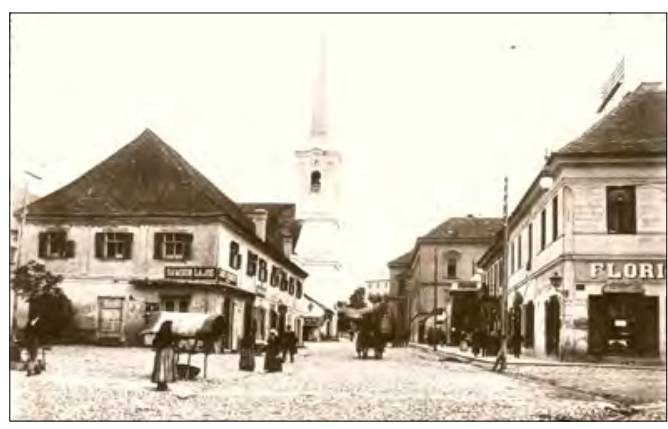

3. kép. A székelyudvarhelyi piactér déli oldala az „árulószinnel” és a Kossuth Lajos utca bejáratát jelző Flórián üzlettel

Emellett most a havasunk el lévén pusztulva, a szomszédos havasos faluktól vagy pénz[z]el, vagy a nyereségből fordulandó gabonával fenyôt árendálunk ki, és abból boronafát, edényeket, szőlőkarót és más müveket csinálunk, s hordjuk eladni. És az ezekből jövő nyereségból segítünk a határunk terméketlenségin." (Takács 2001. 197.)

A Székelykeresztúr szomszédságában lévő Csekefalva lakói számára is Udvarhely és Segesvár volt a „vásáros hely”. Keresztúrt így említették: „egy harmadik hetivásáros hely is, éppen a szomszédban” (Takács 2001. 245.). A kisgalambfalvi jobbágyok számára is Székelyudvarhely és Segesvár a vásáros hely. „Valamiképpen ezen két városokban az ottan található mesteremberek által egy falusi gazdaember minden házi környülállásaira nézve megkívántató dolgokat és szükségeket kipótolhat és megszerezhet." Itt is harmadiknak említik a keresztúri vásárt, amely legközelebb van a faluhoz: „Vagyon még egy harmadik és hasonló vásáros hely, úgymint Keresztúr, amely ide egy órányi járóhely, holott is apróbb dolgokat lehet szerezni és eladni." (Takács 2001. 260.)

A déli irányból, a Homoródok völgyéből Székelyudvarhelyre vezető út mellett a pa- 
takfalviak sajátos pihenőhelyet alakítottak ki. „Hanem a Serestető nevezetü hegy, az Udvarhely felé menő út ott mégyen el, -szabadoson korcsmárolhat ott akárki, mikor sokadalom esik a városban." (Takács 2001. 148.) A szombatfalviak is kihasználták a vásáros hely közelségét, „van a város mellett egy bocskoráruló helyünk melyért árendát fizetnek". (Takács 2001. 195.).

„Udvarhely, az hová is innen Lövétéről szekérrel nem vihetünk semmit eladni a nagy hegyek mián. Hanem marhát, mikor sokadalom esik, elhajthassuk, el is adhassuk. [...] Ez utak mind alkalmatlanok, hegyes és völgyes helyek." (Takács 2001. 88.)

A lövéteiek vallomása figyelmeztet a vásározás nehézségeire. A jó, kövezett utak hiánya fékezte a pénzforgalom nagyobb fokú elterjedését. A kisparaszti gazdaságokban igyekeztek minden szükségest megtermelni, és csak a legszükségesebb árucikkekért mentek a vásárba.

„Különben Homoród Szent Márton a két Homoród mellékének legvirágzóbb községe, mit leginkább látogatott országos sokadalmainak lehet feltudni. Homoród Szent Márton sokadalmait Ugron Pál, Kováts László és Lukácsfi Elek közbenjárásukra és kérelmükre engedélyezi I. Ferenc Bécsből 1808-ban, jan. 29-én maga, gr. Teleki Sámuel és gr. Eszterházi János aláírása alatt kelt okmány által. Engedélyezett pedig három országos sokadalmat, elsőt sz. Valens napjára vagy február 24-ére, másodikat Nep. Sz. János napjára vagy augusztus 29-ére. A fökormányszék kihírdette azt 1808. év szept. 8-án tartott ülésében. Az okmány hiteles másolata megvan Baróthon Zathureczki Lászlónál. Homoród-Sz. Márton sokadalmai nagyon látogatottak, a két Homoród mentén csak is ezen egyetlen vásáros hely lévén. $B a-$ romvásárai árszabályozók a Székelyföld nagy részére nézve."

A szombatfalviak és más falvak lakói is panaszkodtak, hogy a só oly drága lett, hogy nem érdemes kereskedni vele, pedig ez korábban jövedelmező volt. „A sóakna ide két mérföld, s amég így meg nem drágult a só, addig inkább kereskedtünk vele, de most a házunk szükségére valót is alig tudgyuk kiszerezni." A kincstár tulajdonát képező sót, amely a parajdi bányában bőven volt, egyre drágították, míg olcsóbb lett a Moldovából csempészett só (Takács 2001. 197.). A székelyudvarhelyi vásárok sajátossága volt a sóvásár. A vásártér északi részén volt a sóvásártér, ahova a parajdi sót hozták és árusították. A Sópiac utcában volt örökölt háza Téglás Györgynek a 18. század közepén (Téglás 1910. 54.).

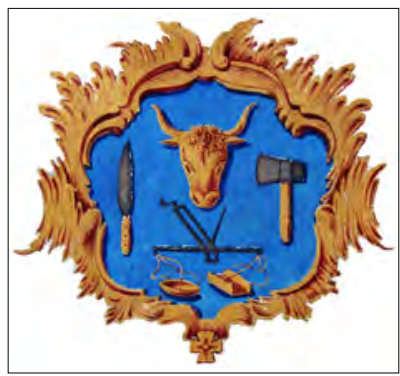

4. kép. Mészároscímer a céhprivilégium dísze

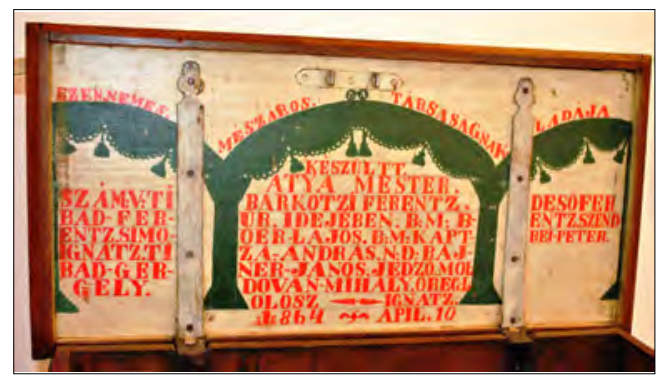

5. kép. Mészároscéhláda fedelének belső feliratos oldala (1864)

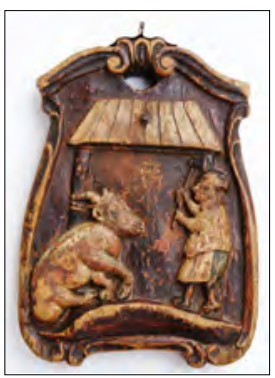

6. kép. Mészárosbehívótábla elólapja 
„A' parajdiak és sófalviak kereskednek föképpen Udvarhellyre fél másás és kisebb darab kô sókkal: ott helyben kaphatni apró darab sót is vékájába. A kő sókat vagy Parajdon adják el az oda egyenesen ment szekereseknek, vagy Udvarhelyre hordják, kiktől a székbeliek, közel fekvő szász helységek, Tsikiak, Háromszékiek, Erdővidékiek szekerekkel veszik, s' hordják haza, fél másáért öt Rforintokat adván váltó tzédulában." (Szigethi 1831. 84.) „Itten a sóbánya az falunkban vagyon, mellyel szabadon lehet kereskedni. Udvarhelyig jó úton, másfelé pedig alkalmatlan úton. Deszkával, léccel s más egyéb fenyőfa eszközökkel is szoktak pénzt keresni. Nevezetesen házi sót is adnak a kamarától minden gazdaembernek a háza népe s marhája menynyisége szerént, melyért pénzt nem kell adni.
Ezeken kívül még kereskednek a gyergyai, vagyis borszéki borvízzel, melyet elvisznek Kolosvárig, Vásárhelyig, s másfelé is, ahol becses ezen borvíz, s jó áron eladgyák. Szabad a colonusoknak a mészárlás, halászat, korcsomállás és a vadászat, a pálinkafözés is, mikor nem tiltatik." (Takács 2001. 227.) Így számoltak be a só-és ásványvíz-kereskedelemről a parajdiak.

A vásár jellegzetes színfoltja a borvízárus volt, aki a távolabbi Borszékről hozott vizet szekerekről árulta, de hoztak ásványvizet a közeli Szejkefürdőről is. „Közben-közben találkozunk egy borszéki borvizes emberrel, ki egyre-másra hat krajcárral adja a borvizet literes üveggel, melyet másutt az üzérek kapzsisága miatt méregdrágán lehet kapni." (Laukó 1888. 395.)

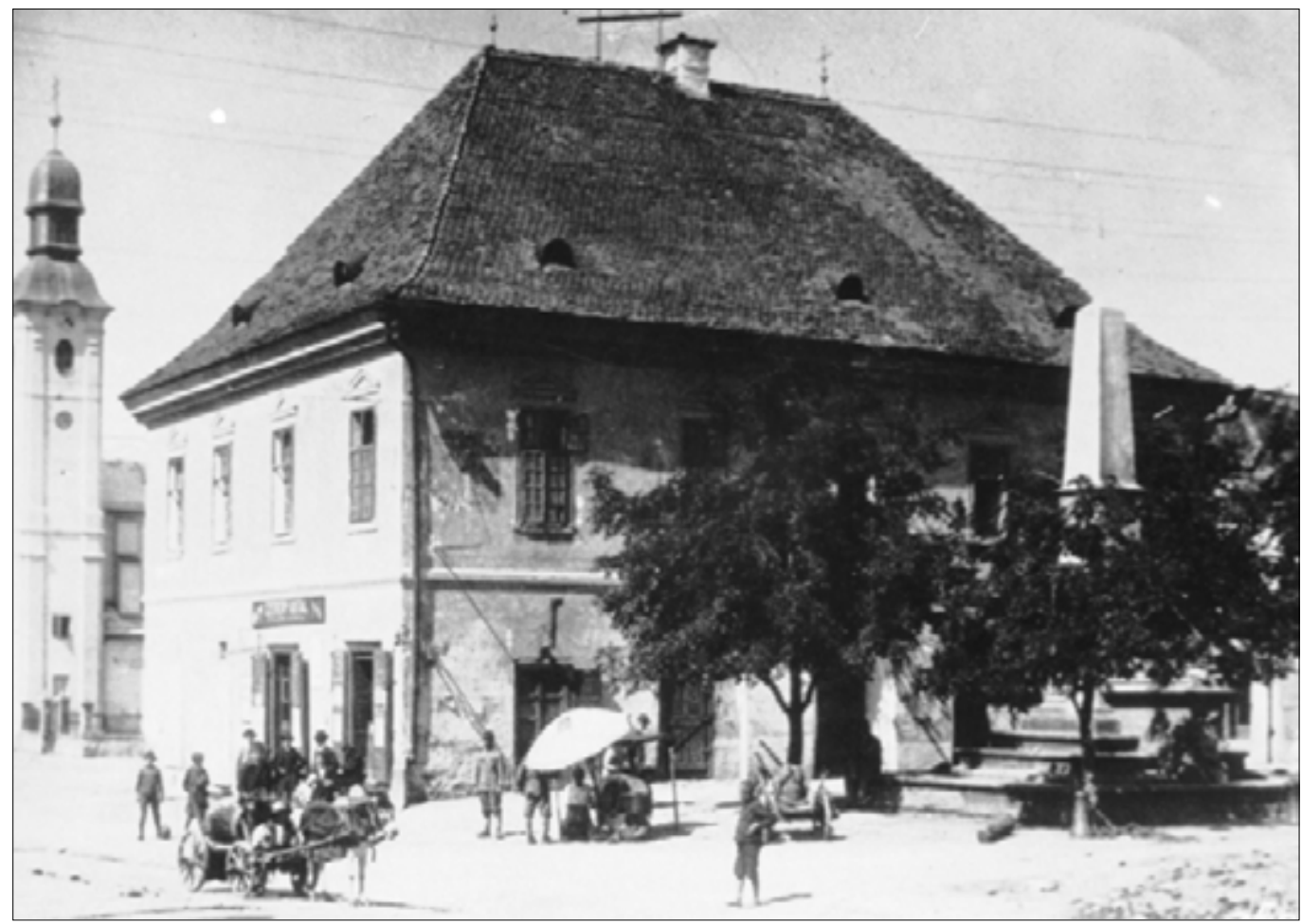

7. kép. A milleniumi emlékoszlop Székelyudvarhelyen, háttérben a vármegyeháza a céhek árulószinjeivel, elötérben az omnibusz 
A székelyudvarhelyi vásárok más nevezetességeit emeli ki 1842-ben Nagy Ferenc a Kolozsváron kiadott Mentor. Erdélyi népkönyv, közhasznú ismeretek tára című gyakorlati ismereteket közlő kiadványban. „Székely Udvarhely. Vásárait két dolog nevezetesíti. Asztalosi mestermívekre való igen szép cseresznye-, kőris- és diófadeszkát Udvarhely s környékén gyakran feles számmal lehet találni. Vásáraiban az Oroszhegyen s Sóvidéken termő eredeti, székely fajtájú lovakat noha nem nagy mennyiségben, az ahhoz értö megismerheti." (Nagy 1842. 338.)

Ugyanitt a székelykeresztúri vásárok esetében a májusi juhvásárt emelték ki és a régen nagyszámban felhozott, helyben készített szitákat (Molnár 1974. 186-189.).

Etédnek a szarvasmarhavására a legfonto- sabb. 1908-ban Székelyudvarhely belügyminiszteri engedéllyel juhvásárok szervezésére kapottengedélyt. Ezeket minden éváprilis 1011-12-én és szeptember hónap 28-29-30-án rendezték. Az udvarhelyi vásárok rendjéről sem sokat tudunk. Késői vásárrendtartása csak 1893-ban jelent meg (Zepeczaner 2010). Feltételezhetjük, hogy a vásárosok elhelyezésében nem történtek nagy változások. Ez nem jelenti azt, hogy korábban ne lettek volna szabályozva vásárai.

A piactér esős időben sáros volt, és csak a 19. század első éveiben kezdték el kövezését. „A Botos-utcza üsmég végig kővel kirakatott” 1817-ben, majd „A Bethlen-utcza is kiköveztetett, kirakatott" 1818-ban, Keszler Daniel bíróságában „a Botos-utcza végétől a Bethlen utcza végéig a ref. templom és collegium

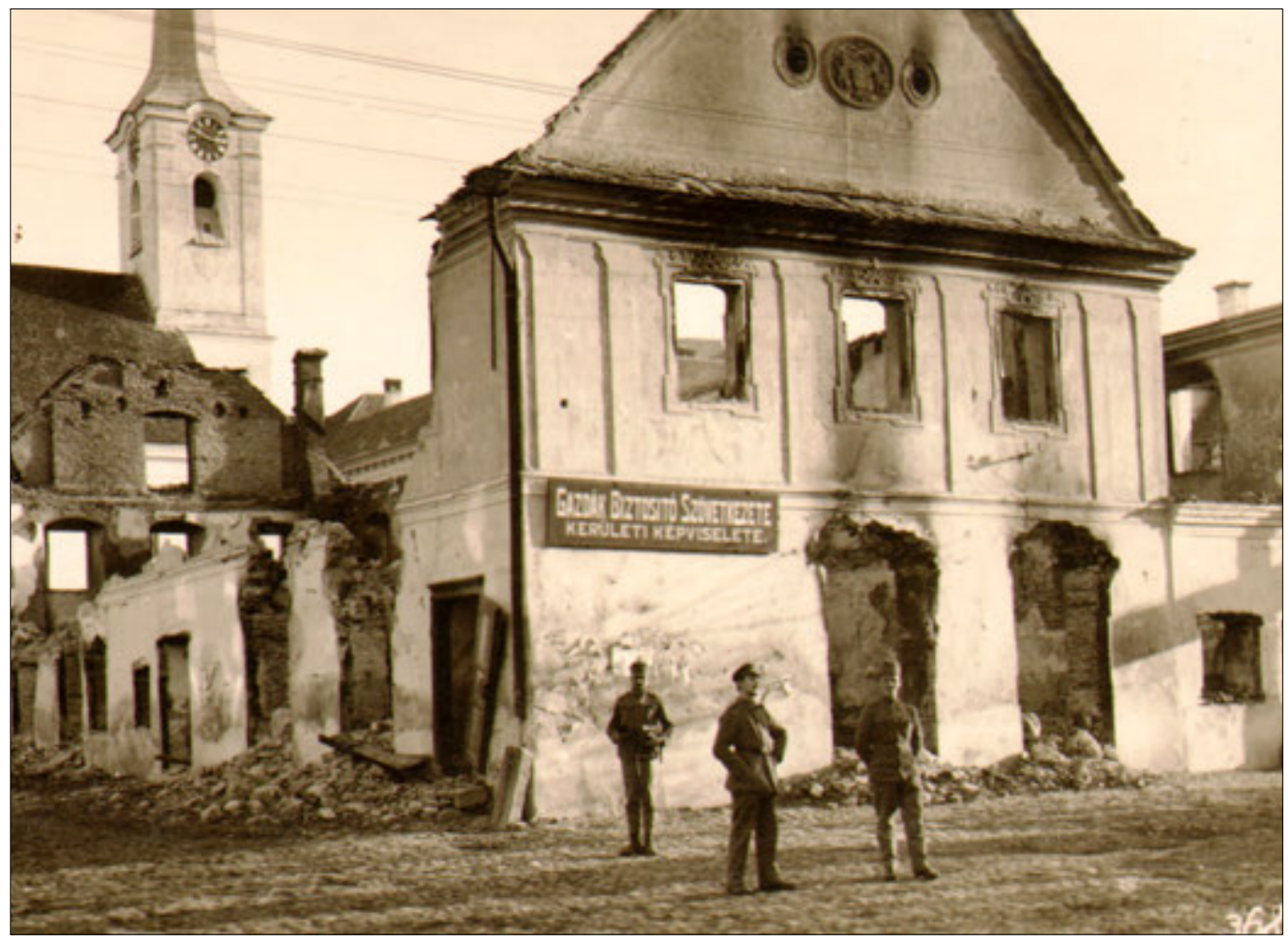

8. kép. Az 1916-ban leégett székelyudvarhelyi árulóhelyek 

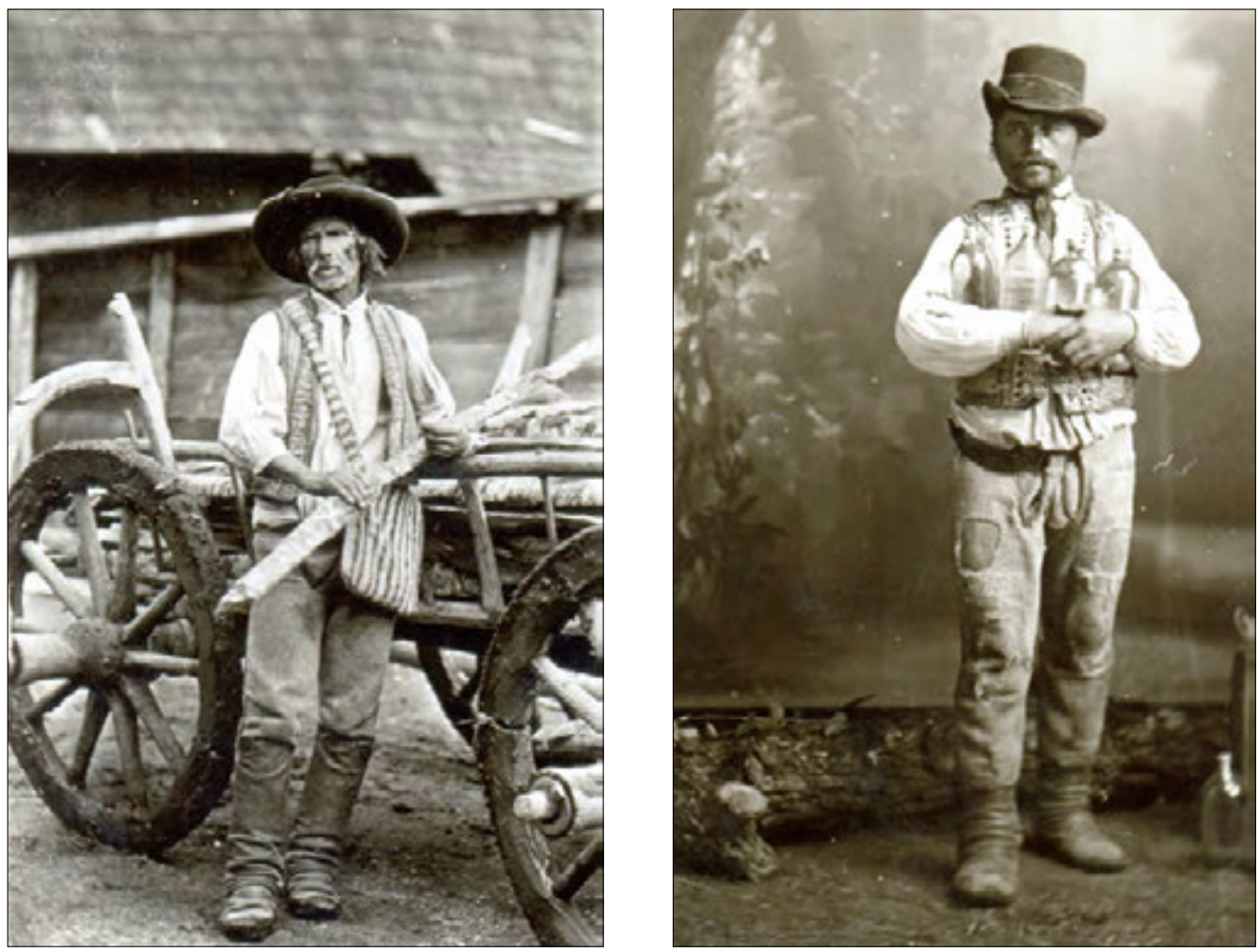

9. kép. Az székelyudvarhelyi vásár jellegzetes alakjai a zetelaki tüzifaárus és a borvízárus

elôtt kővel kirakatott" (Szeles -Szájdler 1898. 602.). A vásárterek használatára vonatkozó igények megerősödése a városiasodás terjedéséhez is hozzájárult.

Homoródszentpéter: „Emporiumai ezen helységnek vagynak. Legjobb Udvarhelly, melly ide szintén másfél mérföldnyire esik. Az hol jó hetivásárok és sokadalmak vagynak vagy esnek. Oda járunk adni, venni, s ott mindent adhatunk, vehetünk jutalmason."

Patakfalva: „Hanem a Serestető nevezetü hegy, - az Udvarhely felé menö út ott mégyen el - szabadoson kocsmárolhat ott akárki, mikor sokadalom esik a városban."

Székelyföldön három város érte el a gazdasági, társadalmi élet fejlődésének azt a szintjét, ahol már megvoltak a feltételei a céhek létrejöttének. A céhek statútumok, privilé- giumok alapján múködő, önkormányzattal rendelkező, feudális jellegű termelőegységek voltak. Megalakultak a statútumok előírásainak betartatásával a tagok, mesterek jogainak védelmére. Téves az az elképzelés, hogy a céhek csak az idegenektől, a külső veszélyforrásoktól védték a tagjaikat. A céhek nagyon szigorúan betartatták szabályzataikat, amelyek átszőtték a tagok életének minden síkját, ugyanakkor a munkát mindenki maga végezte, a maga kockázatára. A rendtartások nem engedték meg a nagyobb mozgásteret a tagoknak és a céh elöljárói számára. Minden határozathozatal és annak végrehajtása is a céh nyilvánossága előtt történt, és ez a szabályok áthágását mindenki számára lehetetlenné tette. A céh hozzájárult a közös érdekből fakadó szükségletek kielégítéséhez - mint a 
2. táblázat. A székelyföldi céhek alakulása és osztályozása a felhasznált nyersanyag szerint

\begin{tabular}{|c|c|c|c|c|}
\hline & $\begin{array}{l}\text { Marosvásár- } \\
\text { hely }\end{array}$ & Székelyudvarhely & Kézdivásárhely & $\begin{array}{l}\text { A mesterség } \\
\text { latin neve }\end{array}$ \\
\hline \multicolumn{5}{|c|}{ Élelmiszer- és vegyi alapanyagok feldolgozása } \\
\hline mészáros & 1493 & 1630 & 1809 & lanio \\
\hline szappanfőző & 1749 & & & saponarius \\
\hline \multicolumn{5}{|c|}{ Fémfeldolgozás } \\
\hline kovács & 1519 & & & fabros \\
\hline lakatgyártó & 1581 & 1613 & & faber serrarius \\
\hline ötvös & 1632 & & & aurifaber \\
\hline csiszár, fegyverkovács & 1615 & & & politor \\
\hline pajzskészítő & 1615 & & & \\
\hline üstgyártó & & & 1844 & ahenarius \\
\hline \multicolumn{5}{|c|}{ Bőrfeldolgozás } \\
\hline csizmadia & 1629 & 1635 & 1639 & coturnarius \\
\hline nyerges & 1519 & & & sellipares \\
\hline tímár- és varga- vegyes céh & 1519 & 1577 & & sutores \\
\hline szíjgyártó & 1519 & 1779 & 1813 & coriagiatores \\
\hline szűcs & 1513 & 1579 & 1649 & pellifices \\
\hline tímár-varga & 1584 & & 1572 & cerdo \\
\hline cipész & & 1863 & & sutor \\
\hline kordovános & 1800 & 1818 & & \\
\hline \multicolumn{5}{|c|}{ Textilanyagok feldolgozása } \\
\hline erszényes & 1657 & & & zonarius \\
\hline süvegesek & 1657 & & & petararius \\
\hline gombkötő & 1670 & & & nodularius \\
\hline kalapos & 103 & & & pileator \\
\hline kötélverő & 1579 & & & restio \\
\hline Szabó & 1586 & 1606 & & sartores \\
\hline takács & & & & textor \\
\hline \multicolumn{5}{|c|}{ Építők és fafeldogozás } \\
\hline asztalos & 1607 & 1779 & 1846 & mensarius \\
\hline ács & 1818 & & & faber lignarius \\
\hline hüvely- és tokkészítő & 1730 & & & vaginarius \\
\hline kádár, bodnár & 1601 & & & vietor \\
\hline bognár, kerekes & 1607 & & & rotarius \\
\hline kőműves & 1817 & $?$ & & lapicida \\
\hline \multicolumn{5}{|c|}{ Agyag nyersanyag feldolgozása } \\
\hline fazekas & 1616 & 1572 & 1649 & figulus \\
\hline \multicolumn{5}{|c|}{ Szolgáltatások } \\
\hline borbély & 1591 & & & chyrurgus \\
\hline \multicolumn{5}{|c|}{ Csont, szarv feldolgozása } \\
\hline fésűs & 1783 & 1779 & & pectenarius \\
\hline \multicolumn{5}{|c|}{ Egyéb } \\
\hline kalmár-boltos & & 1683 & & mercator \\
\hline kalandosok (Boldogasszony céh) & 1657 & & & \\
\hline szántók, földművesek & 1519 & & & agricolarum \\
\hline
\end{tabular}


nyersanyag beszerzése, a vásárhelyeken az árulóhelyek biztosítása és újak szerzése, a felnövekvő munkaerő képzése, a munkaerő egyenlő elosztása, kontárok megfékezése, -, de nem járult hozzá a műhelyekben folyó munka szervezéséhez.

Az iparügyekkel, pontosabban a céhügyek felügyeletével, intézésével felsőfokon a kancellária foglalkozott. „Iparügyekkel már foglalkozik a kancellária. Ezek legnagyobb részét céhügyek teszik: rendelkezések a céhszabályok betartására, városi céh kiváltságainak védelme a külső mesteremberek ellen, vagy éppen a falusi mesterek, céhek müködésének biztosítása a városi céhekkel szemben, falusi mesterek felvétetése a városi céhekbe, városi mesteremberek közti jogvitákban hozott döntések végrehajtása, céh intése a kiváltságaival járó kötelezettségek ellátására." (Trócsányi 1980. 226.)

A kézművesipari termékeket a céhekbe szervezett mesterek és a nekik dolgozó inasok és legények állították elő.

Az udvarhelyi céhek leírására Szeles János, Udvarhely városbírája is kitért várostörténeti munkájában (Szeles-Szájdler 1898. 529534.).

A három székelyföldi céhes városban a céhek századokkal később jöttek létre, ha öszszevetjük a szász városok céheivel, és még nagyobb a lemaradásuk, ha a nyugat-európai céhekkel hasonlítjuk össze őket.

A kézművesek számára a céhtagság nagyon hosszú időn át előnyös volt. A céh biztonságot teremtett, a szervezeten belül is, mert megakadályozta a nagy vagyonok kialakulását, hogy a nyersanyagok és a piacra vihető termékek kisebb csoportok kezében összpontosuljanak, monopolhelyzet kialakulását. Az inasok és legények egyenlő elosztásával elejét vették annak, hogy egyes mesterek aránytalanul nagyobb jövedelmet realizálja-

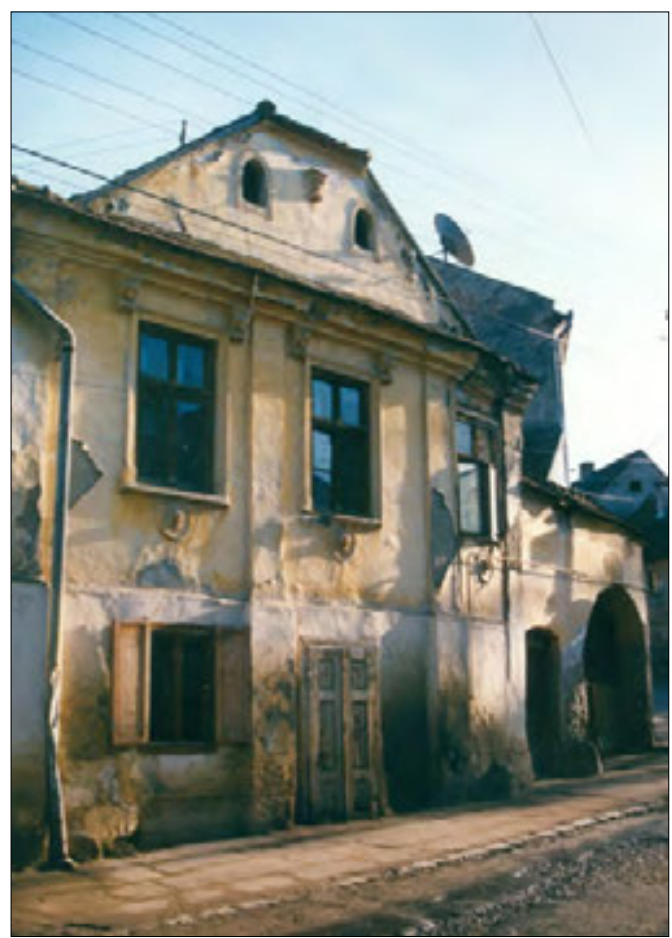

10. kép. Lakóház és mühely a székelyudvarhelyi Szentimre utcában

nak a nagyobb mennyiségű termák előállításának következtében. Joggal megállapíthatjuk, hogy céheink később jöttek létre, mint a hasonló német, francia, angol intézmények vagy akár az erdélyi szász céhek. Azonban a helyi társadalom fejlődése is elmaradott volt. A céhek összhangban voltak a társadalom fejlődésével. Késői megszüntetésük (1872) összefügött a társadalom állapotával, amely 1848-ig, sőt bízvást mondhatjuk, hogy a 19. század végéig hurcolta magával a feudális rendi társadalom örökségét.

A Maros völgyében települt Marosvásárhelynek volt a Székelyföld települései között legelőnyösebb a földrajzi fekvése. Legkorábban itt láthatók a városiasodás jelei. Mátyás király privilégiumai (három országos sokadalom tartására adott vásárjogot), majd a 


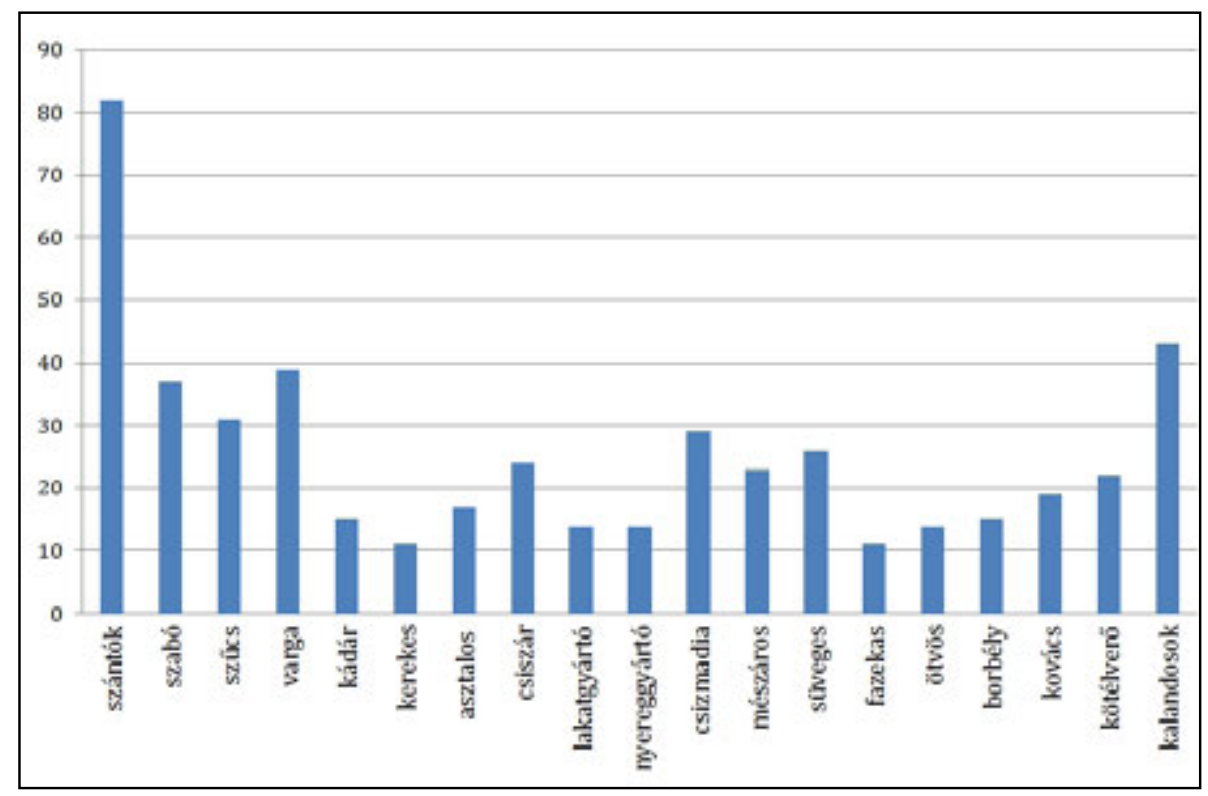

1. ábra. Székelyudvarhely társadalma a 17. században

II. Ulászló, Izabella és János Zsigmond által adományozott kiváltságok előkészítették a mezőváros előrelépését a szabad királyi város rangjára, amit Báthori Gábor fejedelem adományozott 1616-ban. Itt alakult meg az első székelyföldi céh is, amit a mészárosok alapítottak 1493-ban. 1519-ben a szabócéh mellett felsorolták a mészáros-, varga-, szűcs-, kovács-, gyapjúszövő-, takács-, nyerges-, szíjgyártó- és a földművescéheket.

Privilégiumlevelet ${ }^{6}$ a szűcsök 1513-ban, a szíjgyártók 1537-ben, a kötélverők 1579-ben, a lakatgyártók 1581-ben, a tímárok és vargák 1584-ben, a szabók 1586-ban kaptak. A következő században a kádárok-kerekesek és asztalosok közös céhe mellett a csiszárok és pajzskészítők 1615-ben, a fazekasok 1616-ban, a késesek 1629-ben, a csizmadiák 1629-ben és az ötvösök 1632-ben kaptak engedélyt céhalapításra.

A vargák 1607-ben, a szücsök 1608-ban, a nyereg- és szíjgyártók 1615-ben, a szabók 1620-ban, a lakatgyártók 1653-ban megújít- tatták kiváltságaikat. Céhet alapítottak a borbélyok 1628-ban és a kovácsok 1641-ben. Egy 1657-ben összeállított jegyzék szerint 19 céh dolgozott összesen 486 taggal a városban (Bónis 1997; Paál 2009; Paál 2014).

A 16-17. század fordulója háborúkat, a háborúkkal együtt járó éhínséget, járványokat, a lakosság számának csökkenését hozta magával. A következő években, de legerősebben Bethlen Gábor (1613-1629) és I. Rákóczi György (1630-1652) uralkodásának éveiben a gazdasági élet helyreállt és megélénkült. A fellendülésnek és gyarapodásnak II. Rákóczi György meggondolatlan, véres lengyelországi kalandja vetett véget.

Székelyudvarhelyen 1572-ben a város elöljárói - első ízben a város történetében - elfogadták a fazekasmesterek bemutatott kérését, és statútumot adtak a megalakuló fazekascéhnek. Ezt 1613-ban Báthori Gábor átírta, megerősítette és pergamenre írva újra kiadta. Innen ismerjük a korábbi szövegét, mert az eredeti oklevél elveszett (RNL Fond 249). 
A szokásos latin bevezető rész után következik az 1572-es magyar nyelvű oklevél bemásolt szövege: „My vduarhely biro Zabo Balas, eskwt tarsaival egietemben, ugy mint Zabo Thamas, Zeoch Mate, Zabo Jstvan, Melegh Leörincz. Adgiuk emlekezetre mindeneknek az kiknek illik ez leuelnek rendiben, hogy minekwnkre es faratsagunknak altala engette ez my capitan vrunk Banff? Farkas eo nagysaga, hog? az Vduarheliben lakozo fazakas mestereknek tudni illik Fazakas Peter, Fazakas Janos, Fazakas András, Fazakas Ambrus, Fazakas Pall es Fazakas Balasnak ceh leuelet adnank es eö keozeotteok rendet szabnánk. My annak okaert az keozeonseges igassagot megh gondoluan es egieb uarosoknak priuilegiumat es rendtartasat megh tartuan, teottwhk illien vegezest."
Ezután következnek az első udvarhelyi céhstatútum pontjai (átírt szöveg):

„Elöször. Mikor idegen mester ide, az városra be jön, mívelésnek okáért, addig az mühöz ne foghasson akaratuk ellen az céh mestereknek és a fazakas mestereknek, hanem négy forintot adjon a céhbe, kétszer tiszteljen. Az elsô tisztelés legyen öt tál étek, egy pecsenye, négy veder bor, cipó, kalács elég. A második tisztelés legyen hat tál étek, pecsenye, cipó, kalács elég és hat veder bor.

Másodszor. Ha mely idegen mester az levelet magyaráztatni akarja el nem hivén a mesterek szavát, egy forintot tegyen le, a levelet úgy magyaráztathassa meg.

Harmadszor. Ha valamely ifjú mester a városra bejön, esztendönél és három napnál tovább ne legyen szabad mívelni, tisztelettel tar-

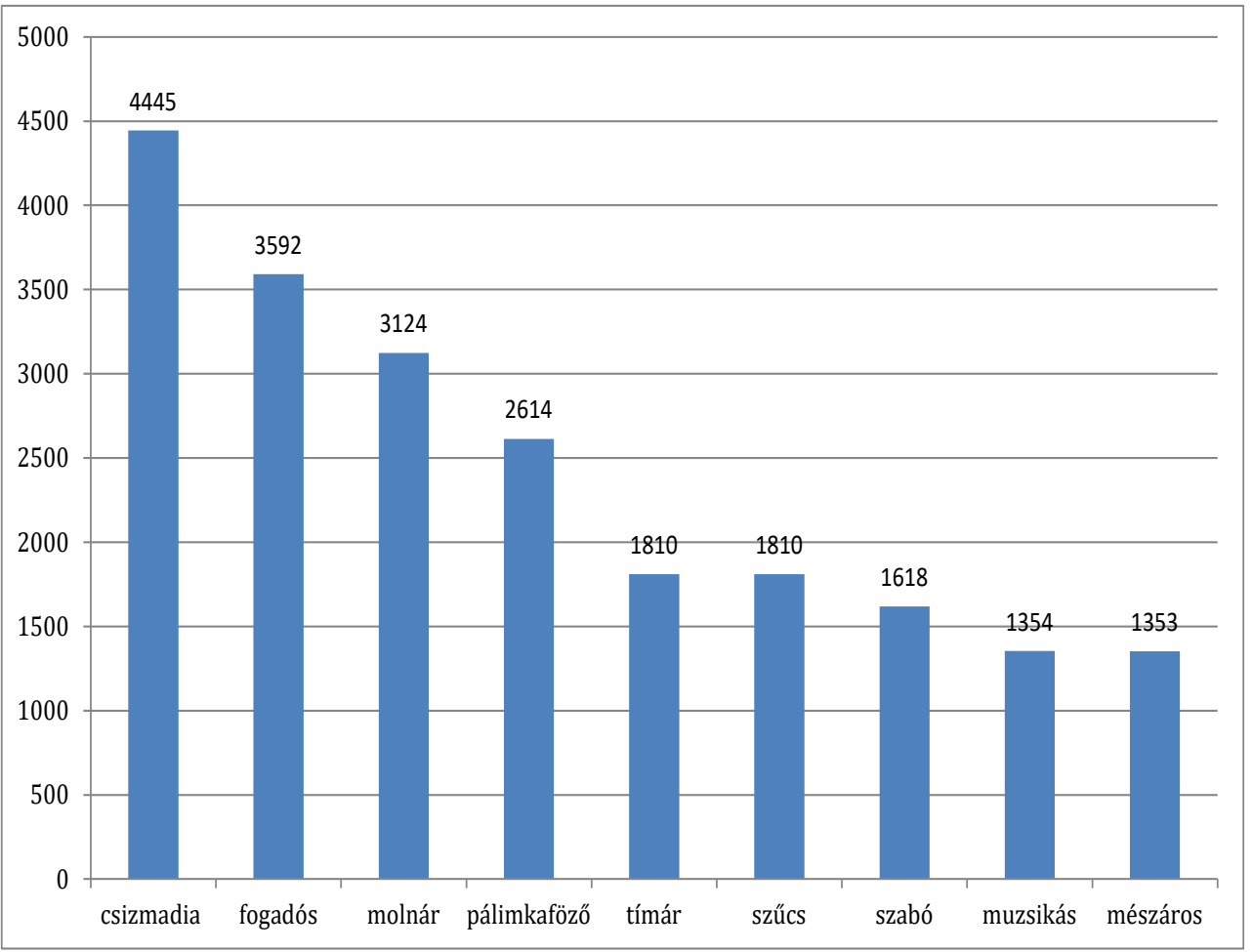

2. ábra. Kézmû́vesmesterek a Székelyföldön a 17. században 
tozzék. Ha pedig ismét az városból kimegyen, három napnál és esztendônél tovább mulat, ha megjön, tisztelettel tartozzék, addig ne legyen szabad mívelni.

Negyedszer. Ha valamely legény be jő, senki a céhmesterek híre nélkül, múvet neki ne adjon.

Ötödször. Ha valamelyik céhbeli mesternek fiai az atyán kívül mesterséget akar tartani kétszeri tiszteléssel és egy, tartozzék és egy font viasszal a céh ládájába.

Hatodszor. Ha valamely idegen mester a céhbe jön, és mester leányát, avagy céhbeli mesternét veszi, kétszeri tiszteléssel tartozzék és két forinttal."

A város elöljárói nem állítottak akadályokat a céhalapítás útjába, de annál nehezebb volt elnyerni az 1562 után épült fejedelmi vár és birtokközpont kapitányának, Bánffy Farkasnak az engedélyét. A 16. század második felére már nagyon jól kialakultak a céhszabályzatok (privilégiumok) formai és tartalmi jegyei. A legkorábbi ismert szabályzatot 1376. november 9-én adták ki Nagyszebenben az erdélyi hét szász szék öregbírái (Kovách Géza - Binder Pál 1981. 57-65).

Jellemző, hogy a 16. században a fazekasok céhe mellett megalakuló három másik céh a bőrfeldolgozó szakmákat képviselte, ezek később is a legerősebbek és legnépesebbek voltak a városban. ${ }^{7}$

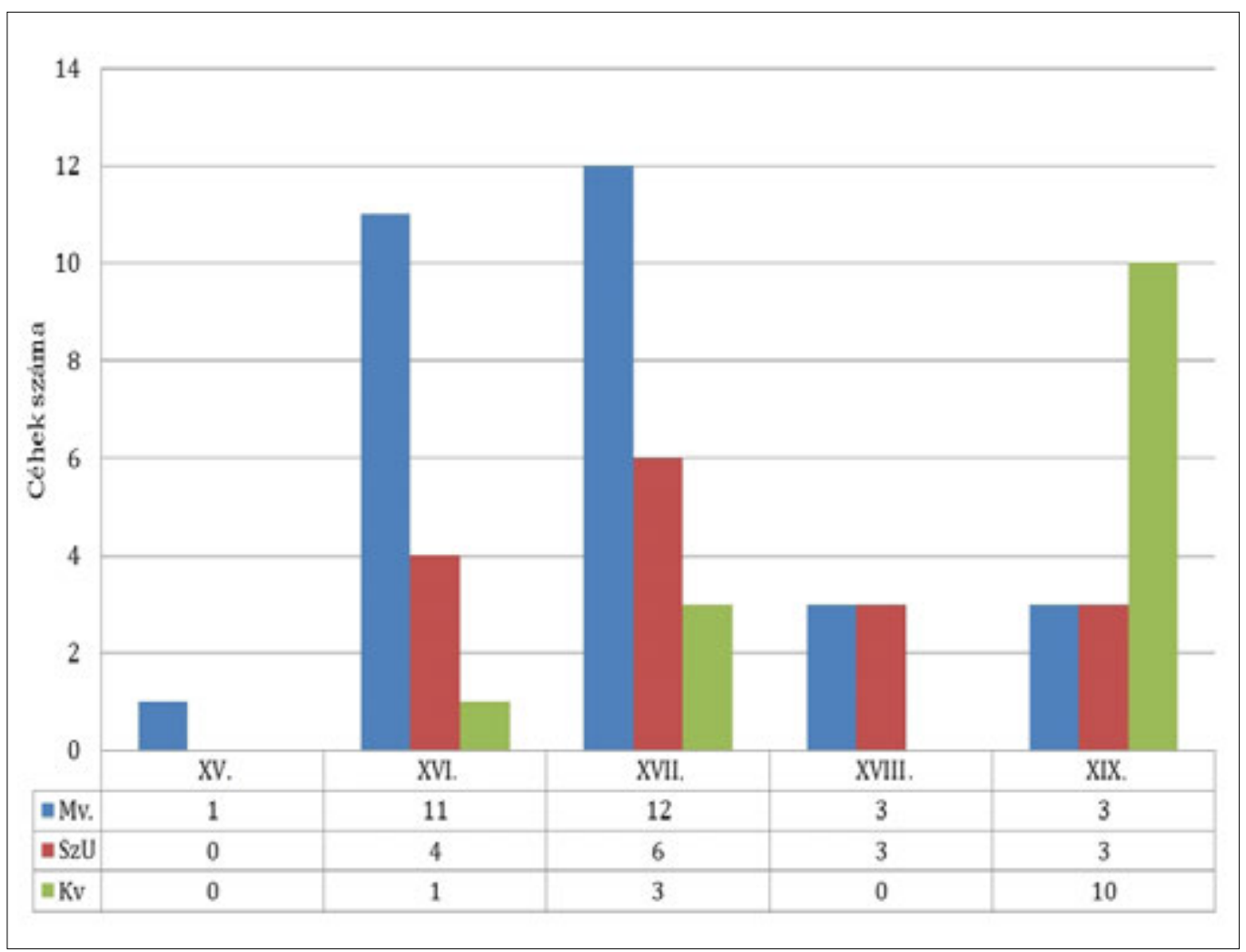

3. ábra. A székelyföldi céhalapítások századokra bontva ( $M v$ = Marosvásárhely; SzU = Székelyudvarhely; Kv = Kézdivásárhely) 


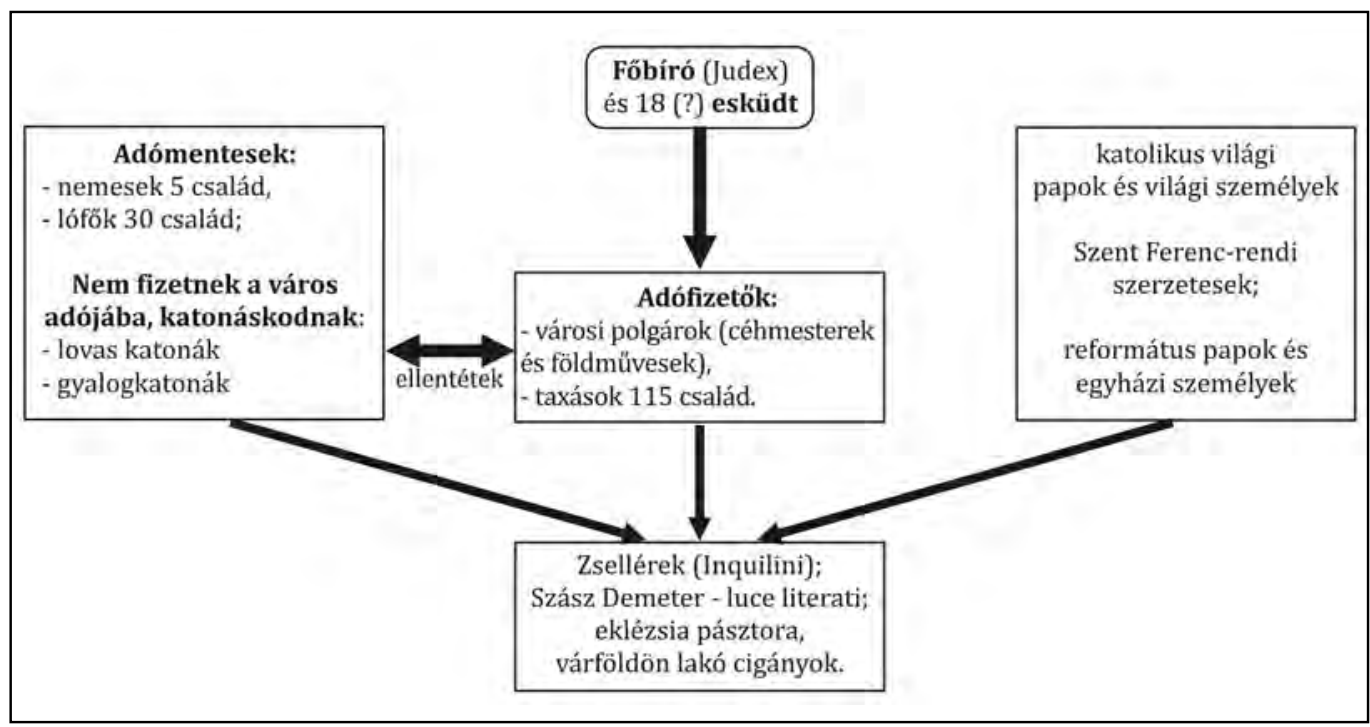

4. ábra. Székelyudvarhely társadalma a 17. században

\section{A székelyudvarhelyi céhek (megalakulásuk időrendjében)}

16. század:

fazekascéh (1572),

vargacéh (1577),

szűcsök céhe (1579),

tímárok és vargák közös céhe (1584).

17. század:

szűcs-szabó közös céh (1606),

lakatos-csiszár (1613),

szabók (1628),

mészáros (1630),

csizmadia (1635),

kalmár, boltos (1683).

18. század:

asztalos (1779),

szíjgyártó (1779),

fésűs (1779).

19. század:

kalapos (1803),

kordoványos (1819),

cipész (1863).

\section{A kézdivásárhelyi céhek (megalakulásuk időrendjében)}

16. század:

tímár (1572).

17. század:

csizmadia (1638),

fazekasok (1649),

szűcsök (1649).

19. század:

mészárosok (1809),

kalaposok (1844),

szabó (1841),

kovács-lakatos-pléhes (1844),

asztalos (1844),

üstgyártó (1844),

kalapos (1844).

Számszerűen is a 17-18. században alakult a legtöbb céh Székelyföldön, de nem tévedünk, ha állítjuk, hogy ezek az évszázadok voltak a céhek működésének legjelentősebb századai a régióban. 
A céhalapítást a Werbőczy István törvénykönyvében, a Tripartitumban megfogalmazott jogszabály tette lehetővé, amely megengedte a statútumok (rendszabályok) alkotását: „És ilyen módon a szabad városok is, nemkülönben saját céhükben és maguk között a kereskedők, kalmárok, szabók, szücsök, vargák, tímárok, és más mesteremberek is a fejedelem megegyezésének hozzájárulásával statútumokat (rendszabályokat) hozhatnak. Csakhogy ezek igazságosak és tisztességesek legyenek, mások jogaiban és szabadságában kárt ne tegyenek, és sérelmet ne okozzanak. De ezek miképpen előadám, csakis közöttük állnak meg és maradnak erőben." (Werbőczi 1514) Ez volt a jogi alapja a székely falutörvényeknek, a városi önkormányzatoknak. A céhes mesterek jogai törvénybe voltak foglalva: „Mives embereknek privilegiumiról. Mindenféle míves embereknek privilegiumok ezekkel a generalis conditiokkal [általános feltételekkel] tartatnak meg és hagyatnak helyben. Elsőben, hogy jó mivet miveljenek. Másodszor, hogy a várost és vidékét mindenek neme szerént való mivekből, vagy mivelt materiakból meg ne fogyatkoztassák, s az eddig való abusus [visszaélés] szerént külső helyekre s néha országokra is hordván, a hazában ne szerezzenek szükséget, holott a székeken kívül lévőket el rekesztik, kik az olyant megbővitenék, $s$ magok is pedig nem satisfaciálnak [eleget tesznek] hivataljoknak. Harmadszor, hogy az időknek mivoltához képest lett s leendő limitaciokat observalják." (Approbata Constitutiok III. R. Titulus LXXXV.)

\section{Limitációk}

A számtalan feudális privilégium meganynyi akadálya volt a termékek szabad áramlásának, adás-vételének. A megkötések csak lassan oldódtak fel. Az állam is beavatkozott a gazdasági élet bonyolult gépezetébe. Leg- többször gazdaságon kívüli eszközökkel, rendeletekkel, határozatokkal akartak segíteni, elérni a lakosság boldogulását. Ebbe a sok évszázados folyamatba illeszkedett be a - nyugat-európai színvonaltól gazdaságilag is elmaradt - Erdélyi Fejedelemség fennállásának éveiben (1541-1690). „Az általános európai fellendülés függvényében Erdélyben is megfigyelhető valaminő olyan növekedési tendencia, amely, ha nem is jelzi a termelési viszonyok forradalmasodását, tanúsítja a termelőerők körének kiszélesedését, különösképpen a mezőgazdaságban. $S$ ha nem is ígéri a nyugathoz való ugrásszerü felzárkózást, megcsillogtatja az iparivárosi-polgári felemelkedés biztató jövőbeli lehetôségeit" - állapította meg Imreh István, aki a kérdés legjobb ismerője volt (Imreh 1999).

A céhek saját bevételeik gyarapítására előszeretettel emelték kész termékeik árait. Ilyen esetben az országgyűlés által megszavazott limitációkba ütköztek. A korszakban is állandósult az ellentét egyfelől a városi céhek, másfelől a piac szabályozására törekedő fejedelem, a kincstár és országgyúlés között. A fejedelem, az állam következetesen, de annál kevesebb eredménnyel igyekezett céljait (a minél nagyobb bevételek megszerzését) érvényesíteni.

A céheket alapító és működtető mesterek, a várost fenntartó és az állami adót fizető „adóalanyokat” a városi polgárjoggal rendelkező taxások között kereshetjük.

\section{A limitációk a céhek életében}

Az állami beavatkozás legáltalánosabb eszközei az ún. árszabályozások vagy limitációk voltak. Nem túlzás, ha azt állítjuk, hogy a céhek számára ezek jelentették a legnagyobb megkötést, akadályt. A limitáció a kötelező piaci árszabást, az árak szabályozását, legtöbbször az árak vagy a bérek vagy mind- 
kettő maximalizálását jelentette. Talán igazságtalanok voltak a céhekkel a kortársak, mikor a limitációk rendszerét is a céheknek tulajdonították. Ezeket végül is nem a céhek kérték és dolgozták ki, hanem a felsőbb hatóságok állították össze és „varrták a céhek nyakába". Ezzel a kérdéssel is foglalkozott a fejedelmi kancellária, majd később a Gubernium, a Főkormányszék. A fejedelemség korában az árszabályozásra vonatkozó „limitációkat" az országgyűlés fogadta el és adta ki. Bethlen Gábor uralkodása éveiben rövid ideig egy külön felügyelőség ellenőrizte. Ezt az 1624. június-júliusi országgyűlés hozta létre az V. tc. alapján, és Kamuthy Balázst nevezték ki vezetőjéül. Hatáskörét az 1625. évi árszabás írta le. 1627-ben ezt a feladatot a három nemzet egy-egy képviselője látta el (Trócsányi 1980. 319-320.).

A fejedelemség korának kezdetén, már János Zsigmond uralkodásának éveiben megjelentek az első jelei az állami beavatkozásnak a gazdasági életben. Az 1566. augusztusi országgyűlés elrendelte, hogy ellenőrizzék a kézműveseket, hogy az árszabás szerint áruljanak a vásárokban.

A limitáció terminus legkorábbi előfordulását erdélyi magyar szövegben 1589-ben találjuk (Szabó T. Attila 1995. 1162-1163.). „Limitálni” az árak megszabását, maximalizálását jelentette. A piacon eladott, megvásárolt termékeken kívül a munkabért is limitálták. Az árak rendeletekkel való szabályozása a gazdasági élet gyengeségének, betegségének a szimptómája. Későbbi korokban is gyakran kísérleteztek ilyen és hasonló módszerekkel, de ez mindannyiszor kudarcot vallott. A gazdasági életbe beavatkozni gazdaságon kívüli eszközökkel eleve kudarcra van ítélve. Az első udvarhelyi céhek alapítását megelőzően már életbe léptek az első szabályozások. Az 1556. évi országgyű- lés elrendelte, hogy a városok elöljárói ellenőrizzék vásáraikon a kézművesek által megállapított árakat. Megtiltották, hogy lovakat, bőrárut, sarukat külföldre eladjanak. Még ugyanabban az évben a kolozsvári országgyűlés latin nyelven szerkesztett limitációt léptetett életbe. A limitált árak nemcsak a céhes mesterekre voltak kötelezők. 1560-ban elfogadták a szászok által előterjesztett árszabást, és előírták, hogy a nemesek házainál dolgozó jobbágyok is tartsák be. A büntetést azok számára, akik nem tartották be az előírt árakat, 200 forintban állapították meg, ami hatalmas összeget jelentett. Az 1572-ben készült limitáció 1592-ig maradt érvényben. Ugyanakkor (1593) könnyítettek a vándor céhlegények terhein, akik be- vagy kiutaztak a fejedelemségből.

1578-ban a drágaság mérséklésére újra a kivitel megszorításával próbálkoztak. 1585ben megtiltották az arany (vert és porarany) kivitelét, megtiltották, hogy „velencei marhával" [ékszerek] kereskedjenek, hogy a nemesfémeket kivigyék (Approbata Constitutiok II, R. Titulus XIV. art. I-IV.).

A fejedelemség kori gazdaságpolitikának nem volt elméleti alapja. 1588-ban a szabad kereskedelemben látják a gyógyírt a drágaságra: „nem a szúk, hanem a bő marha [itt mindenféle áru] teszen olcsóságot". De már 1591-ben határozatot hoztak a külföldi kereskedők kitiltásáról (Szádeczky 1913. 59.).

„Bethlen a merkantilizmus szellemében a termelőket és kereskedőket pénzszerzésre ösztökélte, támogatta és fellendítette a bányászatot, a kézmüvesipart, manufakturákat létesített, ugyanakkor biztosította a vagyoni és szellemi biztonságot." (Csetri 1999) Bethlen Gábor, Erdély legeredményesebben gazdálkodó fejedelme is használta a kereskedelemben gazdát cserélő termékek árának szabályozását az áremelkedések, az infláció 
megfékezésére. Gyakorlatban folytatott gazdaságpolitikája a korai merkantilizmus eszmekörébe illeszthető. Nem volt tudatosan kidolgozott elmélete Erdélyben, de a fejedelem gyorsan felismerte, hogy keveset vásárolni, többet eladni, vagy külföldi viszonylatban is a pozitív mérleg az előnyös. „Bethlen uralkodásának tizenhat esztendeje volt az erdélyi fejedelemség történetének legfényesebb korszaka. Bár mindenkinél erösebben hangoztatta, hogy akarata a törvények felett áll (princeps absolutus), alattvalóinak sem volt oka panaszkodni rá. Erdély földjét 1616 óta nem érte külső támadás, [...]. Az újjáépítés és a gyarapodás rohamléptekben haladt elöre, $s$ bár java hasznát a kereskedelmi és más monopóliumokon keresztül maga a kincstár fölözte le, kihatott a társadalom egészére." (Szakály 1990. 217.)

Bethlen Gábor uralkodásának éveiben háromszor volt kénytelen limitációt megszavaztatni az országgyüléssel.

Az 1622. évi kolozsvári országgyűlés törvényeinek $\mathrm{X}$. articulusában a kézműveseket vádolták, amiért nem tartották be az országos limitációban meghatározott árakat, ezért kérik azok szigorúbb betartatását. ${ }^{8} \mathrm{Az}$ ispánokra és városi bírákra, akik elnézték a limitátió megszegését, 200 forint büntetést is kiszabhattak. ${ }^{9}$

Két évvel később, az 1624. június 24-ijúlius 8-i gyulafehérvári országgyűlésen megszavazott V. articulus „Az mesterembereknek és egyéb kereskedő rendeknek is mívek $s$ árújok limitációjárúl, az limitatio ellen tusakodóknak poenajok, annak exigálásáról, és az kedvezőnek büntetésérôl" - továbbra is a mesteremberekre panaszkodott, akik magas árakat kérnek, annak ellenére, hogy a bőröket olcsón vásárolhatják meg. Ha a városbírák a kötelező árakat nem tartatják be, büntetésük legyen 500 (!) forint. A büntetés ilyen nagyfokú emeléséből arra következtethetünk, hogy a korábbi szigorúság, a büntetés nagysága nem volt eléggé elrettentő, nem javított a helyzeten.

„Az úri és nemes rendek a várasbeliek ellen panaszolkodnak, hogy eladásnak okáért beküldött marhájok az piacon szabadoson el nem adhatják, nemességnek nagy praejudiciumára, kirôl hogy felsége kegyelmesen providealjon, supplicalnak." Tehát az 1622. május 1-23-i kolozsvári országgyűlésen a vármegyei nemesek panaszkodtak a városiakra, a kézművesekre, mert az alacsony árakért nem tudják eladni „marhájok”-at. ${ }^{10}$ Sok kézműves kétszer kockáztatta szerény jövedelmét a piacon, egyszer amikor megvette a munkájához szükséges nyersanyagot (pl. a tímárok, kordovánosok a mészárosoktól vásárolták a nyers bőröket, és feldolgozásuk után továbbadták a csizmadiáknak, a cipészeknek.), majd munkájával új értéket adva hozzá a piacra vitte.

A XXIII. art. az új keresztényeknek (anabaptisták) biztosított engedményeket. „AZ új keresztyének is, kik most itt benn vadnak és ezután és bejönnek ő felsége engedelméből, az minemü helyet és szabadságot ő felsége adott nekik, a statusok is annak consenciálnak és confirmálják articulusokban."11 Ha nem értjük is az első pillanatban, úgy tűnik, hogy nem illik Bethlen Gábor ipart támogató politikájába az anabaptisták behívása és letelepítése Erdélyben, de csakhamar felismerhető az a szándék, hogy a fejlettebb technikai szinten dolgozó és jobb munkaerkölcsöt hozó csoport a hazai ipar fejlődését szolgálja. Ugyanilyen meggondolásból adott letelepedési engedélyt a zsidóknak. ${ }^{12}$

Az országos intézkedések ellenére az árak folytonosan növekedtek. „A hosszabb távon meghatározott árváltozási indexek valóban nagymértékü emelkedést tanúsítanak. Az erdélyi limitációk alapján az iparcikkek (arany- 
90

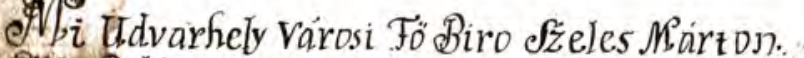

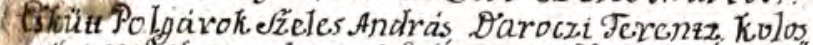

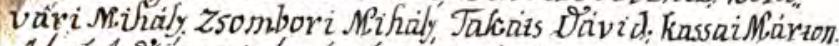

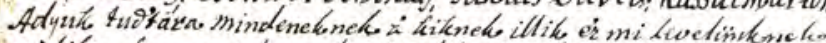

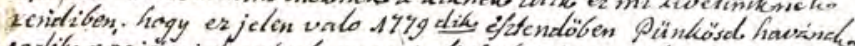

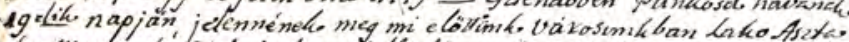

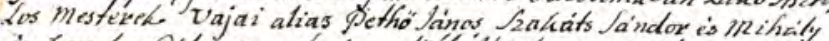

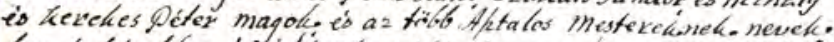

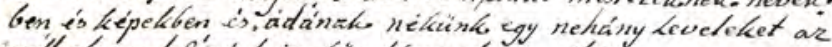

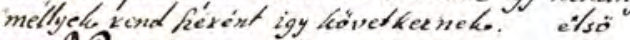

Aos Jabried Deigratia Transyluamia. Valachic. Trans

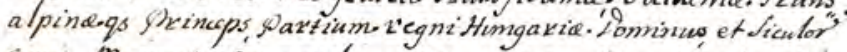
comes. Menovid.Commendamus tenove notentium vigniticantes

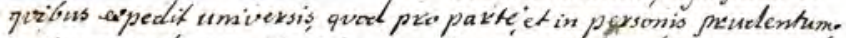

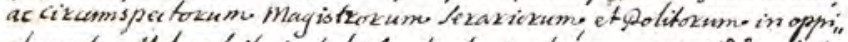

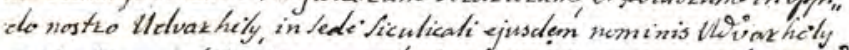
evisfontism, habitantium, vesidentium et connovantium, Qhibitiest

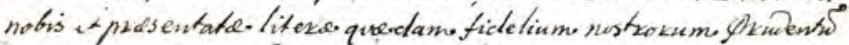

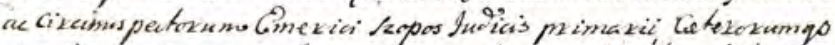

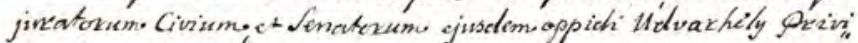
legiales in limplici sapyzo patenter confecte. Sigills go ecrumo usuasti.

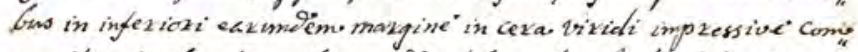

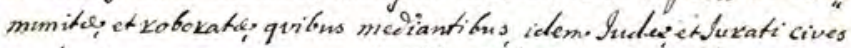

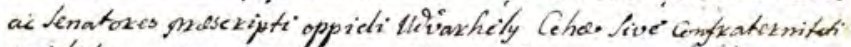

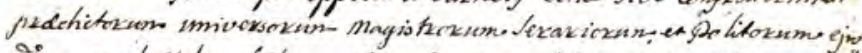

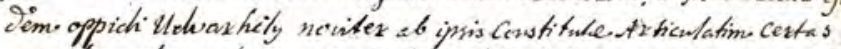
quasdam olsezvationes, imumitates, ac libertates pez eosem magistzos

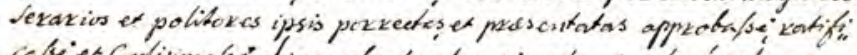

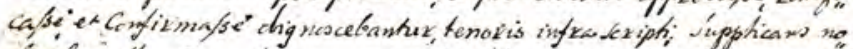

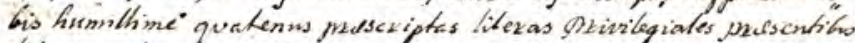

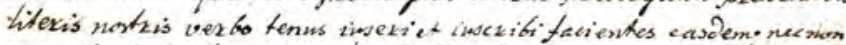

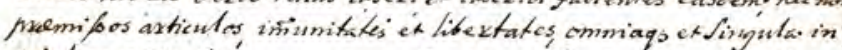

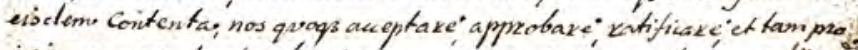

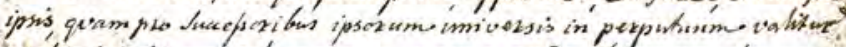

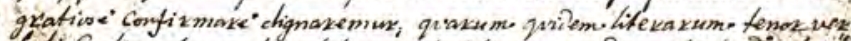

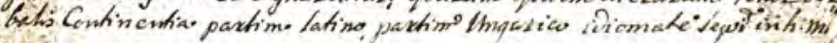

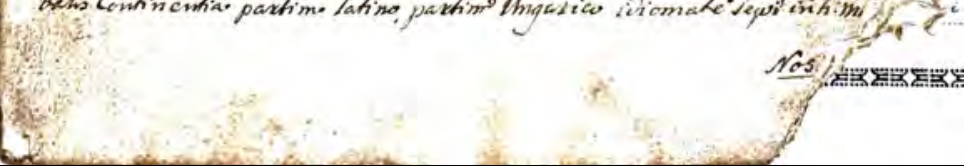

11. kép. A lakatoscéh leveleinek másolata (CL. 953)

forintra átszámított) százalékszámai a következő arányokat tükrözik...” (Imreh 1999. 72; Imreh 1979. 169-198.)

1556-1560 között az árak 10-20\% növekedést értek el (Szádeczky Lajos 1913. 52.), vagyis ennyit romlottak.

\section{3. táblázat.}

\begin{tabular}{|l|c|c|c|}
\hline \multicolumn{1}{|c|}{ Év } & $\mathbf{1 5 7 1}$ & $\mathbf{1 6 0 9}$ & $\mathbf{1 6 2 5}$ \\
\hline iparcikk [\%] & 100 & 150 & 197 \\
\hline bor [\%] & 100 & 158,8 & 200 \\
\hline
\end{tabular}




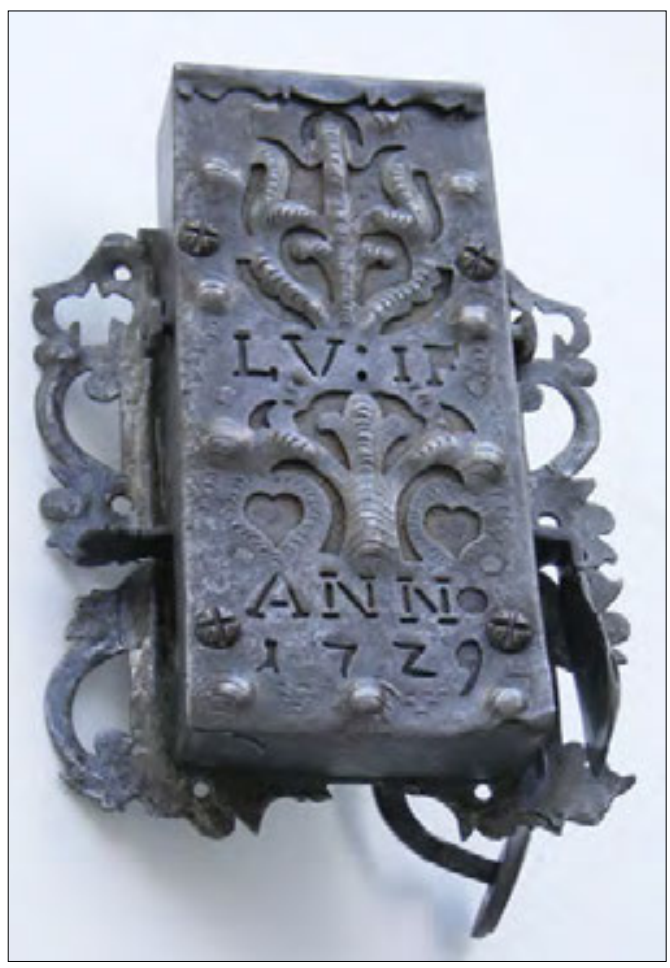

12. kép. 1729-ben készült székelyudvarhelyi ajtózár

A 17. század első évtizedeiben négy országos, az Erdélyi Fejedelemség területén hatályos limitációt szavazott meg az országgyűlés. Az elsőt 1608. június 23-án (EOE. VI. 132-157.). Ezeken kívül még a megyék és székek vagy a városok is adtak ki helyi viszonylatban érvényes árjegyzéket.

Az 1625. májusi gyulafehérvári országgyűlés a termékek limitált árainak új jegyzékét fogadta el. Az ármegállapítás szövege a mészárosmesterekkel kezdődik mint a lakosság élelmezésében fontos szerepet betöltő mesterséggel és úgy is mint a bőrt feldolgozó mestereket nyersanyaggal ellátó iparral. „Az mészáros mesterek dolgát megértettük volna az városbeli fönépektôl mindenütt valóktúl, így szóltunk hozzája, hogy az városbeli polgármesterek és királybírák, minden városo-

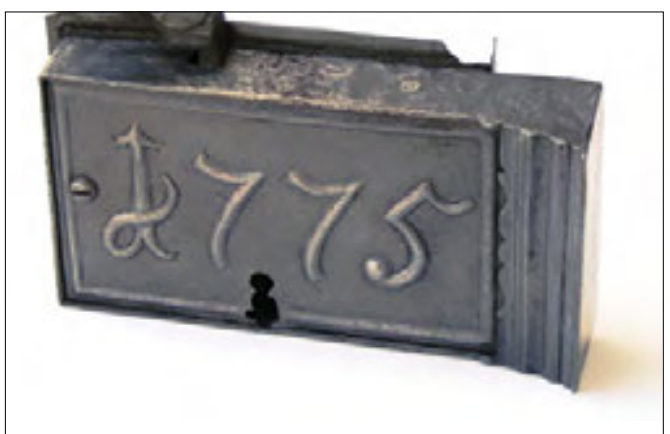

13. kép. 1775-ben készült székelyudvarhelyi ajtózár

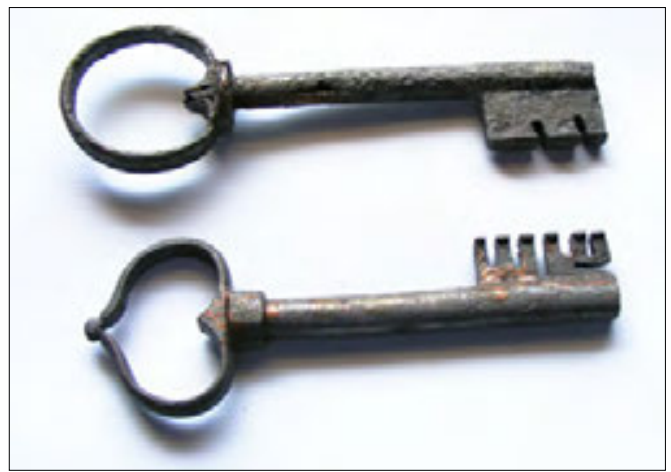

14. kép. Ajtózárkulcsok

kon az baromnak kivételéjért, olcsó-, avagy drágaság ha lenne, jó gondviseléssel hozzálássanak, hogy az szerint képes árán adják el a húst, melyet ők is minden nap pénzen vesznek, ő magokért úgy rendeljék az húsnak fontját adni egyebeknek is hogy az szegény község is meg ne nyomorodjék miatta: sőt ha valami új nép jönne valamely városra, akkoron is ne adassék drágábban a húst, szinte mint annak elötte. Az falukon is azon mód observáltassék." A limitáció rögzítette az állatárakat, melyek között a szarvasmarhaárak voltak a legfontosabbak, a hús kiskereskedelmi árát és a bőr, szaru, csont árait. A mészárosok a borjúhúst igen drágán, „font nélkül” adták el. Ha marhát vásárolt a mészáros, köteles volt azt kimérni. A mészáros „nem tősér, hogy az marhát lábon adja". Ha rajtakapták, hogy lábán adta 
tovább a nyúzni való marhát, vegyék el attól, aki megvette, és a mészáros is fizesse meg a marha árát. Ha pedig nem vágtak eleget, de volt elég vágómarha, „ha vagyon barma, mészárszékrevaló”, zárják ki a céhből, „a céhből kivettessék, soha többet mészárosságával, se tôserséggel, se céhigazságával ne élhessen". Nem követelhet a mészáros „kupa bort” vagy más ajándékot. Tilos hamis fonttal mérni, ennek büntetése „pénze, tisztessége, marhája elvesztése". Falura is a városból vigyenek pecsétes réz- vagy vasfontokat, húsnak valókat. A falun dolgozó mészárosok úgy áruljanak, mint a közeli városban teszik, „hamis fonttal, kővel, sohul senki pénze, tisztessége, marhája elvesztése alatt, ne merjen, hanem városokról vigyenek pecsétes réz, vagy vas fontokat, húsnak valókat, kivel mérjenek, igaz serpenyőjük legyen mindennek, az falusi bírák ezekre jól vigyázzanak tisztek elvesztése alatt" (EOE. VIII. 273.).

Majd a munkamenet sorrendjében előírták, hogy „az tímároktól miképpen adják bőröket az varga- és szígyártó mestereknek és az kik az ő bőrökből [bőreikből] mívelnek". Majd logikai sorrendben „az vargamesterekről miképpen adják el az sarukat” következett.

A csizmadiák is a tímároktól vásárolt kikészített bőrökből dolgoztak. A limitáció 52 féle csizmadiaterméket sorolt fel. Legdrágább volt az „[e]z országban csinált törökországi szép és jó karmazsin csizma, öregembernek való", aminek három forint az ára. Ugyanenynyit ért egy kidolgozott „öreg” ökörbőr is.

Ezután a szíjgyártótermékek következtek. A hámok és a szíjak sokasága fejlett nagyállattartásról tanúskodik.

Következtek a szűcsök, a kerekesmesterek, a csapók, a szűrcsináló szabók, a nemezcsinálók, a szőrmívesek, kik lasnakot, harisnyát, condorát, gubát, csuklyát, pokrócot csinálnak.

A szabók rendelésre 22 féle divatos ruhadarabot szabtak és varrtak.
A pajzs- és kopjagyártók „Egy jó szegődött merő kopját, melyen három gyantár vagyon, adják harminc pénzen. Egy fuallott kopját, jó temérdeket, hatvan pénzen. Az ki ezeknél jobbakat, szebbeket akar csináltatni, alkudjék a mesterrel."

A szappanfőzök egyféle terméket árulhattak, aminek fontja 12 pénz volt. A nyergesek egy jó nyerget, „két kápájút, itt való cseres bőrből, veres vagy fejér bőrből" ugyancsak 3 forintért adhattak. A lóbőröket csak a pajzs- és nyereggyártók használhatták fel.

A vas-árosok az erdélyi és magyarországi hámorok termékeit juttatták el a vásárokra.

A kovácsok „egy jó öreg, erös patkót, a maga vasából" 9 pénzér vertek fel. Legtöbb munkájuk a patkolás és a szekérvasalás és javítás volt. A kapa lehetett toróckói, medgyesi, besztercei vagy segesvári.

Az ötvösök számára meghatározták az arany minőségét, amiből dolgozhattak.

A lakatosok „egy kengyelvasat, öreget, szépet, cifrát, nagy pálhást, gombost, szép ónost, szalamiákkal, egy forinton 50 pénz. Annál alábbvalót szépet, szalamiást, 1 forinton 35. Annál is alábbvalót pálhásokat 1 forinton 25 pénzen. Annál is alábbvalót 75 pénzen. Annál is alábbvalót 60 pénzen."

Az ónmíveseknek a nyersanyag drágulása miatt megengedték, hogy hat font fehér ónhoz keverjenek fél font fekete ónt.

A kádárok „igaz mértékre csinálják az ő míveket", és reá vigyázzanak a céhmesterek városon és falun a bírák. A hordók űrtartalmát szigorúan ellenőrizték, mert mindenik egyben mértékegység is volt. „Az öreg hordó nyolcvan vedres legyen igazán. Az földes negyven vedrös legyen. Az egész hordót, ki nyolcvan vedrös, jó, jól csinált, jól kötött, adják 1 forinton 50 pénzen." A kádárok csináltak még boroshordót, kétfülű csebret, lóitató háromvedres csebret, egyvedres kétfülű csebret, 
vízmelegítő kártot, juhfejő vedret, deberkét, öreg szapulló, feredőt, öreg kádat, nyomót vagy káposzta sózni valót, fenyőfából veder, öreg kádkötésűt, lijut, szőlőhordó botot.

A csiszármesterek termékei a hegyes tőr, szablya "az ki paraszt módon vagyon, 1 forintért 53 pénzért". Egy szablya és egy pallós három forint, volt még demecki szablya és csetneki szablya.

Kőmívesek napibére ellátással 42 pénz. Dolgoztak az építkezéseken még ácsok is.

A zemes csinálók szarvas- és őzbőrt dolgoztak fel.

A téglavetők rakótéglát, pádimentomtéglát, cserepet csináltak.

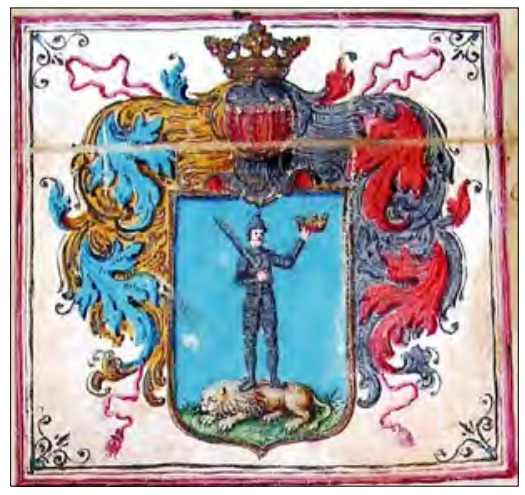

15. kép. Címer az udvarhelyi Ágotha János armálisán. Adományozta II. Rákóczi György 1660. január 13-án Nagyszebenben (Románia Nemzeti Levéltára Hargita megyei Igazgatósága $F$ 249 617. sz.)

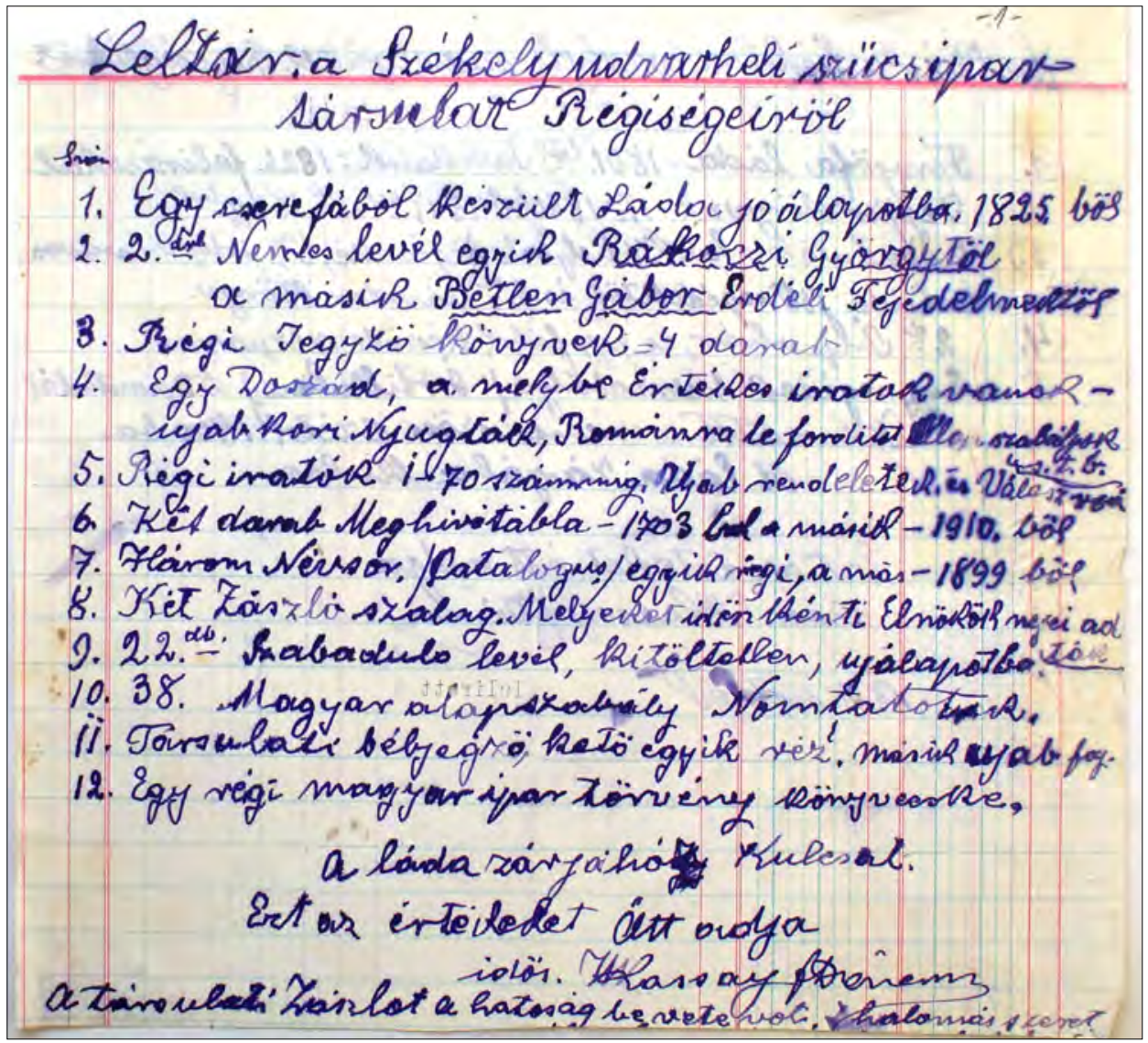

16. kép. $A$ szücs ipartársulat „régiségeinek” leltára 

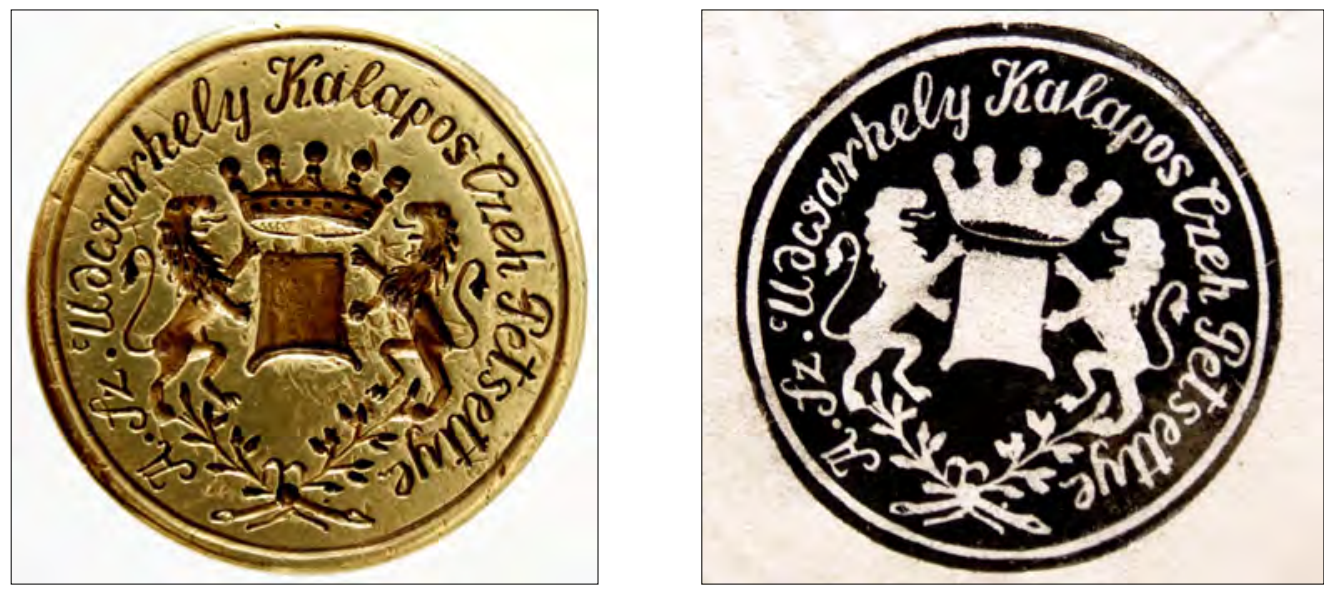

17. kép. Kalaposcéh pecsétje és koromlenyomata

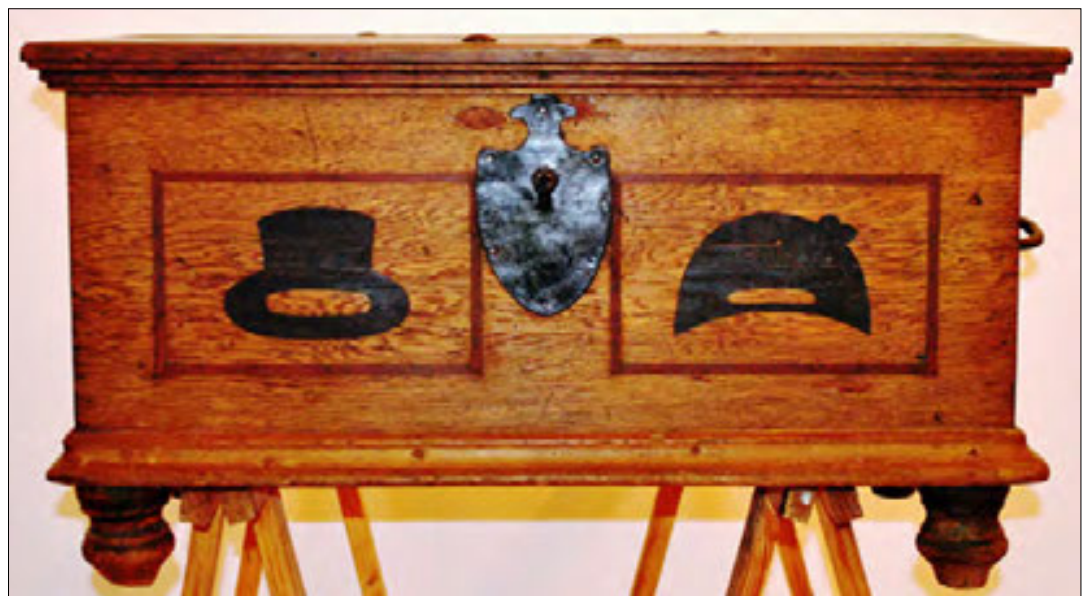

18. kép. Kalapos céhláda, korabeli kalapokkal díszítve

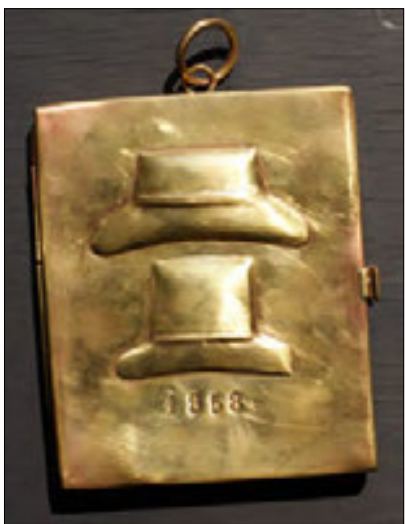

19. kép. Kalapos réz behívótábla 1858-ból 
A fazekasok „egymázas kályhátzöld mázzal, szépet, jót, öreget, cifrásat, egy mázas kályhát, tarkát, fejér mázzal, jót, öreget, német módon csinált szép tarka, öszvejáró virágú, fejér mázast, jót, öreget, paraszt cifrás kályhát" csináltak.

Az asztalosok is az ácsokhoz hasonló béreket kaptak.

A borbélymesterek „emberfömosást” végeztek, de fő foglalkozásuk a sebek és betegségek gyógyítása volt. A 16-17. században a gyógyítás nem volt veszélytelen foglalkozás, mert „az sebesekre híven és szorgalmatoson viseljenek gondot, és ha gondviseletlenségek miá az sebes meghal, [...] fejekkel érjék meg."

A tölcséresmesterek (üvegkorongokból készítettek ablakokat) és a rézművesek következnek, majd a mészégetők, akik a meszet hordóval vagy kemence-, illetve veremmenynyiségben árulták.

„Az kereskedő áros emberek felöl nagy panaszolkodások hallatnak minden rendekről, kik sem Istennel, sem lelkek ismeretével nem gondolván, marhájokat, ha lehetne, úgy adnák el, sok esküvések és csoda kigondolt excusatiojok mellett, hogy ha lehetne, tíz annyit adnak el, az mint vettek, nem gondolván keresztyén felebarátjoknak megcsalásával és értékének megfogyatkozásával."

A limitáció jobb híján használt kényszerítő eszköz volt. Mint ilyen nem érte el célját. 1626. június 12-én a gyulafehérvári országgyưlés egy újabb részletes törvényt fogadott el (EOE. VIII. 378-418.).

A korábbi limitációval szemben újdonság, hogy az „áros emberek”, kalmárok számára is előírják az árakat az olyan termékekre, amelyeket külföldről hoztak be. Ebbe a csoportba a külföldről behozott textilanyagok és füszerek tartoztak. Az említett textilanyagok: skárlát, igen jó, közönséges skarlatin és gránát, cimmazin, rasának singit $3 \mathrm{ft}$, jó fajlan- dis, lazur és angliai fajlandis, stemet, mayszler, karasia, fodor, kentula, morvai, braszlai, morvai posztó, veres és zöld skarlát.

A fűszerek és más élelmiszerek, amit a kalmárok forgalmaztak: mandola, bécsi faolaj, törökországi faolaj, tengeri szőlő, malosa szőlő, kanári vagy velencei nádméz, confreit, bécsi sáfrán, bors, fahéj, török pogácsa, sáfrán, szerecsendió, fejércukor, veres cukor, festetlen és festett gyömbér volt.

Újabb kézművesszakmákat is bevontak a szabályozottak közé. Ilyenek voltak a gombkötők, fegyverderék-csinálók, fürészdeszkaés zsindelycsinálók. Ez utóbbiak esetében az oláhfalvi deszka és a zetelaki zsindely volt az alap, melyekhez viszonyították a többit.

1627 októberében újabb országos limitáció készült (EOE. VIII. 434-480.). A limitációk betartásának ellenőrzésére inspektorokat neveztek ki. Erdélyben Kapyi András, Balási Ferenc, Dávid Deák királybírót nevezték meg.

A limitációkból megismerhetjük a céhek termékeit, melyeket a piacra vittek. „Az árszintben, ízlésben eltérő kívánalmakat, változásokat jól tükrözik a céhbeli mestereknek kiadott árszabályok, limitációk, árlisták." (Imreh 1979. 176.)

A kolozsvári, 1622. május 1-23-i országygyűlés határozatainak 10. articulusa szerint „Nem kicsiny panaszkodásunk vagyon, kegyelmes urunk az míves emberek felöl is, holott noha arról egész országul limitációnk vagyon, mint és hogy kellessék marhájokat adni, az bor fóképpen olcsó, mindazonáltal az ők pothabealván és teljességgel elmenvén mellette, illetlen és felettébb való árat szabtak." Öszszehasonlítva az 1609. évi árakat az 1625. éviekkel 25-50\% drágulást figyelhetünk meg (Szádeczky 1913. 71.).

Az 1696. szeptember 19. és november 28. között ülésező országgyűlés határozatának 1. articulusában „Némely áros mívek limitációjáról" címmel újrarendezik az árakat. 
I. Rákóczi György uralkodásának éveiben (1630-1648) lazult az állami beavatkozás. Csak 1642-ben adtak ki újabb limitációt. Az 1609., 1627. és 1642. évi árakat összehasonlítva Szádeczky Lajos úgy találta, hogy az áremelkedés 20 és 100\% között változott, de olyan termék is volt, melynek ára meghaladta a $100 \%$-os emelkedést is. Ez a limitáció sokáig volt érvényben, és még 1687-ben is megerősítette az országgyűlés.

II. Rákóczi György uralkodásának kezdetén nagy változások történtek, visszaállították a szabad kereskedelem elvét, de fenntartották az állami monopóliumokat. Az 1653-ban jóváhagyott törvénycikk szövege: „Mindenféle míves emberek privilégiumok ezekkel a generális conditiokkal tartatnak meg és hagyatnak helyben: előben, hogy jó mívet míveljenek. Másodszor, hogy a városok és vidékek mindenek neme szerént való mívekből, vagy mívelt materiákból meg ne fogyatkoztassák és az eddig való abusus szerént külső helyekre és néha országokra is hordván, a hazában ne szerezzenek szükséget." (Approbata Constitutiok. III. R Titulus IX.)

A 18. századból származik a szabócéh irattárában talált két szabólimitáció.

$\mathrm{Az}$ 1741-ben készült limitáció része a Mária Terézia rendeletei értelmében hét pontba fogalalt szabályzatnak, mely az inas, a legény és öreg mesterek soraiba lépését szabályozta. A limitált árak be nem tartásának büntetése három forint.

A székelyudvarhelyi szabócéh két fennmaradt árjegyzéke a 18. században használt ruhadarabokat és az árakat tükrözik:

„Nos Maria Theresia, Dei Gratia Romanorum Imperatrix etc. et Siculorum Comes. 64 Sub tutella ab anno '741 fecimus articulos.

1mo. A mely becsületes mester ember, vagy iffiu szabó legény bé jő, az várasunkbe, ha igaz che helyen tanult, tartozzék chehot követni, és ha olyan kuntárkodott vólna addig bé ne vétetődgyék, még az három forintat le nem tészi a chenak, a chebe állás lészen kész pénz 50: id est ötven magyar forint, négy font viasz, két veder bor, négy kenyér, három tészteséges fozik étel, kápaszta, résskársa és tejfeles lév, három sült, a melynek kettee malacz, a harmadik lud.

2do Az mester emberek gyermekei, ha chehot követnek tartozzanak, 20: forintal, 2: font viasszal, s egy veder borral, az étkekkel, a felyebb meg ért mod szerint, és ha valami szabó leginy mester ember gyermekit veszi is ugy.

3tio A mely ifiu mester megházasodik tartazik egy forintal, egy kenyérrel, egy fazék étellel, egy malacz sültel, panko[t] vagy halatis.

4 to Az öreg mester asztalnak adása így van, készpénz három forint, két veder bor, négy kenyér, három fazék étel, három tészteséges sült, két malacz, s harmadik a lud, kürtös kalács, pánkó.

5to. Valaki szabó mesterségre idegen akarja adni fiat, két hétig lakik probahetet, ha tetszik a gazdának, és a gazda is tetszik az inasnak, maradása lehet, az után négy esztendeig szolgálya a gazdát, és óly kontráktust és kötést tégyen a nemes szabó chenak, hogy Udvarhely székben és városban, és a vár földin urak, papok joszágán nem kuntárkodik, ha nem örökös fia lészen a nemes szabó chenek, és két becsületes nemes emberek légyenek kezesek őss joszágos, a melyeken desummálhassan a nemes che 60: idest, hatvan magyar forintokat vinkulummul, tsak a le kötésének és kontrátusának erejével, toties quoties, a le kötésének és kontrátusának erejvel, toties quoties, a bé szegyőtetése kész pénz 12: idest tézes két magyar forint, négy font viasz, két veder bor, négy kenyér, három fozik étel, kápaszta szegyel, risskársa három kontzal, téjfeles lév, három tyúkkal, kettô sült, kettô malacz, a harmadik lud, mikar fel szabadul tartozik három 


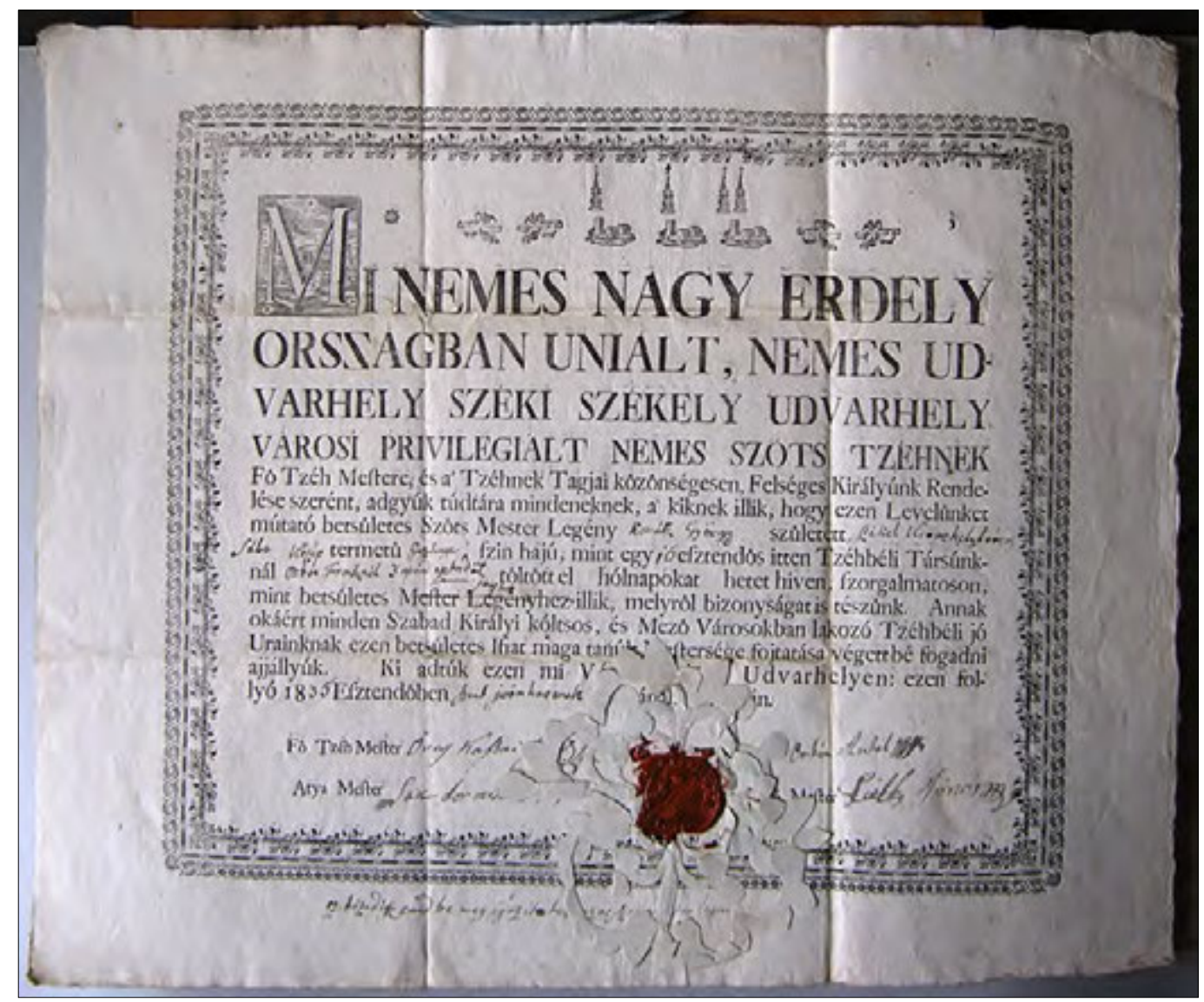

20. kép. A szücscéh munkaigazolása Kováts György „szücs mesterlegény” számára

forintal, pecsét pinzel, két veder borral, és az étkekkel, három tészteséges kalátsal, a mester ember gyermekit, ha sz atya fel nem mondja, vagy inasnak, vagy legyénnek nem tartozik egyebbel csak a pecsét pénzel.

6to Végeztetet a nemes chetól, hogy mikar mester legényt, az atya mestertöl el késérnek más ember méhelyiben, te hát az atya mester késérje méhelyben, és a fézetis szabja ki a gazda és mester legény elött, és lássa jó szívvel, a chenak semmivel sem tartozik, sem a gazda, sem a mester legény. Mihelt a két hete kitelik, tehát a levelit adgya bé a che ládájába, ha be nem adgya [ha be utólagos betoldás] fizessen egy forintot a legény.
$7 m o$ Végeztetett a becsületes nemes chetól magak hasznokra, tapasztalván sok kárakat, a munkának rendes ára e szerint legyen. Ezek mint itt lévén, fel téve, valakik alább kezdik, másak kárával, az mint el rendeltük, 3 forint bírságon maradgyon, mind annyiszor valahányszot meg hallatik és igaz bizonyság által chehunkba bé jő, desummálhassounk, toties quoties.

Egy togát 24

Egy várasi firfinak vala mentét 12

Egy asszonynak valu (!) ángliai mentét 120

Egy frantzia pasztó mentét

120

Egy német kepenyeget 
Egy fél kepenyeget

6. Dolmány Lajbli készülettel

Egy aba kepenyeget

$-60$

7. Sújtásos Nadrág formával átal

Egy anglia dolomány

170

kötve

Egy közönséges háron petséti vagy

frántzia posztóból

Egy bérlet nadrág

Egy sinaras nadrág

Egy paszamantos anglia nadrág

Egy paraszt nadrag

Egy szoknyát primmel tsipkével

Egy paraszt szoknya

Egy sinaros és primes merevalut

140

8. keresztúl kötetlen formával

9. Nadrág k... 3 renddel

$2-$

Egy sinorral pasztu merevalut sinarral - 24

Egy paraszt merevalut

Egy rakot váll

Egy parasz[t]

Egy lájbit arany pálettal

Egy lájblit egy rend gombbal, két felöl jukkal

Egy lájblit két rend bombbal s egy jukkal - 60

Egy világi papnak valu reverendát

Egy harisnyát posztoson

Egy paraszt harisnyát

Az egész che meg egyezett azan kezbe adassal, hogy fel fogatták mind négyen az ifiak ugy mint Szentes Abel, [...] Szakhirda Janos, Szabo Janos es Sojmosi Szabo Janos, hogy őkegelmeket ha rajta talaltatik valaki közöttük (vagy közöttük), hogy alab dolgoznak amint egyenes mután(?) hárman toties quoties.

174-ik határoztatot czéhbeli árticullusok. A szabó céh papirfelzetes pecsétjével.

\section{Specificatio a munkák áráról}

1. Mentének Tsinálása keresztes Bot hajtással

2. Mente Tsinálás Simán, Ismét Ugy

3. Mente keszülettel Tsinálva

4. Dolmány Tsinálás ugyan eszerint

5. Dolmán Laibi Tsinálás súlytással vizfolyt
$-44$

$-30$

$-12$

$-24$

120

$-48$

$-36$

$-15$

128

$-12$

360

$-84$

274

$2 \quad 74$

$-12$

10. víz folyással karikoval 3 rendel 1 - 57

11. Nadrág egy rend Sinorral - 30

12. kissebnek -24

13. Béletlen Nadrág Sujtassal $\quad-30$

14. Béletlen Nadrág egy rend sinorral - 18

15. Béletlen Nadrág Úgy kitsinek $\quad-12$

16. Rövid Laibi Átal Gombolva $\quad-36$

17. Rövid Laibli egy rend jukal $\quad-30$

18. Rovid Lájbi kari kar ikoval $\quad-31$

19. kerek köpenyeg Tsinálása 2 -

20. Ujas köpenyegnek Tsinálása egész Barab

21. Kaput Tsinálás

22. Frák két rend Gombbal a válláig

23. Ujas Lajbi Tsinálás ordinár

24. ... Tsinálás

25. Ordinar vigano

26. Selyem vigano

27. Muszlinbol

28. Sláfrok ordinare

29. Slafrok

30. Szoknya Tsinálás Selyemböl

31. Szoknya ordinar

32. Kom... Tsinálás

33. Stu ... Rekli

34. Ordinar Laibli

35. Selyem Lajbli Tsinálása vak (?)

modra

Rft $\quad x$

36. Rojt ... ... Tsinálása Posztoból

37. Rojt ... Ordinar

$2-$

38. Selyem Melyrevalonak Tsinálása

140

125

$-\quad-$

18
$2-$

$2-$

18

130

128

$2-$

$3-$

$\begin{array}{ll}1 & 25\end{array}$

230

$-51$

$-30$

$-36$

$-36$

$-30$

130

130

$1-$

$2-$

$-30$

- 30

112

18
39. Hal ... kirakva Tsoposzon...

40. Melyrevalo ordinar

41. Fejer nép kerek Lajbli Tsinálás

42. Fejér nép Hosszu Bunda Tsinálás

43. Ferfi Hoszu Bunda Tsinálás 


\section{A pénzforgalom}

A vásárokon megjelenő termékek árának limitálása mellett a „mesteremberek és egyéb kereskedô rendek" (1624) által forgatott pénz és a pénzverés is eszköz volt a fejedelmek, az államhatalom terveinek megvalósításában. A fejedelmek hamar felismerték, hogy a gyenge minőségű ezüstből vert külföldi (fóleg lengyel) pénzérmék behozatala és a jó erdélyi aranyak kivitele szegényíti a kincstárt, „aranyat, tallért és jó dutkát kivinni nem szabad, fó- és vagyonvesztés terhe alatt" (1622). 1625-ben a császárral is tárgyalt a rossz pénz forgalmon kívül helyezéséről (EOE. VIII. 246-247.). Látván „A marháknak és egyéb mindenféle emberi szükségre való dolgoknak és áruknak képtelen és hallatlan drágaságát", szabad legyen mindenféle marhával szabadon kereskedni, a lovakkal és ökörbőrrel való kereskedés a fiskusnak legyen fenntartva (EOE. VIII. 267-268). Bethlen Gábor felülvizsgálta a korábban fejedelmi tulajdont képező földeket 1615 után, ezzel is növelte tervei megvalósításának gazdasági hátterét.

A pénzforgalom szabályozására a fejedelem, súlyos büntetéssel fenyegetve az ellenszegülőket, parancsba adta az új pénz elfogadását a kereskedelemben: „Egynehany felöl való relatiokkal értjük, hogy ismét rút veszekedés kezdett gyakori helyeken az reformált ötlotos 10 pénzünknek ususában, [...] valaki az ellen cselekszik és ez mostani pénzt el nem venné, mindennemú javait confiscaltatjuk és azon pénzt homlokába sütvén fejét is elveszíti." 13

A brassói garas nem volt gyengébb más pénznél, de mivel előszeretettel hamisították, 1615-ben beszüntették verését. A hamis és áldutkák miatt a dutkát, ha mégolyan jó is, el nem fogadják, úgy határoztak, hogyha anyaga nem vas, réz vagy ón, mindenki fizethet vele.

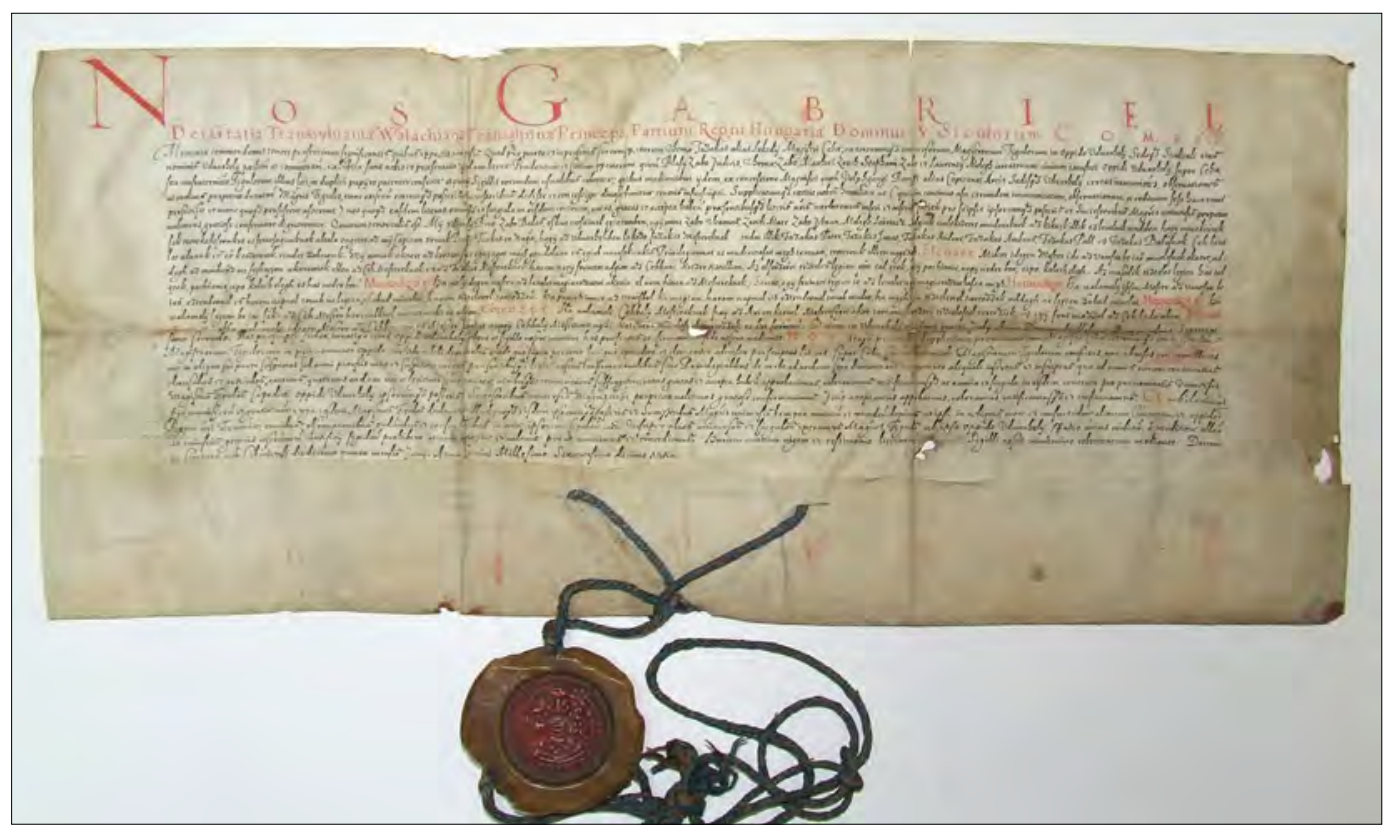

21. kép. A székelyudvarhelyi fazakascéh kiváltságlevele. Kibocsátotta Báthory Gábor fejedelem Nagyszebenben, 1613. június 15-én. F 249, 617 sz... (Fotó Bicsok Zoltán) 
A rossz pénz ügyében a fejedelem rendeletet adott ki 1625-ben. Az újabban vert 3 és 5 garasos és az aprópénzt nagybányai és kassai pénzverdékben verték. Az új veretek megjelenésével egy időben a forgalomban lévő garasokat kivonta a forgalomból. Vagyonvesztés terhe alatt megtiltotta a Lengyelországban vert polturák elfogadását: „ne éljen, ne adjon semmit és el ne vegye, hanem az mostan kibocsátandó jó pénzünkkel, arannyal, tallérral éljen minden, egy aranyat két forintban, egy tallért százhuszonöt pénzben számlálván". A reformot kiterjesztették Ausztriára és Lengyelországra. A lengyelek megígérték, hogy a polturát a liga (Ausztria és Erdély egyezménye a pénzkibocsátás tárgyában) mintájára fogják verni és mindhárom „birodalomban” forgalomba lesz az új pénz, vagyis „az háromféle egy ligára vert pénz egyaránt járjon" (EOE. VIII. 309-310.). Bethlen Gábor is kénytelen volt követni kortársai példáját és kétes eredményű pénzrontást is gyakorolni. Az 1617-1620 között vert pénzek még 0,420 finomságúak, az 1620-1622 közöttiek 0,375, az 1623-1624 közöttiek már csak 0,315 finomságúak.

A rendelet szabad utazást biztosított a kereskedőknek: „Minden kereskedő rendek azért szabadoson menjenek, jőjenek, életeket, nyereségüket keressék, az marhát isten igazsága szerint való árán adják. Azonképpen mészárosok, tôsérek, és az egész község szabadoson adjon-vegyen, kereskedjék, városokra mindent bevihet, jó pénzt adnak érette, ki ez után mind az három birodalomban egyaránt eljár, hogy immár az nagy drágaság és sok panaszkodás forduljon jó állapotra." (EOE. VIII. 310.) A régi garast kivinni az országból nem szabad, hanem akinek ilyen garasa van, vigye a kassai és nagybányai „minczházainkba”, ahol beváltják új garasokra.

A korszak legértékesebb pénzneme a ma- gyar aranyforint vagy dukát volt. „A pénzegység a magyar mintára vert dukát volt, melynek többszörösei közül gyakori a kettôs és tízes arany, elöfordul azonban, bár némelyik csak kivételképpen, a 2, 4, 5, 6, 7 aranyos pénzdarab is." (Honvári 2002.149-150.)

Az ezüsttallért külföldről hozták be, de Szebenben már 1552-ben verték I. Ferdinánd utasítására, és gyorsan a legkedveltebb pénz lett Erdélyben. Jellemző, hogy a pénznek a dénárt nevezték, amely a legnagyobb menynyiségben volt forgalomban. Az osztrák és német krajcárok és a lengyel garasok is nagy mennyiségben kerültek Erdélybe. Forgalomban lévő külföldi tallér volt az imperialis, a gréci és az oroszlános, a szeges, a Ferdinánd.

Az átváltási arány 1 krajcár egy dénár volt. Erdélyben 400-500 dénár volt egy aranyforint. Átváltási pénznem (számítási pénz) volt a magyar forint, amely 100 dénárral volt egyenlő. Számítási pénz volt a rénes vagy rajnai forint, ennek értéke 60 krajcár vagy 120 dénár volt. Újabb rendeletet ad ki a fejedelem 1626. február 24-én az új pénz kötelező elfogadása érdekében (EOE. VIII. 310-311.). Parancsba adta, hogy az új pénzt mindenhol

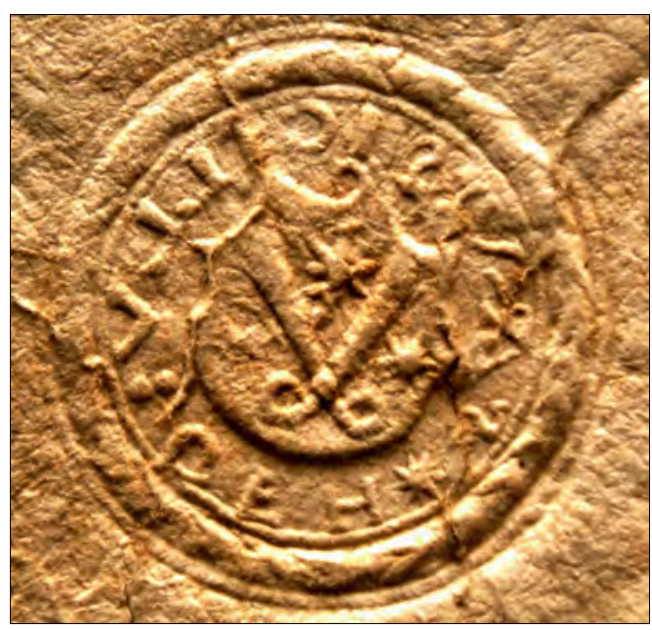

22. kép. A szabócéh régebbi pecsétjének papírfelzetes lenyomata 
fogadják el. „Látván az országban az ó- és új monetában való nagy válogatást, kiváltképpen az együgyü közrend között annyira, hogy ki az ó pénzt, ki az ő felsége mostani öt lótos pénzét nem akarván elvenni", az árfolyamát a régihez igazítják. Minden régi pénz „abrogáltatott'. A rendeletet Debreczeni Tamás kincstárnok írta alá.

1664-ben a januári 31. - február 24. között tartott országgyúlés a XXXVI. tc. elfogadásával újra intézkedett a jó pénz külföldre vitelének megtiltásáról. Mivel káros az országra, a jó pénz „kihordását” mindenki számára megtiltják. A harmincadosok és vámosok szigorúan vegyék el pénzét, ha valaki ilyennel próbálkozna, és halálbüntetést helyez kilátásba a tisztviselők számára, ha tudtukkal történik. A tallérok és arany váltásáról úgy intézkedett az 1666. évi februári országgyülés, hogy „egy tallért két forinton, egy aranyért négy forintot adnak" hivatalosan (Huszár 1995).

A napoleoni háborúk konjunktúráját igyekezett ellensúlyozni 1811. március 15-én elrendelt devalváció, ez 1816-ban ért véget, mikor a pénzrendszer visszatért a konvenciós alapra. A birodalomban 360 millió birodalmi tallér, Erdélyben Kővári László számításai szerint 10 millió tallér lehetett. Az évente bányászott aranyból Gyulafehérváron 120000 érmét vertek, ami forgalomba is került Erdélyben.

\section{Pénzrendszer a birodalomban}

Aranypénzek:

- souverains d' or $=13 \mathrm{ft} 20 \mathrm{x}$

- császári vagy körmöci arany = $4 \mathrm{ft} 30 \mathrm{x}$, ami 4 rf 30-40 x között ingadozik

Ezüstpénzek:

- koronástallér $=2 \mathrm{ft} 12 \mathrm{x}$

- félkoronás tallér $=1 \mathrm{ft}$

- negyedkoronás tallér $=33$

- közönséges tallér $=2 \mathrm{ft}$ félnek $=1 \mathrm{ft}$

- negyednek $=30 \mathrm{x}$

- apróbb ezüst $=20,10,5 \mathrm{~g}$

$-\operatorname{aras}=3 \mathrm{p}$.

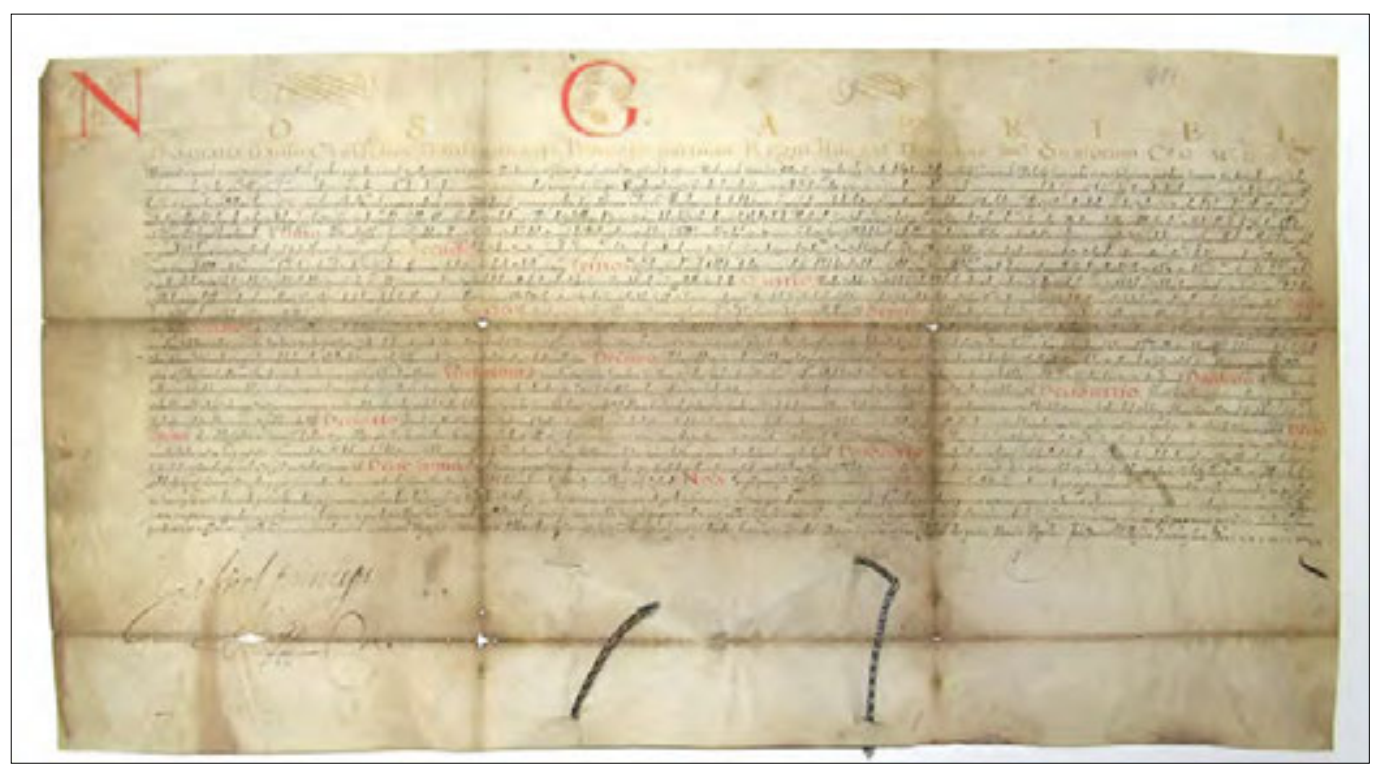

23. kép. A székelyudvarhelyi szabócéh kiváltságlevele. Kibocsátotta Báthori Gábor fejedelem Nagyszebenben 1613. április 1-jén. F. 249, 36. sz. (Fotó Bicsok Zoltán) 
Rézpénz:

- 1 krajcár 1/2 és 1/4 pengő krajcár értékü, 30, 15, 6 krajcár értékben

Virtuális (számítási) pénz:

- rénes vagy német forint $=60 \mathrm{x}$

- vonás forint = 3 Máriás vagy 51 krajcár

- magyar forint $=100$ démár vagy 50 krajcár

- kopac forint = 48 kr váltóban

- susták = 6 váltókrajcár

- poltura = 11 váltókrajcár.
Az erdélyi hivatalokban mindig pengőben, a magyaroknál mindig németben, a székelyeknél pedig mindig magyarban kell érteni (Kőváry 1847). Papírospénzek is forgalomban voltak, az ún. váltócédulák 1, 2, 5, 10, 20, 100 váltó forint értékben.

\section{A mértékekről}

Mindennapi életünk szinte észrevétlen, ugyanakkor fontos velejárója a mértékek használata. Szigethy Gyula Mihály profesz-

4. táblázat. A méterrendszer bevezetése előtt használt erdélyi mértékek

\begin{tabular}{|c|c|c|c|}
\hline Mérték & Használat ideje & Más mértékhez hasonlítva & Nagysága metrikusan \\
\hline \multicolumn{4}{|c|}{ Ürmértékek } \\
\hline hordó, kis & \multirow[t]{3}{*}{1556 után } & 20 erdélyi vödör & $218 \mathrm{l}$ \\
\hline hordó, földes & & 40 erdélyi vödör & 4361 \\
\hline hordó, öreg & & 80 erdélyi vödör & 8721 \\
\hline hordó, kis & \multirow[t]{3}{*}{1823 után } & 5 erdélyi vödör & $56,60 \mathrm{l}$ \\
\hline hordó, közép & & 10 erdélyi vödör & $113,20 \mathrm{l}$ \\
\hline hordó, nagy & & 40 erdélyi vödör & 452,801 \\
\hline icce & 18. sz. & $1 / 2$ erdélyi kupa & $0,6816 \mathrm{l}$ \\
\hline icce & 1823 után & $1 / 2$ erdélyi új kupa & $0,7074 \mathrm{l}$ \\
\hline köböl & 1823 után & 8 új erdélyi vödör & 90,541 \\
\hline kupa & 17. sz. & 1 kolozsvári kupa & 1,36231 \\
\hline \multicolumn{4}{|c|}{ Száraz űrmértékek } \\
\hline mérő & 1823 után & 42 új erdélyi kupa & 44,57 \\
\hline véka & 1647 után & 16 erdélyi kupa & 16,39 kg búza \\
\hline \multicolumn{4}{|c|}{ Súlymértékek } \\
\hline \multirow[t]{3}{*}{ font } & 1680 után & 20 ezred lat & $0,3895 \mathrm{~kg}$ \\
\hline & 1690 után & 32 ezred lat & $0,4489 \mathrm{~kg}$ \\
\hline & 1721 után & egy bécsi font & $0,5600 \mathrm{~kg}$ \\
\hline \multirow[t]{3}{*}{ mázsa } & 1680 után & 144 erdélyi font & $56,09 \mathrm{~kg}$ \\
\hline & 1690 után & & $64,64 \mathrm{~kg}$ \\
\hline & 1721 után & egy bécsi mázsa & $56,00 \mathrm{~kg}$ \\
\hline \multicolumn{4}{|c|}{ Darabmérték - sómérték } \\
\hline sómérték & 12. sz. & & \\
\hline 2 hajósó & 1575 & vízaknai só & \\
\hline 3 kősó & 1423 & & $5,50 \mathrm{~kg}$ \\
\hline
\end{tabular}


szor 1834-ben így írt a mértékekről: „Tárgya a' mérés Tudományának minden kiterjedés, mely hol a' lineákban, széjjel, hoszszban, méjben, hol a' lapokban, hol a' testek üregében, mérōjében fordul elő. Az honnan a' mérés Tudománya három részekből áll. [...] Vagyon haszna a' Mérés tudományának a' közönséges életnek minden nemében: $a^{\prime}$ bányász mesterségben, a' földmüvelésben, az építésben, $a^{\prime}$ kézi-mesterségekben, $a^{\prime}$ testek' természetérôl szóló tudományban, a' festésben, rajzolásban, és a' metszésben." (Szigethy 1834. 543-568.)

„A kolozsvári köbölrendszer a középkorban is nagy elterjedettségnek örvendhetett, mert mindjárt a Fejedelemség kialakulásakor uralomra jutott. Harcot egyedül csak a szászok mértékrendszerével kellett vívnia, de ebből is hamarosan győztesen került ki. 1549-ben az országgyúlés Erdély-szerte a kolozsvári köbölt tette kötelező gabonamértékké, a borvásárra ugyanakkor a szász mértékrendszert hagyta meg." (Jakó 2016. 471.)

Az 1578. évi áprilisi országgyűlés főleg a vásárokban is használt mértékeket „magyarországi atyánkfiaival egyetemben, mivel egy hazába vagyunk, az sok különb-külömb féle helyeken való mértékek, úgy mint köböl, ejtel és mázsa letétessenek, hanem az egész szászság, mindenütt ez országban egy köböllel éljen, mind várasokon, mind falukon, szebeni köböllel, egyéb minden, kolcsos, szabad és mezővárosok, falus helyek az kolosvári köböllel éljenek, ahhoz szabva köblöket. A székelység azonképpen minden helyeken kolosvári köböllel íljenek és másával. (EOE. III. 17.) Az ejtel mérete a kolozsvári legyen [...]. Singgel, fonttal (Finály 1866.) és egyéb efféle mértékkel egyaránt éljenek minden széken minden rend. [...] Köböl pedig az kolosvári legyen [...]"

Az 1578. decemberi országgyűlés határozata szerint állami feladat volt a mértékek ellenőrzése és az azokkal való visszaélések megtorlása. Az 1622. májusi országgyűlés határozatainak 11. articulusa szerint minden városbeliek „vékájok, eyteleket és vedreket megváltoztatták, hol megnagyobbították, hol megkisebbítették, magok hasznát követvén bennük, nekünk nagy kárunkra és fogyatkozásunkra". Leszögezte, hogy minden város vékáját, ejtelét, vedrét Szent Margit napjára produkálja Fejérvárott pecsét alatt, s azt megváltoztatni nem szabad. A pontos mértékek használata közérdek volt (EOE. VIII. 99.). Az Approbata Constitutiók előírták, hogy a „vármegyékben is ejtelekkel, vékákkal, köblökkel, singekkel, mázsákkal és minden egyéb mértékkel egyenlőképpen éljenek, és mindezek a kolozsvári mértékhez alkalmaztassanak, úgy hogy egybealkalmaztatván a mértékeket a kolozsvárival, az egész szászságra Szebenből adattassanak ki a többi városokra, és azokról a falukra. A székelységen Udvarhelyrôl adattassanak ki a több székekre és városokra és azokról falukra."(Approbata Constitutiok. III R. Titulus XLV. art. 1.). Székelyudvarhely város elöljáróinak 1588. évi perében egyik tanú ezt vallotta: „Tudom azt is, hogy ki menének $a z$ Gyepü ciherjébe, mivel hogy sok panasz vala, hogy egy néhányan bírnak az Gyepü ciherjébe, kiment az város, kötelet (!) vittek, hogy meg mérjék, ott azért mindennek részében hagyták, a' kinek ott földje vala, másutt is sok költséggel a' helyett mértek földet."14

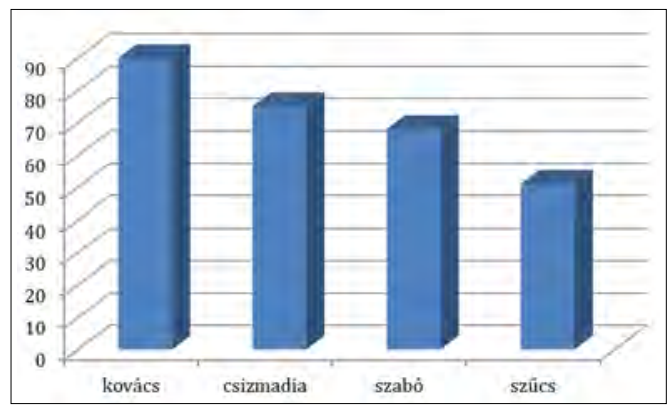

5. ábra. $A$ vidéki kézmüvesek négy legnépesebb csoportja 1820-ban 
Egy udvarhelyszéki 1589. évi perben említik, hogy a románok „oszt úgy adtak neki két disznót, egy tömlöt, s három köböl búzát, vagy kettőt" (SzO. 1983. 59.). Egy 1590-ben folytatott perből megtudjuk, hogy „minden húsz juh után két sós sajtot, két tömlőt és egy vider ordát ad" (SzO. 1983. 104.). Szent Márton-nap utáni pénteken. 1589-ben Farcádi Péter „nyolc forintos (egy ökör ára hat forint volt) és nyolc és fél köböl búza adóságát" említették (SzO. 1983. 89.). A máréfalvi pereskedők 1589-ben „tíz sing héján száz sing vásznat" említettek. Egy ittasan elkövetett gyilkossági perrel kapcsolatos vallomás jegyzőkönyvében olvashatni: „no gazda, hány kupa bort hozattál minekünk? Én mondám, hogy egy vider bort hordottam.” (SzO. 1983. 126.) A sört viszont hordóval mérték: „az egy hordó sert, a pálfalviak lófejek hozták" (SzO. 1983. 23.).

Az 1625. évi májusi országgyülés limitációja kötelezte a kádárokat, hogy „igaz mértékre csinálják az ő míveket és reá vigyázzanak a ché mesterek minden városokon, falukon penig az bírák hütök szerint. Az öreg hordó nyolcvan vedres legyen igazán. Az földes negyvenvödrös legyen. Az egész hordót, ki nyolcvan vödrös, jó, jól csinált, jól kötött, adják 1 forinton 50 pénzen." (EOE. VIII. 293.)

A számtalan mértékek között sajátságos a zetelaki zsindelymérték, amelyben az $1,9 \times 11,0 \times 71,1 \mathrm{~cm}$ nagyságú zsindely, és a deszkamérték, ami egyenlő volt 0,05 cm-rel.

A mértékek használatát a 16. századtól törvényekkel, rendeletekkel szabályozták, hogy kizárják a hamis mérőeszközöket, és lehetetlenné tegyék a hamis mértékek használatát és a hamis méréseket. Törekedtek az egységesítésére is, ez a bécsi rendszer bevezetésével nagyrészt megvalósult, de a dolog csak a méterrendszer bevezetésével oldódott meg minden részletében.

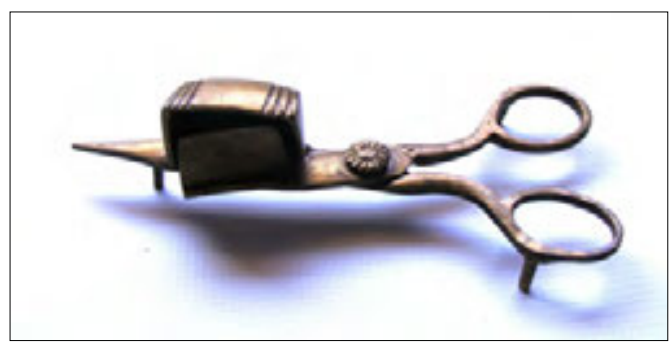

25. kép. Szabóolló

A búza és gabona ára rendkívül növekedett: „félvén attól, hogy az szegénység éhhalásra ne jusson, és egyszersmind akarván az sok rendkívül búzával, gabonával kereskedőket megzabolázni, szükségesnek ítéltük, hogy ámbár ily nagy szükségben legyünk is, hogy a búzának és egyéb gabonának árát meglimitáljuk. Idegen sem a piacon, sem háznál nem vásárolhat. A legszebb búzának vékáját egy forintnál, a zabnak 25 pénzért, az alakornak és árpának vékáját 33 pénznél, a kölesnek 10 pénznél, a haricskának 50 pénznél feljebb adni senki ne merészelje."

A régi mértékrendszerek (számunkra ma már érthetetlen) bonyolultsága megmaradt a méterrendszer bevezetéséig, annak ellenére, hogy Bécsből a mértékek egyszerűsítését akarták elérni. Ez azonban megtört a parasztság gyanakvásán és megrögzött félelmén minden reformkísérlet esetében. ${ }^{15}$

A 4. táblázat csak egy nagyon kis részét mutatja a méterrendszer bevezetése előtt használt mértékeknek. Pontosabban, csak az erdélyi mértékekből tallóztunk.

A zsindelyt (asser tegularis, scandula latinul és Schindel németül) a tetőfedésre használt fenyőfalapok jelentésben az írott forrásokban 1405-től ismerjük. A tetőszerkezet léceire keményfa szegekkel erősítették fel, de már korán megjelentek az erre a célra kovácsolt vasszegek. Az 1627-évi erdélyi limitációban így írnak: „A zetelaki [Udvarhely] és azon vidéken lévő falukban csinált sendely, 


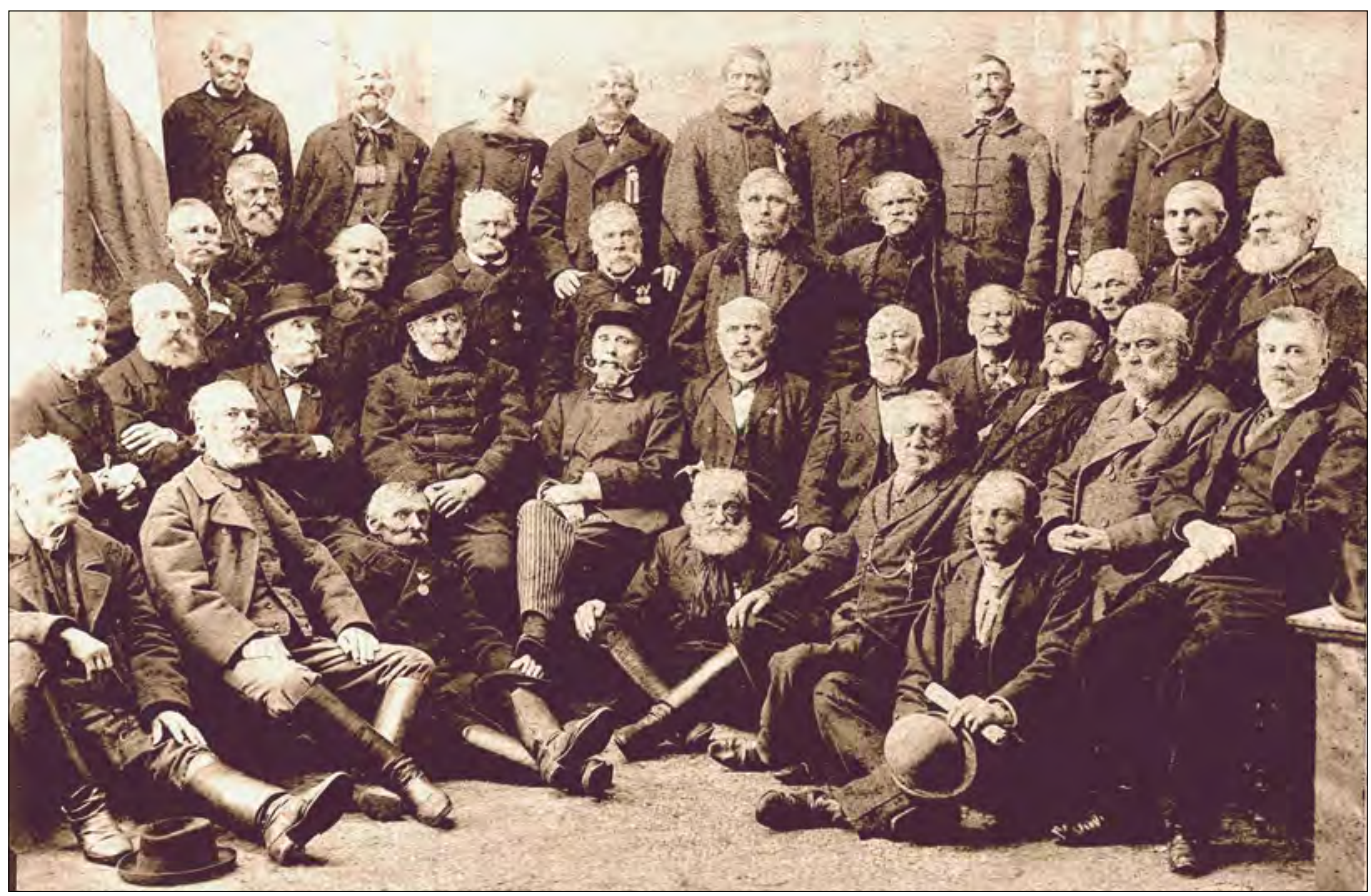

26. kép. A székelyudvarhelyi Szabó Ipartársulat tagjai 1924-ben egy szabásztanfolyam elvégzése után

melynek hoszsza háromarasznyi, szélessége egy hüvelykes tenyér". ${ }^{16}$ Egy másik udvarhelyszéki jellegzetes mérték az oláfalvi deszka volt. A mértékek sokaságának az 1876. évi II. törvénycikk vetett véget, amelyet az akkori szóhasználattal élve „civilizált országok” valamennyien elfogadtak. Ezzel a nemzetközi kereskedelem útjából nagy akadály hárult el. Bécs sikertelen ostroma után (1683) a Török Birodalom magyarországi uralma látványos gyorsasággal összeomlott. A 17. század végén az Erdélyi Fejedelemség a Habsburg Birodalom egyik tartománya lett. A céhek más gazdasági viszonyok közé kerültek. A központi hatalom barátságtalan politikát folytatott az elavultnak ítélt, a gazdasági fejlődést akadályozó céhekkel szemben. Arra törekedett, hogy uniformizálja, központi felügyelet alá vonja a sokszínű céhvilágot.

\section{A céhen kívül dolgozó iparosok, a kontárok}

A városi kézművesek termelését (ezek rendszerint céhtagok voltak) a vidéken, falusi környezetben dolgozók egészítették ki. Számuk nagyobb volt, mint amire az összeírásokból következtethetünk. A közhelyeken túl nem járhatott messze a valóságtól a Kézdivásárhelyen 1820-ban készült összeírás adatközlője, mikor azt állította: „Mi magunk [a jobbágyok] is többnyire mind mesteremberek vagyunk. Ki suszter, ki szabó, ki kalapos, ki üstgyártó, ki asztalos, ki szígyártó. És minden kézimunkánkot készpénzen itten eladhassuk. Emellett vagynak ezen helységben céhok, úgymint: csizmadia-, tímár-, szőcs-, szígyártó-, fazakas- és mészároscéh, melyekben vagynak kiben-kiben 20, kiben 50, kiben 60-70, s még 100 mesteremberek is. Úgyhogy összesen ezen 


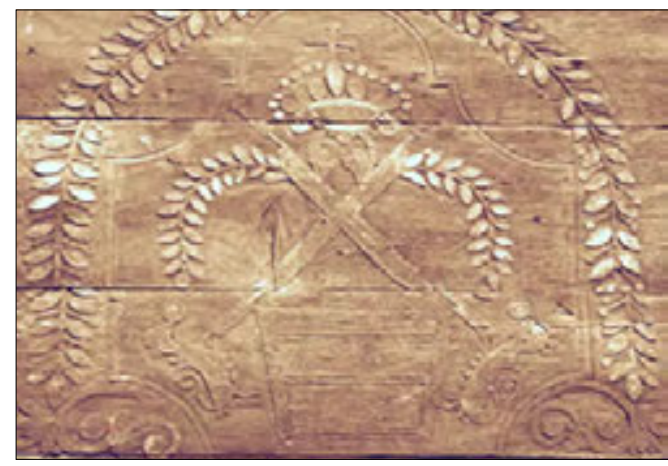

27. kép. Egy városi székelykapu tükrében tímárcímer. A kaput állítatta Tamás Lajos és felesége Laiber Anna 1853. október 27-én. Faragta Kovács Péter. (Jelenleg a szejkefürdői kapuk között a nyolcadik.)

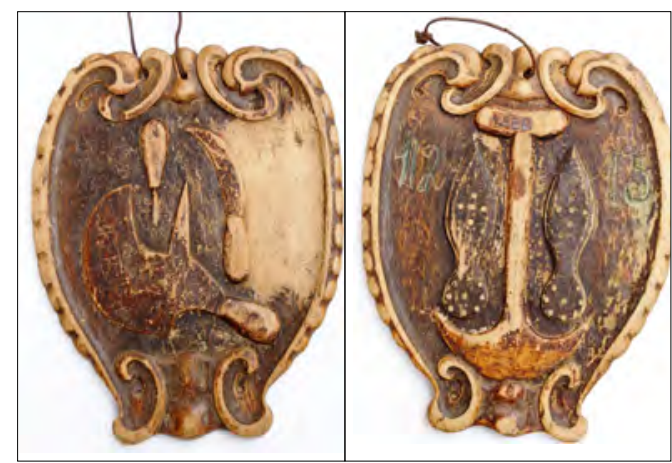

28. kép. A székelyudvarhelyi vargacéh behívótóblájának elō- és hátlapja

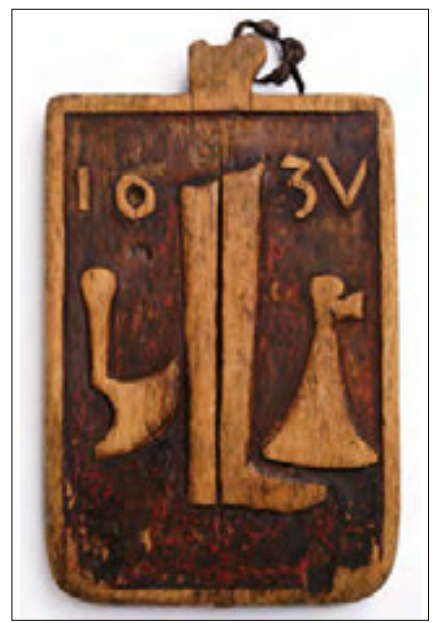

29. kép. A csizmadiacéh behívótáblája 1635-ből helységbe[n] tanáltatnak 300 mesteremberek." (Takács 2002. 201.)

Az udvarhelyi céhekben dolgozó mesterek mellett a szék falvaiban még sok kézműves dolgozott. Ezek a helyi, a lakóhelyük közelében gazdálkodók igényeit elégítették ki. De ennél nagyobb körzetnek is dolgozhattak, sőt a vásárokban is megjelenhettek. Legtöbb volt közöttük a kovács (90), mert állandóan és helyben kellett elvégezni a patkolást (patkoló kovácsok), munkaidőben a szerszámok élesítését, a kisebb-nagyobb javításokat. Mellettük elenyésző számban dolgoztak lakatosok is. A szabók specializált csoportja volt a harisnyaszabóké (székelyharisnya), akik a zeke és más szabókkal együttesen 68an voltak. A székben 1820-ban (lakossága 96929 fő volt 1868-ban Orbán Balázs adatai szerint) 463 falun lakó kézművest számoltak össze a függőségben élők adózását előkészítő felméréskor. A valóságban ennél nagyobb lehetett a kézművesmesterek száma, mert nagyon sokan foglalkoztak fatányér-esztergályozással, borda-, szúszék- és teknőfaragással, szekérkészítéssel, bőrcserzéssel, hordókészítéssel és sok-sok más munkával, eladásra is termelve.

Udvarhelyszéken 1781-ben összeírták a cigányokat. A nem teljes összeírás szerint is öt járásban, a bögözi, homoródszentmártoni, farcádi, etédi és bözödi járásokban összesen 600 cigánycsalád élt, 3500 felnőtt, 779 fiú- és 674 leánygyermekkel. A többi járásban lakókat is beleszámítva 4000 körül volt a számuk, ami a jobbágyok fele volt. Az erdővidéki Bardóc fiúszéken 59 családot írtak össze 112 gyermekkel. ${ }^{17} \mathrm{Ez}$ azt jelentette, hogy 200 körül volt a számuk. Foglalkozásukat tekintve legtöbb volt köztük a kovács. Ezeken túl dolgozott még csizmadia és halász. Ugyanakkor a szék kilenc járásában 1788-ban volt 339 főúri és nemes család, 1786-ban 912 volt 
a számuk, amelyben nem volt beszámítva a közszékelyek száma, csak a birtokos és armalista családokat sorolták a rendbe. A székben volt 119 falu, 10736 házszám, 11119 család, hivatalnok 11, mesterember 185, földmíves 5660, előkelő polgárok és földművesek utódai 4906, belső telkes 4989, katona 69, egyéb foglalkozású 2322, fiúgyermek 12 évig 5553, 13-17 éves fiú volt 2032, nő volt összesen 25 639. Így a lakosság száma összesen 52529 fő volt, 1787-ben ez a szám 51 354-re apadt (Jakab-Szádeczky 1901. 529-530.).

A pénzforgalom viszonylag alacsony szinten mozgott, a parasztgazdaságok minden lehetséges területen önellátásra rendezkedtek be. „A fejérnépek a magok szötteményekkel ruházkodnak" - jegyezték meg Bencéd 1820. évi összeírásában, és még sok hasonló állítást találunk. A ruházat majdnem minden darabját előállították, megszőtték az asszonyok vagy a falusi mesterek. A bonyolultabb ruhadarabok, mint a harisnya vagy a felsőruházat esetében a helyi szabókat hívták segítségül, akik egy zsinegre bogokat vetve jegyezték fel a mértéket. A reformkori feudális társadalom autarchiája tovább élt a Székelyföld falvaiban. Pénzre csak néhány meghatározott helyzetben volt szüksége a földesuraktól függő viszonyban élő jobbágynak vagy akár szabad közszékelynek. Pénzt csak adófizetésre, olyan dolgok megvásárlására használt, amit nem tudtak előállítani, vagy a faluban nem volt fellelhető. „Évente egy-két piacra hajtott barom fedezte az egyes családok számára a nélkülözhetetlen pénzalapot vagy csereterményt." (Gazda 1998.) A 19. században itt is színesebbé vált a ruházat, elsősorban a nőké. „A kiváltságosság tudata hivalkodó fogyasztást vont maga után, státusszimbólumok igénylését. Ilyen meggondolásból építettek maguknak a székelyek mázas kandalóval ellátott, viszonylag módos, tágas házat, állítottak portájuk elé díszes, rangra utaló székelykaput, és ilyen meggondolásból igyekeztek kialakítani, - a divatot bizonyos késéssel követö, - látványos viseletüket. Ugyanakkor a szegénység korlátokat is szabott törekvéseiknek, ezért $e$ javak egy részét házilag voltak kénytelenek előállítani." (Gazda 1998.)

A vidéki mesterek sem voltak minden esetben kontárok (ahogy általában értelmezzük), csak abban az értelemben, hogy nem voltak tagjai valamelyik céhnek. Ennek nagyon sok oka lehetett. A céhkiváltságok hatálya rendszerint csak a városra és annak környékére, négy mérföld ${ }^{18}$ távolságra terjedt ki. Ezen túl a falvakon a földesurak és a lakósok számára dolgozhattak. Ha egy városi céh nem tudta elegendő jó minőségű termékkel ellátni piacát, a város elöljárói beengedhettek vásáraikra máshonnan érkező termelőket is. Más dimenzióban hasonló folyamat ment végbe a kisvárosokban is. Szerződésben kötötték ki, hogy az inas és a legény ruhát is kapott mesterétől. A legények vándorlása eddig fel nem mért változásokat, szokásokat honosított meg.

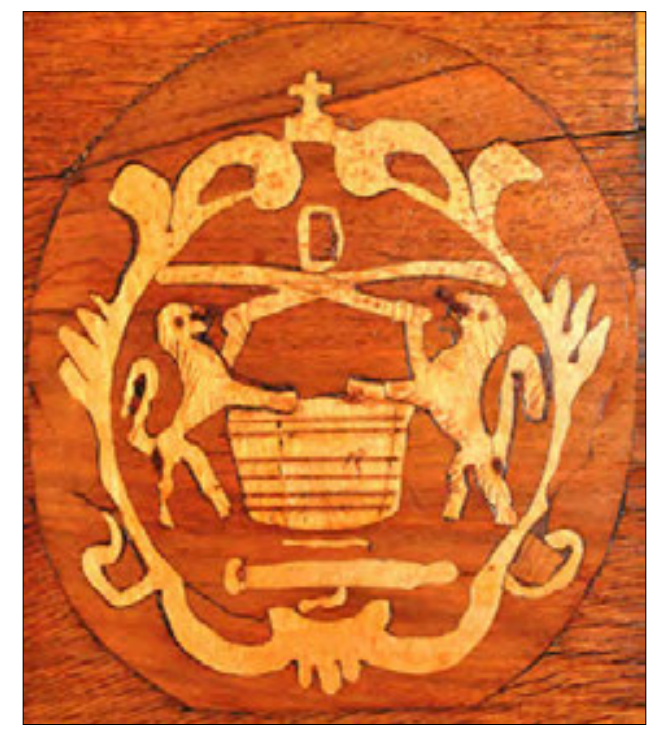

30. kép. Tímárcímer intarziája a céhládán 1863-ból 
1820-ban, a szék 125 falujában 127 lisztelő vízimalom őrölte a helyben aratott és a szék termésének kiegészítésére behozott gabonát. Az összeírásból kimaradt Korond, ahol nagy volt a fazekasok száma. „Korondon minden ember fazakas is; itt készülnek azon mázatlan, és hallatlanul olcsó cserép edények, melyek az egész Székelyföld (kivéve Csíkot) konyhakellékeit fedezik; nyikorgó szekereiken hordják szét a Korondiak ezen gyártmányukat, $s$ azt rendszerént nem pénzért, hanem gabonáért adják el. [...] A falu között lefolyó Korond vizén sok fürész- és lisztelő malom van." A szék malmainak sokkal nagyobb volt a kapacitása, mert voltak két- vagy háromkövűek is.

A bonyolult pénzrendszer változásai nehéz feladat elé állították a piacon eladóként és vevőként is megjelenő kézműveseket. Ráadásul ezekben az években zajlott le az első nagy európai infláció.

Az ország gazdaságára nagy súllyal nehezedett a törököknek fizetett adó, amely évről évre nőtt. Bethlen Gábornak még sikerült a költségvetését egyensúlyban tartani, sőt egyes években a bevétel jelentősen meghaladta a kiadásokat. Pénzügyi politikája sokszor nyomasztóan hatott a céhekre, konkurenciát jelentett a hazai iparnak. Ilyen intézkedése volt az anabaptisták vagy a gdański kézművesek betelepítése. Pillanatnyilag ezek az intézkedései nem kedveztek a hazai ipar fejlődésének, de az „ónmázas, ízléses cserépholmik, tálak, bokályok csempék, csészék szinte elöntik a kastélyokat, udvarházakat. Elviszik a színek és formák örömeit a módosabb polgárotthonokba, solcsóbb kék mázas edényeik mezővárosok és falvak tehetősebb házaiban keverednek el a paraszt fazekasok termékeivel" (Makkai - Szász 1986. 933.).

Udvarhelyszéken a sóbányászatnak csak regionális jelentősége volt, de 1670-ben az udvarhelyi református kollégium építésére és fenntartására a sófalvi bánya jövedelméből utalt ki pénzt a fejedelem. A 17. században is nagyobbrészt a céhek látták el a
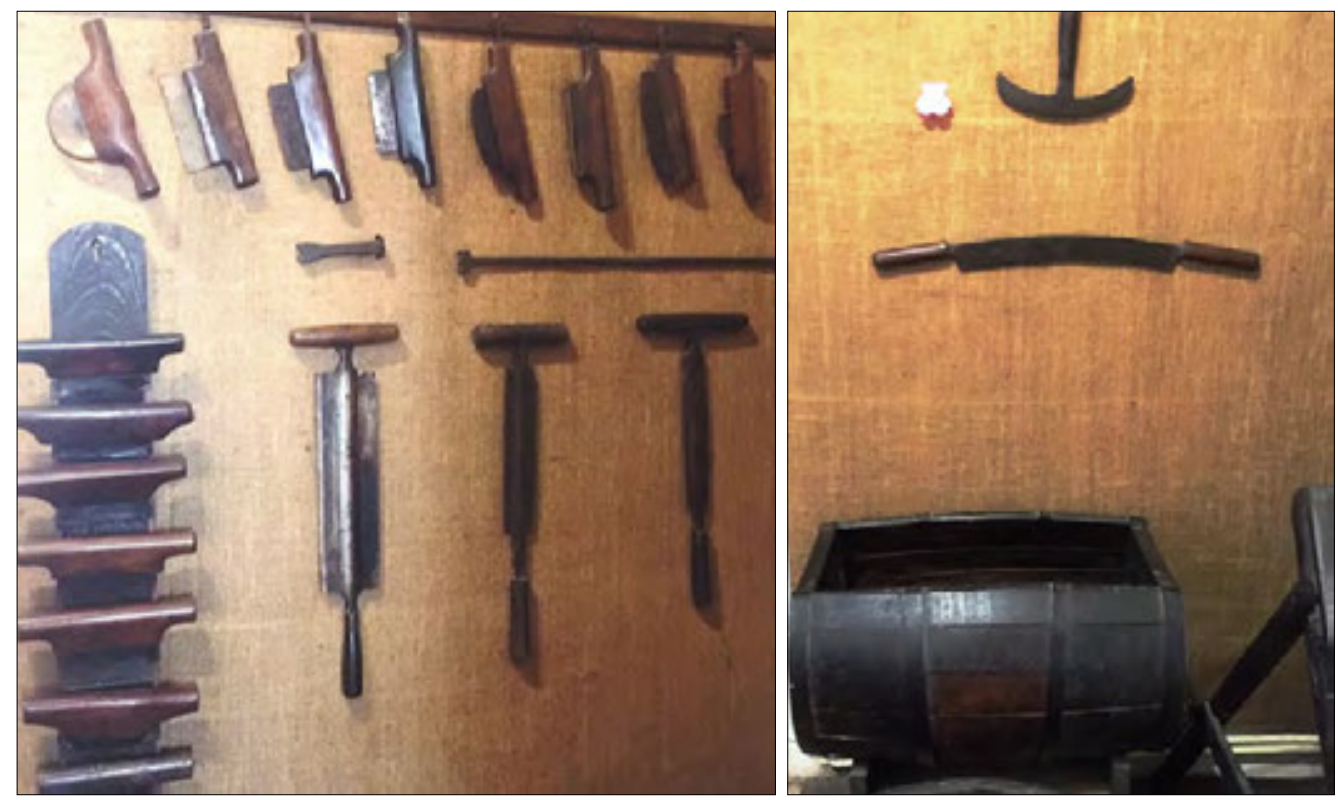

31. kép. Timár mesterek szerszámai a kézdivásárhelyi Incze László Céhtörténeti Múzeumban 


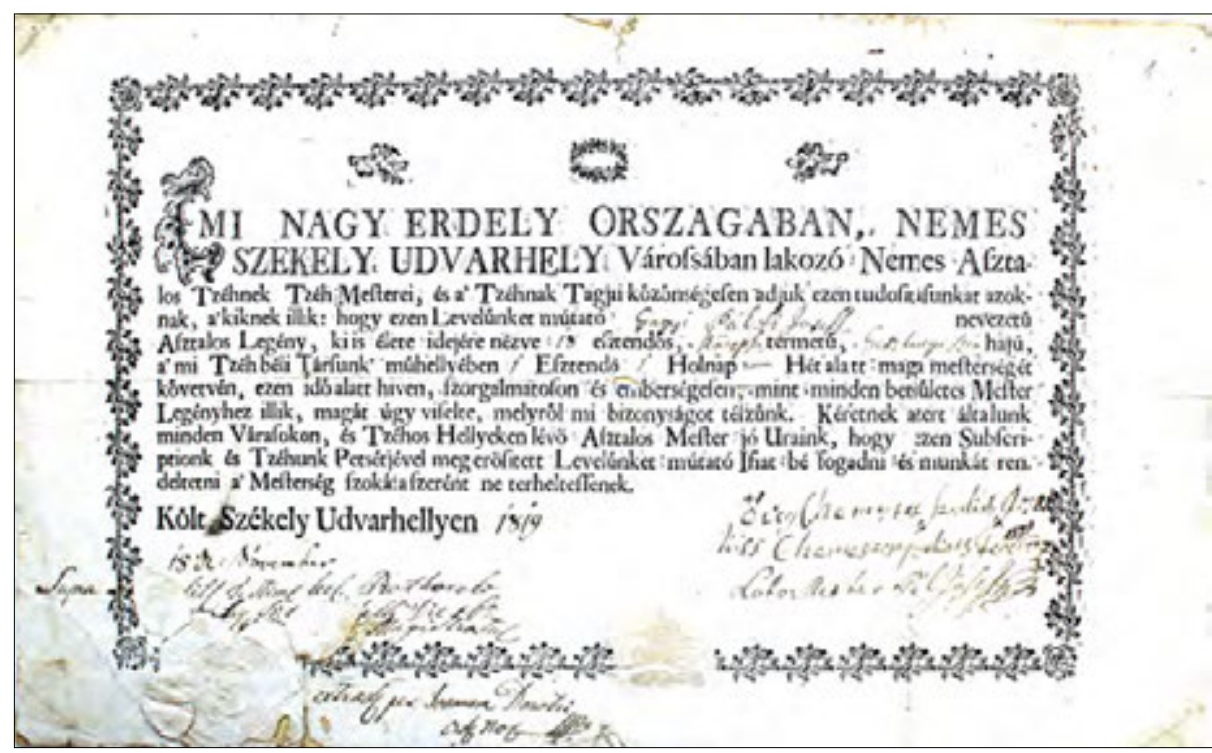

32. kép. Az asztaloscéh munkaigazolása Pálfi József asztaloslegény számára 1819

lakosságot ipari termékekkel. Apafi Mihály „kéneső üzlet”, amihez vargyasi Daniel István uralkodásának éveiben, 1690 előtt a kincstár (korának talán legbefolyásosabb embere bevételei emelkedtek. Egyik bevételi forrása Udvarhelyszékben) és Macskási Boldizsár, a külföldre irányuló kereskedelem volt. A só(Belsőszolnok vármegye főispánja) adták val, arannyal, ezüsttel, vassal, higannyal (kéa szükséges tőkét. 10000 forintot fizettek neső) folytatott kereskedelemből származott be egy közös vállalkozásba, amelynek céla kincstár legnagyobb bevétele. Példa erre a ja az volt, hogy higanyt vigyenek külföldre.

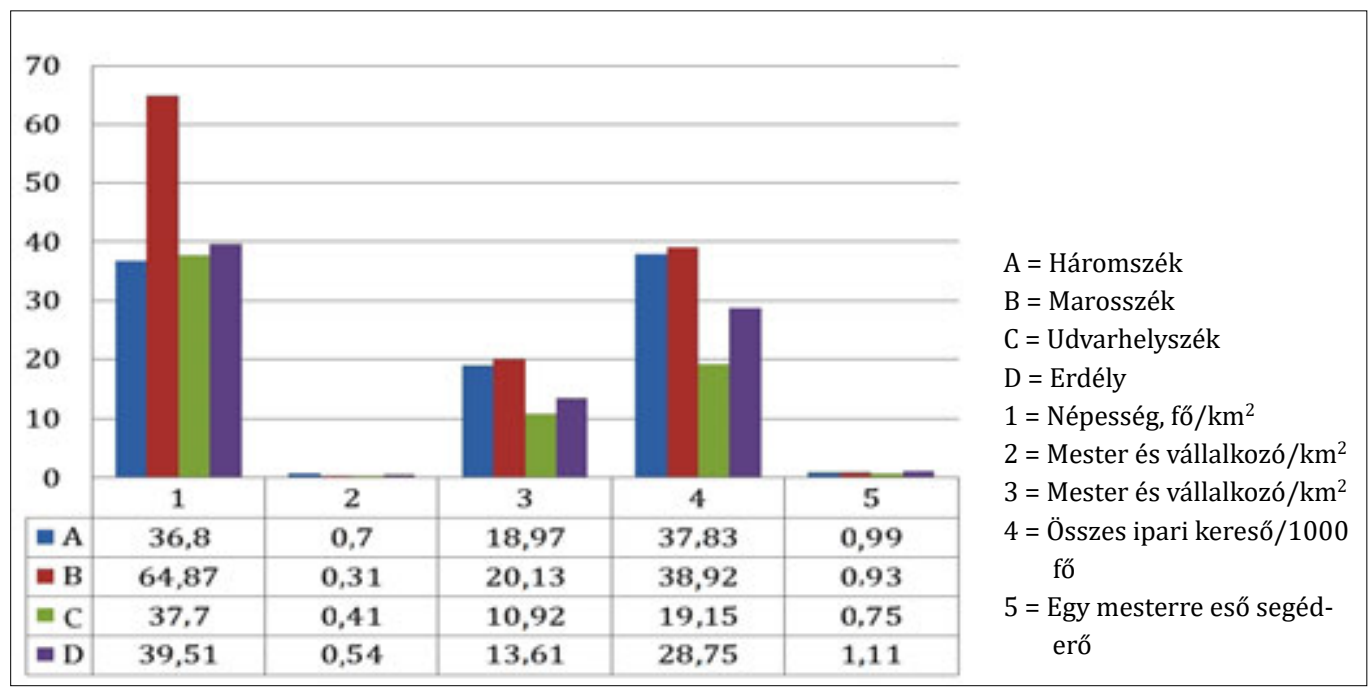

6. ábra. A székely székek összehasonlítása Erdély hasonló adataival 


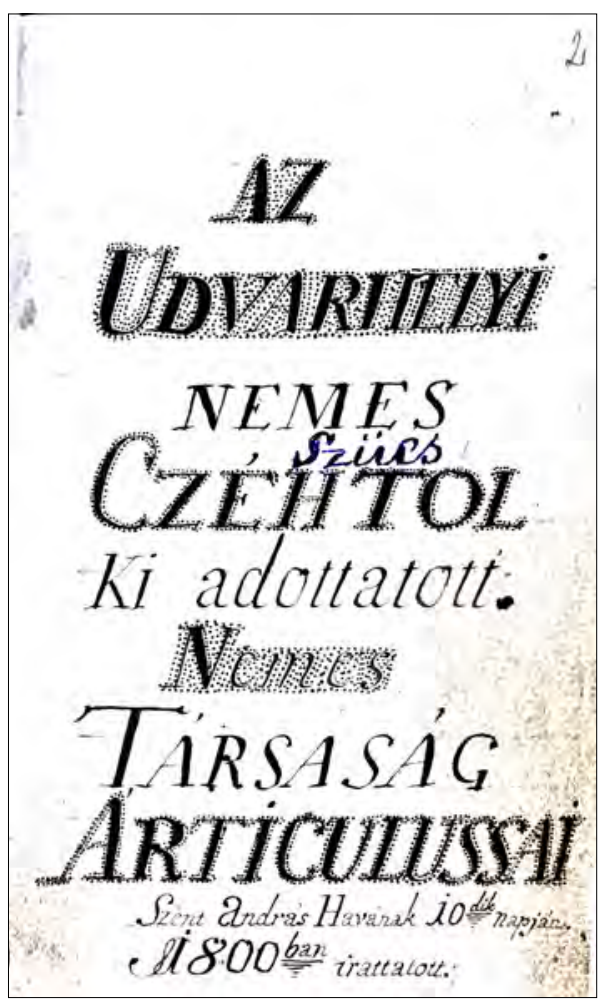

33. kép. A szücs céh artikulusai (1800)

1683-ban Zalatnán 9600 forintra 64 mázsa higanyt vásároltak, és indították el Belgrádba. Eladtak 22 mázsa higanyt 416 Ft 54 krajcárért, a bevételt megbízottaik újra befektették. A bevételt újra áruba fektették, 60 vég „hermelin patyolatot” hoztak haza, és még „két tepsziát” [tepsi] az asszony ő kegyelme számára" és még vásznat és cukrot. Kölcsön is adtak Ábrán zsidónak 245 forintot. 1684. február 9-én az üzletfelek megbízottja, Vízaknai Mihály eladott Bucsi Kozma görög kereskedőnek (Dálnoki 1833) 39 mázsa kénesőt, mázsáját 170 magyar forint értékben, összesen 6630 forint bevétellel. 1683-ban elterjedt a híre, hogy a moldvai vajda 10000 marhát vásárolna, egyenként 1 forint 50 krajcárban darabját. Ez is jó üzletnek ígérkezett, mert a törökök voltak a felvásárlói a hadsereg felszereléséhez szükséges árunak. Később derült ki, hogy a hadsereget Bécs (sikertelen) ostromára készítették fel, és ez volt az oka a szerencsés konjunktúrának (Zepeczaner 2013).

A 18. században az állami beavatkozás egyre nagyobb teherként nehezedett a céhekre, amelyek szívósan védték kiváltságaikat, jogaikat és szokásaikat. Az Erdélyi Fejedelemség csatlakozási alapokmánya a Diploma Leopoldinum volt. Bécsben az erdélyi ügyek vitelére megalakult az Erdélyi Udvari Kancellária. Erdély kormányzását a megalakult Gubernium vagy Főkormányszék végezte (Trócsányi 1988). A tartományt Mária Terézia Nagyfejedelemség rangra emelte.

III. Károly, Mária Terézia és a következő fejedelmek alatt a jobb átláthatóság és kezelhetőség érdekében arra törekedtek, hogy uniformizálják a céheket. Ugyanakkor meg voltak győződve, hogy a céhek a rájuk jellemző, szövevényes privilégiumhálóval akadályozzák a gazdaság fejlődését. Begyűjtötték a privilégiumleveleket tanulmányozás végett, a cél új levelek kiadása és a szabályzatok egész birodalomra kiterjedő egységesítése volt. Elrendelték a katolikus vallási ünnepek megtartását és azt, hogy minden céh vegyen rész a körmeneteken. A céhládákat és a céhvagyonokat ellenőrizték. A Gubernium (1770. október 1. - november 20.) Mária Terézia utasítására, elrendelte, hogy a nőtlen mestereket is felvegyék a céhekbe, betiltotta a mesterasztal és más pazarló lakomák rendezését, csak év végén, a számadás végett összehívott gyűléskor költhettek 12 krajcárt egy-egy résztvevőre. A szabadulólevélbe bekerültek az ifjú mester jogai.

„II. József felismerte, hogy a céhek elavultak és fékei lettek az ipar fejlődésének. A szabad ipar érdekében 1785-ben adta ki azt a gyökeres rendeletét, mely a céhek eltörlésének elvi- 
leg kimondásával, mindenkinek megengedte, hogy bármely ipart szabadon gyakorolhasson." (Szádeczky 1913. 161.) Sajnos II. József, a „kalapos király”, Erdély nagyfejedelmének ez a reformterve sem valósult meg. Halálakor ezt is visszavonta. A rendi társadalom átmeneti győzelmet aratott. ${ }^{19}$

I. Ferenc király uralkodásának éveiben tovább folyt a céhek megreformálása. 1802ben és 1807-ben új, egységesített céhszabályokat adott ki a Főkormányszék. Az 54 pontból álló mintaszabályzat szerint mindenik céh statútumát átfogalmazták. A városokban céhcommissariusokat neveztek ki (akiket a céh fizetett), akik felügyelték a céhgyűlések menetét.

A céhek száma és a művelt szakmák is változtak. Eltűnnek az idejétmúlt mesterségek, mint a pajzsos, a csiszár, a késgyártó. A borbélyokat az orvosi egyetemek végzettjei szorítják ki a gyógyítás területéről. Ugyanakkor újak is megjelennek. Székelyudvarhelyen a kordovánosok és kalaposok alapítottak céhet.

A limitációk és a céhkiváltságok feudális intézmények voltak, amelyek merev rendszert alakítottak ki. A céhek korábbi megtartó bástyái a 18-19. századra már végleg elavultak, az átalakulások, a változások kerékkötőivé váltak. Paradox módon már nemcsak a céhen kívüli ipar fejlődését fékezték, de beszűkítették a céhek mozgásterét is, és a termelés kerékkötőivé váltak. Végső soron, mivel nem fejlődtek a környező világgal, bizonyos mértékben okozói voltak saját maguk pusztulásának.

A 19. században a céhek végleg korszerütlené váltak, privilégiumaikat nem lehetett továbbra is fenntartani. Azt is a számlájukra lehetett írni, hogy akadályozták a társadalmi rendek közötti mozgást.

A kor haladó eszméi elítélték a céhrend- szert (Széchenyi 1828.). „Átka alatt ülnek a szigorú céhrendszernek, amely a legszigorúbb nepotismussal van összekötve, honnan legjobb mester legényeink kénytelenek Oláhországba kiszökni. Minek azon következtetése lett, hogy ott mesteremberekké lévén, a mi gyártmányainkat feleslegessé kezdi tenni Oláhhon piaczain." (Kőváry 1847)

Az ország politikai erői, a császártól a negyvennyolcas forradalmárokig, bármilyen színezetűek voltak is, megegyeztek abban, hogy a céheket fel kell számolni. Ez meg is történt, de már a kiegyezés után, a dualizmus korában, 1872-ben. Pontosan három évszázaddal az első udvarhelyi céh megalakulása után.

$\mathrm{Az}$ 1848-as forradalom elötti években Erdélyben tevékenykedő mesteremberek száma Kőváry szerint (Kőváry 1847. 211, 214.):

106 üveges

120 főkötő

123 zsibárus

130 rézműves

141 borbély

141 kéményseprő

172 szappanyos

200 takács

273 pokróc, paplan és matrac

273 posztókészítő és nyíró

299 lakatos

300 fazekas

323 kötélverő

327 kalapos

349 kertész

438 szíjgyártó

712 vendéglős és szakács

716 halász

756 kőműves

799 bérkocsis és fuvaros

858 kádár

903 kenyérsütő

952 asztalos 
1353 mészáros és hentes

1354 muzsikás

1618 szabó

1810 szűcs

1810 tímár és kordovános

2614 pálinkafőző

3124 molnár

3592 fogadós

\section{5 csizmadia}

A történelmi (vagy Belső-) Erdély lakossága 2010517 volt. A különböző mesterséget „űzők” száma, akik meghaladták a 100-at egy-egy mesterségen belül, összesen 42663 volt, ami azt jelentette, hogy a Nagyfejedelemség 4,71\%-a dolgozott az iparban és szolgáltatásokban. Ezeken kívül még ide kell számoljuk a falusi, az őstermelésben dolgozó különböző mesterségeket kiegészítő foglalkozásként űző kézműveseket, mint az ács-, faragó-, esztergályos- stb. mestereket. Az erdélyi bányák 10410 bányászt foglalkoztattak. Kézművesmesterséget is folytatott a cigányok egy része, de a muzsikusokat 1345 számmal beszámították a mesterséget folytatók közé, akik szintén nem jelentek meg ebben a statisztikában. Jellemző, hogy a legtöbb mestert foglalkoztató ágazatokban benne vannak a fogadósok, pálinkafőzők és a zenészek, összesen 7560 mester, vagyis a dolgozók 18\%-a.

A 19. században a céhek egyre inkább teret veszítettek a szabad iparral és kereskedelemmel szemben. Az 1852-ben Kolozsváron kiadott Ideiglenes utasítás a kereskedés- és Iparviszonyok Szabályozására Erdély Koronaországban 2. paragrafusa a kereskedést négy ágazatra osztotta:
A. Szabad kereskedés,
B. Kalmári kereskedés,
C. Szatócsság,
D. Házaló kereskedés.

A „gyárügyekkel” a II. fejezet foglalkozik.
61.§. „Gyároknak neveztetnek azon iparüzleti vállalkozások, melyek, minthogy üzleteiket nagyobb mértékben folytatják, tehát sok embert foglalatoskodtatnak, tetemes beköltött pénzösszeget kívánnak, terjedelmes forgalmat tartanak fen, a saját engedményeik alapján terjedelmesebb üzleti jogot (országos gyárnok szabadalmat) nyertek." A céhügyeket a 110-222. paragrafusok rendezik. A 111. paragrafus szerint: „Elvül tartandó, hogy a céhek csupán szabad, iparüzleti, jótékony és vallásos célok elérésére és iparrendôri felvigyázat végett tartatnak ott fen, ahol léteznek..." A céhektôl megvonták korábbi legfontosabb jogaikat. Nem követelhettek meg olyan kizárólagos jogokat, melyeket korábban privilégiumaik alapján birtokoltak, csak azokat gyakorolhatták, amelyek azok nem ellenkeztek az iparrendszabályokkal és a céhszabályokkal.

A céhek megszűnésének következő állomása az 1859. december 20-án kiadott császári nyílt parancs volt, amely életbe léptette $A z$ új Iparrendet. Az iparúzés általában engedélyezetté vált. Végül az 1872. VIII. és az 1884. XVII. tc., a két Ipartörvény leszögezi, hogy „ $A$ magyar korona országai területén minden nagykorúnak nyílvánitott egyén, nemre való tekintet nélkül, ezen törvény bármely iparágat, ideértve a kereskedést is, bárhol, önállóan és szabadon gyakorolhat."

\section{Jegyzetek}

1. Az „ipar” szó „mesterség” értelemben csak 1847-ben jelent meg. Lásd Erdélyi magyar szótörténeti tár. V. Anyagát gyűjtötte és szerkesztette Szabó T. Attila. BudapestBukarest, 1993. 748. Azonban használata a korábbi időszakokra is szokásos.

2.Sópiac $=$ itt vásárolhatták meg a parajdi sót a sókereskedelemmel foglalkozó szekeresektől. 
3.1670. évi országgyűlés „XXII. art. Levén székely atyánkfiai közt lakó szegénységnek, kik az sóval való kereskedéssel kényszeríttetnek életeket táplálni, ilyen megbántódások, hogy sokan közűlök megkárosíttatnak városokon sokadalmokon, nem producáltatván minden a kamaraispán, vagy számtartó testimonialisát; mivel sokak közülök Udvarhely városában veszik a sót olyanoktúl, a kiknél feles savakrúl vagyon ugyan közönséges cédulájok, de az cédulát nem adhatja mindenik vivőnek, a kik kevés számú sót vesznek tőlök; azonba az arra való inspektor városokon sokadalmakban megkárosítja őket. Kegyelmes urunk, hogy Nagyságod arra igéri magát, parancsol felőle, hogy az ilyen szegény embereket meg ne károsítsák, Nagyságodnak alázatosan megszolgáljuk." Erdélyi Országgyűlési Emlékek (a továbbiakban EOE) XVI. Budapest, 1893. 176.

4.Udvarhelyszékben az emberi táplálkozás és az állatok takarmányozása számára soha nem volt elég a határain belül megtermelt gabona.

5.Daniel Gábor, 1861-1891 között Udvarhely vármegye főispánja emlékirataiban megjegyezte: „A zetelaki vagy oroszhegyi erdőből lopott fából ezerekkel hordják a zsindelyt az udvarhelyi piacra." 1893. évi bejegyzés. (Kézirat a HRM tulajdonában.)

6. Hivatalosan csak akkortól tekinthetjük megalakultnak egy céhet, ha privilégiumlevelet, statútumot, szabályzatot kapott a várostól vagy a fejedelemtől.

7.A székelyudvarhelyi céhek irományait 1952-ben a Városi Múzeumba (ma Haáz Rezső Múzeum) adták be megőrzésre a céhek jogutódai, a megszüntetett ipartársulatok. Később a Román Nemzeti Levéltár Hargita megyei Igazgatóságának kezelésébe kerültek. A gyüjtemény neve Colecția Muzeului din Odorheiu Secuiesc, a Székelyudvarhelyi Múzeum Gyűjte- ménye. Fond 249. A Székelyföldön az udvarhelyi céheké a legnagyobb fennmaradt céhiratgyüjtemény.

8.,Nem kicsiny panaszolkodásunk vagyon, kegyelmes urunk, az míves emberek felöl is, holott noha arról egész országul közönségesen limitációjuk vagyon, mint és hogy kellessék marhájokat [itt piacra vitt, eladásra szánt termékeik] adni, az bor is mostanában fóképpen olcsó, [...] illetlen és felettébb való árat szabták marhájoknak. [...] az limitáció igen observáltassék, különben marháját senki ne adja, ha különben cselekednek és a várasbeli magisztrátus nem exequáltatja külső ember instantiájára, az nemes ember certifificálván az vármegye ispánjit, az város jószágán mox et defacto kétszáz forintot exequálhasson, melyre ezen constitutiónak vigorával authoritás adatik az ispánoknak." (EOE. VIII. 1882. 98.)

9.Ez óriási összeg volt. Egy zsoldos lovas katona havi járandósága öt, egy gyalogos zsoldja három forint volt.

10.„Az várasbeli uraink, kegyelmes urunk, nemességünk szabadsága ellen olly privilegiumot, szabadságot találtanak, és oly szokást követnek, hogy vagy maguk majorságából, vagy szegény községeink marhájából valami marhát bevisznek várasokba eladni, prohibeálják az várasbeliek, hogy idegen embernek szabad ne legyen megvenni, se el adni, mindaddék valamég ő magok az város népe nem vásárolnak, magok rendelik penig el, mint és hogy adják nekünk nagy fogyatkozásunkra. [...] Könyörgünk Felségednek efféle abususok poenius Tolláltassanak."

11.„Az mely új keresztyének, kegyelmes urunk felséged jó akaratjábul ez országban bejöttenek és immár ugyan meg is telepedtenek, Felséged kegyelmes parancsolatja szerint azoknak állapotjokról országúl így végeztünk, hogy azoknak az új 
keresztyéneknek és az kiket magok mellé azután behozhatnának is ez országban, minden névvel nevezendő mesterségek szerint való munkájok szabadosan exerceálhassák. Az melyet penig tudniillik Alvincet, Felséged nekik rendelt, abban a helyben religiójukkal is az ő szokások szerint szabadon exerceállhassák és senki őket abba meg ne háborítsa."

12.1623. június 23. (EOE. VIII. 1882. 143145.)

13.1828. áprilisi országgyűlés.

14. A források a földmérés eszközéül láncot is említenek, Udvarhelyen ezt „kötéllel” végezték. (A szöveget átírva idéztem). (Székely Oklevéltár. 1983. 41.)

15. Magyarország mértékeit Bogdán István egy 760 oldalas könyvben mutatta be: Magyarországi ûr-, térfogat-, súly-, és darabmértékek 1874-ig. Bp., 1991.

16. Arasz $=23,7 \mathrm{~cm}$, hüvelykes tenyér $=11$ $\mathrm{cm}$, így a zsindelymérték $=11,0 \times 71,10$ cm. Lásd Bogdán István: Magyarországi ür-, térfogat-, súly- és darabmértékek 1874-ig. Budapest, 1991.

17. Tabella de numero et statu Zingarorum in inclito sede Siculorum Bardósz. (1781. 1 Martii). (Jakab-Szádeczky 1901. 530.)

18. magyar mérföld = 8353,5 m; osztrák mérföld $=7585,94 \mathrm{~m}$.

19. Ahogyan később a haladáspártiak emlegették: „A fürdővízzel kidobták a gyermeket is."

\section{Felhasznált irodalom}

Approbata Constitutiok. Approbatae Constitutiones Regni Transylvaniae et Partium Hungariae Eidem Annexarum. Ex Articulis ab Anno Millesimo Quingentesimo Quadragesimo (etc.). Kolozsvár, 1815.

Bónis Johanna: A marosvásárhelyi céhekről. A Maros megyei magyarság történetéből. Mv., 1997.
Csetri Elek: Az erdélyi gazdasági gondolkodás 1800-ig. Kv., 1999.

Dálnoki Incze József: A görög kereskedőkről. Lásd Értekezés A' N. Szebeni és Brassói Görög Compániákról. Nemzeti Társalkodó, 1833. 5. sz. 65-71; 6. sz. 86-73; 7. sz. 97-99.

Erdélyi magyar szótörténeti tár. VII. Anyagát gyűjtötte és szerkesztette Szabó T. Attila. Budapest-Bukarest, 1995.

Erdélyi Országgyúlési Emlékek III. 1576-1596. (EOE. III.) Budapest, 1877.

Erdélyi Országgyúlési Emlékek VI. 1608-1614. (EOE. VI.) Budapest, 1880.

Erdélyi Országgyúlési Emlékek VIII. 16211629. (EOE. VIII.) Budapest, 1882.

Erdélyi Országgyúlési Emlékek XVII. 16791682. (EOE. XVII.) Budapest, 1894.

Finály Henrik: A régi magyar súlymérték. Adalék a hazai pénzverés történetéhez. In: Az Erdélyi Múzeum-Egylet Évkönyve. 4. kötet, 1. füzet (1866-1867).

Gazda Klára: A székely népviselet. Budapest, 1998.

Honvári János (szerk.): Magyarország gazdaságtörténete a honfoglalástól a 20. század közepéig. VII. kiadás. Budapest, 2002.

Huszár Lajos: Az erdélyi fejedelemség pénzverése. Budapest,1995.

Imreh István: Céhbeli kézmúvesek, népi mesterek és vásárlókörük (1750-1830). In: Erdélyi hétköznapok. Társadalom- és gazdaságtörténeti írások a bomló feudalizmus időszakáról. Bukarest, 1979.

Imreh István: A fejedelmi gazdálkodás Bethlen Gábor idejében. Erdélyi eleink emlékezete (1550-1850). Társadalom és gazdaságtörténeti tanulmányok. Kv., 1999. Lásd még Hagyomány és korszerüség az állattartásban. Korunk. 1966. 3. 356-361; Adatok Udvarhelyszék mezógazdaságához. (1570-1610). Aluta. 1969. 131-141. Társszerző Pataki József; Adatok Udvarhelyszék állattartásához. Aluta. 1970. 169-184. Társszerző Pataki 
József; Kelet-európai és hazai agrárpolitika a feudalizmus alkonyán. Korunk. 1972. 9. 1359-1364; A székely falu társadalmi szerkezete a XVII. század elején. Korunk. 1976. 5. 374-378.

Imreh István: Erdélyi hétköznapok. Társadalom és gazdaságtörténeti írások a bomló feudalizmus időszakában. Bukarest, 1979. 169-198.

István Lajos: Visszaemlékezés a korondi sokadalmakra. Kézirat. 1977.

Jakab Elek - Szádeczky Lajos: Udvarhely vármegye története a legrégibb idôtól 1849ig. Budapest, 1901.

Jakó Zsigmond: Az erdélyi mértéktörténet kérdéséhez. Írás, levéltár, társadalom. Budapest, 2016. 471.

Kardalus János: A négynapos sokadalom Bögözben a századforduló után. Művelődés, 1985. 10.28

Kovách Géza - Binder Pál: A céhes élet Erdélyben. Bukarest, 1981. 57-65.

Kőváry László: Erdélyország statistikája. I. Kolozsvárt, 1847.

Kozma Ferenc: A Székelyföld közgazdasági és közmívelődési állapota. Kiadja a Székely Mívelődési és Közgazdasági Egylet, Budapest, 1879. (Reprint, Székely Nemzeti Múzeum, 2008)

Lakatos István: Székelyudvarhely legrégibb leírása. Fordította Jaklovszky Dénes. Kolozsvár, 1942.

Laukó Albert: Udvarhely város leírása. 1888 395. 46

Makkai László - Szász Zoltán (szerk.): Erdély története. II. 1606-tól 1830-ig. Budapest, 1986.

Molnár István: Keresztúri sokadalmak. Hargita Kalendárium 1974.

Nagy Ferenc: Vásárlaistrom - a vásáros helyeket jellemző áruczikkek' szempontjából. In: Nagy Ferenc (szerk.)> Mentor. Erdélyi népkönyv 1. Közhasznu ismeretek tára a' honi szorgalom, 's értelmesedés előmozdítasára. Kolozsvár, 1842.
Orbán Balázs: A Székelyföld leírása történelmi, régészeti, természetrajzi s népismei szempontból. I. Pest, 1868.

Paál-Antal Sándor: Marosvásárhely története. I. A kezdetektől 1848-ig. 2009; Uő: Történeti szimbólumaink. Székelyföldi pecsétek. Marosvásárhely, 2014.

A Román Nemzeti Levéltár (RNL) Hargita megyei Igazgatósága. A székelyudvarhelyi Múzeum Gyújteménye. Fond 249. 36, 38 sz. [A továbbiakban CL.]

Szádeczky Lajos: Iparfejlődés és a czéhek története Magyarországon. I. Bp., 1913.

Szakály Ferenc: Virágkor és hanyatlás 14401711. Bp. 1990.

Széchenyi István: Hitel. 1828-1829.

Székely Oklevéltár. (SzO.) Új sorozat. Közzéteszi Demény Lajos és Pataki József. I. Bukarest, 1983.

Székely-Udvarhely rendezett tanácsú város piacrendezési terve országos és hetivásárok alkalmával. In: Udvarhely-vármegye szabályrendeletei. Székely-Udvarhelyt, 1898 és Székely-Udvarhely rendezett tanácsú város piaci helypénz szabályzata. Székely-Udvarhelyt, 1897. Újrakiadva: Zepeczaner Jenő: Itten esztendőnként négy sokadalmak és heti vásárok szoktak esni. Örökségünk 2. 24-25; Uő: Székelyudvarhely piacrendtartása 1893-ban. Örökségünk 2010. 3. 15-17.

Szeles János - Szájdler János: Székely-Udvarhely története. Erdélyi Múzeum 15/10. (1898).

Szigethy Gyula Mihály: Nemes Udvarhely-Szék statisztikai leírása. Nemzeti Társalkodó, 1831.

Szigethy Gyula Mihály: Nem csupán az elme élesítésére, hanem a' közhaszonra készíttetett Méréstudománya. Felső Magyarországi Minerva. Nemzeti folyó-írás. (Kassa). 3/1834.

Sonkoly Gábor: Vásárok, vásárkörzetek és városok Erdélyben 1820-ban. Korall 1112./2003. 168. 
Takács Péter (sajtó alá rendezte): Udvarhelyszék parasztvallomásai 1820-ból. In: Források Erdély Történetéhez 1. Erdély-történeti Alapítvány, Debrecen, 2001.

Téglás György 1910. 3. 54.

Trócsányi Zsolt: Erdély központi kormányzata 1540-1690. Budapest, 1980.

Trócsányi Zsolt: Habsburg-politika és Habsburg-kormányzat Erdélyben 1690-1740.
Budapest, 1988.

Vámbéri Gusztáv: A font súly. Budapest, 1975.

Werbőczi István: Nemes Magyarország szokásjogának Hármaskönyve. Az ország jogainak és szokásainak harmadik részéről általában 7. §. 1514.

Zepeczaner Jenő: A kénesô üzlet. Örökségünk, 2013.1.13. 


\section{MELLÉKLET}

\section{SZÉKELY-UDVARHELY RENDEZETT TANÁCSÚ VÁROS PIACRENDEZÉSI TERVE ORSZÁGOS ÉS HETIVÁSÁROK ALKALMÁVAL}

\section{1. §. Általános elvek}

Általános elvül kimondatik az, hogy Sz.-Udvarhely város piacterén tilos a fát behozó és lerakó egyéneknek üres szekereit bárhol is megtelepíteni. Tilos a deszkás szekereknek benn a városban bármelyik utcában vagy piactéren megtelepedni. Tilos az úgynevezett molnár szekereknek vagy malomba járóknak az utcákon és tereken megtelepedni. Tilos a cserfás szekereknek benn a városban megtelepedni hétköznap úgy, mint vasárnap alkalmával, csakis a külső fapiacra utaltatnak. Az üzlethelyiségek előtti járdának úgy országos, mint heti vásárokon, valamint hétköznapokon is egyes árucikkekkel elfoglalása tilos. A közlekedési utak fel nem használhatók vásárterekül s az egyes terek is csak úgy használhatók fel, hogy a szabad közlekedés sehol fenn ne akadjon, s véletlen tűz vagy más szerencsétlenség alkalmával a szabad közlekedés fennmaradjon s ezen kívül a rendőrségnek a felügyelet gyakorolhatása végett mindenütt nyílt járhatása legyen. Kimondatik az is, hogy a mely helyekre gyümölccsel vagy cserépedényekkel, zöldséggel terhelt szekerek engedtetnek megtelepedni, ott lovakat, szarvasmarhákat s más igavonó állatokat az áruhelyen tartani tilos. A gabonával és egyéb rakománnyal terhelt szekerekre nézve ezen kedvezmény nem adatik, hanem az illető árusok kötelesek gabonájukat vagy egyéb árucikkeiket a kijelölt helyen lerakni és igavonó állataikat szekereikkel magán udvarokban, vendéglőkbe vagy a város által e célra kijelölt helyre eltávolítani.

\section{2. §. Elhelyezések}

A mérnöki felmérés szerint a felső-, piac-, templom-, városház-, és alsópiacterek a közlekedési utak leszámításával 9389 négyzetméter területet foglalnak magukban, melyek hasonfele a felsőpiactérre esik, ezért és azért is, mert minőségénél fogva legalkalmasabb tér legcélszerúbben hasznosítható. Ezután következik a Kossuth-utca szabad tere 5449 négyzetméter területtel, melybe szintén nincs beleértve a közlekedési útvonal. Azután jön a Szombatfalvi-utca külön tere 800 négyszögöl területtel és a kőkereszt körüli tér 500 négyzetméter területtel. Ezeket szem előtt tartva és szemelőtt tartva az egyöntetüséget is, legcélszerübbnek mutatkozik a következő elhelyezés.

\section{A) Felső́piac-tér}

Az összes nagysátrak, melyekben készruhák, singes árucikkek árultatnak, ide értve a galantéria és tótok sátrait is, a felsőpiacon déltől északi irányban helyezendők el mind, a következő sorrenddel: A ruhasátrak a kúttól kezdve a tér közepén helyeztetnek el egymással szemben két sorban; ezek mellé a déli oldalon a takácsok, flanel árusok, falusi szőttes árusok sátrai, északi oldalon a tótok, ezek végébe és velük szembe a singes kereskedők sátrai. Az összes sátraknak a nyugati végeknél, a közlekedési útig helyezendők el a galantéria sátrak, keleti végénél az északi oldalra jönnek a szíjgyártók, nyugati oldalon a szitások, a cserge és pokróc árulók. Az ev. ref. kollégium bejárójától felfelé az épület közelében a szalmakalaposok. Az ev. ref. templom 
oldala mellett hosszában elkezdve a kollegiummal szemben lévő bolthelyiség szögletétől a templomnak másik szögletén lévő bolthelyiségig a lakatosok és pléhesek. Az ev. ref. templom északi végén lévő bolt szögletétől a szíjgyártók boltja szögletéig, továbbá jobbra a Kassay Ignác házától a megyeházának bejárójáig azon pityóka, hagyma, káposzta és egyéb vetemény árusok, a kik szekér nélkül árulnak.

\section{B) Templom-tér}

A szőcsök két sorba a szíjgyártó bolt elejébe helyezendők, velök egy vonalba, háttal vagy szemben, a mint a helyzet megengedi, az összes pogácsások sátrai, kik között az úgynevezett mandulás pogácsások elsőséggel bírnak, ugyanide helyezendők a nyigocások és a durva kalapot árulók sátrai, úgy hogy a fazakasok és mészárosok boltjai előtt egészen keresztül legalább 2 méter szélességű hely, [hogy] a közlekedés fennmaradjon.

$\mathrm{Az}$ ev. ref. templom szögletétől kezdve a fazekasbolt szögletéig elhelyezendők az órások és ékszerészek sátrai olyformán, hogy az órások sátrai felfelé essenek és a fazakasok boltja szögleténél két méter széles szabad átjáró maradjon fen, a sátrak homlokkal az ev. ref. papilakkal szemben legyenek. A fazekasbolt déli oldalához a fésűsök és más apró sátrak vagy padon árulók helyezendők.

\section{Kossuth-utca}

A Flórián Bogdán háza felső szögletétől a boltokba bejárást és a szabad közlekedést nem akadályozólag a járda előtt helyeztetnek el a kés, kefe, kötél, finom kalap, kis gyermekruha árusok és cukrászok sátrai, a baloldalon a rövidárusok sátrai mellé, a városháza felé irányozva a kesztyűsök, condra árulók sátrai és azok végéhez az iparosok által kiállított szekerek. A cukrász és rövidárusok sátrai után lefelé, azaz délre irányozva, egymással szemben két sorban a cipészek, utánuk a csizmadiák sátrai, ezen sátrak hátánál a járdán a közlekedést nem akadályozólag helyeztetnek el a gabona árusok. Ezek után, jobbra és balra egymással szemben a gyümölcsárusok szekerei és a Maros-Torda megyei zöldségárusok szekerei, a mennyiben az alsó piacról ide utaltatnak, ezek után, szintén egymással szemben az asztalosok és az összes faedény árusok, ide értve a kártya, cseber, kád, tekenyő, lapát, seprü, fakanál, stb. cikkek, továbbá a gyékényesek.

\section{Alsópiac-tér}

Balra a házak mellett egymással szemben két sorban a tímárok és kordoványosok. A vidéki rom. kath. papság háza előtt helyezendők, midőn panorámás és körhintajátékos nincsen, a Maros-Torda megyei zöldségárusok szekerei, ezek előtt maradnak a pecsenyesütők és kenyérárusok. Ezek elébe helyezendők a szappanosok és tejárusok s apró kosarakban és padatlan helyi és idegen gyümölcsárusok. A városház alsó szögletétől kezdve egymással szemben két sorban helyezendők a finomabb edényeket áruló kászoni, parajdi, makfalvi és más községi fazekasok sátrai, üvegesek és porcelánosok sátrai elsőbbséggel bírván, a városház szögleténél egymással szemben két sorban, a közlekedést meg nem akadályozva helyezendők el a helybeli fazekasok. A mely tér a pecsenye- és kenyérsütők előtt a közlekedési úttól balra fennmarad, továbbá a barátok kertje melletti tér a szabad közlekedést nem akadályozólag és az idegen fazekasok és a falusi hentesek sátrai között a városház háta megett fennmaradott tér fordítandó a korondi fazekasok elhelyezésére.

\section{E) Városház-tér}

A városháznak felső szögletétől lefelé, a Szombatfalva felé vezető közlekedési út széléig egymással szemben két sorban helyezendők el a falusi hentesek sátrai és padjai és 
a hagyma árulók, szekerek azonban itt sem engedtetnek meg. A városházatéren ugyanezen megszorítások mellett helyezendők el a mészáros ipartársulat tagjainak és egyes helybeli mészáros iparosoknak kitehető sátraik és padjaik. Ugyan e téren a szőcs és mészáros bolttal szemben helyezendők el a szalonnát és mézet árulók sátraik és padjaik. A Szenkovics János boltja elejébe a sóshal árusok, azon felül a kása és lisztnemű árusok, azon felül a fejtősök sátrai, a füszeres boltok előtt azon finomabb kosár- és szotyorárusok, kik pad nélkül árulnak. A sóshal- és lisztárusok előtt közvetlenül a közlekedést meg nem akadályozólag a szekérnélküli sajtárusok.

\section{F) Kereszt-tér}

A falusi posztó árusok, rongyászok vagy ószeresek.

\section{G) Szombatfalvi-utca}

A gyapjú és nyersbőr árusok.

3. §. Heti vásárok alkalmával az országos vásári elhelyezésektől következő eltérések irányoztatnak elő:

\section{A) Felsöpiac-tér}

A felsőpiac-tér a gabona árulás piaca; a gabona, pityóka, efféle árucikkek a kúttól keleti irányban a tér közepén két, esetleg több sorban úgy helyezendők el, hogy két oldalt, az épületek mellett, a kocsi közlekedésre szabadon elég tér maradjon. A gabona árusok az áruló helyről szekereiket és igavonó állataikat eltávolítani kötelesek.

\section{B) Templom-tér}

A szőcsők és szíjgyártók a boltokban árulnak. Ide helyeztetnek a tótok sátrai, a többiek, a kik az országos vásárra ide utaltatnak, a mennyiben kirakódnak, maradnak helyeiken.

\section{C) Városháza-tér}

A fazekasbolt és a városház közt a Kos- suth-utcával szemben helyeztetnek a mézespogácsások és kifliárusok sátrai; különben marad az országos vásári elhelyezés.

\section{D) Kereszt-tér}

Marad az országos vásári elhelyezés.

\section{E) Alsópiac-tér}

A tímárok a boltokban árulnak. A gyümölcsárusok szekerei utaltatnak a megyei róm. kath. papság bérháza elébe, a vetemény árusok pedig a városháza szögletétől a barátok felé egy vonalba. A város szögletháza felső szegétől egymással szemben két sorban a kézzel hozott vetemények számára, a helybeli kufárok és kofák a pecsenyesütők elejébe külön helyezendők el és pedig azért, hogy a vásárló felismerhesse őket, a kik a lakosok terhére nyerészkednek és az idegen árusoktól már akkor reggel mindent összevásárolnak, ugyanezen térre helyezendők el, a mennyiben jönnek az idegen fazekasok és kosarakbani gyümölcsárusok. A korondi fazekasok maradnak a maguk helyén, hasonlólag a falusi hentesek, gyapjúárulok és mások, a kik az országos vásárnál megemlítettek.

\section{F) Kossuth-utca}

Ide utaltatnak a káposzta árusok szekerei, condra árulók, cukrászok, kasza, köszörükő árulók és efféle apróbb sátrak helyeztetnek a Flórián Bogdán háza alsó szögletétől felfelé s azzal szemben a míg elférnek, úgy, hogy a közlekedés megakadályozva ne legyen. A mennyiben a gyümölcsárusok szekerei az alsópiac-téren el nem helyezhetők, a Kossuth-utcában az országos vásári helyökre utaltatnak. Minden más rendezés marad, mint az országos vásár alkalmával.

4. §.Hétköznapokon, a mennyiben vásári elhelyezésre szükség lesz, a heti vásári elhelyezés irányadó.

5. §. Az országos- vagy hetivásárokon, a 
mennyiben apróbb árusok olyanok jelentkeznek, a kik árucikkeikkel kevés helyet foglalnak el, az ilyeneket, hogy a közlekedés meg ne legyen akadályozva, alkalmas helyre beosztani és a mennyiben kijelölt helyeiken az egyes árusok el nem férnek, vagy kiknek tér kijelölve nincsen, azokat belátása szerint elhelyezni a rendőrfőkapitány feljogosíttatik.
6. §. Ezen tervezet keresztülvitele és felügyeletével a városi rendőrkapitányság bizatik meg.

Sz.-Udvarhely város képviselőtestületének 1893. évi június hó 24-én tartott üléséből.

Gálffy Endre, föjegyző.

Kassay F. Ignác, elnök, polgármester. 


\section{2. ÖRÖKNAPTÁR AZ OKLÁNDI UNITÁRIUS TEMPLOM MENNYEZETI KAZETTÁINAK EGYÜTTESÉBEN}

A homoródoklándi unitárius templom a 13. század második felében épült, és freskókkal díszített Árpád-kori építmény lehetett egykor. Az eltelt évszázadok alatt azonban olyan átépítéseken, javításokon ment keresztül, amelyek során eredeti jellegét és formáját elveszítette. Azonban - mintegy kárpótlásként az elpusztult részekért - olyan szépen festett mennyezetekkel gyarapodott, amelyek a 18. századi magyar deszkamenynyezet-festés szép és minőségi emlékei.
A templomhajó kazettás mennyezetét 1771-ben festette Elekes András oklándi festőasztalos. Ha figyelmesen szemügyre veszszük ennek a $8 \times 9$ kazettából álló mennyezetnek a motívumvilágát, a növény és virágornamentikát, valamint az ezeket kiegészítő állatalakokat, akkor a stílus és formák alapján egy önfeledten és szabadon festő művészi alkatra következtethetünk. Erre egy felírat is utal, amely szerint az oklándi asztalos Elekes András ISTEN JÓINDULATTYÁBÓL festette.

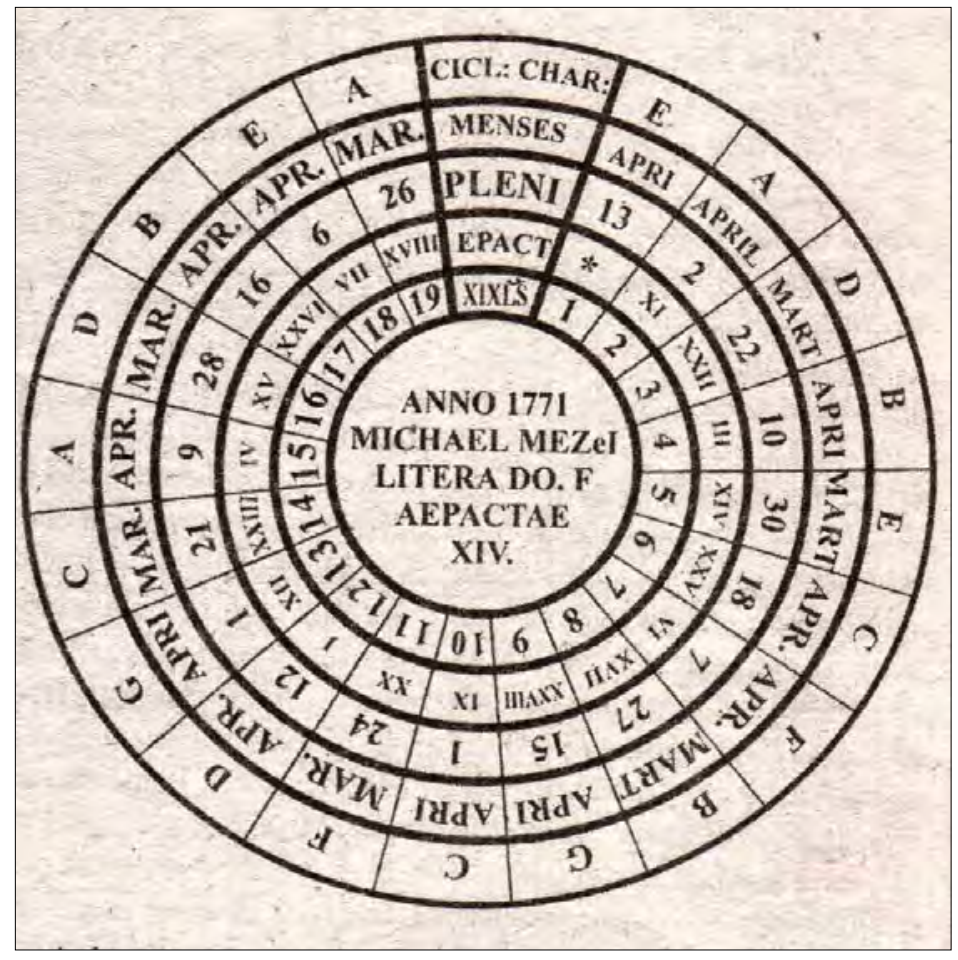

1. kép. A homoródoklándi húsvét-kazetta megszerkesztett változata 


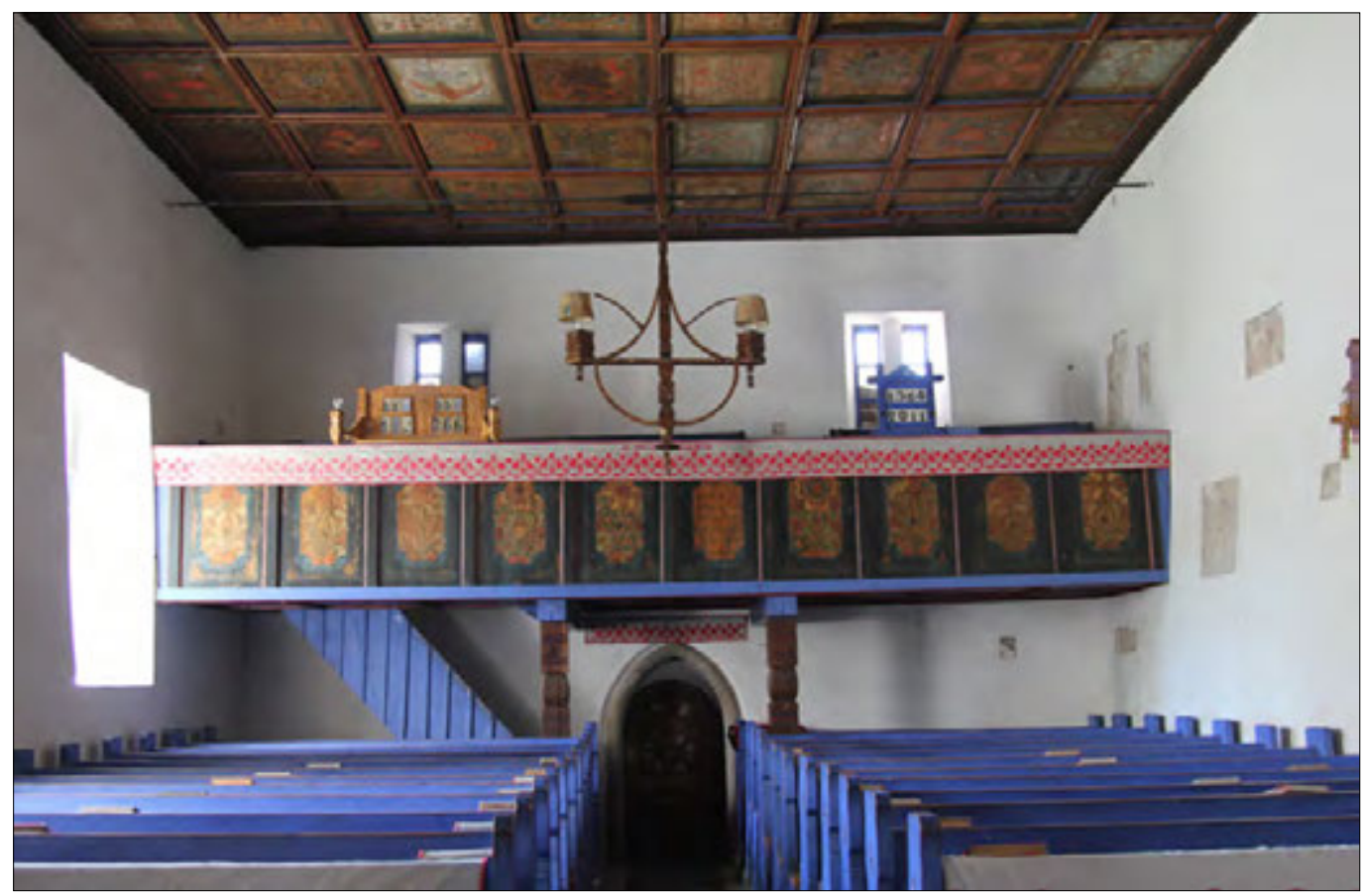

2. kép. A homoródoklándi unitárius templom kazettás mennyezete

Tovább vizsgálódva a festett kazettás mennyezeten, a templom diadalívétől számított második és harmadik sorban két olyan különös kazetta ragadja meg figyelmünket, amelyek mindenben eltérnek a többitől.

Az egyiken - a harmadik sorban - legnagyobb meglepetésünkre a SYSTEMA COPERNICANUM feliratot olvashatjuk, naprendszerünk vázlatos rajzának kíséretében (Nap, bolygók és azok holdjai), a másik kazettán - a második sorban - pedig egy koncentrikus körökből álló táblázatot láthatunk rövidítésekkel, arab és római számokkal. Azt, hogy mire szolgált egykor, nem tudjuk ma már, használata a feledés homályába merült.

\section{A kazetta leírása}

A téglalap alakú kazetta közepén 6 koncentrikus, pirossal festett kör található, amelyek értelemszerűen 5 körgyűrűt és egy köz- ponti kört határoznak meg. Minden gyürü sugárirányba húzott fekete vonallal 20 részre van felosztva, amely részek közül 19 egyforma nagyságú, míg a húszadik mérete másfélszerese a többinek. Ez utóbbi öt nagyobb részben latin szavak, rövidítések olvashatók. Ha figyelmesen szemléljük, akkor egy kör alakúra görbített táblázattal állunk szemben, ahol a nagyobb részekben a sorok megnevezése található, az egyforma gyürűcikkekben pedig a megnevezéseknek megfelelő értékek. Ha a legbelső körben található szöveg fekvése alapján határozzuk meg a kazetta síkjának topográfiáját, azaz a lent és fent, illetve a jobb és bal fogalmát, akkor a kazettán a kör alakú táblázat jobb oldalán egy lentről felfelé vastagodó, S alakban kanyargó fekete kígyót találunk. Bal oldalán, erős fekete kontúrral pedig egy három hurkot formázó, önmagába visszatérő zárt szalag látható. A kazetta 
négy sarkában egy-egy fehérrel kontúrozott piros tulipáncsokor helyezkedik el, amelyek a kazetta átlói mentén többé-kevésbé szimmetrikusak.

A belső, központi körben a következő felirat áll: ANNO 1771/ MICHAEL MEZeI/ LITERA DO. F/ AEPACTAE/ XIV.

A belülről kifelé számított első gyűrű megnevezésmezejében XIX LS olvasható, az L és az $\mathrm{S}$ betűk felett pedig egy rövid hullámos vonal. A második gyűrűben az EPACT szó áll. Fölötte PLENI, a negyedik gyürüben pedig MENSES, e fölött, az ötödik külső gyűrűben CICL.: CHAR. latin szavak, illetve rövidítéseik olvashatók.

A belső gyürüben 1-től 19-ig növekvő arab számok, a másodikban római számok, a harmadikban megint arab számok találhatók. A negyedik gyűrűben az APRI és MART (április és március) hónapok rövidítései, a külső gyűrű minden rekeszében pedig egy-egy betű található A-tól G-ig, látszólag minden rendszer nélkül.

\section{Feltételezések és magyarázatok}

A központi körben olvasható Mezei Mihály név minden bizonnyal arra utal, hogy ezt a táblázatot ő szerkesztette. Mezei Mihályról annyit tudunk, hogy Homoródoklándon teljesített papi szolgálatot 1771 és 1777 között.

A MENSES (latinul hónapok) és a PLENI (latinul tele) gyűrűkben olvasható rövidítések és értékek alapján egyfajta naptárra gondolhatunk, feltételezve azt, hogy Mezei felsőbb tanulmányokat végezve érthetett a naptárkészítéshez. Talán öröknaptár, esetleg valamilyen egyházi vagy világi esemény időpontjának meghatározására szolgáló táblázat? Ilyen és ehhez hasonló kérdések merülhetnek fel e táblázat láttán. Ezek a feltételezések aztán szertefoszlanak, ha a MENSES gyűrűkben olvasható rövidítésekre koncentrálunk.
Az, hogy a hónapokat jelölő részben csak a március és április hónapok szerepelnek, arra enged következtetni, hogy húsvét napjának meghatározását szolgáló táblázattal állunk szemben. Ugyanis húsvét ünnepe, mozgó volta ellenére, mindig vagy március vagy április hónapra esik. Mindez húsvét vasárnapjának meghatározásából következik. Ennek értelmében húsvét vasárnapja a tavaszi napéjegyenlőséget követő első telehold utáni első vasárnap. Legkorábban a húsvétvasárnap akkor van, ha március 21-én telehold van, és a következő nap vasárnap, azaz március 22-én. A húsvétvasárnap legkésőbbi dátuma pedig április 25., ami akkor áll fenn, ha március 20-án volt telehold, azaz a napéjegyenlőség előtt 1 nappal, és ennek megfelelően a következő telehold 29 nap múlva éppen vasárnapra esik. Ilyenkor a rá következő vasárnap lesz húsvét vasárnapja. Ez pedig április 25. Ha ezt a felismerést továbbgondoljuk, és a MENSES gyűrűben található számokkal vetjük egybe - feltételezve ezekről, hogy napokat jelölnek -, olyan dátumokat kapunk, amelyek mindenike március 21-e és április 18-a közé esik, beleértve a két dátumhatárt is. E két szélső érték viszont éppen azokat a napokat jelöli, amely napokon, ha telehold van, akkor húsvét vasárnapja legkorábbra, illetve legkésőbbre kerül.

Ezen felismerések alapján egyre inkább hajlunk arra, hogy a kazettában található koncentrikus körökön álló táblázat a húsvétvasárnap pontos dátumának meghatározására szolgál, szolgált.

Folytatva az előző gondolatmenetet, vizsgáljuk meg a többi gyűrűben található kifejezést. XIX LS a legbelső gyűrű megnevezése. A gyürűn számok helyezkednek el növekvő sorrendben 1-től 19-ig. Ez arra enged következtetni, hogy az úgynevezett aranyszámokkal van dolgunk. 


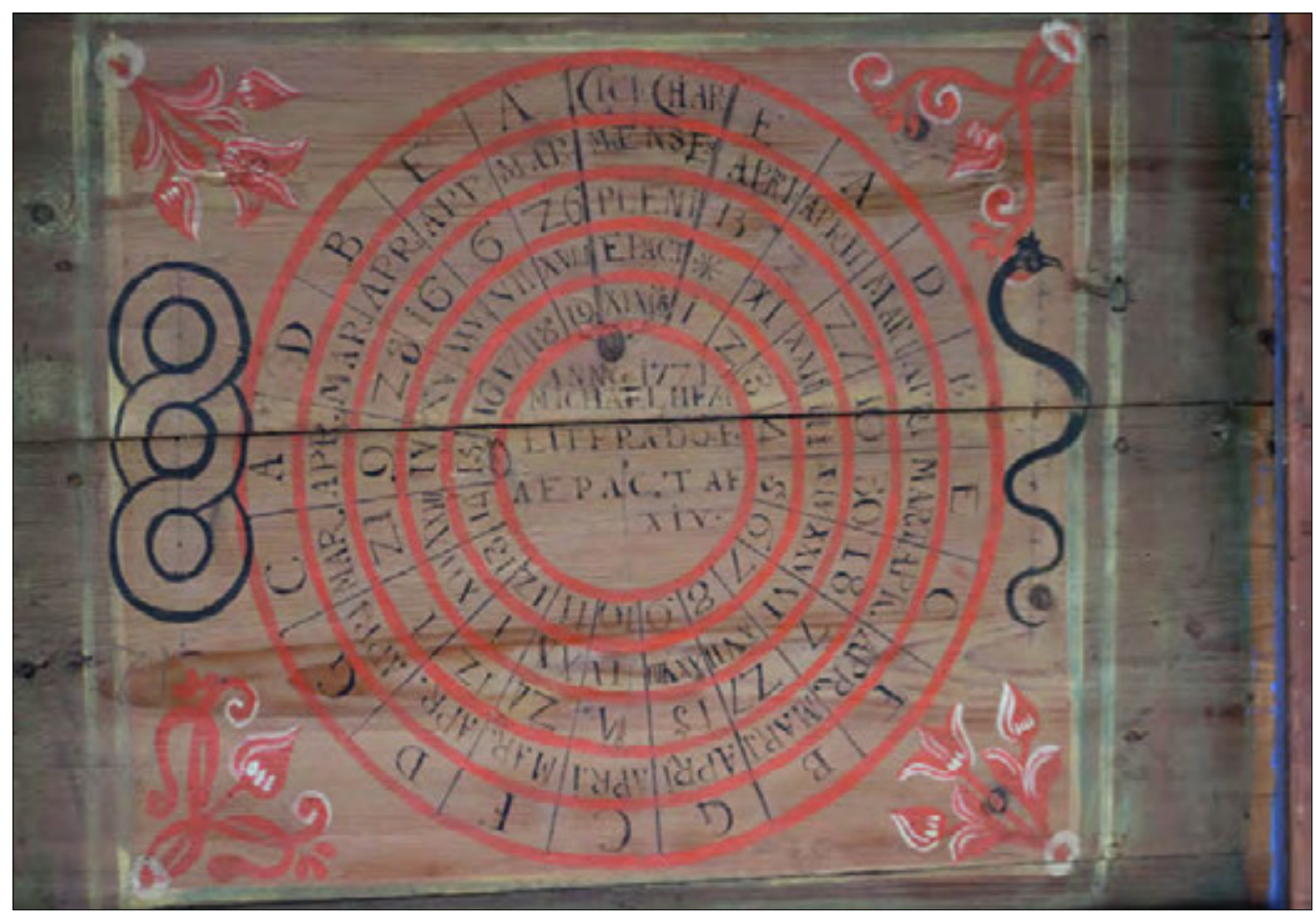

3. kép. A homoródoklándi unitárius templom kazettás mennyezetén a húsvétkazetta

Az éveket napévben számoljuk, ám a húsvét ünnepe, amint az köztudott, a hold járásához igazodik. Ezért szükséges a napévnek a holdévvel való kiegyenlítése. 19 tropikus évet követően a hold fényváltozásai az év ugyanazon napjára esnek. Ezt a 19 éves ciklust nevezik Metón-ciklusnak, amelynek segítségével a nap és a holdév közötti különbség kiegyenlítődik.

Ezt látszik megerősíteni az LS betűk fölött található kis hullámos vonal, amely mintegy jelzi a Hold, latinul L(una) és a Nap S(ol) öszszekapcsolását.

Azt, hogy egy adott év a ciklus hányadik éve, az a következő egyszerű számítás alapján határozható meg: az évszámhoz egyet adva, azt elosztjuk 19-cel, és az osztás maradéka megadja a cikluson belüli helyét az adott évnek. Mivel a húsvét kiszámítása során ennek a számnak kiemelt fontossága van, numerus aurusnak, azaz aranyszámnak nevezték el. Pl. 1771 aranyszámát a következőképpen kapjuk meg: $1771+1=1772,1772: 19=93+5$ (vagyis a maradék 5), tehát 1771 aranyszáma 5. Az EPACT, aepactae kifejezés görögül felesleget jelent, amelyet időmérésnél használnak. Vagyis az a felesleg, az az időköz, amellyel egy időpont egy korábbit, egy előzőt túlhalad. Ezt a kifejezést gyakorlatilag csak a csillagászatban, a nap- és a holdév összehasonlításánál használták, használják. Ebben az összefüggésben pedig az epakta is azt mutatja meg, hogy az év egy adott napján hány napos a Hold, azaz hány nap telt el a legutóbbi újhold óta. Még általánosabban megfogalmazva az epakta nem más, mint a nap- és holdév közötti különbség napokban kifejezve egy adott napév szerinti dátumkor. 
A húsvéttábla külső gyưrűjének magyarázószövegében a CICL (ciklus) s a CHAR (karakter) fogalmak latin elnevezéseinek rövidítése olvasható. Egykor az év napjait január 1-jétől kezdve folytatólagosan 7 betűvel jelölték A-tól G-ig. Ebből azt a betűt, amely az év első vasárnapját jelölte, vasárnapbetűnek (littera Domenicalis) nevezték. Közönséges évben (nem szökőév) egész éven át ugyanaz a betű jelölte a vasárnapot. Ha pl. egy évben január elseje péntekre esett, akkor másodika szombatra és harmadika vasárnapra. Így erre az évre a vasárnap betű $C$. Ennek megfelelően január 10 . is vasárnap, és betűjele $C$. Szökőév esetén a zavart, a csúszást úgy küszöbölték ki, hogy a február 24-i ún. szökőnapot és az azt követő február 25-ét ugyanazon betűvel jelölték.

A CICL (ciklus) és a CHAR (karakter) jelölés a fentiek figyelembevételével a holdciklus dátumait jelölő karaktereket, betűket jelenti. Esetünkben ezek a karakterek a telehold napjainak betűi. Segítségükkel, ha ismert az adott év vasárnapbetüje, kiszámítható pontosan, hogy holdtölte után mikor lesz vasárnap.

A húsvétkazettán található felíratok tisztázása után és az azok között fellelhető öszszefüggések vizsgálata során megállapítható, hogy egy olyan különleges húsvétkazettával van dolgunk, amelynek az volt, az lehetett a célja, hogy bizonyos ismeretek birtokában segítsen előre megállapítani egy adott évben húsvét vasárnapját.

\section{A húsvétkazetta használata}

1. Próbálkozzunk a kazettán olvasható évszámmal 1771. Leghamarabb az év aranyszámát számítsuk ki. Ezt az (1771+1)/19 osztásból származó maradék egész szám adja, ami 5, mert ha az 1772-t elosztjuk 19-cel, akkor 93-at kapunk, a maradék pedig 5. Az 5-ös szám 1771 aranyszáma. A húsvétkazettán a belső körön megkeressük az 5-ös számot, és sugárirányba, kifelé leolvassuk a harmadik gyűrüben (PLENI) található értéket, ami 30, a fölötte levő 4-ik (MENSES) gyűrűben pedig a MART kifejezést. Vagyis a belső gyűrűben található 5-ös számra épülő oszlopból kiolvashatjuk a MENSE MART és a PLENI 30 értékeket. Ez azt jelenti, hogy március 30án volt telehold 1771-ben. Az adott oszlop legfelső mezejében, azaz az 5-ik gyűrüben $\mathrm{E}$ betű olvasható. Feltételezzük, hogy az E betű ez esetben a telehold napjának betűjele.

Azt, hogy az 1771-es évnek melyik volt a vasárnapbetűje, ma különböző szakkönyvekből hamar megállapíthatjuk. Egykor egy adott év vasárnapbetűjének ismerete teljesen természetes és általános volt az írni és olvasni tudók körében. Ám ha véletlenül valamiért nem tudták, akkor egyszerű viszszaszámítással meg tudták határozni, hogy január elseje milyen napra esett, és ennek függvényében meghatározhatták a vasárnapbetűt. 1771 vasárnapbetűje F volt. A kazettáról leolvasott adatok szerint a holdtölte napja március 30., és betűje E. A vasárnapbetű pedig $\mathrm{F}$, tehát 1771-ben húsvét vasárnapja március 31-én volt, mert az E-t követő első vasárnapbetű az F.

A húsvétkazetta belső körén MICHAEL MEZeI alatt a LITERA DO. F most már értelmet nyer, és a rövidítés feloldható ilyenformán: LITERA DOMENICA F-nek a megadásával Mezei Mihály mintegy megadja a naptárhasználat kulcsát.

2. Ellenőrzésként próbáljuk meghatározni azt, hogy mikorra esett húsvét vasárnapja 1786-ban. Ez fontos dátum lehetett az oklándi gyülekezet életében, mert a szentély menynyezetén látható kazettákat ekkor festették. Ezt a következő felirat jelzi: KÉSZITTETETT SZOLGA GYÖRGY CURATORSÁGÁBAN NA- 
GYOBB ÉS KISSEBB ELEKES ANDRÁS ÁLTAL 1786 PÜNKÖST HAVÁBAN.

1786 ARANYSZÁMA 1, $(1786+1): 19=94$ + 1. A belső gyürű 1-es oszlopából leolvasható PLENI: 13, MENSE: APRI, CHAR: E. Vagyis 1786-ban holdtölte április 13-án volt, mely napnak a betűje E. Az 1786. év vasárnapbetűje $A$ volt, vagyis az év első napja, január elseje vasárnapra esett. A kazettán olvasható E után $\mathrm{A}$ betűs nap három nap múlva következik. Vagyis a holdtölte után három nap múlva lesz leghamarabb vasárnap. Tehát húsvét vasárnapja 1786-ban az április 13-át követő harmadik napra, azaz április 16-ára esett.

\section{A Julianus-naptár szerinti húsvét- számítás}

Felmerül a kérdés, hogy mi szükség van a második, EPACT elnevezésű gyűrüre, illetve az abban található római számokkal jelzett értékre. Bármilyen formában és bármilyen szabály szerint igyekeztem bevonni a húsvét dátumának kiszámításába, vagy mint fölösleges adat szerepelt, vagy pedig rossz dátumokat eredményezett.

Az ellentmondást, számos kísérlet után, úgy sikerült feloldani, hogy nem a Gergely-, hanem a Julianus-naptárra jellemző dátumok szerint végeztem a számításokat. Az epaktákat mindig valamilyen nevezetes dátumhoz kötik, adják meg, amit az epakta székhelyének vagy epacta sedesnek neveznek. A középkorban az epakta székhelye a lehetséges legkorábbi húsvétvasárnap dátumának napján, azaz március 22-én volt. Az egyház, hogy könnyítsen a számítás menetén, mindig a 14 napos holdat, a luna XIV-et vette alapul. Esetünkben a központi körben olvasható szöveg, az AEPACTAE XIV-is erre hívja fel a figyelmet.

Vagyis ha tudjuk az adott év epaktáját, akkor abból kiszámíthatjuk, hány nap kell még ahhoz, hogy a Hold 14 napos legyen, vagyis telehold.

A Julianus-naptár esetében csak 19 epakta volt lehetséges, és ezek változatlanok voltak az évszázadok során, minek következtében az újholdak az egyes hónapokban csak 19 napra esnek, a többi napokon soha nincs újhold. (Mindez természetesen csak akkor érvényes, ha figyelembe veszik azokat a korrekciókat, amelyeket általában 100 évenként hajtanak végre, és arra hívatottak, hogy a nap- és a holdfázisok között fellépő különbségeket kiegyenlítsék. Ezek az ún. holdegyenlítések, illetve napegyenlítések.) A Gergely-naptár bevezetésével az új, ún. Lilius-epakták léptek érvénybe 1582-től kezdve. Ezeknek az új epaktáknak székhelye már január 1.

Megvizsgálva a homoródoklándi húsvétkazettán szereplő epaktákat, azt állapíthatjuk meg, hogy ezek a Julianus-naptárnál használt epakták kiigazított változatai, amelyek 1700-tól 1899-ig érvényesek.

Ezek ismeretében adódik az a felismerés, hogy az oklándi húsvétkazetta a Julianus-naptár szerinti húsvét dátumnak a megállapítására is szolgál. E számítás menete a következő:

Ha ismerték az adott év epaktáját, akkor annak segítségével már könnyen ki tudták számítani a húsvéthatárt, pontosabban azt a napot, amikor telehold van. Vagyis ha tudjuk az adott év epaktáját, akkor abból kiszámíthatjuk, hány nap kell még ahhoz, hogy a Hold 14 napos legyen.

Bármilyen meglepő, ha a Julianus-naptár szerint keressük a húsvétvasárnap dátumát, akkor az oklándi húsvéttáblán feltüntetett epakták segítségével egyszerúen és pontosan meghatározhatjuk azt. Az eljárás a következő: az adott évnek megkeressük az aranyszámát, és leolvassuk a fölötte található epakta értékét. Ez az érték megadja, 
hogy március 22-én hány napos a Hold. Ha az érték 14 alatt van, akkor március 22-höz hozzáadunk annyi napot, amennyivel az adott érték kevesebb, mint 14. Ha az epakta értéke nagyobb, mint 14, akkor március 22höz annyi napot adunk, amennyi az újhold megjelenéséhez kell, majd ehhez a dátumhoz adunk hozzá 14 napot. Ezt a gyakorlatban egyszerűen úgy számították ki, hogy a leolvasott epaktaértéket kivonták 30-ból vagy 31-ből. (Hogy melyik számot használjuk, az attól függ, hogy újhold melyik hónapra esik. Ha az újhold márciusra esik, akkor 31, ha pedig áprilisra, akkor 30.) Táblázatból vagy a mindennapi életből könnyen ki lehet számítani az adott nap betűjét, és ha ismert volt az adott év vasárnapbetűje, akkor könnyen meg lehetett határozni a húsvét dátumát.

Példák:

1. 1771-ben a Julianus-naptár szerint a húsvét napját a következőképpen határozhatjuk meg: az év aranyszáma 5. Az ennek megfelelő epakta érték 14, ami azt jelenti, hogy éppen március 22-én 14 napos a Hold. A Julianus-naptár szerint 1771. március 22-ének betűjele D (számítások alapján), vasárnapbetűje pedig $\mathrm{B}$ (számítások alapján). Ebből következik, hogy húsvét vasárnapja a Julianus-naptár szerint 1771-ben március 22-t követő 5. napon, azaz március 27-én volt (a Gergelynaptár szerint, amint azt az előző példából láttuk, húsvétvasárnap 1771-ben március 31-ére esett).

2. 1786 húsvét dátumának meghatározása a Julianus-naptár szerint: az év aranyszáma 1. Az epakta értéke * (a nulla, a semmi jele), vagyis újhold. Ennek értelmében luna XIV (a tizennégy napos Hold ) tizennégy nap múlva lesz. Tehát március $22+14$ nap = április 5. Április 5-ének betűje D (számítások alapján), 1786 vasárnapbetűje pedig D (számítások alapján). Ekkor az a szabály érvényesül, hogy ha a holdtölte napja vasárnapra esik, akkor a húsvétvasárnapja a következő vasárnap lesz. Tehát a Julianus-naptár szerint 1786-ban április 5-én volt a tavaszi napéjegyenlőséget követő első holdtölte. Mivel ez éppen vasárnapra esett, a húsvétszámítás szabályainak értelmében húsvét vasárnapja 7 nappal későbbre került, azaz április 12-re.

A homoródoklándi húsvétkazettán található adatokból az derül ki, hogy csak 200 évig lehetett pontosan használni, 1700-tól 1899-ig. Alkotójáról, szerkesztőjéről, Mezei Mihály unitárius papról csak annyit tudunk, hogy 1771 és 1777 között a faluban teljesített papi szolgálatot. Nem tudjuk azt sem, hogy honnan jött, és mi lett vele az Oklándon töltött szolgálat után. Mint ahogy azt sem tudjuk, hogy milyen meggondolásból helyezte el a húsvétkazettát a templomhajó mennyezetén.

Csak fokozódó csodálattal és tisztelettel gondolhatunk Mezei Mihályra, az egykori titokzatos unitárius papra, aki egy olyan táblázatot szerkesztett, amely nemcsak a Gergely-, hanem a Julianus-naptárt használók számára is lehetővé tette a legfontosabb keresztény ünnep dátumának meghatározását.

Anélkül, hogy önmagunk becsülésén és lelkiismeretén csorbát ejtenénk, biztosan és büszkén állíthatjuk, hogy a homoródoklándi unitárius templomban található húsvétkazetta az erdélyi magyar művelődéstörténet jelentős és fontos emlékeinek egyike. 


\section{EPILóGUS}

E kötet olvasója, de maguk a szerzők sem gondolták volna kutatásaik kezdetén, hogy itt a Kárpát-medence keleti régiójában, a Kárpát-vonulat gyönyörű medencéiben, azon a területen, amelyet közel nyolcszáz éve Székelyföldnek hívnak, ennyire változatos műszaki fejlődés kibontakozhatott. Ennek a fejlődésnek meghatározó tényezői voltak a terület természeti adottságai, gazdag érclelőhelyei, beláthatatlan erdőségei, gyors folyású patakjai, amihez szerencsésen társult peregrinus mesterek szaktudása, amit a lakosság helyi sajátosságokhoz igazítva továbbfejlesztett. Ne felejtsük a pozitív ráhatások sorából az örökséget sem, amit betelepülésükkor találtak: a megelőző évszázadok népeinek hagyatékát.

Minden, ami a műszaki fejlődés kategóriájába tartozik, az itt élő népek közös munkájának eredménye. Meggyőződésünk, hogy ezt az olvasó is megállapítja, és így is értékeli.

E tanulmánykötet szerzői, kutatásaik több évtizedre visszatekintő eredményeit helyezték az olvasó figyelmébe, tudatában annak, hogy teljességre törekvésük ellenére munkájuk csupán új utakat nyitó, új kutatási irányokat sugalló kezdet, ami nem hiányossága munkájuknak, hanem tudatos önértékelés.

Szerzők annak is tudatában vannak, hogy a műszaki fejlődés nem állt meg ott, ahol a kötetben szereplő egyes tanulmányok behatárolnak egy bizonyos korszakot. Nem is állhat meg, még akkor sem, ha időnként lelassul a fejlődés üteme, netán megszűnik ideig-óráig. Ezért kaptak teret a kötetben a kordovángyártás, a borszéki üveg, a Gyilkos-tó és Békási-szoros vízerőmű építésének kísérletei vagy a Kommandó-Kovászna siklópálya, amelyeknek esélyük sem lehet a folytatáshoz.

E tanulmánykötet tartalma is azt bizonyítja, hogy a műszaki fejlődés tulajdonképpen a békés építő évek története, ami kiegészítője a történelem tudományának. Csak a békés években volt igény és pénz, és volt alkotókedv egy új malom építéséhez, új szerszámok vagy egy új cserge elkészítéséhez. Ha belegondolunk, mi mindent tudunk Székelyföld történetéből, és mily keveset műszaki fejlődésének történetéről, hézagpótló feladatainkat annál sürgetőbbeknek érezzük. 
Azt is megjegyezheti az olvasó, hogy tanulmánykötetünkből Székelyföldre jellemző fejezetek maradtak ki, mint pl. a faipar technikatörténete, a vasútépítés, az ágyúöntés és puskaporgyártás technikája, amelyeknek döntő jelentőségük volt az 1848-49-es forradalom és szabadságharc eseményeiben, és még néhány műszaki tevékenység. Szerzők is tudatában voltak ennek, de ismerve az említett témakörrel kapcsolatos, a közelmúltban megjelent könyveket, amelyek könyvészetünkben is szerepelnek, nem tartották fontosnak ezek tartalmát tanulmány terjedelmű írásokkal helyettesíteni. Ezért is viseli kötetünk a Fejezetek címet. Értékelje ilyen meggondolások alapján kedves olvasó is munkánkat.

Az epilógus egyszersmind a köszönetnyilvánítás helye is. Szerkesztő köszöni a kötet szerzőinek a kiváló csapatmunkát, a bizakodást és a hitet, hogy fáradozásuk, a sok munkával járó, többéves kutatómunka, terepen és levéltárban végzett vizsgálódások nem voltak hiábavalók, és elkészülhetett ez a Székelyföld múltját új, technikatörténeti szempontok szerint bemutató kötet.

Köszönet illeti a Sepsiszentgyörgyi Székely Nemzeti Múzeum, a Csíki Székely Múzeum, a Marosvásárhelyi Történelmi Múzeum, a Székelyudvarhelyi Haáz Rezső Múzeum, a Gyergyószentmiklósi Tarisznyás Márton Múzeum, a Kézdivásárhelyi Múzeum, valamint a Baróti múzeum vezetőségét dokumentálódásunkban nyújtott önzetlen segítségükért.

A Magyar Országos Levéltár, a Magyar Tudományos Akadémia Könyvtára, az Országos Széchényi Könyvtár felbecsülhetetlen dokumentálódási lehetőségeit, dolgozóinak segítőkészségét példaértékűnek tartjuk.

A Hargita megyei Megyei Könyvtára dolgozóinak, a gyergyószentmiklósi Városi Könyvtár könyvtárosainak köszönjük segítségüket a felhasznált irodalomban szereplő kötetek rendelkezésünkre bocsátásáért.

Köszönet Véninger Péter kerámiatechnika-történésznek a Székelyföldi kerámia fejezethez hozzáfüzött javaslataiért.

Köszönet a Communitas Alapítványnak munkánk pozitív elbírálásáért és a kiadás anyagi hátterének biztosításáért. Az Erdélyi Múzeum-Egyesület vezetőségének külön köszönetünket fejezzük ki amiatt, hogy felvállalta a kötet megjelentetését rangos kiadójánál.

Külön köszönet illeti Kerekes Györgyöt, a könyv olvasószerkesztőjét körültekintő munkájáért.

Az igényes és esztétikus műszaki szerkesztés, szövegtördelés Szilágyi Júliat dicséri. Türelmét, magas szakmai tudással végzett munkáját elismeréssel és tisztelettel köszönjük.

Köszönjük a Gyergyószentmiklósi F\&F Nyomda igényes munkáját, igazgatójának szívélyes hozzáállását kötetünk megjelenése ügyéhez.

És végül, de nem utolsósorban köszönjük az olvasónak, hogy időt szakított kötetünk elolvasására, reméljük, haszonnal tanulmányozta írásainkat, és talált magának eddig ismeretlen részeket Székelyföld technikatörténetéből. 


\section{Capitole ale istoriei tehnici în Ţinutul Secuiesc}

(Rezumat)

Cartea este structurată pe 12 capitole de sine stătătoare, care surprind aspecte ale istoriei tehnicii în domenii specifice ținutului, reflectând creativitatea locuitorilor acestor meleaguri.

Fiind considerată regiune periferică subdezvoltată față de vestul Europei, capitolele cărții vin să demonstreze, că în multe domenii ale vieții sociale, în special cele cu specific tehnic, Ținutul Secuiesc s-a situat la un nivel de dezvoltare comparabil cu cel din vestul Europei.

Bazat pe o vastă bibliografie, capitolul 1 este o autentică retrospectivă a celei mai vechi ocupații cu caracter tehnic, obținerea obiectelor gospodărești din argilă. Sunt prezentate prelucrarea argilei și realizarea obiectelor de uz gospodăresc respectiv cahle pentru sobe de teracotă. Ancorat în trecutul istoric al ținutului, autorul capitolului realizează o legătură organică dintre ceramica antică descoperită cu ocazia săpăturilor arheologice și tehnica de prelucrare a argilei din secolele 12-13, prin secolele16-17 până în secolul al 20-lea.

Este descrisă pregătirea argilei brute, precum și fabricarea coloranților adecvați în tehnica ceramicii, smălțuirea, arderea obiectelor formate în vederea transformării acestora în ceramică adevărată. Sunt prezentate diverse obiecte de ceramică specifice centrelor de fabricație ca de exemplu Corundul și Dănești din județul Harghita. În finalul capitolului sunt redate aspecte ale fabricării cahlelor sobelor de ceramică cu ornamentații specifice, adecvate.

Capitolul 2 se referă la una din bogățiile naturale ale ținutului și anume zăcămintele de minereuri. Cuprul și fierul sunt cele două metale a căror fabricare a fost posibilă datorită resurselor însemnate de minereu de cupru, respectiv unei largi varietăți de minereu de fier. Exploatând aceste resurse minerale a luat ființă mineritul zăcământului cuprifer de la Bălan, județul Harghita, a minereului de fier din zona sudică a munților Harghita și în continuare prelucrarea cuprului și fierului obținut. 
Capitolul 3 se referă la mineritul și metalurgia fierului. Rămășițele unor cuptoare de pudlaj și zgură în cantități considerabile ca rezultate a unor descoperiri arheologice sunt dovada unui intens proces metalurgic al fierului în acest ținut.

Tot în acest capitol sunt prezentate centrele de minerit și metalurgie a fierului suficient de productive să asigure necesarul de metal, de exemplu în secolul 16-lea, în timpul Principatului Transilvaniei.

Mădărași Ciuc și Lueta au fost puternice centre siderurgice care au funcționat deja în secolul 16-lea, fapt datorat și vastei utilizări a energiei roții hidraulice antrenate de apele pârâurilor de munte cu debit relativ constant în lunile fără ingheț.

Siderurgia secolului al 19-lea este redată prin prisma activității centrelor de la Bodvei, Filia din actualul județ Covasna și de la Lueta din Harghita, și a aportului acestora la desfășurarea evenimentelor revoluției din 1848 din Transilvania, în special pe teritoriul Ținutului Secuiesc. În incheierea capitolului sunt enumerate câteva încercări de înființare a unor fabrici de prelucrare a minereurilor de fier, cum ar fi cel de la Ciumani și Ditrău aflate în actualul județ Harghita, Papolț și Brețcu din județul actual Covasna .

In continuarea volumului, capitolul 4 prezintă turnarea de clopote în Ținutul Secuiesc. Sunt prezentate turnătoriile de la Târgu Secuiesc și Sfântu Gheorghe din județul Covasna, și cele de la Miercurea Ciuc și Corund din județul Harghita. Capitolul se încheie cu prezentare actualei turnătorii de clopote din Odorheiul Secuiesc.

Mineritul sării, comerțul cu sarea în anii Principatului Transilvaniei pot fi studiate în capitolul al 5-lea.

Un aspect specific industriei lemnului este transportul materialului lemnos și a produselor prelucrării lemnului. Această activitate de loc simplă este tema capitolului 6. Aici se prezintă localitatea Comandău, cu o industrie de prelucrare a lemnului exploatat din pădurile inconjurătoare. Producția celor 36 de gatere este transportată până în localitatea Covasna cu un funicular care funcționează pe baza utilizării forței gravitaționale. Vagonul încărcat, fixat la un capăt al unui cablu de oțel, coboară, trăgând în sus, fără vreo altă energie suplimentară, vagonul gol legat de celălat capăt al cablului pe o cale ferată special construită. Un sistem ingenios și economic.

Capitolul 7 este consacrat industriei textile și a pielăriei. Inaintea apariției industriei textile în Ținutul Secuiesc locuitorii își fabricau singuri țesăturile necesare nevoilor proprii. 0 piesă numită cergă ce se folosea ca lenjerie de pat, datorită unor caracteristici nu era produsul care se realiza la toate gospodăriile. Anumite zone din teritoriu posedau utilaje de pregătire, filare și țesere a lânii pentru cergă. Capitolul descrie toate fazele tehnologiei de fabricare a acestui obiect.

Un produs special al tăbăcarilor armeni din Gheorgheni îl constituia produsul numit cordovan, obținut prin tăbăcirea pirlii de țap. Tehnologia avea ca rezultat o piele fină, 
moale, viu colorată în roșu, albastru sau negru. Fiind foarte apreciat și căutat, produsul a fost exportat și în Europa de Vest. Cantități de zeci de mii de bucăți au fost valorificate anual.

Morile de apă, răspândirea lor, tipurile, structura lor, funcționarea și utilizarea lor sunt subiectele celui de al 8-lea capitol al cărții.

Datorită condițiilor de mediu a ținutului, sute de pâraie de munte cu debit relativ constant și viteză de curgere adecvată antrenării roților de apă au determinat construirea unui mare număr de mori de apă cu multiple utilizări. Marea diversitate a morilor de apă, de la cele de măcinat cereale sau de prelucrare a lemnului până la cele care antrenau diverse utilaje tehnologice ale industriei textile și de pielărie, respectiv foalele uzinelor metalurgice, reflectă ingeniozitatea locuitorilor acestor meleaguri.

Fabricarea sticlei este tema capitolului 9. Borsec și Bixad Olt sunt doar două locații în care fabricarea sticlei a atins dimensiuni cu adevărat industriale. Produsele de o mare varietate și de un aspect plăcut ale acestor hute (denumire a fabricilor de sticlă) erau apreciate și căutate pe piețele din Transilvania. Apa minerală din Borsec era imbuteliată în sticle fabricate pe plan local.

Electrificarea unor localități este tratată în capitolul 10. Procesul a determinat schimbări bruște în modul de viață a locuitorilor acestor meleaguri. Este de remarcat faptul, că localitatea Comandău a fost electrificată încă la sfârșitul secolului al 19-lea înaintea altor localități din ținut, nu mult după electrificarea orașului Timișoara.

Răspândirea centralelor electrice a început doar în primii ani ai secolului al 20-lea, înlocuind iluminatul cu lampa cu petrol și facilitând utilizarea energiei electrice și în industria vremii.

Un subcapitol este consacrat incercărilor de realizare a unei hidrocentrale electrice la Lacul Roșu, unde s-ar fi putut obține energie electrică sub 1 MW. Datorită celor două războaie mondiale și a situației economice de după ele, planul nu a putut fi concretizat.

Ultimele două capitole nu abordează teme strict legate de domeniul tehnic, însă vin să realizeze o legătură între meșteșuguri și dezvoltarea industrială a ținutului prin apariția breslelor.

Capitolul 11 prezintă organizarea și funcționarea breslelor din Odorheiu Secuiesc, rolul acestora în dezvoltarea orașului, produsele realizate de ele, activitatea acestora în formarea pieții de desfacere și calificarea forței de muncă.

Tema capitolului 12 este descrierea calendarului permanent de pe o casetă a tavanului cu casete pictate al bisericii unitariene din comuna Ocland, județul Harghita. Cu ajutorul acestuia se poate determina ziua paștelui atât în sistemul calendarului Iulian, cît și în cel Gregorian. Este o curiozitate demonstrând ingeniozitatea unui preot al bisericii în secolul al 18-lea. 
Cartea este opera unei colectiv de autori cu o vastă experiență de specialitate, fiind prima încercare de a prezenta câteva aspecte ale istoriei tehnicii, parte a istoriei, a anilor pașnici, în care dezvoltarea generală a constituit caracteristica principală a ținutului. 


\section{Chapters of Tehnical History in the Székely Land}

\section{(Abstract)}

The volume is structured in 12 independent chapters, each dealing with aspects of technical history in branches that are specific to the region. These chapters reflect the creativity of the people who live on these lands, there were periods when their creativity was comparable to that of the whole of Transylania and of Western Europe.

The Székely Land is usually considered to be an underdeveloped periphery compared to Western Europe, yet the chapters of this volume prove that in many areas of life, especially those that involve technologies, the Szekely Land was at a developmental level comparable to that of Western Europe.

Chapter 1. discusses the processing of clay in creating household objects and stove tiles. The authos of the chapter being deeply anchored to the historical past of the region, realizes an organic connection between the antique pottery discovered at archaeological explorations and the clay processing technologies from the $12^{\text {th }}-13^{\text {th }}$ century era, through the $16^{\text {th }}-17^{\text {th }}$ century and up to the $20^{\text {th }}$ century.

The chapter presents the preparations of raw clay, the production of dyes in ceramic production, the enameling, burning of the objects in order to transform them into real pieces of pottery. Different ceramic objects are presented that are specific to the manufacturing centres such as Corund/Korond and Dănești/Csíkdánfalva in Harghita/Hargita county. At the end of the chapter the production of stove tiles is discussed, tiles that have a specific, adequate ornamentation.

Based on a vaste bibliography, the chapter is a true retrospective of the oldest technical trade, the obtaining of household items from clay.

Chapter 2. deals with one of the natural riches of the area, mineral resources. Copper and iron are the two metals that could be produced due to the significant resources of copper ore and a lagre variety of iron ore. By exploiting these resources the copper ore mining of Bălan/Balánbánya in Harghita/Hargita county was born, also the iron ore mining in the Southern area of the Harghita/Hargita mountains and last but not least the processing of the obtained copper and iron could also happen. 
The second part of the chapter discusses iron mining and metallurgy. The remains of some forges and the substantial quantities of slag discovered during archaeological explorations are proof of an intense metallurgical process of iron in these lands.

Also in this chapter the mining and forging centres are presented, those were sufficiently productive to provide the necessary quantities of metal for instance in the $16^{\text {th }}$ century, in the age of the Principate of Transylvania.

Mădărași Ciuc/Csíkmadaras and Lueta/Lövéte are powerful centres of iron industry already in the $16^{\text {th }}$ century, due also to the large scale use of water wheels as a source of energy. These wheels were powered by the waters of the mountain creeds which had a relatively constant discharge during the frostless months of the year.

The $19^{\text {th }}$ century iron production is presented through the activity of centres such as Bodvei/Bodvaj, Filia/Erdőfüle fom today's Covasna/Kovászna county and Lueta/Lövéte in Harghita/Hargita, the contribution of these to the unfolding of the events during the 1848 revolution in Transylvania and especially the Szekely Land. In the closing part the chapter the author describes several attempts to build iron ore processing factories such as those in Ciumani/Gyergyócsomafalva and Ditrău in today's Harghita/Hargita county, also Papolț/Papolc, Brețcu/Bereck in Covasna/Kovászna county.

A natural sequel of this chapter is Chapter 4. which discusses bell casting in the Szekely Land. The casting workshops of Tg. Secuiesc/Kézdivásárhely and Sf. Gheorghe/Sepsiszentgyörgy in Covasna/Kovászna county are presented, also those from Miercurea Ciuc/ Csíkszereda and Corund/Korond in Harghita/Hargita county. The chapter ends with the presentation of the actual bell casting workshop in Odorheiul Secuiesc/Székelyudvarhely.

Salt mining and salt trade during the years of the Principate of Transylvania can be studied in the $5^{\text {th }}$ chapter.

An important aspect of wood processing industryis the shipping of wood and of wooden products. This rather complex activity is discussed in Chapter 6. The settlement of Comandău/Kommandó is presented with its industry that processed the wood that came from the surrounding forests. The output of the 36 sawmills was shipped to Covasna/ Kovászna using a means that exploited gravitational force. The railway cars loaded with the products are launched downhill on special tracks. While the loaded car descended, another empty one ascended, being tied to the loaded one with a steel cable. This is an ingenious and economic system.

Chapter 7. deals with the textile and leather industry. Before the birth of this branch of industry in these areas, the inhabitants made their own textile and leather objects according to their own needs. A type of thick woolen blanket was used as bedsheet and it wasn't the type of object that could be produced in any household. Certain areas in the region possesseed the tools that are necessary for preparing, combing and weaving the wool in order to produce such blankets. Chapter 7. comprises all the technological phases of making thisk woolen blankets. 
A specific product of the Armenian tanners from Gheorgheni/Gyergyószentmiklós was the product named "kordován” obtained by tanning male goat skins. The result of this technology was a fine, soft leather dyed in strong colors such as red, blue or black. This product was very much appreciated and sought after, it was exported including to Western Europe. Tens of thousands were sold each year.

Water mills, their distribution, structure, working and usage are presented in Chapter 8. The natural conditions, the hundreds of alpine creeks wit a relatively constant discharge and a flow speed that is good for moving the wheels were the foundation upon which hundreds of water mills were built for diverse purposes. From those that milled grains to woodworking ones and those that supplied energy to diverse types of machinery, the diversity of these water mills reflects the creativity of the inhabitants of this region.

Glass production in the factories of this area is the tpic of Chapter 9. The actories of Borsec/Borszék, Bixad Olt/Sepsibükszád are only two of the settlements where glass production has truly reached industrial scales. The products of these factories were highly apreciated and sought after all over the markets of Transylvania. Mineral water from Borsec/Borszék was bottled in glass bottles made locally.

Glass products from Bixad Olt/Sepsibükszád had a great variety and a pleasant aspect, they were appreciated by the buyers from the big cities in Transylvania.

Connecting certain settlements to the electric power grid, as discussed in Chapter 10. brought significant changes in the inhabitants' way of life. It is remarcable that Comandău/Kommandó was connected to the grid already at the end of the $19^{\text {th }}$ century, earlier than other settlements in Szekely Land, only a short time after Timișoara/Temesvár was.

The spreading of the hydroelectric plants began only in the first years of the $20^{\text {th }}$ century replacing illumination by petrol-based lamps with electric light and facilitating the use of electric power also in the industry of the age.

A subchapter is dedicated to the attempts to build a hydroelectric plant at Lacul Roșu/ Gyilkos Lake where just under $1 \mathrm{MW}$ of electric power could be obtained. Due to the two world wars and the dire economic situation that followed, this couldn't be realized.

The last two chapters - nr. 11 and nr. 12 are not strictly connected to the technical domain but they come to show a link between trade and pre-industrial development in the regiun due $t$ the aparition of the guilds.

Chapter 11. presents the organizing and the workings of guilds in Odorheiu Secuiesc/ Székelyudvarhely, the part that those played in the development of the city, the products made within the guilds, their market-type activity and the qualifying of the apprentices.

The topic of Chapter 12. is a perpetual calendar by means of which the exact date of Easter can be calculated according to both the Julian and the Gregorian calendar. This calendar can be found in one of the painted coffers of the Unitarian church of Ocland/ 
Oklánd in Harghita/Hargita county. It's a curious and ingenious piece of work made by one of the priests who served in the church during the $18^{\text {th }}$ century.

The book is the output of a cllective of authors who possess a vaste experience in the field. It's a first attempt to present several aspects of technical history, a part of history, of the peaceful years during which a general development was the main characteristic of the region. 


\section{Cuprins}

Prolog

1. Istoria tehnicii fabricării ceramicii ……………………………………………….....11

Aptitudinile Ţinutului Secuiesc privind fabricarea ceramicii......................................11

Argile și coloranţi pe teritoriul actual al Ţinutului Secuiesc ......................................11

Evoluția fabricării ceramicii în diferitele epoci ale istoriei tehnicii ....................... 17

Prelucrarea lutului în epoca primitivă pe teritotiul actual al

Ţinutului Secuiesc........................................................................................... 18

Ceramica romană şi meşteşugul prelucrării argilei în epoca migraţiilor ............ 20

Meşteşugul ceramicii în epoca Arpadiană............................................................... 21

Instituţionalizarea olăritului în Ţinutul Secuiesc în secolele 16-17 ...................... 23

Olăritul rural în Ţinutul Secuiesc............................................................................ 26

Caracteristicile tehnice ale olăritului din Ţinutul Secuiesc în trecutul

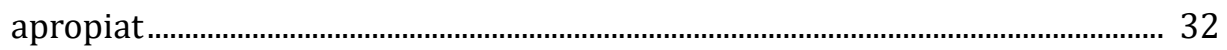

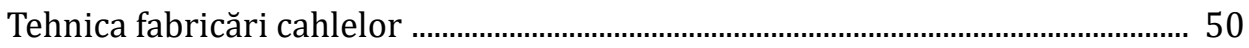

Ateliere de fabricare a vaselor de piatră şi a maiolicii .............................................. 54

2. Locații de minereuri pe teritoriul Ţinutului Secuiesc …………………...................59

Mineralizaţii de cupru vulcano-sedimentare în spaţiul pârâurilor

Belchia şi Cianod .......................................................................................................6

Mineralizaţia de cupru de la Bălan ........................................................................... 60

Mineralizaţii de plumb-zinc-cupru de tip vulcano-sedimentar în valea

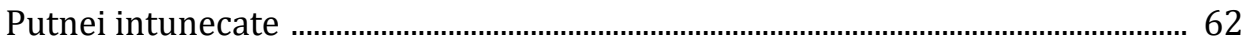

Mineralizaţii hidrotermale de tip Paltin ..................................................................... 62

Mineralizaţii polimetalice apărute în zona pâraielor Hărlăgia, Putna și Huruba 63

Apariţii ale minereului de fier pe teritoriul Ţinutului Secuiesc ............................... 63

Minereul de fier sideritic de la Mădăraş Ciuc ............................................................... 64

Mineralizaţii de fier de tip sideritic în prajma localităţilor Lueta și Chirui ............ 64

Depozite de minereu de fier în Covasna ..................................................................... 66 
3. Mineritul şi metalurgia Ţinutului Secuiesc ............................................................ 69

Mărturii ale prelucrării metalelor în epoca primitivă ............................................... 69

Mineritul şi metalurgia minereului de fier.................................................................. 86

Analiza materialelor provenite din prelucrarea minereului de fier........................ 100

Analiza microstructurilor …………......................................................................... 101

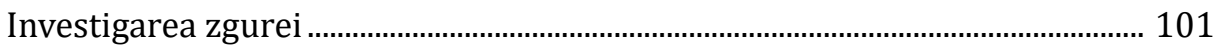

Investigarea rămăşiţelor de fontă ....................................................................... 102

Investigarea rămăşiţei de oţel ............................................................................. 105

Metalurgia fierului din zona Luetei ............................................................................ 106

Metalurgia fierului din zona Depresiunii Baraolt ................................................... 112

Metalurgia fierului în valea Kormos, la Filia ............................................................ 115

Experimentări de fabricare a fierului............................................................................ 118

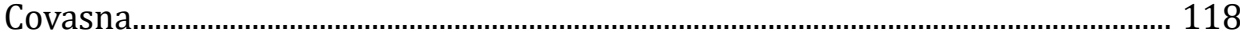

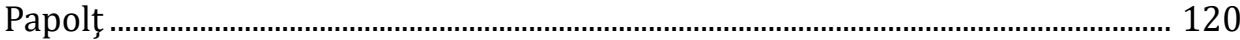

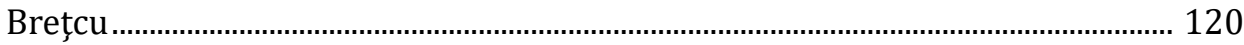

Experimentări de fabricare a fierului în Depresiunea Gheorgheni.......................... 121

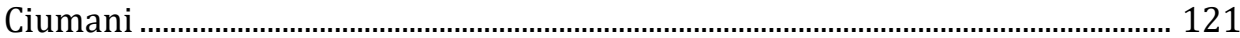

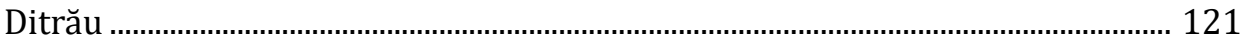

4. Turnare de clopote în Thinutul Secuiesc ………………………………………...... 127

Fabricat la Odorheiul Secuiesc, în turnătoria lui Lázár Imre ................................... 132

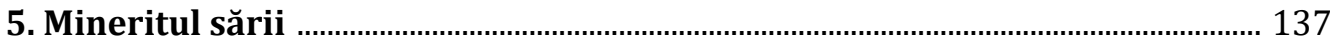

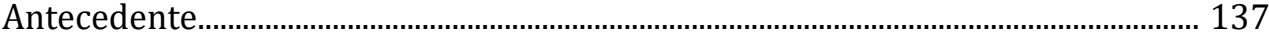

Mineritul şi comerţul cu sarea în evul mediu ............................................................. 138

Exploatarea zăcămintelor de sare la inceputul anilor

Principatului Transilvaniei ......................................................................................... 144

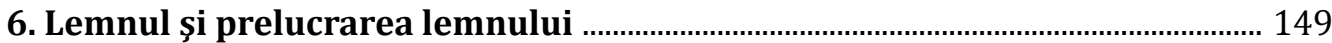

Funicularul de la Comandău-Covasna......................................................................... 149

Structura şi funcţionarea funicularului ................................................................. 149

Exploatarea și întreținerea funicularului ............................................................. 156

Situaţia actuală......................................................................................................... 163

7. Industria textilă şi de pielărie a Ţinutului Secuiesc ………………………………. 167

Despre țesutul cergii.............................................................................................. 167

Ce este cerga?......................................................................................................... 167

Tunsul lânii ..................................................................................................... 168

Înmuierea, spălarea, uscarea lânii ........................................................................... 171 


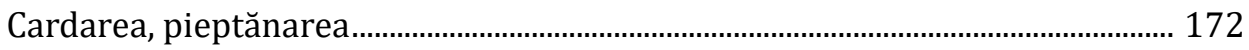

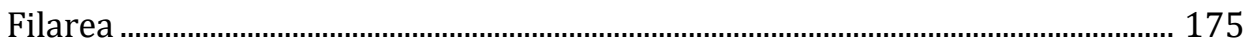

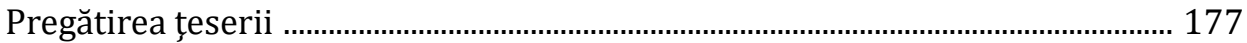

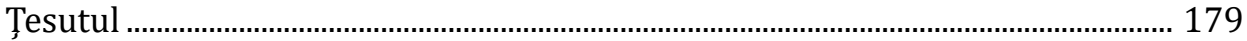

Dărăcirea.................................................................................................................... 180

Utilizarea şi intreţinerea cergii ............................................................................. 184

Schimbarea fabricării cergii .................................................................................... 185

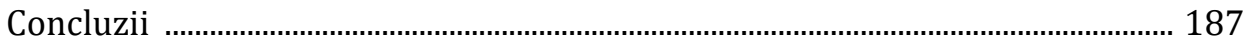

Cordovanul, un produs de renume a tăbăcarilor armeni din Gheorgheni ............ 192

Fabrica de postavuri din Covasna .............................................................................. 195

8. Morile de apă din Ţinutul Secuiesc în timp şi spaţiu ........................................... 199

Însemnătatea energiei hidraulice în minerit şi prelucrarea metalelor .................. 221

9. Fabricarea sticlei în Ţinutul Secuiesc …………………………………………..... 223

Glăjăriile din Bazinul Carpatic.................................................................................... 223

Glăjăriile din Ţinutul Secuiesc.................................................................................. 224

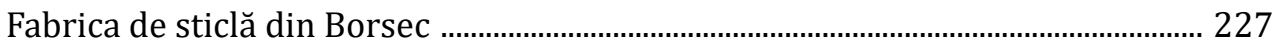

Muncitorii din fabrica de sticlă .................................................................................. 231

Supravieţuirea produselor de sticlă din Borsec ……….......................................... 232

Technica fabricării sticlei........................................................................................ 233

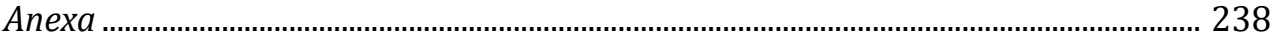

10. Începuturile utilizării energiei electrice ……………………………………...... 239

Capitole din istoria electrificării oraşului Miercurea Ciuc ....................................... 239

Inceputurile ................................................................................................... 239

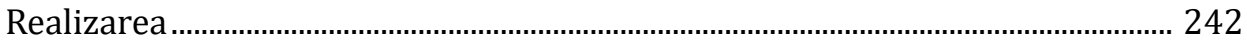

Anii de război ............................................................................................................... 244

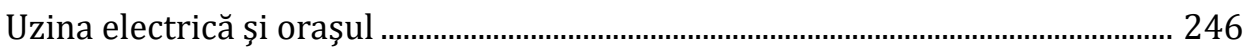

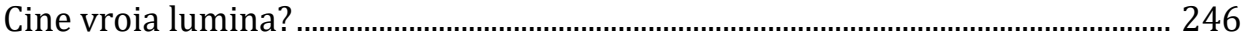

Luminile lumii noi ............................................................................................... 248

Primele decenii ale electrificării Odorheiului Secuiesc............................................ 251

Inceputurile utilizării energiei electrice în Gheorgheni şi în localităţile

Depresiunii Gheorghenilor ............................................................................ 255

Planurile de construcţiei ale unei centrale hidroelectrice la Lacu Roşu și

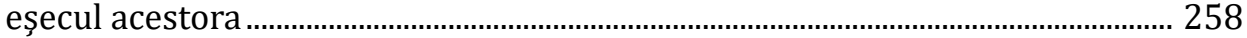

Istoricul electrificări localităţii Comandău ........................................................... 265

Proiect de centrală hidroelectrică …………………………………………….... 269 
11. Breslele din Thinutul Secuiesc ………………....................................................... 271

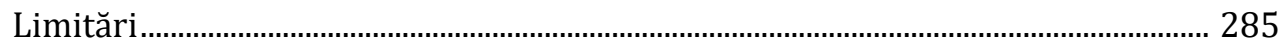

Influența limitărilor în viaţa breslelor ....................................................................... 285

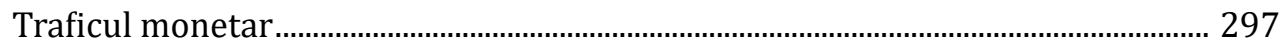

Sistemul monetar din imperiu .............................................................................. 299

Despre unitățile de măsură........................................................................................... 300

Meseriaşii din afara breslelor .................................................................................... 303

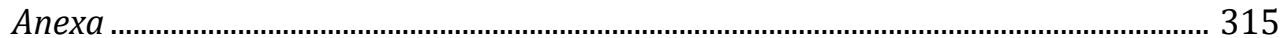

12. Calendar permanent pe o casetă pictată al ansamblului tavanului bisericii unitariene din comuna Ocland (HR)_............................................. 319

Descrierea calendarului de pe casetă....................................................................... 320

Presupuneri şi explicaţii .............................................................................................. 321

Utilizarea casetei pascale........................................................................................... 323

Determinarea zilei paştelui conform calendarului Iulian........................................... 324

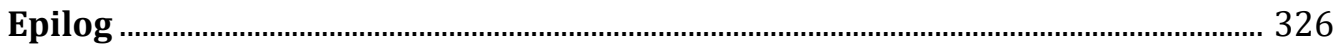

Capitole ale istoriei tehnicii în Ținutul Secuiesc (rezumat) …………………………….... 328

Chapters of Tehnical History in the Székely Land (abstract) ......................................... 333 


\section{ConTEnTS}

Prologue

1. An Outline of Ceramic Production from a Technical History Viewpoint. .11

Facilities of Ceramic Production in the Székely Land. 11

Materials, Dyes in the Territory of Present Time Székely Land ...............................11

Changes from Time to Time in Technical History .................................................... 17

Prehistoric Ceramic Production in the Territory of Present Time

Székely Land........................................................................................................... 18

Roman Ceramics and the Ceramic Manufacturing in the Age Of Migrations .... 20

Ceramic Manufacturing in the Árpád Era ............................................................... 21

$16^{\text {th }}-17^{\text {th }}$ century - the Institutionalization of Pottery .......................................... 23

Pottery in the villages of Székely Land ................................................................ 26

Technical Characteristics of Pottery in Székely Land's Recent Past..................... 32

The Technique of Stove Tiles Production ............................................................... 50

Stone Dish and Majolica Workshops in Székely Land .............................................. 54

2. Ore Sources in Székely Land

Volcanic-Sediment Copper Ore Forming in the Area of the Belcina/Békény and the Cianod/Csanód Creeks..............................................................................60

Copper Ore Forming in Bălan/Balánbánya................................................................. 60

Volcanic-Sediment Led, Zinc and Copper Ore Forming in the Sötétputna Valley 62

Paltini-Type Hydrothermal Ore Forming. 62

Polymetallic Ore Forming in the Region of the Hărlăgia and the Huruba Creeks 63

Occurence of Iron Ore in the Székely Land 63

Sideritic Iron Ore in Mădăraș/Csíkmadaras 64

Sideritic Iron Ore Forming in the Lueta/Lövéte - Băile Chirui/Kiruly Area.......... 64 Iron Ore Fields in Kovászna 66 


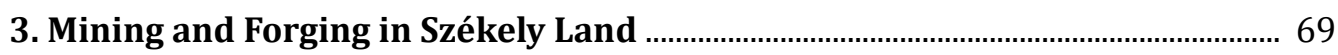

Remnants of Prehistoric Metal Production ................................................................ 69

Iron Ore Mining, Iron Forging...................................................................................... 86

Analysing Material Residue in a Forge................................................................... 100

Analysing the Micro-Structure of the Residue ……................................................ 101

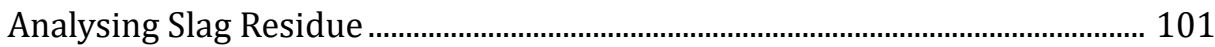

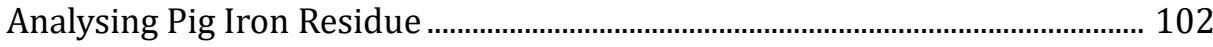

Analysing Steel Residue...................................................................................... 105

Iron Production in Lueta/Lövéte ............................................................................. 106

Iron Production in Erdővidék .................................................................................. 112

Iron Production in the Brăduț/Kormos Creek River and in Filia/Erdőfüle ......... 115

Attempting Iron Production.................................................................................. 118

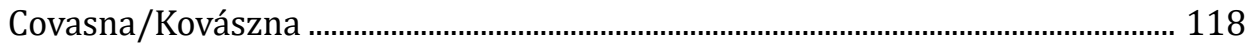

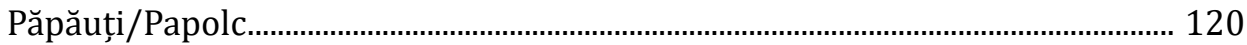

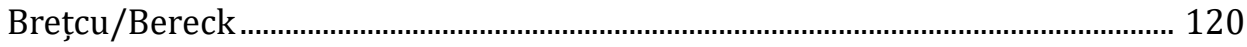

Attempting Iron Production in the Gheorgheni/Gyergyó Basin ............................. 121

Ciumani/Gyergyócsomafalva ............................................................................. 121

Ditrău/Gyergyóditró ........................................................................................... 121

4. Bell-Founding in Székely Land ............................................................................... 127

Made in Odorhei/Udvarhely, in Lázár Imre’s Foundry ............................................. 132

5. Salt mining in Székely Land ................................................................................... 137

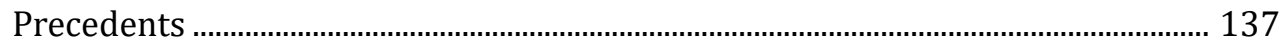

Salt Mining and Salt Trading in the Middle Ages..................................................... 138

Salt Production in Székely Land in the First Period of the Principate

of Transylvania

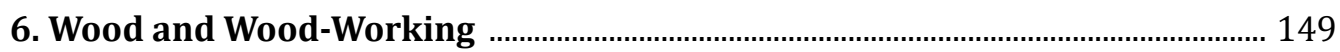

The Comandău/Kommandó - Covasna/Kovászna Glide Path................................... 149

The Structure and Working of the Glide Path .......................................................... 149

The Operation and Maintenance of the Glide Path................................................. 156

The Glide Path's Present ............................................................................................. 163

7. Textile and Leather Industry in Székely Land ..................................................... 167

On the Production of Thick Woolen Blankets.............................................................. 167

What are Thick Woolen Blankets? .............................................................................. 167

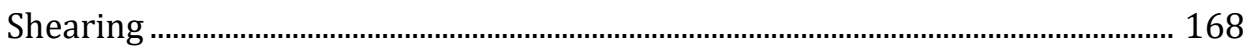




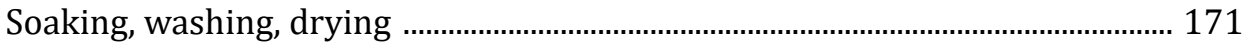

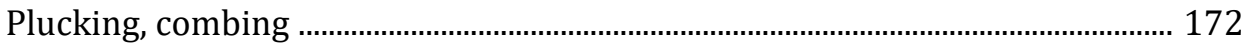

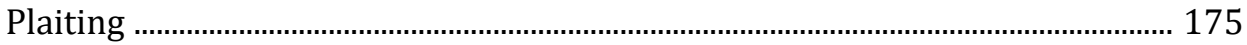

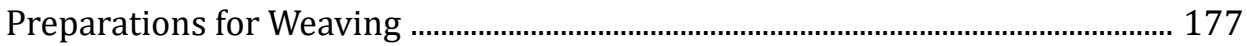

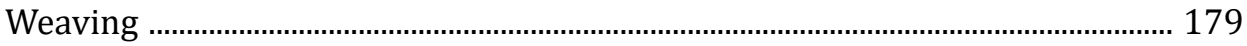

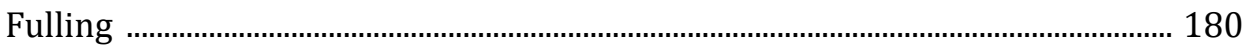

Using and Care of Thick Woolen Blankets ........................................................... 184

Changes in the Production of Thick Woolen Blanket ............................................. 185

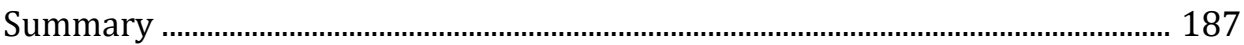

The Famous Product of the Gheorgheni/Gyergyószentmiklós Armenien

Curriers: the Kordwain .................................................................................... 192

The Covasna/Kovászna Cloth Factory ....................................................................... 195

8. Székely Land's Water Mills in Time and in Space ................................................ 199

The Importance of Water Power in Mining, Metallurgy and Metal-Working....... 221

9. Glass-Works in Székely Land .................................................................................. 223

Glass-Works in the Carpathian Basin .................................................................... 223

Glass Manufacturing Workshops in Székely Land .................................................... 224

The Glass Factory of Borsec/Borszék …………….................................................... 227

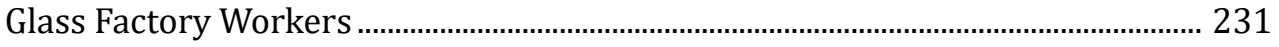

The Afterlife of the Borsec/Borszék Glass ................................................................ 232

Glass Manufacture Technique ............................................................................... 233

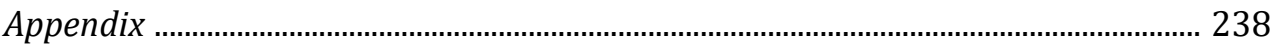

10. The beginnings of the use of electric power ...................................................... 239

Chapters from the history of Miercurea Ciuc/Csíkszereda's Electrification....... 239

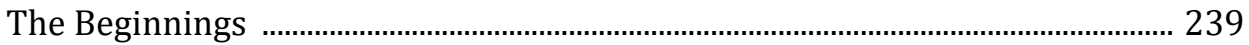

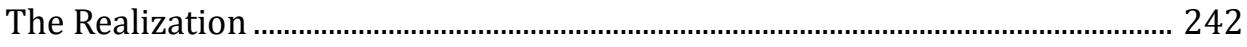

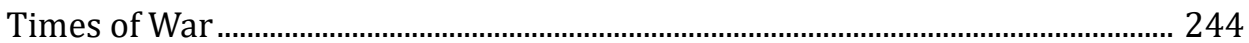

The Electric Plant and The City ......................................................................... 246

Who Needed the Light? ....................................................................................... 246

Lights of a New World ......................................................................................... 248

The First Decades of Electric Power in Odorheiu Secuiesc/

Székelyudvarhely ..

Beginnings of the Use of Electric Power in Gheorgheni/Gyergyószentmiklós

and the Settlements of the Ghorgheni/Gyergyó Basin 255

The Plans and the Failure of the Building of a Water-Power Station in 
Lacul Roșu/Gyilkos Lake, Cheile Bicaz/Békás ....................................................... 258

The history of Comandău/Kommand'a Electrification .............................................. 265

A Plan of a Hydroelectric Station ............................................................................. 269

11. On Székely Land's guilds ................................................................................. 271

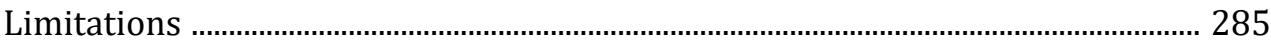

The Limitations in the Guilds' Life ........................................................................... 285

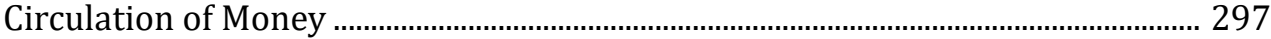

Financial System in the Empire ………………………........................................... 299

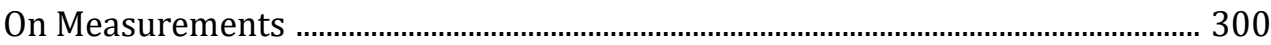

Tradesmen Outside the Guilds .................................................................................... 303

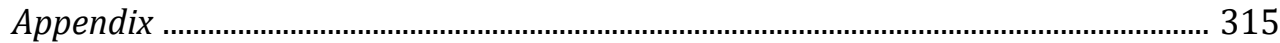

12. Perpetual Calendar in the coffers' Structure of the Ocland/

Oklánd Unitarian Church ........................................................................................... 319

Description of the Coffer ............................................................................................. 320

Hypotheses and Explanations ................................................................................... 321

Using the Easter Coffer ............................................................................................. 323

Calculating the Date of Easter According to the Julian Calendar ............................. 324

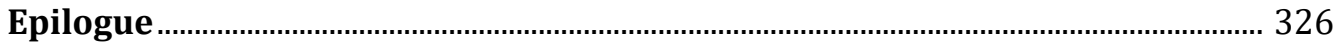

Capitole ale istoriei tehnicii în Ținutul Secuiesc (rezumat) .............................................. 328

Chapters of Tehnical History in the Székely Land (abstract) .......................................... 333 